UNIVERSIDADE DE SÃO PAULO

FACULDADE DE FILOSOFIA, LETRAS E CIÊNCIAS HUMANAS

DEPARTAMENTO DE GEOGRAFIA

PROGRAMA DE PÓS-GRADUAÇÃO EM GEOGRAFIA HUMANA

SUZANA CRISTINA LOURENÇO

\title{
Formação e influência política das redes ambientalistas amazônicas a partir das experiências mato-grossenses
}

TESE DE DOUTORADO

Versão Corrigida

São Paulo

2018 
UNIVERSIDADE DE SÃO PAULO

FACULDADE DE FILOSOFIA, LETRAS E CIÊNCIAS HUMANAS

DEPARTAMENTO DE GEOGRAFIA

PROGRAMA DE PÓS-GRADUAÇÃO EM GEOGRAFIA HUMANA

\section{Formação e influência política das redes ambientalistas amazônicas a partir das experiências mato-grossenses}

(Genesis and political influence of Amazonian environmental networks from Mato Grosso experiences.)

Suzana Cristina Lourenço

Versão Corrigida

Tese de doutorado apresentada ao Programa de Pós-Graduação em Geografia Humana, como parte dos requisitos necessários à obtenção do título de Doutora em Geografia Humana. Bolsa de estudos: Coordenação de Aperfeiçoamento de Pessoal de Nível Superior (CAPES).

Orientadora: Neli Aparecida de Mello-Théry

De acordo em 15 de março de 2018

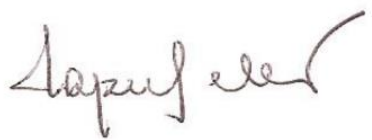

São Paulo

2018 
Autorizo a reprodução e divulgação total ou parcial deste trabalho, por qualquer meio convencional ou eletrônico, para fins de estudo e pesquisa, desde que citada a fonte.

Catalogação na Publicação

Serviço de Biblioteca e Documentação

Faculdade de Filosofia, Letras e Ciências Humanas da Universidade de São Paulo

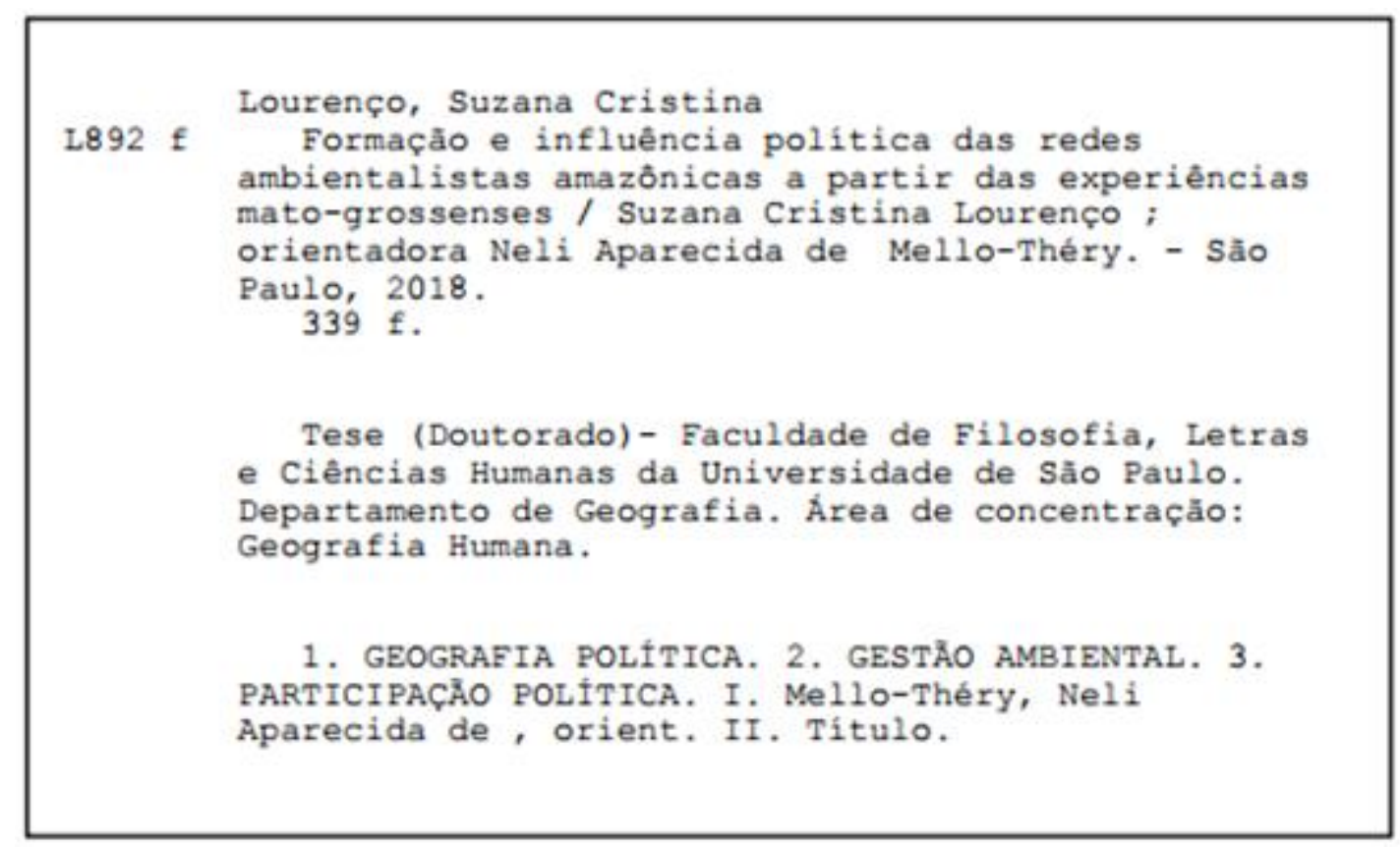




\section{RESUMO}

LOURENÇO, Suzana Cristina. Formação e influência política das redes ambientalistas amazônicas a partir das experiências mato-grossenses. 2018. 339 f. Tese (Doutorado em Geografia Humana) Faculdade de Filosofia, Letras e Ciências Humanas da Universidade de São Paulo, São Paulo, 2018.

O presente trabalho analisa, partindo do estudo de caso do Fórum Mato-grossense de Meio Ambiente e Desenvolvimento (FORMAD), como essa rede ambientalista de organizações desenvolveu estratégias de influência na tomada de decisões socioambientais nas esferas dos municípios e do estado mato-grossenses e federal brasileira. Consideramos o período entre a Conferência das Nações Unidas sobre o Meio Ambiente e o Desenvolvimento (CNUMAD) até a Conferência das Nações Unidas sobre Desenvolvimento Sustentável (1992 a 2012), período esse que coincide com os vinte anos de intensificação dos debates ambientais entre governo e as diversas camadas da sociedade civil no Brasil. Usamos uma abordagem dialética para a reflexão sobre as entrevistas e análise de documentos governamentais referentes à participação nos processos decisórios ambientais, dados abertos, portais de transparência governamentais e os arquivos do fórum. Explicitam-se na análise: 1) a complexidade das negociações entre a rede (cuja realidade é compartilhada com outras redes de semelhante escopo) e as esferas governamentais; 2) as repercussões da descentralização, configurada desde a Constituição de 1988 até o presente momento, à participação; 3) a necessidade de refletir sobre a efetividade das instituições participativas (neste caso, voltadas ao ambiente); 4) a dificuldade de atribuição de uma escala à atuação das redes. A importância das ideologias geográficas à geopolítica perpassa o raciocínio de grande parte do trabalho. Como resultado, esta pesquisa visa, a partir das experiências de negociação desse fórum, reconhecer as possibilidades participação social.

PalaVRas-ChaVE: participação social, organizações, redes ambientalistas, Mato Grosso. 


\section{RESUMEN}

LOURENÇO, Suzana Cristina. Formação e influência política das redes ambientalistas amazônicas a partir das experiências mato-grossenses. 2018. 339 f. Tese (Doutorado em Geografia Humana) Faculdade de Filosofia, Letras e Ciências Humanas da Universidade de São Paulo, São Paulo, 2018.

En este trabajo se evalúa, en base al estudio de caso del Foro Mato Grosso de Medio Ambiente y Desarrollo (FORMAD), como esta red de organizaciones dedicadas al ambiente ha desarrollado sus estrategias de influencia en la toma de decisiones ambientales a nivel municipal y estatal Mato Grosso y federal (Brasil). Consideramos el periodo entre la Conferencia de Naciones Unidas sobre Medio Ambiente y Desarrollo (CNUMAD) a la Conferencia de las Naciones Unidas sobre el Desarrollo Sostenible (1992 hasta 2012), período que coincide con los veinte años en que se intensifican las articulaciones ambientales entre el gobierno y la sociedad civil en Brasil. Utilizamos un enfoque dialéctico tras reflexionar sobre las entrevistas y analizar los documentos (gubernamentales y del FORMAD) relacionados con la participación en la toma de decisiones. Los resultados nos muestran: 1) la complejidad y dificultad de establecimiento de negociaciones entre esta red (cuya realidad es compartida con otras redes de igual temática) con los niveles federal, estatal y municipal; 2) los rumbos a la participación que configuraron la descentralización política, establecido por la Constitución de 1988 hasta la fecha; 3) la necesidad de reflexionar sobre la eficacia de las instituciones participativas al medio ambiente); 4) la dificultad de definir una escala de actuación de la red. La importancia de las ideologías geográficas a la geopolítica hace parte del raciocinio de grande parte del trabajo. Como resultado, esperamos recomendar formas para una mejor adecuación entre las posibilidades de gobernabilidad y participación con el fin de fortalecer la gobernanza ambiental.

Palabras Clave: participación social, organizaciones, redes ambientalistas, Mato Grosso. 


\begin{abstract}
LOURENÇO, Suzana Cristina. Formação e influência política das redes ambientalistas amazônicas a partir das experiências mato-grossenses. 2018. 339 f. Tese (Doutorado em Geografia Humana) Faculdade de Filosofia, Letras e Ciências Humanas da Universidade de São Paulo, São Paulo, 2018.

This research evaluates, based on the case study of Mato Grosso Environment and Development Forum (FORMAD), how this environmental network has developed their influence strategies in environmental decision making, regarding municipal and state Mato Grosso spheres of government and the Brazilian federal government. We consider the period between the United Nations Conference on Environment and Development (UNCED) and the United Nations Conference on Sustainable Development (1992-2012), which coincides with the twenty-year intensification of environmental debates between government and civil society in Brazil. We use a dialectical approach in order to analyze the interviews and government documents regarding participation in environmental decision-making. In this analysis some relevant questions have emerged: 1) the complexity and difficulty of establishing negotiations between this network (whose reality is shared with other networks regarding the same subject) and federal, state and municipal levels; 2) the impact of decentralization on civil society participation set from the 1988 Constitution; 3) the need to think about effectiveness of participatory institutions (in this case, concerning the environment); 4) the difficulty of assigning a scale to network performance. We also argue that geographical ideologies play an important role in geopolitics. As a result, this research aims recommending ways for a better match between the possibilities of governability and participation in order to strengthen environmental governance between government spheres.
\end{abstract}

KEYWORDS: social participation, organizations, environmental networks, Mato Grosso. 


\section{LISTA DE SIGLAS}

ABONG - Associação Brasileira de Organizações Não Governamentais

ACRIMAT - Associação dos Criadores de Mato Grosso

ADERCO - Associação de Defesa do Rio Coxipó

ADUFMAT - Associação dos Docentes da Universidade de Mato Grosso

AEMA - Associação Ecológica e Meio Ambientalista

AME - Associação Mato-grossense de Ecologia

AMEC - Associação Ecológica Melgassense

AMPA - Associação Mato-grossense de Produtores de Algodão

APA - Área de Proteção Ambiental

APNE - Associação Plantas do Nordeste

APP - Área de Preservação Permanente

APROSOJA - Associação dos Produtores de Soja e Milho de Mato Grosso

ARA - Articulação Regional Amazônica

ARCA - Associação para Recuperação e Conservação do Ambiente

ARPA - Programa Áreas Protegidas da Amazônia

AT - Associação Takiná

ATIX - Associação Terra Indígena Xingu

ATV - Associação Terra Viva

AXA - Articulação Xingu-Araguaia

BID - Banco Interamericano de Desenvolvimento

BIRD - Banco Internacional para Reconstrução e Desenvolvimento

BNDES - Banco Nacional de Desenvolvimento Econômico e Social

CAPADR - Comissão de Agricultura, Pecuária, Abastecimento e

Desenvolvimento Rural

CAR - Cadastro Ambiental Rural

CCE - Comissão das Comunidades Europeias

CCZEE - Comissão Coordenadora de Zoneamento Ecológico-Econômico

CDB - Convenção sobre Diversidade Biológica

$\mathrm{CDH}$ - Comissão de Direitos Humanos e Legislação Participativa

CDHDMB - Centro de Direitos Humanos Dom Máximo Biennés

CEAP - Conselho Estadual de Administração do PRODEAGRO

CEB - Comunidades Eclesiásticas de Base

CEFEGETE - Conselho Estadual Gestor do Fundo de Erradicação do Trabalho

Escravo

CES - Conselho Estadual de Saúde

CETIC - Centro de Estudos sobre as Tecnologias da Informação e da

Comunicação

CGU - Controladoria-Geral da União

$\mathrm{Cl}$ - Conservation International

CIAP - Comitê Independente de Avaliação do PRODEAGRO

CIFA - Comitê Interinstitucional de Fiscalização Ambiental e Terras Indígenas

$\mathrm{CIMI}$ - Conselho Indigenista Missionário

CINDRA - Comissão de Integração Nacional, Desenvolvimento Regional e da

Amazônia

CIPEM - Centro das Indústrias Produtoras e Exportadoras de Madeira do Estado

de Mato Grosso

CMA - Comissão de Meio Ambiente 
CMADS - Comissão de Meio Ambiente e Desenvolvimento Sustentável

CMMC - Comissão Mista Permanente sobre Mudanças Climáticas

CNA - Confederação de Agricultura e Pecuária do Brasil

CNBB - Conferência Nacional dos Bispos do Brasil

CNPCT - Comissão Nacional dos Povos e Comunidades TradicionaCNPq -

Conselho Nacional de Desenvolvimento Científico e Tecnológico

CNS - Conselho Nacional de Saúde

CNUMAD - Conferência das Nações Unidas sobre Meio Ambiente e

Desenvolvimento

CNZEE - Comissão Nacional do Zoneamento

COETRAE - Comissão Estadual de Erradicação do Trabalho

COIAB - Coordenação das Organizações Indígenas da Amazônia Brasileira

COICA - Coordinadora de Organizaciones Indígenas de la Cuenca Amazónica

CONAB - Companhia Nacional de Abastecimento

CONAMA - Conselho Nacional do Meio Ambiente

CONATRAE - Comissão Nacional de Erradicação do Trabalho

CONDEMA - Conselho Municipal de Defesa do Meio Ambiente

CONDESSA - Consórcio de Desenvolvimento Socioambiental

CONSEA - Conselho Estadual de Segurança Alimentar e Nutricional

CONSEMA - Conselho Estadual do Meio Ambiente

COP - Conferência das Partes

CPRM - Companhia de Pesquisa de Recursos Minerais

CPT - Comissão Pastoral da Terra

CRA - Comissão de Agricultura e Reforma Agrária

CTA - Centro de Tecnologia Alternativa

CTFC - Comissão de Transparência, Governança, Fiscalização e Controle e

Defesa do Consumidor

CUT - Central Única dos Trabalhadores

DSEE - Diagnóstico Socioeconômico Ecológico

ECOTRÓPICA - Fundação de Apoio à Vida nos Trópicos

EDF - Environmental Defense

EMATER - Empresa de Assistência Técnica e Extensão Rural

EMBRAPA - Empresa Brasileira de Pesquisa Agropecuária

FAMATO - Federação da Agricultura e Pecuária do Estado de Mato Grosso

FAO - Food and Agriculture Organization of the United Nations

FASE - Federação de Órgãos para Assistência Social e Educacional

FBOMS - Fórum Brasileiro de ONGs e Movimentos Sociais para o Meio Ambiente

e Desenvolvimento

FDHT - Fórum de Direitos Humanos e da Terra

FEMA - Fundo Estadual do Meio Ambiente

FEMAN - Fundo Estadual do Meio Ambiente

FETAGRI - Federação dos Trabalhadores na Agricultura

FETE - Fundo de Erradicação do Trabalho Escravo

FIEMT - Federação das Indústrias do Estado de Mato Grosso

FLEC - Fórum de Luta das Entidades de Cáceres

FNMA - Fundo Nacional do Meio Ambiente

FORMAD - Fórum Mato-grossense de Meio Ambiente e Desenvolvimento

FUNAI - Fundação Nacional do Índio

FUNBIO - Fundo Brasileiro para a Biodiversidade 
FUNDAGRO - Fundo de Desenvolvimento Agroambiental de Mato Grosso

FVPP - Fundação Viver, Produzir e Preservar

GAPA - Grupo Agroflorestal de Proteção Ambiental

GEF - Global Environmental Facility

GEP - Gerência Estadual do PRODEAGRO

GIAS - Grupo de Intercâmbio em Agroecologia de Mato Grosso

GIBRAH - Gestão Integrada da Biodiversidade Aquática e dos Recursos Hídricos

GOB - Governo do Brasil

GRAUNA - Grupos de Amigos Unidos pela Natureza

GT - Grupos de Trabalho

GTA - Grupo de Trabalho Amazônico

GTI - Grupo de Trabalho Interministerial

GTME - Grupo de Trabalho Missionário Evangélico

GTZ - German Organisation for Technical Cooperation

IBAMA - Instituto Brasileiro do Meio Ambiente e dos Recursos Naturais

Renováveis

IBDF - Instituto Brasileiro de Desenvolvimento Florestal

IBGE - Instituto Brasileiro de Geografia e Estatística

ICCO - International Communications Consultancy Organization

ICMBio - Instituto Chico Mendes de Conservação da Biodiversidade

ICMS - Imposto sobre Circulação de Mercadorias

ICV - Instituto Centro de Vida

IDH - Índice de Desenvolvimento Humano

IECLB - Igreja Evangélica de Confissão Luterana no Brasil

IFPDS - Instituto Floresta de Pesquisa e Desenvolvimento Sustentável

IIRSA - Iniciativa para a Integração da Infraestrutura Regional Sul-americana

INBRACO - Instituto Brasileiro de Pesquisas, Participação Social e

Acompanhamento

INCRA - Instituto Nacional de Colonização e Reforma Agrária

INPE - Instituto Nacional de Pesquisas Espaciais

INTERMAT - Instituto de Terras de Mato Grosso

IPA - Instituto Pró-Ambiência

IPAM - Instituto de Pesquisa Ambiental da Amazônia

ISA - Instituto Socioambiental

IUCN - International Union for Conservation of Nature

LAI - Lei de Acesso à Informação

MAB - Movimento dos Atingidos por Barragens

MacroZEE - Macrozoneamento Ecológico Econômico

MAPA - Ministério da Agricultura, Pecuária e Abastecimento

$M C$ - Ministério da Comunicação

MDA - Ministério do Desenvolvimento Agrário

MDIC - Ministério do Desenvolvimento, Indústria e Comércio Exterior

MEC - Ministério da Educação

MI - Ministério da Integração

MINTER - Ministério do Interior

MMA - Ministério do Meio Ambiente

MNMMR - Movimento Nacional de Meninos e Meninas de Rua

MOPS - Movimento Popular de Saúde

MPF - Ministério Público Federal 
MPOG - Ministério do Planejamento, Orçamento e Gestão

MS - Ministério da Saúde

MTSD - Projeto Mato Grosso Sustentável e Democrático

NEOM - Associação de Estudos e Organização da Mulher

OEMA - Órgão Esstadual de Meio Ambiente

OIT - Organização Internacional do Trabalho

ONG - Organização Não Governamental

ONGARA - ONG Ambientalista Roncador Araguaia

OPAN - Operação Amazônia Nativa

OSC - Organizações da Sociedade Civil

OSCA - Organizações da Sociedade Civil Ambientalistas

OSCIP - Organização da Sociedade Civil de Interesse Público

PA - Projeto de Assentamento

PAB - Plano de Bacias

$P A C$ - Programa de Aceleração do Crescimento

PADEQ - Projetos de Alternativas ao Desmatamento e às Queimadas

PADIC - Programa de Apoio Direto às Iniciativas Comunitárias

PAN-Brasil - Programa de Ação Nacional de Combate à Desertificação

PAS - Plano Amazônia Sustentável

$\mathrm{PCH}$ - Pequenas Centrais Hidrelétricas

PDI - Programa de Desenvolvimento Integrado

PIB - Produto Interno Bruto

PIX - Parque Indígena do Xingu

PLANAFLORO - Plano Agropecuário e Florestal de Rondônia

PLANAPO - Plano Nacional de Produção Orgânica e Agroecológica

PLP - Plano de Longo Prazo

PMABB - Programa de Monitoramento Ambiental dos Biomas Brasileiros

PNAP - Plano Estratégico Nacional de Áreas Protegidas

PNGC - Plano Nacional de Gerenciamento Costeiro

PNMA - Política Nacional do Meio Ambiente

PNMR - Política Nacional para os Recursos do Mar

PNOT - Política Nacional de Ordenamento Territorial

PNUD - Programa das Nações Unidas para o Desenvolvimento

PNUMA - Programa das Nações Unidas para o Meio Ambiente

POLONOROESTE - Programa Integrado de Desenvolvimento do Noroeste do

Brasil

PP - Programa Pantanal

PPA - Plano Plurianual

PPCDAM - Plano de Prevenção e Controle de Desmatamento na Amazônia Legal

PPG7 - Programa Piloto para a Proteção das Florestas Tropicais do Brasil

PR - Presidência da República

PROAMBIENTE - Programa de Desenvolvimento Socioambiental da Produção

Familiar Rural

PROCONVE - Programa de Controle de Poluição do Ar por Veículos

Automotores

PRODEAGRO - Programa de Desenvolvimento do Agronegócio

PRODEIC - Programa de Desenvolvimento Industrial e Comercial de Mato

Grosso

PROFOR - Projeto de Fortalecimento da Participação Social 
PRONABIO - Programa Nacional da Diversidade Biológica

PRONAR - Programa de Controle da Poluição do Ar

PRONEA - Programa Nacional de Educação Ambiental

PRONORA - Programa Nacional de Redução de Uso de Agrotóxicos

PTA - Plano de Trabalho Anual

RAG - Relatório da Ação Governamental

REDD+ - Redução de Emissões por Desmatamento e Degradação

REMTEA - Rede Mato-grossense de Educação Ambiental

RFT - Fundo Fiduciário das Florestas Tropicais

RIAA - Rede de Informações Agroecológicas da Amazônia

$\mathrm{RL}$ - Reserva Legal

SACI - Sistema de Análise de Capacidade Institucional

SAE - Secretaria de Assuntos Estratégicos

SBPC - Sociedade Brasileira para o Progresso da Ciência

SDR - Secretaria de Desenvolvimento Regional

SEMA - Secretaria do Meio Ambiente

SEMAM/PR - Secretaria de Meio Ambiente da Presidência da República

SEPLAN - Secretaria de Estado de Planejamento

SINDACOOL - Sindicato das Indústrias Sucroalcooleiras do Estado do Mato

Grosso

SINDENERGIA - Sindicato da Construção, Geração, Transmissão e Distribuição

de Energia Elétrica e Gás no Estado de Mato Grosso

SINTEP - Sindicato dos Trabalhadores no Ensino Público de Mato Grosso

SISNAMA - Sistema Nacional do Meio Ambiente

STRLRV - Sindicato dos Trabalhadores Rurais de Lucas do Rio Verde

SUDAM - Superintendência do Desenvolvimento da Amazônia

SUDECO - Superintendência do Desenvolvimento da Região Centro-Oeste

SUDEPE - Superintendência da Pesca

SUDHEVEA - Superintendência da Borracha

TCN - The Nature Conservancy

TI - Terra Indígena

UC - Unidade de Conservação

UFMT - Universidade Federal de Mato Grosso

UHE - Usinas Hidrelétricas

UNEMAT - Universidade Estadual do Mato Grosso

USAID - Agência dos Estados Unidos para o Desenvolvimento Internacional

USDA - Departamento de Agricultura dos EUA

USEE - Unidades Sócio-Econômicas-Ecológicas

WWF - World Wide Fund For Nature

ZEE - Zoneamento Ecológico-Econômico

ZSEE - Zoneamento Socioeconômico-Ecológico 


\section{SUMÁRIO}

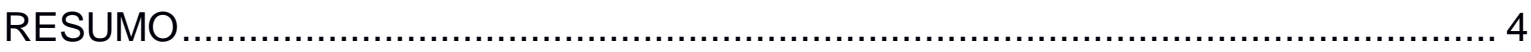

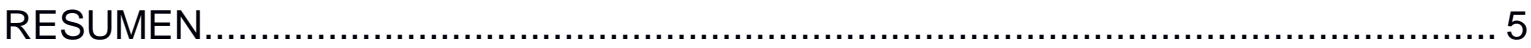

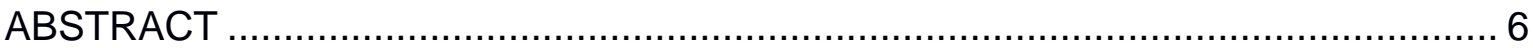

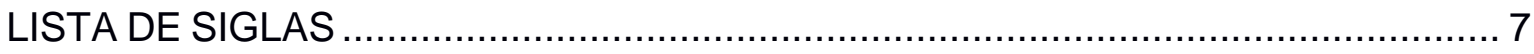

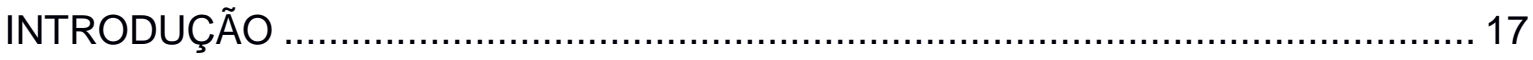

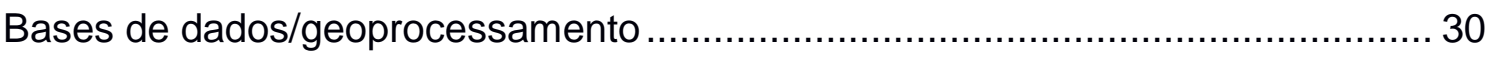

CAPÍTULO 1 - A QUESTÃO AMBIENTAL NO ESTADO BRASILEIRO ..................... 31

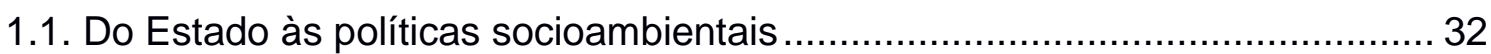

1.2. Herança colonial e gestão da socio e biodiversidade.................................... 38

1.3. A construção da política ambiental brasileira ............................................... 42

1.4. A política ambiental como elemento territorial ............................................ 52

1.5. O Estado brasileiro contemporâneo e o processo político ambiental .............. 55

1.6. Dominâncias refletidas na distribuição orçamentária entre os ministérios ...... 62

CAPÍTULO 2 - CONTEXTO SOCIOAMBIENTAL MATO-GROSSENSE .................. 82

2.1. O planejamento estratégico mato-grossense ............................................ 84

2.2. A concepção das regiões de planejamento mato-grossenses ....................... 99

2.3. A produção de soja e cana-de-açúcar no estado do Mato Grosso................. 105

2.4. Ações e objetos e uma representação da produção do território e da natureza

CAPÍTULO 3 - SOCIEDADE CIVIL E REDES AMBIENTALISTAS.

3.1. A relação entre o Estado e a sociedade civil no contexto ambiental .............. 132

3.1.1. Tipos de aglutinações na formação das organizações ambientalistas ... 135

3.2. Organizações, tipologias de ambientalismos e interações em redes ............ 139

3.2.1. Diversificação das linhas ambientalistas no contexto latino-americano.. 140

3.3. A importância das redes ambientalistas nas relações territoriais .................. 145

3.4. Composição da rede FORMAD e suas interações ....................................... 147

3.4.1. Articulações com outras redes .......................................................... 165

3.4.2. Principais momentos de inserção política das redes ambientalistas mato-

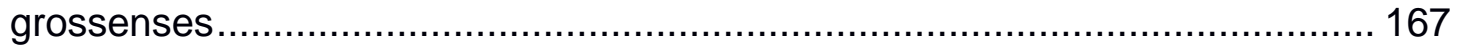

CAPÍTULO 4 - ORDENAMENTO TERRITORIAL MATO-GROSSENSE: A RELEVÂNCIA DAS DECISÕES POLIITICO-AMBIENTAIS E O ZONEAMENTO ....... 176

4.1. O Zoneamento Ecológico Econômico mato-grossense como instrumento de

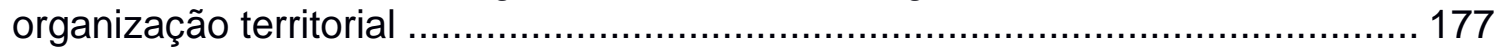

4.2. O PPG7 e seu papel no processo de fomento à participação ...................... 182 
4.3. O zoneamento, o mais suspeito dos componentes do PRODEAGRO. 187

4.4. A Carta de Santarém como manifestação das demandas civis 198

4.5. Interação entre Estado e sociedade: os conflitos no caso do Zoneamento Socioeconômico e Ecológico do Estado do Mato Grosso. 204

4.6. Novas amplitudes: escalas de influência das redes ambientalistas amazônicas, sua relação com o território e com as instituições governamentais 215

4.7. O Zoneamento Ecológico-Econômico no Plano BR-163 Sustentável 218

CAPÍTULO 5 - PROJETO MATO GROSSO SUSTENTÁVEL: ASPECTOS SOCIOAMBIENTAIS E POSSIBILIDADES DE INFLUÊNCIA DAS DECISÕES AMBIENTAIS 226

5.1. Uma proposta em parceria com um projeto nacional .................................. 227

5.2. Disputa pela agenda ambiental e participação........................................... 234

5.3. Metodologia, resultados e proposições do MTSD .................................... 237

5.3.1. Resultados sobre a conjuntura das Terras Indígenas ........................... 239

5.3.2. Conclusões sobre agricultura e uso da terra ..................................... 242

5.3.3. Considerações sobre grandes projetos e recursos hídricos ................... 243

5.3.4. Panorama das Unidades de Conservação ............................................ 246

5.4. O mapeamento das possibilidades de participação em políticas públicas .... 250

5.5. A diversidade de organizações ambientalistas nos processos decisórios e seus contras

5.6. A diversidade de organizações ambientalistas nos processos decisórios e seus prós 260

5.7. O que oferece a institucionalidade do Estado: conjuntura governamental matogrossense e seu avanço 262

CAPÍTULO CONCLUSIVO - REFLEXÕES SOBRE AS OPORTUNIDADES POLÍTICAS E O AMBIENTALISMO AMAZÔNICO ……………………………...... 270

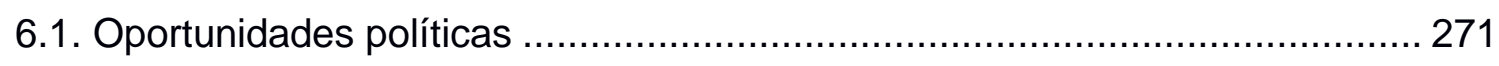

6.2. Institucionalidade ambiental, participação e o pacto federativo...................... 279

6.3. Pacto federativo, níveis decisórios e pluralidade de interesses no ambientalismo 287

6.4. A experiência do FORMAD nos espaços deliberativos e consultivos ambientais

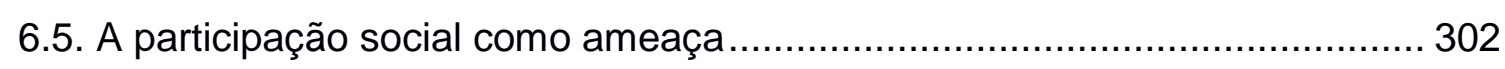

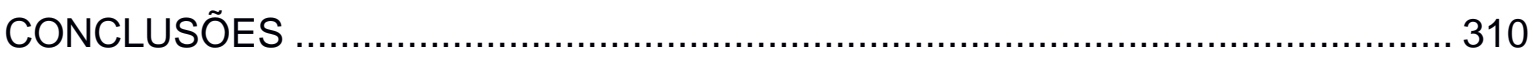

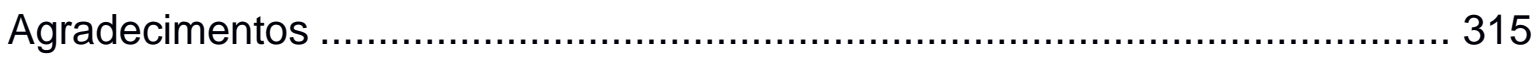

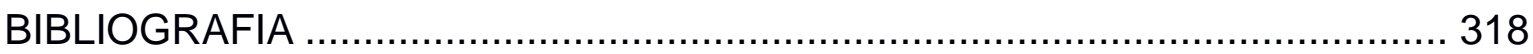




\section{LISTA DE GRÁFICOS}

Gráfico 1. Número de assassinatos de militantes ambientalistas por país (2002-

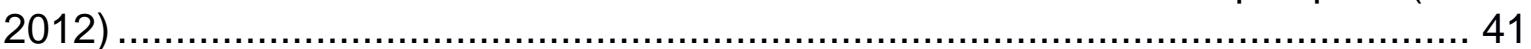

Gráfico 2. Evolução da composição do CONAMA ………………………….... 48

Gráfico 3. Composição dos membros do CONAMA (em \%) .............................. 50

Gráfico 4. Taxas anuais do desmatamento: 1988 até 2015 ( $\left.\mathrm{km}^{2} / \mathrm{ano}\right)$................. 51

Gráfico 5. Empregos no funcionalismo público (2009 e 2013, em \% da força de

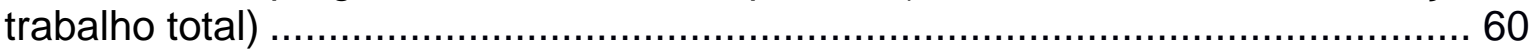

Gráfico 6. Distribuição dos orçamentos ministeriais (em R $\$$ bilhões) entre 2004 e

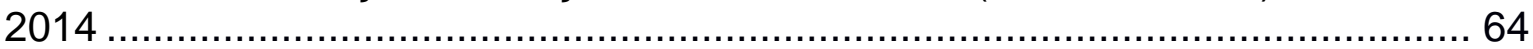

Gráfico 7. Repasses orçamentários feitos ao MMA, entre 2004 e 2014 (em

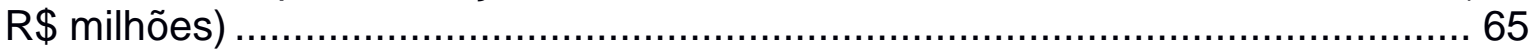

Gráfico 8. Média entre o orçamento previsto e o utilizado pelo MMA, valores totais,

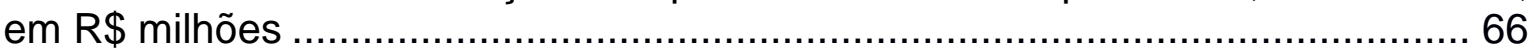

Gráfico 9. Execução orçamentária do MMA, em R \$ milhões (2005) .................... 70

Gráfico 10. Execução orçamentária do MMA, em R \$ milhões (2006) ................... 71

Gráfico 11. Execução orçamentária do MMA, em R \$ milhões (2007) .................. 72

Gráfico 12. Execução orçamentária do MMA, em R \$ milhões (2008) .................. 73

Gráfico 13. Execução orçamentária do MMA, em R \$ milhões (2009) ................... 74

Gráfico 14. Execução orçamentária do MMA, em R \$ milhões (2010) ................... 75

Gráfico 15. Execução orçamentária do MMA, em R \$ milhões (2011) ................... 76

Gráfico 16. Execução orçamentária do MMA, em R \$ milhões (2012) ................... 77

Gráfico 17. Execução orçamentária do MMA, em R \$ milhões (2013) .................. 78

Gráfico 18. Execução orçamentária do MMA, em R \$ milhões (2014) .................. 79

Gráfico 19. Recursos públicos transferidos da União para o estado do Mato Grosso,

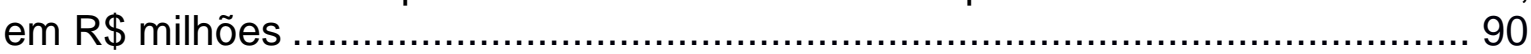

Gráfico 20. Emissões no estado do Mato Grosso entre 1990 e 2014, em Mt CO2e

(t) GWP-AR2

94

Gráfico 21. Principais exportações pelo estado do Mato Grosso entre 2006 e 2015, em US\$ F.O.B. (milhões) ................................................................ 108 Gráfico 22. Principais importações do estado do Mato Grosso entre 2006 e 2015

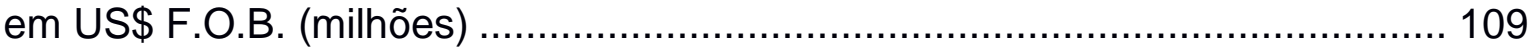
Gráfico 23. Imóveis rurais cadastrados (\%) no Cadastro Ambiental Rural (CAR) até 31.03.2017 ........................................................................... 213

Gráfico 24. Ocorrências de exploração de TI Regularizadas registradas nos arquivos do FORMAD até 2009...............................................................237 Gráfico 25. Índice de Transparência dos governos municipais por estado da Federação. Primeira Avaliação (2015) e Segunda Avaliação (2016) ................. 265 Gráfico 26. Índice de Transparência dos governos estaduais por estado da Federação. Primeira Avaliação (2015) e Segunda Avaliação (2016) ................. 267 Gráfico 27. Índices de transparência ativa (\%) das informações ambientais por estado e agenda prioritária 268 


\section{LISTA DE QUADROS}

Quadro 1. Servidores ativos na estrutura de meio ambiente em 31.12.2002, com ou sem vínculo empregatício, por nível de cargo ocupado, segundo classe de tamanho da população, nos estados da Amazônia Legal .............................................. 61 Quadro 2. Municípios, total, com Fundo Municipal de Meio Ambiente na Amazônia Legal (2012) 91 Quadro 3. Macro-objetivos do Plano de Longo Prazo mato-grossense, entre 2011 e 2031 92 Quadro 4. Comparação da produção científica entre Mato Grosso e a região CentroOeste..... 95 Quadro 5. Comparação da produção científica entre a região Centro-Oeste e as demais regiões brasileiras........................................................................ 95 Quadro 6. Municípios, total e com estrutura na área de meio ambiente, por caracterização do órgão gestor, segundo as Grandes Regiões e as Unidades da Federação - 2012 103 Quadro 7. Municípios, total, dos estados da Amazônia Legal com Conselho Municipal de Meio Ambiente, por algumas características do conselho - 2012104 Quadro 8. Municípios, total e com existência e características de conselhos municipais de meio ambiente, ano-base 2002 105 Quadro 9. Áreas prioritárias para a conservação no Estado do Mato Grosso, segundo parâmetros para a Amazônia Legal, elaborados em parceria do MMA com organizações ambientalistas .................................................................. 118 Quadro 10. L-M-P relacionados aos eixos de atuação do FORMAD .................. 124 Quadro 11. L-M-P relacionados aos eixos de atuação do PLP ........................ 125 Quadro 12. Pontos de contato entre os eixos de ação governamental e da rede

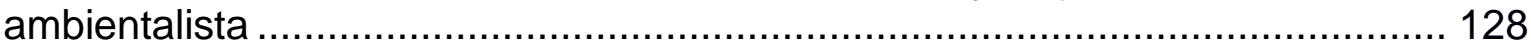
Quadro 13. Eixos temáticos da rede FORMAD .......................................... 153 Quadro 14. Nomes, siglas, área temática e abrangência de atuação das organizações que participam da rede ambientalista FORMAD ......................... 163 Quadro 15. Principais políticas, planos e programas ambientais nacionais entre 1981 e 2012 168

Quadro 16. Estrutura original organizacional do PRODEAGRO ...................... 190 Quadro 17. Estrutura organizacional do PRODEAGRO depois da Avaliação de Meio Termo .................................................................................. 193

Quadro 18. Relação temática entre o MTSD e os eixos de atuação FORMAD . 238 Quadro 19. Desmatamento por grupo de análise............................................. 248 Quadro 20. Dados do desmatamento por categoria de manejo ........................ 249 Quadro 21. Análise do escopo dos conselhos gestores pelo Seminário de Políticas Públicas FORMAD ............................................................................ 253 Quadro 22. Abrangência da atuação das organizações da sociedade civil ....... 285 Quadro 23. Municípios, total e com existência de conselhos municipais de meio ambiente, por características dos conselhos municipais de meio ambiente: Amazônia Legal................................................................................ 291 Quadro 24. Municípios, total e com conselhos municipais de meio ambiente, por tipo de entidade participante, Amazônia Legal (2002) .................................. 292 Quadro 25. Dimensões dos efeitos das instituições participativas ambientais... 307 


\section{LISTA DE FIGURAS}

Figura 1. Interpretação das fases do processo decisório, segundo autores e

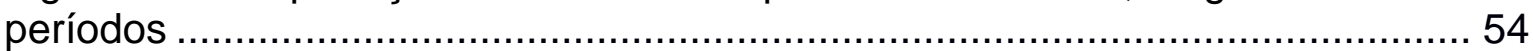

Figura 2. Índice de Palma nos estados brasileiros entre 2004 e 2012 .............. 89

Figura 3. Regiões de planejamento no Mato Grosso anteriores ao PPA 2004-2007

Figura 4. Regiões de planejamento do MT a partir do ZSEE ........................... 102

Figura 5. Expansão da fronteira agrícola no Brasil e no bioma do Cerrado em diferentes períodos............................................................................. 107

Figura 6. Distribuição de áreas protegidas, conformação social e pressões ao ambiente............................................................................... 116

Figura 7. Distribuição dos vínculos internacionais do FORMAD entre o período de 1992 e 2012 e distribuição das frentes de desmatamento na Pan-Amazônia.... 152

Figura 8. Distribuição do FORMAD e suas conexões …….......................... 157

Figura 9. Rede de atuação da Articulação Regional Amazônica......................... 167

Figura 10. Participantes da validação do ZSEE, cartilha divulgada pelo governo do estado do Mato Grosso ……………................................................... 207

Figura 11. Cronologia do processo de ZEE no estado do Mato Grosso ............. 209

Figura 12. Mapa de relações entre as redes GTA e FORMAD .......................... 217

Figura 13. Área de influência da BR-163 no estado de Mato Grosso ................ 221

Figura 14. Zoneamento da área de influência da BR-163 por categoria de uso e frentes de exploração florestal .............................................................. 222

Figura 15. Desmatamento e Unidades de Conservação até 2005 no estado do Mato Grosso ......................................................................................... 247 Figura 16. Escala Brasil Transparente: Panorama dos Governos Municipais -

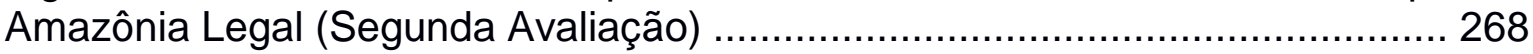
Figura 17. Características de abertura e fechamento de oportunidades políticas pelos Estados 277

Figura 18. Esquema das principais institucionalidades participativas utilizadas pelo FORMAD 299 


\section{INTRODUÇÃO}

O papel que desenvolve a geopolítica na história recente da Amazônia dá fortes indicações de como esta interage com a vida política nacional (FORESTA, 1992). Resta saber em que medida nosso longo histórico de colonização e militarismo deixam margem para um aprofundamento democrático que permita que a categoria de participação social seja exercida em sua plenitude.

Haja vista que o contexto histórico, social, político e territorial das nações são fatores determinantes da formação e cultura política que define qual o papel do Estado, a transformação do papel deste se daria por aspectos que incluem a transparência na divulgação de informações usadas na tomada de decisões, o desenvolvimento tecnológico científico e as formas de inclusão das demandas das diversas camadas da sociedade civil nos processos decisórios. Na medida em que o Estado, o território, as políticas públicas (STEINBERGER, 2013) e o ambiente são inseparáveis, a relação entre esses componentes tem potencial ora mantenedor, ora transformador da superestrutura.

No que diz respeito à geografia, tratamos principalmente da abstração do conceito de rede, especificamente a ambientalista, enquanto laços de solidariedade que tentam incidir na ação da superestrutura e, por conseguinte, do Estado. Primeiramente, tomamos como aspecto a relação entre o Estado brasileiro, a consolidação de seu território e as políticas ambientais. O segundo aspecto diz respeito às redes ambientalistas e as dialéticas no território; e, finalmente, o terceiro elemento trata da dos conflitos - travados no processo decisório, no qual estão implícitas ideologias geográficas - que refletem sobre o padrão vigente da distribuição dos recursos naturais e sua articulação com espaço brasileiro.

Atendemos às bases da geografia política na medida em que nos atemos aos estudos dos fenômenos políticos em sua área de contexto (JACKSON, 1964, p. 1), à análise de um recorte espacial de um fenômeno político (KASPERSON E MINGHI, 1969, p. xi) e às consequências desses fenômenos políticos nesses espaços (COHEN, 1973, p. 6).

A partir de um marco conceitual que localiza o processo de construção das políticas ambientais focadas na experiência amazônica brasileira, em especial a 
mato-grossense, analisamos aqui as mudanças na forma de fazer política e democracia que ocorreram após o advento da Constituição da República Federativa do Brasil de 1988 e as políticas ambientais que ajudaram a conformar o cenário atual no estado de Mato Grosso. Refletindo sobre como as organizações socioambientalistas vêm usando sua expertise em técnicas de análise e negociação em meio ambiente para inferir nos processos decisórios em âmbito estadual e federal, esta pesquisa visa avaliar a influência e a escala de atuação do Fórum Mato-grossense de Meio Ambiente e Desenvolvimento (FORMAD) - como principal estudo de caso - sobre as políticas ambientais referentes aos eixos temáticos do fórum nas esferas municipal, estadual e nacional. Elucidaremos como as cooperações entre as Organizações da Sociedade Civil Ambientalistas (OSCA) participantes do Fórum - as quais estão próximas a bases historicamente marginalizadas do processo político no Estado -, interagiram nas tomadas de decisão, identificando e analisando o papel dos múltiplos atores participantes e as posições dos tomadores de decisão desse processo.

Ao longo do trabalho, demonstramos que as ofertas de espaços à sociedade civil na tomada de decisão não foram e não são acompanhadas de um processo de participação, ou, mais ainda, de incorporação das demandas das OSCA, maiormente ligadas aos grupos marginalizados, nas três esferas governamentais (municipal, estadual e federal). Ainda que essas organizações tenham desenvolvido a produção de relatórios técnicos e estudos acadêmicos, contestando as decisões sobre o uso do solo, esses não alcançam as instituições e esferas de tomada de decisão a ponto de interferir na agenda política. Isso leva a que a governança ambiental não se concretize em sua plenitude porque, no contexto do jogo político estadual e federal, traria desvantagens políticas e econômicas aos grupos da sociedade civil que exercem a hegemonia sobre outros, à sociedade política resultante dessas relações hegemônicas e à sua relação com o governo. Sobre a escala pretendida, esperamos mapear a permeabilidade política (espectro de sua inserção nas arenas políticas, e sua derivada espacialidade) do objeto de estudo, o FORMAD, rede ambientalista que se fundou, acompanhou e atuou fortemente na política ambiental no estado de Mato Grosso e na região amazônica desde a promulgação da Constituição Brasileira de 1988. Partimos, assim, de um contexto regional, tendo como referência a Amazônia Legal, a partir do momento 
em que as ações e temáticas da rede são absorvidas (ou não) pelas instituições do Estado, governos e sociedade civil nas esferas municipais, estaduais e federais em formas de políticas e planejamento ambiental.

Em geral, as redes ambientalistas possuem frentes ou eixos de atuação bastante definidos, relativos às políticas de cunho ambiental ou socioambiental. Esses eixos têm incidência nas esferas municipal, estadual e nacional. A cooperação entre as OSCA em torno desses eixos visa incidir, técnica e politicamente, nos processos de tomada de decisão. São identificados os múltiplos atores envolvidos e seus interesses, a fim de se delinear uma estratégia de ação. Dada essa relativa similaridade na forma de atuação das redes ambientalistas, as conclusões a partir do estudo de caso podem ser replicáveis a outras redes. Por esse motivo, refletimos também sobre quais os possíveis caminhos ao processo de formulação e aplicação da política ambiental mato-grossense e federal, comparando o particular (as experiências políticas ao longo dos vinte anos na rede estudada) e o geral - o contexto de participação na tomada de decisões em política ambiental.

Nos países de formação colonial, como o Brasil, a dimensão espacial é relevante para a explicação dos processos sociais e políticos. Tal determinação colonial se insere nos padrões da organização territorial, em sua estrutura e nos modos de apropriação da natureza e de uso de recursos naturais (MORAES, 2002, p. 175). Apesar de considerarmos o marco da colonização como principal herança histórica, centramo-nos no período entre 1992 e 2012 em programas políticos estabelecidos no Mato Grosso ou no contexto, que o inclui, da Amazônia Legal. Usamos essa temporalidade por três questões estratégicas, ligadas à escala dos acontecimentos no ambientalismo mundial. Primeiramente porque, em um contexto internacional, situa-se entre conferências marcantes para o pensamento ambiental brasileiro: a Conferência das Nações Unidas sobre Meio Ambiente e Desenvolvimento (Rio-92), contexto que projetou a esperança pela sustentabilidade, e a Conferência das Nações Unidas sobre Desenvolvimento Sustentável (Rio +20 ), que mostrou que a sustentabilidade tem diversas faces, as quais refletem a estratificação da sociedade. Segundo, porque abrange parte da temporalidade da experiência nacional de redemocratização, promulgada em 1988 e em sucumbência no momento de término desta pesquisa. Terceiro, porque 
coincide com o estabelecimento da rede ambientalista FORMAD. Esses três eventos, ainda que mencionados separadamente, são interconectados na medida em que, no cenário geopolítico internacional, estabelecem certa decorrência entre uns e outros.

Lançamos mão da análise de processos políticos chave no cenário ambiental estadual, a saber: o Programa de Desenvolvimento do Agronegócio (PRODEAGRO), o Zoneamento Socioeconômico-Ecológico (ZSEE) e o Zoneamento Ecológico-Econômico (ZEE) da BR-163 como principais exemplos de construção de uma identidade de participação, a qual evolui para uma configuração de rede ambientalista. Como suporte, analisamos estatísticas pertinentes à produção agrícola, aos recursos naturais e ao orçamento, de forma a pensar o cenário no qual se insere o cerne da hipótese deste trabalho.

Similarmente, o uso de referências escritas ou faladas (documentos e entrevistas) é a base dos métodos qualitativos interpretativos como a policy analysis, onde são encontrados significados e correlações com outras informações obtidas. Os dados numéricos, resultado de pesquisas quantitativas ou qualitativas positivistas complementam a análise, por exemplo, explorando a construção de uma categoria (CLIFFORD, 2012; FISCHER et al, 2007).

O método qualitativo interpretativo é, portanto, particularmente favorável à pesquisa política argumentativa. Ele permite a abordagem crítica, auxiliando no entendimento da influência política e o processo de negociação entre os governos dos países, assim como suas estratégias de influência. Igualmente, o método permite refletir sobre a interação entre os diferentes atores (sociais, políticos, governamentais) e não somente sobre as decisões políticas na qual se pretende chegar (FISCHER et al, 2007).

Frey (2000) indica que a análise de políticas públicas deve ser composta por três dimensões: polity, que é a estrutura institucional do sistema político administrativo; 'politcs', o processo político, frequentemente conflituoso; policy, a configuração dos programas políticos, problemas técnicos e conteúdo material das decisões políticas. A complexidade (BOHMAN, 1996; DRYZEK, 1990), ambiguidade, contingência (SCHWANDT, 1997), conflito e incompatibilidades que emergem das práticas pluralistas e posições institucionais (KEKES, 1993; WAGENAAR, 2002) a partir dos valores, percepções, crenças e como estas são 
expressas e comunicadas entre os vários grupos são objeto e contexto da policy analysis (DYE, 2008, 2009; FREY, 2000).

Assim, o objetivo e a hipótese aqui propostos serão trabalhados por meio da policy analysis, e do entrelaçamento e influência das suas três dimensões (KOSIK, 1976). Em um segundo momento, e lançando mão de uma aproximação com a abordagem dialética (CHEPTULIN, 2004),

Optamos pelas seguintes técnicas de coleta de dados: 1) a análise documental das atas de reuniões, seminários, plenárias e assembleias governamentais e específicas da rede ambientalista em questão; 2) o uso das bases de dados abertos e dos portais da transparência governamentais, analisando se são intuitivos e consistentes para diversos públicos; 3) entrevistas semiestruturadas com os principais interlocutores históricos do FORMAD, em caráter complementar às informações obtidas por meio de documentos sobre suas principais intervenções nas decisões governamentais e nas formas como foram empreendidas.

Com a finalidade de provar a hipótese central deste trabalho, a organização dos capítulos foi pensada de forma a expor o leitor ao objeto de estudo de forma aprofundada. Ao longo dos cinco anos que separaram a idealização do projeto de pesquisa e a tese final, a autora deste trabalho notou a pouca atenção científica que se dá ao papel do centro-oeste brasileiro, em especial ao Mato Grosso. Além do reduzido número de trabalhos acadêmicos existentes, os que existem abordam mais os problemas existentes do que o contexto nos quais esses se desenrolam. A autora percebeu também um desconhecimento, sobretudo no sudeste brasileiro, da realidade vivida no oeste. Foi devido a essa observação que este trabalho explicou antes o que é e como se encontra o estado do Mato Grosso, para posteriormente provar a hipótese.

No Capítulo 1, centramo-nos na relação entre o Estado brasileiro, a sociedade civil, a sociedade política e o território. Abordando brevemente tanto o histórico dessas relações quanto a maneira como foram pensadas por diversos autores, atemo-nos em como isso refletiu no processo político ambiental interno.

O esforço reflexivo se dá no sentido de demonstrar que, em verdade, o processo decisório na questão ambiental é fundamentado em um discurso consolidado pelas elites, polarizando as prioridades da agenda ambiental para 
suas necessidades. A influência das oligarquias brasileiras sobre o Estado e sua forma de pensar o território não foi superada pela fraca redemocratização de 1988. Esta, antes de se centrar em aspectos de distribuição de recursos (econômicos, naturais, etc.), apenas dividiu os Poderes de tal forma que, nessa divisão, as elites pudessem não somente se realocar, mas também ampliar seu poder através de um leque maior de estratégias de opressão e coerção, sob a égide da democracia. A institucionalidade da questão ambiental, relegada a segundo plano desde então e contando com orçamentos pífios, não conseguiu, portanto, responder à demanda social por uma distributividade igualitária de uso e conservação de recursos, abrindo margem às manifestações de insatisfação das camadas marginalizadas ao funcionamento do sistema.

O Capítulo 2 explicita como o histórico de gestão e conflitos socioambientais se consolidou em uma realidade como base das demandas sociais, reivindicada por meio de redes ambientalistas. Partimos do princípio que, apesar de haver concordância sobre as prioridades no planejamento no estado do Mato Grosso, há diferentes possibilidades de produção do território pelos atores no ambiente. Voltando-se ora ao polo agroexportador, ora a uma economia verde, a proposta para longo prazo é tratada nos espaços decisórios compartilhados em situação de desigualdade de forças entre governo e sociedade (conselhos gestores, mesas de negociação, etc.) que permitam a negociação sobre aspectos fundamentais de conservação de ecossistemas e sua funcionalidade para a qualidade de vida das populações que deles são econômica ou culturalmente dependentes.

O Estado é dotado de legitimidade para optar pelas técnicas de estudo que serão adotadas, bem como por quais decisões de planejamento serão tomadas. Assim, temos que a forma como se pensou a política e a gestão socioambiental no Mato Grosso esteve em consonância com a história geopolítica e geoeconômica entrelaçadas ao papel do estado do Mato Grosso na formação territorial brasileira. Para tanto, conduzir racionalmente o metabolismo entre o ser humano e a natureza ${ }^{1}$ foi imprescindível para metabolizar as riquezas naturais em monetárias. Por meio do estabelecimento de preceitos e sob uma visão específica de planificação, as relações capitalistas convertem as diferenças naturais em diferenças sociais fazê-lo, transforma sua própria natureza (MARX, 1985). 
(FOLADORI, 2001; FOSTER, 2005). Esse foi o princípio fundamental na sociedade de produtores associados nas relações capitalistas e na separação cidade-campo no Centro-Oeste, em direção à Amazônia, apresentando importantes desdobramentos em termos de representatividade, qualidade e posição da participação popular na questão ambiental atual, bem como nas possibilidades de cada ator intervir no território e nas territorialidades

No terceiro capítulo abordamos como se configuraram as diversas tipologias de ambientalismos e ecologismos nas redes ambientalistas, e a relação entre estas e o Estado. Definimos as diferenças de atribuições entre movimentos, redes e organizações ambientalistas. Demonstramos também que as redes de organizações ambientalistas transcendem uma visão física, mostrando-se como uma abstração que pode servir de controle tanto das instituições formais como das não formais, potencializando seu caráter transformador. As redes ambientalistas se desenvolvem dentro de uma dialética territorial na qual competem forças de poder que as determinam. Sem desmerecer a vertente que acredita nas organizações e nos movimentos sociais como parte de um movimento global, inter e transnacional, colocamos a estruturação de redes como uma estratégia de sobrevivência nos contextos territoriais nos quais persistem relações clientelistas: as mobilizações em rede seriam mais eficientes e eficazes do que iniciativas individualizadas das organizações para fazer frente às forças hegemônicas históricas. Propomos aqui que a ideia de metabolismo entre ser humano e natureza pode ser interessante como elemento para se pensar nas lacunas e vitórias da participação das vertentes do ambientalismo.

O Capítulo 4 trata de que forma o momento do estabelecimento do ZSEE estadual mato-grossense e do ZEE da BR-163, no Plano BR-163 Sustentável, agregou em si diversos momentos precedentes e posteriores das ações e da política ambiental regional amazônica, em que as categorias Estado, redes ambientalistas e território tiveram um grande ponto de contato. É por essa razão que o Capítulo 4 reflete sobre o Zoneamento Ecológico-Econômico como importante exemplo da arena na qual vêm sendo refletidas as disputas entre as camadas da sociedade civil e o Estado no planejamento territorial e na intervenção sobre o ambiente. 
Ficou claro no transcurso de ambos zoneamentos que a incorporação da participação social na organização territorial em que um Estado democrático se reporta como tal foi e continua a ser um desafio. Tratamos do ZSEE no Mato Grosso contrastado com o ZSEE da BR-163, também importante no cenário estadual. A organização do território tem sido dos temas mais complexos da história ambiental mato-grossense, que se relaciona, em maior ou menor grau, com todas as outras questões nas quais as redes ambientalistas estaduais tiveram seu papel, em diferentes graus de protagonismo. Esperamos demonstrar como se deu em um caso concreto a relação entre o Estado e suas diretrizes de planejamento em contraste com o cenário e a organização de cunho socioambiental, conformada em redes ambientalistas de diferentes escopos, inerentes às classes sociais que representam. Tratamos como se deu a organização do território em âmbito matogrossense tendo como referência o ordenamento territorial amazônico como um todo. Abordamos planos, programas e projetos ${ }^{2}$ importantes no cenário socioambiental mato-grossense e que conformaram os primeiros passos em transformar a questão ambiental - enquanto aspecto territorial e em harmonia com outros, como a questão urbana, rural, agrícola, de infraestrutura, dentre outras "segmentações" do território, pulverizadas em diferentes políticas setoriais -, a fim de avaliar as decisões tomadas pelos diferentes atores sociais e políticos envolvidos no processo de negociação, como o Plano BR-163 Sustentável, o

2 Os planos governamentais estabelecem diretrizes, prioridades e objetivos gerais com vistas ao estabelecimento de um guia de ações cuja vigência engloba o período de alguns anos. A partir dos Planos Plurianuais, por exemplo, são estabelecidos o conjunto das políticas públicas governamentais para um período de quatro anos, bem como as formas pelas quais serão atingidos os objetivos (MINISTÉRIO DO PLANEJAMENTO, 2015). Programas consistem em conjuntos de projetos articulados por diferentes estratégias. Em nível governamental, são o instrumento usado para a concretização de ações e objetivos traçados na agenda. Em geral, as organizações da sociedade civil, categorizadas no terceiro setor, trabalham ou deveriam trabalhar com o primeiro e o segundo setores no estabelecimento de programas. Sendo parte de um programa ou, eventualmente, de um plano, um projeto tem a responsabilidade de execução atribuída a uma unidade organizacional ou a grupos de unidades; tem atividades visando resultados estabelecidos e prazos específicos, dentro de determinadas restrições. Para um projeto são definidos custos, benefícios e retornos (BOBBIO, 1998). O Projeto BR-163 - Floresta, Desenvolvimento e Participação, por exemplo, se propunha a buscar novos modelos de desenvolvimento, baseado no uso múltiplo da Floresta Amazônica. Já o Projeto Manejo Florestal, Apoio à Produção Sustentável e Fortalecimento da Sociedade Civil na Amazônia Brasileira objetivava apoiar o Ministério do Meio Ambiente na execução do Plano de Desenvolvimento Sustentável da BR-163, com apoio técnico e gestão financeira da Organização das Nações Unidas para a Agricultura e Alimentação (ONU/FAO Brasil) e recursos doados pela Comissão Europeia. 
Programa Integrado de Desenvolvimento do Noroeste do Brasil (POLONOROESTE), o PRODEAGRO e o Projeto Mato Grosso Sustentável.

Esses planos, programas e projetos tiveram desdobramentos importantes na definição e formulação do ZSEE dos estados que, juntos, compartilham a região onde o bioma amazônico é predominante; nos processos de integração da infraestrutura, em especial nos planos visando à sustentabilidade em torno da BR163; na sua relevância dentro dos Planos Plurianuais 2004-2007 e 2008-2011, quanto à problemática da regulação das terras indígenas, dentre outros. Discutimos o panorama - político, orçamentário e da confrontação entre atores em busca de hegemonia e de momento democrático - que as OSCA encontraram para abordar as questões prioritárias aos grupos da sociedade civil historicamente excluídos da tomada de decisão, principais afetados e sinérgicos às causas socioambientais defendidas. Em seguida, analisamos especificamente os passos do zoneamento, como foi sua evolução em âmbito governamental, seu acompanhamento pelas organizações e a sua "consolidação inconclusa", já que ele é tido como realizado nas esferas governamentais, ainda que seus resultados sejam fortemente contestados pelo Ministério Público Federal (MPF) e pela Comissão Coordenadora de Zoneamento Ecológico-Econômico (CCZEE). Finalmente, apontamos por que esse processo fortaleceu as iniciativas de participação por meio das redes ambientalistas como forma de resolver, ou ao menos minimizar, as lacunas de participação social nos processos decisórios.

No Capítulo 5 avaliamos a incidência dos múltiplos atores participantes e as posições dos tomadores de decisão. Os anos anteriores de mobilização em torno de temas como o ZSEE e o PRODEAGRO, dentre outras diversas ações promovidas pelas redes ambientalistas amazônicas no período, convergiram em um produtivo período de produção técnica e novos horizontes e estratégias de negociação. Tratamos como as propostas de sustentabilidade desenhadas no Projeto Mato Grosso Sustentável refletem a maturidade científica sobre as vulnerabilidades e potencialidades socioambientais. Avaliamos também se 0 governo estadual evoluiu da mesma forma em termos de qualidade técnica e científica e se houve sinergia entre esses atores. Ainda com tal qualidade técnica e científica da rede nesse momento e sua interlocução com programas maiores 
como o Plano Amazônia Sustentável (PAS), partimos do princípio de que houve baixa influência sobre a agenda de planejamento territorial em vista à sustentabilidade socioambiental.

Concluímos este estudo analisando as estratégias de atuação da rede FORMAD a partir das possibilidades de participação oferecidas pelo Estado em três vertentes. Discutimos a maneira em que se deu a participação nas questões ambientais, segundo a forma e desenho da institucionalidade da participação na qual se inseriu o FORMAD desde 1992. Usamos três parâmetros para tecer a discussão: a análise de Avritzer (2008) sobre desenhos participativos, a "escada de participação cidadã" de Arnstei (1969) e de efetividade das instituições participativas (PIRES, 2011). Em todos os casos, vemos que a permeabilidade das demandas sociais é baixa. No caso das estratégias "de baixo para cima", vemos que sua prática ainda não conforma a base de sustentação da participação na questão ambiental. A graduação de estratégias de participação, sobretudo as "de cima para baixo", serão demonstradas como majoritárias na forma de fazer política ambiental, contendo as estratificações da sociedade civil, com o objetivo da manutenção da ordem e do status quo. Finalmente, consideramos as possibilidades de mensuração da efetividade na participação, levantando a dificuldade de alcançar esta etapa, dada a fragilidade da estrutura tanto de dados abertos à população e a seus representantes, quanto de dados da dinâmica da participação social nos Três Poderes.

Além dos referenciais teóricos usados ao longo dos seis capítulos marcadamente buscados nas áreas de geografia e ciência políticas -, das entrevistas com representantes tanto dos governos quanto das organizações ambientalistas da rede FORMAD e da análise documental que respaldam este trabalho, aqui se desenha o que será defendido como tese pela pesquisadora ao longo de todo o trabalho e com a confirmação de suas hipóteses. $O$ território, as políticas públicas e a relação entre os atores não podem ser vistos de forma segmentada, pois os espaços somente fazem sentido se considerados como a relação entre todos esses elementos. No entanto, é possível analisar aspectos do território, segundo a perspectiva da pesquisadora que o avalia (no caso, ambiental), sem perder a dimensão de sua totalidade. Essa totalidade, no caso estudado, se 
funda na experiência histórica brasileira em torno à sua democracia, e é compartilhada com diversos países latino-americanos que, apesar de suas singularidades ambientais, ecossistêmicas, federativas e de processos de descentralização política, possuem diversas semelhanças no que diz respeito à fragilidade que o tema ambiental encontra para tomar sua real importância nos processos políticos.

Entrevistas utilizadas para a pesquisa*

\begin{tabular}{|c|c|c|c|}
\hline Entrevistado & Filiação & Data & Relevância ao trabalho \\
\hline Inácio José Werner & $\begin{array}{c}\text { Centro Burnier de Fé e } \\
\text { Justiça/Coordenaçãa do } \\
\text { FORMAD }\end{array}$ & $30 / 01 / 2014$ & $\begin{array}{l}\text { Participou dos primórdios de } \\
\text { algumas redes ambientalistas } \\
\text { mato-grossenses e teve } \\
\text { interlocução importante com } \\
\text { os governos ao longo de } 1992 \\
\text { e } 2012 .\end{array}$ \\
\hline Ivar Busatto & $\begin{array}{l}\text { Operação Amazônia Nativa/ } \\
\text { Coordenação do FORMAD }\end{array}$ & $23 / 01 / 2014$ & $\begin{array}{l}\text { Participou dos primórdios do } \\
\text { FORMAD e teve interlocução } \\
\text { importante com os governos } \\
\text { ao longo de } 1992 \text { e } 2012, \\
\text { notadamente sobre a questão } \\
\text { indígena. }\end{array}$ \\
\hline João Andrade & $\begin{array}{l}\text { Instituto Centro Vida/ } \\
\text { Conselho Estadual de Meio } \\
\text { Ambiente de Mato Grosso }\end{array}$ & $27 / 01 / 2014$ & $\begin{array}{l}\text { Participou em representações } \\
\text { no CONSEMA }\end{array}$ \\
\hline Vicente Puhl & $\begin{array}{l}\text { Ex-Coordenador do } \\
\text { FORMAD (2000-2005) }\end{array}$ & 01/09/2014 & $\begin{array}{c}\text { Participou nas negociações } \\
\text { com o Governo ao longo do } \\
\text { PRODEAGRO }\end{array}$ \\
\hline $\begin{array}{l}\text { Prof. Dr. José } \\
\text { Goldemberg }\end{array}$ & $\begin{array}{l}\text { Ex-Ministro do Meio } \\
\text { Ambiente (1992) }\end{array}$ & 29/07/2015 & $\begin{array}{c}\text { Selecionado devido ao seu } \\
\text { entendimento sobre o } \\
\text { panorama ambiental em } \\
1992 .\end{array}$ \\
\hline Luciana Marcolino & Técnica Agrícola & $24 / 09 / 2016$ & $\begin{array}{l}\text { Estudiosa sobre agricultura } \\
\text { familiar, atualmente } \\
\text { trabalhando na interface com } \\
\text { Terras Indígenas no Mato } \\
\text { Grosso }\end{array}$ \\
\hline
\end{tabular}

*Outras duas entrevistas foram realizadas. Entretanto, dada a incerteza demonstrada pelos entrevistados em mais de duas perguntas, não foram consideradas. 


\begin{tabular}{|c|c|}
\hline \multicolumn{2}{|c|}{ Documentos Analisados } \\
\hline Documento & Local de consulta \\
\hline $\begin{array}{l}\text { Atas do Conselho Nacional do Meio Ambiente } \\
\text { (CONAMA) - } 1992 \text { a } 2012\end{array}$ & CONAMA (2015): base de informações on-line \\
\hline Relatório da Assembleia FORMAD 2016 & $\begin{array}{l}\text { Acessado durante trabalho de campo no Mato } \\
\text { Grosso (FORMAD) (FORMAD, 2016) }\end{array}$ \\
\hline Relatório do Seminário de Políticas Públicas & $\begin{array}{l}\text { Acessível pela página www.formad.br (FORMAD, } \\
\qquad 2013 b)\end{array}$ \\
\hline $\begin{array}{c}\text { Relatório do Seminário Estadual de } \\
\text { Conselhos }\end{array}$ & $\begin{array}{l}\text { Acessível pela página www.formad.br (FORMAD, } \\
\qquad 2013 c \text { ) }\end{array}$ \\
\hline Relatório da Assembleia FORMAD 2013 & $\begin{array}{l}\text { Acessado durante trabalho de campo no Mato } \\
\text { Grosso (FORMAD) (FORMAD, 2013a) }\end{array}$ \\
\hline Relatório da Assembleia FORMAD 2012 & $\begin{array}{l}\text { Acessado durante trabalho de campo no Mato } \\
\text { Grosso (FORMAD) (FORMAD, 2012) }\end{array}$ \\
\hline Relatório da Assembleia FORMAD 2011 & $\begin{array}{l}\text { Acessado durante trabalho de campo no Mato } \\
\text { Grosso (FORMAD) (FORMAD, 2011) }\end{array}$ \\
\hline Relatório da Assembleia FORMAD 2010 & $\begin{array}{l}\text { Acessado durante trabalho de campo no Mato } \\
\text { Grosso (FORMAD) (FORMAD, 2010) }\end{array}$ \\
\hline $\begin{array}{l}\text { 3a Conferência Nacional de Produtores e } \\
\text { Usuários de Informações Estatísticas, } \\
\text { Geográficas e Ambientais - INFOPLAN } 2016\end{array}$ & $\begin{array}{l}\text { Conferência realizada pelo Instituto Brasileiro de } \\
\text { Geografia e Estatística (IBGE, 2016). Acessado } \\
\text { durante trabalho de campo no Rio de Janeiro }\end{array}$ \\
\hline Plano de Longo Prazo - Mato Grosso & $\begin{array}{l}\text { Documento acessado no local. Secretaria de } \\
\text { Estado de Planejamento e Coordenação Geral } \\
\text { (SEPLAN, 2012) }\end{array}$ \\
\hline Gastos diretos do Governo & $\begin{array}{l}\text { Portal da Transparência do Governo Federal: base } \\
\text { de dados on-line } \\
\text { (GOVERNO FEDERAL, 2015) }\end{array}$ \\
\hline Balanços Orçamentários MMA & MMA (2015a): base de dados on-line \\
\hline $\begin{array}{l}\text { Balança comercial: Exportações e } \\
\text { Importações do Mato Grosso }\end{array}$ & $\begin{array}{l}\text { Ministério da Indústria, Comércio Exterior e } \\
\text { Serviços (MDIC, 2015): base de dados on-line }\end{array}$ \\
\hline PPG7 - Proposta Preliminar & $\begin{array}{l}\text { Acessado durante trabalho de campo em Brasília } \\
\text { (ISA) (BRASIL, 1991) }\end{array}$ \\
\hline PPG7 - Informações Adicionais & $\begin{array}{c}\text { Acessado durante trabalho de campo em Brasília } \\
\text { (ISA) (BRASIL, 1991a) }\end{array}$ \\
\hline Mapas do ZSEE & $\begin{array}{c}\text { Acessados no local (SEPLAN): Governo do Estado } \\
\text { do Mato Grosso (2008-2011) }\end{array}$ \\
\hline Escala Brasil Transparente & $\begin{array}{l}\text { Controladoria-Geral da União (CGU, 2017): base de } \\
\text { dados on-line }\end{array}$ \\
\hline Ranking da Transparência & MPF (2017): base de dados on-line \\
\hline Assembleias & $\begin{array}{c}\text { Acessado durante trabalho de campo no Mato } \\
\text { Grosso (FORMAD) (FORMAD, relatórios de } \\
\text { assembleias entre 2010-2016) }\end{array}$ \\
\hline $\begin{array}{c}\text { Workshop de Avaliação da Metodologia do } \\
\text { ZEE (Amazônia) }\end{array}$ & $\begin{array}{c}\text { Documento disponível na Empresa Brasileira de } \\
\text { Pesquisa Agropecuária (EMBRAPA), Brasília } \\
\text { (MMA/SDS, 2001) }\end{array}$ \\
\hline $\begin{array}{c}\text { Detalhamento da Metodologia para } \\
\text { Execução do Zoneamento Ecológico- } \\
\text { econômico }\end{array}$ & $\begin{array}{l}\text { Acessado durante trabalho de campo em Brasília } \\
\text { (EMBRAPA). Secretaria de Assuntos Estratégicos }\end{array}$ \\
\hline
\end{tabular}




\begin{tabular}{|c|c|}
\hline $\begin{array}{l}\text { pelos Estados da Amazônia } \\
\text { Legal - Prof. }{ }^{\text {a }} \text { Dr. }{ }^{\text {a }} \text { Bertha K. Becker e } \\
\text { Prof. Dr. Claudio A.G. Egler }\end{array}$ & $\begin{array}{c}\text { (SAE) e MMA, maio de 1996 (BECKER E EGLER, } \\
\text { 1996) }\end{array}$ \\
\hline $\begin{array}{c}\text { Caderno Diagnóstico do Projeto Mato Grosso } \\
\text { Sustentável }\end{array}$ & $\begin{array}{l}\text { Acessado durante trabalho de campo no Mato } \\
\text { Grosso (FORMAD) (ALVES, 2006) }\end{array}$ \\
\hline $\begin{array}{l}\text { Ata da Reunião do Conselho Diretor da } \\
\text { ABONG }\end{array}$ & $\begin{array}{c}\text { Acessado durante trabalho de campo no Mato } \\
\text { Grosso (FORMAD), Associação Brasileira de } \\
\text { Organizações Não Governamentais (ABONG), maio } \\
\text { de } 1995\end{array}$ \\
\hline $\begin{array}{c}\text { Relatório do Comitê Estadual da Ação da } \\
\text { Cidadania contra a Fome, a Miséria e pela } \\
\text { Vida em Mato Grosso }\end{array}$ & $\begin{array}{l}\text { Acessado durante trabalho de campo no Mato } \\
\text { Grosso (FORMAD), Ação da Cidadania contra a } \\
\text { Fome, a Miséria e pela Vida, abril de } 1994\end{array}$ \\
\hline $\begin{array}{l}\text { Relatório "Violência contra os Povos } \\
\text { Indígenas no Brasil" }\end{array}$ & $\begin{array}{l}\text { Acessado durante trabalho no Mato Grosso } \\
\text { (FORMAD), Conselho Indigenista Missionário (CIMI, } \\
\text { 2010) }\end{array}$ \\
\hline $\begin{array}{c}\text { Avaliação e Identificação de Ações } \\
\text { Prioritárias para a Conservação, Utilização } \\
\text { Sustentável e Repartição dos Benefícios da } \\
\text { Biodiversidade na Amazônia Brasileira }\end{array}$ & $\begin{array}{l}\text { Acessado durante trabalho de campo em Brasília } \\
\text { (ISA) (MMA/SDS, 2001) }\end{array}$ \\
\hline $\begin{array}{l}\text { Relatório Estadual de Direitos Humanos e da } \\
\text { Terra Mato Grosso - } 2011\end{array}$ & $\begin{array}{c}\text { Acessado durante trabalho de campo no Mato } \\
\text { Grosso (FORMAD), Fórum de Direitos Humanos e } \\
\text { da Terra (FDHT, 2011) }\end{array}$ \\
\hline $\begin{array}{c}\text { Relatório Estadual de Direitos Humanos e da } \\
\text { Terra Mato Grosso - } 2013\end{array}$ & $\begin{array}{c}\text { Acessado durante trabalho de campo no Mato } \\
\text { Grosso (FORMAD) (FDHT, 2013) }\end{array}$ \\
\hline $\begin{array}{c}\text { Dois Casos no Mato Grosso: Soja em Lucas } \\
\text { do Rio Verde e Cana de Açúcar em Barra do } \\
\text { Bugres }\end{array}$ & $\begin{array}{l}\text { Acessado durante trabalho de campo no Mato } \\
\text { Grosso (FORMAD) (FORMAD, 2013) }\end{array}$ \\
\hline $\begin{array}{c}\text { Relatório de Planejamento/ ABONG - } \\
\text { Regional Mato Grosso }\end{array}$ & $\begin{array}{c}\text { Acessado durante trabalho de campo no Mato } \\
\text { Grosso (FORMAD) (ABONG, 1999a) }\end{array}$ \\
\hline Resenha ABONG - Regional Mato Grosso & $\begin{array}{c}\text { Acessado durante trabalho de campo no Mato } \\
\text { Grosso (FORMAD) (ABONG, } 10 \text { semestre de 1998) }\end{array}$ \\
\hline Reunião ABONG - Região Sul & $\begin{array}{l}\text { Acessado durante trabalho de campo no Mato } \\
\text { Grosso (FORMAD) (ABONG, 1995a) }\end{array}$ \\
\hline Reunião da ABONG - Regional Mato Grosso & $\begin{array}{c}\text { Acessado durante trabalho de campo no Mato } \\
\text { Grosso (FORMAD) (ABONG, 1999) }\end{array}$ \\
\hline $\begin{array}{c}\text { Relatório "La sociedad civil frente a la política } \\
\text { social em America Latina". }\end{array}$ & $\begin{array}{c}\text { Acessado durante trabalho de campo no Mato } \\
\text { Grosso (FORMAD) (Foro de la Ciudadanía de } \\
\text { Ecuador, 1995) }\end{array}$ \\
\hline $\begin{array}{l}\text { Carta de São Paulo - Asociaciones } \\
\text { Nacionales de ONGs de América Latina }\end{array}$ & $\begin{array}{l}\text { Acessado durante trabalho de campo no Mato } \\
\text { Grosso (FORMAD) (ABONG, 1995) }\end{array}$ \\
\hline $\begin{array}{c}\text { Compêndio do Programa de Desenvolvimento } \\
\text { Sustentável do Pantanal }\end{array}$ & $\begin{array}{l}\text { Acessado durante trabalho de campo no Mato } \\
\text { Grosso (FORMAD) (FORMAD, setembro de 2003) }\end{array}$ \\
\hline PRODEAGRO - Informações Gerais & $\begin{array}{l}\text { Acessado durante trabalho de campo no Mato } \\
\text { Grosso (OPAN), Ministério do Interior (MINTER, } \\
\text { 1989) }\end{array}$ \\
\hline $\begin{array}{l}\text { Seminário de Avaliação do PRODEAGRO/ } \\
\text { PADIC }\end{array}$ & $\begin{array}{c}\text { Acessado durante trabalho de campo no Mato } \\
\text { Grosso (OPAN) (FORMAD, s/d) }\end{array}$ \\
\hline Propostas de Reformulação do PADIC & $\begin{array}{c}\text { Acessado durante trabalho de campo no Mato } \\
\text { Grosso (OPAN) (FORMAD, s/d) }\end{array}$ \\
\hline
\end{tabular}




\begin{tabular}{|c|c|}
\hline $\begin{array}{c}\text { Documento-base do Seminário de Avaliação } \\
\text { do PADIC }\end{array}$ & $\begin{array}{l}\text { Acessado durante trabalho de campo no Mato } \\
\text { Grosso (FORMAD) (FORMAD, s/d) }\end{array}$ \\
\hline $\begin{array}{l}\text { Carta de Solicitação de Cumprimento de } \\
\text { Compromissos ao BIRD }\end{array}$ & $\begin{array}{l}\text { Acessado durante trabalho de campo no Mato } \\
\text { Grosso (FORMAD) (FORMAD, 1997a) }\end{array}$ \\
\hline $\begin{array}{l}\text { Assembleia Geral - Retirada do FORMAD } \\
\text { das negociações do PRODEAGRO }\end{array}$ & $\begin{array}{c}\text { Acessado durante trabalho de campo no Mato } \\
\text { Grosso (FORMAD) (FORMAD, 1997) }\end{array}$ \\
\hline $\begin{array}{l}\text { PROJETO BRA/87/37 - Cooperação Técnica } \\
\text { de Implementação do Programa Integrado de } \\
\text { Desenvolvimento POLONOROESTE - } \\
\text { Zoneamento Agroecológico e Ordenamento } \\
\text { Territorial da Região Florestal Amazônica - } \\
\text { Documento de Trabalho no } 4\end{array}$ & $\begin{array}{l}\text { Acessado durante trabalho de campo em Brasília } \\
\text { (Ministério do Planejamento), Superintendência do } \\
\text { Desenvolvimento da Região Centro-Oeste } \\
\text { (SUDECO/MINTER/FAO/PNUD, novembro de } \\
\text { 1989) }\end{array}$ \\
\hline $\begin{array}{l}\text { Propostas de Reformulação do } \\
\text { PRODEAGRO - Deliberações do Seminário } \\
\text { de Avaliação Pública }\end{array}$ & $\begin{array}{l}\text { Acessado durante trabalho de campo no Mato } \\
\text { Grosso (FORMAD) (FORMAD, dezembro de 1996) }\end{array}$ \\
\hline Carta de Santarém & $\begin{array}{l}\text { Publicada em } 31 \text { de março de } 2004 \text {. Acessível em: } \\
\text { www.camara.gov.br/sileg/integras/211401.doc. }\end{array}$ \\
\hline
\end{tabular}

Bases de dados/geoprocessamento

\begin{tabular}{|c|}
\hline Ministério do Meio Ambiente \\
\hline Agência Nacional de Águas \\
\hline Corregedoria-Geral da União \\
\hline Ministério Público Federal \\
\hline Portal da Transparência do Governo Federal \\
\hline Contas Abertas do Ministério do Meio Ambiente \\
\hline Instituto Brasileiro de Geografia e Estatística \\
\hline
\end{tabular}




\section{CAPÍTULO 1 - A QUESTÃO AMBIENTAL NO ESTADO BRASILEIRO}

O presente capítulo situa a trajetória do Estado brasileiro na relação entre a sociedade civil e a política da superestrutura, seus atores e agentes ${ }^{3}$, e a forma como essa relação se traduziu em políticas (socio)ambientais. Demonstramos que o cenário político ambiental no Mato Grosso e as possibilidades de participação neste são resultados da forma como se consolidou a funcionalidade do referido estado no contexto brasileiro desde seus primórdios históricos. Abordamos diferentes formas de entendimento da relação entre Estado e sociedade, instrumental para os demais capítulos.

O processo que culmina na implementação das políticas ambientais se daria "de cima para baixo", ou seja, seria fundamentado em um discurso consolidado pelas elites, modificando o território inoperante tanto no acesso igualitário aos recursos ambientais quanto na conservação dos ecossistemas, portanto, longe de prover uma economia com base na sustentabilidade ambiental. Por essa razão, partimos da ideia de que a prática da política ambiental se deu em ciclos de processos de políticas ambientais marcados pelos conflitos entre as camadas da sociedade civil.

Refletindo como se deu a construção da noção de Estado no contexto brasileiro, em seguida tratamos do fim dos regimes autoritários no Brasil, substituídos por precária redemocratização subsequente (BORÓN, 2004).

3 Distinção deve ser feita aos conceitos de "agente", "ator" e "sujeito": o primeiro, indivíduos ou grupos considerados na prática, imersos na ação e que agem por necessidade (BOURDIEU, 1994, p. 67), ou seja, mais instrumentais que reflexivos enquanto seu papel social nas relações de poder. Diferem do "autor" pois este reconhece sua territorialidade e sua atividade no tempo. Por isso ele não é mero produtor de um ato, mas responsável e proprietário deste. Seus atos são criativos e o autor possui legitimidade sobre eles (DUBAR, 2004). O ator diz respeito ao indivíduo ou agrupamento com relativo grau de autonomia, por isso, capaz de elaborar estratégias, adaptar-se e reinventar-se segundo as circunstâncias e a movimentação de seus parceiros (CROZIER \& FRIEDBER, 1977) e concorrentes. A subjetividade do ator é mobilizada por suas estratégias de poder, no sentido da influência, incluindo a cooperação e a aliança, e, por isso, subordinada à ação coletiva. Dubar (2004, p. 60) afirma que, ao contrário do agente, que é um produto do sistema e elemento dos dispositivos para a ação, o ator é definido pela sua situação e pela estrutura de jogos na qual ele está imerso, ou seja, "pelo contexto vivido que o define como um ator participante de um coletivo", o qual será por ele avaliado em oportunidades em traçar estratégias e táticas, a partir dos recursos de que dispõe. Já o sujeito diz respeito ao indivíduo que, refletindo sobre sua existência no mundo, responsabiliza-se por si e por aqueles que reconhece como afins. Ou, ainda, o "sujeito no mundo, que se sente responsável por si mesmo e pela sociedade" (TOURAINE, 1992, p. 262). 
Acompanhando as vicissitudes sobre as quais essa redemocratização foi tropeçando, amplia-se o interesse público pela multiplicidade de significados e promessas contidos na proposta democrática. Uma das políticas setoriais que apostou na promessa do fortalecimento das instituições baseado na participação foi a ambientalista. Por isso, analisamos como esse setor foi tratado pelo Estado brasileiro a partir do estabelecimento da Constituição de 1988.

Finalizamos este capítulo apontando como é a distribuição dos orçamentos entre as instituições formais do Estado brasileiro contemporâneo, atendo-nos à institucionalidade ambiental. Nesse ponto, observamos primeiramente que o Ministério do Meio Ambiente é relegado a uma posição marginal na distribuição de recursos governamentais. Em um país de proporções continentais como o Brasil, no qual a descentralização depende de uma distribuição de recursos a partir do Governo Federal para os demais níveis federativos, o orçamento minguado significa uma precarização dos órgãos ambientais estaduais e municipais e da estrutura de fiscalização.

\subsection{Do Estado às políticas socioambientais}

Segundo Foucault (1979, p. 283), o governo, enquanto instituição de administração do Estado, "é a reta disposição das coisas [entendemos 'coisas' como o território, os habitantes e suas relações, e 'disposição' o conjunto de leis e estratégias] e seu cuidado para conduzi-las a um fim conveniente a cada uma delas". O Estado, por sua vez, seria resultado de uma série de relações entre "governantes e governados", que atribuem singularidades às escalas de tomada de decisão (municipal, estadual e federal). É possível notar, no entanto, que nos Estados que se conformaram a partir de colônias, como o Brasil, a interação entre "governantes" e "governados" é muito mais distante, talvez herança das distâncias relacionais nas representações, herdadas do Império.

O Estado, como relação social e como institucionalização da Nação, sustenta a tipologia econômica que the é inerente (POULANTZAS, 2000). No que diz respeito à participação social, as características atribuídas ao Estado tanto por Foucault quanto por Poulantzas podem dizer até que ponto é possível ou não a descentralização do poder entre esferas federativas e entre "governantes e 
governados", no caso brasileiro. Sobre isso, pode-se afirmar: 1) a tipologia econômica condicionou as regionalidades dos países - que têm suas economias baseadas na exportação de matéria-prima desde o período colonial - a uma funcionalidade específica dentro da economia global; 2) a relação entre governantes e governados é também mediada por essa funcionalidade. Em âmbito brasileiro, esse papel econômico específico das localidades na economia global promoveu a estratificação da sociedade e dicotomizou representantes e representados em uma interatividade (ou accountability) que apenas recentemente tem ido além, não sem dificuldades, das relações clientelistas; 3) salvo exceções, o quadro de governantes é composto, em âmbito nacional, por representantes das elites agrárias, categoria coesa na manutenção dos interesses dessa classe social. As demais camadas da sociedade civil, dada a inserção ruralista nos quadros do Executivo e Legislativo, sobretudo, permeiam o processo político do Estado com maior êxito por meio do Judiciário e do Ministério Público Federal.

É nesse contexto que a complexidade da atuação do Estado se manifesta na miríade de tensões que vêm à tona quando tratamos da questão ambiental (SWYNGEDOUW, 2004). Os conflitos de interesse produzem disputas e tensões que se materializam em arranjos territoriais adequados a interesses de uma elite, manifestos em diferentes momentos históricos e contestados pelas camadas subalternas. Torna-se, portanto, um difícil desafio articular a proteção ao ambiente e atender as prioridades econômicas e sociais.

O Brasil, como Estado representativo, tem uma estrutura flexível o suficiente para unificar interesses políticos de um bloco no poder (POULANTZAS, 2000) e amortecer esses conflitos inerentes às democracias federativas. Exemplificamos com a histórica participação dos grandes latifundiários no Congresso, a qual desmobiliza as classes subalternas por meio da restrição do protagonismo na arena política e da diminuição de repasse de recursos para as instituições participativas do Estado (conselhos gestores, comitês, etc.). Por outra via, essas elites agrárias asseguram o consentimento das massas populares por meio de seus aparelhos ideológicos, como ocorre com o discurso de que a produção de alimentos depende, necessariamente, da ampliação do agronegócio. 
Para as camadas marginalizadas da sociedade civil, trava-se uma batalha constante, em nível individual e coletivo, entre a consciência espontânea da experiência diária de trabalho e as ideias disseminadas pelas classes dominantes por meio de seu vasto arsenal ideológico. Mesmo a experiência diária imbui-se dessa ideologia abstrata (SMITH, 2008). Outrossim, a relação com a natureza desenvolve-se em meio às relações sociais, e na medida em que estas são contraditórias, assim também é a relação com a natureza (SMITH, 2008).

Com a produção para a troca, segundo a especificidade das localidades na economia global, os seres humanos não somente produzem a natureza imediata à sua existência, mas também a natureza social de sua existência. Atrelada a essa produção está uma complexa diferenciação da relação com a natureza e uma natureza social diferenciada de acordo com sexo, classe, etnia, atividade mental e manual, atividades de produção e distribuição, etc. (SMITH, 2008).

Em outra frente, com a generalização da produção de mercadorias e das relações de troca, grupos de pessoas previamente isoladas estão unidas em um conjunto social concreto. Elas estão unidas como um todo social, não mais pela unidade geral dos indivíduos sociais, mas por meio das instituições sociais que necessariamente se desenvolveram para o mercado: o Estado, o dinheiro, a classe, a propriedade privada e a família. A sociedade como tal, claramente distinguível da natureza, emerge (SMITH, 2008, p. 65).

Assim, o uso da natureza - e, por extensão, do território produzido a partir do espaço (RAFFESTIN, 1993) - constitui a essência da ação reguladora. No espaço de elaboração e implementação das políticas ambientais, independentemente da esfera governamental, vigora a potencialidade de reproduzir a submissão das camadas marginalizadas da sociedade civil, mas também se apresenta a possibilidade de superação desse status quo. Para Santos (2006), na medida em que o ambiente possui uma dimensão territorial, ancorada no conceito de espaço, ela também pode ser decisiva para a quebra do dualismo entre ser humano e natureza 4 (MARX, 1989[1844]).

4 Em tempo, a tradição dessa relação ao longo da história, pela filosofia, centra a dinâmica nos termos "homem" e natureza". Apesar do ruído que isso possa constituir em um primeiro momento, trataremos essa relação como um metabolismo entre "seres humanos" e "natureza". Explicamos 
Na prática, o lócus das políticas ambientais nas esferas governamentais pode ter pontos de contato com o lugar - enquanto ponto do recorte territorial por cujo intermédio a pluralidade total dos elementos encontra sua síntese - com o território, enquanto espaço apropriado, e com o espaço (STEINBERGER, 2013; SANTOS, 2006).

No que concerne à política ambiental, à estrutura institucional do Estado, aos grupos historicamente no poder e à sua visão do uso dos recursos naturais, a forma com que se conduz o planejamento territorial e como se estabelecem as mobilizações socioambientalistas nesse contexto aparece também como elementos de inter-relação entre território e ambiente.

A dificuldade desse endereçamento entre ambiente e território está relacionada ao processo de produção do território que se dá em um intrincado metabolismo entre ser humano e natureza. Nesse panorama, a perda de biodiversidade e a mudança estrutural da sociodiversidade a ela atrelada se apresentam como consequências da apropriação, legitimadas tecnicamente pelos grupos sociais dominantes dentro da sociedade. A produção da natureza e do território é, pois, dirigida por atores sintagmáticos ${ }^{5}$ que interagem por meio de relações de poder. O endereçamento do ambiental no territorial é, pois, plástico no sentido de apresentar-se como moldável -, dependente das forças de poder que regulam as relações de produção as quais promovem o metabolismo (mútuo e cíclico) entre ser humano e natureza.

As formas de apropriação e organização do território, por sua vez, têm forte relação com os fundamentos constitutivos do Estado e das sociedades políticas e civil que Ihe concernem, enquanto elementos superestruturais. É aqui que o Estado, seus governos e demais instituições, e a diversidade de reivindicações sociais que repousa sobre 0 termo sociedade são conceitos-chave para que entendamos a política ambiental herdada desde o processo de colonização, o estabelecimento das capitanias hereditárias e, posteriormente, sua inserção como país cujo capitalismo tardio se manifesta por ondas agroexportadoras nos dois últimos séculos. Esse cenário se complexifica com as crescentes insatisfações populares

essa relação reportando-nos à designação referente à espécie humana, e não a um dos gêneros inerentes a essa categoria.

5 Ator que realiza um programa, combinando elementos para produzir território. 
sobre a distributividade dos recursos naturais e do poder de sua voz para legislar sobre o tema.

A concepção de Estado e superestrutura não é imutável, tendo sido definida de diferentes maneiras ao longo dos diferentes momentos históricos. No processo de construção dos Estados, convém considerar como os pensadores viram a sua formação e os aspectos relacionais com a sociedade no Velho Mundo, como epicentro colonizador, aos quais as populações encontradas foram submetidas nelas se constituindo sentido próprio de Estado. Há de se pensar, portanto, como essa história conformou o papel da sociedade nas especificidades dos Estados formados.

Na concepção da política aristotélica, o Estado tem a finalidade da formação moral dos cidadãos. O Estado seria um fato natural, pois o homem é um ser naturalmente sociável, sendo que aquele que vive fora da sociedade por organização e não por efeito do azar seria ou um degradado ou um ser superior à espécie humana. Aristóteles (1885) separa o público do privado para dizer que o Estado é o único responsável por zelar pelo público.

Para Hobbes (1651), a consolidação do Estado é resultado de um processo civilizatório baseado em uma forma de organização política da vida em sociedade, em que os homens deixariam de viver no estado de natureza, caracterizado pela guerra de todos contra todos. Spinoza (1675), influenciado por Hobbes, diverge deste realista por entender que o poder não pode ser transferido aos governantes, tratando o Estado como instância de poder reguladora das individualidades e voltada para a coletividade humana que reside em um mesmo território. Fora do escopo desta pesquisa, o autor ainda desenvolve a ideia de "natureza naturante" e "natureza naturada", com potencialidade de uso geográfico e entendimento das relações natureza-sociedade-território.

A perspectiva realista hobbesiana, retomada nas teorias de relações internacionais, identifica o Estado na sua função política de assegurar o bem-estar do indivíduo pela imposição de uma ordem fundada em princípios racionais e científicos. Também dentro de uma perspectiva realista, Maquiavel (2010) propunha que a organização da sociedade estaria atrelada à centralidade de um governante, que zelaria pela segurança do Estado através da razão. Para o autor, 
o governante tem pleno aval para agir sem restrições quando o objetivo for a manutenção de seu poder e do Estado.

O idealismo político - outra corrente de análise do Estado que, com o realismo político, conformam as duas abordagens principais usadas principalmente nas relações internacionais - aborda a busca de valores universais com a finalidade de produzir um bem para a humanidade, preceito adotado nos fundamentos de muitos dos organismos internacionais, enquanto o realismo pensa o sistema internacional como uma arena em que os participantes se regulam por meio de relações de poder.

Na perspectiva idealista, Rousseau (1792) entende que o Estado emerge como base legítima na qual o indivíduo não aliena sua liberdade natural, apenas a delega ao Estado por meio do contrato social, já que os anseios coletivos de humanidade ultrapassam os individuais. O Estado contratualista, para ele, seria uma forma de associação que defende e protege com toda a força comum a pessoa e os bens de cada associado. Para Rousseau, cada um, unindo-se a todos, não obedece, portanto, senão a si mesmo, e permanece tão livre como anteriormente. Locke (1689), por sua vez, entende o Estado como liberal, juiz dos conflitos sociais e garantidor das liberdades e direitos individuais. Para ele, ao contrário de Hobbes, o estado de natureza é harmônico, não baseado na insegurança. A propriedade seria uma realidade no estado de natureza, algo que não poderia ser contestado pelo Estado.

Segundo Steinberger (2013) é Hegel que rompe com a corrente contratualista, comum aos autores anteriormente citados, elaborando que não existe um contrato, estabelecido de forma voluntária ou compulsória, entre indivíduos que viveriam, hipoteticamente, em um estado de natureza. A sociedade pré-política, sem a existência do Estado, é marcada por contradições e conflitos entre diferentes grupos. Sem a presença do Estado, a sociedade civil sucumbiria aos seus conflitos de estratificação interna que lhe são inerentes. O Estado teria, então, a função de imprimir racionalidade à sociedade civil, fundando a sociedade política. Esses dois conceitos serão amadurecidos por Marx tendo como base as relações econômicas.

É Gramsci (2002) quem detalha as relações na superestrutura e com a estrutura, considerando a importância da intelectualidade orgânica e da ideologia 
na formação nesse bloco histórico. Recentemente, autores como Harvey (2006) reelaboraram a relação entre Estado e sociedade civil. Harvey refuta que, nas relações neoliberais, o Estado tenha desaparecido como centro de autoridade. Para o autor, os arranjos institucionais do Estado, com sua centralidade garantida, mediam os fluxos de capital no mundo, apoiando o capital financeiro.

Mészaros (2012) vê o Estado como em mutualismo com o neoliberalismo. O autor analisa a atuação especificamente das Organizações Não Governamentais, as ONGs (ou a "onguização" das organizações da sociedade civil), com muito ceticismo, já que, para ele, tais organizações, com grande parte de seus recursos provenientes de fundos governamentais, apenas reafirmam a agenda governamental e neoliberal, sem contestações de fundo estrutural. Esta autora compartilha dessas preocupações, já que, em termos de participação das camadas da sociedade civil nos processos decisórios, é de se esperar que sua atuação seja antes pelo êxito de sua inserção nesses processos, e não como meras executoras de ações pensadas pelo Estado, sob a justificativa de "maior agilidade administrativa" das organizações da sociedade civil.

Elemento comum a toda a América Latina, a formação do Estado brasileiro tem estreita relação com as oligarquias ou elites agrárias. Essa elite passa a centralizar o poder, relegando à sociedade o papel de espectador passivo de suas decisões. Nesse processo, para cujo sucesso a produção da natureza foi elemento fundamental, o ambiente tem papel decisivo como elemento territorial para o Estado conformado.

\subsection{Heranca colonial e gestão da socio e biodiversidade}

O processo de colonização no Brasil se deu pela integração gradativa de territórios e população a uma determinada unidade política (ANDRADE, 1995, p. 164). A dimensão histórica que remonta ao processo de colonização dos países latino-americanos é, novamente, importante de ser considerada a fim de se compreender sua consequência na estrutura das instituições participativas ambientais. O processo de colonização implica a criação de uma estrutura de terras incorporada ao patrimônio da sociedade que se expande e uma estrutura articulada aos interesses de expansão localizados no centro difusor original. A colônia, como anexo territorial da metrópole, representa ser uma adição de espaço à economia 
do país colonizador (MORAES, 2002a, p. 78), explorado indiretamente pelos países hegemônicos aos países colonizadores. As características de organização sociopolítica de cada Estado projetam-se nas instituições coloniais geradas para cada processo colonizador, com o elemento comum da necessidade das estruturas militares de apoio à colonização. Na relação entre Portugal e Brasil, por exemplo, a delimitação entre ação privada e estatal não se demarcava claramente. No caso brasileiro, tais determinações orientaram a base estrutural de como se pensa a relação território-Estado-ambiente (MORAES, 2002). Já bem conhecida, a tradição agroexportadora e de centralização de terras foi responsável pela supressão de sócio e biodiversidades endêmicas, processo este em pleno andamento e gerador de diversos conflitos entre as elites agrárias e a sociodiversidade, marginalizadas do processo político.

O neoliberalismo latino-americano tem, portanto, raízes profundas que começam com a matriz colonial e avançam na forma de desenvolvimento dependente como as sociedades latino-americanas se integraram com os mercados mundiais (BORÓN, 2004). O aspecto socioambiental está, dessa forma, no centro da expansão colonial mercantilista da qual se desenvolveram as relações de dependência no Brasil (MORAES, 2000). Mesmo dois séculos de vida independente ainda não foram capazes de produzir mudanças suficientes que culminassem no estabelecimento de uma democracia associada ao neoliberalismo (BORÓN, 2004).

É importante que entendamos a política ambiental como uma das expressões da ideia de que a democracia no contexto brasileiro seria um projeto que se esgota na "normalização das instituições políticas" (BORÓN, 2004, p. 228). Nessa perspectiva, o empreendimento da instalação da democracia se reduziria à criação e institucionalização de um sistema de regras que se abstrai dos conteúdos éticos e da profunda natureza dos antagonismos sociais, reduzindo-se e se escondendo, assim, na análise dos problemas de governabilidade e eficácia administrativa. Essas análises, baseadas nas concepções schumpeterianas, reduzem a democracia a uma questão de método (SCHUMPETER, 1961, p. 297), dissociada dos valores e interesses que levam aos conflitos entre os atores coletivos. 
A ordem política sobre a qual o Brasil construiu seu arcabouço político e legal é reflexo desse histórico, que ainda conforma as relações entre a sociedade e o Estado e entre estes e os espaços (ARAÚJO, 2015). Na Amazônia do século XVII, por exemplo, a estratégia de sedentarização dos indígenas já era aplicada para controle das etnias, para que o comércio se desenvolvesse utilizando-os também como mão de obra (ANDRADE, 1995). Com a Constituição Federal de 1891, a apropriação das terras por coronéis locais era facilitada, já que eram as oligarquias locais que elegiam os deputados e senadores (MELLO-THÉRY, 2011). A estratificação social e as desigualdades de acesso aos recursos naturais, portanto, estão atreladas ao processo de colonização e hoje sobrevivem, no Brasil, graças a um colonialismo interno.

Assim, a redemocratização dos países latino-americanos tem sido equivocadamente focada no atributo essencialmente político da relação entre Estado e sociedade civil, desvinculada das características do neoliberalismo latinoamericano que se pretendia dissipar, estruturalmente problemático por estar fundado e centralizado nas oligarquias ${ }^{6}$ modernizadoras (CUEVA, 1988). A democratização consolidada no Brasil é mais resultante das relações de poder entre os atores sociais e os agentes políticos do que uma consequência de decisões administrativas. A consequência desse erro de atribuição se evidenciou a partir da década de 1980, mediante o empobrecimento generalizado de extensas franjas da sociedade civil que assistiam, impotentes, à deterioração de sua cidadania, paradoxalmente ao enaltecimento de sua emancipação política.

Quanto mais fortes os movimentos em seu potencial de mobilização e de demanda por sua inserção nas instituições formais, tão maior seria a coerção. As ações dos movimentos ambientalistas brasileiros - atores coletivos compostos por etnias indígenas, seringueiros, populações deslocadas pelos grandes projetos infraestruturais, entre outros - passaram a ser divulgadas, quando conveniente, como imprescindíveis ao fortalecimento da democracia, em especial em algumas linhas dos ambientalismos, como o ecodesenvolvimento. No entanto, as

6 Para Aristóteles, os regimes políticos eram distintos em tipologias de forma pura (para o bem geral) e viciadas (em benefício de quem detém o poder). Assim, distinguia-se a monarquia (governo de um só), a aristocracia (governo de poucos), e a democracia, governo de todos. Respectivamente, as formas viciadas seriam a tirania, a oligarquia e a demagogia (BOBBIO, 1998, p. 1081). 
mobilizações realmente focadas no componente estrutural brasileiro, classista e cada vez mais desigual, eram marginalizadas nas decisões políticas, invisibilizadas ou coagidas ao silenciamento, como demonstra o Gráfico 1.

O componente de violência, assim como outros aspectos herdados do processo colonizador que se deu no Brasil, acompanha a apropriação de novas terras quando possuem habitantes autóctones, pois esses devem ser submetidos ao poder que se instala. Na questão ambiental, por ser chave no processo de produção da natureza e, correlatamente, na produção do espaço, atores como as OSCA, os movimentos e as redes ambientalistas tendem a sofrer maior repressão pelos aparelhos do Estado. Não por acaso, o Brasil lidera mundialmente o ranking de assassinatos cometidos a militantes com motivações ambientalistas, mesmo após a repercussão do assassinato de Chico Mendes.

Entre 2002 e 2012, 448 ativistas com motivações ambientais foram assassinados no Brasil, perfazendo, sozinho, metade do valor mundial para o mesmo período. Esses conflitos estão estritamente ligados ao desmatamento na Amazônia, onde foram registrados $68 \%$ de todos os assassinatos motivados pela disputa de terras em 2012, sendo as comunidades indígenas as mais afetadas. Os locais de maior ocorrência dessas mortes foram locais de extração florestal e expansão de cultivos de soja.

\section{Gráfico 1. Número de assassinatos de militantes ambientalistas por país (2002-2012)}

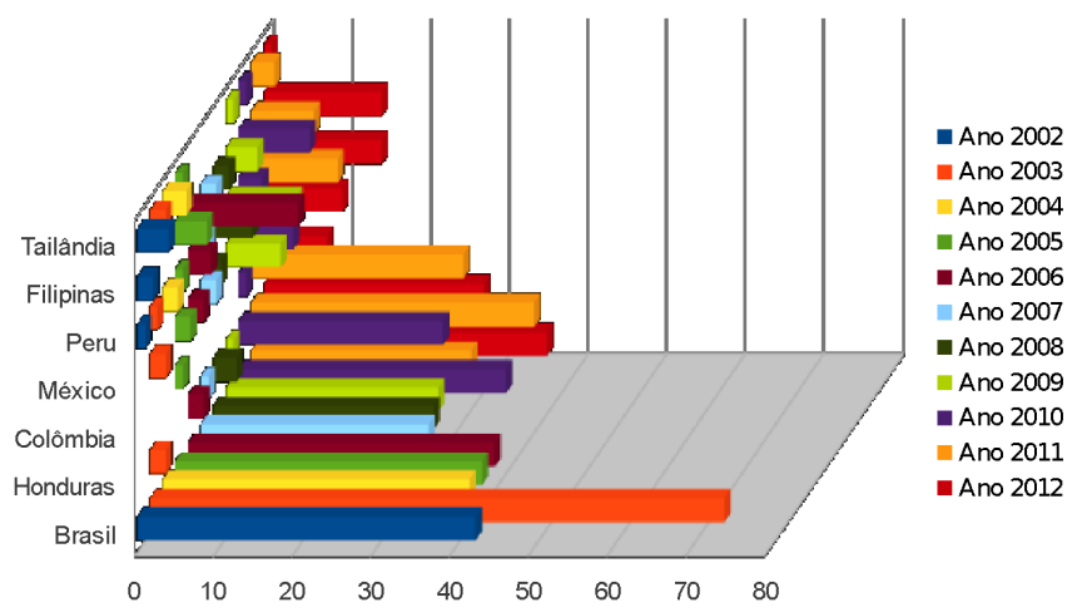

Fonte: KA'APOR et al (2016). Elaboração própria. 
No caso do Mato Grosso, os relatórios internos do FORMAD e do FDHT apontam que, entre 2000 e 2014, cerca de 110.420 famílias foram envolvidas em conflitos relativos ao uso da terra (FORMAD, 2011). Cerca de 130 assassinatos foram registrados desde 1985, sendo que nenhum assassino ou mandante respondeu criminalmente pelos ocorridos. A condição contemporânea da coerção aos movimentos de reforma agrária e ambientalistas, um reflexo do que é priorizado na agenda governamental sobre os territórios, é resultado das relações de poder que se desenvolveram nas relações dos Estados.

\subsection{A construcão da política ambiental brasileira}

No Brasil, a conquista e o ordenamento dos fundos territoriais (recursos naturais para apropriação futura) perpassaram todos os projetos nacionais desde a colônia, passando pelo período ditatorial e permanecendo após a redemocratização. O domínio sobre esses fundos territoriais aparece como elemento de coesão das elites regionalizadas (MORAES, 2002).

No caso das políticas ambientais, há um elemento essencial para que entendamos como as decisões vêm se desenrolando nas três décadas que sucederam o estabelecimento da Constituição Brasileira de 1988. Esse elemento é o histórico da apropriação dos territórios amazônicos e de seus recursos naturais, remetendo-nos ao período colonial.

Remontando ao período imperial, com a manutenção da centralidade do poder em uma monarquia que não rompeu de fato a relação de colônia com a metrópole europeia, o momento pós-independência mostrava um cenário de aceitação na arena internacional. Com isso, o Estado em formação dispunha de vastos fundos territoriais e uma população que não era reconhecida como nação dentro dos modelos identitários vigentes nos centros hegemônicos. É aí que se estabelece a ainda presente problemática socioambiental brasileira: o Brasil foi fundado não na concepção de seu povo, mas sim como uma porção de espaço terrestre sobre o qual se estabeleceram as relações que o conformaram como território, levado adiante por uma elite oligárquica em um Estado autoritário.

A hegemonia, cultural e ideológica de um grupo social dominante sobre os outros, e a conquista da sociedade política por este grupo preponderante, estendendo-a ao conjunto do Estado (PORTELLI, 1977), corroboraram para 
qualificar uma expansão territorial que "reafirma as determinações da conquista territorial: apropriação da terra e submissão dos naturais" (MORAES, 2002, p. 119) usando a força coerciva do Estado e a influência ideológica e política das elites. Essa expansão territorial seguia a fórmula dos processos de valorização dos espaços, de apropriação dos meios naturais, de produção da natureza e do espaço.

Os séculos XIX e XX provaram a consolidação dos princípios das elites do País, iniciados desde a colonização, que evoluíram para ideologias e discursos que, uma vez reiterados, os reifica, lançando-os como verdades inquestionáveis, já que são postas como as melhores soluções ao País e não são questionadas por uma invisibilidade das causas ou coerção dos representantes ambientalistas.

O primeiro período republicano no Brasil foi marcado pelo conflito de interesses entre as diversas oligarquias regionais heterogêneas entre si, asseguradas desde então por uma engenharia consolidada como a "política dos governadores" e em uma economia agroexportadora, protagonizadas pela aliança entre a oligarquia paulista e a mineira, hegemônicas em relação às demais.

Já na primeira república cada região era marcada por relações de poder entre uma oligarquia dominante e os subalternos, com específicas estruturas regionais de classes dominantes coesas entre si, protagonistas na apropriação dos territórios que, como observado anteriormente, precediam as sociedades que lhe eram inerentes em termos de importância no planejamento regional (PERISSINOTTO, 1994).

Essa realidade seguiu no período Vargas, com o diferencial que, além das oligarquias, emergiam as rivalidades também com os militares. A organização do Estado em três poderes (Executivo, Legislativo e Judiciário) se assentou sobre as bases historicamente construídas no processo de ocupação e de ordenamento territorial brasileiro, excludentes das populações autóctones, fomentando o avanço das frentes pioneiras ao Centro-Oeste e à Amazônia, a partir de 1950, sob a alcunha da proteção das fronteiras e de ocupação dos espaços.

No que diz respeito ao processo de retomada da consciência conservacionista no Brasil, nem mesmo o estabelecimento dos Parques Nacionais, que se inicia em 1937, incorporou as populações que ali já estavam, ou ali circundavam, como parte do todo. Para além de uma separação entre o que é natureza e sociedade, levantada por muitos teóricos do conservacionismo que 
escreveram sobre a história do ambientalismo no Brasil, esse movimento de segregação dos povos originários também se explica pela estratificação da sociedade. $O$ forte caráter geopolítico dessas iniciativas aliado à centralização do poder - ainda ferrenhamente disputado entre as oligarquias e os militares - tiveram consequências imperativas sobre aqueles que não estavam no bloco de poder, ou seja, as classes subordinadas, que tentavam, em ondas migratórias cada vez mais densas, escapar dos reflexos ambientais derivados da política territorial nacional. Para Moraes (2002, p. 128), "a ótica espacialista dos governos militares contribuiu para acentuar o divórcio entre o Estado e a nação que se sedimenta no período".

Temos até aqui exposto o jogo de forças que, ao longo da história, conformou-se como cenário à política ambiental. Neste ponto é importante ressaltar a observação de Steinberger e Abirached (2013). Apesar de intimamente relacionadas, já que ambas estão ancoradas em uma mesma história, não podemos confundir o que é a construção do pensamento ambiental brasileiro com a construção da política ambiental brasileira. Complementarmente a essa ideia, não podemos dissociar o processo de consolidação dessa política ambiental sem ter em conta a transição que houve entre o período ditatorial e os vinte anos subsequentes da redemocratização, mesmo que essa transição não tenha sido tão contundente a ponto de representar um aprofundamento democrático. Há de se considerar também a consolidação do Brasil na posição de país emergente, notadamente ao longo da primeira década de 2000, a qual influenciou muito as posteriores decisões políticas voltadas ao ambiente.

O componente militar, que sempre perpassou o processo de apropriação da natureza e do território, teve, entre 1964 e 1985, papel decisivo na implementação das políticas ambientais nacionais, e em seus desdobramentos, contradições e enclaves até o presente (PAGNOCCHESCHI E BERNARDO, 2006). Desde então, é indubitável que houve um esforço político, sobretudo dos atores sociais e políticos mais progressistas, em caminhar a uma governança ambiental baseada na descentralização política e na participação popular. Engessados em uma estrutura institucional historicamente consolidada, foi necessário aproveitar momentos nos quais as oportunidades do cenário internacional eram positivas para se avançar nessas conquistas. 
Nesse cenário, os desdobramentos da Conferência das Nações Unidas sobre o Meio Ambiente Urbano (Estocolmo-72) abriram espaço para se pautar a necessidade de estruturação e fortalecimento das instituições ambientais.

A participação brasileira em Estocolmo-72 foi paradoxal, já que o País estava representado, de um lado, pela diplomacia de vanguarda no pensamento ambiental, propositora de princípios basilares para a gestão ambiental, e de outro, pelo Ministro do Interior, o qual defendia a fórmula do crescimento (para fora) com o argumento de combate à pobreza. Ainda assim, houve desdobramentos positivos: a criação da Secretaria Especial de Meio Ambiente (SEMA), vinculada ao Ministério do Interior, foi um avanço que se deu pela pressão das organizações ambientalistas, e que projetou os movimentos no cenário nacional e internacional (PAGNOCCHESCHI E BERNARDO, 2006).

A criação da Secretaria, no entanto, já mostrou nesse momento suas principais características, as quais perdurariam no tempo: o enclave do tema ambiental no governo; atribuições voltadas à gestão ambiental confusas e difusas pelos ministérios e secretarias; e, como se tratará mais detalhadamente adiante, constrangimentos políticos e institucionais pela pouca interlocução política e pelos baixos orçamentos (PAGNOCCHESCHI E BERNARDO, 2006). Essa evidência acarreta a baixa força política para dialogar com os demais ministérios, secretarias, órgãos e outras instituições, fazendo valer a agenda interna das instituições voltadas à questão ambiental. Estocolmo-72 abriu precedente a uma institucionalidade ambiental básica, ainda que insuficiente, no Brasil - via SEMA, que se transformou posteriormente em Ministério do Meio Ambiente (MMA), o qual também dispõe de menor prestígio comparado ao Ministério da Agricultura, Pecuária e Abastecimento (MAPA) -, legitimada pela Conferência das Nações Unidas sobre o Meio Ambiente e o Desenvolvimento.

Criada pelo Decreto 73.030 de 30 de outubro de 1973, a SEMA tinha como finalidade: 1) a racionalização do uso dos recursos naturais e ambiente do País; 2) o estabelecimento de normas de controle da poluição; 3) a coordenação de ações nacionais de controle da poluição; 4) a orientação e assistência às agências estaduais de proteção ambiental.

A SEMA foi transferida para o Ministério do Desenvolvimento Urbano e Ambiental em junho de 1985, sendo reintegrada ao Ministério do Interior em 
setembro de 1988 antes de ser dissolvida em janeiro de 1989 para formar acompanhada de outras agências federais nas áreas de floresta (Instituto Brasileiro de Desenvolvimento Florestal - IBDF), extrativismo (Superintendência da Borracha - SUDHEVEA) e de desenvolvimento da indústria da pesca (Superintendência da Pesca - SUDEPE), todas também dissolvidas - o Instituto Brasileiro do Meio Ambiente e dos Recursos Naturais Renováveis (IBAMA). No âmbito do CONAMA, várias divergências eram manifestadas sobre o andamento do Programa Nossa Natureza, o qual desencadeou as mudanças e a implementação do IBAMA. Registra-se na fala dos conselheiros, por exemplo, que a dissolução das agências se deveu ao clientelismo político e à corrupção - loteamento de cargos e claro favoritismo a grupos de atores sociais (CONAMA, 1990, p. 15). Sobre o Programa Nossa Natureza, discutia-se internamente no CONAMA a falta de acesso aos dados dos Grupos de Trabalho Interministeriais (GTI) do programa para tomada de posicionamento do conselho (CONAMA, 1989, p. 04).

Já o Fundo Nacional do Meio Ambiente (FNMA), criado pela Lei 7.797 de 10 de julho de 1989 como uma unidade do MMA, foi instituído com o objetivo de apoiar, por meio do fomento a projetos finalísticos, a implementação da Política Nacional do Meio Ambiente. O Fundo, além de resposta aos compromissos assumidos em Estocolmo, foi também um elemento que se consolidaria em outras modalidades de fundos públicos após a promulgação da Constituição de 1988, com um modelo de funcionamento baseado no controle social, inovador para aquele momento. Os projetos financiados eram submetidos à aprovação de um conselho, de caráter deliberativo, composto por representantes da sociedade civil e do governo. Como grande parte dos recursos do Governo Federal se destinam ao pagamento de dívidas e, em menor fração, à Previdência Social, o repasse dos recursos ao FNMA é insuficiente para garantir o funcionamento dos órgãos estaduais e municipais de meio ambiente, garantindo espaços participativos com a sociedade.

A Conferência das Nações Unidas sobre Meio Ambiente e Desenvolvimento (CNUMAD), em 1992, como as demais etapas do ambientalismo no Brasil, não se deu sem divergências, que começaram desde o foco que direcionaria a Conferência - alguns países categorizados como subdesenvolvidos defendiam que a Conferência deveria pautar o desenvolvimento; outros, que deveria pautar a sustentabilidade - até conflitos internos dentro do CONAMA ( $31^{\text {a }}$ Reunião Plenária, 
em abril de 1992). Estes envolviam a participação de funcionários sob inquérito participando das comissões que conformaram a Rio-92. Para além dos conflitos, a ideia do Governo Federal era a afirmação de uma imagem positiva do País, passando credibilidade ao cenário internacional no que diz respeito ao desenvolvimento sustentável. De fato, o que se notou posteriormente foi a ampliação da agenda brasileira na consolidação da denominada "economia verde".

Nessa e nas demais conferências sobre meio ambiente, nota-se o paralelismo da participação das organizações ambientalistas, na maioria das vezes realizada em evento paralelo ao deliberativo. Esse padrão de participação não é generalizável a outras conferências setoriais. A participação das comumente chamadas ONGs tem sido, geralmente, relegada à própria posição denotativa de seu nome: tal como são, por definição, não governamentais, não são incluídas pelo governo em seu mecanismo de tomada de decisões. É plausível que, por não serem governamentais, essas organizações não participem nos momentos epicêntricos dos ciclos políticos? Nova interposição ideológica, a força que se dá aos nomes também dá o tom de qual será o papel das organizações formadas pela sociedade civil: secundário, a menos que a classe que as conforma tenha força política e financeira de fazer-se ouvir. Essa é a primeira razão pela qual não adotamos a nomenclatura ONG neste trabalho, pela carga ideológica que implica.

Apesar das divergências ideológicas, a longa preparação prévia da participação brasileira rendeu frutos positivos. Dois meses depois da Conferência das Nações Unidas para o Meio Ambiente e o Desenvolvimento, o CONAMA contava com uma diversidade de ministérios participando em suas plenárias, com uma estrutura de conselho mais bem definida, saindo do relativo isolamento que se encontrava anteriormente (FONSECA, 2011). Ademais, foi também na ocasião da CNUMAD que o Programa Piloto para a Proteção das Florestas Tropicais do Brasil, do Grupo dos Sete países industrializados (PPG7), que objetivava, dentre outras coisas, a estruturação das instituições ambientais nas esferas federativas, foi oficialmente lançado no Brasil (seus primeiros projetos foram aprovados em 1994, com execução iniciada em 1995). 


\section{Gráfico 2. Evolução da composição do CONAMA}

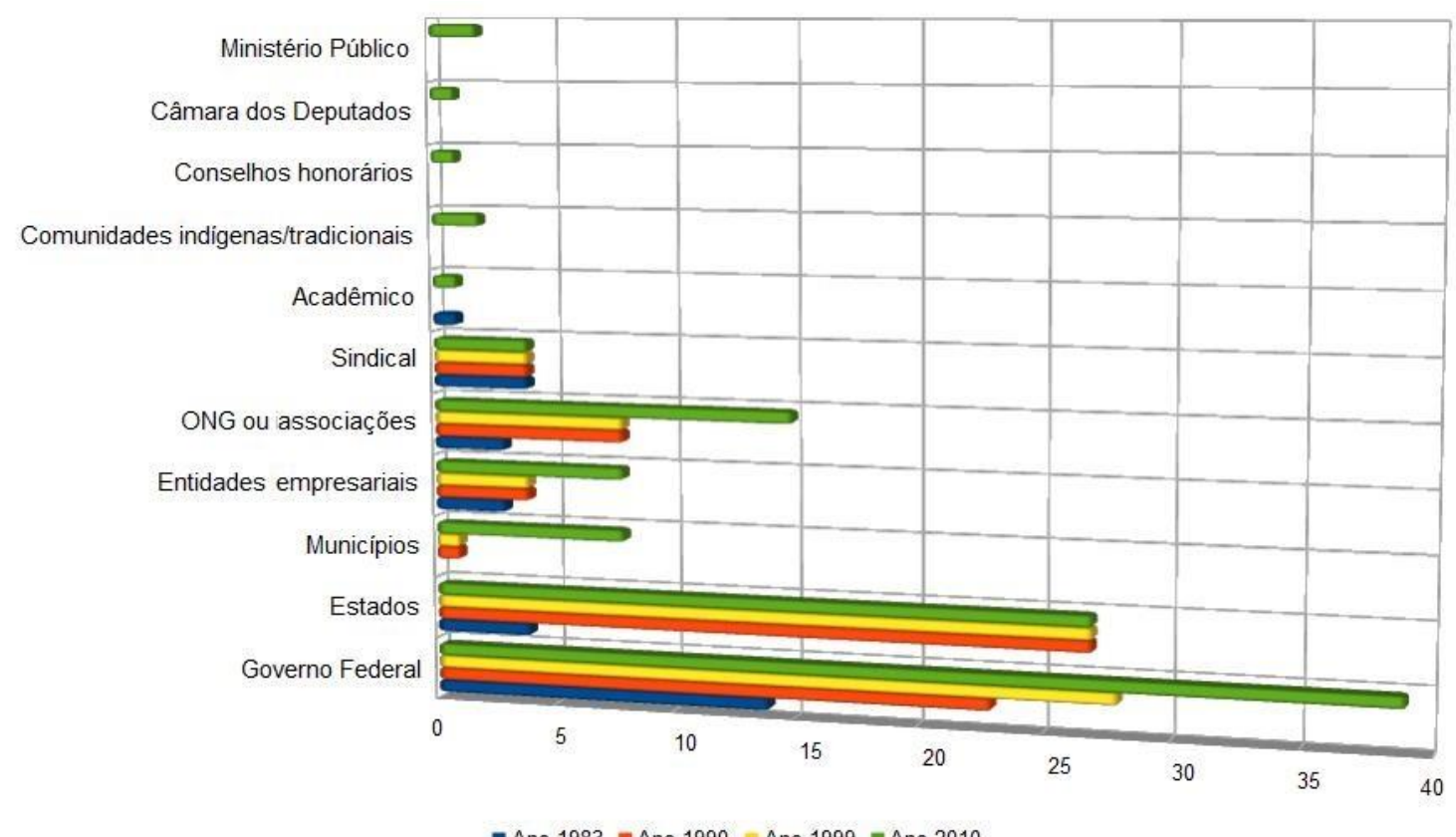

Fonte: FONSECA (2011).

Desde então, houve evolução na diversidade do quadro de atores participantes e intervenientes no conselho (Gráfico 2). Há maior participação de conselheiros com maiores graus de especialização, ainda que não haja uma representatividade equilibrada das diversidades étnicas e culturais no quadro de conselheiros (Gráfico 3). Vemos claramente que o perfil dos decisores é pouco diversificado, predominando representantes brancos, masculinos, com altos rendimentos e com maior grau de escolaridade. Conhecendo o processo de exclusão que acompanha a história do País, tal evidência demonstra os favoritismos também nas instituições participativas.

A $32^{\text {a }}$ Reunião Plenária do CONAMA, realizada em agosto de 1992, ainda em período de assimilação da CNUMAD ocorrida em junho, foi marcada pelo debate sobre o papel do CONAMA e do IBAMA e a participação da sociedade civil, sua suficiência econômica para participar das plenárias e o alerta de restrição orçamentária governamental para o pagamento de passagens até as reuniões em Brasília.

Também aí ficou manifesto pela Sociedade Brasileira pelo Progresso da Ciência (SBPC) o grau de sucateamento tecnológico das instituições de pesquisa 
para que estas avançassem nos estudos técnicos de temas como o clima, por exemplo. Nesse momento, também começa a evidenciar-se a seletividade do Estado sobre quais organizações ambientalistas conformariam o quadro institucional participativo que o auxiliaria nas suas gestões relativas ao ambiente.

Esta autora, nesse ponto, se alinha a Dagnino (2004), no que diz respeito à cooptação de organizações ambientalistas pelo governo, servindo não como participantes nas decisões, mas sim como braços executores das decisões governamentais tomadas, fazendo valer a agenda estatal com um suposto aval e apoio da sociedade civil. Entretanto, a autora deste trabalho aponta uma outra dimensão da cooptação, menos generalizável: reportada em espaços como, por exemplo, as eleições para composição de conselhos gestores, a cooptação das organizações ambientalistas se trata, mais bem, de elencar "representações" que já são, de antemão, alinhadas à agenda da sociedade política ligada às elites. Assim, o que se tem não é a deturpação de todas as formas de organizações ambientalistas, mas uma polarização dessa categoria, que favorece as que reagem facilmente à ideologia dominante. As clivagens internas do conhecido como "movimento ambientalista", tratadas no Capítulo 3, favorecem a formação de perfis mais ou menos aderentes à proposta do Estado, do mercado, ou dos estratos marginalizados da sociedade.

O IBAMA - até então gerenciador das questões ambientais, vinculado à Secretaria do Meio Ambiente da Presidência da República (SEMAM/PR), ligada à Presidência da República - teve seu papel político reformulado, passando a conformar, como autarquia federal que compõe a Administração Indireta, a estrutura do MMA (órgão da Administração Direta), criado em outubro de 1992. O Ministério seguiu e segue padecendo dos mesmos problemas orçamentários e de protagonismo político reportados nas formas institucionais que o precederam. No entanto, entre 2000 e 2010, foi inovador, ao respaldar sua atuação por meio da aliança com as organizações da sociedade civil, permitindo um espaço fértil para a análise de como promover a democratização das informações e decisões setoriais.

$\mathrm{Na}$ CNUMAD em 1992, o Brasil tentou demonstrar seu potencial para ser um dos principais interlocutores sobre o tema da sustentabilidade no mundo e nos 
mercados em que tal setor pudesse estar inserido ${ }^{7}$. No entanto, o que se notou foi um aumento do desmatamento nos anos subsequentes. Fearnside (2005, p. 116) atribui a flutuação no desmatamento entre 1995 e 2005 (Gráfico 4) às oportunidades políticas na esfera ambiental.

\section{Gráfico 3. Composição dos membros do CONAMA (em \%)}

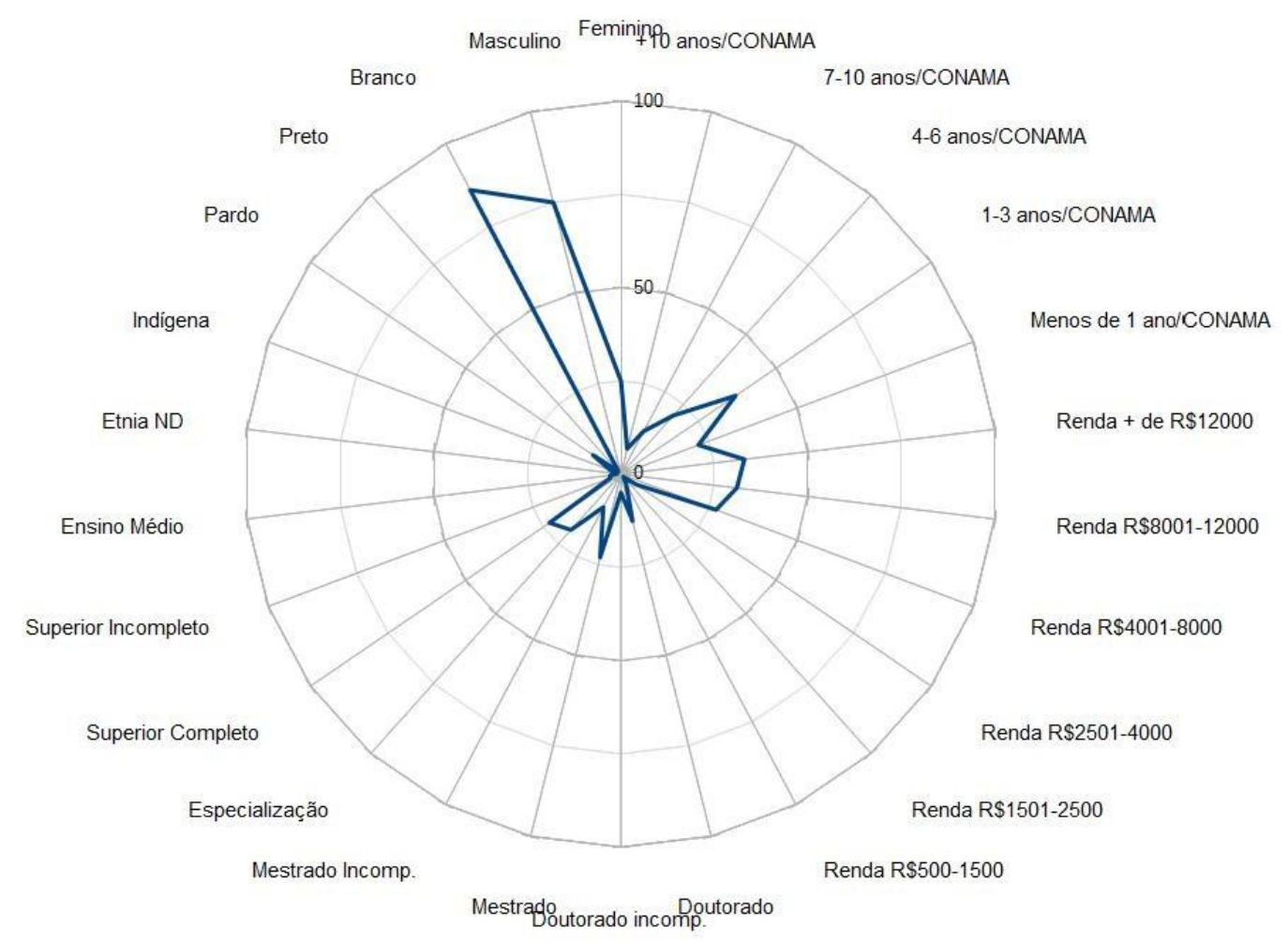

Fonte: FONSECA (2011). Adaptação própria.

O pico no desmatamento em 1995 estaria relacionado ao momento econômico decorrente do Plano Real, iniciado em 1994. Em 2005, com o advento de programas como o Plano de Prevenção e Controle de Desmatamento na Amazônia Legal (PPCDAM) e ações como a Operação Curupira, reprimindo a exploração madeireira ilegal, houve grande queda no desmatamento na região amazônica. No gráfico também é possível notar que o Mato Grosso desponta como principal estado da Amazônia em termos de desmatamento entre os anos $1991 \mathrm{e}$ 2005. A alteração massiva sobre os ecossistemas nesse período também pode

7 José Goldemberg, ex-ministro do MMA. Entrevista realizada em setembro de 2015. 
explicar a reação das sociedades locais e a conformação de redes ambientalistas. Preocupadas com a conservação ecossistêmica, base de suas economias específicas, houve forte reatividade para garantir a manutenção das diversas etnias indígenas no estado, dentre outras diversidades sociais.

\section{Gráfico 4. Taxas anuais do desmatamento: 1988 até 2015 (km²/ano)}

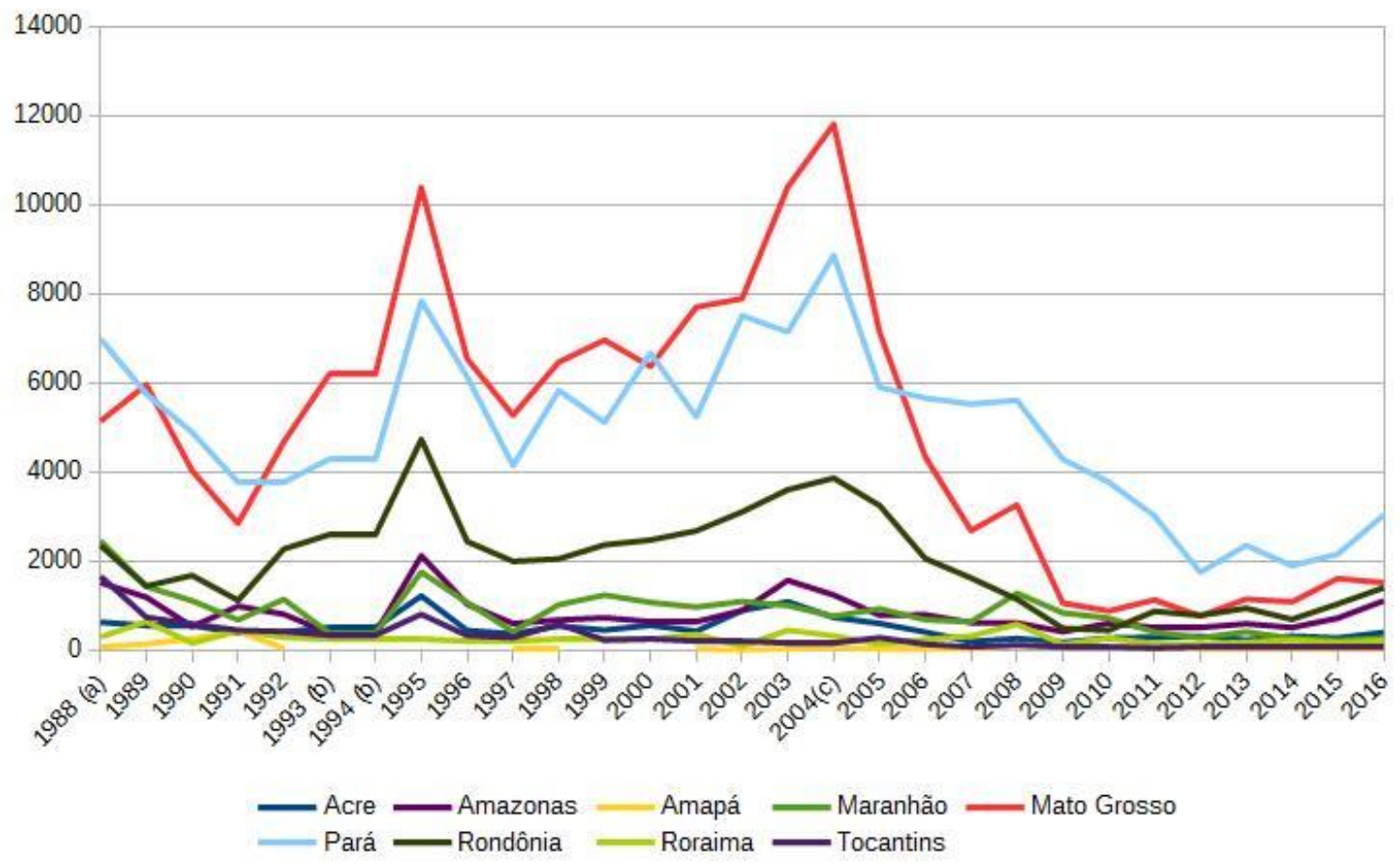

Fonte: INPE (2016). (a) Média entre 1977 e 1988; (b) Média entre 1993 e 1994; (c) Início PPCDAM.

Teixeira e Dagnino (2002) consideram que a transição para a Constituição de 1988 marcou a participação da sociedade civil nos processos de discussão e de tomada de decisões relacionadas com as questões de políticas públicas no Brasil. Ainda que muito possa ser levantado sobre quais grupos da sociedade civil se sobressaíram nas possibilidades de participação nos processos decisórios, o Estado brasileiro redemocratizado passa a se refletir na forma como são pensadas as políticas públicas, dadas as forças que se embatem no âmbito político mas também as mobilizações sociais cada vez mais fortes e numerosas.

Assim, por meio do projeto dos governos, o Estado implementa, em diferentes contextos e momentos históricos, programas e ações em distintos setores voltados para as diferentes classes que conformam a sociedade civil. 
Apesar das demandas, as políticas de fomento à agricultura familiar e à agroecologia, por exemplo, avançam com morosidade e são esparsas quando comparadas à celeridade e agregação das medidas em prol do agronegócio. Aos subsequentes governos, caberia garantir transparência no processo de tomada de decisões que envolvem órgãos públicos e diferentes organismos e agentes da sociedade, em relação às políticas implementadas, de forma a evitar a tendência de se considerarem "dois pesos e duas medidas" de acordo com a camada da sociedade civil que se visa beneficiar.

Assim, apesar de valorizar o local (as municipalidades) como base de uma descentralização política, não se chega a romper com essa estrutura consolidada de poder que se estabeleceu desde a colonização brasileira. Por inúmeras instâncias, os herdeiros das oligarquias regionais e dos militares têm vantagens em relação às classes marginalizadas por várias lacunas que se abrem desde a redação da Constituição até as infindáveis emendas constitucionais, leis e decretos vinculados, relativos ao funcionamento dos Três Poderes.

\subsection{A política ambiental como elemento territorial}

A política ambiental é uma das faces das políticas espacialmente fundamentadas e, como toda política pública é resultado da ação de uma autoridade investida de poder público e legitimidade para tal (STEINBERGER, 2006, p. 31). Assim como as outras políticas setoriais, a politics ambiental é resultado de uma disputa de poder que envolve a concorrência entre partidos políticos, grupos de interesse, categorias sociais e indivíduos e o exercício de influência em uma coletividade nos processos de decisão. Seu discurso "tem ligação intrínseca com o território, seja a partir dos interesses dos agentes envolvidos na sua produção, seja na qualidade de indutor de ações que se realizam materialmente" (STEINBERGER, 2013, p. 102).

Tomemos como ponto de referência as três dimensões, aplicáveis aos ciclos da política, para nossa fundamentação. Segundo o definido por Frey (2000, p. 217), essas três dimensões institucionais abarcam: 1) a polity, que diz respeito à ordem do sistema político, delineada pelo sistema jurídico, e à estrutura institucional do sistema político-administrativo; 2) a politics, ou seja, o processo político no qual se traçam, negociam e estabelecem os objetivos, os conteúdos e as decisões de 
distribuição; e 3) a policy, que consiste na configuração dos programas políticos, nos problemas técnicos e no conteúdo material das decisões políticas. A conceituação derivada de policy networks, trabalhada nesta pesquisa sob o prisma das "redes ambientalistas", inclui interações das diferentes instituições e grupos. Essas redes se conformam tanto no executivo quanto no legislativo e na sociedade, na implementação de determinadas policy.

A apropriação do espaço em território carrega a dinâmica das relações de poder, refletidas nas hegemonias entre os atores que se relacionam e modificam um determinado espaço. As fases que correspondem aos ciclos das políticas ambientais - como qualquer projeto no espaço e, portanto, expresso por uma dada representação - revelam a imagem desejada de um território, como um local de relações (RAFFESTIN, 1993, p. 144). No modelo democrático contemporâneo, é a partir das análises do ciclo das políticas públicas que encontramos um importante instrumento de identificação da estratificação em grupos sociais da sociedade civil e os agrupamentos políticos envolvidos nas questões da esfera pública (policy) e política (politics). Igualmente, é possível reconhecer os conflitos e as disputas de poder travados nas arenas decisórias em cada momento do ciclo da política (FREY, 2000, p. 217; DAGNINO, 2002).

As etapas dos processos decisórios em cada fase do ciclo político têm sido estudadas por diversos autores, principalmente a partir da segunda metade do século XX. Na medida em que tais estudos se desenvolveram, diversas variáveis internas e externas ao processo passaram a ser consideradas como decisivas em cada etapa da tomada de decisões. Podemos, entretanto, definir que três momentos são encontrados em todas as análises. Nas subdivisões de cada etapa do ciclo da política ambiental, as relações de poder se manifestam tanto pelo acesso privilegiado a informações quanto pela habilidade de agentes, atores políticos e governos em direcionar as agendas que favorecem as elites - no caso, principalmente as agrárias - dentro da institucionalidade do Estado. Em cada subetapa desses três momentos principais, novas relações de poder se estabelecem, táticas à estratégia geral. No que se refere aos lugares do processo decisório, entendemos tática e estratégia sob a visão de Certau (1998). Embora as táticas sejam relativas às possibilidades oferecidas pelas circunstâncias, não obedecem e nem se definem à lei do lugar. São localizáveis como as estratégias 
tecnocráticas, que criam lugares segundo modelos abstratos. Distinguem-se destas pelo tipo de operação nesses espaços, os quais as estratégias são capazes de produzir, mapear e impor, ao passo que as táticas somente podem utilizá-los, manipulá-los e alterá-los (CERTAU, 1998, pp. 93-94). Nesse sentido, é na tática que as classes da sociedade disputam a estratégia geral, já conformada em um âmbito ideológico que permeia o ciclo das políticas ambientais.

Neste trabalho, o caso relativo ao zoneamento mato-grossense, que será tratado no Capítulo 3, é bastante claro no que diz respeito ao jogo de forças que se deu no contexto do ciclo da política, bem como aos favoritismos que se perceberam, segundo os atores intervenientes no processo. Nos demais momentos que incluíram a participação da rede FORMAD, o controle sobre as etapas dos diferentes ciclos políticos, se não notado em termos globais como o foi 0 zoneamento, foi bastante contundente nos momentos em que a decisão demandava a participação das organizações ambientalistas (como o PPG7, PRODEAGRO e Plano BR-163 Sustentável).

Figura 1. Interpretação das fases do processo decisório, segundo autores e períodos

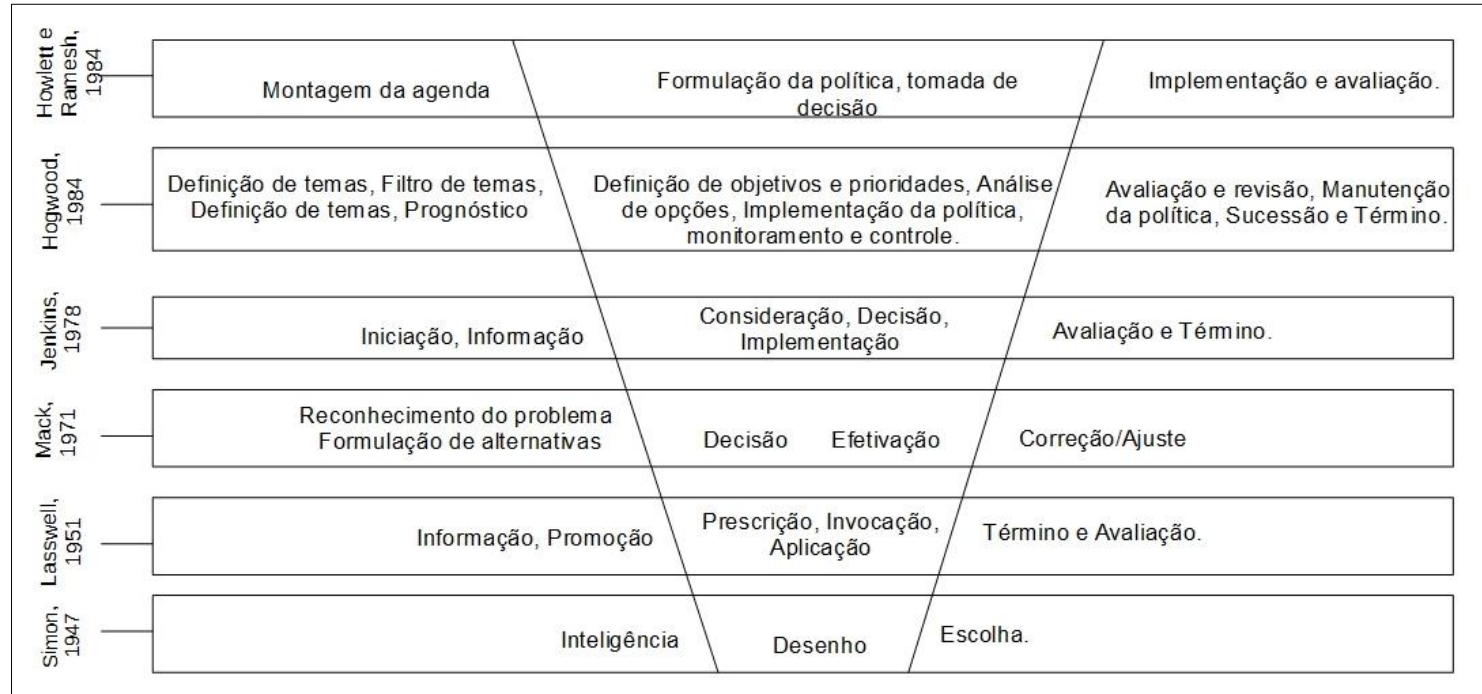

Fonte: Elaboração própria.

O território, enquanto "sentimento de consciência da sua apropriação" (BRUNET et al, 1993, p. 480) por aqueles que dele se apropriaram, é o espaço das relações onde os sujeitos que se apropriam física e simbolicamente tentam, em 
uma disputa de forças e sobre a base do dissenso, controlar ações por meio do controle do território. Assim, é com base no território que se materializam as relações de poder que, finalmente, conformam a gestão territorial (BECKER, 1991, p. 179) correspondente "à prática das relações de poder necessária para dirigir, no tempo e no espaço, a coerência das múltiplas finalidades, decisões e ações".

O entendimento dos conflitos, das coalizões e dos equilíbrios de poder modifica-se segundo qual política pública está em jogo. Em senso estrito, a esfera pública determina a política ("policies determine politics", LOWI, 1972, p. 299). Assim, o controle sobre o território e sobre os usos dos recursos naturais está, na contemporaneidade, diretamente ligado ao ciclo das políticas ambientais e seus instrumentos.

Como um processo interativo, o ciclo das políticas públicas é um elemento a ser considerado nas decisões políticas da contemporaneidade. Em cada fase desse ciclo, que não é linear, existem padrões distintos de negociação, barganha, trocas, dissensos ou contradições nos objetivos. Assim, em cada etapa ocorrem novas decisões políticas, com momentos de reformulação. Sobre estes, foram problemáticos, no Mato Grosso, os momentos e as formas de reformulação das políticas ambientais, mais ou menos reagentes com as bases da sociodiversidade.

\subsection{O Estado brasileiro contemporâneo e o processo político ambiental}

A dinâmica entre o Estado, as políticas públicas e o território é, na prática, inseparável. No entanto, o entendimento de cada parte foi empreendido por autores que, ao trabalharem com o contexto de formação econômica, social, espacial, cultural e política, tornam evidentes as ligações entre eles existentes. Os mesmos autores e vários outros sugeriram, na tentativa de apontar soluções ao caso específico da formação territorial brasileira, soluções em justiça social e ambiental, democracia representativa e participativa, e legitimidade nos processos decisórios (STEINBERGER, 2013).

Também há uma convergência desses autores na necessidade da incorporação de todas as camadas sociais e suas instituições nos processos políticos. Mészaros é um dos mais críticos à forma dessa inserção, argumentando que as crises estruturais que surgem dos conflitos sociais necessitam igualmente de mudanças estruturais. $\mathrm{O}$ autor é, nesse ponto, sinérgico com Gramsci quanto à necessidade 
de romper o aspecto hegemônico das ideologias vigentes por novas ideologias emancipatórias (MÉSZAROS, 2004).

Segundo Mészaros (2012), se não há desenvolvimento sustentável, então, de fato, não há desenvolvimento. Apesar dos riscos pretéritos e atuais em se posicionar em favor de uma igualdade substantiva, o fato é que a adoção desta é imprescindível para que tal desenvolvimento ocorra. Por igualdade substantiva entende-se 0 ativo envolvimento de todos e a consciência da responsabilidade de cada um, implícita na operação em uma tomada de decisões que, apesar dos inerentes conflitos, não supõe adversidades. O que haveria, em realidade, seria uma igualdade formal na esfera política - exaltada pelos mecanismos de institucionalidade participativa, anulados por meios corruptivos e autoritários -, mas persistiria uma desigualdade substantiva.

Dada a mediação do Estado na relação entre ser humano e natureza (MORAES, 2002a), torna-se difícil estabelecer precisamente uma diferenciação entre as políticas de ordenamento territorial e as políticas ambientais, dado o protagonismo desses processos pelo Estado e pela sociedade política. No Brasil, tendemos a separar funcionalmente a Política de Ordenamento Territorial e a Política Ambiental. A segunda parece estar incluída na primeira: ambas receberam como legado o histórico das disputas de poder que emergem no período colonial ${ }^{8}$. Em verdade, essa separação, mesmo que puramente metodológica, permite que as mesmas relações de poder que se estabeleceram ao longo da história sigam vigentes. Posteriormente, ao tratar do Zoneamento Ecológico e Econômico, veremos que esse instrumento de ordenamento territorial está tão intrinsecamente atrelado a políticas como o Código Florestal que este último não avança pela não consolidação do ZSEE, criando um cenário de incerteza que favorece os grandes proprietários de terra.

Em termos gerais, o conjunto de práticas e normas emanadas de um ou vários atores públicos (politics) se conforma dentro de uma "ordem do sistema político, delineada pelo sistema jurídico, e da estrutura institucional do sistema políticoadministrativo" (FREY, 2000; MENY E THOENIG, 1992). De fato, essa categoria se assemelha à definição de sociedade política usada por Gramsci (2002) nos

8 Sobre o tema, indicamos: DEAN (2004). 
Quaderni, em que ele a categoriza separadamente da sociedade civil, por razões metodológicas, ainda que, efetivamente, ambas tenham estrita relação na prática. Essas dimensões institucionais e processuais se relacionam com os momentos e contextos dados, em que uma autoridade adota práticas desta ou daquela forma, atua ou não atua, refletindo configurações de programas políticos expressos em formas materiais de intervenção, regulamentação, provisão de prestações e soluções de problemas técnicos; aspectos imateriais como discursos e campanhas de comunicação; e, também, repressão (ideológica ou física) dos fatores ou ações, na imanência de alterar a intencionalidade e os valores governamentais (implícitos ou explícitos) estabelecidos na relação das dimensões da polity, policy e politics.

As políticas públicas são divisíveis no campo das políticas econômicas (cambial, financeira, tributária, etc.), sociais (educação, saúde, previdência, etc.) e territoriais (urbanas, regionais, de transportes, etc.) (COSTA E MENDES, 2014). As políticas ambientais são modalidades da política territorial; logo, são produtoras do espaço. As políticas econômicas e sociais influem nas escalas dos fenômenos que, a fim e a cabo, se relacionam com as políticas territoriais.

As características das políticas públicas (logo, aplicáveis às políticas ambientais) são definidas por seu conteúdo, programa, fatores de coerção, orientações normativas e competência social (MENY E THOENIG, 1992). No Brasil, os Planos Plurianuais têm, recentemente, orientado o curso das políticas públicas a cada quatro anos, condicionando a distribuição orçamentária nacional (aprovada anualmente) às prioridades por eles estabelecidas, como exposto adiante.

Meny e Thoenig (1992) ressaltam a dificuldade de estabelecer os limites entre as políticas públicas - especialmente nos seus setores específicos, no processo de construção que envolve o estabelecimento do conteúdo a ser concebido - e os programas que lhe servirão de apoio, as orientações e normas que as regularão e as competências sociais de accountability e participação. E, em última instância, quais serão as medidas coercivas e punitivas para casos de descumprimento dessa cadeia de elaboração estabelecida. Segundo os autores, é muito difícil saber onde uma política ambiental começa e como termina. Para isso, é determinante o momento histórico no qual essas políticas são construídas, já que ele define quais são as prioridades em um dado um momento, a espacialidade e o contexto a ser pensado. 
Swyngedouw (2011) ainda menciona a tendência pós-política em considerar a dinâmica de decisões como uma redução do terreno político ao consenso governamental e às decisões políticas, centrando-se na administração técnica, de gestão e de consenso dos domínios ambientais, sociais, econômicos, etc. Esses aspectos e suas inter e intra-relações estão, na verdade, repletos das relações sociais dadas em um momento histórico.

Zizek (2002, p. 303) argumenta que "o último sinal de pós-política em todos os países ocidentais é o crescimento de uma abordagem gerencial para o governo: o governo é concebido como em uma função gerencial, privado de sua dimensão política adequada". A busca por um suposto consenso desfoca a evidência de que as decisões são elaboradas sobre uma base de desacordos, ou seja, "tudo é politizado e pode ser discutido, desde que de uma forma não comprometedora e como um não conflito". Dificuldades e problemas como a discussão de orçamentos ministeriais, medidas às estratégias de adaptação e mitigação das mudanças ambientais e organização do ambiente são encenados e aceitos como necessidade problemática a ser tratada através de compromisso, arranjo gerencial e técnico e produção de consenso. A chave no recurso de consenso é a anulação do dissenso, isto é, o fim da política (DIKEN E LAUSTSEN, 2004).

Em suma, precedentes ao estabelecimento das políticas públicas, vêm à tona os consensos e dissensos políticos e é articulada a engenharia partidária que dará suporte à agenda governamental em um dado contexto econômico, social e de política interna e externa, dentre outros aspectos intervenientes da dinâmica governamental. Consolidam-se, a partir disso, os instrumentos de planejamento, execução, monitoramento e avaliação, encadeados de forma integrada e lógica em uma agenda que se reflete em planos, programas, ações, projetos e atividades. As políticas territoriais e ambientais, como as demais políticas públicas, concretizamse no território, este sempre presente, implícita ou explicitamente, nas políticas públicas. Admite-se, assim, que todas as políticas públicas detêm uma dimensão territorial (STEINBERGER, 2013).

É na montagem da agenda que emergem as hegemonias da sociedade civil e política, incidindo no Estado, já que a maneira como os problemas públicos são reconhecidos é determinante de como eles serão tratados pelos policy makers. Há uma imensa diferença de percepção de problemas públicos, dependendo de que 
estrato social tomamos como referência. Tomemos o caso dos grandes detentores de terras e dos grandes agroexportadores: são os problemas sentidos por tais elites aqueles priorizados pelos policy makers, já que essas mesmas elites, especialmente na América Latina, também compõem o corpo da sociedade política e dos tomadores de decisão.

Temos que o momento de formulação de uma política ambiental já se estabelece como resultado de uma agenda consolidada mediante relações de poder. Essa etapa é composta, primeiramente, pela fase de apreciação, que consiste em levantamento de informações, como consultas a experts, bem como a acervos documentais de interesse; segundo, pelo diálogo entre os atores políticos com diferentes perspectivas. A partir dessa etapa, a formulação é de competência da sociedade política que a elabora e consolida e escolhe os instrumentos que serão utilizados para sua implementação. Aos agentes da esfera pública, cabe o direcionamento e a fiscalização das ações para um determinado fim.

Por sua função no estabelecimento das políticas, os quadros de funcionalismo público com pessoal capacitado para as diferentes finalidades da política são denotativos do grau de amadurecimento das democracias. Notamos que países mais desenvolvidos, nesse aspecto, possuem amplos quadros de servidores públicos. A qualidade dos quadros institucionais é, pois, importante nos Estados que têm a democracia como base, para que exista uma estrutura decisória operativa e, portanto, com resultados também sobre a qualidade da participação que, sob essa estrutura, se consolida e intervém.

No Brasil, cabe ressaltar a deficiência nos quadros de funcionalismo público em comparação com outros países. No Gráfico 5 e no Quadro 1, demonstramos o quadro geral da porcentagem de funcionalismo público no Brasil e o quadro de funcionários, segundo informações estatísticas nacionais disponíveis, nos estados que compõem a Amazônia Legal. Os motivos dessa deficiência são vários, entre eles, os poucos recrutamentos, sobretudo nas áreas técnicas ambientais, e o contingente de cargos comissionados e de estagiários.

Ademais, constata-se também a obsolescência dos registros de funcionalismo nos quadros das instituições de meio ambiente. Apesar de haver dados sobre a gestão ambiental e os espaços participativos sobre o tema entre 2002 e 2015, não há assiduidade de todas as variáveis analisadas, ou seja, há 
dados que foram divulgados em 2002 pelo IBGE que não se repetem nos anos subsequentes, dificultando comparações.

\section{Gráfico 5. Empregos no funcionalismo público $(2009$ e 2013, em \% da força de trabalho total)}

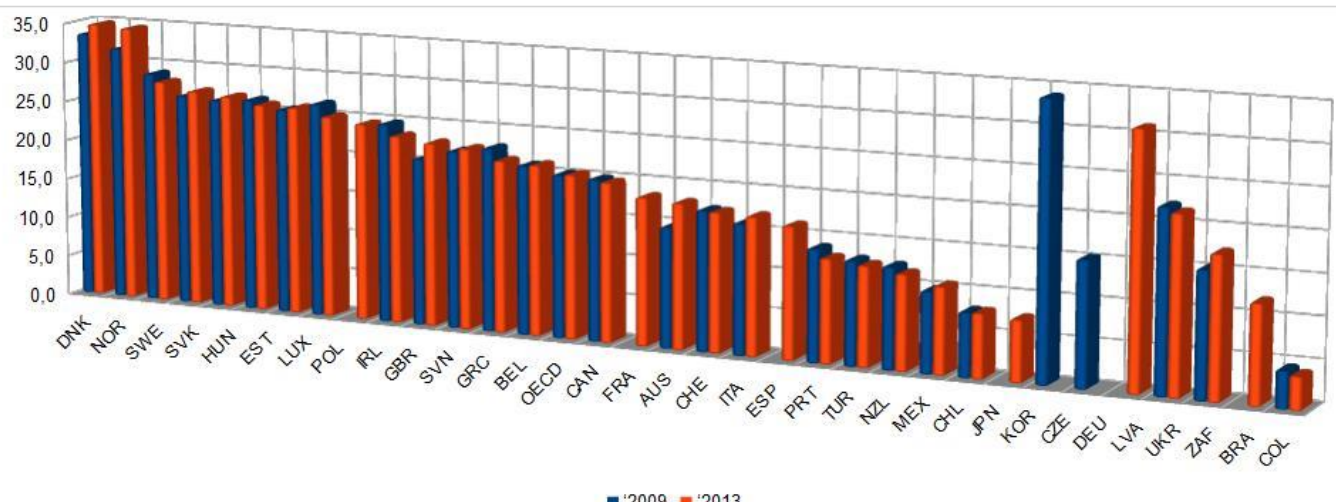

Fonte: Organização Internacional do Trabalho (OIT). Os dados para a Itália são do Instituto Nacional de Estatística e do Ministério das Finanças. Os dados relativos a Portugal são do Ministério das Finanças. Os dados para a Coreia foram fornecidos pelas autoridades nacionais. Os dados para a Áustria, Finlândia, Islândia, Israel, Holanda e os Estados Unidos não estão disponíveis. Os dados relativos à Austrália, República Checa, Alemanha, Coreia, Irlanda e Portugal não estão incluídos na média da OCDE, devido à falta de séries temporais. Os dados para República Checa e Nova Zelândia são expressos em equivalentes a tempo completo (ETI). Austrália, Grécia, Hungria, Eslovênia e Ucrânia: 2012 em vez de 2013. Dinamarca, Luxemburgo, Nova Zelândia e Turquia: 2011 em vez de 2013. Suíça: 2008 em vez de 2009 (OECD, 2015).

O quadro de funcionários com nível superior é bastante inferior quantitativamente, quando comparado com o quadro preenchido por profissionais de ensino médio. Não há estatísticas do quadro composto por pós-graduados. Com isso, temos que o grau de especialização nos quadros de meio ambiente é baixo, a julgar pelo grau de instrução. Em termos de relevância desta observação para os processos decisórios, notamos que tais índices implicam a dificuldade de elaboração do planejamento e gestão dos recursos. Por exemplo, durante a realização do ZSEE mato-grossense, um dos pontos levantados como sendo uma dificuldade no processo era o quadro insuficiente de funcionários especialistas (FORMAD, 2016).

Também no caso específico da Amazônia Legal e na questão ambiental, o quadro de servidores é composto ainda por grande número de pessoas sem vínculo 
empregatício, perfazendo, em 2002, 77\% em Roraima, 52\% no Acre, 31\% no Pará e $23 \%$ no Mato Grosso.

\section{Quadro 1. Servidores ativos na estrutura de meio ambiente em 31.12.2002, com ou sem vínculo empregatício, por nível de cargo ocupado, segundo classe de tamanho da população, nos estados da Amazônia Legal}

\begin{tabular}{|c|c|c|c|c|c|c|}
\hline \multirow{4}{*}{ Unidades da Federaçâo } & \multicolumn{6}{|c|}{ Servidores ativos na estrutura de meio ambiente em 31.12} \\
\hline & \multirow{3}{*}{ Total } & \multicolumn{3}{|c|}{ Estatutário e CLT } & \multicolumn{2}{|c|}{ Sem vinculo empregaticio } \\
\hline & & \multirow{2}{*}{$\begin{array}{l}\text { Total } \\
(1)\end{array}$} & \multicolumn{2}{|c|}{ Nivel do cargo } & \multirow{2}{*}{ Total } & \multirow{2}{*}{$\begin{array}{l}\text { Práticos } \\
\text { (2) }\end{array}$} \\
\hline & & & Superior & $\begin{array}{l}\text { Médio ou } \\
\text { auxillar }\end{array}$ & & \\
\hline Rondônia & 222 & 176 & 39 & 135 & 4 & 9 \\
\hline Acre & 196 & 94 & 26 & 68 & 10 & 1 \\
\hline Amazonas & 847 & 688 & 81 & 607 & 15 & 39 \\
\hline Roraima & 58 & 13 & 1 & 12 & 4 & 34 \\
\hline Pará & 829 & 569 & 75 & 494 & 26 & 33 \\
\hline Amapá & 200 & 168 & 22 & 146 & 3 & 4 \\
\hline Mato Grosso & 469 & 361 & 94 & 267 & 10 & 96 \\
\hline
\end{tabular}

Fonte: IBGE (2002). (1) Inclusive sem declaração de nível do cargo. (2) Prático é a pessoa que tem conhecimento local dos rios e matas, contratado para trabalhar por prestação de serviços, sem vínculo empregatício, para determinada ação ambiental em lugares remotos.

As demais etapas das políticas públicas são essencialmente decorrentes das etapas de estabelecimento da agenda e formulação das políticas, as quais dependem de profissionais qualificados inseridos no processo. A tomada de decisões relativas à implementação de uma política formulada é afetada pela natureza do subsistema político envolvido, isto é, os atores envolvidos, o cenário institucional e as ideias por trás de ambos. O contexto da implementação da política envolve novamente a participação dos servidores públicos e os funcionários administrativos (HOWLETT et al, 2013).

É nesse momento que emerge a dissonância entre aqueles que elaboraram as etapas da política pública, ou seja, Estado e sociedade política, e os estratos da sociedade civil. Sendo o processo de elaboração da política eminentemente político, recebe influência de determinadas camadas da sociedade civil junto aos tomadores e implementadores de decisão, fundamentalmente compostos pela sociedade política aderida ao Estado, a fim de que as ações públicas sejam executadas em nome de seus interesses (STEINBERGER, 2013). Essas forças políticas e disputas de poder expressas pelo discurso dominante evidenciam, no ciclo das políticas 
públicas, a possibilidade de sua análise sob a visão materialista histórica, pois derivam de um contexto socio-histórico estabelecido.

A implementação, como produto do ciclo de políticas públicas que aqui delimitamos, é entendida como uma ação governamental baseada em um discurso que, executada de cima para baixo (top down), se reflete em planos, programas, ações, projetos e atividades públicas, nos diversos setores públicos.

\begin{abstract}
O discurso como prática política estabelece, mantém e transforma as relações de poder $\mathrm{e}$ as entidades coletivas (classes, blocos, comunidades, grupos) entre as quais existem relações de poder. $O$ discurso como prática ideológica constitui, naturaliza, mantém e transforma os significados do mundo de posições diversas nas relações de poder. Como implicam estas palavras, a prática política e a ideológica não são independentes uma da outra, pois a ideologia são os significados gerados em relações de poder como dimensão do exercício do poder e da luta pelo poder. Assim, a prática política é uma categoria superior. Além disso, o discurso como prática política não é apenas um local de luta pelo poder, mas também o marco delimitador na luta pelo poder: a prática discursiva recorre a convenções que naturalizam relações de poder e ideologias particulares e as próprias convenções, e os modos em que se articulam são os focos de luta. (FAIRCLOUGH, 2008, p. 91).
\end{abstract}

O discurso ambientalista teve importante interferência das prioridades das oligarquias no País. Os interesses desses grupos econômicos, ligados à exportação, ocuparam áreas produtoras de mercadorias ao mercado externo e áreas subsidiárias das culturas de exportação. No processo de colonização, Andrade (1995) aponta a compartimentalização do território brasileiro para este ou aquele fim. À base do clientelismo historicamente consolidado, impulsionou-se a agroexportação e as estruturas que permitem sua expansão como alternativas à sustentabilidade ambiental, em detrimento de outras estratégias produtivas menos impactantes.

As relações de poder que se desenvolvem em busca do poder político se refletem na forma como os recursos são distribuídos por pasta, ou seja, entre as temáticas ministeriais do âmbito do Executivo.

\title{
1.6. Dominâncias refletidas na distribuição orçamentária entre os ministérios
}

Um dos avanços em vista da análise do desempenho dos ministérios, sobretudo a partir do ano de 2002, foi a divulgação dos portais de transparência. 
Por meio de dados retroativos dos montantes direcionados a cada ministério - e, dentro deles, quais as principais aplicações dos recursos -, é possível avaliar como as leis orçamentárias respondem aos Planos Plurianuais (PPAs) e como se distribuem os recursos segundo as funções orçamentárias.

A primeira observação que se pode fazer sobre o Gráfico 6 diz respeito à desproporcionalidade da distribuição de recursos entre os ministérios. Bem conhecida é a fração do orçamento da União destinada ao pagamento de dívidas, principalmente internas, razão pela qual o Ministério da Fazenda é o destinatário protagonista em todo o período entre 2004 e 2014. É possível notar, no entanto, que nesse período houve sensível melhora no quadro de distribuição: do valor total, as transferências a todos os ministérios, excluindo o da Fazenda e o da Previdência Social, elevaram-se de 11\% para 22\%, entre 2004 e 2013.

Mesmo com os poucos recursos dotados às outras áreas, notamos que o orçamento do Ministério da Agricultura, Pecuária e Abastecimento é ainda quatro vezes superior ao do Ministério do Meio Ambiente, o qual recebeu uma média de $0,13 \%$ do orçamento total destinado aos ministérios. Isso aponta que, em termos de poder na decisão, o ramo do agronegócio, também no aspecto de distribuição orçamentária, ainda tem maior influência.

É importante ter em vista que, segundo o pacto federativo que se estabeleceu, cada setor do Governo Federal é responsável por redistribuir seus recursos por meio de transferências aos outros níveis governamentais. Assim, no caso ambiental, cabe ao Ministério do Meio Ambiente repassar seus reduzidíssimos recursos para a gestão e fiscalização do ambiente em todo o País. Sobre a gestão, e a intenção da gestão participativa, a situação se agrava.

O Gráfico 7 trata especificamente do orçamento repassado ao Ministério do Meio Ambiente e do uso dos recursos a ele destinados por gastos diretos do Governo Federal. O FNMA, o mais antigo fundo ambiental da América Latina, recebeu, entre 2004 e 2014, menos de $1 \%$ do orçamento total do Ministério. $O$ Fundo tem a missão de contribuir, como agente financiador, por meio da participação social (em que destacamos a atuação do Fórum Brasileiro de ONGs e Movimentos Sociais para o Meio Ambiente e Desenvolvimento - FBOMS), para a implementação da Política Nacional do Meio Ambiente (PNMA). Mesmo com os 
poucos ingressos, no ano de 2006 o FNMA apoiou projetos ambientais relacionados a doze ações do PPA 2004/2007.

\section{Gráfico 6. Distribuição dos orçamentos ministeriais (em R\$ bilhões) entre 2004 e 2014}

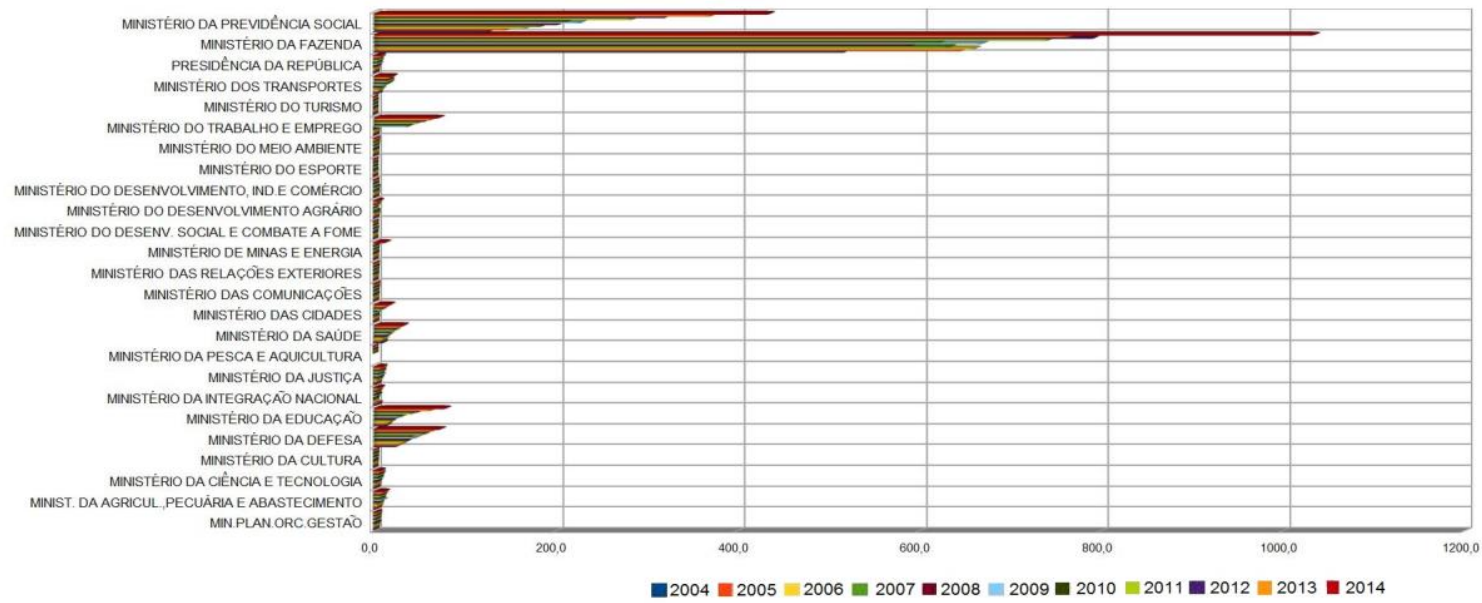

Fonte: Governo Federal (2015).

Sendo decorrentes de doações internacionais e, principalmente, de dois empréstimos junto ao Banco Interamericano de Desenvolvimento (BID), celebrados em 1992 e 1998 - este com término em 2008 -, os recursos operados pelo Fundo nas duas décadas que se seguiram à sua criação possibilitaram o fortalecimento do Sistema Nacional do Meio Ambiente (SISNAMA), por meio do apoio à elaboração e implementação de agendas de planejamento e controle da gestão ambiental por municípios e Estados, conduta acompanhada da adoção dos mecanismos de participação e controle social. 


\section{Gráfico 7. Repasses orçamentários feitos ao MMA, entre 2004 e 2014 (em}

$\mathbf{R}$ \$ milhões)

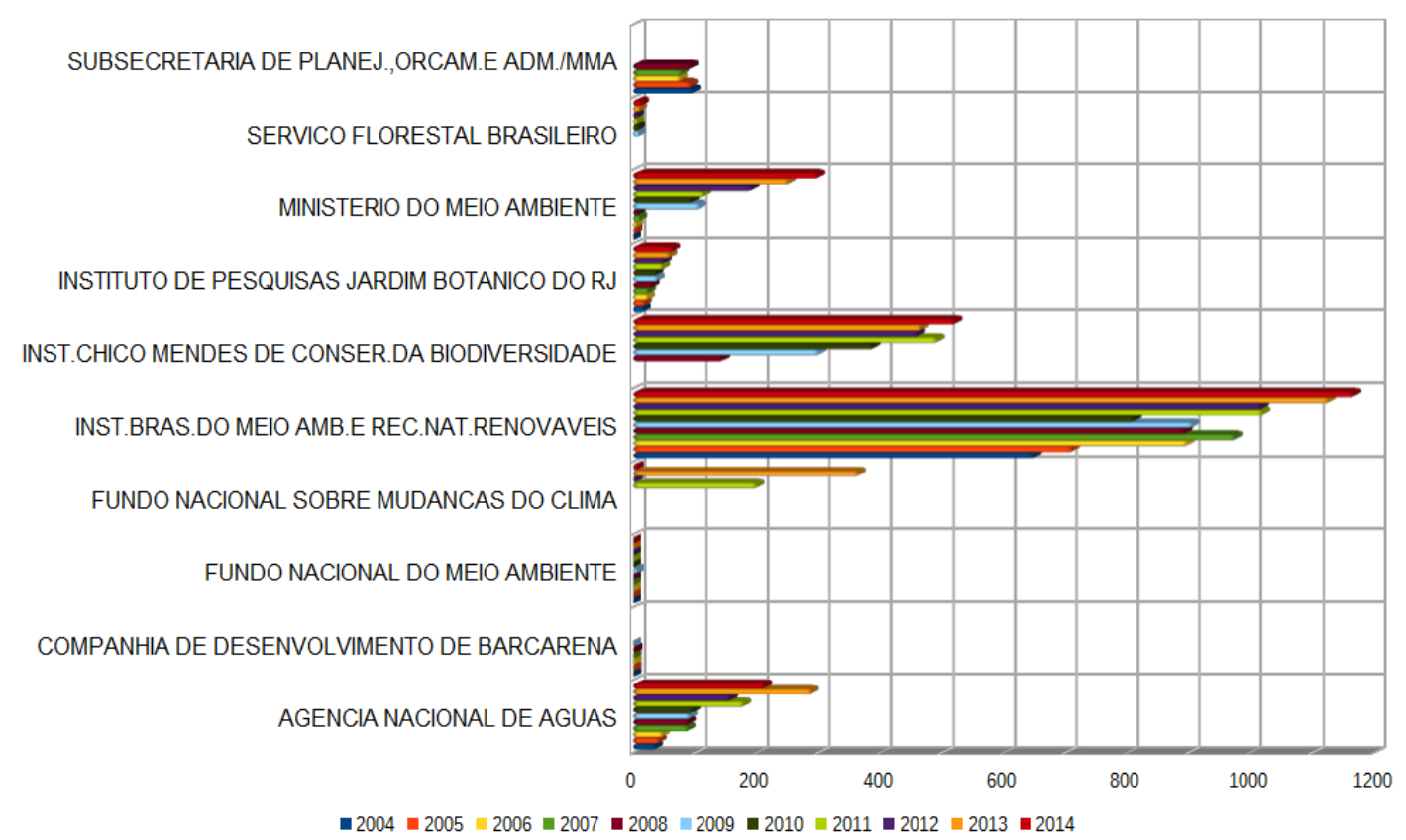

Fonte: MMA (2015).

A partir da parceria com outros ministérios (do Desenvolvimento Agrário MDA, da Integração - MI, da Saúde - MS, da Educação - MEC e da Comunicação - MC), o FNMA lançou editais abordando temas (por exemplo, Pronaf, P2R2, CIMAs), cuja transversalidade da política ambiental se fez materializar.

Os relatórios de gestão do FNMA (disponíveis até o ano de 2013) pontuam a drástica redução das capacidades orçamentária e financeira desde o final do empréstimo do BID e do ingresso dos valores decorrentes das doações internacionais. Os recursos ao FNMA passaram a provir exclusivamente do Orçamento Geral da União (MMA, 2014).

Como tal evidência se replica em todos os programas e planos ambientais, temos então que esse problema não é um caso isolado: ele é agravado pela desigualdade orçamentária entre os ministérios. Com a redução dos valores paulatinamente ao longo dos anos, sobretudo em 2012, o recurso destinado centralizou-se na sobrevivência da estrutura ministerial, sendo que todo o orçamento era executado somente em gestões administrativas, sobrando pouco aos programas desenvolvidos, como mostra o gráfico. 


\section{Gráfico 8. Média entre o orçamento previsto e o utilizado pelo MMA, valores totais, em R\$ milhões}

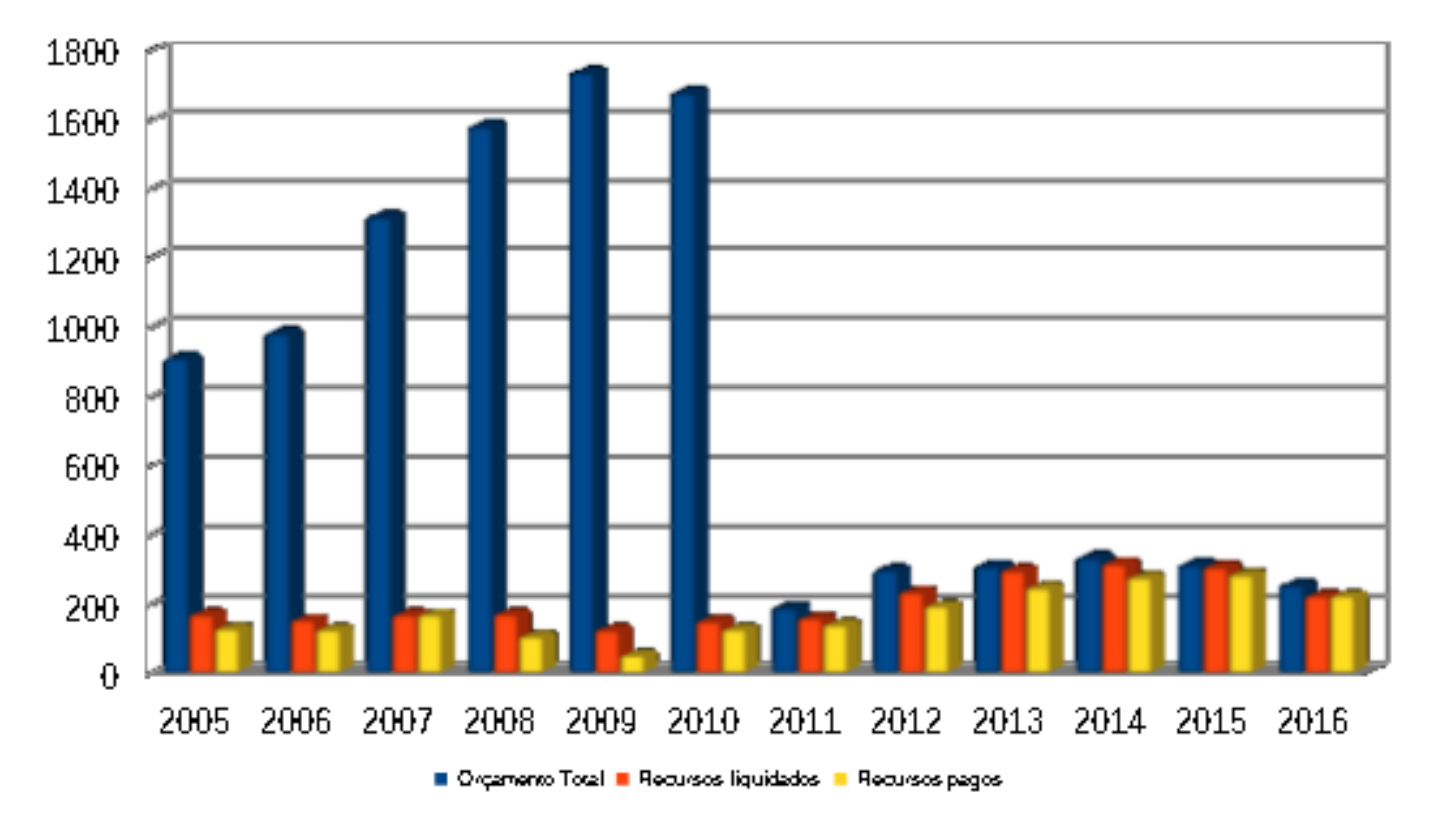

Fonte: MMA (2015).

Os cortes a partir de 2011, sob uma justificativa estritamente econômica, acompanham o orçamento utilizado nos anos anteriores. No entanto, revelam que a estratégia governamental em uma situação de insuficiência institucional não é a resolução das vulnerabilidades institucionais, e sim a adaptação orçamentária para tal debilidade, reforçando-a. Apesar dessa evidência em si não estar relacionada à qualidade da participação social nas esferas institucionais ambientais, tratada neste estudo, ela demonstra, em termos gerais, a má qualidade do funcionamento de tais instituições. São os desdobramentos dessa evidência que atravessam as possibilidades de participação.

O ZEE nunca configurou entre os maiores detentores de recursos. Consonante com o pacto federativo e com o SISNAMA, o ZEE é executado de forma compartilhada entre a União, os estados e os municípios, conforme o disposto pela Lei Complementar 140/11. Assim, a diminuição dos aportes financeiros federais aos demais entes tenderia naturalmente ao decréscimo na medida em que o zoneamento avançasse de forma global.

O Programa de Gestão e Manutenção do Ministério do Meio Ambiente, por exemplo, faz parte das ações orçamentárias integrantes da Lei Orçamentária para 
2012, e assegura o pagamento da contribuição da União, de suas Autarquias e Fundações para o custeio do regime de previdência dos servidores públicos federais (art. 8o da Lei 10.887, de 18 de junho de 2004). Notamos com isso que, se por um lado o aumento de repasses da União explicita a consolidação da questão ambiental na agenda governamental, por outro, as diversas questões que fazem parte da temática não recebem igual atenção.

Se pensarmos que a descentralização da política ambiental passa por um sistema de incentivos e colaborações entre entes federativos, então temos que o problema estrutural das instituições ambientais federais terá desdobramentos negativos nas atribuições estaduais e locais.

Temos até aqui a estrutura nacional à qual se reportam e em que se incluem as realidades estaduais. No estado do Mato Grosso a influência das oligarquias dirigiu fortemente as decisões políticas estaduais, notadamente as ambientais, em seu favor.

Para análise dos momentos orçamentários do Ministério do Meio Ambiente podemos fazer dois recortes: o primeiro pautado nos Planos Plurianuais e outro pela análise das agendas governamentais do Executivo, em nível federal. A primeira observação a ser feita é a carência de dados anteriores a 2002. Para esta análise específica, duas fontes de informação foram contrastadas: os gastos diretos do Governo Federal por órgão executor e a execução orçamentária por programa governamental, sendo a unidade orçamentária referenciada no MMA. Os Gráficos 9 a 18 dizem respeito aos orçamentos disponíveis e valores liquidados e pagos em programas governamentais federais em meio ambiente entre os anos de $2005 \mathrm{e}$ 2014, isto é, entre os momentos: do último ano da primeira gestão do presidente Luís Inácio "Lula" da Silva (2005) até a primeira e a segunda gestões da presidenta Dilma Rousseff (2010 e 2014, respectivamente). Nesse mesmo período eram Ministros do Meio Ambiente: Maria Osmarina Marina da Silva Vaz de Lima (2003 a 2008), Carlos Minc (2008 a 2010) e Izabella Teixeira (de 2010 até 2016).

Os esforços no ano de 2005 se centravam no Plano Amazônia Sustentável, lançado em 2004, e no apoio à Política Nacional de Meio Ambiente, ao Programa Nacional de Florestas e à revitalização de bacias hidrográficas. O primeiro sofreu grandes cortes já no ano de 2007, desaparecendo da lista de prioridades no ano de 2008. O deslocamento dos recursos da Política Nacional do Meio Ambiente ao 
funcionamento administrativo e interno do MMA talvez seja um dos fatores preocupantes. Notamos que no período considerado o leque de prioridades ambientais deixou de ser a questão ambiental e como ela era tratada no território nacional e passou a ser a manutenção da própria existência do MMA. Em 2011, enquanto quase a totalidade das políticas ambientais recebia menos de $R \$ 10$ milhões, o gasto voltado para o apoio administrativo alcançava $\mathrm{R} \$ 90$ milhões.

Houve uma queda na diversidade dos programas governamentais paulatinamente entre 2005 e 2010, agravando-se entre os anos 2011 e 2014. Isso prova que a ineficiência e a ineficácia institucionais apontadas em 1992 no PPG7 seguiam pairando sobre as instituições ambientais brasileiras ainda em 2012. Comparando a distribuição dos gastos entre 2005 e 2012 (Gráficos 9 a 18) ${ }^{9}$, é possível inferir que esses problemas não somente não foram solucionados como se agravaram. Reforça essa evidência o fato de que, mesmo em cada programa individualmente, ao longo dos anos existe uma grande distância entre o orçamento previsto e o realmente liquidado e pago. A primeira questão é que, apesar de orçado, não existem mecanismos que garantam que o recurso esteja disponível em ministérios com menor prestígio político que outros, tornando-se mais vulneráveis institucionalmente. A segunda é a diferença entre valores previstos e realizados nos programas ambientais. Para além da divergência desses valores pela vulnerabilidade ministerial, temos que a especificidade dos objetivos traçados para tais programas possivelmente não foi alcançada, já que o orçamento disponível foi inferior ao solicitado para que as metas fossem atingidas. $\mathrm{Na}$ execução orçamentária do MMA, mesmo com poucos recursos, percebe-se entre os anos de 2005 e 2007 uma intencionalidade de fortalecer a sociodiversidade - distribuindose valores para os temas de comunidades tradicionais e manejo da agrodiversidade, por exemplo -, além das ações de preservação da biodiversidade. Os gastos com o setor administrativo aumentam gradativamente nas contas ministeriais ${ }^{10}$ ao longo de todo o período, seguidos dos valores repassados para a gestão da Política de Meio Ambiente. A partir de 2011, no entanto, pouca distinção é feita entre estas

9 As informações relativas aos programas do Ministério do Meio Ambiente encontram-se na Página de Transparência interna do Ministério, no qual se repartem os recursos vindos do Governo Federal. Portanto, o recurso que foi destinado ao MMA é gerenciado internamente e, por falta de informações como se fazem essas divisões, as contas não foram fechadas.

$10 \mathrm{Em}$ 2006, em reunião com equipe do CONAMA, a autora observou os altos gastos administrativos no Ministério, vistos como um problema naquele momento. 
duas cifras. As demais ações do MMA desaparecem ou enfraquecem após esse período, devido aos profundos cortes para sua manutenção. Ainda assim, ações voltadas para a conservação e a soberania alimentar sobrevivem até 2013 , quando um novo período de crise política se instala no País. 
Gráfico 9. Execução orçamentária do MMA, em R\$ milhões (2005)

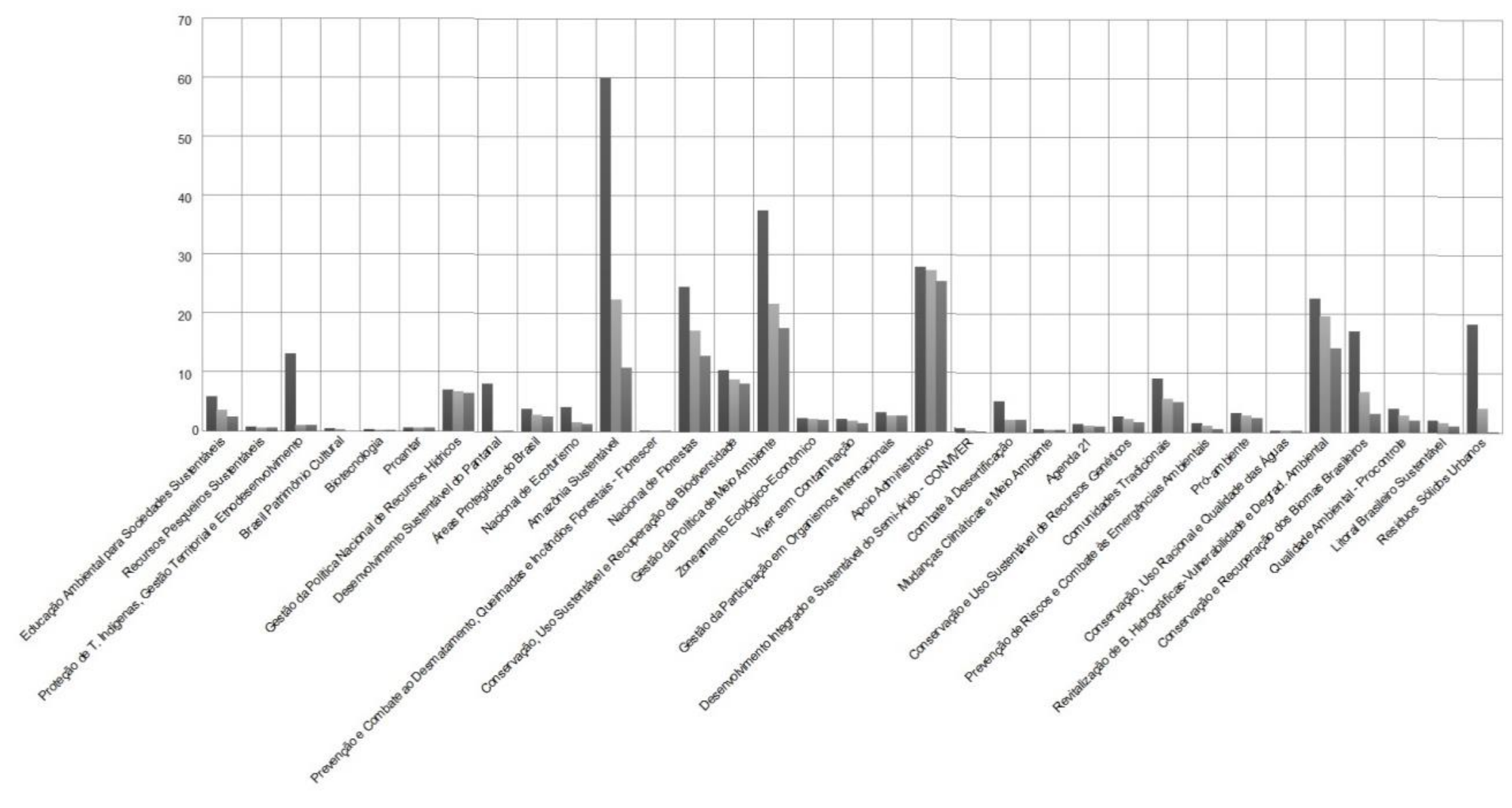

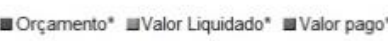

Fonte: Governo Federal (2015). 
Gráfico 10. Execução orçamentária do MMA, em R\$ milhões (2006)

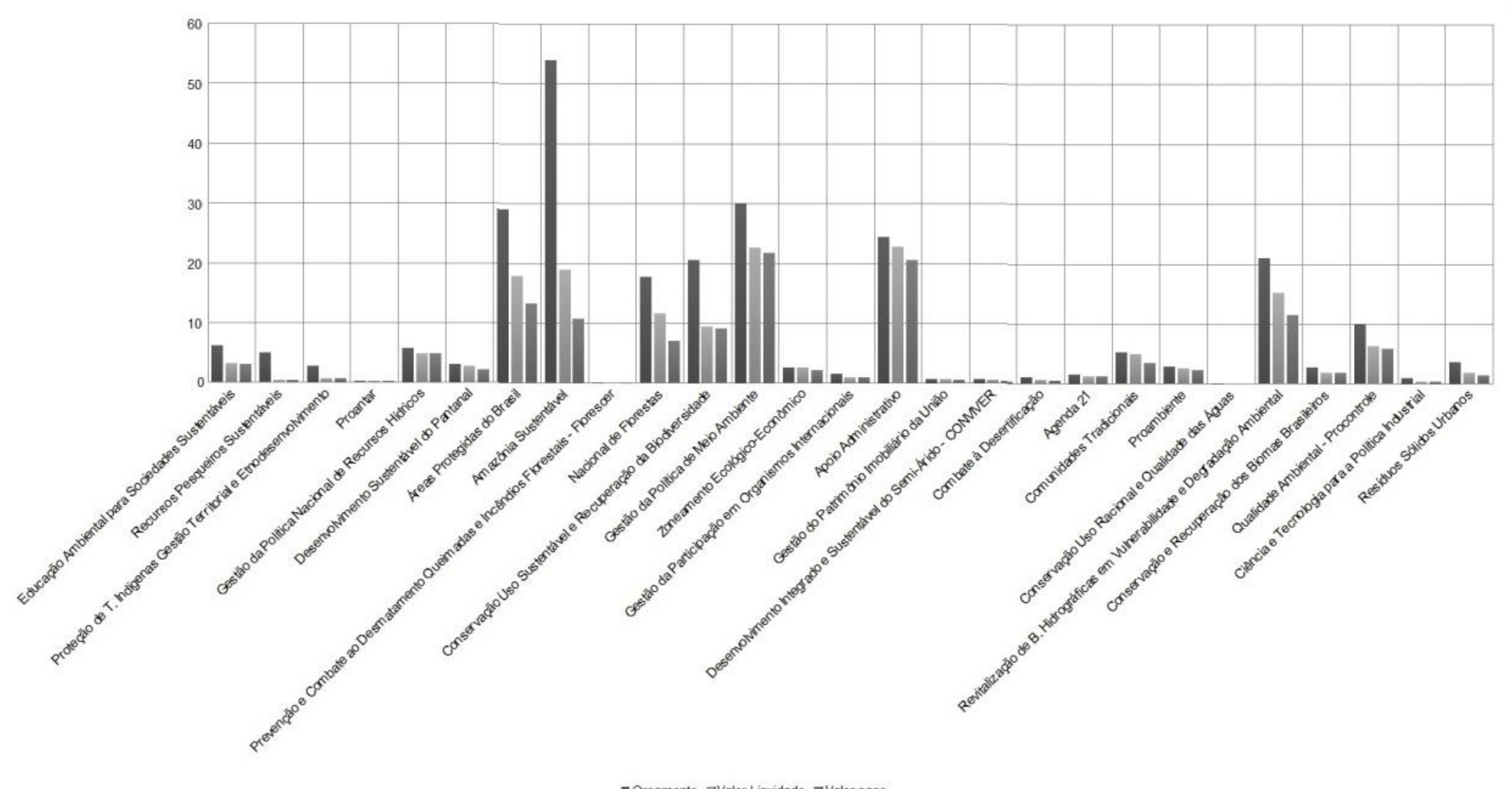

Fonte: Governo Federal (2015). 


\section{Gráfico 11. Execução orçamentária do MMA, em R \$ milhões (2007)}

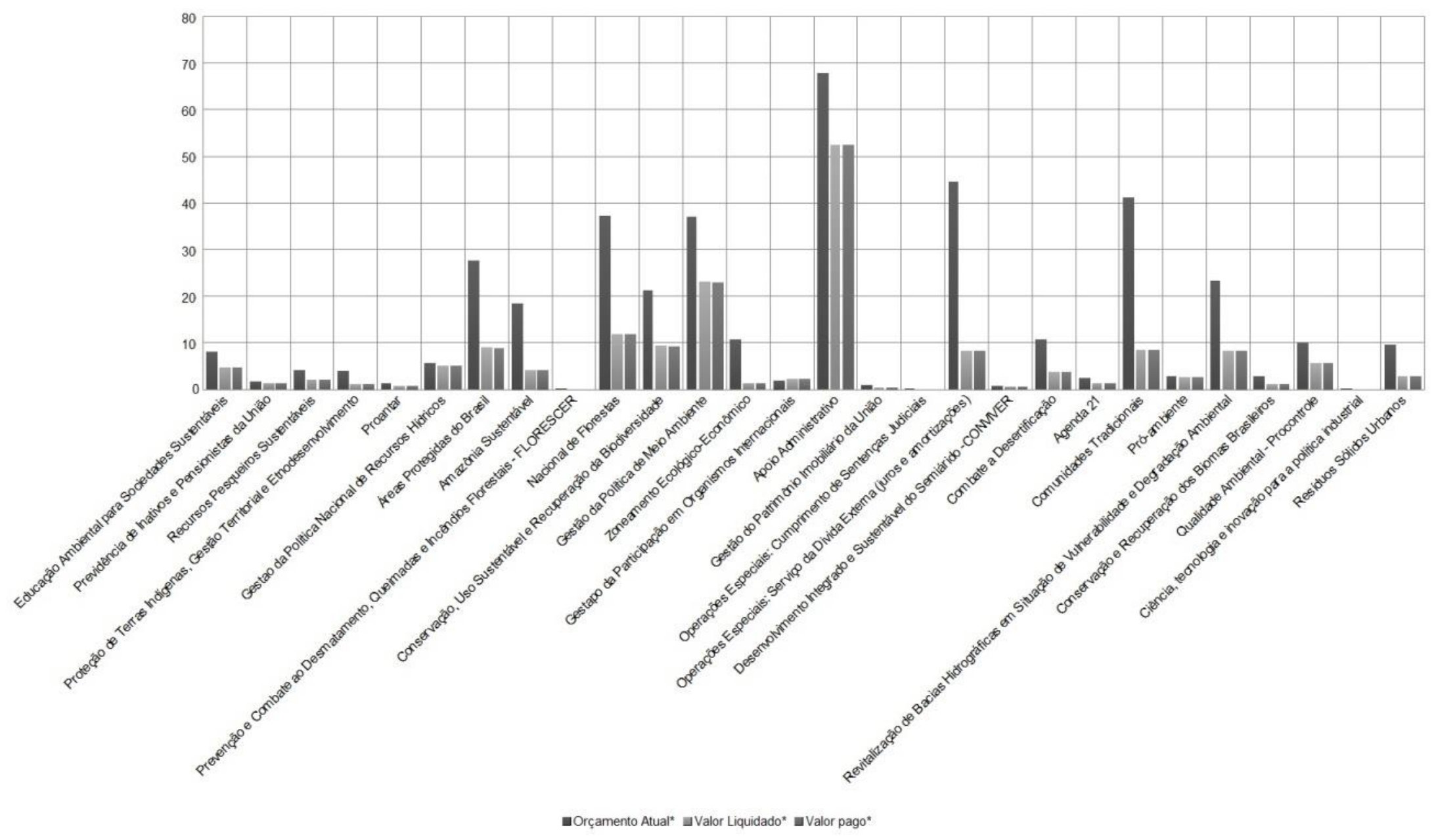

Fonte: Governo Federal (2015). 
Gráfico 12. Execução orçamentária do MMA, em R\$ milhões (2008)

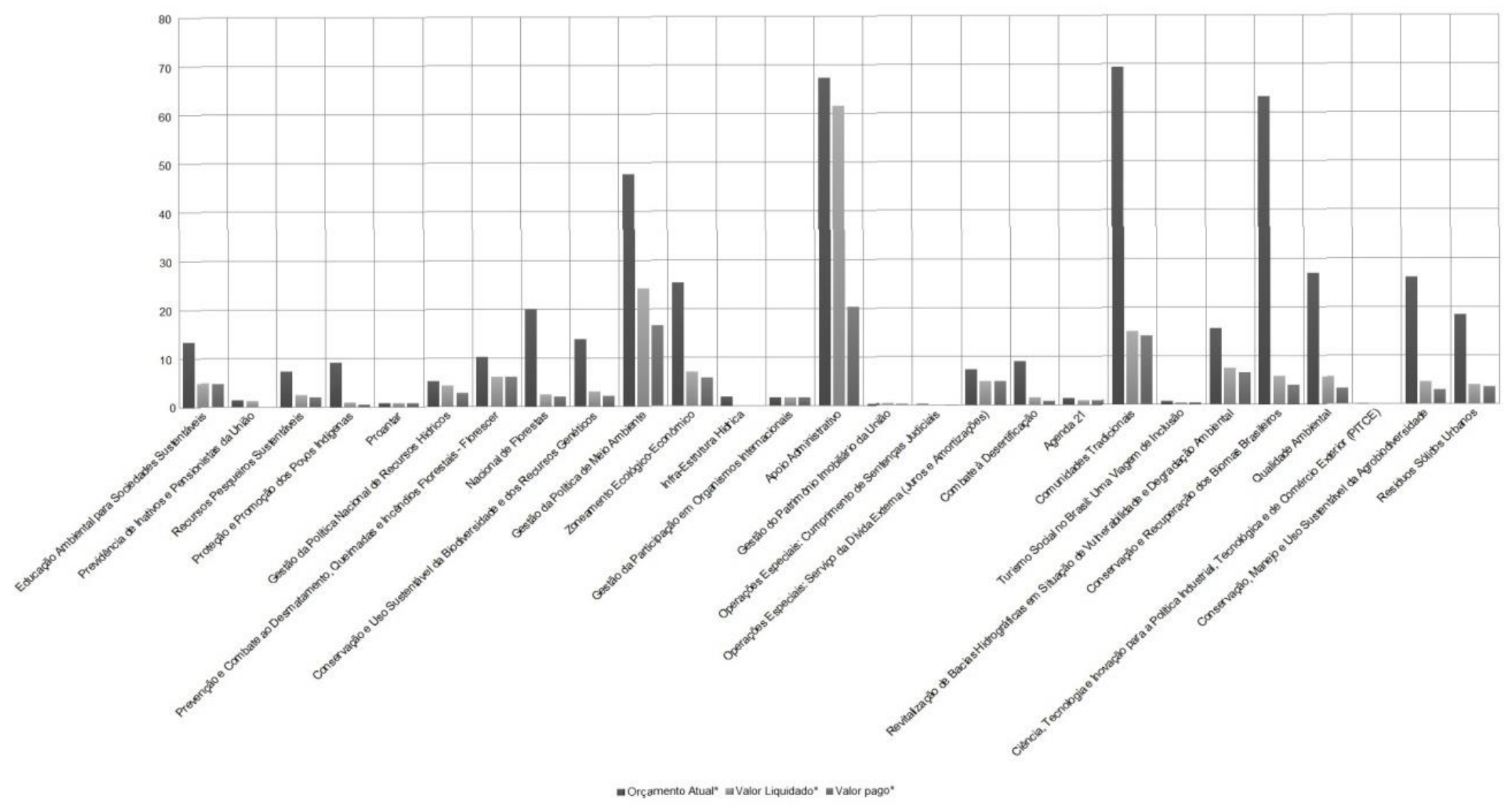

Fonte: Governo Federal (2015). 
Gráfico 13. Execução orçamentária do MMA, em R \$ milhões (2009)

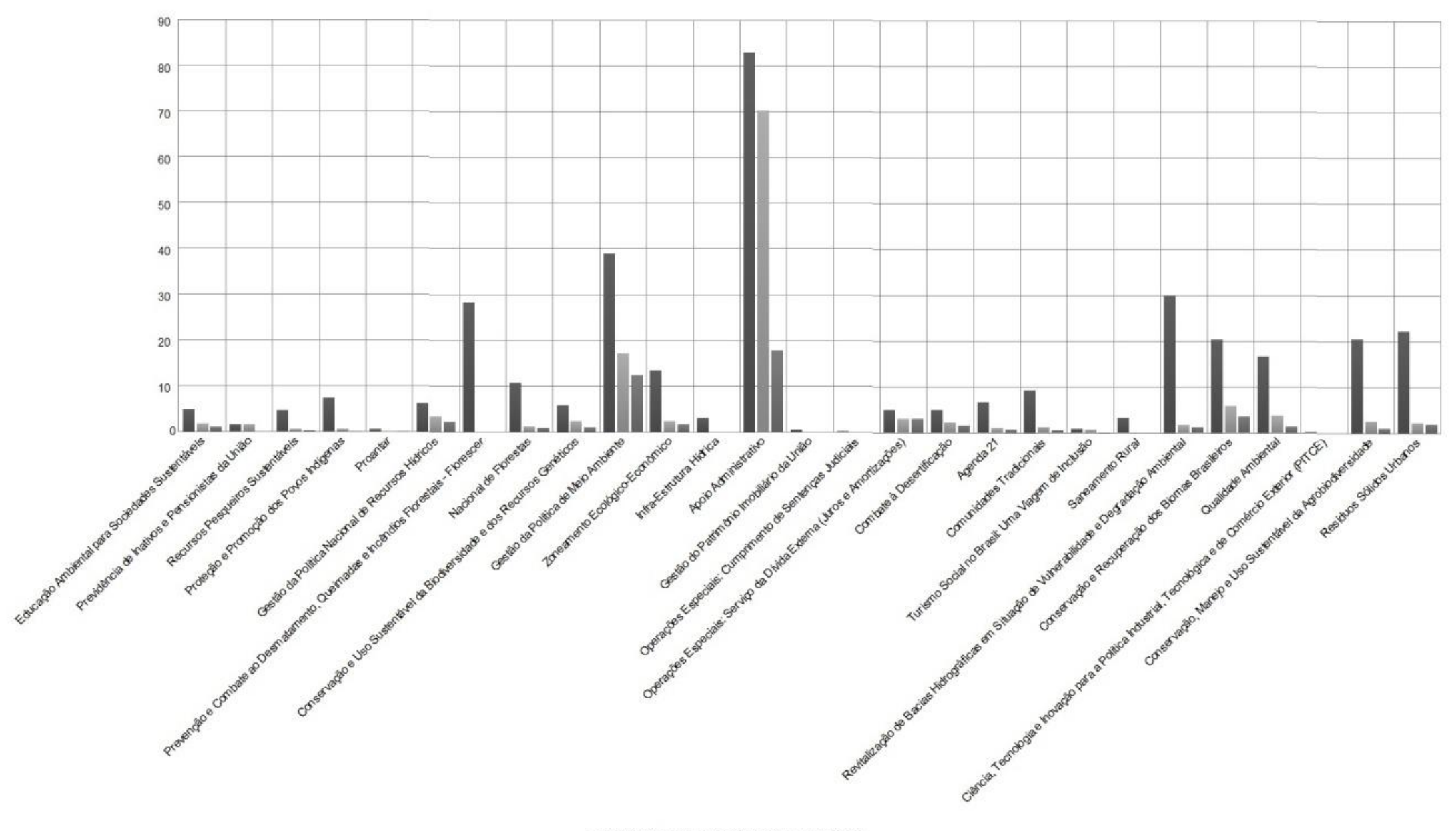

Fonte: Governo Federal (2015). 
Gráfico 14. Execução orçamentária do MMA, em R \$ milhões (2010)

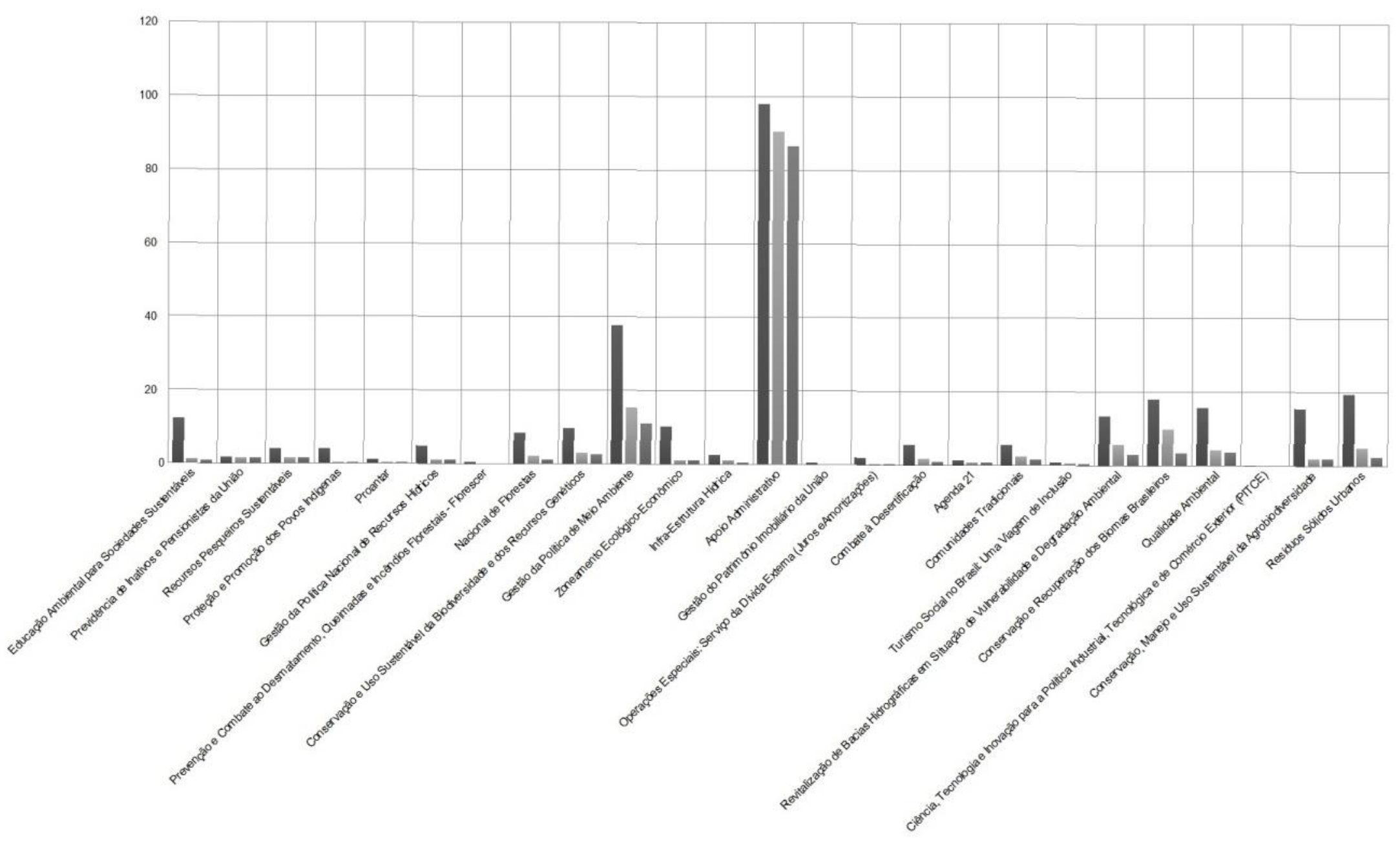

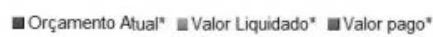

Fonte: Governo Federal (2015). 
Gráfico 15. Execução orçamentária do MMA, em R\$ milhões (2011)

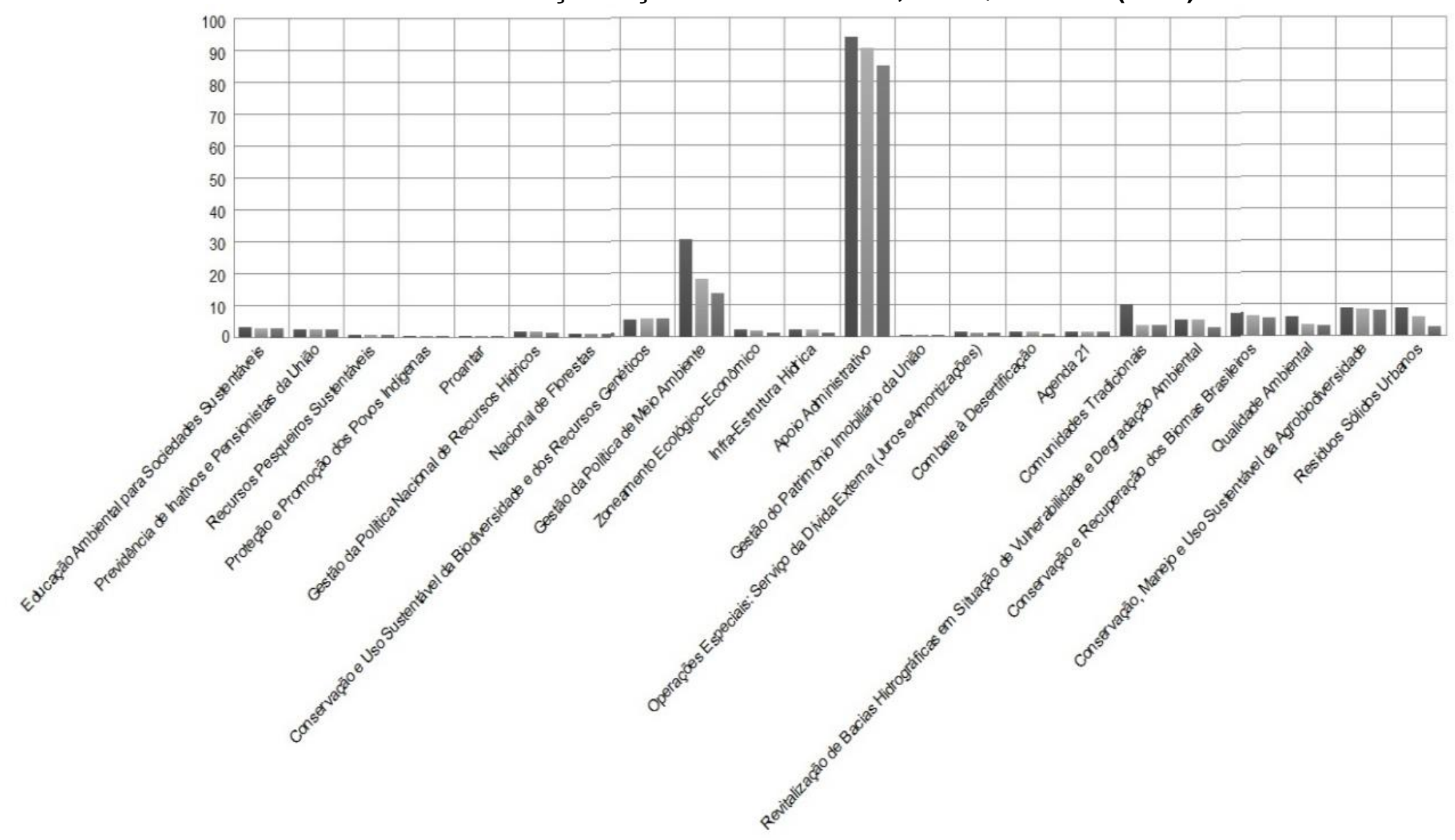

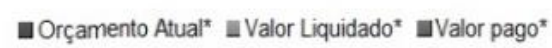

Fonte: Governo Federal (2015). 


\section{Gráfico 16. Execução orçamentária do MMA, em R\$ milhões (2012)}

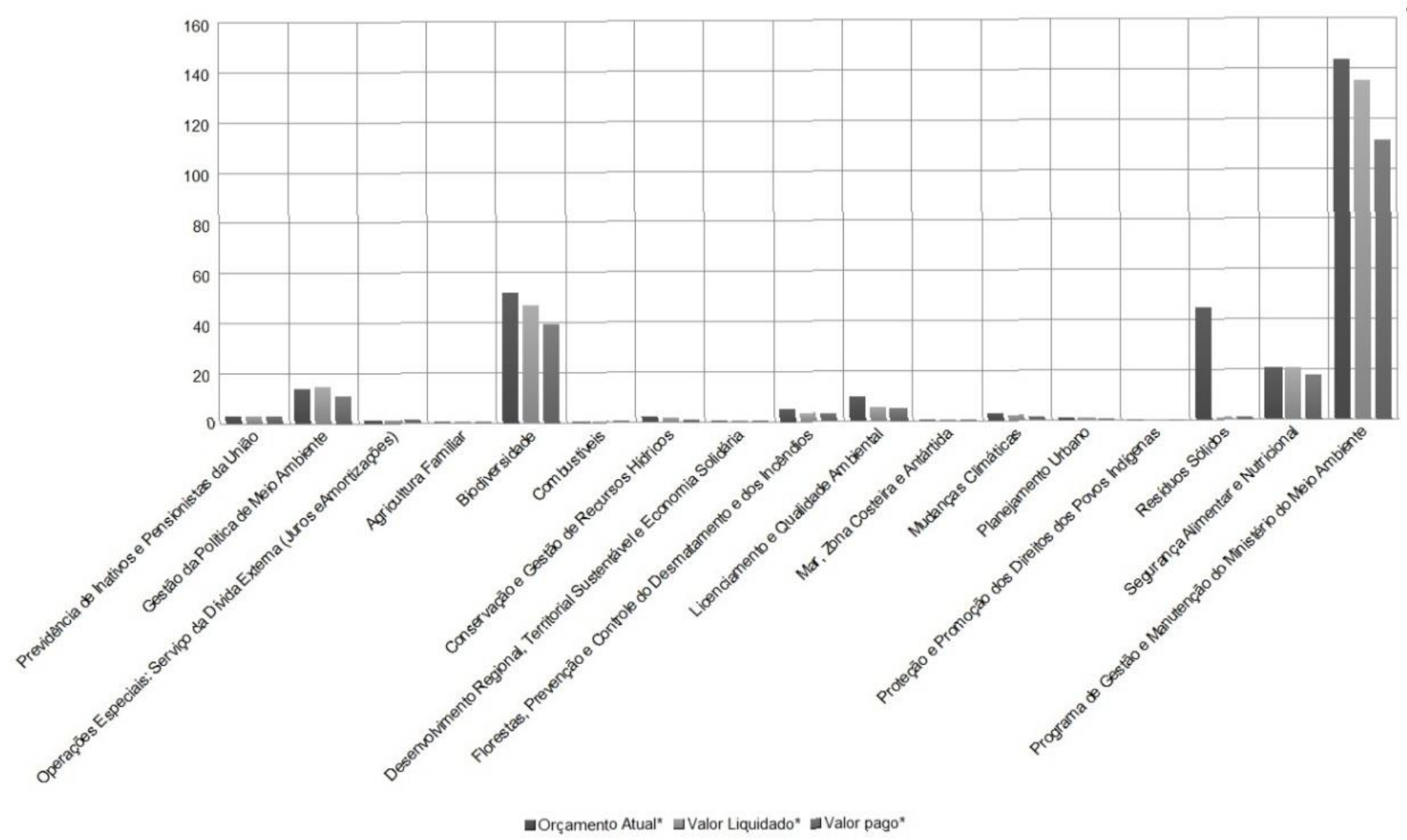

Fonte: Governo Federal (2015). 
Gráfico 17. Execução orçamentária do MMA, em R \$ milhões (2013)

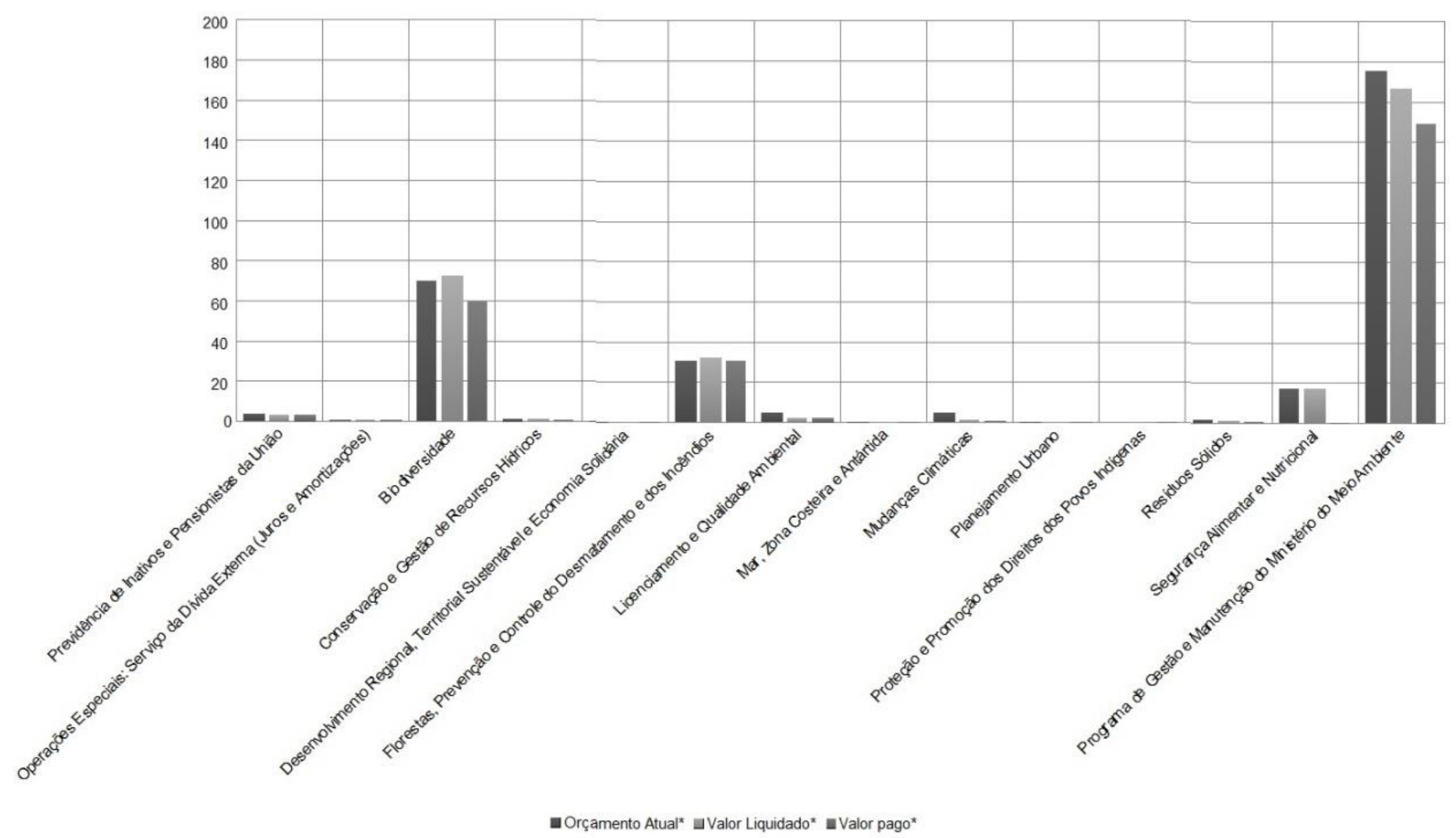

Fonte: Governo Federal (2015). 


\section{Gráfico 18. Execução orçamentária do MMA, em R\$ milhões (2014)}

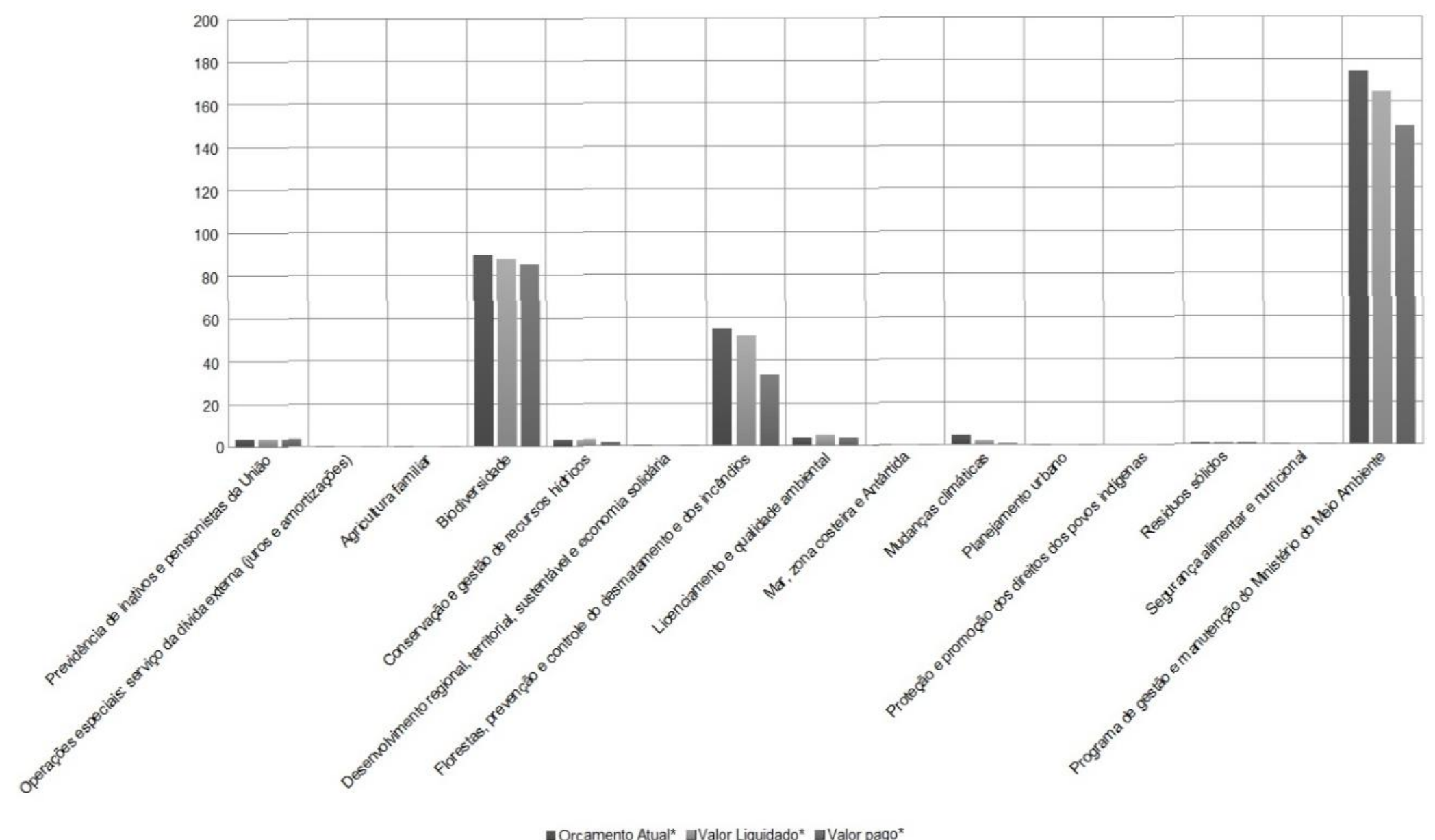

Fonte: Governo Federal (2015). 
Observamos a diversidade de forças de poder que, no jogo político, competem para o sucesso das políticas ambientais. Mesmo com o estabelecimento de uma política, as limitações orçamentárias são determinantes para que alguns setores da política se desenvolvam e outros caiam no ostracismo.

A política ambiental mato-grossense se incorpora à Política Nacional de Meio Ambiente de acordo com o que estabeleceu o pacto federativo na questão ambiental, como abordado nos capítulos seguintes. Competem, para tanto, elementos contextuais, como o histórico de relações entre sociedade e ambiente, que precede a história contemporânea da questão; a forma como evoluiu a institucionalidade ambiental após a redemocratização; e a qualidade e distribuição dos recursos humanos e financeiros dessas instituições. A viabilidade e aplicabilidade dos aprofundamentos democráticos no setor ambiental apenas são possíveis se há possibilidade da superação do papel histórico do País no cenário internacional. Nesse sentido, a ampliação do leque de possibilidades de desenvolvimento econômico para além da agroexportação e a continuidade dos esforços para que o Brasil mantenha sua importância diplomática, posicionando-se como protagonista das discussões ambientalistas no cenário internacional, são elementos de fortalecimento do Estado. Para tanto, faz-se necessário encontrar maneiras de romper o dualismo governo e sociedade, ainda que pareça se aprofundar na política brasileira em sua totalidade.

Repensando também as funções das regiões do País, que se mantêm em uma estrutura pouco diferente do que há quatro ou cinco séculos, é possível também reavaliar o Estado para que este atenda antes as sociedades que sua necessidade de expansão territorial.

Necessário se faz pensar que, além das funções que foram atribuídas às regiões do País, internamente nos estados há subdivisões de funções, replicando a distribuição desigual dos recursos nas municipalidades, estratificando também nesses locais a distribuição dos recursos, criando novos mosaicos nos quais a natureza é produzida segundo a especificidade do local ao todo do estado.

É nesse cenário, exposto no capítulo seguinte, que as camadas sociais marginalizadas, cientes de seu papel, pressionam o Estado a responder suas demandas e criam, na atuação de suas redes de solidariedade, novos ciclos políticos. Segundo as possibilidades oferecidas na dinâmica de relações que 
configura o Estado, variam as chances de reatividade desses grupos com as esferas governamentais. No caso mato-grossense, tal processo se desenvolveu durante todo o período entre 1988 e o presente. Ainda que apresentadas de forma simples no presente estudo, é possível lançar mão de ferramentas de análise dessas relações que urgem ser desenvolvidas.

Por essa razão, o Capítulo 2 aborda as concepções balizadoras do planejamento estadual mato-grossense, no que diz respeito ao contexto socioambiental, e as capacidades dos diferentes atores de intervirem sobre os pontos de contato entre ambiente e território. 


\section{CAPÍTULO 2 - CONTEXTO SOCIOAMBIENTAL MATO- GROSSENSE}

A construção material do espaço é influenciada pela concepção que a ele foi atribuída, refletindo sobre um domínio territorial e, consequentemente, sobre os instrumentos das políticas que a ele se reportam, a sua gestão e as aberturas à participação social. Essa é a base do raciocínio que trataremos a seguir.

Nos países que se consolidaram a partir de colônias, o Estado é o organizador do espaço e gestor do território. Ele se impõe como mediação básica na relação entre sociedade e meio (MORAES, 2002, p. 176). Pleno em sua gestão, o processo decisório político também tem no Estado sua centralidade. Do Estado emanam as decisões, prática na qual a participação popular tem restrita ou nula inserção.

Nesse contexto, as histórias geopolíticas e geoeconômicas estiveram fortemente entrelaçadas na formação territorial brasileira e, por conseguinte, na forma como se pensou a política e a gestão socioambiental aplicadas às subdivisões do País. Essa ideia se aplica na contemporaneidade do caso mato-grossense no que se refere a um modus operandi em planejamento e gestão do território, que priorizou a economia por meio da agricultura industrial em detrimento de outras propostas. Esse foi o princípio fundamental aplicado pela sociedade de produtores agrícolas, inseridos na sociedade política estadual e regional para exercer o controle político sobre as camadas da sociedade que se relacionam na abrangência estadual.

Esse elemento também se fez presente na história de expansão da frente agrícola sobre os ecossistemas e as diversidades sociais de todo o Centro-Oeste em direção à Amazônia, e em seus desdobramentos na atualidade. Com tal centralização do poder pelo Estado, poucos foram os avanços na oferta de espaços oferecidos (pelo Legislativo em diferentes níveis governamentais, ou mesmo nos espaços do Executivo) para a negociação entre as camadas da sociedade e o governo em busca de soluções compartilhadas ao ambiente. Em grande medida, as experiências de negociação se limitaram a aprendizados a tais atores no que se refere a estratégias e táticas de intervenção política, com poucos reflexos efetivos nas decisões tomadas. O grande contingente de intervenções das camadas 
marginalizadas da sociedade em relação a temas socioambientais é feito por meio de interposições no Ministério Público Federal, respaldando-se na atuação do Judiciário. É evidente que essas poucas vias de mobilização não vêm suprindo a demanda.

O legado histórico da consolidação do Mato Grosso que se materializou no ambiente também apresenta outros pontos que, na cena contemporânea, destoam do momento democrático. A recente ampliação das bases de dados públicas, portais de transparência e instrumentos de análise socioambiental ganha força a partir de 2000, principalmente quanto à forma como se distribui o orçamento na União. Apesar da qualidade de dados e da interface aos usuários, ressalta-se a importância de tais plataformas, quando acessíveis tanto a pesquisadores quanto à sociedade civil. De qualquer sorte, a abertura de dados em portais de transparência brasileiros e a dedicação na padronização dos dados das diversas políticas setoriais oferecem-nos a possibilidade de dimensionar o Brasil que herdamos, como ele se comporta mediante o pacto federativo e quais rumos podemos esperar a partir desse panorama da participação social na temática ambiental.

Conhecer os detalhes, orçamentários, estatísticos e técnicos, sobre o substrato no qual se desenvolveram os processos decisórios, a produção de território pelo Estado e a gestão ambiental, permite às organizações ambientalistas entender como as políticas e os instrumentos de gestão ambiental refletiram sobre a sociodiversidade e foram influenciados por ela, via institucionalização da participação social.

Neste capítulo exploramos essas ferramentas com o objetivo de conhecer o cenário ambiental atual do estado do Mato Grosso, a fim de entender qual a motivação da rede ambientalista FORMAD em priorizar determinados eixos de atuação e o espaço de que essa rede dispôs, no cenário estatal, para a manifestação de seus argumentos.

Há similaridades entre o que se tem como eixo estratégico no âmbito governamental mato-grossense e os eixos da rede ambientalista FORMAD. Portanto, analisaremos as possibilidades disponíveis a redes ambientalistas como o FORMAD, enquanto ator coletivo, de produção do território no ambiente (RAFFESTIN, 2009), diante das possibilidades de intervenção dos atores 
governamentais. Para tanto, contrastamos documentos referentes a esses dois atores. Quanto ao governo estadual, é analisado o Plano de Longo Prazo de Mato Grosso, o PLP, ou MT+20, instituído pelo Decreto 2.944, de 27 de outubro de 2010 (o qual revoga a Lei 8.431 , de 30 de dezembro de 2005, que definia a Política de Desenvolvimento de Mato Grosso), e quais forças políticas o definiram. Referente ao FORMAD, analisamos seus eixos de atuação - um dos seus componentes estatutários, definido em 2010 em assembleia entre as organizações ambientalistas que o conformam. Apesar de existirem atualizações desses eixos, oriundas de assembleias posteriores, avaliamos que não seria possível exceder a temporalidade considerada como parâmetro na concepção dos objetivos nesta pesquisa. O período de instabilidade no contexto nacional que se estabeleceu entre 2013 e meados de 2017 reforçou que, por opção metodológica, nos debruçássemos majoritariamente sobre documentos circunscritos ao período proposto.

Outras informações contextuais são usadas, a partir de documentos da SEPLAN (MT), da Assembleia Legislativa do estado de Mato Grosso, do IBGE, ISA, MMA e do Programa Nacional da Diversidade Biológica (PRONABIO), os quais serviram de base para a elaboração de cartografias específicas.

\subsection{O planejamento estratégico mato-grossense}

O planejamento das regiões mato-grossenses atribui uma configuração intermunicipal, projetando-se para além dos domínios do estado e sendo um dos elementos que conformam a gestão nos estados e países vizinhos. Haesbaert (2002) entende que na dinâmica das redes entrelaçadas entre o local, o regional, o nacional e o internacional desenvolvem-se os fenômenos territoriais.

Nesse caso, tais fenômenos desenvolvem-se em um cenário de diversidade em que $40 \%$ da população residente no Mato Grosso não é natural do estado, padrão semelhante a outros estados da Amazônia Legal, como Rondônia e Roraima, onde cerca de $46 \%$ da população provêm de outras localidades no País IBGE (2004; 2015). Como, então, convergir em um planejamento que atenda às demandas sociais de uma população tão heterogênea em demandas, culturas e realidades? Essa questão, apesar de importante para a fixação das comunidades, aparece timidamente nos planejamentos estaduais. 
Para Lefébvre (2000), produzir a representação de um espaço também representa sua apropriação. A partir dessa observação, é relevante considerar que o complexo universo da cultura, da política e da ideologia está por trás dos padrões estabelecidos para os espaços, das formas criadas, dos usos do solo e dos arranjos locacionais (MORAES, 2005).

Heidrich (2009), avaliando as Unidades de Conservação como estratégia territorial de preservação da natureza e áreas de implantação de novas territorialidades, aponta que a relação geradora do território e da territorialidade envolve poder. Ao citar Arendt (1999), o autor reafirma que tal poder existe somente nessa relação, sendo, portanto, não armazenável. A partir dessa ideia, é plausível afirmar que todas as categorias de uso do solo, consideradas nas normativas e no ordenamento territorial, são igualmente estratégias perpassadas por relações de poder. A noção de território, assim, implica o domínio sobre uma extensão e uma delimitação, em relação com outros domínios, em um conjunto de relações não armazenáveis.

Para Moraes (2005) a disposição dos objetos fixados ao solo e sua datação conferem à paisagem uma historicidade do ser humano. Para o autor, essa agregação do trabalho ao solo é o reflexo das representações que humanos estabelecem com seu espaço. As paisagens, como representação, desenhar-seiam a partir dessa apropriação, como fotografias, interpretativas das relações de poder, que, sucessivamente, conformam o filme da disposição dos objetos ao longo de nossa história.

A ocorrência pertinente à ação, esta a qual permite a fixação, a separação, o uso e a posse, vai para além da paisagem, a qual, contemplável, é posterior ao território, este enquanto sistema material, cuja produção é atrelada a um valor de uso (RAFFESTIN, 2009). Não se trata apenas de traçar limites ou distribuir objetos no espaço. $O$ elo entre ator e objeto resulta nessas marcas objetivadas em busca do domínio sobre o espaço (HEIDRICH, 2009). Essas marcas também podem representar possibilidades futuras de novos domínios, reproduzindo as relações sociais entre os atores mediante as possibilidades de produção da natureza que aí se abrem.

Enquanto conjunto de estratégias não territoriais que garantem as territoriais, a política oferece diversas possibilidades de intervenção, fortemente controladas 
pelas elites. São nas brechas das estratégias ao planejamento que se abrem as táticas para a inserção das agendas das diferentes camadas da sociedade civil no processo decisório, não em igualdade de condições, mas mediadas pelo poder e, frequentemente, no caso brasileiro, pela corrupção. A conformação territorial resultante é também resultado da mediação por estratégias e táticas, segundo a inserção dos atores no processo político.

É por isso que podemos afirmar que o cerne dos aspectos aqui analisados se baseia no fato de que a ocupação, o uso e a representação são aspectos constituintes da produção do território (HEIDRICH, 2009) e da natureza, já que a produção desta está atrelada à produção territorial. Portanto, a análise de como esse território é representado é fundamental para o entendimento das relações de poder que o condicionam como tal e que permitem, ou não, a participação dos sujeitos, o envolvimento dos distintos atores e a idoneidade dos agentes e da sociedade política, refletindo-se na forma como se organiza o Estado na questão ambiental.

É importante compreender como as relações de poder ocorrem em diferentes escalas geográficas, variando do âmbito de ação do indivíduo aos limites de ação das sociedades políticas, mas sempre ligadas à objetividade de um ator (HEIDRICH, 2009). Na medida em que essas relações derivam de ações sociais, elas mantêm íntima ligação com o processo que, de uma forma abstrata, mas sempre reportada à objetividade da expressão espacial, leva à conformação das redes de solidariedade.

A questão ambiental e o desenvolvimento sustentável, como elementos-chave do planejamento estadual e dos planos diretores municipais mato-grossenses, demandam o encadeamento de decisões e ações. Tanto no planejamento quanto nas ações, incorporar-se-ia a representatividade da sociodiversidade vinculada à biodiversidade, de forma a convergir para o desenvolvimento sustentável desde o âmbito federal até as municipalidades. Teria sido isso alcançado no planejamento mato-grossense e nos planos diretores municipais? Quase retórica, a resposta a essa questão é contundente se esmiuçarmos as possibilidades de informação providas pelos níveis governamentais e os espaços decisórios que podem ser compartilhados. 
Como prolegômenos ao que virá, adiantamos algumas observações relativas a tais portais. Chama a atenção, por exemplo, a descontinuidade de dados sobre a estrutura ambiental e a participação social nesse setor, tanto em bases de dados federais quanto estaduais e municipais. Sobre a sociodiversidade, há alguns equívocos sobre a estimativa dos povos que constituem o território nacional. As bases de dados referentes ao perfil dos municípios brasileiros, disponível para a população pelos portais de estatística federal, frequentemente fazem levantamentos que consideram apenas a população branca e a afrodescendente, parte da constituição étnica nacional. Desprezamos o uso de tais arrolamentos, pois, neles, a população de negros levantada foi de $75 \%$ em estados de sabida ancestralidade indígena, como Amazonas, Pará e Roraima. Com base nas experiências anteriores da pesquisadora em censos populacionais, apontamos que tal erro se deu no momento da autodeclaração: perguntados seu reconhecimento como brancos ou negros, os indígenas categorizaram-se por aproximação, ou de cor de pele ou de exclusão social, reportando-se majoritariamente como negros.

Sobre aspectos socioambientais e de participação nesse setor, as melhores informações se encontram sistematizadas nos portais do IBGE, sobretudo na descrição dos perfis municipais ${ }^{11}$. No entanto, a descontinuidade de dados sobre todo o período anterior e posterior a 2002 se concretiza em todas as esferas governamentais. Chegamos a especular a razão pela qual os levantamentos sobre meio ambiente no Brasil foram realizados com robustez apenas em 2002. Poderíamos levantar a possibilidade de tal estudo fazer parte das discussões referentes à Cúpula Mundial sobre Desenvolvimento Sustentável (Rio+10). Isso porque tais dados vêm à luz após o encontro. Tais recenseamentos, mais detalhados, coincidem com o momento de discussão da fragilidade das instituições ambientais, já apontadas no início da década de 1990 e não superadas pelo PPG7, no qual também se buscava encontrar consensos sobre a agenda ambiental (FELDMAN, 2002). Basicamente, os dados que apresentam maior descontinuidade se referem à composição dos conselhos ambientais e à origem de seus representantes. Outro dado levantado exclusivamente no ano de 2002 diz

11 É uma informação importante a tentativa de centralização dos dados ambientais dos níveis governamentais nas bases do IBGE, com tratamento estatístico adequado e com validação dos dados (IBGE, 2016). 
respeito ao grau de instrução nos quadros institucionais em meio ambiente. Em ambas as investigações ainda se mostrava evidente a fragilidade institucional e de representatividade no Mato Grosso e nos demais estados da Amazônia Legal quanto à questão ambiental.

Apesar da fragilidade de informações disponíveis à população, usadas pelas organizações socioambientalistas para a pauta de seus argumentos, vemos que o estado do Mato Grosso seguiu uma tendência nacional, ainda que sensível neste estado quando comparado com outros estados do Norte e do Nordeste, de diminuição das desigualdades, medidas aqui pelo índice de Palma ${ }^{12}$ (Figura 2). É possível que a redução de até um ponto nos índices de vários estados da Federação tenha se dado pela atenção do Governo Federal a demandas sociais de base, protagonizadas pela sociedade organizada em diversos setores e manifestas pela ampliação dos programas de assistência social.

Os diversos setores do Estado brasileiro (ambiente, participativo, transparência) orientam-se pelos mesmos princípios de cooperação entre os níveis da Federação. Assim, a assunção de atribuições em qualquer área das políticas públicas é diretamente associada à estrutura de incentivos oferecida pelo nível de governo interessado na transferência de atribuições. Essa observação não se aplica na ausência de interposições constitucionais (ARRETCHE, 2000, p. 52).

Para estimular a colaboração entre os entes governamentais e diminuir os possíveis ônus econômicos, a Lei Complementar 140/11 define as competências dos entes federativos, 23 anos depois de estabelecida a Constituição. Propõe uma série de mecanismos para a cooperação institucional (art. 4), como os consórcios públicos, convênios, acordos de cooperação técnica e outros instrumentos similares com órgãos e entidades do Poder Público (respeitado o art. 241 da Constituição Federal); a Comissão Tripartite Nacional, as Comissões Tripartites Estaduais e a Comissão Bipartite do Distrito Federal; os fundos públicos e privados e outros instrumentos econômicos; a delegação de atribuições de um ente federativo a outro; e a delegação da execução de ações administrativas de um ente federativo a outro, desde que o ente delegado disponha de órgão capacitado a renda dos $10 \%$ mais ricos e os $40 \%$ mais pobres, relação em que se localiza a desigualdade. 
atender à demanda, com técnicos habilitados e em número suficiente, e de conselho de meio ambiente, formado por representantes da sociedade civil e do governo.

\section{Figura 2. Índice de Palma nos estados brasileiros entre 2004 e 2012}

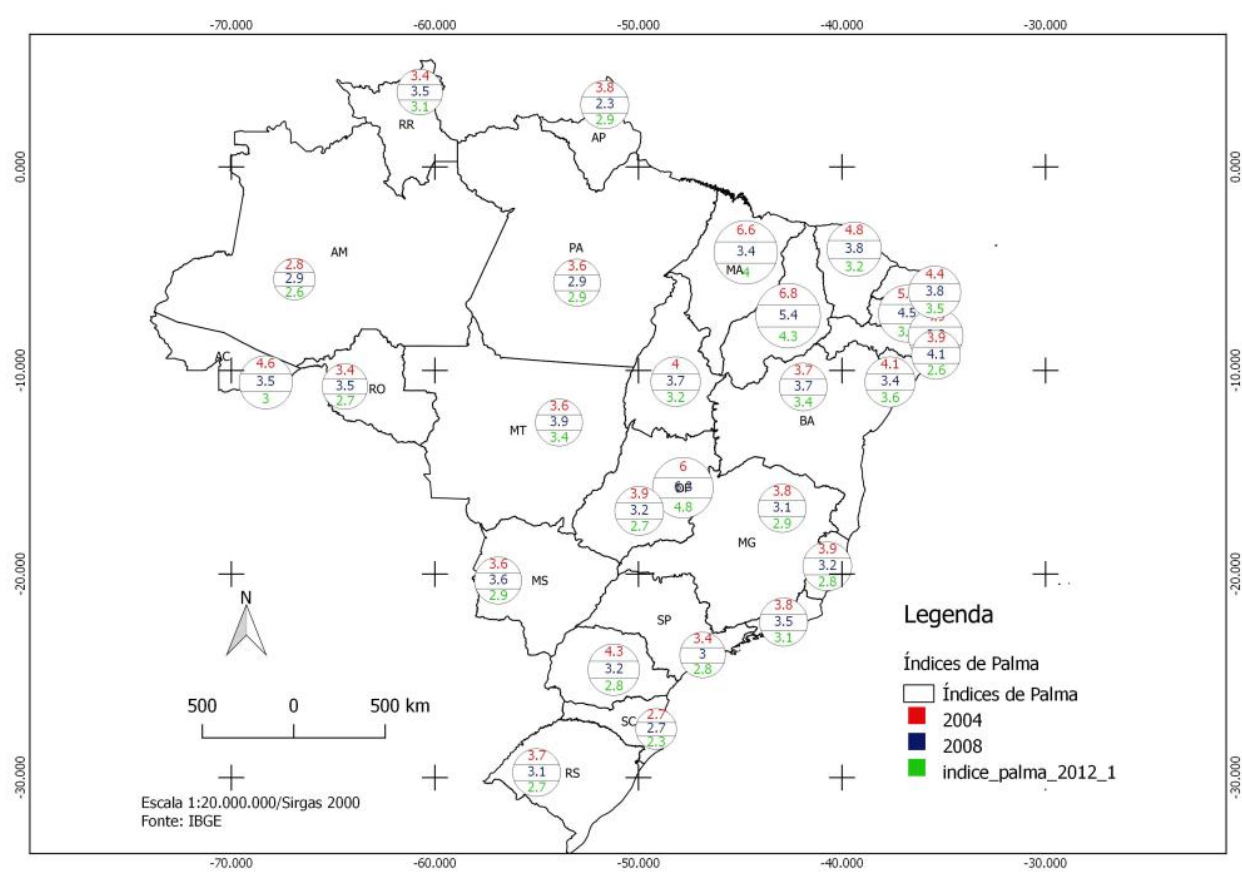

Fonte: IBGE (2015). Elaboração própria.

No que se refere à transferência de recursos do Governo Federal ao Mato Grosso no período entre 2007 a 2017 (único período disponível de dados nesse quesito pelos portais de transparência) ${ }^{13}$, é possível notar como a desigualdade de distribuição dos recursos na esfera federal se consolida no reparte de tal orçamento nos estados e, por conseguinte, nos municípios. Nota-se, por exemplo, que praticamente não foram repassados recursos para a gestão ambiental ao estado no período de 2007 a 2015 (Gráfico 19).

Talvez seja por essa razão que apenas uma média de $40 \%$ dos municípios de cada estado da Amazônia Legal possui fundo ambiental municipal, com poucos projetos na área ambiental em finais de 2012 (Quadro 2).

13 Durante a realização da pesquisa, houve profunda mudança nos formatos e dados disponíveis nos portais de transparência. Alguns dados levantados anteriormente a esse período não foram localizados. Exemplo disso são os dados orçamentários do MMA. Foram considerados dados bianuais, desconsiderando o ano de 2017, incompleto no momento desta pesquisa. 


\section{Gráfico 19. Recursos públicos transferidos da União para o estado do Mato Grosso, em R\$ milhões}

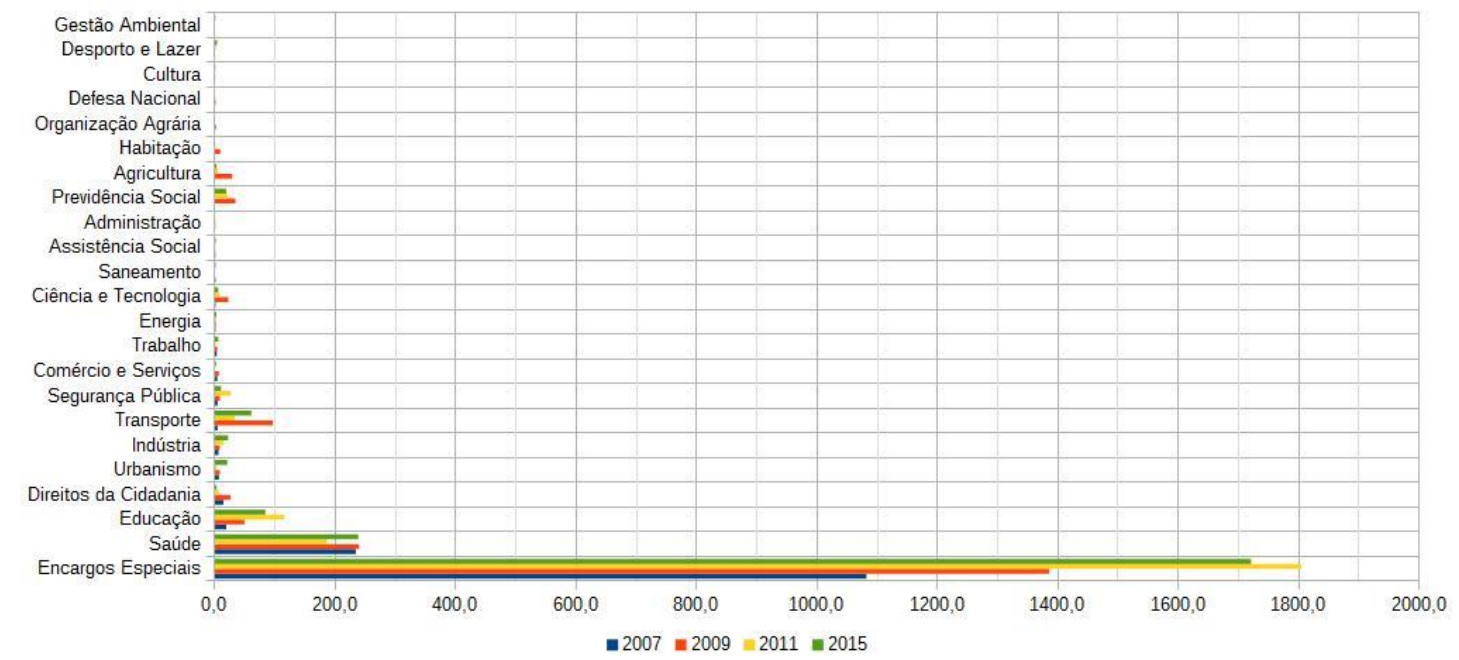

Fonte: Governo Federal (2015).

Algumas contradições aparecem quando se comparam as informações sobre o estado do Mato Grosso, sua inserção política, econômica e ambiental no País e as projeções no PLP mato-grossense. As informações que sustentam os macro-objetivos são pouco precisas na identificação das fontes de dados. Apesar de se mencionar repetidas vezes a importância da participação da sociedade civil no planejamento, também poucas são as evidências apresentadas de como e quando essa participação ocorre e como se espera ampliá-la. Igualmente, não há evidência, ao longo do documento, que aponte as formas pelas quais as organizações da sociedade civil cooperaram para a elaboração do Plano.

O problema de se traçarem metas ao planejamento, devido à falta de dados completos e validados sobre as diversas variáveis ambientais e sociais, não é um problema restrito à realidade mato-grossense, entretanto. Mello-Théry (2011), ao se referir sobre as diferenças entre os valores das fontes que calculam as áreas de floresta, cerrado, água e superfície total da Amazônia Legal, menciona que "a definição da Amazônia é tão variável quanto suas fronteiras" (pp. 113-114). Com base nos levantamentos da autora, variáveis como a mensuração da área de florestas podem ter uma diferença, entre os valores das diversas fontes que estudaram a questão, que alcança $1.000 .000 \mathrm{~km}^{2}$. Essa 
variabilidade das medidas dos limites físicos e de vegetação é, portanto, vista com cautela por produtores e usuários de informações estatísticas, geográficas e ambientais. Isso porque margens de erro dessa proporção podem ter implicações importantes à agenda governamental.

\section{Quadro 2. Municípios, total, com Fundo Municipal de Meio Ambiente na Amazônia Legal (2012)}

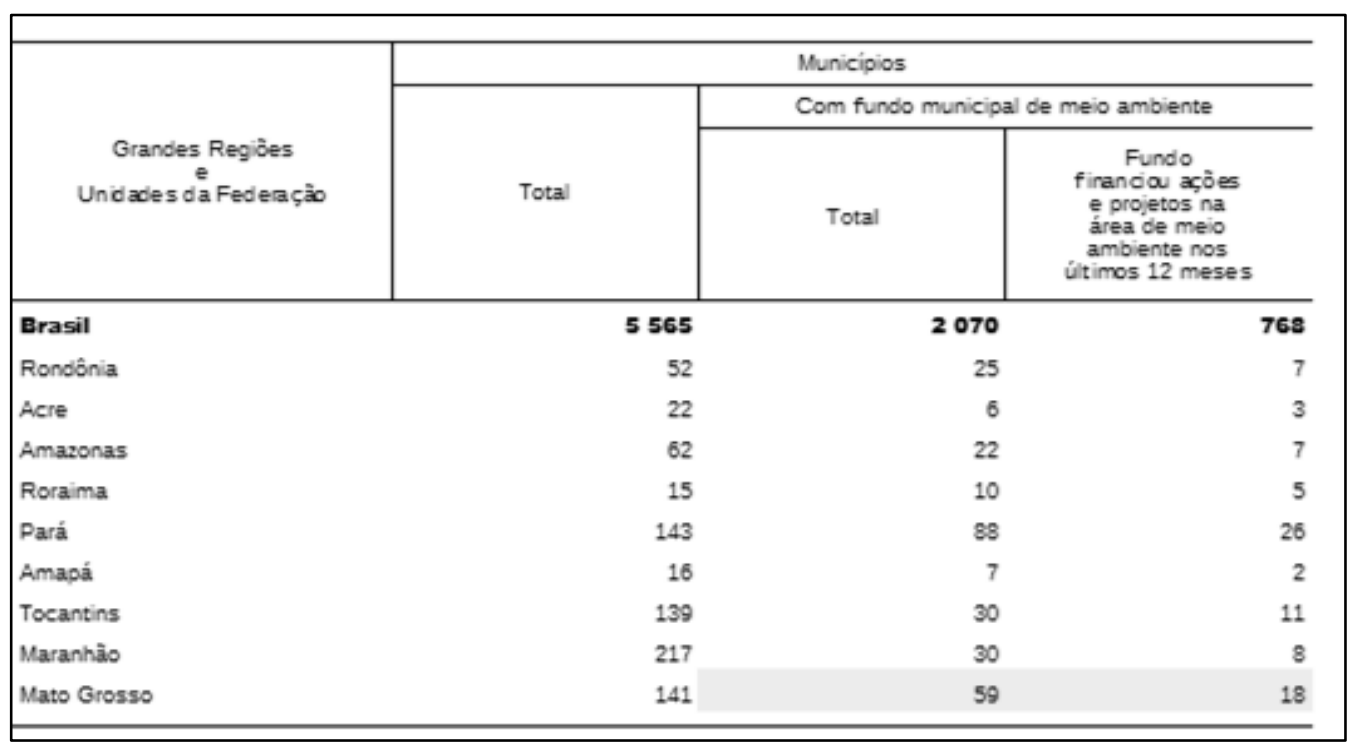

Fonte e elaboração: IBGE (2012). Adaptação própria.

Possíveis repercussões desses erros não estão ligadas apenas à accountability ${ }^{14}$ pelas populações que devem ser envolvidas no processo, mas também à impossibilidade de estabelecer metas tangíveis de planejamento. Previsto em 2011 e publicado em 2012, o PLP já demonstra que muitas das metas previstas para 2015 não foram alcançadas. Dos 12 macro-objetivos publicados em 2012 e com horizonte até 2031, três serão considerados aqui como relevantes metodologicamente a esta análise: o primeiro, referente às metas globais para conservação ambiental e práticas sustentáveis no uso de recursos naturais; o quarto, sobre o fortalecimento da capacidade científica e inovação tecnológica no estado; e o sexto, relativo à redução de pobreza e riscos sociais, detalhados na Quadro 3.

14 Termo cuja tradução ao português ainda é complexa, já que denota mais do que apenas a responsabilidade pela transparência. Diz respeito ao reconhecimento e à assunção de responsabilidades por ações, decisões e políticas, incluindo a governança e implementação de medidas de escopo administrativo. 
Quadro 3. Macro-objetivos do Plano de Longo Prazo mato-grossense, entre 2011 e 2031

\begin{tabular}{|c|c|c|}
\hline \multirow{9}{*}{ Macro-objetivo 1} & Objetivo específico & Indicador \\
\hline & \multirow{2}{*}{$\begin{array}{l}\text { Ampliar conhecimentos e } \\
\text { melhorar a gestão da } \\
\text { biodiversidade }\end{array}$} & Áreas protegidas \\
\hline & & $\begin{array}{l}\text { Áreas remanescentes de } \\
\text { vegetações nativas }\end{array}$ \\
\hline & $\begin{array}{c}\text { Controlar o uso dos recursos } \\
\text { naturais }\end{array}$ & Áreas desmatadas \\
\hline & $\begin{array}{l}\text { Melhorar a gestão dos } \\
\text { recursos hídricos }\end{array}$ & Qualidade da água \\
\hline & $\begin{array}{l}\text { Ampliar a recuperação de } \\
\text { áreas degradadas }\end{array}$ & $\begin{array}{l}\text { Áreas de florestas em } \\
\text { regeneração }\end{array}$ \\
\hline & $\begin{array}{c}\text { Melhorar o controle de } \\
\text { contaminações e poluições } \\
\text { ambientais }\end{array}$ & Qualidade do ar \\
\hline & \multirow[t]{2}{*}{$\begin{array}{l}\text { Implementar ações de } \\
\text { proteção do clima }\end{array}$} & $\begin{array}{c}\text { Emissões de gases de efeito } \\
\text { estufa, decorrentes de } \\
\text { desmatamentos e } \\
\text { queimadas }\end{array}$ \\
\hline & & $\begin{array}{l}\text { Emissões de gases de efeito } \\
\text { estufa, decorrentes da } \\
\text { agropecuária }\end{array}$ \\
\hline \multirow[t]{3}{*}{ Macro-objetivo 4} & \multirow{3}{*}{$\begin{array}{l}\text { Desenvolver ambientes } \\
\text { favoráveis à inovação e } \\
\text { competitividade }\end{array}$} & $\begin{array}{l}\text { Pesquisador por milhão de } \\
\text { habitantes }\end{array}$ \\
\hline & & $\begin{array}{l}\text { Percentual de receita total em } \\
\text { gastos em pesquisa e } \\
\text { desenvolvimento }\end{array}$ \\
\hline & & $\begin{array}{l}\text { Percentual da receita total em } \\
\text { gastos com ciência e } \\
\text { tecnologia }\end{array}$ \\
\hline \multirow{4}{*}{ Macro-objetivo 6} & \multirow{4}{*}{$\begin{array}{c}\text { Redução de pobreza e } \\
\text { concentração de renda no } \\
\text { estado }\end{array}$} & $\begin{array}{c}\text { Percentual da população em } \\
\text { situação de pobreza }\end{array}$ \\
\hline & & $\begin{array}{l}\text { Percentual da população em } \\
\text { situação de extrema pobreza }\end{array}$ \\
\hline & & Índice de Gini \\
\hline & & Índice $L$ de Theil \\
\hline
\end{tabular}

Fonte: SEPLAN, 2012, pp. 28-35.

Do macro-objetivo 1, selecionamos o quesito "controle de desmatamento" e "redução de emissões de gases de efeito estufa". Em termos de desmatamento, a projeção era reduzir de 828 hectares para a meta de 621 hectares em área degradada, segundo o documento oficial do $\operatorname{SEPLAN}(2012$, p. 28). A medida usada no documento impresso é equivocada, pois se refere a 828 quilômetros quadrados em 2010, número elevado a $1.036 \mathrm{~km}^{2}$ entre agosto de 2014 e julho de 2015, com 
redução para 949 km² entre agosto de 2015 a julho de 2016, observáveis no Gráfico 4.

Quanto à redução das emissões, a combinação entre a expansão da atividade agroexportadora e a perda de biodiversidade é um fator que aumenta a suscetibilidade à emissão de gases de efeito estufa (SEPLAN, 2012, p. 28). O Centro-Oeste está em terceiro lugar no ranking de emissões nacionais, com $21 \%$. Usamos como parâmetro o carbono equivalente com potencial influência no balanço energético terrestre (GWP), pela métrica do segundo relatório do IPCC (AR2).

Os picos de emissões condizem com os períodos de maior desmatamento (Gráfico 20) no estado. Dessas emissões, 8\% foram por energias fósseis, 56\% por mudança de uso na terra (destes, 92,4\% por alterações de uso do solo; 3,6\% por calagem e $4 \%$ por queima de resíduos), 34\% pela agropecuária, 1\% por resíduos e 1\% pela atividade industrial. A redução prevista no PLP de 5\% para 2015 não é clara em relação a qual emissão seria diminuída, sendo difícil precisar se este objetivo foi alcançado.

Para o macro-objetivo 6 (SEPLAN, 2012, p. 32) tomemos o Índice de Gini como parâmetro de análise. Apesar dos elevados Produto Interno Bruto (PIB) em cada região, descritos com pormenores no final deste texto, e da alta produtividade e exportação de soja, o Índice de Gini de Mato Grosso oscila entre 0,857 em 1985, 0,856 em 1995/1996 e 0,854 em 2006 (IBGE, 2006), sendo um dos estados mais desiguais no País, apesar dos grandes ingressos pela produção de soja e cana-deaçúcar, os quais não se traduzem em uma garantia de políticas sociais, sanitárias e ambientais minimamente apropriadas para a sociedade, principalmente os indígenas (autodenominados, dispersos ou em Terras Indígenas - Tls), assentados, produtores familiares e quilombolas que, juntos, configuram o perfil socioambiental do estado. 


\section{Gráfico 20. Emissões no estado do Mato Grosso entre 1990 e 2014, em Mt CO2e (t) GWP-AR2}

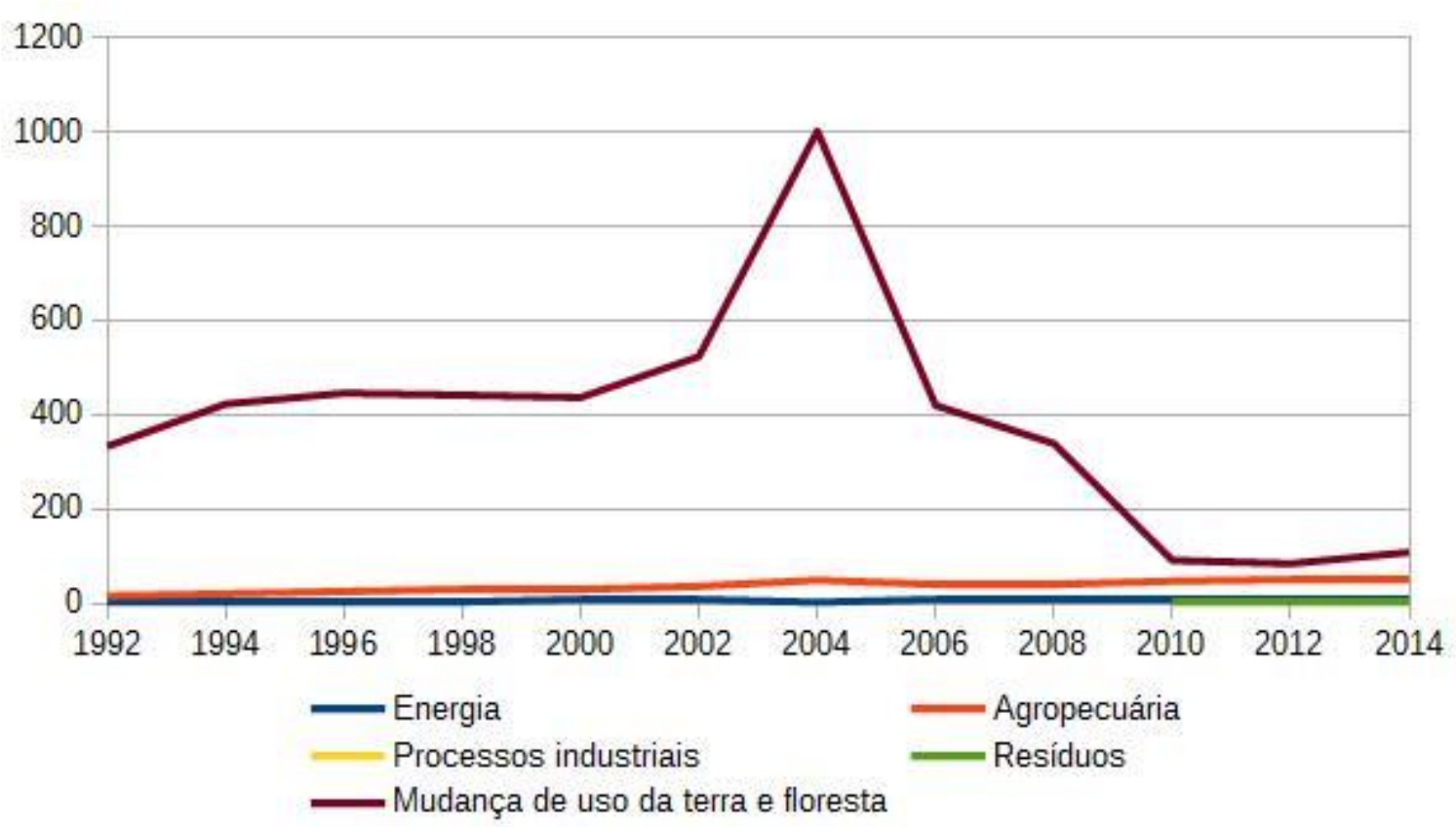

Fonte: Observatório do Clima (2016). Elaboração própria.

A qualidade da produção científica e o desenvolvimento tecnológico são um dos aspectos relacionados. Uma matriz diversa de pesquisas, contemplando igualitariamente as áreas do conhecimento, é elemento fundamental para a criação de tecnologia necessária às demandas de um determinado contexto. Ademais, bons repositórios de pesquisas são de extrema importância para que haja contestação da sociedade civil fundamentada durante as mesas de negociação.

Consideramos para a análise desse parâmetro, contemplado no macro-objetivo 4 (p. 30) do PLP, a participação das instituições acadêmicas mato-grossenses. A partir dos Censos Estatísticos de Produção Acadêmica, disponíveis nas bases de dados do Conselho Nacional de Desenvolvimento Científico e Tecnológico (CNPq), avaliamos a produtividade acadêmica e tecnológica do estado em relação ao Centro-Oeste e entre este e as demais regiões brasileiras. Usamos como variáveis as grandes áreas de conhecimento, bem como a soma das produções bibliográficas, técnicas, artísticas e culturais do estado e do CentroOeste. Como resultado, o desempenho do estado é baixo em termos de representatividade quando comparado com a região Centro-Oeste, com média de 13\% das produções entre 1998 e 2010. 


\section{Quadro 4. Comparação da produção científica entre Mato Grosso e a região Centro-Oeste}

\begin{tabular}{|c|c|c|c|c|c|c|}
\hline \multicolumn{7}{|c|}{$\begin{array}{l}\text { Produção científica } \\
\end{array}$} \\
\hline Área & 1998-2001 & (Censo CNPq 2002) & $2003-2006$ & (Censo CNPq 2006) & $2007-2010$ & (Censo CNPq 2010) \\
\hline & MT & Centro Oeste & MT & Centro Oeste & MT & Centro Oeste \\
\hline Ciências Agrárias & 974 & 20789 & 5894 & 51860 & 9146 & 62110 \\
\hline Ciências Biológicas & 1303 & 17814 & 4252 & 40205 & 8549 & 58488 \\
\hline Ciências Exatas e da Terra & 1527 & 9514 & 3233 & 20107 & 5841 & 24647 \\
\hline Ciências Humanas & 3013 & 19928 & 12604 & 64513 & 16604 & 98911 \\
\hline Ciências Sociais Aplicadas & 267 & 6198 & 2071 & 17354 & 3860 & 33154 \\
\hline Ciências da Saúde & 1702 & 9176 & 4179 & 32007 & 6816 & 43411 \\
\hline Engenharias & 157 & 5346 & 1761 & 14894 & 2388 & 17238 \\
\hline Linguística, Letras e Artes & 292 & 3684 & 1551 & 15291 & 2914 & 27703 \\
\hline $\begin{array}{c}\text { Porcentagem da participação da } \\
\text { produção em C\&T }\end{array}$ & & $9,61 \%$ & & 13,06 & & 15,19 \\
\hline
\end{tabular}

Fonte: CNPq (2016). Elaboração própria.

A baixa representatividade da produção do estado no cenário nacional, dada pela interpretação de ambos os gráficos (vide Quadro 4 e 5), sugere que há muito a ser desenvolvido para que as pesquisas acadêmicas supram a quantidade de variáveis necessárias ao planejamento local. É importante ressaltar, nesse sentido, que apesar de empresas de consultoria possuírem boas estratégias de coleta e análise de dados, estas não substituem a informação produzida com o rigor científico das universidades.

O Centro-Oeste, por sua vez, participa com um dos menores índices de produção de ciência e tecnologia (6\%), quando comparado com as demais regiões (Quadro 5). Sua participação na produção de conhecimento somente é superior à região Norte (3\%).

\section{Quadro 5. Comparação da produção científica entre a região Centro-Oeste e as demais regiões brasileiras}

\begin{tabular}{|cccccc|}
\hline Região & 2002 & 2006 & 2010 & Média da Prod. em C\&T & \% Prod. C\&T \\
Centro-Oeste & 92449 & 256231 & 365662 & 238114 & 6,54 \\
Nordeste & 228625 & 603621 & 811388 & 547878 & 15 \\
Norte & 46009 & 131721 & 185342 & 121024 & 3,3 \\
Sudeste & 916242 & 2252366 & 2490580 & 1886396 & 51,8 \\
Sul & 389991 & 1034161 & 1115173 & 846441,7 & 23,0 \\
Total & 1673316 & 4278100 & 4968145 & 3639853,7 & 100,0 \\
\hline
\end{tabular}

Fonte: CNPq (2016). Elaboração própria.

Mesmo com a elaboração de relatórios pelas redes ambientalistas ou pelas Organizações da Sociedade Civil (OSC), a produção acadêmica é imprescindível para a sustentação dos argumentos necessários ao debate nos espaços decisórios. $\mathrm{Na}$ verdade, por sua facilidade de acesso e gratuidade, muitas vezes esse é o único recurso de tais atores para elaboração de análises. 
Considerando 1) a capacitação técnica e o fortalecimento institucional como bases para a descentralização governamental e a participação popular nos processos decisórios em meio ambiente; e 2) as demandas de investimento na capacitação das instituições governamentais, em vista a uma maior governança ambiental, produzidas no contexto da ampliação das obras infraestruturais, é possível afirmar que a distribuição orçamentária governamental federal (de $\mathrm{R} \$ 3.679 .870,00$ em 2009 para $\mathrm{R} \$ 100.000,00$ em 2012), repassada ao Mato Grosso, não foi eficaz no atendimento das metas previstas nos macro-objetivos analisados (GOVERNO FEDERAL, 2015).

Apesar de o PLP identificar a biodiversidade como uma das maiores potencialidades do estado e descrever a sujeição à agroexportação no mercado internacional e a insuficiência do sistema de ciência e tecnologia como estrangulamentos, as soluções apontadas não superam a dependência e sugerem muitas contradições na elaboração de soluções de planejamento. Aponta-se no documento (SEPLAN, 2012, pp. 37-48), por exemplo, a ampliação do comércio internacional com produtos agropecuários e a economia verde (mercado de carbono) como formas de superação desses mesmos problemas.

O MT+20 constitui-se o instrumento balizador na formulação dos Planos Plurianuais de 2008-2011 e 2012-2015, com expectativa de duração de vários mandatos. Por essa razão tende a dirigir as políticas setoriais em longo prazo, bem como direcionar a ação empresarial e do terceiro setor.

O MT+20 é base para a formulação dos Planos Plurianuais 2008-2011 e 2012-2015, diferentemente da sua precedente, a Política de Desenvolvimento do Estado de Mato Grosso de 2005, que não chegou a inferir no Plano Plurianual 20042007. Este e o de 2008-2011 foram elaborados com base na metodologia adotada pelo Ministério do Planejamento, Orçamento e Gestão (MPOG), que considera o programa uma forma de resolver problemas da unidade básica de gestão.

O PPA 2004-2007 incluiu participação popular com Fóruns Regionais realizados em todas as regiões do Estado e com os servidores nos Comitês Intersetoriais por áreas de Políticas Públicas: Social, Econômico, Ambiental e Instrumental (GOVERNO DO ESTADO DO MATO GROSSO, 2011, pp. 76-77). Também foi estabelecido o Plano de Trabalho Anual (PTA) como instrumento de integração plano-orçamento - com um módulo específico no Sistema Integrado de 
Planejamento, Contabilidade e Finanças (FIPLAN) -, e o Relatório da Ação Governamental (RAG), que passou a resumir as principais realizações em todos os setores da Administração Pública estadual. Já o Decreto 1.528/08 criou uma estrutura para melhor monitoramento dos programas.

Especialmente no PPA 2004-2007 houve forte atividade e participação das redes ambientalistas. Nem todas as suas demandas foram, entretanto, contempladas. Diversos projetos infraestruturais, notadamente as Usinas Hidrelétricas (UHE) e as Pequenas Centrais Hidrelétricas ( $\mathrm{PCH})$, seguiram adiante nas tramitações, apesar de amplamente rejeitadas pelos atores individuais e coletivos sensíveis à causa ambientalista. Nos espaços de negociação oferecidos (audiências e consultas, principalmente), esses atores apontaram como entraves à expansão das obras o aumento da pressão sobre os ecossistemas e os grupos que dele dependem em áreas limítrofes de conservação e proteção, aprofundando, portanto, as tensões entre as camadas sociais.

Os planos que se sucederam abordam o planejamento do estado segundo aptidões regionais. Sobre esse aspecto, cabe a retomada de alguns pontos, ainda que breves. A discussão atual sobre a pertinência da escala regional, sua relevância como instância particular de análise que se situa entre o local e o global (LENCIONI, 2005) e o caráter homogeneizador da chamada globalização sobre o regional emergem sucedendo um elenco de visões sobre a questão ${ }^{15}$. Para La Blache (1954), a região podia ser distinguida na paisagem: os seres humanos teriam consciência das regiões à medida que constroem identidades regionais, entendendo o ser humano e a natureza como não opostos. À diferença da região evidenciada na paisagem de La Blache, Hettner (1927) não a considera autoevidente. Seu cerne estaria no estudo das diferenciações da superfície terrestre, e seus limites seriam resultados de um exercício intelectual do pesquisador. Hartshorne (1939) segue este raciocínio, considerando que é na apreensão das inter-relações entre os fenômenos que a diversidade da superfície terrestre é produzida. O positivismo lógico veio antepor-se a esta visão, buscando o rigor e a neutralidade científica e a homogeneização de procedimentos e unidade. A questão do determinismo geográfico ressurge, dessa vez, como a de uma 
variável independente, sobrepondo-se às dependentes, agrupando objetos em classes segundo semelhanças. Regionalizar passou, então, a significar a classificação de regiões, antes por suas relações funcionais do que por suas características historicamente definidas.

As duas concepções de região, portanto, teriam a ver com a forma como se deu o pensamento geográfico. A primeira entende a relação entre o ser humano e o meio, ambientalista; a região é autoevidente, cabendo ao pesquisador reconhecê-la. Na segunda, o regional se conforma, no final do processo de investigação, como recorte espacial elaborado por critérios definidos, ou seja, esta linha remonta a um campo de conhecimento particular voltado a estudar as diferenciações entre as áreas. A elaboração das regiões de planejamento no estado do Mato Grosso, nos registros oficiais de tais delimitações, se deu de forma mais alinhada à segunda vertente.

A fenomenologia e o marxismo ofereceram outros caminhos ao positivismo lógico. A primeira, por discutir como o espaço é percebido, e como os valores e significados são a ele atribuídos pela cultura e estrutura social, culminando no sentido de pertencimento dos indivíduos na região. As fragilidades metodológicas frente ao positivismo lógico e a refutação a alguns vínculos com as ciências ambientais colaboraram para o relativo insucesso desta linha analítica. $O$ segundo trouxe novas categorias de análise para os estudos regionais. Ressalta-se a crítica à fetichização do espaço e a importância da reconstrução histórica para a compreensão das regiões e do processo geral de produção capitalista.

Ainda sobre a questão regional, Martin (2005) propõe que, no caso brasileiro, os desequilíbrios regionais sejam corrigidos pelo redesenho dos estados da Federação, sem prejuízo do território, mediante o estabelecimento de um novo pacto federativo e a redefinição da atual interpretação acerca da atuação da chamada globalização financeira, rompendo o movimento pendular que ora centraliza o poder na burocracia federal, ora nos governos estaduais. Para o autor, o aperfeiçoamento no federalismo brasileiro pelo reordenamento territorial ajudaria a responder às reivindicações dos subalternos.

Compreendendo a complexidade desta discussão, inclusive dentro da disciplina da Geografia, neste estudo entendemos que, apesar de necessário em algumas áreas de investigação, a concepção positivista deve ser respaldada por 
uma reflexão contextual (cultural, histórica, ambiental, social) das porções que são identificadas sob a alcunha de "região". A questão se complica quando, na multidisciplinaridade entre os tomadores de decisão, não há uma padronização do entendimento deste termo.

Segundo a Assembleia Legislativa de Mato Grosso (2003), estabelecemse as regiões de planejamento segundo parâmetros peculiares que diferenciam uma área contínua que pode ser individualizada e delimitada. Essa diferenciação é definida por uma análise do meio natural ou derivada da formação socioeconômica. Operacionalmente, e considerando a diversidade de entendimentos sobre a questão da região na Geografia, adotaremos a posição oficial como balizadora de nossas elucubrações. Nesse sentido, chamamos a atenção para como Lencioni (2005) define a instrumentalização técnico-operacional da região, em vista a organizar o espaço. Como categoria de análise geográfica voltada à elaboração dos planejamentos, a autora ressalta que tanto os planos, quanto, por conseguinte, a região, caíram em descrédito, como fruto de uma improbidade teórica e metodológica.

\subsection{A concepcão das regiões de planejamento mato-grossenses}

As regiões de planejamento mato-grossenses carregam em sua gênese e interpretação uma série de preconcepções de sua funcionalidade, a qual diz respeito à posição histórica do estado não só como fronteiriço do País, mas como provedor de recursos às metrópoles nacionais.

A regionalização do estado do Mato Grosso incluía grandes espaços com poucos municípios em meados de 1960 (VELHO, 2009). Composta por cinco zonas fisiográficas (Aripuanã, Chapada, Poxoréo, Encosta Norte e Baixada Norte), onde se distribuíam 29 municípios, os recortes eram dados essencialmente por características naturais. A partir de 1980, como resultado das intervenções infraestruturais no governo $\mathrm{JK}$, o adensamento populacional e a incipiente dinâmica econômica subdividiram essa regionalização com parâmetros pertinentes à atividade econômica e às transformações fisiográficas crescentes. Os 55 municípios foram distribuídos em mesorregiões (Norte e Sudeste mato-grossenses e Cuiabá), microrregiões (Norte, Alto Guaporé-Jauru, Alto Paraguai, 
Baixada Cuiabana, Rondonópolis e Barra do Garças). As subdivisões em meso e microrregiões passaram de seis para vinte e duas em 2007.

Até 2003 a Secretaria de Planejamento do Estado de Mato Grosso utilizava as mesorregiões do IBGE (Figura 3) para o planejamento, com ressalva feita à região do Parecis e Alto Teles Pires, por exemplo, originalmente separadas, mas unificadas no planejamento estratégico estadual (SEPLAN, 2016).

No entanto, o desenrolar das atividades econômicas e políticas desencadeou transformações territoriais que não correspondiam às meso e microrregiões definidas pelo IBGE. Tendo em conta também a necessidade de incorporar os elementos socioambientais, foi adotada a regionalização do estado produzida a partir dos estudos do ZSEE para o planejamento e dos instrumentos legais oriundos da elaboração do PPA 2004/2007. Este definiu as regiões de planejamento ao longo do processo de criação das Unidades Sócio-Econômicas-Ecológicas (USEE), para as quais foram considerados os modos de uso e ocupação e de organização da produção, os graus diferenciados de consolidação das atividades econômicas e os componentes da base natural. A esses critérios foram adicionados os estudos da hierarquia urbana, resultando nas Regiões de Influência (CAMARGO, 2011, p. 24).

Para a utilização dessas regiões nos instrumentos de planejamento (que exigem limites administrativos), foi realizado um ajuste incorporando os limites dos municípios, considerando-se que o município pertencia à região onde estava localizada a sua sede. Por conseguinte, o estado de Mato Grosso foi subdividido em 12 regiões (Figura 4), as quais passaram a responder de maneira relativamente pertinente à extensão do estado e às suas mudanças territoriais ${ }^{16}$. Cada região de planejamento seria dividida por unidades socioeconômicas e ecológicas.

16 A presente contextualização foi feita lançando mão de dados disponibilizados pelo IBGE entre os anos de 2000 e 2012. Muitas informações sobre as Regiões de Planejamento foram extraídas do Plano de Desenvolvimento do Estado de Mato Grosso - MT+20, realizado pela SEPLAN, referente ao ano de 2006. Dados mais recentes foram preteridos dado o recorte temporal da pesquisa. No entanto, não desconsideramos as tendências encontradas entre 2000 e 2012, que se afirmaram posteriormente. 
Figura 3. Regiões de planejamento no Mato Grosso anteriores ao PPA 2004-2007

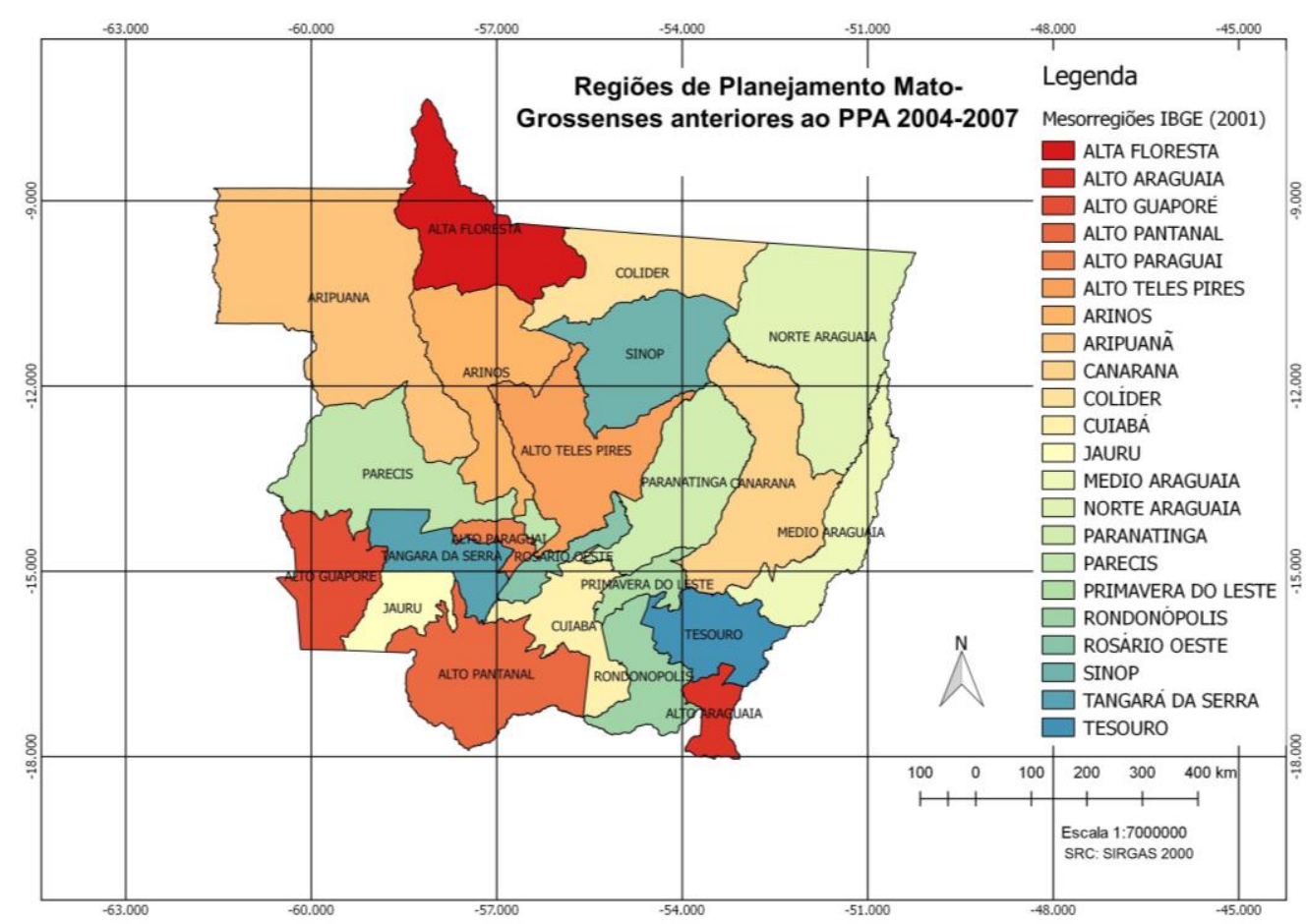

Fonte: IBGE (2001). Elaboração própria.

Sobre a institucionalidade da participação em meio ambiente (Quadro 6), $89,4 \%$ da totalidade dos municípios mato-grossenses dispõem de secretarias municipais de meio ambiente. Desses, em $55,6 \%$ dos municípios a questão ambiental é tratada entre outros temas da secretaria responsável. Em 19,1\%, a questão ambiental é plenamente subordinada a outra área. Apenas 24,6\% possuem secretaria exclusiva para a área ambiental e 0,8\% está subordinado diretamente à secretaria do Executivo. 
Figura 4. Regiões de planejamento do MT a partir do ZSEE

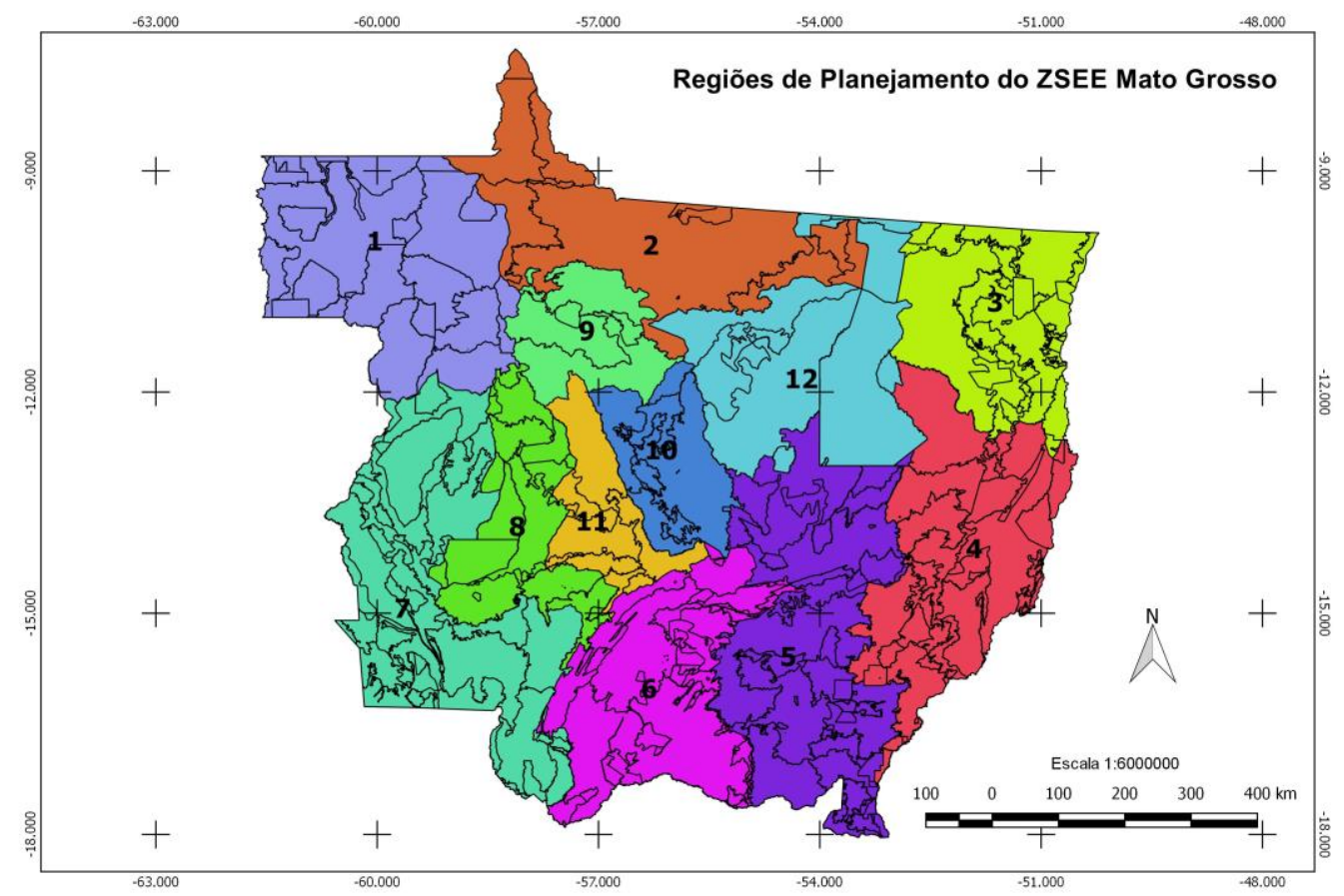

Fonte: MMA (2015).

Dadas as proporções dos municípios no estado em termos de área, tal porcentagem, já alta, toma uma proporcionalidade ainda maior em termos de espaço. Por mais que esse fato pareça preocupante para um estado com tamanha importância territorial, outros estados da Amazônia Legal possuem uma organização estatal ainda mais frágil de suas instituições ambientais.

Os conselhos ambientais no estado do Mato Grosso sempre representaram um espaço de disputa. Entre os anos de 2003 e 2012 aparecem repetidas vezes nos documentos (relatórios, reuniões, matérias de jornais e entrevistas) as dúvidas dos membros do FORMAD sobre a eficiência de tais espaços participativos. Em relação aos prós de se transitar pelos espaços dos conselhos ambientais, municipais e estaduais, alinhavam-se as organizações ambientalistas, que defendiam que seria melhor pertencer a algum espaço de negociação que a nenhum. 


\section{Quadro 6. Municípios, total e com estrutura na área de meio ambiente, por caracterização do órgão gestor, segundo as Grandes Regiões e as Unidades da Federação - 2012}

\begin{tabular}{|c|c|c|c|c|c|c|c|c|}
\hline \multirow{3}{*}{$\begin{array}{c}\text { Grandes Regiôes } \\
e \\
\text { Unidades da Federa çào }\end{array}$} & \multicolumn{8}{|c|}{ Municipios } \\
\hline & \multirow[b]{2}{*}{ Total } & \multicolumn{6}{|c|}{ Com estrutura na área de meio ambiente, por caracterizaçâo do órgào gestor } & \multirow[b]{2}{*}{$\begin{array}{l}\text { Nâo possui } \\
\text { estrutura } \\
\text { especifica }\end{array}$} \\
\hline & & Total & $\begin{array}{l}\text { Secrearia } \\
\text { municipal } \\
\text { exdusiva }\end{array}$ & $\begin{array}{c}\text { Secretaria } \\
\text { municipal } \\
\text { em conjunto } \\
\text { com outras } \\
\text { politicas }\end{array}$ & $\begin{array}{l}\text { Setor } \\
\text { subordinado } \\
\text { a outra } \\
\text { secretaria }\end{array}$ & $\begin{array}{c}\text { Setor } \\
\text { subordinado } \\
\text { diretamente } \\
\text { à chefia do } \\
\text { executivo }\end{array}$ & $\begin{array}{l}\text { Orgào da } \\
\text { adminis- } \\
\text { traçâo } \\
\text { indireta }\end{array}$ & \\
\hline Brasil & 5565 & 4926 & 1379 & 2516 & 730 & 249 & $5:$ & 639 \\
\hline Rondônia & 52 & 47 & 19 & 21 & 7 & - & & 5 \\
\hline Acre & 22 & 21 & 9 & 9 & 2 & 1 & & 1 \\
\hline Amazonas & 62 & 61 & 38 & 20 & - & 3 & & 1 \\
\hline Roraima & 15 & 14 & 7 & 7 & - & $\cdot$ & & 1 \\
\hline Pará & 143 & 142 & 110 & 26 & 4 & 2 & & 1 \\
\hline Amapá & 16 & 16 & 7 & 9 & - & $\cdot$ & & $\cdot$ \\
\hline Tocantins & 139 & 132 & 34 & 85 & 13 & - & & 7 \\
\hline Maranhào & 217 & 171 & 78 & 59 & 33 & 1 & & 46 \\
\hline Mato Grosso & 141 & 126 & 31 & 70 & 24 & 1 & & 15 \\
\hline
\end{tabular}

Fonte: IBGE (2012).

A positividade da participação se sustentava sobre outros argumentos, dentre os quais a ampliação do poder de influência nos espaços políticos e, principalmente, a ciência das estratégias e táticas de que tanto o Executivo quanto o Legislativo mato-grossenses dispunham para fazer valer seus interesses. Os que se posicionavam contra alegavam que a participação das organizações ambientalistas acabava por legitimar as decisões tomadas nessas esferas de poder, imobilizando os argumentos da rede. Seguiu-se então uma sequência de tentativas de inserção nesses espaços participativos, com sucessos e fracassos.

Como podemos depreender do Quadro 7, grande parte dos conselhos ambientais municipais assume funções normativas, consultivas, fiscalizadoras e deliberativas, por meio de reuniões. Grande parte também possui reuniões, no mínimo, anuais. No entanto, nas bases de dados do MMA, especificamente do CONAMA, registra-se que a atividade dos conselheiros é menos frequente do que o retratado pelo levantamento do IBGE. Segundo o levantado pela autora, por meio de buscas por município do estado nessas bases de dados, há atividade periódica ao longo do ano nesses conselhos municipais em menos de 30 municípios. Sobre 
o conteúdo das reuniões, os relatórios das assembleias do FORMAD apontam controvérsias, por exemplo, nos processos de aprovação orçamentária, apontados como tendenciosos a determinados grupos internos.

\section{Quadro 7. Municípios, total, dos estados da Amazônia Legal com Conselho Municipal de Meio Ambiente, por algumas características do conselho - 2012}

\begin{tabular}{|c|c|c|c|c|c|c|c|c|}
\hline \multirow{5}{*}{$\begin{array}{c}\text { Grandes Regiôes } \\
\text { Unidades da Federaçầo }\end{array}$} & \multicolumn{8}{|c|}{ Municipios } \\
\hline & \multirow{4}{*}{ Total } & \multicolumn{7}{|c|}{ Com Conselho Municipal de Meio Ambiente } \\
\hline & & \multirow{3}{*}{ Total } & \multicolumn{6}{|c|}{ Algumas características do conselho } \\
\hline & & & \multirow[b]{2}{*}{ Paritário } & \multicolumn{4}{|c|}{ Caráter do conselho } & \multirow{2}{*}{$\begin{array}{l}\text { Realisou } \\
\text { reuniâo nos } \\
\text { útimos } 12 \\
\text { meses }\end{array}$} \\
\hline & & & & Consultivo & $\begin{array}{l}\text { Delibe- } \\
\text { rativo }\end{array}$ & Normativo & Fiscalizador & \\
\hline Brasil & 5565 & 3540 & 3247 & 2788 & 296 & 1422 & 1656 & 2674 \\
\hline Rondônia & 52 & 29 & 23 & 21 & & 14 & 15 & 19 \\
\hline Acre & 22 & 12 & 12 & 11 & & 7 & 6 & 9 \\
\hline Amazonas & 62 & 34 & 30 & 27 & & 18 & 15 & 24 \\
\hline Roraima & 15 & 11 & 11 & 6 & & 4 & 7 & 9 \\
\hline Pará & 143 & 100 & 88 & 82 & & 41 & 45 & 84 \\
\hline Amapá & 16 & 10 & 10 & 10 & & 10 & 10 & 9 \\
\hline Tocantins & 139 & 76 & 75 & 62 & & 46 & 58 & 53 \\
\hline Maranhâo & 217 & 56 & 52 & 40 & & 28 & 35 & 49 \\
\hline Mato Grosso & 141 & 87 & 79 & 57 & & 32 & 35 & 61 \\
\hline
\end{tabular}

Fonte: IBGE (2012).

Nas estimativas do IBGE em 2002 (Quadro 8), as últimas que mensuravam a atividade dos conselhos ao longo do ano, registrou-se, por exemplo, que foram realizadas reuniões mensais dos conselhos ambientais em 13 municípios; 10 realizaram encontros bimestrais; quatro conselhos, encontros quadrimensais; três tiveram apenas uma reunião ao longo do ano, e dez deles tiveram reuniões em periodicidades irregulares (IBGE, 2002).

Apesar da recente tendência de conversão dos conselhos gestores deliberativos em consultivos, notou-se na Amazônia que os conselhos municipais de meio ambiente seguiram uma linha mais de conselhos deliberativos do que de consultivos entre 2002 e 2012, inclusive com grande expansão de seu número nos municípios. 
Quadro 8. Municípios, total e com existência e características de conselhos municipais de meio ambiente, ano-base 2002

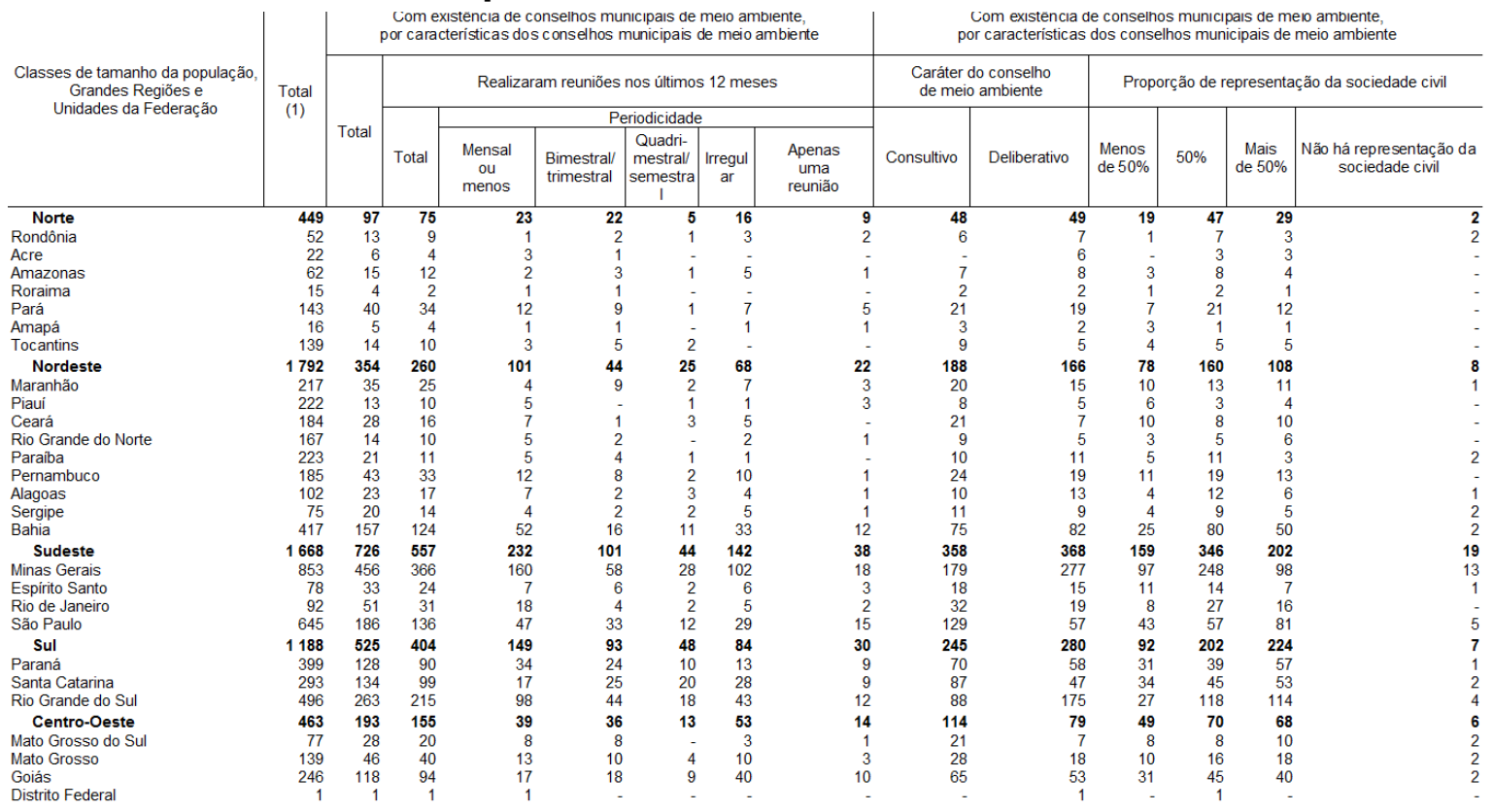

Fonte: IBGE (2002). (1) Inclusive os ignorados e sem declaração de existência.

Ressaltamos, porém, a dificuldade de mensuração da efetividade e eficácia dessa expansão, por falta de dados que sustentem essa análise nas bases de dados dos entes federativos.

\subsection{A produção de soja e cana-de-acúcar no estado do Mato Grosso}

A fronteira agrícola cresce ao longo de todo o intervalo de tempo considerado neste estudo, ou seja, entre 1992 e 2012, e avança ao norte do Mato Grosso, na zona de contato entre os biomas Amazônia e Cerrado, em direção aos ambientes florestais amazônicos, com predominância do cultivo de grãos como soja e milho; em menor proporção, há o avanço de pastagens ligadas à pecuária bovina (IBGE, 2016a).

A produção da soja em escala industrial remonta ao início da década de 1970 (MINTER, 1989, p. 8), quando a introdução dos primeiros cultivos dessa oleaginosa foi possível depois das pesquisas agropecuárias e da oferta de incentivos governamentais. Já apareciam como regiões potencialmente produtoras os estados de Mato Grosso, Tocantins, Rondônia e o nordeste do Maranhão (Figura 5). Na década de 1990 os cultivares já haviam reconfigurado o território amazônico 
mato-grossense juntos à exploração madeireira, ambos abrindo novas frentes de expansão do agronegócio, ainda em curso.

O principal bioma afetado pela expansão das frentes agrícolas é o Cerrado. Apesar de bastante resiliente a impactos ambientais sucessivos, a intensidade de uso da terra já comprometeu a diversidade do bioma e das sociedades que dependem dele para sua produção em pequena escala. Estimativas do IBGE indicam que o Cerrado é o segundo bioma brasileiro em número de espécies de flora e fauna em extinção (131 e 99, respectivamente $)^{17}$.

Uma das consequências, observadas ao longo deste estudo, é o aumento da vulnerabilidade social dos grupos que dependem da disponibilidade desses recursos, de sua abundância e diversidade genética. No caso de Mirassol d'Oeste, caso observado presencialmente pela pesquisadora e autora deste trabalho, tal vulnerabilidade se reflete sobre coletivos de mulheres que usam a flora local para complementação de renda familiar.

A discussão internacional em prol da diversificação na matriz energética é um argumento que impulsiona o padrão de uso da terra no estado do Mato Grosso, enquanto produtor de matéria-prima para biocombustíveis. Exemplos dessa influência são a expansão das áreas agrícolas voltadas para a produção de soja (Figura 5 e Gráfico 21) e a arbitrariedade nas mudanças no Zoneamento Ecológico e Econômico Estadual associadas às alterações da Lei 12.651 de maio de 2012, o Código Florestal.

Em termos de ranking internacional, o Departamento de Agricultura dos EUA (USDA) aponta que o total de soja produzida no mundo foi de 312,362 milhões de toneladas em 2015, demandando 119,73 milhões de hectares de área plantada. O primeiro produtor mundial do grão são os Estados Unidos, produzindo 106,9 milhões de toneladas em uma área de 33,109 milhões de hectares, terras estas já distribuídas por reforma agrária.

O Brasil, ainda sem uma reforma agrária consolidada, é o segundo produtor mundial, com 95,63 milhões de toneladas que demandaram, também em 2015, 33,17 milhões de hectares de área, segundo a Companhia Nacional de extinção; a Amazônia, o terceiro (118 e 24). IBGE (2012a). 
Abastecimento (CONAB). O estado do Mato Grosso sozinho foi responsável por $27 \%$ da produção nacional (2015), ocupando 9,1 milhões de hectares.

\section{Figura 5. Expansão da fronteira agrícola no Brasil e no bioma do Cerrado em diferentes períodos}

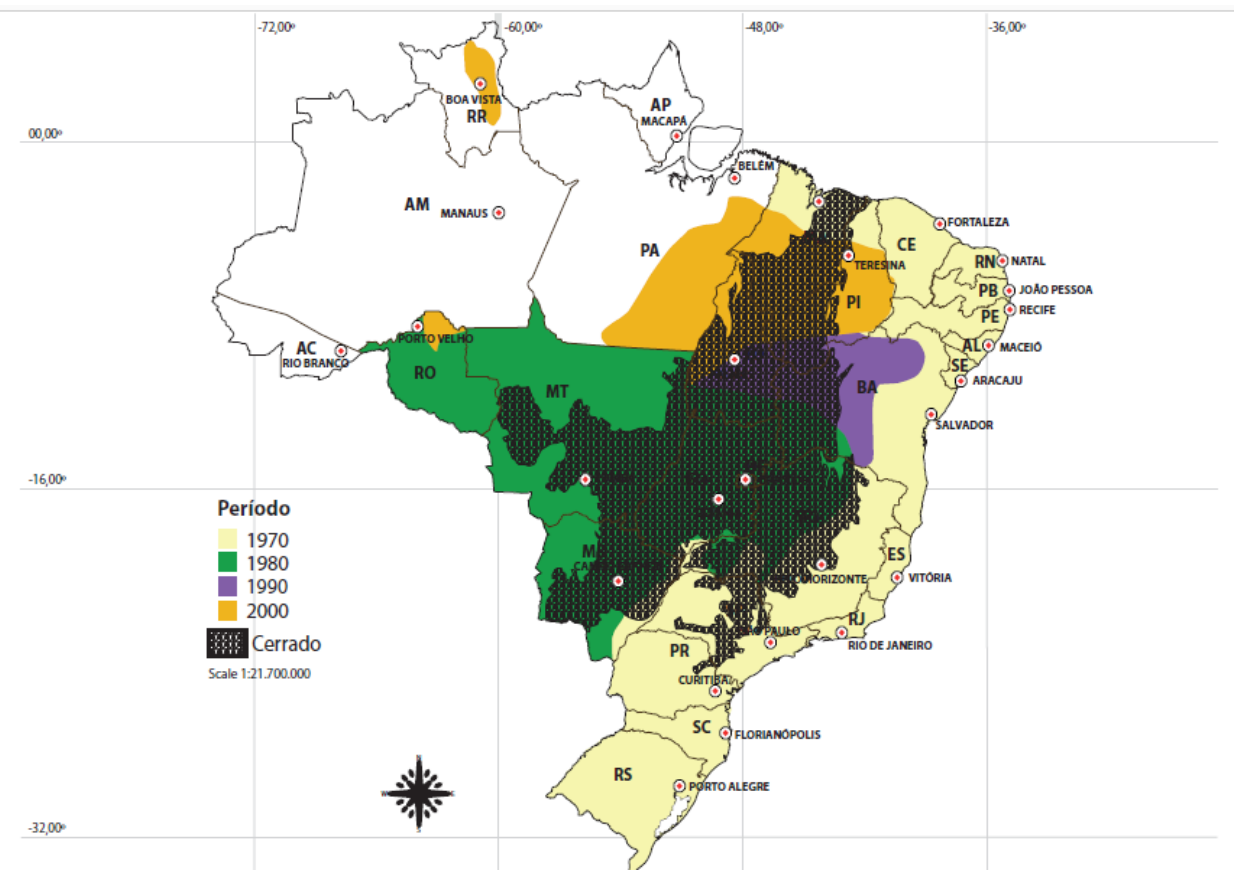

Fonte: Vieira (2016). Elaboração: José Eustáquio Ribeiro Vieira Filho. Escala: 1:21.700.000.

O Gráfico 21 demonstra as principais exportações pelo estado do Mato Grosso. A soja, o milho e seus derivados são os principais produtos exportados, e estão dentre os dez primeiros itens levantados como prioritários nos últimos anos, com grande parte do PIB estadual destinado à produção agrícola. Comparando este gráfico com o 22, vemos que, em termos de balança comercial, persiste o padrão de exportações de matérias-primas (commodities) e importações de tecnologias. Em escala nacional, a exportação de manufaturados e commodities é de $40 \%$ e $60 \%$, respectivamente, sendo a China o principal importador. A economia brasileira, portanto, se sustenta na saúde econômica da China (Castro, 2016). Os sindicatos de trabalhadores rurais notificaram, em mais de uma localidade, que os mesmos caminhões que vão para os portos brasileiros carregados com soja e milho voltam ao estado com as cargas de agrotóxicos ${ }^{18}$. nos municípios do estado, em atividade de campo anterior ao início desta tese. 
Gráfico 21. Principais exportações pelo estado do Mato Grosso entre 2006 e 2015, em US\$ F.O.B. (milhões)

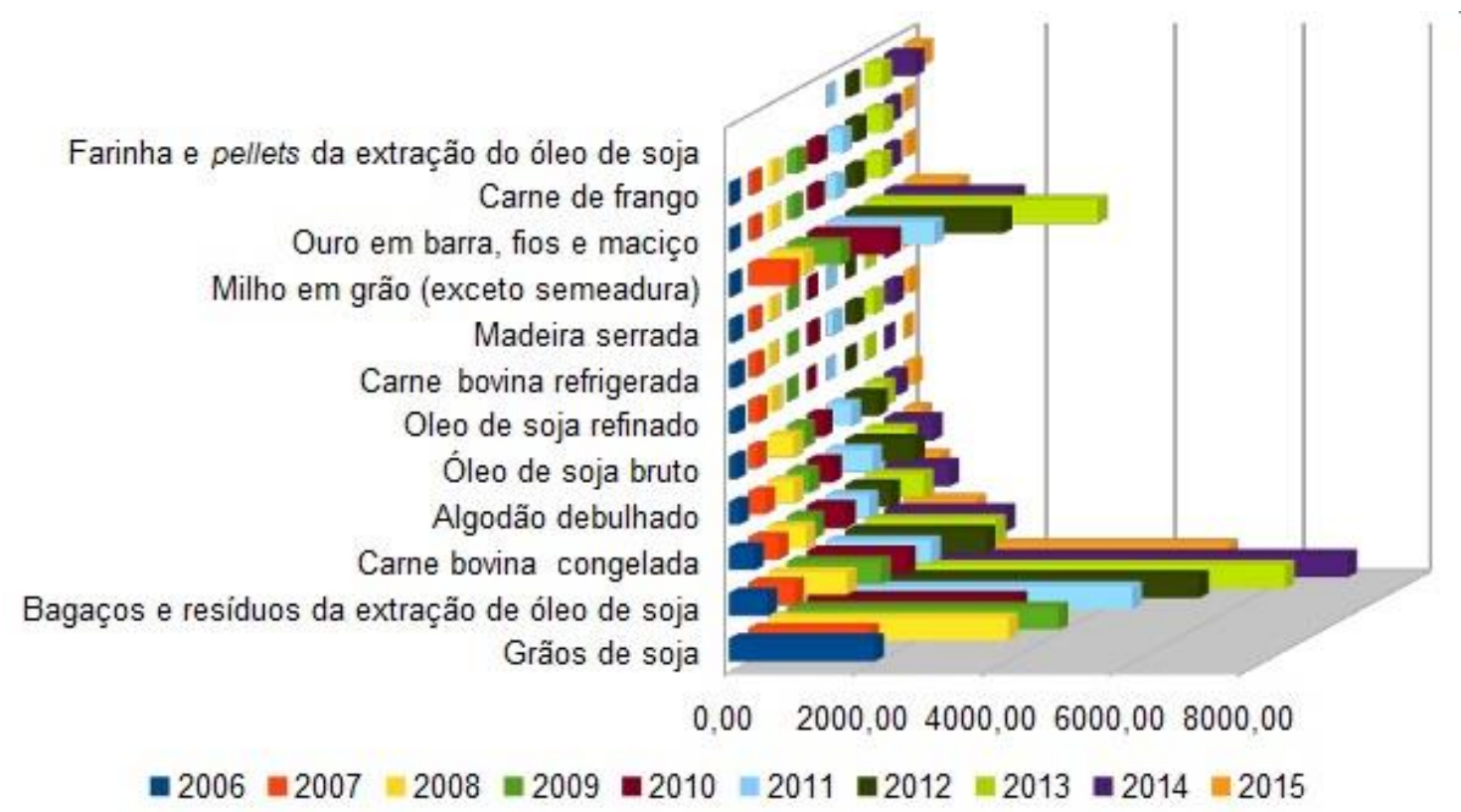

Fonte: Ministério do Desenvolvimento Indústria e Comércio Exterior (2015). Elaboração própria.

Corrobora para essa afirmação os dados de exportações e importações realizadas pelo estado do Mato Grosso, divulgadas pelo Ministério do Desenvolvimento, Indústria e Comércio Exterior (MDICE) (Gráficos 21 e 22).

Há grandes importações de fertilizantes pelo Mato Grosso, destacando-se os cloretos de potássio, superfosfato P2O5, ureia e diidrogeno-ortofosfato de amônio. Os fertilizantes representam um problema no balanço energético ecossistêmico. Nas situações de monocultura o balanço energético não se completa, tampouco os ciclos de nitrogênio e carbono, diferentemente da cobertura por florestas tropicais, onde os ciclos de nutrientes entre solo-planta e ar, como o nitrogênio e o carbono, permanecem balanceados, mantendo o sistema (CATÃO et al, 2016). Já os fungicidas e inseticidas, importados em menor proporção, são responsáveis pela extinção de importantes polinizadores e dispersores de sementes, importantes para manter o fluxo gênico das comunidades dentro do ecossistema. Nota deve ser feita à proibição da importação do glifosato em 2009, razão pela qual as estatísticas de importação desse item se estendem até 2010. 
Dependente da demanda para escoamento da soja, o Brasil acaba se tornando refém da sua exportação para manutenção do PIB. Para manter o mercado, grandes extensões de terra e uma estrutura fundiária cada vez mais concentrada são requeridas. Com amplo poder nos espaços legislativos, nos três níveis governamentais, a chamada "bancada ruralista" apresenta notável capilaridade em todos os espaços onde se possa exercer poder no estado do Mato Grosso. Essa camada social, que conforma a elite agrária do estado e tem longa tradição agroexportadora, constitui os quadros de altos cargos nas esferas governamentais, detendo privilégios não somente econômicos, mas também políticos.

\section{Gráfico 22. Principais importações do estado do Mato Grosso entre 2006 e 2015 em US\$ F.O.B. (milhões)}

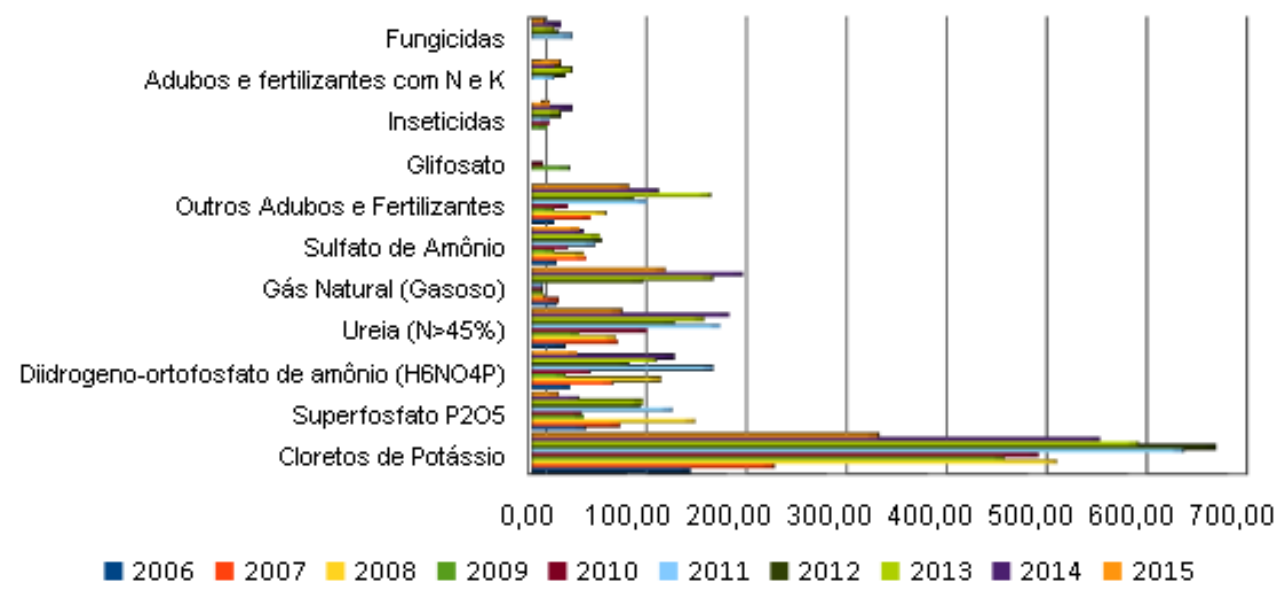

Fonte: Ministério do Desenvolvimento Indústria e Comércio Exterior (2015). Elaboração própria.

A produção às custas de uma alimentação de má qualidade dos estratos sociais menos abastados e as degradações ambientais derivadas do uso intensivo de defensivos agrícolas não é uma solução oriunda de um planejamento, mas de uma ideologia estabelecida por uma elite que se vale de múltiplos meios para naturalizá-la no senso comum.

Persiste a ideia de uma suposta limitação de produção de alimentos de qualidade a uma população em crescimento exponencial. Dessa forma, o implícito por trás da fala no Senado Federal protagonizada por Katia Abreu está na herança do raciocínio malthusiano das limitações externas ao crescimento populacional em progressão geométrica, e nas soluções partindo-se deste princípio, e não nas raízes históricas da desigualdade. 


\begin{abstract}
O grande responsável pelo motivo desta audiência pública é o autor de uma entrevista no jornal Le Monde Diplomatique Brasil, que publicou uma entrevista bastante prejudicial ao País: "Brasil Envenenado", e o subtítulo "alimentos contaminados". Então, a partir do momento que o diretor da ANVISA, que é o responsável em avaliar, aprovar ou não os defensivos para a agricultura, genéricos ou não, faz uma declaração desta na imprensa, ele tinha a obrigação de vir se justificar no Senado Federal. Ele está dando prejuízo a um patrimônio nacional, Sr. Presidente! Essas pessoas se esquecem que elas também comem e que elas querem comer barato. Se ele tem um bom salário na ANVISA, não é o caso de milhares e milhares de brasileiros que ganham salário mínimo ou que não ganham nada e, portanto, precisam comer comida com defensivo, sim! Porque é a única forma de se fazer alimento mais barato, infelizmente. Se nós pudéssemos produzir orgânico para o todo Brasil e todo o mundo, nós precisaríamos de, no mínimo (nunca fiz essa conta), mas no mínimo três Brasis, eu acho que precisaríamos, ou quatro, daí pra mais, para produzir o mesmo tanto que produzimos hoje para os brasileiros e para exportar. Então eu não compreendo onde estas pessoas querem chegar. (...) É burocracia para dificultar a vida da maioria (pausa) e beneficiar uma pequena minoria. (pausa) $\mathrm{E}$ o pior de tudo isso, o mais desonesto de tudo isso, Senador [Neri] Geller, é que a bandeira é bonita! "É a saúde humana em jogo". A população toda fica a favor deles! ${ }^{19}$
\end{abstract}

A afirmação contundente quanto à prioridade da produção agrícola em escala industrial interfere no planejamento estadual e nacional e reafirma-se nos planos de longo prazo. A interpretação da senadora sobre a divulgação dos dados da ANVISA à sociedade também diz muito sobre a noção de "transparência" do Poder Legislativo, que é parcial. O planejamento de um país, inclusivo à participação da sociedade, não se faz com a omissão de dados públicos. Mesmo que não correspondente às necessidades socioambientais de todas as camadas sociais, tal ideia tem suas origens em um passado remoto.

Foster (2005) indica que as teorias marxistas já criticavam as noções de crescimento populacional malthusianas, assumindo relações historicamente distintas, isto é, diferentes formações sociais em diferentes momentos históricos em vez de relações consideradas por ele como numericamente abstratas. Para o autor, a taxa numérica de crescimento usada por Malthus não reconheceria o caráter histórico e social da reprodução humana.

No que concerne à realidade mato-grossense, sobressaem-se marcadas diferenças entre as camadas sociais que se dedicam à agricultura.

19 Trecho da Audiência Pública da Comissão da Agricultura e Reforma Agrária do Senado (TENDLER, 2011). 
A primeira, detentora dos meios de produção, voltada à agroexportação, composta por grandes produtores rurais, detém protagonismo político e econômico, tendo maior atenção do Estado para sua manutenção como classe dominante; aquela [é] composta por produtores familiares, ribeirinhos, [indígenas], quilombolas e outros. Estes, pequenos produtores organizados, têm menor prestígio político e econômico que os primeiros, sofrendo marginalização dos processos decisórios. (LOURENÇO, 2015, p. 208).

Inclui-se também os grupos desapropriados de tal sistema produtivo, político e econômico decorrente da concentração de terras, como, por exemplo, etnias indígenas com pequena população. Essa camada, ainda que numerosa e organizada, tem participação quase inexistente ou, ainda, duramente reprimida pelo aparelho do Estado. Sua participação nos processos decisórios ambientais é quase nula.

\subsection{Acões e objetos e uma representação da produção do território e da natureza}

Santos (2006, p. 89) parafraseia Brentano (1935, p. 29), dizendo que "não há pensamento sem objeto pensado, nem apetite sem objeto apetecido". A intencionalidade sobre o objeto seria, portanto, também um processo dialético, já que essas duas categorias se apresentam integradas e inseparáveis, auxiliando no entendimento da produção do espaço em território e do metabolismo entre ser humano e natureza, também dialéticos (MARX, 1989).

Para Raffestin (2009), o processo em que o ser humano constrói cotidianamente o território poderá torná-lo paisagem, ainda que nem todas as etapas desse processo impliquem essa materialização. Assim, o território se torna paisagem pela mediação da imaginação condicionada por um mediador particular. Em verdade, o quesito paisagem, aqui, é menos importante que território e territorialidade. Sobre isso, segue o autor, em Atenas, a distribuição de terras aos colonos e a localização dos campos foram reguladas exclusivamente por magistrados, que trabalhavam com base em um plano previamente estabelecido. A geometria e a matemática foram, nesse sentido, importantes mediadores da construção do mundo antigo.

Portanto, por um lado temos que a intencionalidade sobre o objeto e o processo político levam à formação de territórios e, tal como a ponta do iceberg, podem se imprimir nas paisagens. A história foi determinante na geografia do Mato 
Grosso. Assim, sua representação, tal como é concebida no Plano de Longo Prazo e nos impasses sobre o ZSEE, nos ajuda a entender como o espaço foi apropriado como território nesse caso específico.

No intento de delimitar como se dão as variáveis da interação que podem vir a condicionar o que emerge como desenho nas paisagens, Raffestin (2009) propõe um modelo, em princípio não matemático e em pequena escala, que elucida as transformações que acontecem no processo de territorialização, mostrando os mecanismos e seus efeitos nas morfologias espaciais e territoriais. As redes ambientalistas, como variável comportada pelo modelo, aparecem entre outros nexos causais. A limitação evidente desse modelo é a ausência de parâmetros numéricos que o tornem inteligível a técnicas de amostragem e interpretação de dados, aspectos certamente considerados pelo autor. No entanto, a autora deste trabalho reconhece o esforço reflexivo do autor como bastante plausível ao cenário identificado na rede FORMAD, podendo, inclusive, gerar equações mais complexas e aplicáveis a modelos de análises entre sociedade e ambiente, sempre quando respeitadas as escalas e as realidades consideradas, necessárias para o desenho de políticas ambientais.

A equação definida por Raffestin $(2009$, p. 28) se dá na seguinte representação:

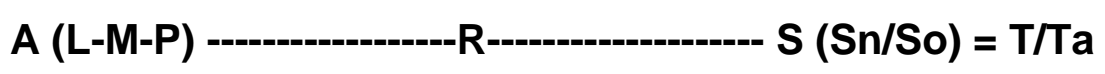

(II)

(III)

Reformulada da seguinte maneira para este trabalho, apenas para reforçar o caráter sistêmico de cada elemento, ressaltado pelo autor:

$$
\{A[L+M+P(I p)] /(S n+S o)\}=T / T a
$$

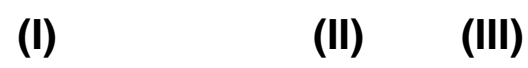

A primeira parte da equação (I) resume a relação antropológica da resultante territorial. A variável, ou elemento, ator (A), é composta pela diversidade de atores, representantes dos diferentes grupos de sujeitos que conformam o cenário político mato-grossense, e os meios de que cada ator dispõe para agir no ambiente orgânico, inorgânico e social. Esses atores seriam os representantes, individuais e coletivos, das camadas sociais inseridas no jogo político, ainda que em 
desigualdade de forças. Seriam, por exemplo, as organizações ambientalistas do FORMAD quando em sua atuação em separado, ou a rede quando atua como um todo, e os representantes individuais e coletivos dos grandes, médios ou pequenos produtores agrícolas.

À variável trabalho (L) é atribuída a combinação entre energia e informação, sendo, no decorrer da História, a segunda mais importante que a primeira. A energia gasta se aproximaria à ideia de estratégia e tática, as quais são alcançáveis quando se tem informação. Portanto, estratégia e tática (energia) mais bem são dependentes do elemento "informação", condicionando o trabalho como um todo. É nesse sentido que prover o cidadão de informações, por intermédio de meios adequados de transparência de dados governamentais, torna-se crucial para a participação dos atores $(\mathrm{A})$ no processo. $\mathrm{O}$ acesso a informações privilegiadas talvez seja o aspecto mais relevante no processo de produção do espaço e da natureza. Para Raffestin (2009), a quantidade variável de energia e de informação determina os tipos de trabalho, de reprodução ou de invenção ${ }^{20}$.

Como mediadores (M), Raffestin (2009) se refere aos instrumentos materiais e imateriais, conhecimento e/ou algoritmos disponíveis ao(s) autor(es) em um lugar ou momento específico, ainda que possam existir mediadores que não sejam contemporâneos uns aos outros. Na perspectiva deste trabalho, consideramos que a noção de ideologias geográficas de Moraes (2005) nos ajuda no entendimento dos componentes imateriais e de conhecimento, na medida em que a cultura e a ciência são perpassadas vigorosamente por uma ideologia dominante, elitista. É por essa razão que este componente, reportado aqui quando tratamos do conhecimento científico produzido no estado do Mato Grosso, também aparece em descompasso, dependendo do ator tomado como referência. Tal como a transparência das informações foi demonstrada como sendo insuficiente, ou melhor, desigual no que se refere a quem tem acesso à informação, também é insuficiente e desigual a construção do raciocínio que a elabora. O conjunto das instituições e suas possibilidades aos diferentes atores constituiria outro conjunto de mediadores.

20 Em tempo, o desenho das paisagens também possibilita alternativas futuras de reprodução ou invenção do trabalho como elemento da produção do território, agindo como mediadores materiais na equação mencionada. Temos, por exemplo, que a abertura das primeiras estradas na Amazônia foram elemento para que, nas décadas seguintes, novos projetos fossem incorporados à ideia original. 
O conjunto de programas, políticas e planos governamentais poderia ser classificado no que Raffestin entende como "programa" $(P)$, ou seja, um conjunto de intenções realizáveis e dos objetivos ou metas. Outros exemplos estariam incluídos nesta variável, como o PLP mato-grossense tratado anteriormente, em âmbito governamental estadual, ou o Projeto Mato Grosso Sustentável e Democrático, elaborado no escopo do FORMAD e tratado no Capítulo 5. Como as demais variáveis, esta envolve diretamente os aspectos aqui levantados sobre os momentos das políticas públicas, espaço no qual grande parte dessas variáveis se relacionam na contemporaneidade. Neste ponto, inserimos à equação de Raffestin a variável de inserção política (Ip), escalonável e, por isso, constante, na medida em que a permeabilidade dos atores sociais (sociedade civil) entre os atores políticos (sociedade política) é um aspecto importante para definir a incorporação ou não dos programas desenvolvidos.

L, M e P seriam a tríade fundamental dos meios de intervenção sobre o ambiente.

A segunda parte da equação (II) gira em torno das relações que se dão no ambiente ecológico, biológico e lógico-cultural cristalizado (RAFFESTIN, 2009, p. 29). A disposição das áreas protegidas, o ciclo dos nutrientes e a manipulação da natureza realizada, por exemplo, na interferência nas cadeias ecológicas por meio dos agrotóxicos e dos fertilizantes, estariam englobados neste fragmento.

Assim, Sn conformaria todo o ambiente orgânico e inorgânico referente à escala pretendida. Isso implica a relação entre todos os aspectos climáticos, pedológicos, hidrográficos, florísticos, faunísticos, microbiológicos, etc. A variedade de estudos referentes a esses subtemas não caberia neste trabalho e nem é relevante à nossa hipótese. Há, entretanto, uma grande base de dados sobre essas informações, no que diz respeito à produção do conhecimento.

Deve-se ressaltar, no entanto, que grande parte das informações sobre os meios bióticos ou abióticos potencialmente gera informações estatísticas que, após um processo de validação, podem ser divulgadas, também por meio de portais de dados, conformando, assim, a argumentação dos atores (organizações e redes ambientalistas) nos processos decisórios. Essa temática é debatida amplamente em espaços de discussão de produtores e usuários de dados ambientais, como 
vem se realizando nas conferências temáticas promovidas pelo IBGE, idealizado como canalizador dessas informações.

O ambiente social (So) seria um outro universo de variáveis possíveis, composto por todos os subsistemas sociais, dentre os quais a economia, a política (nacional e internacional), a cultura, etc. Na relação de Sn com o ambiente social (So), chamado de $S$ pelo autor, as escolhas dos atores são feitas com base nos sistemas locais à disposição.

A resultante dessa equação, ou desse sistema, seria a relação entre o território ( $T$, relativo à parte material), produzido pelo ator no ambiente (RAFFESTIN, 2009, p. 28), e o conjunto das relações desenvolvidas pelo ator no território ou na territorialidade ( $\mathrm{Ta}$ ), imaterial, constituindo o conjunto de relações que permitem satisfazer as necessidades da comunidade ou da sociedade. São exemplos desses resultados territoriais os sistemas de territórios agrários, rurais, turísticos, de redes infraestruturais, urbanos e industriais. Como o processo territorial parte de uma forma precedente, de estado da natureza ou de território, a fórmula elaborada pode ser desenvolvida de maneira que a relação território/territorialidade $(\mathrm{T} / \mathrm{Ta})$ ofereça novas possibilidades de intencionalidades, de forma que:

\section{$\mathrm{T} / \mathrm{Ta} \rightarrow\{\mathrm{A} 1 \quad[\mathrm{~L} 1+\mathrm{M} 1+\mathrm{P} 1(\mathrm{Ip} 1)] / \quad(\mathrm{Sn} 1+\mathrm{So} 1)\}=\mathrm{T} 1 / \mathrm{Ta} 1 \rightarrow\{\mathrm{A} 2$} $[\mathrm{L} 2+\mathrm{M} 2+\mathrm{P} 2(\mathrm{Ip} 2)] /(\mathrm{Sn} 2+\mathrm{So} 2)\}=\mathrm{T} 2 / \mathrm{Ta} 2 \rightarrow\{\mathrm{A} 3[\mathrm{~L} 3+\mathrm{M} 3+\mathrm{P} 3(\mathrm{Ip} 3)] /(\mathrm{Sn} 3+\mathrm{So} 3)\}=$ $\mathrm{T} 3 / \mathrm{Ta} 3 \rightarrow \ldots$

Com isso, a forma como se relacionam os elementos e as oportunidades que se ofereçam na relação L-M-P torna as possibilidades de participação mais ou menos igualitárias entre as camadas da sociedade no modo como se interage com o ambiente e na produção territorial.

Apesar de suas limitações matemáticas, tal representação sintetiza bastante bem o conjunto de relações que se estabelecem e a amplitude das interações entre a política ambiental e a atuação de redes ambientalistas como o FORMAD. No caso mato-grossense, as implicações dessas interações, múltiplas na diversidade tanto de atores intervenientes quanto de ambientes ( $\mathrm{Sn}$ e SO), e dinâmicas temporal e espacialmente, jogam um papel sobre as pressões socioambientais que se desenvolvem no estado, detalhadas na Figura 6. Por meio destas, notamos que os desbalanços nas relações sistêmicas entre os elementos não se mostram capazes de satisfazer as diversidades sociais, o que é esperado para a relação T/Ta. Essas 
relações, pela própria lógica da equação e seus desdobramentos, não somente se estabelecem, como também perduram, caso não haja alterações nos elementos constitutivos.

É sob a égide dessa afirmação que se sustentam as táticas de atuação das redes ambientalistas, mediante seus eixos de atuação, em vista a alterar tais variáveis em seu favor. Ao fim, essas táticas podem levar a grandes resultados, como veremos nos Capítulos 4, 5 e 6 . De qualquer forma, também no universo das estratégias e táticas, os territórios e as territorialidades oferecidos também podem se apresentar profícuos à imaginação daquele cuja intencionalidade seja um desenvolvimento igualitário.

Figura 6. Distribuição de áreas protegidas, conformação social e pressões ao ambiente

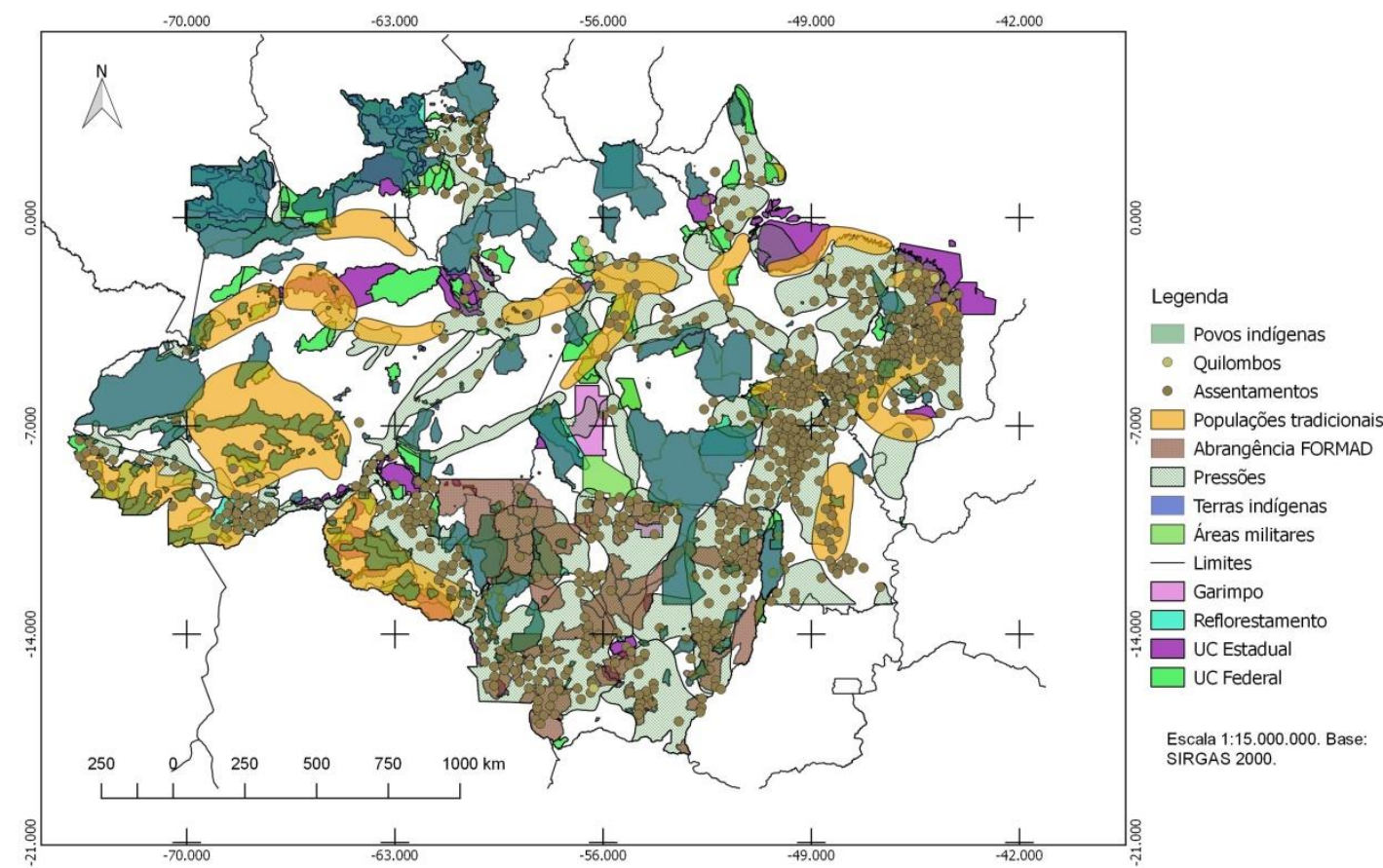

Fontes: ISA (1999); FORMAD (2012). Elaboração própria.

Também Jaber (2012) identifica que grande parte dos conflitos se dá exatamente nas áreas de indefinição territorial, onde a necessidade de ampliação dos limites agrícolas entra em choque com o território e a territorialidade indígenas. No caso mato-grossense, note-se que há uma complementaridade das áreas de conflito com as áreas de estabelecimento de assentamentos no estado. Estes são apontados por Mello (2006, p. 332) como uma nova expansão de redes físicas, 
servindo para o atendimento das necessidades do agronegócio e das organizações privadas. Com o claro objetivo de minimizar a pressão das organizações da sociedade civil pela reforma agrária, a autora aponta que o padrão de estabelecimento para tais assentamentos agrários, nas fases de seleção da área, definição do projeto com número de famílias a seres assentadas e instalação das famílias, ainda reproduz um antigo modelo de colonização, principalmente na incorporação de terras em regiões pouco estruturadas. Tal panorama se nota em diferentes lugares da Amazônia Legal.

Assim, tenhamos em conta que, nessa situação, interajam atores (A) ligados ao agronegócio, de um lado, e atores representantes da causa indígena, do outro. Para cada ator, corresponde uma tríade de trabalho-mediadores-programas (L-M$\mathrm{P}$ ), mediada pela relação com o ambiente orgânico e social ( $\mathrm{Sn}$ e So) que the compete. Considerando que L-M-P oferecem as características imprescindíveis que $\mathrm{o}$ ator deve possuir para intervir sobre o ambiente, partindo de um território consolidado, resta fácil concluir que, em um contexto agroexportador, que vem configurando o estado do Mato Grosso ao longo das últimas décadas, há um panorama profícuo (material e socialmente) para a ação dos grandes produtores agrícolas, em detrimento das populações indígenas.

Sobre a relação entre $\mathrm{A}$ e $\mathrm{Sn}$, existiram iniciativas recentes de descrição e recomendações às áreas prioritárias no âmbito da relação entre Grupo de Trabalho Amazônico (GTA) e FORMAD, em coordenação com outras organizações ambientalistas, nacionais e internacionais, entre elas o MMA, com apoio da União Europeia, da Agência dos Estados Unidos para o Desenvolvimento Internacional (USAID) e do Global Environmental Facility (GEF). Realizado dentro do escopo financeiro do PRONABIO, o chamado subprojeto (que também envolveu recursos do Banco Internacional para Reconstrução e Desenvolvimento - BIRD e do Banco Mundial - BM) visava avaliar a diversidade biológica do bioma Floresta Amazônica, tendo como base a Amazônia Legal (BRASIL, 2001, p. 7).

O subprojeto do PRONABIO $(\mathrm{P})$, portanto, canalizava as vozes de diferentes organizações, ambientalistas, universidades, sindicatos, etc. (A) por meio da estrutura ministerial do MMA (M) e de um esforço na "análise do maior número possível de informações sobre o bioma". As experiências prévias de negociação entre atores governamentais e a sociedade civil, em espaços como o PPG7, 
PRODEAGRO e outros, são consideradas pela autora deste trabalho como cruciais para tal aprendizagem. No entanto, apesar da qualidade desse material em termos científicos e do esforço das organizações e do Governo Federal, as análises do PRONABIO não aparecem nos planejamentos dos níveis federativos, como no PLP mato-grossense, nem nos planos diretores municipais.

O levantamento de áreas prioritárias subdivide a Amazônia Legal em categorias de importância e, o mais inovador, com base na integração de dados biológicos e socioeconômicos, portanto, também levantando variáveis pertinentes a So. A Amazônia Legal foi, então, subdividida em sete regiões, segundo os critérios (BRASIL, 2001): ecorregiões, bacias hidrográficas, eixos de desenvolvimento, grau de ação antrópica atual (desmatamento, demografia, infraestrutura de transporte, focos de incêndio, risco de incêndio florestal) e atividade econômica (madeireiras, agricultura de soja/milho e pecuária). A abrangência do estado do Mato Grosso foi classificada nas sub-regiões Alto Xingu/Tapajós/Roraima/Mato Grosso (AX), ao norte, Baixo Xingu/Tapajós/Madeira (BX), ao sul, e, no extremo leste do estado, Araguaia/Tocantins/Maranhão (TO). As áreas reportadas como prioritárias em cada uma dessas sub-regiões no estado seguem no Quadro 9. Haja vista tais parâmetros para estabelecimento das necessidades de planejamento, nota-se a diferença conceitual entre as subdivisões consideradas pelo Governo do Estado para análise conjuntural e ações necessárias e as subdivisões consideradas na parceria entre Governo Federal e redes ambientalistas. A primeira prioriza regiões por critérios de produção e $\mathrm{PIB}$, deixando de lado aspectos ecorregionais e necessidades de preservação.

\section{Quadro 9. Áreas prioritárias para a conservação no Estado do Mato Grosso, segundo parâmetros para a Amazônia Legal, elaborados em parceria do MMA com organizações ambientalistas}

\begin{tabular}{|c|c|c|c|c|c|}
\hline Área & Prioridade & $\begin{array}{c}\text { Município } \\
\text { principal }\end{array}$ & $\begin{array}{l}\text { Municípios } \\
\text { abrangidos }\end{array}$ & Importância & $\begin{array}{c}\text { Ação recomendada } \\
\text { (organizações + MMA) }\end{array}$ \\
\hline \multicolumn{6}{|c|}{ Baixo Xingu/Tapajós/Madeira } \\
\hline $\begin{array}{c}\text { Cabeceiras do } \\
\text { Xingu }\end{array}$ & A & $\begin{array}{c}\text { Gaúcha do } \\
\text { Norte }\end{array}$ & 8 & $\begin{array}{c}\text { Aves, biota } \\
\text { aquática, } \\
\text { botânica, } \\
\text { répteis e } \\
\text { anfíbios }\end{array}$ & $\begin{array}{c}\text { Criação de Área de } \\
\text { Proteção Ambiental (APA) } \\
\text { protegendo as nascentes } \\
\text { do Xingu, incentivo e apoio } \\
\text { aos comitês de bacia, } \\
\text { programa de educação } \\
\text { ambiental }\end{array}$ \\
\hline
\end{tabular}




\begin{tabular}{|l|l|l|l|c|c|}
\hline Rio das Mortes & $\mathrm{N}$ & $\begin{array}{c}\text { Ribeirão } \\
\text { Castalheira }\end{array}$ & 3 & $\begin{array}{c}\text { Aves, biota } \\
\text { aquática }\end{array}$ & $\begin{array}{c}\text { Transformação da área em } \\
\text { UC de preservação } \\
\text { integral, elaboração de } \\
\text { inventários biológicos, } \\
\text { programa de educação } \\
\text { ambiental }\end{array}$ \\
\hline
\end{tabular}

\begin{tabular}{|c|c|c|c|c|c|}
\hline $\begin{array}{c}\text { Parque Indígena } \\
\text { do Xingu/TI } \\
\text { Batovi }\end{array}$ & B & $\begin{array}{l}\text { Gaúcha do } \\
\text { Norte }\end{array}$ & 11 & $\begin{array}{l}\text { Aves, biota } \\
\text { aquática, } \\
\text { botânica, } \\
\text { répteis e } \\
\text { anfíbios }\end{array}$ & $\begin{array}{c}\text { Faixa tampão no entorno } \\
\text { do Parque Indígena do } \\
\text { Xingu (PIX) }\end{array}$ \\
\hline TI Wawi & A & Querência & 2 & $\begin{array}{l}\text { Aves, biota } \\
\text { aquática }\end{array}$ & $\begin{array}{l}\text { Uso sustentável de } \\
\text { recursos naturais, } \\
\text { elaboração de inventários } \\
\text { biológicos e fiscalização }\end{array}$ \\
\hline Xingu 1 & A & $\begin{array}{l}\text { São Félix do } \\
\text { Araguaia }\end{array}$ & 2 & $\begin{array}{l}\text { Aves, biota } \\
\text { aquática }\end{array}$ & $\begin{array}{l}\text { Fiscalização e elaboração } \\
\text { de inventários biológicos }\end{array}$ \\
\hline Xingu 2 & B & Marcelândia & 4 & $\begin{array}{l}\text { Aves, botânica, } \\
\text { répteis e } \\
\text { anfíbios }\end{array}$ & $\begin{array}{l}\text { Criação de UCs, } \\
\text { transformação de áreas de } \\
\text { UCs de uso sustentável e } \\
\text { revisão dos planos de } \\
\text { manejo com exploração de } \\
\text { madeira em matas ciliares }\end{array}$ \\
\hline TI Capoto/Jarina & B & $\begin{array}{l}\text { Peixoto de } \\
\text { Azevedo }\end{array}$ & 2 & $\begin{array}{l}\text { Aves, biota } \\
\text { aquática, } \\
\text { botânica e } \\
\text { mamíferos }\end{array}$ & $\begin{array}{c}\text { Uso sustentável de } \\
\text { recursos naturais, } \\
\text { proteção e fiscalização de } \\
\text { limites e faixa tampão } \\
\text { adjacente }\end{array}$ \\
\hline TI Paraná & A & Altamira & 3 & $\begin{array}{l}\text { Botânica, } \\
\text { mamíferos, } \\
\text { répteis e } \\
\text { anfíbios }\end{array}$ & $\begin{array}{l}\text { Proteção e fiscalização de } \\
\text { limites e implementação } \\
\text { de programa de } \\
\text { sustentabilidade } \\
\text { econômica e } \\
\text { socioambiental na área }\end{array}$ \\
\hline Rio Teles Pires & $A$ & $\begin{array}{c}\text { Novo } \\
\text { Progresso* }\end{array}$ & 23 & $\begin{array}{l}\text { Aves, biota } \\
\text { aquática, } \\
\text { botânica, } \\
\text { mamíferos, } \\
\text { répteis e } \\
\text { anfíbios }\end{array}$ & $\begin{array}{c}\text { Criação de UCs, } \\
\text { inventários biológicos e } \\
\text { estudos antropológicos, } \\
\text { desenvolvimento de } \\
\text { programas de educação } \\
\text { ambiental }\end{array}$ \\
\hline Rio Juruena & A & Cotriguaçu & 4 & $\begin{array}{l}\text { Aves, biota } \\
\text { aquática, } \\
\text { invertebrados, } \\
\text { mamíferos, } \\
\text { répteis e } \\
\text { anfíbios }\end{array}$ & $\begin{array}{l}\text { Criação de UCs, } \\
\text { transformação de áreas de } \\
\text { UCs de uso sustentável, } \\
\text { inventários biológicos e } \\
\text { estudos antropológicos }\end{array}$ \\
\hline TI Escondido & $A$ & Cotriguaçu & 1 & $\begin{array}{l}\text { Biota aquática, } \\
\text { mamíferos, } \\
\text { répteis e } \\
\text { anfíbios }\end{array}$ & $\begin{array}{l}\text { Uso sustentável dos } \\
\text { recursos naturais, } \\
\text { inventários biológicos e } \\
\text { estudos antropológicos e } \\
\text { desenvolvimento de } \\
\text { programas de educação } \\
\text { ambiental }\end{array}$ \\
\hline $\begin{array}{l}\text { TI Arara do Rio } \\
\text { Branco }\end{array}$ & $A$ & Aripuanã & 1 & $\begin{array}{l}\text { Biota aquática, } \\
\text { invertebrados, } \\
\text { mamíferos }\end{array}$ & $\begin{array}{l}\text { Uso sustentável dos } \\
\text { recursos naturais, } \\
\text { inventários biológicos e } \\
\text { estudos antropológicos }\end{array}$ \\
\hline
\end{tabular}




\begin{tabular}{|c|c|c|c|c|c|}
\hline TI Japuíra & A & Juara & 2 & $\begin{array}{c}\text { Aves, biota } \\
\text { aquática, } \\
\text { botânica, } \\
\text { mamíferos }\end{array}$ & $\begin{array}{c}\text { Uso sustentável dos } \\
\text { recursos naturais, } \\
\text { inventários biológicos e } \\
\text { estudos antropológicos e } \\
\text { desenvolvimento de } \\
\text { programas de educação } \\
\text { ambiental }\end{array}$ \\
\hline
\end{tabular}

\begin{tabular}{|c|c|c|c|c|c|}
\hline TI Erikpatsa & A & Brasnorte & 4 & $\begin{array}{l}\text { Aves, biota } \\
\text { aquática, } \\
\text { botânica }\end{array}$ & $\begin{array}{l}\text { Uso sustentável dos } \\
\text { recursos naturais, } \\
\text { inventários biológicos e } \\
\text { estudos antropológicos e } \\
\text { desenvolvimento de } \\
\text { programas de educação } \\
\text { ambiental }\end{array}$ \\
\hline $\begin{array}{l}\text { Reserva } \\
\text { Florestal } \\
\text { Juruena }\end{array}$ & $A$ & Juara & 7 & $\begin{array}{l}\text { Aves, biota } \\
\text { aquática, } \\
\text { botânica, } \\
\text { mamíferos }\end{array}$ & $\begin{array}{l}\text { Uso sustentável dos } \\
\text { recursos naturais, } \\
\text { inventários biológicos e } \\
\text { desenvolvimento de } \\
\text { programas de educação } \\
\text { ambiental e extensão }\end{array}$ \\
\hline TI Serra Morena & A & Juína & 2 & $\begin{array}{l}\text { Aves, biota } \\
\text { aquática, } \\
\text { botânica }\end{array}$ & $\begin{array}{l}\text { Uso sustentável dos } \\
\text { recursos naturais, } \\
\text { inventários biológicos e } \\
\text { estudos antropológicos e } \\
\text { criação de zonas tampão }\end{array}$ \\
\hline TI Aripuanã & A & Aripuanã & 3 & $\begin{array}{l}\text { Aves, biota } \\
\text { aquática, } \\
\text { mamíferos }\end{array}$ & $\begin{array}{l}\text { Inventários biológicos e } \\
\text { estudos antropológicos e } \\
\text { criação de zonas tampão }\end{array}$ \\
\hline $\begin{array}{l}\text { Cabeceira do } \\
\text { Rio Aripuanã }\end{array}$ & $A$ & Aripuanã & 8 & $\begin{array}{l}\text { Aves, biota } \\
\text { aquática, } \\
\text { botânica, } \\
\text { mamíferos }\end{array}$ & $\begin{array}{l}\text { Criação de UC, criação de } \\
\text { UC de proteção integral ao } \\
\text { sul da TI Escondido, } \\
\text { elaboração de inventários } \\
\text { biológicos e } \\
\text { implementação de } \\
\text { programa de educação } \\
\text { ambiental }\end{array}$ \\
\hline \multicolumn{6}{|c|}{ Araguaia/Tocantins/Maranhão } \\
\hline $\begin{array}{l}\text { TI Tapirapé/ } \\
\text { Karajá }\end{array}$ & $A$ & $\begin{array}{l}\text { Santa } \\
\text { Teresinha }\end{array}$ & 2 & $\begin{array}{l}\text { Aves, biota } \\
\text { aquática, } \\
\text { mamíferos }\end{array}$ & Proteção \\
\hline $\begin{array}{c}\text { Rio Araguaia e } \\
\text { Foz do Rio das } \\
\text { Mortes }\end{array}$ & $A$ & Cocalinho & 5 & $\begin{array}{l}\text { Aves, biota } \\
\text { aquática, } \\
\text { mamíferos }\end{array}$ & Proteção \\
\hline \begin{tabular}{|c|} 
APA dos \\
Meandros do Rio \\
Araguaia
\end{tabular} & $A$ & Cocalinho & 5 & $\begin{array}{l}\text { Aves, biota } \\
\text { aquática, } \\
\text { mamíferos, } \\
\text { répteis e } \\
\text { anfíbios }\end{array}$ & $\begin{array}{l}\text { Mudança de categoria de } \\
\text { UC para proteção integral }\end{array}$ \\
\hline \multicolumn{6}{|c|}{ Alto Xingu/Tapajós/Rondônia/Mato Grosso } \\
\hline $\begin{array}{c}\text { Interflúvio } \\
\text { Araguaia/Mortes }\end{array}$ & $A$ & Cocalinho & 6 & $\begin{array}{l}\text { Aves, biota } \\
\text { aquática, } \\
\text { répteis e } \\
\text { anfíbios }\end{array}$ & $\begin{array}{c}\text { Transformação da área em } \\
\text { parque ou APA }\end{array}$ \\
\hline $\begin{array}{l}\text { TI Pimentel } \\
\text { Barbosa }\end{array}$ & $A$ & $\begin{array}{l}\text { Ribeirão } \\
\text { Castalheira }\end{array}$ & 4 & $\begin{array}{l}\text { Aves, biota } \\
\text { aquática }\end{array}$ & $\begin{array}{l}\text { Uso sustentável dos } \\
\text { recursos naturais }\end{array}$ \\
\hline
\end{tabular}




\begin{tabular}{|c|c|c|c|c|c|}
\hline $\begin{array}{l}\text { Cabeceiras do } \\
\text { Xingu e Teles } \\
\text { Pires }\end{array}$ & $A$ & Paranatinga & 14 & $\begin{array}{l}\text { Aves, biota } \\
\text { aquática, } \\
\text { répteis e } \\
\text { anfíbios }\end{array}$ & $\begin{array}{l}\text { Definição de ações } \\
\text { prioritárias }\end{array}$ \\
\hline TI Parabubure & $A$ & Campinápolis & 5 & $\begin{array}{l}\text { Aves, biota } \\
\text { aquática }\end{array}$ & $\begin{array}{l}\text { Definição de ações } \\
\text { prioritárias }\end{array}$ \\
\hline $\begin{array}{l}\text { RESEC do } \\
\text { Culuene }\end{array}$ & $A$ & Paranatinga & 2 & $\begin{array}{c}\text { Aves, biota } \\
\text { aquática, répteis } \\
\text { e anfíbios }\end{array}$ & $\begin{array}{l}\text { Definição de ações } \\
\text { prioritárias, vigilância e } \\
\text { fiscalização }\end{array}$ \\
\hline $\begin{array}{l}\text { TI Marechal } \\
\text { Rondon }\end{array}$ & $A$ & Paranaitinga & 2 & $\begin{array}{l}\text { Aves, biota } \\
\text { aquática, } \\
\text { répteis e } \\
\text { anfíbios }\end{array}$ & $\begin{array}{l}\text { Definição de ações } \\
\text { prioritárias }\end{array}$ \\
\hline TI Bakairi & $A$ & Paranaitinga & 2 & $\begin{array}{l}\text { Aves, biota } \\
\text { aquática }\end{array}$ & $\begin{array}{l}\text { Definição de ações } \\
\text { prioritárias }\end{array}$ \\
\hline $\begin{array}{l}\text { APA das } \\
\text { Cabeceiras do } \\
\text { Rio Cuiabá }\end{array}$ & $A$ & $\begin{array}{l}\text { Rosário } \\
\text { Oeste }\end{array}$ & 5 & $\begin{array}{l}\text { Aves, biota } \\
\text { aquática }\end{array}$ & $\begin{array}{l}\text { Transformação de parte da } \\
\text { área, atualmente APA das } \\
\text { Cabeceiras do Rio Cuiabá, } \\
\text { em UC de uso indireto, } \\
\text { proteção das nascentes do } \\
\text { Rio Cuiabá, elaboração de } \\
\text { plano de manejo da APA } \\
\text { existente e fiscalização }\end{array}$ \\
\hline TI Santana & $A$ & Nobres & 1 & $\begin{array}{l}\text { Aves, biota } \\
\text { aquática }\end{array}$ & $\begin{array}{l}\text { Uso sustentável dos } \\
\text { recursos naturais }\end{array}$ \\
\hline $\begin{array}{c}\text { Cabeceiras do } \\
\text { Juruena, } \\
\text { Papagaio, } \\
\text { Sangue e } \\
\text { Guaporé }\end{array}$ & $A$ & $\begin{array}{c}\text { Tangará da } \\
\text { Serra }\end{array}$ & 12 & $\begin{array}{l}\text { Aves, biota } \\
\text { aquática, } \\
\text { botânica }\end{array}$ & $\begin{array}{l}\text { Criação de APA nas } \\
\text { cabeceiras do Juruena }\end{array}$ \\
\hline TI Rio Formoso & $A$ & $\begin{array}{l}\text { Tangará da } \\
\text { Serra }\end{array}$ & 1 & $\begin{array}{l}\text { Aves, biota } \\
\text { aquática }\end{array}$ & $\begin{array}{l}\text { Uso sustentável dos } \\
\text { recursos naturais }\end{array}$ \\
\hline TI Estivadinho & $A$ & $\begin{array}{c}\text { Tangará da } \\
\text { Serra }\end{array}$ & 1 & $\begin{array}{l}\text { Aves, biota } \\
\text { aquática }\end{array}$ & $\begin{array}{l}\text { Uso sustentável dos } \\
\text { recursos naturais }\end{array}$ \\
\hline $\begin{array}{c}\text { TI Capitão } \\
\text { Marcos/Uirapuru }\end{array}$ & $A$ & Nova Lacerda & 2 & $\begin{array}{l}\text { Aves, biota } \\
\text { aquática }\end{array}$ & $\begin{array}{l}\text { Uso sustentável dos } \\
\text { recursos naturais }\end{array}$ \\
\hline TI Pareci & $A$ & $\begin{array}{l}\text { Tangará da } \\
\text { Serra }\end{array}$ & 6 & $\begin{array}{l}\text { Aves, biota } \\
\text { aquática }\end{array}$ & $\begin{array}{l}\text { Uso sustentável dos } \\
\text { recursos naturais }\end{array}$ \\
\hline TI Utiariti & $A$ & $\begin{array}{l}\text { Campo Novo } \\
\text { dos Parecis }\end{array}$ & 3 & $\begin{array}{l}\text { Aves, biota } \\
\text { aquática, } \\
\text { botânica }\end{array}$ & $\begin{array}{l}\text { Criação de Reserva } \\
\text { Indígena de Recursos } \\
\text { Naturais e fiscalização }\end{array}$ \\
\hline TI Tirecatinga & $A$ & Sapezal & 3 & $\begin{array}{l}\text { Biota aquática, } \\
\text { botânica }\end{array}$ & $\begin{array}{l}\text { Uso sustentável dos } \\
\text { recursos naturais }\end{array}$ \\
\hline TI Juininha & $A$ & $\begin{array}{l}\text { Pontes e } \\
\text { Lacerda }\end{array}$ & 4 & $\begin{array}{l}\text { Aves, biota } \\
\text { aquática }\end{array}$ & $\begin{array}{l}\text { Uso sustentável dos } \\
\text { recursos naturais }\end{array}$ \\
\hline
\end{tabular}

${ }^{*}$ Considerou-se a abrangência dos outros municípios, em MT. Fonte: BRASIL (2001).

Sobre o processo de avaliação de áreas prioritárias, Mello (2006, p. 325), baseada na identificação de Théry (1995), aborda o modelo de desenvolvimento a duas velocidades. A autora defende que há uma defasagem entre a disponibilização de dados científicos e a velocidade de ocorrência dos impactos, e 
que tal modelo não só separa o espaço-tempo ligado aos rios e às rodovias, mas transpõe-se para o espaço-tempo da proteção dos recursos naturais e dos usos impactantes da infraestrutura econômica. A reafirmação dessa autora das velocidades de maturação e implantação diferenciadas também se aplica ao componente participativo que as concerne.

Haja vista que os resultados do subprojeto do PRONABIO são fruto de uma exitosa parceria entre organizações ambientalistas e MMA, seria de se esperar, em um estado democrático, sua absorção pelos entes federativos no planejamento de suas respectivas circunscrições. Porém, não há menção no PLP mato-grossense a produções compartilhadas, como a avaliação citada realizada no PRONABIO. Ainda que haja similaridade entre as metas do PLP mato-grossense $e$ as análises feitas na parceria entre MMA e organizações ambientalistas do GTA, não há espaço no PLP que as incorpore como documento a ser considerado. $O$ documento da avaliação foi sumamente esquecido nos arquivos governamentais.

A não observância pela Assembleia Legislativa mato-grossense do produto da avaliação das áreas prioritárias é identificada na expansão das áreas consolidadas ou a se consolidarem, para fins de agricultura mecanizada, sobre os municípios de Ribeirão Castanheira, Querência, Gaúcha do Norte e outros, de acordo com o ZSEE elaborado por tal casa em 2010 (Capítulo 4). O contraste do Quadro 9 com o mapa do ZSEE mato-grossense proposto pela AL do estado também aponta para o não cumprimento das diversas áreas tampão propostas em 2001. No que se refere ao uso dos agrotóxicos, sabidamente negativos à cadeia alimentar e que afetam diretamente a diversidade de pássaros, a ampliação de seu uso nas lavouras e os subterfúgios para que se mantenham, apesar dos alertas da ANVISA, são nova afronta à avaliação feita em parceria pelo MMA e redes ambientalistas. Temas como o baixo fomento à educação ambiental e a limitação de espaços de comitês e conselhos também se destacam nas omissões do governo estadual e da Assembleia Legislativa.

Podemos apresentar outros elementos de relação entre as esferas administrativas presentes no Quadro 9 e o Governo Federal, partindo dos argumentos de Mello (2006). Assim, aparecem novas categorias de produção territorial, como o fomento à infraestrutura e a expansão das áreas plantadas, 
prioridades no PPA, e outra, que permeia todas as estratégias, por meio das táticas usadas por todos os atores aqui envolvidos: o lobby político. Por meio dessa relação são definidos, por exemplo, itinerário traçado, corredores multimodais, modernização da agricultura e suas áreas de influência. Mediados pelos eixos nacionais de integração e desenvolvimento, são viabilizados pela sincronia de ações entre a política ambiental, política econômica, etc., criando novas redes de fluxos, irradiadoras de influências.

No Quadro 10 é possível perceber como os atores da rede ambientalista FORMAD, por meio de seus eixos temáticos, permeiam a relação entre L-M-P(Ip), apresentados por Raffestin (2009) como características mínimas necessárias aos atores para incidir sobre as relações T/Ta. As demais categorias, mais dificilmente sistematizáveis, perpassam toda a conjuntura histórica, material (território tornado ou não paisagem), relacional, na rede ambientalista e entre esta e outras, e institucional, nas possibilidades que se abrem a essa participação.

A sistematização que apresentamos aqui obviamente é uma simplificação. Portanto, não abrange a diversidade e o número de organizações intervenientes na rede. Porém, oferece um panorama das categorias de cada variável, considerando os eixos trabalhados pela rede no período estudado.

Consideramos como "energia" uma categoria da variável T, respaldando-nos nos eixos de atuação da rede ambientalista nos quais as organizações investem seus recursos financeiros e humanos.

Em seguida traçamos, a partir do PLP, os elementos e as variáveis atribuídas à ação dos atores governamentais (Quadro 11). É possível notar nesse contraste que várias organizações convergem para um mesmo gasto de energia referente ao modelo de desenvolvimento e uso da terra, aspectos que também são imperativos no PLP mato-grossense. No entanto, novamente outro aspecto chama a atenção: as variáveis relacionadas aos atores governamentais circulam, em sua totalidade, na esfera governamental, enquanto as variáveis que se referem às redes ambientalistas basicamente se circunscrevem em seu escopo de influências. Isso traz à baila uma das questões basilares na administração e no planejamento ambiental brasileiro, representada pela separação que existe entre povo e governo, como se ambos estivessem desconectados um do outro. 
Quadro 10. L-M-P relacionados aos eixos de atuação do FORMAD

\begin{tabular}{|c|c|c|c|c|c|c|}
\hline \multicolumn{2}{|l|}{ A } & \multicolumn{2}{|r|}{$\mathbf{L}$} & \multirow[b]{2}{*}{ m } & \multirow[b]{2}{*}{$\mathbf{P}$} & \multirow[t]{2}{*}{ Ip } \\
\hline Atores & $\begin{array}{l}\text { Categoria da } \\
\text { produçáo } \\
\text { territorial }\end{array}$ & Energia & Informaçăo & & & \\
\hline $\begin{array}{c}\text { ADERCO, AEMA, AMEC, } \\
\text { ARCA, ECOTROOPICA, } \\
\text { Instituto GAIA, ICV, GRAUNA, } \\
\text { MOPS, Sociedade Formigas }\end{array}$ & $\begin{array}{l}\text { Conservação do } \\
\text { meio ambiente }\end{array}$ & $\begin{array}{c}\text { Impactos } \\
\text { ambientais e } \\
\text { legislação } \\
\text { ambiental; grandes } \\
\text { projetos - Brasil e } \\
\text { Mato Grosso }\end{array}$ & \begin{tabular}{|l|} 
\\
Dados próprios \\
(sistematizados ou \\
năo), planos diretores \\
municipais, deunióes \\
(conselhos, audiências, \\
conferências), Portais \\
de Transparência \\
(INPE, MMA, AL), \\
estudos acadêmicos, in \\
loco
\end{tabular} & 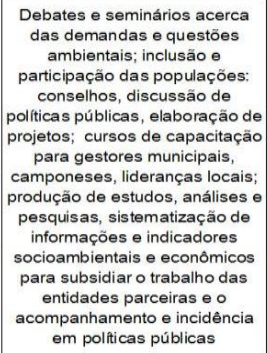 & 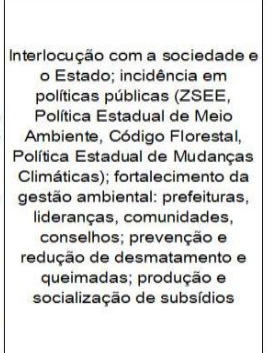 & 5 \\
\hline ADUFMAT, IFPDS, SINTEP & Educaçāo & Formaçāo & $\begin{array}{c}\text { Planos curriculares, } \\
\text { reuniöes (conselhos, } \\
\text { audiênncias, } \\
\text { conferếncias), Portais } \\
\text { de Transparência } \\
\text { (IBGE, MEC, etc.) }\end{array}$ & 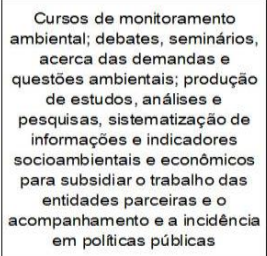 & $\begin{array}{c}\text { Participaçăo na Politica } \\
\text { Nacional de Educaçăo } \\
\text { Ambiental }\end{array}$ & 4 \\
\hline $\begin{array}{l}\text { ATVAAEA, CTA, FETAGRI, } \\
\text { IFPDS, SF, CPT }\end{array}$ & $\begin{array}{c}\text { Agricultura em } \\
\text { pequena } \\
\text { escala/agroecologia }\end{array}$ & $\begin{array}{c}\text { Terra e modelo de } \\
\text { desenvolvimento } \\
\text { (uso da terra) }\end{array}$ & $\begin{array}{c}\text { IBGE (Censo } \\
\text { Agropecuário), MDA, } \\
\text { MAPA, MDS, INCRA }\end{array}$ & 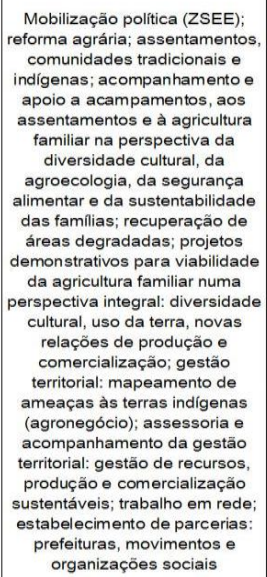 & 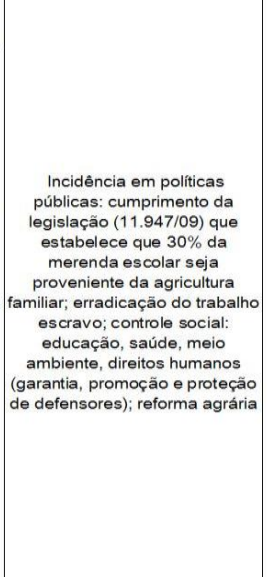 & 3 \\
\hline CUT, SINTEP & Direitos trabalhistas & \begin{tabular}{|c|} 
Grandes projetos - \\
Brasil e Mato \\
Grosso; terra e \\
modelo de \\
deservolvimento \\
(uso da terra)
\end{tabular} & $\begin{array}{l}\text { Dados próprios, } \\
\text { FIOCRUZ, MTE, MS }\end{array}$ & $\begin{array}{l}\text { Grandes obras: hidrelétricas, } \\
\text { rodovias, hidrovias e ferrovias }\end{array}$ & 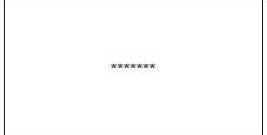 & 1 \\
\hline $\begin{array}{l}\text { GTME, MAIWU, OPAN, CIMI, } \\
\text { TAKINA, MOPS, ADDTDM, } \\
\text { CDHDMB, DHDMB, FÉ E } \\
\text { ALEGRIA, IECLB, CBFJ }\end{array}$ & $\begin{array}{l}\text { Povos indígenas/ } \\
\text { populaçöes } \\
\text { tradicionais/ } \\
\text { conhecimentos } \\
\text { populares/direitos } \\
\text { humanos }\end{array}$ & $\begin{array}{c}\text { Terra e modelo de } \\
\text { desenvolvimento } \\
\text { (uso da terra): } \\
\text { impactos } \\
\text { ambientais; } \\
\text { diversidade cultural; } \\
\text { grandes projetos - } \\
\text { Brasil e Mato } \\
\text { Grosso }\end{array}$ & \begin{tabular}{|} 
Dados próprios \\
(sistematizados ou \\
não), planos diretores \\
municipais, reuniões \\
(conselhos, audiências, \\
conferências); Portais \\
de Transparência \\
(FUNAl, INCRA, MDS), \\
estudos académicos, \\
observaçăo in loco
\end{tabular} & 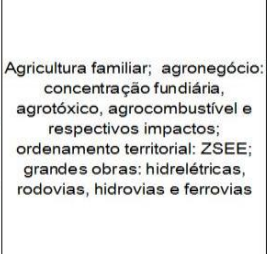 & \begin{tabular}{|c|} 
Apoio e fortalecimento dos \\
povos e comunidades indígenas \\
e tradicionais; fortalecimento \\
das organizaçóes e \\
movimentos incígenas; \\
interlocução (diálogo) com os \\
povos indigenas; fortalecimento \\
das organizaçōes das \\
mulheres; encontros de \\
intercâmbio de mulheres \\
indigenas, quilombolas e \\
assentadas.
\end{tabular} & 3 \\
\hline NEOM, MOPS & Saúde & $\begin{array}{c}\text { Impactos } \\
\text { ambientais e } \\
\text { legislaçăo } \\
\text { ambiental; terra e } \\
\text { modelo de } \\
\text { desenvolvimento } \\
\text { (uso da terra) }\end{array}$ & \begin{tabular}{|} 
Dados próprios, planos \\
diretores, reuniöes \\
(conselhos, audiências, \\
conferências), Portais \\
de Transparência \\
(IBGE, MS, etc.), \\
organismos \\
internacionais (OMS).
\end{tabular} & \begin{tabular}{|l|} 
Agricultura familiar; agronegócio: \\
concentração fundiária, \\
agrotóxico, agrocombustivel e \\
respectivos impactos; \\
ordenamento territorial : ZSEE
\end{tabular} & $x+x+x+x+x$ & 2 \\
\hline NEOM & $\begin{array}{l}\text { Igualdade de } \\
\text { Género }\end{array}$ & Diversidade cultural & $\begin{array}{l}\text { Dados próprios, dados } \\
\text { compartilhados, } \\
\text { reuniōes (consélhos, } \\
\text { audiências, } \\
\text { conferênciass), Portais } \\
\text { de Transparência } \\
\text { (IBGE, MP, etc.) }\end{array}$ & 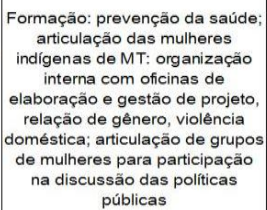 & $\begin{array}{l}\text { Controle social: capacitação de } \\
\text { conselheiros para participação } \\
\text { em conselhos; participação nas } \\
\text { polfiticas de agricultura familiar é } \\
\text { agroecológica; fortalecimento } \\
\text { das organizaçoes das mulheres }\end{array}$ & 1 \\
\hline
\end{tabular}

Fonte: FORMAD (2012). Elaboração própria. 
Essa observação valida o uso da equação proposta em dois sentidos: primeiramente, porque guarda profunda relação com as transformações que acontecem no processo de territorialização, relacionando as causas, os mecanismos e os efeitos nas morfologias espaciais e territoriais. Segundo porque demonstra a importância de como se consolidou o uso da terra no Mato Grosso e as oportunidades que se oferecem, pensando na relação T/Ta e T'/Ta'.

\section{Quadro 11. L-M-P relacionados aos eixos de atuação do PLP}

\begin{tabular}{|c|c|c|c|c|c|c|}
\hline Atores & $\begin{array}{c}\text { Categoria } \\
\text { de ação }\end{array}$ & Energia & Informação & M & $\mathbf{P}$ & Ip \\
\hline $\begin{array}{l}\text { SEFAZ, } \\
\text { SEPLAN, } \\
\text { SECEX, } \\
\text { SICME }\end{array}$ & $\begin{array}{c}\text { Desenvolvim } \\
\text { ento } \\
\text { econômico }\end{array}$ & $\begin{array}{c}\text { Macro-objetivo 9: } \\
\text { saumentar a } \\
\text { competitividade e a } \\
\text { performance } \\
\text { econômica do } \\
\text { estado de Mato } \\
\text { Grosso" }\end{array}$ & $\begin{array}{c}\text { IBGE/Contas } \\
\text { Nacionais; } \\
\text { MDIC/SECEX } \\
\text { Aliceweb; IMEA- } \\
\text { MT; } \\
\text { IBGE/Pesquisa } \\
\text { agrícola; SICME- } \\
\text { MT }\end{array}$ & $\begin{array}{c}\text { PPAs, programas } \\
\text { setoriais, LDOs, } \\
\text { LOAs, instituições de } \\
\text { pesquisa e tecnologia } \\
\text { (UNEMAT, } \\
\text { EMBRAPA, UFMT), } \\
\text { fundos setoriais, } \\
\text { linhas de crédito }\end{array}$ & $\begin{array}{l}\text { 1. Ampliação e melhoria da infraestrutura econômica e } \\
\text { da logística; } 2 \text {. Fortalecimento da agricultura familiar; } 3 \text {. } \\
\text { Diversificação da estrutura produtiva da economia; } 4 \text {. } \\
\text { Regularização fundiária; } 5 \text {. Criação de um sistema de } \\
\text { avaliação da conformidade de processos e produtos }\end{array}$ & 5 \\
\hline
\end{tabular}

Fonte: SEPLAN (2012). Elaboração própria.

As fontes de informação da rede foram inferidas por esta autora, com base em sua participação na própria rede. Sabe-se, por esse meio, que são usados portais de dados abertos e outras fontes, pertinentes a cada organização ambiental, 
segundo seus respectivos escopos de atuação. Nos eixos de ação do FORMAD, entretanto, não há detalhamento das fontes de informação usadas, como ocorre no PLP mato-grossense. Essa evidência pode ser apontada como uma fragilidade da rede de organizações ambientalistas em relação aos atores governamentais.

É possível também notar a necessidade de que os mecanismos de difusão da informação tenham certa integração entre órgãos governamentais e organizações, ou mesmo do incentivo a mecanismos próprios de levantamento de dados e tratamento estatístico, já que muitas das organizações têm condições de realizar suas próprias amostragens in loco.

$\mathrm{Na}$ medida em que a rede FORMAD funciona segundo eixos temáticos gerais, mesmo que L, M e P se repitam neste e naquele eixo, isso não significa que a abordagem dada para cada elemento seja igual, pois depende da tipologia de cada ator que o condiciona, da energia que motiva esse ator e da informação usada - e as categorias que lhe pareçam interessantes - nas variáveis M e P.

Finalmente, avaliamos que é comum, em P do FORMAD, que não haja uma definição clara do que se tem como programa, a se considerar mediante os eixos de atuação. Ressalta-se que os eixos da rede ambientalista se alteram ao longo do tempo, na medida em que as relações não são estáticas. A variável Ip, utilizada nesta pesquisa, foi escalonada entre 1 e 5 , e é aplicável exclusivamente à relação entre a rede FORMAD e o governo, por não dispormos de meios para projetá-la em maior escala. Essa gradação varia segundo a força dos grupos de atores, primeiramente dentro da rede e, portanto, de acordo com a sua capacidade tanto de pautar os eixos internamente na rede quanto de projetá-la em vista a uma intervenção política nas esferas governamentais.

À luz dessas evidências, temos a trajetória de como as decisões sobre o estado do Mato Grosso desenharam seus espaços e como foi sendo apropriado o território em esfera estatal. Ao longo deste trabalho, há de se ressaltar que houve tanto evoluções quanto involuções, ao menos na forma como as informações relativas ao território foram divulgadas pelos portais de transparência.

Neste ponto, a observação permite perceber que, apesar da habilidade em produzir informação e levantar demandas, há um abismo entre atores da sociedade civil e atores governamentais preponderantes em vários setores. Consideramos que, no jogo político entre esses atores, as variáveis dos elementos como M e So 
deveriam oferecer igualdade de participação e intermediação para todos, de acordo com a Constituição.

O conjunto das variáveis das equações aplicadas a governo estadual e à rede FORMAD aponta para lados distintos de concepção da relação Estadoambiente-território. Essas diferenças de perspectiva encontram no espaço dos conselhos ambientais a situação mais profícua para negociações, dentre as opções de institucionalidades participativas. Isso porque a atividade nos conselhos permite que os atores intervenientes tenham conhecimento de suas agendas e prioridades. Porém, tais espaços, por diversas razões políticas e estruturais, não chegam a suprir essa heterogeneidade de objetivos dos atores, mesmo que tratando de temas ambientais de interesse comum a todos eles. Por essa razão, e baseando-nos no PLP mato-grossense e em seus eixos, o Quadro 12 indica pontos de contato entre a ação e entre os atores aqui considerados, os quais abririam possibilidades de territórios produzidos por tais atores no ambiente e, por conseguinte, novas territorialidades. Considerando que o esforço principal das redes ambientalistas aqui tratadas é a inserção nos processos decisórios pertinentes aos ecossistemas vinculados às populações, utilizamos os eixos 1 e 7 do PLP como epicentro da consolidação de programas $(P)$ comuns.

Os programas específicos para a questão ambiental, presentes no eixo do PLP que os comporta, são generosos em possibilidades de espaços participativos (Quadro 12). Com diversos subtemas que apontam à necessidade de planejamento e de instrumentos de política e gestão, o conhecimento e a capacidade de negociação da rede, quando em espaços paritários de poder decisório e dispondo de recursos suficientes, oferecem possibilidades tanto de conflitos como de acordos nas diversas vertentes temáticas ambientais, com protagonismo do Estado em instrumentos como fiscalização, ações e organização institucional e financeira.

No Quadro 12, consideramos os eixos temáticos do PLP e suas linhas estruturantes para estabelecer quais seriam as sinergias com os eixos desenvolvidos pelo FORMAD, como exemplo de rede ambientalista. 


\section{Quadro 12. Pontos de contato entre os eixos de ação governamental e da rede ambientalista}

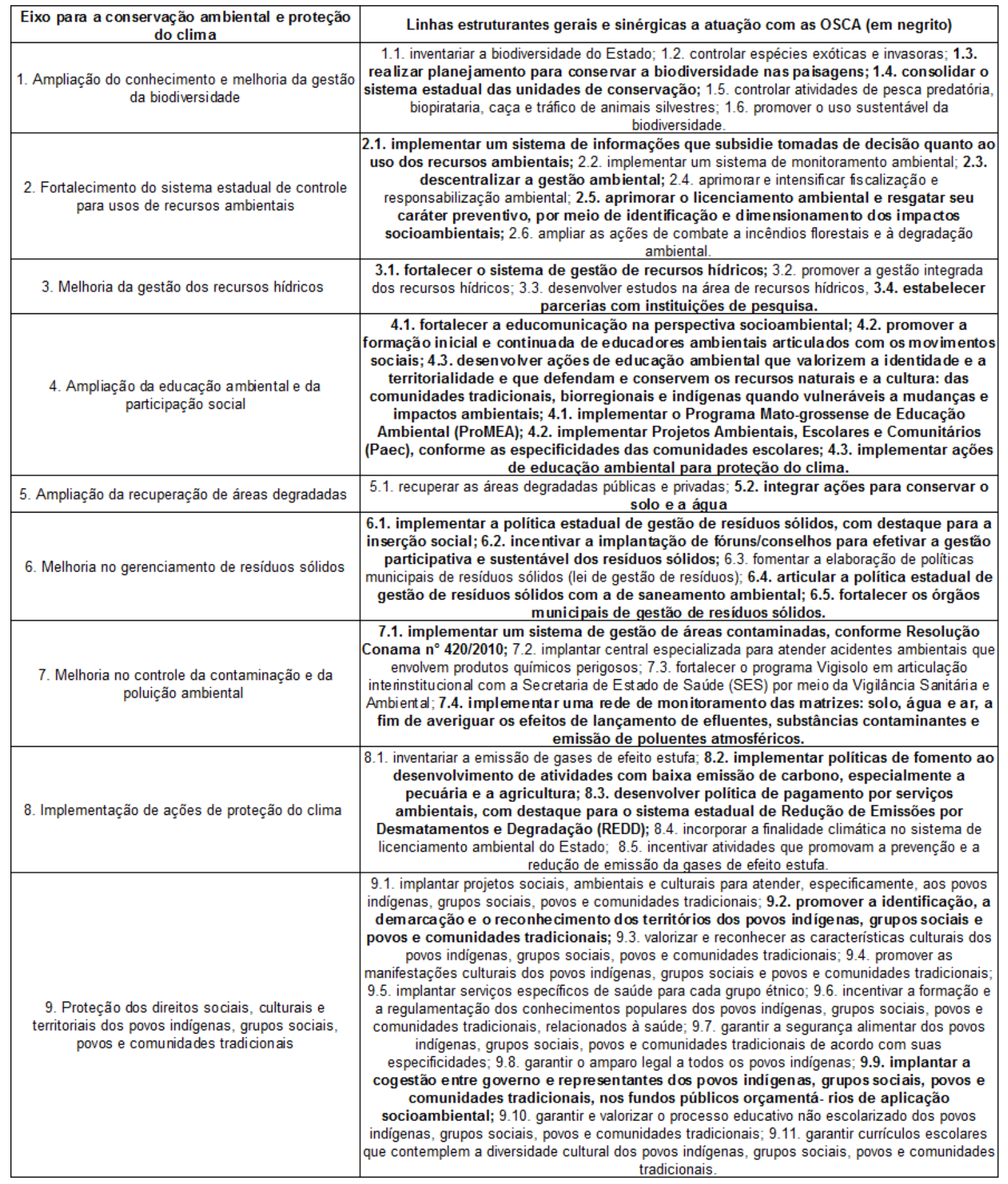

Fonte: SEPLAN (2012). Elaboração própria.

Dos sete eixos existentes no PLP, selecionamos especificamente 0 ambiental, por ser o cerne das relações estudadas neste trabalho e por considerar 
as singularidades étnicas que do componente ambiental se valem. No que diz respeito ao fomento à participação, objetivo do eixo 4, o protagonismo das redes ambientalistas se dá na totalidade das linhas estruturantes. Apenas por este eixo, portanto, vemos que há uma riqueza de material e de entendimentos sobre 0 território e sobre o ambiente desenvolvidos no âmbito governamental e pelas OSCA que aumentariam o nível de qualidade das negociações ao longo dos processos decisórios voltados a metas de planejamento e da gestão.

Apesar dessas potencialidades, ressalta-se que, ao longo de todos os levantamentos, reflexões e análises feitas neste trabalho, a autora observou certas tendências inquietantes referentes ao registro de informações. O mal descarte ou a má conservação de dados previamente levantados e de processos vividos acomete tanto organizações e redes ambientalistas quanto governos. Mesmo que a rede FORMAD tenha disponíveis suas informações desde 1992, há dificuldade na manutenção dos registros numéricos, que possam permitir análises estatísticas desde o período de sua consolidação. O GTA é uma rede que, atualmente, sequer dispõe de plataforma na Internet, tal qual outras redes espalhadas pelo Brasil. Em termos de avaliação de processos e de políticas implementadas, essa característica representa ser uma fragilidade para o avanço do planejamento ambiental estadual.

Chamamos a atenção também quanto à qualidade das bases de dados abertos à população, oferecidas pelo governo estadual. Entre 2012 e 2017, as páginas de transparência fiscal foram ampliadas às gestões de todas as secretarias estaduais. No entanto, a forma como esses dados são divulgados é bastante dificultosa ao usuário de informações estatísticas. As planilhas desconfiguradas, o acesso aos dados orçamentários disponibilizados de forma mensal e a pouca disponibilidade de ferramentas para download de dados completos torna a missão de busca de informações um processo cheio de obstáculos. A interface dos portais, aparentemente intuitiva, é de péssima qualidade para a sistematização de informações.

As melhores informações obtidas ainda são de domínio federal. No entanto, também nesse ambiente o usuário avançado de informações estatísticas se sente em um garimpo, pois as informações ou estão obsoletas, no que diz respeito às decisões do Estado, ou desaparecem, ou se escondem em rincões inatingíveis das instituições estatísticas. 
Mediante tal cenário, é possível afirmar que usuários menos especializados de informações estatísticas e de geoprocessamento, como o são a maioria dos representantes das organizações ambientalistas, têm como difícil missão o acesso não só à informação considerada pelo Estado na gestão ambiental, como também às decisões tomadas. Resumidamente, a presente autora afirma que não há informação de qualidade, provida pelas esferas governamentais, sobre a gestão do território e sobre a gestão ambiental disponível ao cidadão, nem em âmbito federal, nem estadual no Mato Grosso, e muito menos no âmbito de grande parte das municipalidades brasileiras ${ }^{21}$.

É no contexto de desinformação e exclusão processual, identificados pela autora, que as redes ambientalistas se consolidam por solidariedade das organizações, muitas vezes suprindo as lacunas desse tipo de informação por meio de produção própria de levantamentos.

No Capítulo 3 pensamos sobre o escopo das organizações e redes ambientalistas e seu papel no entendimento de que o Estado é um complexo heterogêneo de participantes nas decisões. O quase adjetivo "não governamental" - que vigora na definição das organizações, tentando excluí-las do processo decisório sob a justificativa de que as organizações da sociedade, em sua diversidade, não são o governo (teoricamente o que tem legitimidade para tal) não é suficiente para conter a evidência de que sim, a base da sociedade é parte do processo. Ora, se uma organização socioambientalista é formada diretamente pelas camadas sociais, deveria ser tão ou mais representativa e legítima, dentro de seu escopo direto de atuação, do que o próprio governo. É, portanto, de se pensar se as organizações não são até mais adequadas do que o governo para retratar as diversas demandas sociais nas arenas decisórias.

21 Para que pudéssemos refletir sobre o uso da terra no estado do Mato Grosso, aspecto importante para o entendimento dos eixos de ação das redes ambientalistas, analisamos pormenorizadamente as regiões de planejamento mato-grossenses. Devido ao seu caráter longo e descritivo, tais informações serviram apenas como apoio documental. 


\section{CAPÍTULO 3 - SOCIEDADE CIVIL E REDES AMBIENTALISTAS}

A partir de suas especificidades no contexto geopolítico regional, refletimos sobre as principais tipologias de ambientalismos abarcadas pelas redes de influência amazônica avaliadas e a relação entre essas e o Estado. Consideramos que a hegemonia das oligarquias agroexportadoras e sua influência na institucionalidade estatal constituem uma combinação profícua para o protagonismo de linhas do ambientalismo que caibam nos interesses produtivos. Nesse percurso, a ciência e a tecnologia - que poderiam ser desenvolvidas para fins de planejamento econômico, ambiental e territorial - perdem sua magnitude, servindo para algumas áreas de interesse, e condicionando outras ao ostracismo.

Apesar das tentativas de ordenar o território e atender à sociodiversidade regional, a pressão pela expansão das fronteiras agrícolas no Mato Grosso e na Amazônia Legal fragilizou as políticas ambientais voltadas para a regulação do uso do solo e para o ambiente. As tipologias do ambientalismo que se estabeleceram no País e, especificamente, no estado do Mato Grosso, também resultam do histórico de consolidação territorial exposto nos capítulos anteriores e refletem, em suas linhagens, as perspectivas que as camadas da sociedade têm sobre sua relação com a natureza.

Conformou-se, então, um cenário em que a máquina estatal, na qual as elites agrárias exercem protagonismo, se torna ineficiente e ineficaz para atender adequadamente à demanda da multiplicidade de etnias indígenas, ribeirinhos, pantaneiros, agricultores familiares, quilombolas, etc.

O período entre 1992 e 2012, no entanto, abre margem a um aprofundamento democrático ainda em curso, processo no qual o reconhecimento dos sujeitos como portadores de sua própria história vem tendo consequências na forma como os atores individuais e coletivos buscam táticas e estratégias para fazer valer suas demandas. No entanto, a institucionalidade do Estado, ainda arraigada ao protagonismo dos grupos elitistas, responde com distintas formas de coerção, velada ou física, ao potencial dessa movimentação na produção do território. Frente a essas ameaças, a organização por meio de redes passa a se tornar também uma alternativa de proteção às OSCA que se dedicam às linhas do ambientalismo menos prestigiadas do que as alinhadas ao mercado ou que se desenvolvem em 
contextos territoriais onde persistem relações clientelistas. Com isso, a ação em rede seria mais eficiente e eficaz do que iniciativas individualizadas das organizações para fazer frente às forças hegemônicas historicamente consolidadas.

Evidencia-se, pois, que se por um lado é difícil avançar em uma institucionalidade participativa ambiental, por outro, é impossível retroceder o status quo ao período pré-redemocratização. A partir do momento em que se revelam as fragilidades relacionais e os erros estratégicos históricos entre os distintos ambientalismos e as instituições do Estado, é possível vislumbrar soluções estruturais. Por isso, demonstramos também que as redes de organizações ambientalistas, sobretudo as vinculadas às causas das classes subalternas, têm potencial transformador das instituições do Estado.

\subsection{A relação entre o Estado e a sociedade civil no contexto ambiental}

A política por trás das políticas ambientais depende da definição de quem é Estado e quais as camadas da sociedade civil que são fundamentais para entender de onde surge e para onde vai o socioambientalismo. Em relação ao ambientalismo, Martínez-Alier (2007), é um dos autores que defende que o Estado seria o centro do poder no qual as classes dominantes têm o protagonismo, contestado pelas classes subalternas.

Tendo essa prerrogativa em vista, o fazer político em meio ambiente depende de um rol de variáveis que poderiam ser atribuídas ao escopo de "ambiente social" (So), definido no Capítulo 2, na equação descritiva de Raffestin (2009). Dentre essas, está a linha de raciocínio que cada forma de organização social segue para fazer valer os interesses da camada da sociedade civil por ela representada e a reatividade dessas organizações com o Estado.

A partir da década de 1970, o termo sociedade civil ${ }^{i}$ passou a ser considerado como sinônimo de oposição ao regime ditatorial, tomando também conotação de oposição ao governo (OLIVEIRA \& HADDAD, 2001). O termo também pode ser identificado com a participação cidadã em temas pertinentes à esfera pública, a causas diversas e à justiça (social e/ou ambiental). Neste caso, às OSCA caberia a ação dos atores coletivos pautando causas e interesses difusos, entendimento que acaba por gerar a falta de clareza quanto a até onde vão suas 
atribuições e qual sua real finalidade.

Sem perder de vista as observações de Oliveira \& Haddad (2001), vemos a sociedade civil nesta pesquisa como uma evolução da conceituação elaborada por Gramsci (2002), que a define como um complexo das relações ideológico-culturais, o momento de hegemonia da superestrutura que vai além da força, concretizando-se pelo domínio ideológico - respaldado pelas instituições do Estado - e coercivo. Sociedade civil é, então, a esfera das relações entre os indivíduos, grupos e classes sociais que se desenvolvem à margem das relações de poder que caracterizam as instituições estatais. Porém, mesmo margeando essas instituições, as diversas camadas da sociedade civil podem ter maior ou menor aderência ao seu funcionamento, o que vai depender da relação entre a sociedade civil com a sociedade política. Portanto, a noção de sociedade civil está representada: como o terreno dos conflitos econômicos, ideológicos, sociais e religiosos que o Estado tem a seu cargo resolver, intervindo como mediador ou suprimindo-os; como a base da qual partem as solicitações às quais o sistema político é chamado a responder; e como o campo das várias formas de mobilização, de associação e de organização das forças sociais que impelem à conquista do poder político. Em contínuo relacionamento, a sociedade civil possui o poder de fato, e o Estado, o poder legítimo (BOBBIO, 1998).

No âmbito da sociedade civil e de sua relação com o Estado, surgem as formas de organização entre os indivíduos que compõem a sociedade, a qual depende da forma como esses se relacionam com o território e com os outros indivíduos. Esse ator coletivo, apesar de não contemplar as ânsias individuais, se comunica com a realidade que lhe é externa pelo consenso entre os indivíduos.

Sobre isso, Oliveira \& Haddad (2001) indicam outras formas de aglutinação, como:

1. Organizações de base (grassroots) ou entidades comunitárias, voltadas para a promoção do desenvolvimento local e liderança de lutas populares.

2. Organizações intermediárias de assessoria e pesquisa (think tanks) ou de defesa e promoção de direitos (advocacy).

3. Fundações que realizam programas de interesse social (operadoras) ou financiam projetos sociais realizados por terceiros (grantmakers). 
4. Antigas entidades assistenciais, de atendimento direto a populações carentes, que praticam a filantropia em sentido estrito.

O confronto e o antagonismo que marcaram a relação entre o Estado e os grupos historicamente marginalizados da sociedade civil cederam lugar a uma aposta na possibilidade da sua ação conjunta para o aprofundamento democrático. Há autores, entretanto, que apontam essa solidariedade como estratégia de redução das atribuições do Estado, transferindo algumas de suas funções inerentes para a sociedade civil organizada (DAGNINO, 2004; EIZENSTAT, 2004). Essa confluência perversa atestaria as OSC como representantes legítimas das camadas da sociedade civil, assumindo as responsabilidades das instituições permanentes que configuram o Estado. Em verdade, a dinâmica dessa relação desprovê essas OSC do seu caráter de contestação, tornando-as parceiras da agenda governamental e dos conflitos entre as classes que se desenvolvem para a conquista de poder.

$\mathrm{Na}$ medida em que os sucessivos governos consistem em conjuntos de programas e projetos que, em determinada conjuntura política, desempenham as funções de Estado por um determinado período, as várias formas de organização social, incluindo as ambientais, condicionariam suas metas e estratégias tendo em vista os projetos políticos (agendas) dos sucessivos governos, em diferentes momentos históricos e considerando como se dão as relações de poder entre as instituições governamentais.

É nesse sentido que o Estado moderno representativo oferece uma estrutura ao mesmo tempo forte e suficientemente flexível para unificar os interesses políticos de longo prazo de um bloco de poder (de outra forma fragmentado), para desorganizar as classes subalternas e para assegurar o consentimento da maioria da sociedade (POULANTZAS, 2000). Para tanto, o Estado dispõe de uma separação institucional entre economia e política e de uma matriz institucional baseada em um Estado territorial soberano, hierarquicamente organizado, centralizado, fundado no império da lei (rule of law) e combinado com a democracia burguesa. Esse regime político traz um aspecto importante à análise da participação social, na medida em que é orientada para sujeitos políticos como cidadãos individuais, eufemizando a oposição e o conflito das classes que 
compõem as sociedades (ou mesmo ressaltando a colaboração entre as classes sociais), distinguindo, assim, a realidade objetiva da exploração econômica e do poder de classe (POULANTZAS, 2000).

Complementarmente à análise sobre hegemonia de Gramsci (2002), Poulantzas (2000) afirma que a combinação da estrutura institucional e a individualidade política dos sujeitos possibilita uma vantagem a uma classe dominante, dentro das diversas que compõem a sociedade civil, em promover um projeto hegemônico (respaldado por uma ideologia e garantido pela coerção) que vincula interesses individuais aos nacional-populares, também servindo ao interesse de uma classe ligada ao mercado e aos aliados do bloco no poder.

\subsubsection{Tipos de aglutinações na formação das organizações ambientalistas}

A forma como um coletivo se agrupa e se insere em espaços como as arenas políticas depende das possibilidades na dinâmica da política por trás das políticas ambientais ${ }^{22}$. A política ambiental - e, por conseguinte, as ideias e ideais ambientalistas que lhe servem de suporte - possui necessariamente uma dimensão territorial, na medida em que o uso da natureza (e, por consequência, o uso do território) é a essência da ação reguladora (STEINBERGER, 2013). No entanto, os diferentes pensamentos ambientais brasileiros não são derivados da história da política ambiental em si, mas sim de como se deu o processo de apropriação do espaço no Brasil.

A forma como os seres humanos e a natureza se relacionaram ao longo da consolidação do neoliberalismo como caminho econômico abriu precedente para as interpretações sobre o conceito de ambiente, derivando daí a variedade de tipologias ambientalistas, algumas vinculadas propriamente à história da América Latina. Considerando-se, dessa forma, em cada conformação de territorialidade haver a construção de uma ou mais percepções ambientalistas, e delas derivarem distintos princípios de mobilização, estes se organizarão por esta ou aquela estratégia de aglutinação e posicionamento coletivo (grupos de interesses, de

22 A interdependência entre ambiente e território está ancorada no conceito de espaço, elementochave para entender como não dual a relação entre ser humano e natureza (FOSTER, 2005). Tal relação é, por vezes, mencionada como "conflito", "dualidade" ou "contradição" entre sociedade e natureza, como consta na Avaliação da Metodologia do ZEE Centro-Oeste: Transcrição de Debates (MMA/SDS, 2001). 
pressão, movimentos), em torno das linhas de interpretação do ambientalismo, que podem ser mais ou menos conectadas, entretanto, à ideologia dominante.

A gênese e o exercício dessas tipologias por atores coletivos podem ser, na formulação de políticas, um dos pontos de contato entre as camadas da sociedade civil, o ambiente e o território. $O$ endereçamento de cada manifestação coletiva e seu ambientalismo correlato são elementos importantíssimos para a definição de quem são os atores por trás das políticas de cunho ambiental, aspecto que vem sendo negligenciado pela maioria dos trabalhos sobre o tema, aprofundando a falta de clareza sobre quem é quem na questão ambiental. Dado que as redes ambientalistas são compostas por uma pluralidade de tipologias de ambientalismo e de formas de aglutinação dos indivíduos em torno destas, cabe localizar o que se entende por cada uma das nomenclaturas e seus significados.

Os grupos de pressão, dentro dos quais a categoria dos grupos de interesse estaria incluída, são formalmente organizados e buscam influenciar a política (STEWART, 1958) ou promover a formação (CARTER, 2001). Os grupos de interesse não necessariamente apresentam atividade política explícita, também podendo trabalhar na provisão de serviços para seus membros (CESÁRIO, 2016, p. 150). Ambos se diferenciam dos movimentos socioambientalistas de acordo com seu grau de institucionalização, o qual tende a ser menor nos movimentos (SAUNDERS, 2013). Doherty (2002) e Diani (1992) sugerem que os movimentos se assemelham às redes - porém, com pouca ou nenhuma institucionalidade como, por exemplo, sedes próprias de cada organização vinculada - na medida em que são formados por indivíduos que compartilham de uma identidade coletiva. Tais movimentos se engajam em ações coletivas e têm um oponente comum. Além disso, identificam-se em suas territorialidades, as quais, ainda que aparentemente distintas, reúnem elementos em comum.

Já Gohn (1997) separa os movimentos sociais das outras formas de organização social com as quais eles interagem, como partidos, igrejas, sindicatos, ONGs - nacionais e internacionais -, setores da mídia e atores sociais formadores de opinião pública, universidades, parlamentares municipais, estaduais e federais, setores da administração governamental e até pequenos e médios empresários. Essa interação se dá por meio de interesses comuns. A diferença da rede é a característica desta de ter como base referencial diferentes valores culturais e 
políticos, mesmo que não sejam compartilhados por todo o grupo, mas que aumentam seu escopo de intervenção nas decisões sobre o território. Movimentos sociais são ações coletivas construídas por atores sociais pertencentes a diferentes classes e camadas sociais. As ações desenvolvem um processo social e políticocultural que cria uma identidade coletiva ao movimento, a partir de interesses em comum, por força do princípio da solidariedade.

Compartilhando esta última característica, este trabalho define redes como FORMAD e GTA - como estruturas com alto grau de institucionalidade. Para tanto, valemo-nos da definição de Saunders (2013), que as localiza como organizações que se agregam em torno da preservação do ambiente e das sociedades a ele vinculadas, geralmente mediante coalizões temporárias entre combinações de organizações, usando uma ampla variedade de táticas, como atividades de formação e estratégias de negociação. São institucionalizadas porque têm identidade estatutária e uma malha de organizações bem-definidas, historicamente estáveis em suas participações, que compartilham informações e colaboram entre si.

Sendo assim, movimentos e redes socioambientalistas e ideologias ambientalistas se apresentam, em nossa análise, como dimensões do território e de seu planejamento, cada qual com sua atribuição específica, sempre relacionados. A multiplicidade de movimentos e redes em um mesmo contexto regional depende das sinergias ideológicas que ali se desenvolvem.

A unidade em uma rede ambientalista se dá segundo as formas pelas quais as aglutinações dão origem às organizações e, uma vez que estas estejam formadas, à sua conformação no desenho da própria rede, além do momento histórico em que tais agrupamentos se desenvolvem. Saunders e Andretta (2009) evitam o termo ONG por ser pouco preciso. O termo geral "organizações ambientalistas", referindo-se aos grupos que compõem as redes desse tipo, é mais adequado por permitir a subdivisão de tal categoria em subcategorias (ONGs, movimentos, grupos de pressão, grupos de interesse, associações, sindicatos, academias, OSCIPs, federações, etc.).

Através desta opção conceitual, ou seja, pensar nas organizações como parte de uma rede, é possível localizar esses atores em um contexto coletivo, de 
forma a facilitar o entendimento de sua posição nas arenas políticas, sua inserção no Estado e sua ligação com o ambiente e com o território.

Outros termos perfazem o cenário conceitual dos estudiosos, como "organizações de movimentos sociais". Há também os que usam termos diferentes para noções semelhantes: Rawcliffe (1998), por exemplo, fala de "grupos de pressão ambiental", em referência a muitas das mesmas organizações que Rootes (2007) chama de "organizações do movimento ambientalista".

Neste quesito, a noção de grupos de pressão é importante, na medida em que, entre eles, se destacam os grupos de interesse nas redes ambientalistas, estabelecendo a agenda ambiental e moldando a percepção pública. Na prática, todas as organizações ambientalistas são, ao menos parcialmente, institucionalizadas (ROOTES, 2007). Muitas organizações começaram em pequenos grupos de pressão, evoluindo para interlocutores respeitados em algumas tomadas de decisão, como foi o caso da Federação de Órgãos para Assistência Social e Educacional (FASE), que surge como grupo na década de 1960, com caráter assistencialista e cooperativista. Ao longo das décadas de 1970 e 1980, a FASE se aproxima ao campesinato no Norte do Brasil, junto aos trabalhadores rurais do Nordeste, aos trabalhadores da construção civil e das indústrias metalúrgicas do Sudeste e aos movimentos de associações de moradores de norte a sul do País. Posteriormente, articula-se com redes, fóruns e plataformas, de maneira a expandir sua participação nas arenas decisórias.

Outras organizações usaram essa estratégia, ampliando sua atuação local, nacional e internacional. Convênios e parcerias com órgãos públicos e universidades também diversificam o escopo dos estudos técnicos e científicos usados nas mesas de negociação.

Muitas estruturações organizacionais, assim, evoluíram com o tempo, de acordo com as possibilidades e necessidades políticas de cada momento. Segundo Saunders (2013), há autores que consideram que as organizações de movimentos sociais incorporam tanto os movimentos sociais não institucionalizados como as políticas de grupos de interesse (MCCARTHY E ZALD, 1977; DIANI, 1992; DALTON, 1994; DELLA PORTA E DIANI, 1999; MCADAM, 2002). Burstein e Linton (2002), por exemplo, consideram organizações de movimentos sociais e organizações políticas como parte de um continuum sem divisões formais. 
A projeção das organizações ambientalistas e as redes por estas formadas ao longo da década de 1990 e na virada do século, além de aumentarem o foco para a participação, vieram acompanhadas das polêmicas sobre gestão de recursos e corrupção. É importante ressaltar que os problemas de gestão interna e as relações de competição inter e intraorganizações sociais são aqui menos importantes do que sua relevância e papel político. As propostas do Marco Regulatório da atuação das ONGs, seguidas pela Associação Brasileira de Organizações da Sociedade Civil e em trâmite no Governo Federal, já se mostram operativas na averiguação das inconsistências que fizeram parte do histórico das organizações.

\subsection{Organizações, tipologias de ambientalismos e interações em redes}

Como mencionado, diversas são as linhas às quais as organizações ambientalistas podem aderir, dada sua heterogeneidade estatutária, a identificação das bases que as conformam, o reconhecimento mútuo entre os stakeholders e, sobretudo, as divergências que emanam das diferentes classes e grupos que as constituem.

A evolução filosófica do tema ambiental e sua crescente participação nas agendas governamentais globais têm ganhado diferentes interpretações teóricas. Igual esforço é realizado em reflexões metodológicas, epistemológicas, em uma necessidade em estabelecer tipologias às diversas correntes de ambientalismo (MORAES, 2002; ACSELRAD, 2010). Além disso, é necessário considerar a diversidade dos ambientalismos pelo globo, segundo as especificidades históricas regionais que configuraram e configuram a apropriação dos territórios.

Outra questão é a definição clara sobre de que ser estamos falando, identificando cada um e localizando filosoficamente os fenômenos e as relações. Moraes (2002), nesse sentido, aponta a falta de clareza dos conceitos usados e a diversidade de métodos de abordagem da realidade, que complicam a reflexão epistemológica. Assim, faz-se necessário definir as diferentes formas de entendimento das organizações, e como estas se relacionam com a pluralidade de linhas de entendimento sobre o ambientalismo. 
3.2.1. Diversificação das linhas ambientalistas no contexto latino-americano

Atualmente existe uma grande diversidade de entendimentos sobre o que é o ambiente e as formas, concretas ou ideais, de relacionamento entre este e o ser humano. Essa diversidade de entendimentos tem grandes diferenciações ao redor do mundo, relativas às diferentes sociedades e possibilidades de interação entre estas e a natureza. No entanto, há macroentendimentos em voga nas negociações entre os países sobre esse tema, e que foram (e são) objeto de reflexão de pesquisadores sobre a temática. É possível, por isso, abordar as principais linhas que se desenvolvem no escopo das redes ambientalistas amazônicas.

O aumento numérico das OSC de cunho ambientalista e sua conformação por malhas têm relação com a projeção da questão ambiental no cenário internacional, impulsionada pela Conferência das Nações Unidas sobre o Meio Ambiente e o Desenvolvimento, realizada no Rio de Janeiro em junho de 1992. Esse foi um marco importante no desenvolvimento tanto do movimento ambiental quanto da definição das linhagens das organizações ambientalistas no Brasil. Foi também a partir desse momento que se tornou possível delinear quem eram os atores coletivos ambientalistas, e qual seu background e seus objetivos em longo prazo.

Em um contexto de dificuldade de reflexão sobre o que é e como analisar a questão ambiental, Moraes (2002) traça algumas linhas que ele identifica como principais na discussão. As posturas (naturismo, tecnicismo e romantismo) identificadas pelo autor naquele momento foram desdobradas em outras, à medida que a questão ambiental se elevava internacionalmente em importância e que outros autores se debruçavam sobre a questão.

Para o naturismo, a dimensão social é afastada da ambiental. Nessa perspectiva, o determinismo histórico ainda persiste na interpretação do ambientalismo. Posteriormente, Farhi Neto (2006) se aproxima ao naturismo de Moraes, nomeando como ambientalismo libertário o que reconhece como novas formas de organização política das sociedades, em que a questão ecológica passa a orquestrar o modo humano de viver. Entretanto, existiria uma relação entre as sociedades e o território na medida em que aí aparecem as "biorregiões", ou seja: 
A biorregião pode ser entendida como continuidade expandida da noção de lugar, ou, como o correlativo da crítica radical ao Estado. Assim, a biorregião tem pelo menos esses dois aspectos: o de território vinculado a uma cultura, traçado por critérios naturais, não unívocos nem artificiais, que seguem os contornos imprecisos de uma espécie de planta ou de uma condição climática, compatíveis, portanto, com uma percepção humana; e 0 aspecto de uma unidade política descentralizada, eventualmente federada em grupos mais abrangentes. (FARHI NETO, 2006, p. 41).

Para o tecnicismo de Moraes (2002), a técnica está acima dos conflitos e das disputas, representando ser uma vertente mais positivista de tratamento da questão ambiental. Visa atomizar a ciência em relação à sociedade que a criou, elevando a técnica em relação aos conflitos, a partir de uma aura de verdade acessível apenas aos seus próprios formuladores. Estudiosos, em especial os mais diretamente envolvidos com órgãos públicos, aferem um maior peso às decisões técnicas, professadas como neutrais e, por isso, idôneas (MORAES, 2002, p. 54).

Já o romantismo se fundamentaria por uma excessiva politização. Sinérgico a este raciocínio, Avner de-Shalit (1995) propõe tratar as questões ecológicas dentro da esfera política, e não apenas sob seus aspectos econômicos.

No romantismo, além da dimensão política, o ambientalismo tem suas vertentes de compreensão sobre seu papel em relação ao mercado. Similarmente, Farhi Neto (2006) define como ambientalismo liberal a corrente com o protagonismo do mercado, no qual as questões ecológicas são exclusivamente soluções a este, podendo ser resolvidas pela via economicista. Outra interpretação, dada por Paul Hawken (1996), é o "mercado verde", no qual o funcionamento de mercado deveria ser estruturado segundo concepções e regras radicalmente diferentes das atuais, direcionado por regras macroeconômicas de governo.

Em termos gerais, essas estratificações do ambientalismo refletiam um momento em que, na América Latina, a questão ambiental ainda desenvolvia sua singularidade metodológica em pensar a questão, de forma que, para as redes que se aglutinavam em torno da causa, as definições como a de Moraes (2002) serviram como norteadoras para a consolidação de suas próprias visões quanto a que tipo de raciocínio sobre a relação ser humano e ambiente melhor as definia.

Mediante essa evidência, em uma leitura mais recente, Alier, Sejenovich e Baud (2015) identificam uma variedade de posicionamentos ambientalistas, cuja diversificação remete às raízes históricas da América Latina. A singularidade dos acontecimentos que se sucederam na consolidação de cada país dessa fração do 
continente americano levou ao desenvolvimento de especificidades no pensar a questão ambiental. Para tais autores, ainda que algumas modalidades de ambientalismo tenham vindo de fora, elas adquiriram uma tradição própria quando incorporadas ao cenário latino-americano.

Os pensamentos ambientalistas e ecologistas na América Latina apresentam diversas características próprias, dentre as quais aqui são ressaltadas as seis de maior aplicabilidade à discussão proposta nesta tese, que as diferem dos demais enfoques ambientalistas no mundo (ALIER, SEJENOVICH E BAUD, 2015). Essas características ora coincidem, ora divergem, com vertentes de outros continentes, o que torna mais complexo o entendimento quando em colaborações estudadas por autores que refletem sobre $o$ ambiente na perspectiva das relações internacionais.

A primeira, originária, deriva da refutação do enfoque malthusiano relativo às superpopulações (ALIER, SEJENOVICH E BAUD, 2015, p. 41). A alta densidade populacional na América Latina seria resultado da política de povoamento dos governos modernizadores, como o que sucedeu na Amazônia para a proteção das fronteiras ao longo da década de 1970. Nos governos modernizadores da América Latina, o princípio de "governar é povoar" é simbólico do pensamento das elites. Assim, a atribuição dos problemas ecológicos à superpopulação, estimulada pelas próprias elites, nada mais seria do que o projeto dos Estados.

A segunda, vinculada ao conceito de agroecologia, é a retomada de um orgulho das técnicas de agricultura milenares nas Américas, deturpadas pelo modelo agroexportador que acabou por saturar os solos e romper relações ecológicas estritas entre os biomas e as agriculturas preexistentes (ALIMONDA, 2011; ALIER, SEJENOVICH E BAUD, 2015). Autores como Miguel Altieri (Chile), Vitor Toledo (México), Wanderlei Pignatti, Sebastião Pinheiro (Brasil) e outros defendem, além de diversas organizações da agricultura familiar e indígena, estratégias políticas e ecológicas de estabelecimento de sistemas agrícolas que aumentam a biodiversidade nos distintos ecossistemas. No Equador, o ambientalismo agroecológico se consolida como estratégia política, convertendo-se em objetivo nacional na Constituição de 2008, assim como na Bolívia, na Constituição de 2009 (HIDALGO-CAPITÁN et al., 2014). É possível dizer, nesse sentido, que as organizações de linha agroecológica que compõem as redes 
ambientalistas consideradas neste estudo estão inclinadas a essa linha de entendimento sobre a relação entre seres humanos e a natureza.

A terceira característica, conservacionista, deriva da admiração e do interesse científico dos países centrais pela diversidade e riqueza biológica nos vários ecossistemas que compõem o ambiente. A evolução dos estudos sobre biogeografia nas Américas, a partir de Alexander van Humboldt e Charles Darwin, trouxe consigo uma crescente apreciação às ideias conservacionistas. $O$ estabelecimento de Parques Nacionais desprovidos de presença humana, mesmo que autóctones, e as atuais iniciativas de adaptação às mudanças ambientais globais, como a Redução de Emissões por Desmatamento e Degradação (REDD+), poderiam ser classificados nesta vertente. Segundo Alier, Sejenovich e Baud (2015), o conservacionismo, dentre as demais linhas do ambientalismo, é a que mais angaria recursos internacionais, como a International Union for Conservation of Nature (IUCN) e a Food and Agriculture Organization of the United Nations (FAO), e a que possui organizações ambientalistas com maiores recursos, como a World Wide Fund For Nature (WWF) e a The Nature Conservancy (TCN). Em menor proporção, existem organizações ambientalistas amazônicas, incluídas nas conformações em rede e atentas à temática da conservação ambiental, que estão aderidas a esta forma de pensar o ambientalismo.

A quarta característica, o ecologismo popular, baseia-se na evidência da inequidade política e econômica mundial, sendo que, pelas relações hegemônicas que se estabelecem nessa escala, despojam-se os recursos naturais daqueles países em maior vulnerabilidade. Tal como a primeira linha, reconhece-se 0 histórico da exploração colonial e o seu legado à sustentabilidade socioecossistêmica. No entanto, outro componente se soma à análise do Estado como impulsor dessas desigualdades: as desigualdades entre as camadas da sociedade civil. Assim, o ecologismo popular tem se dissipado desde os anos 1980, "com redes de ativistas denunciando a extração dos recursos naturais e a destruição de bens comuns" (ALIER, SEJENOVICH E BAUD, 2015, p. 42). Os membros que trabalham a temática dos direitos humanos, povos indígenas e demais sociodiversidades consideram os elementos abordados por esta vertente.

A linha do ecossocialismo, quinta tipologia do ambientalismo latino-americano, tem como princípio que o capitalismo rompe com o metabolismo entre 
seres humanos e natureza, reportando-se, portanto, à noção de metabolismo social anteriormente abordada. Portanto, as evidências de quebra do ciclo de nutrientes no ecossistema, fomentada pelo agronegócio, e a destruição da biodiversidade pelas forças produtivas do capitalismo são elementos norteadores desta vertente. Os movimentos sociais, sobretudo os que estão ligados à reforma agrária, são protagonistas deste entendimento, em sua relação com as redes ambientalistas.

Finalmente, a sexta tipologia se refere ao romantismo, abordado por Alier, Sejenovich e Baud (2015), distinto do romantismo de Moraes (2002). Se este se aproxima do conservadorismo, a linha romântica vista pelos primeiros autores se manifesta na literatura e nas artes latino-americanas. É interessante a percepção desta linha devido à sua acessibilidade aos subalternos e ao seu grau de influência na formação de posturas ambientalistas ao longo das décadas. Ao longo do século $X X$, diversas obras denunciavam, por meio da literatura, das artes cênicas e da música, os efeitos sociais da produção capitalista e o aumento da desigualdade, misturando crítica social com consciência ecológica. Alguns exemplos dessas obras são: "Os sertões", de Euclides da Cunha; Grande Sertão: Veredas, de João Guimarães Rosa; Huasipungo, de Jorge Icaza, dentre diversos outros.

A análise sobre a singularidade do ambientalismo latino-americano e suas vertentes permite pensar sobre a permeabilidade dos diversos ambientalismos nos governos, segundo propostas mais moderadas ou mais radicais. Por outro lado, permite perceber as especificidades decorrentes da forma como se deu 0 metabolismo entre o ser humano e a natureza na América Latina, com a consequente ruptura de relações agroecológicas, pela valorização da agricultura industrial em detrimento de outras alternativas de uso do solo mais adequadas ao ciclo de nutrientes (FOSTER, 2005). Esse aspecto tem diversos desdobramentos socioambientais - dentre eles as mudanças nos regimes do clima, o desmatamento, a deriva ecológica e as migrações de populações humanas de diversas etnias marginalizadas - e, principalmente, consequências na forma de fazer a política ambiental nos países com essas condicionalidades.

Temos, portanto, o desenvolvimento de posições ambientalistas, dentro das organizações das redes, essencialmente "de baixo para cima" 23 (bottom up), as políticas devem ser elaboradas e decididas em uma esfera política, sendo sua implementação 
que em geral emanam de um espectro das camadas sociais aos governos. Vinculadas em especial à segunda e quarta vertentes aqui descritas, estariam na categoria de "radicais" na perspectiva dos governos, por tentarem promover mudanças estruturais (SAUNDERS, 2013). Outras têm o Estado como protagonista das decisões, muitas vezes defendendo uma agenda colaborativa entre Estado, mercado e sociedade civil, baseada em interpretações difusas de "desenvolvimento sustentável". São tidas como mais moderadas por Saunders (2013), e geralmente seu perfil é o mais reativo aos demais atores na tomada de decisões. No entanto, esse caráter colaborativo, no qual se tenta desconsiderar a existência de conflito entre os atores, em vista a uma colaboração entre classes sociais, Estado e mercado, é frágil, por não resolver os impasses historicamente construídos e ainda não resolvidos.

Frente às seis interpretações aqui descritas e suas correlações com o ambiente social, o ambientalismo na América Latina se abre em uma complicada conjuntura entre o neoliberalismo e o nacionalismo popular, reportando-se a conceitos como racionalidade ecológica produtiva, dívida ecológica, justiça climática, justiça hídrica, direitos da natureza, pós-extrativismo, pós-desenvolvimentismo e bem-viver.

Ainda que tenha havido avanços nas estratégias de negociação com os tomadores de decisão nas esferas governamentais nacionais e internacionais, essas singularidades devem ser legitimadas nos debates internacionais, incorporadas por estes para que se possa superar a visão dos países centrais e reconhecer esse ambientalismo específico nas políticas ambientalistas dos países que compõem a América Latina.

\subsection{A importância das redes ambientalistas nas relações territoriais}

Existem múltiplas interpretações recentes do conceito de rede aplicado às formas de organização entre atores coletivos e seu vínculo com o território. Igualmente, existem diferentes categorias de atores coletivos, segundo sua institucionalidade, endereçamento e formas de ação.

um mero esforço administrativo. Já o modelo bottom up (de baixo para cima) permite que a política ambiental possa adquirir formatos diversos ao definido na tomada de decisão, padrão que é modificado pelos que implementam essa política no dia a dia (SECCHI, 2012). 
Castells (2001), desde a sociologia, refere-se às redes como intrínsecas à localidade, e interpreta-as como resultado da inovação das tecnologias da informação, as quais remodelaram a base material da sociedade. As redes constituiriam a nova morfologia social, e a difusão de sua lógica modificaria substancialmente a operação e os resultados dos processos produtivos e de experiência, poder e cultura (CASTELLS, 2001, p. 565). O poder dos fluxos seria, para o autor, mais importante que os fluxos de poder.

Entretanto, nem sempre as localidades têm uma estrutura de comunicação que permita a máxima potencialidade de tais fluxos. O problema do princípio levantado por Castells, aplicado às grandes distâncias amazônicas, encontra-se na dificuldade de coleta, sistematização, validação e difusão de dados socioambientais na Amazônia Legal. Este representa ser um desafio estrutural tanto para instituições governamentais (federais, estaduais e municipais), quanto para organizações socioambientalistas (IBGE, 2016).

Raffestin (1993) também se refere aos fluxos de todos os tipos, de mercadorias a informações, como premissas à existência de redes, vinculadas ao conceito de território. Os nós das redes seriam os lugares de conexão, poder e referência. Essa conexão pode ser exclusiva ou inclusiva, na medida em que "os organismos de gestão da rede, quer se trate de gestão técnica, econômica ou jurídica, não são neutros. Eles colocam em jogo relações sociais entre os elementos solidarizados e aqueles que permanecem [por qualquer razão] marginalizados" (DUPUY, 1984, p. 241).

Por outro lado, o termo rede também pode se referir a uma forma de estruturação social e política, baseada na dinâmica de valores dos atores sociais que a compõem. Para Santos (2006), o conceito de rede é uma abstração que corresponde à noção de um espaço reticulado, isto é, o espaço como quadro de vida, reativo aos estímulos de produção materiais e imateriais. Neste entendimento, a intencionalidade não segue o sentido de ocupar áreas, mas de ativar ou criar novos pontos e linhas por meio de redes. Os espaços contínuos e o território, visto como controle de áreas (lógica territorial zonal), se relacionariam com os espaços descontínuos, ou de controle de redes (lógica territorial reticular). Nesse sentido, "espaço-tempo" e "territórios-redes" seriam indissociáveis na medida em que incorporam a noção de que o território é construído "no e pelo movimento" 
(HAESBAERT, 2004; 2014; COSTA E MENDES, 2014).

Baseando-nos na experiência do FORMAD e GTA, é possível reconhecer o caráter imanente da multiterritorialização para os grupos sociais vinculados a essas redes. Assim, a dinâmica de desterritorialização e reterritorialização ${ }^{24}$, descontínua espacial e temporalmente, implica a potencialidade para perspectivas políticas inovadoras.

Dessa forma, as aqui abordadas redes ambientalistas, assim como qualquer outra rede de cunho social e político, são compostas por pontos, posicionados em diversos momentos, sendo essa sucessão não aleatória. Tais redes devem ser entendidas pela correspondência de suas técnicas e estratégias no momento histórico mundial, por sua pertinência na região onde atuam, pela quantidade e distribuição de suas unidades (aqui, organizações ambientalistas), bem como por suas atribuições e, finalmente, pelas relações que elas estabelecem para além de seu escopo regional. Relacionam-se com esses fatores a identidade ambientalista de cada organização e os "nós" que se formam a partir dessas identidades, elementos tais que impelem a elaboração da agenda das redes ${ }^{25}$.

\subsection{Composição da rede FORMAD e suas interações}

No que diz respeito ao estabelecimento de organizações ou redes ambientalistas, é possível dizer que seus estritos pontos de contato com o território fazem com que esses coletivos representem uma categoria de mobilização coletiva cujas demandas dizem respeito à soberania por parte dos grupos sociais pertencentes a essas redes sobre um espaço apropriado (PEDON, 2013).

O movimento das intencionalidades dos indivíduos, produzidas na dialética entre as demandas individuais e as coletivas, conforma a territorialização das mobilizações promovidas pelas redes em torno de questões ambientais. As intencionalidades envolvem crenças e desejos e dizem respeito a deliberação, planejamento, projeções, direções, significados e interpretações que denotam,

24 Para Haesbaert (2004), a desterritorialização seria mais do que a perda de territórios, incluindo complexos processos de (re)territorialização em que estamos envolvidos, tornando complexa nossa multiterritorialidade.

25 Raciocínio elaborado a partir de Santos (2006, pp. 263-266). 
individual e coletivamente, ação e relações de poder (SEARLE, 2002; SANTOS, 2006).

O que notamos nas redes é que a escala de ação de um determinado grupo transcende sua territorialidade quando se reconhece e compartilha elementos dessa relação com o espaço apropriado e ressignificado com outros grupos a ele sinérgicos. Logo, as redes ambientalistas se constituem de acordo com sua capacidade de articulação e seu grau de organização (PEDON, 2013). Também sujeitas a relações de poder, com atores internos ou externos, das redes ambientalistas derivam escalas geográficas que permitem um mapeamento das políticas territoriais e ambientais. Esses aspectos escalares (tipos de alianças, abrangência das parcerias, etc.) dizem muito sobre os sucessos e os fracassos políticos das redes ambientalistas ou sobre a limitação de sua ação (BERNARDES, 1983; MIZUBUTI, 1986).

No caso do FORMAD, há uma articulação escalar dos movimentos e das organizações que o conformam em diferentes níveis, a partir do momento em que derivam as participações no GTA, no ARA e na Campanha Permanente Contra os Agrotóxicos e pela Vida. Apesar da malha de possibilidades consolidadas de articulação, nem todas são exploradas simultaneamente. Algumas se cristalizaram em um momento específico, outras são sazonais e outras, ainda, perduraram por toda a história do fórum.

O Fórum Mato-grossense de Meio Ambiente e Desenvolvimento teve a sua origem no contexto da primeira Conferência das Nações Unidas pelo Meio Ambiente e Desenvolvimento, ocorrida no Rio de Janeiro. Nessa época, em nível regional e nacional, aconteceram várias mobilizações feitas pelo Fórum Brasileiro de Organizações Não Governamentais (ONGs) e por movimentos sociais em vista à preparação para uma participação qualificada no evento. No entanto, o contexto nacional, ainda com o desenvolvimento das instituições do Estado voltadas ao meio ambiente, ainda se apresentava em estrutura pouco desenvolvida à participação da sociedade civil e à multiplicidade de atores sociais. Algumas iniciativas para fortalecimento das instituições ambientais estavam em curso naquele momento, notadamente o Programa Piloto para a Proteção das Florestas Tropicais do Brasil (PPG7).

O PPG7 representou uma tentativa de mudanças, aproveitando o know 
how das organizações em rede, para o desenho de uma gestão ambiental compartilhada. Na tentativa de propor soluções aos Órgãos Estaduais de Meio Ambiente (OEMAs) amazônicos, no entanto, no desenvolvimento do PPG7 foram identificados que os problemas da institucionalidade ambiental eram profundos. Portanto, um programa com o escopo do PPG7 teria dificuldade de sanar todas as questões que demandavam solução, muitas delas relacionadas com os graves problemas fundiários.

Regionalmente, os encontros realizados no Mato Grosso relacionados ao meio ambiente, e que tinham como pauta o PRODEAGRO, o PPG7 e o ZEE estadual, foram significativos para a criação dos laços de solidariedade entre as organizações que compunham o FORMAD.

O surgimento do FORMAD enquanto rede esteve atrelado à repercussão e importância política que a CNUMAD de 1992 poderia representar em termos de oportunidades políticas para grupos locais mato-grossenses, os quais, apesar de já naquele momento convergirem em pautas comuns, ainda não estavam articulados em forma de malhas coesas, com ampla distribuição no estado.

Foi nesse contexto que a Associação Mato-grossense de Ecologia (AME), a VIVA ALTERNATIVA-DF e a Sociedade Brasileira para o Progresso da Ciência (SBPC) organizaram o Encontro do Centro-Oeste, que aconteceu na Universidade Federal de Mato Grosso (UFMT), em maio de 1991. O tema central era a CNUMAD. Nesse mesmo ano, em novembro, foi realizado o Encontro de ONGs de Mato Grosso, organizado pela AME, pela SBPC e pelo Instituto Centro de Vida (ICV). Em fevereiro de 1992, a FASE promoveu um encontro em Pontes e Lacerda, discutindo sobre a Campanha Meio Ambiente e Cidadania. Nele, foi constituída uma comissão pró-fórum, articuladora de reuniões preparatórias para sedimentar a proposta de articulação do fórum estadual de entidades e movimentos sociais. Na ocasião, a FASE localizada na Amazônia havia lançado, previamente à CNUMAD, uma campanha de educação ambiental para pensar em produzir um material direcionado a movimentos sociais.

Durante a apresentação desse material surgiu uma proposta de criar um fórum ambiental específico para o atendimento das demandas mato-grossenses, considerando a diversidade sociocultural presente na região. A iniciativa, que viria a ser o FORMAD, teria como foco o monitoramento e a discussão do 
desenvolvimento no estado do Mato Grosso, com enfoque na questão ambiental e na sustentabilidade ${ }^{26}$. Paralelamente, teria como foco a descentralização da gestão e da política ambiental, por meio de atuação em nível político municipal.

Por conseguinte, foi deliberada como missão institucional do FORMAD a postura crítica em relação ao modelo de desenvolvimento vigente, contestando os problemas ecológicos, econômicos e sociais no Mato Grosso e articulando ações em rede, mobilizando diversos setores da sociedade civil organizada para intervenções em favor do desenvolvimento sustentável e democrático, sob os princípios da inclusão social, da valorização da biodiversidade e da diversidade cultural.

Dada a vulnerabilidade dos OSCAs, uma organização em rede impede que as instituições sejam atacadas individualmente por suas posições políticas. Assim, essa estrutura, além de fomentar a articulação para uma determinada ação política, serve também de proteção para eventuais represálias por parte dos prejudicados.

Outra potencialidade levantada é a articulação do FORMAD com outras redes locais, nacionais e internacionais, aumentando o intercâmbio de informações e ampliando o rol de atuação em relação a problemas socioambientais averiguados em territórios compartilhados ou entre fronteiras. Em âmbito local, destacam-se os vínculos com o Fórum Teles Pires e a Rede Pantanal, o Fórum de Direitos Humanos $\begin{array}{llll}\text { e da } & \text { Terra } & \text { (FDHT), } & \text { a }\end{array}$ -grossense de Educação Ambiental (REMTEA), o Grupo de Intercâmbio em Agroecologia de Mato Grosso (GIAS) e diversos outros; em âmbito nacional, o Grupo de Trabalho Amazônico (GTA); e, no internacional, a Articulação Regional Amazônica (ARA). Nesses espaços, os membros se reúnem antecipadamente, traçando as estratégias de negociação em plenárias - a fim de conseguir adesões de outros membros à pauta defendida pelo grupo de instituições articuladas -, os objetivos que esperam ser alcançados e as formas de se trabalhar ou mesmo votar conjuntamente.

No que diz respeito aos vínculos internacionais, estes se deram por diferentes razões ao longo da história. De forma resumida, pode-se dizer que as interações se davam em três escalas: as que tinham como foco a colaboração financeira, 
consolidadas com os países do Norte; as que tinham como pauta a similaridade de eixos de atuação, como os laços estabelecidos em torno da contestação ao Prosavana, em especial, em Moçambique (UNAC et al, 2013); e as que tinham como foco biomas e ecossistemas compartilhados. Neste tipo de ligação, centrouse em manter relação com os países que compartilham a Pan-Amazônia, região que divide preocupações pertinentes ao avanço do desmatamento e, por conseguinte, ao impacto aos ecossistemas (Figura 7).

A estrutura da rede ambientalista conformada teve muitas alterações sobre suas prioridades de ação e seus participantes, dependendo de fatores como quais eram as problemáticas mais emergenciais no estado e quais os atores organizacionais da sociedade civil que tinham melhor estrutura financeira e de recursos humanos para seguir com as negociações. No entanto, os eixos de ação sobre os quais giravam as estratégias de intervenção nas decisões políticas seguiram muito semelhantes à proposta inicial (Quadro 13).

Tanto porque os problemas não se esgotaram por si quanto porque, apesar de se alcançarem vitórias em uma linha de incidência política, havia uma contrarresposta por parte das elites (oligarquias), que traziam o status quo para o seu estado original, favorável a estes grupos. 
Figura 7. Distribuição dos vínculos internacionais do FORMAD entre o período de 1992 e 2012 e distribuição das frentes de desmatamento na Pan-Amazônia

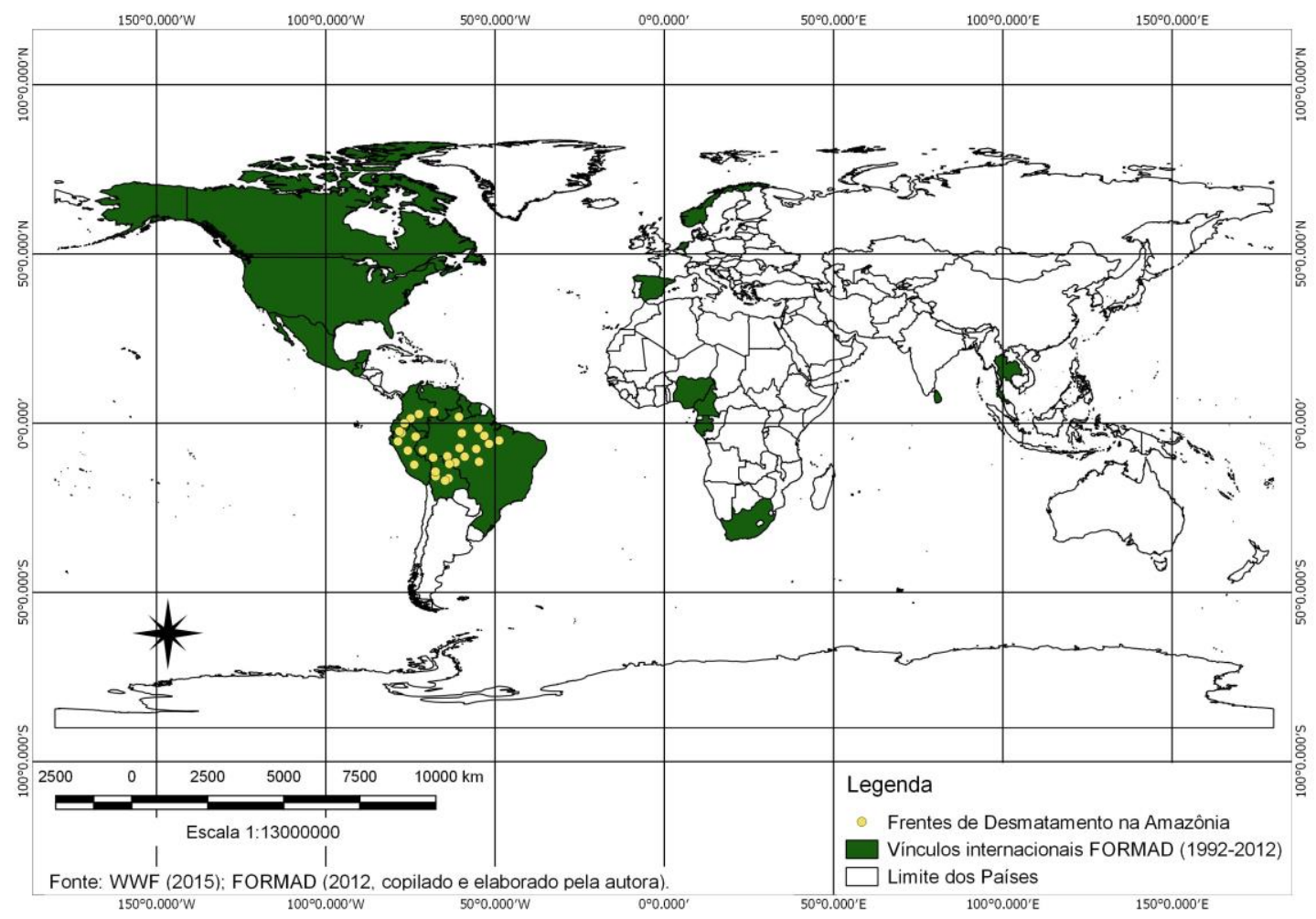

Fonte: Dados copilados de documentos do FORMAD, WWF (2015). Elaboração própria.

Já os produtores rurais do estado de Mato Grosso estão representados por canais institucionalizados de representação, os quais também configuram redes de solidariedade. Além dos sindicatos rurais, são organizações com alto poder financeiro e político a Federação da Agricultura e Pecuária do Estado de Mato Grosso (FAMATO) e a Confederação de Agricultura e Pecuária do Brasil (CNA). A Associação dos Produtores de Soja e Milho de Mato Grosso (APROSOJA), a Associação dos Criadores de Mato Grosso (ACRIMAT) e a Associação MatoGrossense de Produtores de Algodão (AMPA), também representações de grandes produtores, financiam o Instituto Ação Verde, com o Sindicato das Indústrias Sucroalcooleiras do Estado do Mato Grosso (SINDACOOL), Sindicato da Construção, Geração, Transmissão e Distribuição de Energia Elétrica e Gás no Estado de Mato Grosso (SINDENERGIA), Federação das Indústrias do Estado de Mato Grosso (FIEMT) e o Centro das Indústrias Produtoras e Exportadoras de 
Madeira do Estado de Mato Grosso (CIPEM). Fortemente coesos, dotados de grandes recursos e com alto poder de influência política, tais representantes do setor agropecuário podem agir em bloco, mesmo com única representação nos conselhos ambientais do estado de Mato Grosso e em outros espaços de discussão da sociedade civil (THUAULT, 2012).

\section{Quadro 13. Eixos temáticos da rede FORMAD}

\begin{tabular}{|c|c|}
\hline Eixo temático & Ações \\
\hline $\begin{array}{l}\text { 1. Terra e modelo de } \\
\text { desenvolvimento (uso da terra) } \\
\text { a) Agricultura familiar. } \\
\text { b) Agronegócio: concentração } \\
\text { fundiária, agrotóxico, agrocombustível } \\
\text { e respectivos impactos. } \\
\text { c) Ordenamento territorial: ZSEE. }\end{array}$ & 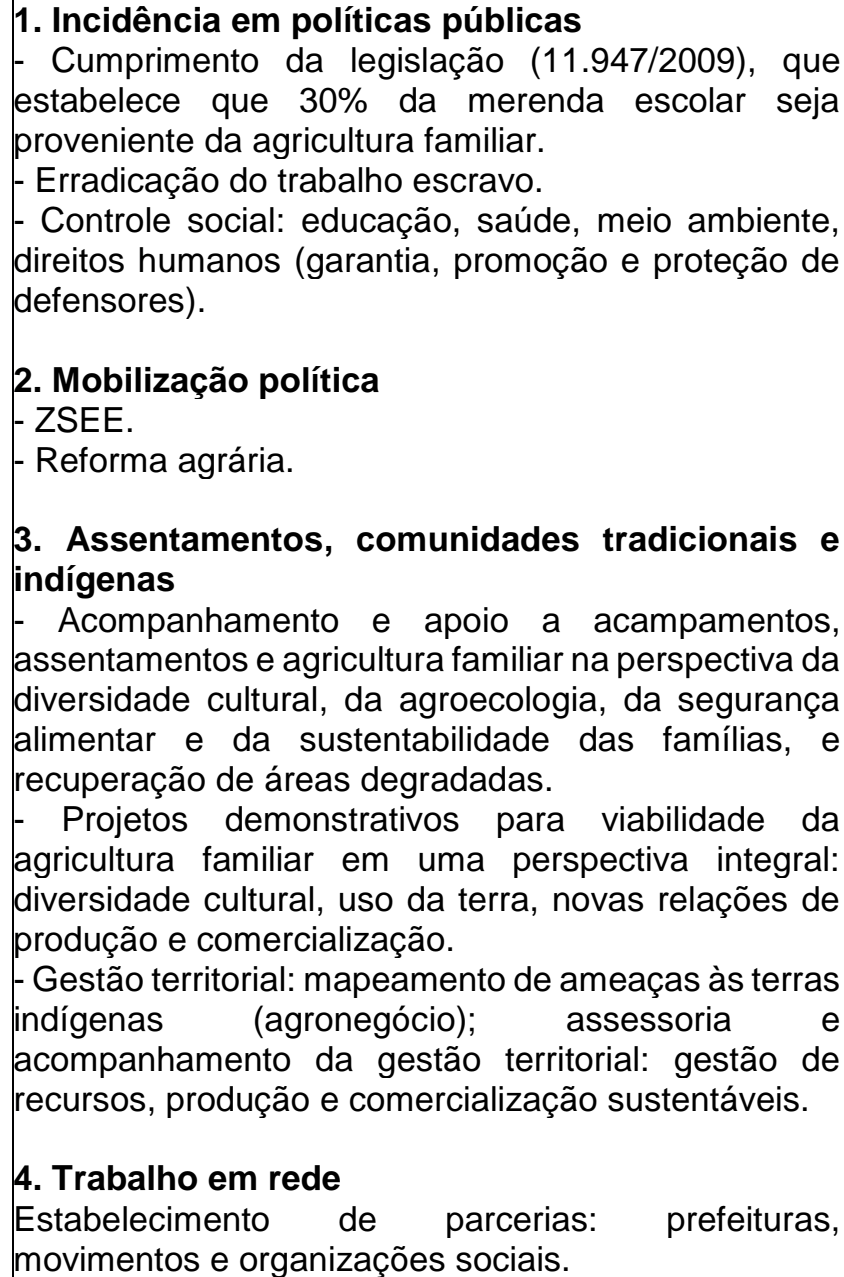 \\
\hline $\begin{array}{l}\text { 2. Grandes projetos - Brasil e Mato } \\
\text { Grosso } \\
\text { Grandes obras: hidrelétricas, rodovias, } \\
\text { hidrovias e ferrovias. }\end{array}$ & $\begin{array}{l}\text { 1. Construção de hidrelétricas, PCHs } \\
\text { Barragens e impactos socioambientais: alcoolismo, } \\
\text { drogas, prostituição, famílias afetadas que não são } \\
\text { assentadas, desinformação das populações afetadas, } \\
\text { falsas promessas dos gestores públicos às } \\
\text { comunidades. }\end{array}$ \\
\hline $\begin{array}{l}\text { 3. Impactos ambientais e legislação } \\
\text { ambiental (incidência em políticas } \\
\text { públicas) }\end{array}$ & $\begin{array}{l}\text { 1. Interlocução com a sociedade e o Estado } \\
\text {-Debates e seminários acerca das demandas e } \\
\text { questões ambientais. } \\
\text { - ZSEE. } \\
\text { 2. Mobilizacão política }\end{array}$ \\
\hline
\end{tabular}




\begin{tabular}{|l|l|}
\hline $\begin{array}{l}\text { b) Ordenamento territorial: ZSEE, } \\
\text { legislação ambiental, Código Florestal. }\end{array}$ & - ZSEE e Código Florestal. \\
& 3. Capacitação e incidência em políticas públicas \\
- Fortalecimento da gestão ambiental: prefeituras, \\
lideranças, comunidades, conselhos.
\end{tabular}

Fonte e elaboração: FORMAD, 2010.

A distribuição espacial da rede FORMAD foi se modificando ao longo do tempo, inicialmente centrando-se nas questões mato-grossenses e relativas aos estados vizinhos, que compartilham a Amazônia Legal (Figura 8). Posteriormente, e mediante a integração com outras redes e organizações, ampliou-se a distribuição das colaborações para outras partes do Brasil. Em relação à distribuição geral das organizações da sociedade civil registradas, a malha conexões da rede FORMAD configura OSCAs de diferentes tipos. Elencamos, a 
seguir, os que tiveram participação em atividades de coordenação e acompanhamento ao longo de todo o período de estudo.

O Sindicato dos Trabalhadores Rurais de Lucas do Rio Verde (STRLRV) tem seu escritório central no município de Lucas do Rio Verde, na região centro-norte do estado de Mato Grosso, que é cortada pela rodovia BR-163 (Cuiabá - estado de Mato Grosso e Santarém - estado do Pará).

Essa organização trabalha em Lucas do Rio Verde e em assentamentos da reforma agrária em Vera, Cláudia e outros municípios situados nas vizinhanças, para fortalecer comunidades de agricultores familiares e suas instituições. Ela oferece cursos de desenvolvimento de capacidades para agricultores familiares recuperarem reservas legais e áreas de proteção permanente em suas chácaras, visando preservar a biodiversidade local e estimular a conservação e o uso de sementes nativas. Dentro de suas atribuições estatutárias, apoia alternativas econômicas sustentáveis, particularmente projetos de horticultura e apicultura. Também oferece cursos de desenvolvimento de capacidades políticas a fim de preparar agentes ambientais locais para participar de processos de formulação, implementação e monitoramento de políticas públicas relacionadas com a preservação do meio ambiente.

Entre outras ações, o STRLRV está envolvido na implementação dos Projetos de Alternativas ao Desmatamento e às Queimadas (PADEQ), os quais fizeram parte de um projeto do Ministério do Meio Ambiente (MMA) dirigido a assentamentos da reforma agrária. Este foi concebido para promover um mecanismo de produção e geração de renda para grupos locais e, ao mesmo tempo, a recuperação e a conservação de recursos naturais. É importante mencionar que o STRLRV está ativo em uma região marcada pelas taxas mais elevadas de produção de soja do estado, que inclui os municípios de Sinop e Sorriso.

Recentemente, um complexo industrial começou a surgir na região, com a empresa Sadia desempenhando um importante papel no seu desenvolvimento. Desde que o STRLRV começou a participar do FORMAD, houve um fortalecimento da sua capacidade de mobilizar associações de assentamentos da reforma agrária e organizações de pequenos produtores para participar e apresentar propostas em audiências públicas sobre o ZSEE. Alternativas econômicas agroecológicas têm sido defendidas nessas audiências, bem como o reconhecimento territorial de áreas 
assistidas por projetos de assentamentos da reforma agrária, que foram levados em consideração em planos de organização territorial e em diretrizes sociais e econômicas. O STRLRV conseguiu aumentar a visibilidade dessas demandas em consultas públicas e em documentos encaminhados a assembleias legislativas.

O sindicato é também membro da rede Grupo de Trabalho Amazônico. No GTA, participou de debates em torno do impacto da pavimentação da Rodovia BR163 e do Projeto de Fortalecimento da Participação Social (PROFOR), este concebido para melhorar a capacidade de uso de rodovias, que vão além do seu propósito comum de facilitar o escoamento da produção do agronegócio. Sua ideia é que rodovias e estradas devem garantir um melhor acesso à saúde pública e à educação, além de permitir o escoamento da produção de médios e pequenos agricultores. $\mathrm{O}$ projeto envolve também um componente de combate ao uso intensivo de pesticidas, o que impacta o meio ambiente e prejudica a saúde de populações urbanas e rurais. 
Figura 8. Distribuição do FORMAD e suas conexões

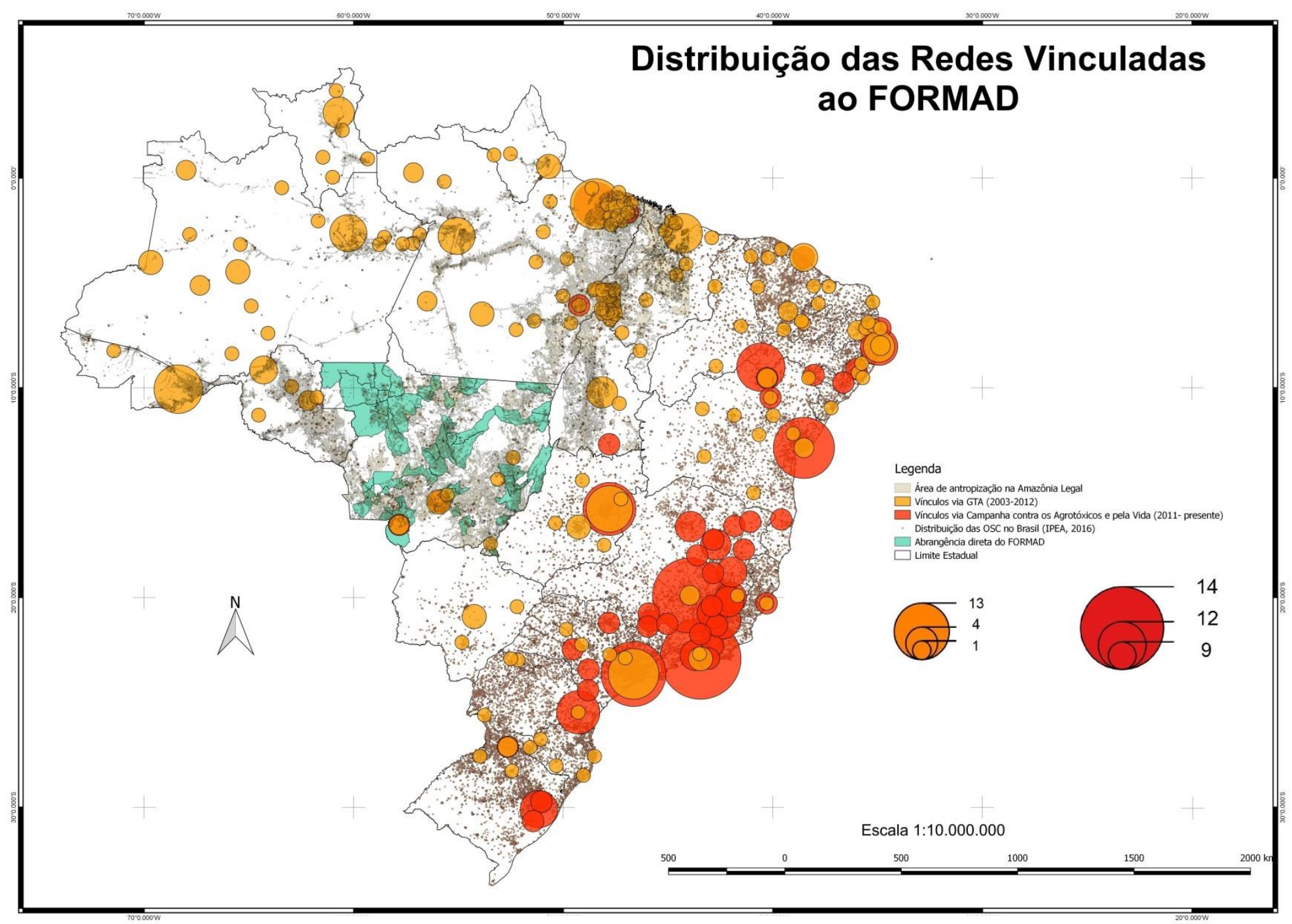

Fonte: IPEA (2016); GTA (2015); FORMAD (2012). 
A Operação Amazônia Nativa (OPAN) é uma organização não governamental estabelecida em 1969, pioneira na promoção e defesa dos direitos de povos indígenas, sobretudo dos Irantxe, Myky e Enawene Nawe, na região Noroeste do estado de Mato Grosso, e das aldeias Xavante, intervindo na área em torno da região da bacia do rio Araguaia. No estado de Amazonas, a ONG tem trabalhado com os Deni, Paumari, Katukina, Zuruaha e outros povos.

No Mato Grosso, o agronegócio da soja e da cana-de-açúcar foi expandido para áreas que fazem fronteira com territórios indígenas, afetando suas atividades tradicionais de caça e pesca e sua biodiversidade. Essa expansão ameaça a soberania alimentar dos povos indígenas, além de contaminar intensamente nascentes, córregos, cabeceiras e rios com pesticidas. Rodovias federais projetadas para facilitar o escoamento da produção do agronegócio cruzam terras indígenas, gerando impactos culturais e sociais. Pequenas usinas hidrelétricas na bacia do rio Juruena representam uma ameaça adicional à integridade física e cultural desses povos.

A OPAN trabalha no sentido de promover a autonomia de sociedades indígenas na construção de um diálogo entre sociedades. A manutenção de equipes de trabalho em comunidades indígenas é uma metodologia baseada no imperativo de se familiarizar com as diferenças étnicas entre sociedades indígenas e seus anseios. As intervenções são contextualizadas de acordo com os traços culturais específicos.

A organização tem defendido os direitos fundamentais de populações tradicionais, como à terra e à sua autonomia. Apoia assembleias e organizações indígenas, oferecendo atividades de desenvolvimento de capacidades e treinamento em políticas para comunidades locais.

Nas décadas de 1970 e 1980, contribuiu para garantir a demarcação de diversas terras indígenas, principalmente no contexto de projetos de desenvolvimento implementados pelo regime militar, cujos projetos de assentamentos e rodovias federais ameaçavam a integridade física e cultural de populações locais. Desde então, a OPAN tem incidido em áreas como as de assistência médica, educação e economia, de acordo com o princípio da contextualização cultural e linguística e o da conscientização de autoridades públicas quanto à necessidade de prestar uma assistência específica e diferenciada 
para populações indígenas, em sintonia com os projetos de suas sociedades. Em última análise, seu objetivo é intervir em uma região abordando temas transversais que incluem a conservação da biodiversidade, a soberania alimentar, alternativas econômicas sustentáveis, articulação política em nível regional e o empoderamento político e organizacional de comunidades e associações indígenas.

O Centro Burnier trabalha com a realidade da violência em áreas rurais e questões relacionadas a conflitos fundiários, concentração de terras, trabalho forçado, desigualdades econômicas e concentração de renda. É ligado às Comunidades Eclesiásticas de Base (CEB), ao Movimento dos Sem-Terra, à Via Campesina, à Comissão Pastoral da Terra, ao Centro Pastoral para Migrantes e a outras organizações.

O Centro Burnier tem como um dos principais focos o desenvolvimento de políticas públicas relacionadas ao combate do trabalho escravo, participando como membro na Comissão Estadual de Erradicação do Trabalho (COETRAE) ${ }^{27}$, decretada no estado de Mato Grosso pelo Decreto 985/2007 e representação estadual da Comissão Nacional de Erradicação do Trabalho (CONATRAE), do Conselho Estadual Gestor do Fundo de Erradicação do Trabalho Escravo (CEFEGETE) e do Fundo de Erradicação do Trabalho Escravo (FETE).

Nessa inserção, o Centro Burnier tem como principal pauta a garantia de disponibilidade de mecanismos por meio dos quais o trabalho escravo possa ser denunciado, medidas corretivas possam ser aplicadas aos responsáveis e proteção possa ser garantida às vítimas. Ele tem desenvolvido vínculos com órgãos públicos competentes com vistas a promover a gestão de ações punitivas e preventivas, a fim de proporcionar condições estáveis de trabalho em sintonia com o imperativo de garantir direitos humanos e qualidade de vida para a sociedade humana. Suas ações também estão focadas para a realização de um plebiscito para estabelecer limites ao tamanho de propriedades rurais. A concentração de terras é um problema

27 A COETRAE é vinculada à Secretaria de Estado de Justiça e Segurança Pública e tem representantes das Secretarias de Estado de Saúde; Educação; Justiça e Segurança Pública; Trabalho, Emprego, Cidadania e Assistência Social; Meio Ambiente; Desenvolvimento Rural; da Polícia Militar; Polícia Judiciária Civil; do Tribunal de Justiça; da EMPAER; do Ministério Público Estadual; Tribunal Regional do Trabalho; Ministério Público do Trabalho; da Superintendência Regional do Trabalho; Polícia Rodoviária Federal; Polícia Federal; Associação dos Magistrados da Justiça do Trabalho; Comissão Pastoral dos Migrantes; Centro Burnier Fé e Justiça; Central Única dos Trabalhadores; Comissão Pastoral da Terra; do Ministério Público Federal; Gabinete de Gestão Integrada e do INCRA. 
histórico enfrentado por populações tradicionais no estado, que afeta pequenos e médios agricultores também. Garantir o acesso democrático à terra constitui, portanto, outro objetivo de suas ações de mobilização e articulação.

O Sindicato dos Trabalhadores no Ensino Público de Mato Grosso (SINTEP) tem cerca de 30.000 membros. É uma das organizações fundadoras do FORMAD e tem uma agenda ampla, que inclui ações para promover capacitação para profissionais em educação e campanhas salariais. Propõe também políticas para garantir uma educação de qualidade que leve em consideração a diversidade cultural, étnica e social da sociedade de Mato Grosso.

O sindicato promove debates sobre temas como diversidade étnica-racial, assistência médica e prevenção de doenças sexualmente transmissíveis, educação ambiental, agenda do trabalho decente e outras questões em eventos realizados em intervalos regulares para profissionais de educação de todos os municípios do estado de Mato Grosso. Com sua grande capilaridade temática, o SINTEP (ligado à Central Única de Trabalhadores) acaba por potencializar as atividades da rede ambientalista, na medida em que tem grande atualização de informações institucionais, úteis na elaboração de argumentação à negociação.

A Federação de Órgãos para Assistência Social e Educacional (FASE) é uma organização não governamental que tem atuado no Brasil há mais de 50 anos. Mantém escritórios regionais nos estados do Pará, Espírito Santo e Rio de Janeiro, em Cáceres e em outras regiões. A FASE, também uma das organizações fundadoras do FORMAD, trabalha muito ativamente em apoio a organizações de pequenos produtores na área da Baixada Cuiabana, e suas intervenções enfocam principalmente o bioma do Pantanal. Está ativamente envolvida na gestão de políticas públicas e em ações para defender e demonstrar a viabilidade da agroecologia e de um modelo de desenvolvimento econômico sustentável.

A monocultura da cana-de-açúcar representa uma ameaça para essa região, particularmente, já que prejudica sua diversidade social e cultural, afetando populações ribeirinhas, pescadores artesanais, comunidades quilombolas e os Chiquitano (povo indígena). A produção de rapadura e derivados da banana e a extração de cumaru (uma fruta tropical) caracteriza o potencial produtivo dessas comunidades. 
A FASE promove processos de desenvolvimento de capacidades e apoia grupos de pequenos produtores em sua busca por alternativas econômicas sustentáveis. Suas ações enfocam a promoção da visibilidade da agricultura em pequena escala, em contraste com um modelo de desenvolvimento estatal baseado na monocultura, nas grandes propriedades e na economia para exportação. Recentemente, a FASE tem investido no estabelecimento de uma rede e um banco de dados de sementes. A organização está preocupada com a conservação e a conscientização sobre a importância da diversificação de sementes na produção agrícola. Além disso, conduz as ações contra o uso de pesticidas, por meio da Campanha Permanente Contra os Agrotóxicos e pela Vida. Ao mesmo tempo, apoia discussões sobre uma rede de comercialização para fortalecer a produção da agricultura familiar e sua implementação em algumas regiões do estado. Suas ações em defesa da agroecologia e de alternativas econômicas sustentáveis visam manter pessoas em áreas rurais e promover o direito à terra, à saúde e à qualidade de vida com uma segurança alimentar fortalecida.

O Instituto Centro de Vida (ICV) conta com uma equipe de técnicos especializados envolvidos no monitoramento de práticas de desmatamento e queimadas no Mato Grosso, em resposta a ameaças à conservação da biodiversidade nos biomas do estado. Tem trabalhado para produzir e documentar dados para serem usados como insumos em planos de ação, a fim de controlar a degradação ambiental, e está envolvido em ações sólidas de defesa do bioma amazônico. O envolvimento com políticas públicas relacionadas ao meio ambiente e seu monitoramento é outro enfoque de suas ações. O ICV tem atuado para manter e criar unidades de conservação que possam contribuir para planos de organização territorial sustentáveis e ecológicos. Ao mesmo tempo, apoia e promove a recuperação de reservas legais e áreas de proteção permanente em fazendas, disponibilizando insumos técnicos para esse fim. Em relação ao ZSEE, - ICV contribuiu significativamente para produzir documentos que comprovam as ameaças ambientais geradas pela expansão do agronegócio.

Estabelecido por lideranças e profissionais indígenas com o objetivo de promover ações e pesquisas voltados para a proteção do meio ambiente, da herança cultural e dos direitos de povos indígenas, o Instituto Maiwu apoia o etnodesenvolvimento. Procura conscientizar populações indígenas sobre leis que 
abordam questões indígenas com o objetivo de fortalecer o direito aos seus territórios, realizar abordagens educacionais e de assistência médica específicas e reforçar a estrutura institucional voltada a questões indígenas.

A organização dá atenção às terras indígenas que continuam sendo invadidas por madeireiros, garimpeiros, pescadores e grandes produtores agrícolas. O uso intensivo de pesticidas, o desmatamento descontrolado e as queimadas são fatores que ameaçam a saúde, a segurança alimentar e a integridade cultural de povos indígenas. O Instituto Maiwu desenvolve programas em apoio a projetos educacionais, de assistência médica, de regularização de terras e econômicos, em sintonia com a realidade desses povos. Suas ações enfocam, particularmente, a oferta de cursos de treinamento para agentes comunitários locais.

Organização vinculada à Conferência Nacional dos Bispos do Brasil (CNBB) e colaboradora em atividades do FORMAD, o Conselho Indigenista Missionário (CIMI) realiza um trabalho missionário de natureza política em defesa de povos indígenas. Desde que foi estabelecido, dedica-se à demarcação de terras indígenas e contra projetos de latifundiários e empresas que ameaçam a integridade física e cultural de povos ameríndios. Mantém muitos escritórios regionais em todo o território nacional. O escritório do CIMI em Mato Grosso mantém equipes de trabalho em aldeias Karajá e Tapirapé, na região Nordeste, em comunidades Nambiquara, na região Noroeste, e em vilarejos de outros povos indígenas.

O CIMI tem a educação indígena específica e intercultural como uma de suas linhas de ação, contribuindo, assim, para fortalecer uma proposta política e pedagógica que satisfaça os interesses de sociedades indígenas. Por meio de reuniões e seminários, o CIMI oferece oportunidades de desenvolvimento de capacidades e treinamento em políticas para lideranças indígenas, em temas relacionados a direitos indígenas, grandes projetos (de ferrovias federais, usinas, estradas, etc.) e outros. Seu objetivo é formar líderes comunitários com vistas a promover a autodeterminação de povos indígenas. A participação na gestão de políticas públicas é outra prioridade dessa organização, que mantém representantes em conselhos e fóruns que tratam de questões econômicas, culturais, educacionais e de temas relacionados à saúde e à terra.

A Associação Takiná (AT) é a primeira organização de mulheres indígenas do estado e é composta por diferentes povos indígenas, como os Xavante, Bakairi, 
Rikbaktsa, Umutina, Karajá, Bororo, Pareci, Irantxe, Kaiabi e outros. Trabalha com diferentes temas que envolvem violência contra mulheres, alcoolismo, defesa de terras indígenas, gestão de projetos e associações, alternativas econômicas sustentáveis e questões ambientais.

Outras organizações têm menor incidência nas discussões presenciais ou não presenciais da rede (Quadro 14).

Quadro 14. Nomes, siglas, área temática e abrangência de atuação das organizações que participam da rede ambientalista FORMAD

\begin{tabular}{|c|c|c|}
\hline Organização & Temas & $\begin{array}{l}\text { Região na qual } \\
\text { atua }\end{array}$ \\
\hline $\begin{array}{l}\text { ADERCO - Associação de } \\
\text { Defesa do Rio Coxipó }\end{array}$ & \multirow{6}{*}{$\begin{array}{l}\text { Conservação } \\
\text { ambiental }\end{array}$} & $\begin{array}{l}\text { Área do Rio } \\
\text { Coxipó }\end{array}$ \\
\hline $\begin{array}{c}\text { AEMA - Associação Ecológica e Meio } \\
\text { Ambientalista }\end{array}$ & & Inativa \\
\hline $\begin{array}{c}\text { AMEC - Associação Ecológica } \\
\text { Melgassense }\end{array}$ & & Barão de Melgaço \\
\hline $\begin{array}{c}\text { ARCA - Associação para Recuperação } \\
\text { e Conservação do Ambiente }\end{array}$ & & Inativa \\
\hline $\begin{array}{l}\text { ECOTRÓPICA - Fundação de Apoio à } \\
\text { Vida nos Trópicos }\end{array}$ & & $\begin{array}{l}\text { Chapada dos } \\
\text { Guimarães e } \\
\text { outras áreas }\end{array}$ \\
\hline $\begin{array}{c}\text { GRAUNA - Grupos de Amigos Unidos } \\
\text { pela Natureza }\end{array}$ & & Inativa \\
\hline $\begin{array}{c}\text { Instituto Gaia - Instituto de Pesquisa e } \\
\text { Educação Ambiental }\end{array}$ & $\begin{array}{l}\text { Conservação } \\
\text { ambiental e } \\
\text { populações } \\
\text { tradicionais }\end{array}$ & $\begin{array}{l}\text { Baixada Cuiabana } \\
\quad \text { (Pantanal) }\end{array}$ \\
\hline $\begin{array}{l}\text { GTME - Grupo de Trabalho } \\
\text { Missionário Evangélico }\end{array}$ & $\begin{array}{l}\text { Povos } \\
\text { indígenas }\end{array}$ & $\begin{array}{l}\text { Embora não tenha } \\
\text { uma equipe no } \\
\text { Mato Grosso, a } \\
\text { organização } \\
\text { monitora políticas } \\
\text { públicas no } \\
\text { estado }\end{array}$ \\
\hline Instituto MAIWU & $\begin{array}{l}\text { Povos } \\
\text { indígenas }\end{array}$ & Em todo o estado \\
\hline $\begin{array}{l}\text { ADUFMAT - Associação dos Docentes } \\
\text { da Universidade de Mato Grosso }\end{array}$ & $\begin{array}{l}\text { Educação } \\
\text { universitária }\end{array}$ & Em todo o estado \\
\hline $\begin{array}{l}\text { IFPDS - Instituto Floresta de Pesquisa } \\
\text { e Desenvolvimento Sustentável }\end{array}$ & $\begin{array}{l}\text { Agricultura em } \\
\text { pequena }\end{array}$ & Norte \\
\hline
\end{tabular}




\begin{tabular}{|c|c|c|}
\hline & $\begin{array}{l}\text { escala, } \\
\text { educação } \\
\text { ambiental }\end{array}$ & \\
\hline $\begin{array}{l}\text { Associação Terra Viva de Agricultura } \\
\text { Alternativa e Educação Ambiental }\end{array}$ & $\begin{array}{l}\text { Agricultura em } \\
\text { pequena } \\
\text { escala, } \\
\text { agroecologia }\end{array}$ & $\begin{array}{l}\text { Nordeste, região } \\
\text { do Araguaia }\end{array}$ \\
\hline Sociedade Formigas & $\begin{array}{l}\text { Agricultura em } \\
\text { pequena } \\
\text { escala, } \\
\text { conservação } \\
\text { ambiental }\end{array}$ & Norte \\
\hline CTA - Centro de Tecnologia Alternativa & Agroecologia & $\begin{array}{l}\text { Baixada Cuiabana } \\
\text { (Pantanal) }\end{array}$ \\
\hline $\begin{array}{c}\text { FETAGRI-MT - Federação dos } \\
\text { Trabalhadores na Agricultura no Estado } \\
\text { de Mato Grosso }\end{array}$ & $\begin{array}{l}\text { Pequenos } \\
\text { produtores }\end{array}$ & Em todo o estado \\
\hline $\begin{array}{c}\text { CPT-MT - Comissão Pastoral da Terra } \\
\text { - Regional Mato Grosso }\end{array}$ & $\begin{array}{l}\text { Reforma } \\
\text { agrária }\end{array}$ & $\begin{array}{c}\text { Norte, nordeste } \\
\text { (região do } \\
\text { Araguaia) e } \\
\text { outras áreas }\end{array}$ \\
\hline $\begin{array}{c}\text { CUT - Central Única dos } \\
\text { Trabalhadores }\end{array}$ & $\begin{array}{l}\text { Direitos } \\
\text { trabalhistas }\end{array}$ & Em todo o estado \\
\hline $\begin{array}{l}\text { CDHDMB - Centro de Direitos } \\
\text { Humanos Dom Máximo Biennés }\end{array}$ & \multirow{4}{*}{$\begin{array}{l}\text { Direitos } \\
\text { humanos }\end{array}$} & $\begin{array}{l}\text { Baixada Cuiabana } \\
\text { (Pantanal) }\end{array}$ \\
\hline $\begin{array}{c}\text { Associação de Defesa dos Direitos, } \\
\text { Trabalho e Desenvolvimento das } \\
\text { Mulheres }\end{array}$ & & Inativa \\
\hline FÉ E ALEGRIA & & Em todo o estado \\
\hline $\begin{array}{l}\text { IECLB - Igreja Evangélica de } \\
\text { Confissão Luterana no Brasil }\end{array}$ & & Em todo o estado \\
\hline MOPS - Movimento Popular de Saúde & $\begin{array}{c}\text { Saúde, } \\
\text { conhecimentos } \\
\text { populares e } \\
\text { questões } \\
\text { ambientais }\end{array}$ & Em todo o estado \\
\hline $\begin{array}{l}\text { NEOM - Associação de Estudos e } \\
\text { Organização da Mulher }\end{array}$ & $\begin{array}{l}\text { Questões } \\
\text { relacionadas à } \\
\text { mulher e à } \\
\text { saúde }\end{array}$ & Em todo o estado \\
\hline $\begin{array}{l}\text { MNMMR - Movimento Nacional de } \\
\text { Meninos e Meninas de Rua }\end{array}$ & $\begin{array}{l}\text { Direitos } \\
\text { humanos }\end{array}$ & Inativa \\
\hline
\end{tabular}




\begin{tabular}{|c|c|c|}
\hline $\begin{array}{c}\text { ONGARA - ONG Ambientalista } \\
\text { Roncador Araguaia }\end{array}$ & $\begin{array}{l}\text { Conservação } \\
\text { ambiental }\end{array}$ & Inativa \\
\hline $\begin{array}{l}\text { INBRACO - Instituto Brasileiro de } \\
\text { Pesquisas, Participação Social e } \\
\text { Acompanhamento }\end{array}$ & $\begin{array}{l}\text { Direitos } \\
\text { humanos }\end{array}$ & Inativa \\
\hline $\begin{array}{l}\text { IPA - Instituto Pró-Ambiência } \\
\text { (Embaúba) }\end{array}$ & $\begin{array}{l}\text { Conservação } \\
\text { ambiental }\end{array}$ & Inativa \\
\hline
\end{tabular}

Fonte: FORMAD, 2010. Elaboração própria.

\subsubsection{Articulações com outras redes}

Além da relação de organizações individuais, a rede está em comunicação próxima com outras redes ambientalistas regionais, dentre as quais citamos 0 Grupo de Intercâmbio em Agroecologia de Mato Grosso (GIAS) ${ }^{28}$. Criado em 1999, o grupo tem por objetivo desenvolver ações coletivas para alertar a população mato-grossense sobre os riscos do atual modelo de produção do agronegócio. A intenção é demonstrar a viabilidade socioeconômica e ambiental de outro modelo de agricultura, baseado na cooperação, no acesso coletivo a diferentes mercados e na produção sustentável de alimentos. Ao longo dos seus mais de dez anos de existência, o GIAS vem promovendo encontros para a troca de sementes tradicionais, mercados regionais abertos para a comercialização de produtos de pequenos produtores e reuniões nas quais produtores trocam informações entre si. O GIAS também participa da organização de atividades de desenvolvimento de capacidades e extensão rural, que visam apoiar pequenos produtores e povos indígenas e tradicionais no processo de implementação de sistemas de produção mais sustentáveis em Mato Grosso. Também é ativo em algumas iniciativas na região amazônica e outras em nível nacional, sendo membro da Rede de Informações Agroecológicas da Amazônia (RIAA), a qual tem como objetivo sistematizar e divulgar informações sobre as experiências agroecológicas que centenas de pequenos produtores e povos indígenas e tradicionais desenvolvem na região amazônica.

28 Composto por: Movimento dos Sem-Terra (MST), Movimento de Mulheres Campesinas (MMC), Pastoral da Juventude Rural, Centro de Tecnologia Alternativa (CTA), Comissão Pastoral da Terra (CPT) e Federação de Órgãos para Assistência Social e Educacional (FASE). 
O Fórum de Luta das Entidades de Cáceres (FLEC) é outra rede formada por organizações que trabalham na região da Baixada Cuiabana. A FASE e o CTA são os membros do FORMAD que participam do FLEC.

O principal objetivo do FLEC é agregar movimentos sociais, ONGs e representantes de organizações de povos indígenas e tradicionais que trabalham para promover a preservação ambiental na região do Pantanal. Entre outras, o FLEC aborda as seguintes questões: direito à terra; segurança alimentar; e acesso e preservação da água. Nesta linha, também tem atuado ativamente no lobby contra a inclusão da Bacia do Alto Paraguai nas áreas liberadas para o plantio de cana-de-açúcar.

A possibilidade de expansão da produção de biocombustíveis na Bacia do Alto Paraguai (local responsável pela água que vai para o Pantanal) e os consequentes impactos ambientais e sociais são uma das principais questões abordadas.

A Articulação Xingu-Araguaia ${ }^{29}$ ( $\left.A X A\right)$ tem como área de atuação as regiões do Xingu e do Araguaia, promovendo a preservação de recursos naturais, fortalecendo a agricultura familiar e apoiando o desenvolvimento de alternativas econômicas sustentáveis para habitantes locais. A articulação envolve pequenos produtores, assentamentos da reforma agrária, populações ribeirinhas e povos indígenas, trabalhando em campanhas de controle de queimadas e em processos de desenvolvimento de capacidades em matéria de legislação ambiental e alternativas econômicas sustentáveis de produção (AXA, 2014).

29 Rede formada pelas seguintes organizações: Associação Terra Viva (ATV), Comissão Pastoral da Terra Regional Araguaia (CPT-Araguaia), Operação Amazônia Nativa (OPAN), Instituto Socioambiental (ISA), Associação Nossa Senhora da Aparecida (ANSA) e Fórum Mato-grossense de Desenvolvimento e Meio Ambiente (FORMAD). 
Em âmbito internacional, o FORMAD se articula com a Articulação Regional Amazônica por meio do ICV, abrangendo sete dos nove países que compõem a Pan-Amazônia (Brasil, Colômbia, Suriname, Venezuela, Bolívia, Peru e Equador).

\section{Figura 9. Rede de atuação da Articulação Regional Amazônica}

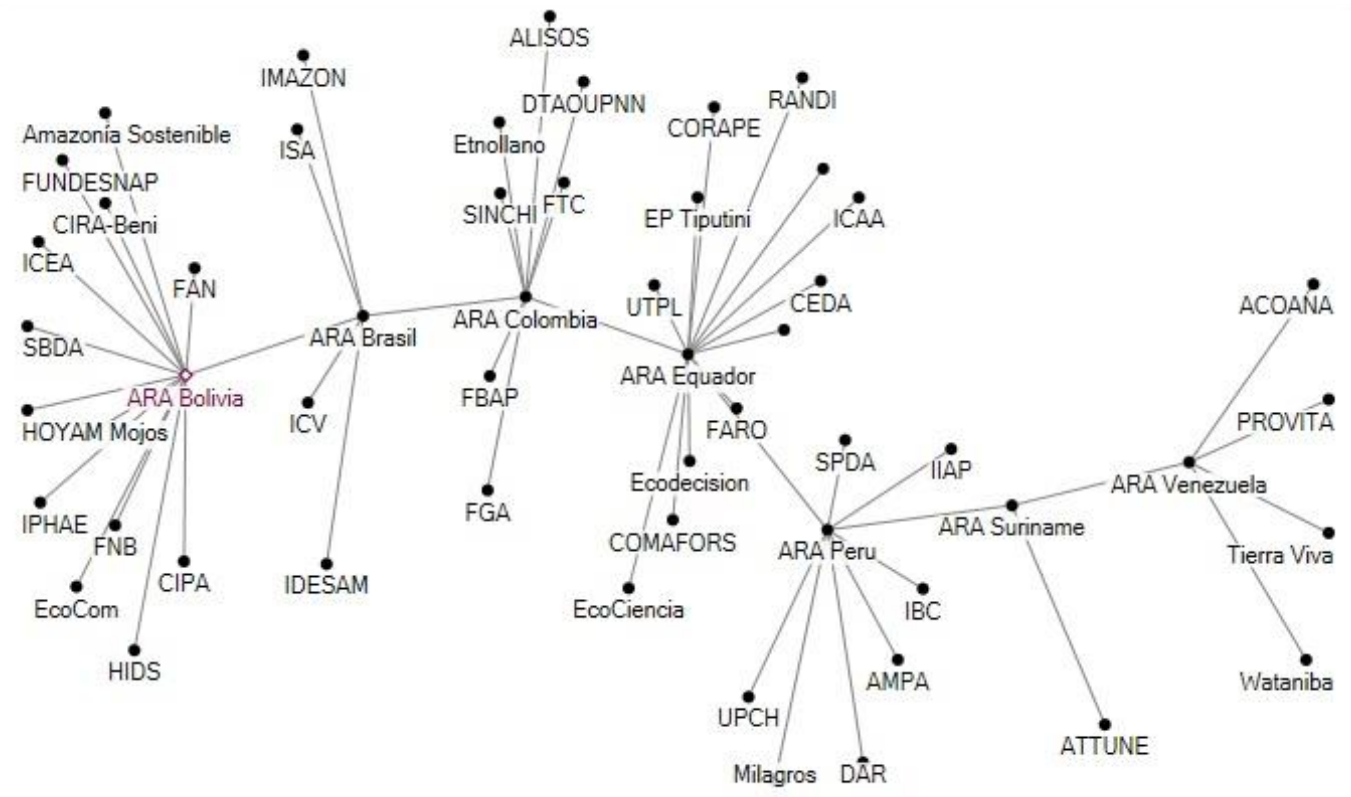

Fonte: Articulación Regional Amazónica (2015). Elaboração própria.

3.4.2. Principais momentos de inserção política das redes ambientalistas matogrossenses

O FORMAD participou ativamente em diversos momentos do processo decisório em políticas nacionais, amazônicas e mato-grossenses voltadas à sociedade e a seu ambiente. Com o passar do tempo, outras redes se formaram no estado, inserindo-se também em processos decisórios específicos em temas como direitos humanos, agroecologia, dentre outros. Foi salutar, ao longo dessa atuação, a dificuldade de interlocução com as esferas do governo quando não mediada ou por agentes financiadores inclinados favoravelmente à participação, ou por instâncias do Estado, como o Ministério Público.

Mesmo com as pressões existentes, mencionadas no Capítulo 2, o escopo e a amplitude de atuação da rede extrapolaram os limites estaduais e mesmo os circunscritos à Amazônia Legal. No histórico político nacional relativo ao meio ambiente, a rede chegou a influir em uma ampla gama de processos decisórios. 
No Quadro 15 é possível ver a evolução das políticas ambientais e como a agenda evoluiu de aspectos estritamente técnicos e conservacionistas para uma pauta socioambiental, fomentada pela ação organizada de atores, sujeitos e autores sociais e coletivos. Destacamos o cenário favorável criado por ocasião da CNUMAD em 1992, acompanhado pelo PPG7, o qual tinha marcadamente o princípio da participação social nas decisões como estrutural ao programa.

Quadro 15. Principais políticas, planos e programas ambientais nacionais entre 1981 e 2012

\begin{tabular}{|c|c|c|c|}
\hline Ano & Políticas & Planos & Programas \\
\hline 1981 & $\begin{array}{l}\text { Política Nacional do } \\
\text { Meio Ambiente }\end{array}$ & & \\
\hline \multicolumn{4}{|l|}{1982} \\
\hline \multicolumn{4}{|l|}{1983} \\
\hline \multicolumn{4}{|l|}{1984} \\
\hline \multicolumn{4}{|l|}{1985} \\
\hline 1986 & & & $\begin{array}{c}\text { Programa de Controle de } \\
\text { Poluição do Ar por } \\
\text { Veículos Automotores } \\
\text { (PROCONVE) }\end{array}$ \\
\hline \multicolumn{4}{|l|}{1987} \\
\hline 1988 & & $\begin{array}{c}\text { Plano Nacional de } \\
\text { Gerenciamento Costeiro } \\
\text { (PNGC) I }\end{array}$ & \\
\hline 1989 & & & $\begin{array}{l}\text { - Programa Nossa } \\
\text { Natureza } \\
\text { - Programa de Controle } \\
\text { da Poluição do Ar } \\
\text { (PRONAR) }\end{array}$ \\
\hline \multicolumn{4}{|l|}{1990} \\
\hline 1991 & & & $\begin{array}{l}\text { Programa Nacional de } \\
\text { Meio Ambiente } \\
\text { (PNMA) I }\end{array}$ \\
\hline 1992 & & & $\begin{array}{c}\text { Programa Piloto para a } \\
\text { Proteção das Florestas } \\
\text { Tropicais do Brasil } \\
\text { (PPG7) }\end{array}$ \\
\hline \multicolumn{4}{|l|}{1993} \\
\hline 1994 & & & $\begin{array}{c}\text { Programa Nacional da } \\
\text { Diversidade Biológica } \\
\text { (PRONABIO) }\end{array}$ \\
\hline 1995 & & & \\
\hline
\end{tabular}




\begin{tabular}{|c|c|c|c|}
\hline \multicolumn{4}{|l|}{1996} \\
\hline 1997 & $\begin{array}{c}\text { - Política Nacional de } \\
\text { Controle da } \\
\text { Desertificação } \\
\text { - Política e Sistema } \\
\text { Nacional de Recursos } \\
\text { Hídricos }\end{array}$ & PNGC II & \\
\hline 1998 & $\begin{array}{l}\text { Lei de Crimes } \\
\text { Ambientais }\end{array}$ & & \\
\hline 1999 & $\begin{array}{l}\text { Política Nacional de } \\
\text { Educação Ambiental }\end{array}$ & & \\
\hline 2000 & $\begin{array}{c}\text { Lei do Sistema Nacional } \\
\text { de Unidades de } \\
\text { Conservação da } \\
\text { Natureza }\end{array}$ & & $\begin{array}{c}\text { - Programa Nacional de } \\
\text { Florestas } \\
\text { - Programa ZEE Brasil } \\
\text { - PNMA II }\end{array}$ \\
\hline \multicolumn{4}{|l|}{2001} \\
\hline 2002 & $\begin{array}{c}\text { Decreto sobre a Política } \\
\text { Nacional da } \\
\text { Biodiversidade }\end{array}$ & & $\begin{array}{c}\text { - Programa Meio } \\
\text { Ambiente e Qualidade } \\
\text { de Vida } \\
\text { - Programa Áreas } \\
\text { Protegidas da } \\
\text { Amazônia (ARPA) }\end{array}$ \\
\hline 2003 & & & $\begin{array}{c}\text { Programa de } \\
\text { Revitalização de Bacias } \\
\text { Hidrográficas }\end{array}$ \\
\hline 2004 & & $\begin{array}{c}\text { - Plano de Prevenção e } \\
\text { Controle de } \\
\text { Desmatamento na } \\
\text { Amazônia Legal } \\
\text { (PPCDAM) } \\
\text { - Plano Amazônia } \\
\text { Sustentável (PAS) }^{\star}\end{array}$ & $\begin{array}{c}\text { - Programa Agenda } 21 \\
\text { - Programa Água Doce } \\
\text { - Programa Nacional de } \\
\text { Educação Ambiental } \\
\text { (PRONEA) } \\
\text { - Programa Cerrado } \\
\text { Sustentável } \\
\text { - Programa de Ação } \\
\text { Nacional de Combate à } \\
\text { Desertificação (PAN- } \\
\text { Brasil) } \\
\text { - Programa de } \\
\text { Desenvolvimento } \\
\text { Socioambiental da } \\
\text { Produção Familiar Rural } \\
\text { (PROAMBIENTE) }\end{array}$ \\
\hline 2005 & $\begin{array}{c}\text { Política Nacional para } \\
\text { os Recursos do Mar } \\
\text { (PNMR) }\end{array}$ & & \\
\hline 2006 & $\begin{array}{l}\text { - Lei da Mata Atlântica } \\
\text { - Lei de Gestão de } \\
\text { Florestas Públicas }\end{array}$ & $\begin{array}{l}\text { - Plano Estratégico } \\
\text { Nacional de Áreas } \\
\text { Protegidas (PNAP) } \\
\text { - Plano BR-163 } \\
\text { Sustentável }\end{array}$ & Programa Pantanal \\
\hline
\end{tabular}




\begin{tabular}{|c|c|c|c|}
\hline & & $\begin{array}{l}\text { - Plano Nacional de } \\
\text { Recursos Hídricos }\end{array}$ & \\
\hline 2007 & $\begin{array}{l}\text { - Política Nacional de } \\
\text { Desenvolvimento } \\
\text { Sustentável de Povos } \\
\text { e Comunidades } \\
\text { Tradicionais } \\
\text { - Lei de diretrizes para a } \\
\text { Política de Saneamento } \\
\text { Básico }\end{array}$ & & $\begin{array}{c}\text { - Programa de } \\
\text { Monitoramento Ambiental } \\
\text { dos Biomas Brasileiros } \\
\text { (PMABB) } \\
\text { - Programa Nacional de } \\
\text { Águas Subterrâneas }\end{array}$ \\
\hline 2008 & & $\begin{array}{l}\text { Plano Nacional sobre } \\
\text { Mudança do Clima }\end{array}$ & \\
\hline 2009 & $\begin{array}{l}\text { Política Nacional } \\
\text { sobre Mudança do } \\
\text { Clima }\end{array}$ & $\begin{array}{c}\text { - Plano de ação para a } \\
\text { PPCDAM } \\
\text { - Plano de Prevenção e } \\
\text { Controle do } \\
\text { Desmatamento e } \\
\text { Queimadas no Cerrado }\end{array}$ & \\
\hline 2010 & $\begin{array}{l}\text { Política Nacional de } \\
\text { Resíduos Sólidos }\end{array}$ & $\begin{array}{c}\text { Subsídios para a } \\
\text { elaboração do Plano de } \\
\text { Ação para a Prevenção e } \\
\text { Controle do } \\
\text { Desmatamento na } \\
\text { Caatinga }\end{array}$ & \\
\hline 2011 & & & Programa Bolsa Verde \\
\hline 2012 & $\begin{array}{l}\text { - Código Florestal } \\
\text { - Política Nacional de } \\
\text { Gestão Territorial e } \\
\text { Ambiental de Terras } \\
\text { Indígenas }\end{array}$ & $\begin{array}{l}\text { - Planos setoriais de } \\
\text { mitigação e adaptação à } \\
\text { mudança do clima } \\
\text { - PPCDAM III }\end{array}$ & $\begin{array}{c}\text { Cadastro Ambiental } \\
\text { Rural (CAR) }\end{array}$ \\
\hline
\end{tabular}

*Este plano teve um módulo mato-grossense, elaborado no âmbito do FORMAD. Destacamos aquelas políticas, planos e programas que repercutiram regionalmente e foram foco no âmbito de atuação das redes aqui consideradas (notadamente FORMAD e GTA). Adaptado e complementado a partir de Steinberger e Abichared, 2013.

Durante o PPG7, a participação do FORMAD se deu como membro da coordenação no Consórcio pelo Desenvolvimento Socioambiental da BR-163, apoiado pelo PPG7, acompanhando o processo de pavimentação da rodovia. $O$ consórcio foi constituído em 2004 e seu papel seria agir como intermediador da sociedade civil com o Governo Federal, para viabilizar a implantação de ações prioritárias levantadas pelos movimentos sociais e ambientais e produtores familiares em relação ao asfaltamento da estrada. Em termos de desenho institucional à participação, focava-se na transparência das informações - passo inicial para qualquer iniciativa que tivesse como meta o envolvimento da 
sociodiversidade nos processos de decisão -, as quais, até aquele momento, ainda eram escassas em muitas regiões da Amazônia Legal.

Entendendo que a educação política é uma das bases do estabelecimento das estratégias de participação, o modo pelo qual se buscava essa transparência era por meio da articulação entre lideranças e de parcerias institucionais, comunicação comunitária, disseminação de informações e formação de lideranças. Como evolução dessa etapa, nos anos seguintes a participação evoluiu para a elaboração do planejamento e modelo de gestão para o Plano BR-163 Sustentável (ordenamento territorial, gestão ambiental, fomento a atividades produtivas sustentáveis, infraestrutura para o desenvolvimento e inclusão social à cidadania). No âmbito dessa atuação já se solicitava, pelo FORMAD, GTA e outros, a inclusão da região da Serra do Cachimbo como prioritária no ARPA, pois era influenciada pela BR-163 e portadora de alta biodiversidade. O Comitê do ARPA aprovou a adesão dessa região como Unidade de Conservação (UC) federal.

O Programa Nacional da Diversidade Biológica (PRONABIO) ${ }^{30}$ foi criado por meio do Decreto 1.354/1994, visando à implementação da Convenção sobre Diversidade Biológica (CDB). Tal decreto também conformou sua comissão coordenadora com a finalidade de coordenar, acompanhar e avaliar as ações do PRONABIO. O GTA (onde estava incluído o FORMAD) participava dos trabalhos de avaliação e identificação de ações prioritárias para a conservação, utilização sustentável e repartição dos benefícios da biodiversidade na Amazônia brasileira, coordenados pelo MMA.

Fora do escopo do GTA, o FORMAD participou nos trabalhos de diagnóstico institucional e legal do Projeto Manejo Integrado da Biodiversidade Aquática e dos Recursos Hídricos na Amazônia - AquaBio, o qual tinha como objetivo global gerar e compartilhar experiências que promovessem a longo prazo a Gestão Integrada da Biodiversidade Aquática e dos Recursos Hídricos (GIBRAH) na Amazônia. Naquele momento, o FORMAD, que posteriormente (em 2012) já se reconhecia como rede ambientalista inserida nos processos decisórios, ainda era denominado "organização não governamental”. Em 2005, o fórum se reconhecia como "entidade" destinada a democratizar informações, proporcionar o debate 
sobre as questões socioambientais e, principalmente, propor alternativas de desenvolvimento sustentável para a melhoria das condições de vida da população mato-grossense.

Com a finalidade de coordenar e acompanhar a Política Nacional dos Povos e Comunidades Tradicionais, a Comissão Nacional dos Povos e Comunidades Tradicionais foi criada e vinculada ao Ministério do Meio Ambiente (MMA) e ao Ministério do Desenvolvimento Agrário (MDA). O objetivo foi construir políticas públicas específicas para as populações tradicionais nos eixos territorial, de infraestrutura e segurança alimentar. O FORMAD assumiu uma vaga nessa comissão representando os pantaneiros, dado o seu histórico de atuação nesse bioma, abordando as questões das hidrovias e do agronegócio que ameaçavam a sustentabilidade ambiental e social dos pescadores tradicionais, ribeirinhos, indígenas e quilombolas. A agricultura familiar e o exercício de cidadania ${ }^{31}$ dessas populações locais fizeram parte da atuação na comissão. Também foi criada uma comissão dos pantaneiros, que reúne lideranças dessas comunidades locais. O fórum realizou um seminário para articular e mobilizar este público, a fim de construir reflexão e gestão de propostas para a Comissão Nacional de Povos e Comunidades Tradicionais.

Nas discussões governamentais em torno da federalização do Programa Pantanal, ocorridas em Mato Grosso e Mato Grosso do Sul, o FORMAD elaborou o documento com os fundamentos básicos de tal federalização. Um dos desdobramentos de sua ação foi o Programa de Formação de Educadores Ambientais e a deliberação da Portaria 113/2006, que institui o Conselho Deliberativo da Reserva da Biosfera do Pantanal. Também em 2006, e ainda no que diz respeito à formação em meio ambiente, o fórum participou na elaboração do Programa Nacional de Educação Ambiental (PRONEA).

A participação do FORMAD no Plano e na Política Nacional sobre Mudança do Clima se dá apenas em consequência do art. 3o da Lei 12.187/2009. Nessa lei estabelece-se que "as ações de âmbito nacional para o enfrentamento das alterações climáticas, atuais, presentes e futuras, devem considerar e integrar as ações promovidas no âmbito estadual e municipal por entidades públicas e privadas". 
Decreto 2.197/2009, então, dispõe sobre a composição do Fórum Mato-grossense de Mudanças Climáticas, vinculado à Secretaria de Meio Ambiente mato-grossense. Este não teve aplicabilidade desde sua promulgação, já que a Política Estadual de Mudanças Climáticas apenas foi sancionada em janeiro de 2017. Após algumas reuniões e participação do FORMAD, este foi declinando paulatinamente a participação nesse espaço. Posteriormente, insatisfeitos com as arbitrariedades no fórum estadual, que engessava as possibilidades de participação, alguns membros do FORMAD passaram a se articular em outros espaços alternativos relativos ao tema, como o Fórum de Mudanças Climáticas e Justiça Social. Apesar de esse imperativo no fórum estadual se apresentar como uma resistência ao status quo, perdeu-se protagonismo nos espaços de partilha de poder.

No processo de elaboração do Novo Código Florestal e sua relação com o Cadastro Ambiental Rural (CAR), as ações do FORMAD se deram mais fortemente por meio de participação virtual e mobilização social. Para simplificar o entendimento da população, foram divulgados infográficos que explicavam os cenários prévio e posterior ao Código Florestal, bem como o papel da população nos processos de consolidação tanto do código quanto do CAR.

Também nos âmbitos estadual e regional, a ação prioritária do FORMAD foi tanto de monitorar as políticas socioambientais quanto de articular as camadas basilares da sociedade civil, a fim de intervir nos processos decisórios.

Um dos momentos da atuação do fórum (dentre outras redes e organizações ambientalistas) se deu ao longo das negociações referentes ao Projeto de Desenvolvimento Agroambiental do Estado de Mato Grosso (PRODEAGRO). O FORMAD contribuiu para reunir dados e elaborar um diagnóstico e indicadores dos danos sociais, econômicos e ambientais e, desse modo, subsidiar as entidades filiadas e parceiras na elaboração de planos de intervenção em políticas públicas.

No período entre 1998 e 2001, as articulações eram centradas em torno do Programa de Apoio Direto às Iniciativas Comunitárias (PADIC), inserido no PRODEAGRO. O FORMAD contribuiu para a articulação e mobilização da sociedade civil organizada a fim de divulgar e esclarecer essa proposta governamental, avaliada positivamente pelos ambientalistas. $O$ objetivo foi 
promover a participação qualificada da diversidade social nas audiências públicas e nos seminários técnicos promovidos pela Assembleia Legislativa.

Um dos resultados foi atribuir visibilidade à relevância do projeto do ZSEEMT e, sobretudo, favorecer a condição dos agricultores familiares, indígenas, retireiros, educadores e assentados como sujeitos ativos nas audiências públicas realizadas em 12 regiões do estado.

O Projeto Mato Grosso Sustentável e Democrático, desenvolvido entre 2006 e 2008, foi proposto pelo FORMAD tendo como objetivo desenvolver um modelo de desenvolvimento alternativo, a fim de promover mudança ambiental e social. Os princípios orientadores eram a inclusão social, a prudência ecológica, a participação política e o fortalecimento e criação de cooperativas solidárias. Foram formados Grupos de Trabalho (GTs) para construir ideias, indicadores e alternativas em diversos campos. Formaram-se GTs de agricultura, agroindústria, cidade, educação, infraestrutura, mineração, extrativismo mineral e animal, turismo, recursos hídricos, terras indígenas e unidades de conservação. O FORMAD e a Universidade Estadual de Mato Grosso coordenaram o trabalho dos GTs, por sua vez, compostos pelas entidades filiadas e parceiras.

Governança Florestal foi um projeto protagonizado por múltiplos atores. $\mathrm{O}$ Instituto Socioambiental (ISA) foi o proponente, mas a elaboração e a execução das propostas tiveram a participação do STRLRV, ICV, Instituto de Pesquisa Ambiental da Amazônia (IPAM) e FORMAD. Teve como foco central recuperar e revitalizar a bacia do rio Xingu, comprometendo para esse fim os diversos segmentos ocupantes dela, como grandes fazendeiros, assentados, indígenas e moradores dos centros urbanos. O FORMAD, em especial, fez a articulação entre os poderes públicos e agentes comunitários locais, fomentando a incorporação de compromissos e agendas de atividades socioambientais; além disso, promoveu cursos de capacitação com vistas à recuperação das Áreas de Preservação Permanente (APP), de Reserva Legal (RL), dos Projetos de Assentamento (PA) e, no âmbito urbano, às alternativas econômicas sustentáveis, ao monitoramento de políticas públicas (ZSEE, legislação ambiental) e à educação ambiental na rede de ensino público.

Apesar dos vários momentos de influência, avaliaremos a seguir dois momentos de relevância em termos de participação política do FORMAD. Em 
termos de institucionalidade de participação e oportunidades políticas para tal, esses momentos oferecem ferramentas para que analisemos os principais componentes da participação cidadã e seu funcionamento. No Capítulo 4 discorreremos sobre o PRODEAGRO e seus desdobramentos no ZSEE. Ainda sobre zoneamento, avaliaremos a participação da rede no Plano BR-163 Sustentável (Capítulo 4) e no Projeto Mato Grosso Sustentável e Democrático (Capítulo 5). Tais momentos tiveram profundos reflexos na forma como diversos atores se reportavam ao território. Por essa razão, tiveram impacto nas recentes políticas e gestões ambientais, bem como na participação da sociodiversidade, enquanto sujeitos e atores, nos processos decisórios. 


\section{CAPÍTULO 4 - ORDENAMENTO TERRITORIAL MATO-GROSSENSE: A RELEVÂNCIA DAS DECISÕES POLÍTICO-AMBIENTAIS E O ZONEAMENTO}

Diferentemente do que se notou em outros países da América Latina, o papel do Estado no ordenamento territorial brasileiro é tratado de forma imprecisa e difusa (MELLO, 2006). O Capítulo 4 analisa o Zoneamento Ecológico-Econômico como importante exemplo da arena onde vêm sendo refletidas as disputas entre as camadas da sociedade civil $^{32}$ e o Estado no planejamento territorial e na intervenção sobre $\mathrm{O}$ ambiente. $\mathrm{Na}$ relação entre esses, a incorporação da participação social na organização territorial onde um Estado democrático se reporta como tal foi e continua a ser um desafio. Tanto o ZEE estadual como o ZSEE da BR-163 trouxeram à tona a diversidade de leituras sobre a finalidade da organização territorial. Por isso, ambos os momentos tiveram sua importância para a identificação de quais as divergências históricas entre as diferentes camadas da sociedade civil e entre elas e o Estado.

A organização do território tem sido dos temas mais controversos da trajetória ambiental mato-grossense, que se relaciona, em maior ou menor grau, com todas as outras questões nas quais as redes ambientalistas estaduais tiveram seu papel, nos seus diversos eixos de atuação e em diferentes graus de protagonismo. Neste capítulo esperamos demonstrar como se deu em um caso concreto a relação entre o Estado e suas diretrizes de planejamento em contraste com o cenário e a organização socioambiental, conformada em redes ambientalistas de diferentes escopos, inerentes às classes sociais que representam. Analisamos os passos do zoneamento, como foi sua evolução em âmbito governamental, seu acompanhamento pelas organizações e a sua "consolidação inconclusa", já que ele é tido como realizado nas esferas governamentais, ainda que seus resultados sejam fortemente contestados pelo Ministério Público Federal e pelo CCZEE. Veremos o processo de negociação e as propostas pelas redes ambientalistas para o ZEE estadual e o ZSEE da BR-163 abordando como esses momentos fortaleceram as iniciativas de

$32 \mathrm{Na}$ sociedade de classes, o conceito de sociedade civil apresenta estratificações internas quando pensamos na realidade brasileira. Assim, no espectro entre os grupos subalternos e as elites, existem subdivisões internas às classes, desde os mais marginalizados aos hegemônicos. 
participação via redes ambientalistas e resolveram as lacunas de participação social nos processos decisórios.

\subsection{O Zoneamento Ecológico Econômico mato-grossense como instrumento de organização territorial}

A Política Nacional de Meio Ambiente e os diversos programas, projetos, planos e instrumentos que dizem respeito ao ambiente possuem ampla gama de pontos de contato com o território (STEINBERGER E ABICHARED, 2013). Para esses autores, o meio ambiente faz parte do "conjunto de sistemas de objetos e ações permeados pelas técnicas" (STEINBERGER E ABICHARED, 2013, p. 127), na medida em que é considerado pela PNMA como patrimônio público e, por isso, é derivado de uma construção realizada pela interação entre Estado, iniciativa privada e sociedade. O meio ambiente está presente na materialidade dos recursos naturais e objetos naturais e artificiais distribuídos sobre o território. Aos recursos naturais concerne a apropriação intelectual dos lugares, elemento este constitutivo da humanização do planeta. Por conseguinte, como aponta Moraes (2005), as formas no espaço são resultado de materializações de projetos elaborados por sujeitos históricos e sociais. Esses sujeitos, no entanto, não são homogêneos em termos de sua posição nas categorias, ou camadas, sociais, tampouco dispõem do mesmo poder de influência sobre as decisões.

O ordenamento territorial, enquanto política, inclui explícita e implicitamente os pontos de contato que estabelecem a interdependência entre ambiente e território. Leis e instrumentos como o ZEE englobam pontos explícitos desse vínculo, como a preservação de ecossistemas, a recuperação de áreas degradadas e as interpretações convencionais do território como substrato.

Outras partes desse contato entre ambiente e território, implícitas, são abordadas por diferentes áreas do conhecimento. Para Santos (2006), essa relação tem três etapas: a natureza como base material da vida; a mecanização do território pós-Revolução Industrial (meio técnico); e a terceira fase, o desenvolvimento da ciência, da técnica e da informação (meio técnico-científico).

A tomada de decisões envolve também a identificação e análise de um problema, a seleção da melhor solução entre outras possíveis, a definição de ações e sua implementação. Esse processo que organiza e estabelece o funcionamento 
dos pontos de contato implícitos e explícitos é uma realidade que envolve o Estado (e a forma como este organiza), o mercado e as organizações da sociedade civil de diferentes escopos, dentre elas as ambientalistas, com toda sua multiplicidade de personificações historicamente construídas, abordadas no capítulo anterior. No que diz respeito à produção do espaço ao território, a escolha dos lugares onde será conduzida uma ação não é neutral, mas prevê alguns objetivos em vista a maximizar o valor produzido, por meio da manipulação da heterogeneidade espacial.

No caso de uma indústria, por exemplo, se calculará o ponto ótimo de encontro entre matérias-primas, energia, recursos humanos, capital, mercado, etc., de forma a diminuir os custos de implementação e operação, maximizando os lucros pelo fluxo das mercadorias produzidas (SANCHEZ, 1992; HARVEY, 2006). O encadeamento da seleção desses lugares e as posições ótimas de cada finalidade a eles atribuída faz parte das decisões tomadas em vista ao ordenamento territorial de um estado (Mato Grosso) ou de uma região (macrozoneamento da Amazônia).

Essa distribuição não aleatória dos elementos se relaciona de forma a conformar diferentes tipos de redes, algumas fisicamente reconhecíveis e outras que, apesar de abstratas, também se relacionam com as demais. Para Mello e Théry (2001), essas estruturas do espaço são identificáveis por configurações da rede de transportes e da rede urbana, normalmente desiguais e dissimétricas. Essa realidade desigual e assimétrica das redes é expansível para as redes de solidariedade ambientais, enquanto abstração do conceito de rede. Estas também são desiguais e assimétricas, dependendo dos sujeitos que as conformam e dos atores que delas são protagonistas.

O protagonismo dessas redes depende do acesso a uma conectividade física e informacional, cuja suficiência dependerá da posição hierárquica da rede, definida pelos sujeitos e atores que a conformam. Por isso, redes ambientalistas constituídas por sujeitos e atores hegemônicos, facilmente intervenientes nos processos decisórios, disporão de melhor estrutura do que redes ambientalistas compostas por sujeitos e atores ligados a grupos marginalizados dos processos de decisão. 
Cada setor possui um posicionamento distinto para suas atribuições e finalidades, fator que implica a dificuldade em estabelecer uma organização espacial que atenda às necessidades de todos. É o resultado da relação entre essas forças setoriais com o objetivo de um ordenamento que é definido pelas relações de hegemonia entre sujeitos, atores e agentes envolvidos. Como exposto por Mello e Théry (2001, p. 182), a espacialização da ação estatal em determinada região "é marcada por ações econômicas, sociais e ambientais e de conflitos resultantes de diferentes visões de desenvolvimento".

Segundo consta na versão preliminar da Política Nacional de Ordenamento Territorial (PNOT), o "ordenamento territorial é a regulação das tendências de distribuição das atividades produtivas e equipamentos no território nacional ou supranacional decorrente das ações de múltiplos atores, segundo uma visão estratégica e mediante articulação institucional e negociação, de modo a alcançar os objetivos desejados" (BRASIL, 2006, p. 10). É um desafio conceitual porque ordenar significa definir em uma configuração territorial, em um dado momento, onde e como as atividades produtivas vão ser desenvolvidas. Assim, é "uma questão política associada à mudança de natureza do Estado e do território, e da relação do Estado com seu território". Discutindo-se mais amplamente, e ainda usando como subsídio teórico os lineamentos do PNOT, relacionam-se o Estado, a heterogênea sociedade civil que lhe concerne e os agentes privados como sujeitos ou atores territoriais que intervêm nessa organização.

O ordenamento territorial é, assim, o substrato no qual se refletem os estágios das políticas públicas, na medida em que, da sua definição, emergem as principais forças de disputa entre: o Estado (ou Estado de governo, protagonista porque detém a estrutura institucional e jurídica para definir como o território será ordenado); a "articulação institucional entre as instâncias decisórias, refletindo, como um corte transversal, todas as decisões públicas com repercussão territorial" (BRASIL, 2006, p. 15); as diferentes escalas de decisão envolvidas no processo (pertinentes aos governos federais, estaduais e municipais); e os atores privados e as diversas faces da sociedade civil envolvidas.

Brunet, Ferras e Théry (1993) apontam que não se pode esperar que o ordenamento territorial resolva as disparidades entre o que chamam de "centro e periferia", já que o poder de crescimento dos centros não tem limites. Dessa 
maneira, a organização territorial já deveria ter incorporado elementos de distribuição igualitária, considerando as especificidades dos diversos grupos que conformam a sociedade para que seja efetivo, eficiente e eficaz.

Entretanto, a forma e o modelo de organização do território amazônico são tratados de maneira distinta (MELLO E THÉRY, 2001). A forma é composta pelos eixos de força, isto é, a produção derivada da agropecuária e do extrativismo, escoada pela malha de transportes. Já o modelo deriva da valorização da oposição de quadrantes diferenciados, a saber: o Sudeste, densamente ocupado, transpassado por uma malha mais densa de vias de transportes e com ativa frente pioneira; o Noroeste esvaziado; o Sudoeste, dependente e estruturado pela BR364; e o Nordeste, como prolongação do Sudeste.

Uma vez que as desigualdades na distribuição dos recursos permanecem irresolutas no Brasil, tanto a definição metodológica do ordenamento territorial quanto a própria descentralização política estão envolvidas, por extensão, com tal problema estrutural. Como definição metodológica, entende-se a escolha da base geográfica como unidade territorial (bacia hidrográfica, ecossistema, bioma ou município, cidade ou região); a definição da escala de intervenção (municipal, macrorregional); o grau de detalhamento das informações e sua integração a bases de dados; a adequação das informações à escala pretendida; e, finalmente, o método de negociação entre os atores (BERTONE E MELLO, 2006, p. 140). Notamos, entretanto, que o método de negociação entre os atores depende da definição de todas as etapas anteriores.

Com base nas experiências das redes ambientalistas, a imprecisão da unidade geográfica pode mobilizar estas ou aquelas organizações em diferentes momentos, as quais tentam especular qual é, afinal, a escala pretendida a uma determinada política ambiental. Muitas vezes a escala sobre a qual se quis influenciar somente é descoberta no final do processo, com o balanço das atividades, e inclui diferentes unidades territoriais ao longo dos anos. Se por um lado esse quesito é um fator de debilidade no transcurso do processo, quando analisado por períodos pode dizer muito sobre o modus operandi do Estado sobre o território, sendo possível prever os seus desdobramentos socioambientais ${ }^{33}$. atuação até 2012, com escalas e unidades territoriais por ação desenvolvida. 
Sobre isso, é clara a perspectiva de Moraes (2005), apontando que o país deve ser pensado como sociedade e não apenas como Estado. Assim, a estrutura fundada no clientelismo e nas desigualdades sociais em favor de uma pequena elite são as responsáveis pelas indefinições metodológicas ${ }^{34}$. $O$ crescimento pautado na ampliação dos mercados internos e externos se caracterizaram nas políticas territoriais pós-PPA 1995-1999. As lacunas de bases de dados e informação sobre o planejamento estatal disponíveis à população se contrapunham com informações sistematizadas e organizadas, disponíveis a investidores, em parceria com empresas (BERTONE E MELLO, 2006). Essa discrepância também deixa expropriado o sujeito na ponta final, receptor último das políticas arbitrariamente concebida $^{35}$ : o cidadão comum, socioambientalmente localizado, porém marginalizado do processo decisório. Este também não consegue, muitas vezes, representatividade pelas organizações sociais, independentemente da temática sobre a qual elas estejam focadas, já que a sua fundamentação também pode ser assistencialista e não processual das razões centrais que levam à distribuição desigual do acesso à natureza.

Somando-se à dificuldade de definição teórica, outro elemento importante no ordenamento territorial é sua divisibilidade em múltiplas políticas públicas de diferentes escopos e com diferentes objetivos, incluindo-se aí as políticas ambientais. Fearnside (2001), por exemplo, apontava que o zoneamento da

34 O Workshop sobre a Metodologia de Zoneamento Ecológico-Econômico para a Região CentroOeste e para a Região Amazônica ocorreu nos dias 30 e 31 de agosto de 2001, no Instituto de Meio Ambiente, em Campo Grande, MS. Teve participação de: Secretaria de Desenvolvimento Sustentável (SDS)/MMA; Secretaria do Meio Ambiente/MS; Companhia de Pesquisa de Recursos Minerais (CPRM); Instituto Nacional de Pesquisas Espaciais (INPE); Empresa Brasileira de Pesquisa Agropecuária (EMBRAPA); IBAMA; SODEPLAN; SEMACT/MS; UFBA; SEPLAN/MS; IBGE; Fórum das ONGs Brasília; Agência Goiana de Desenvolvimento Industrial e Mineral (AGIM/GO); Agência Ambiental de Goiás; Associação de Atrativos Turísticos de Bonito e Região; SEMARH/DF; Universidade de Brasília (UNB); EMBRAPA Pantanal; EMBRAPA Campo Grande; PLANURB Campo Grande; UFU; Prefeitura Municipal de Campo Grande; Secretaria Estadual de Meio Ambiente, Cultura e Turismo; Programa Pantanal/MMA; Secretaria do Desenvolvimento do Turismo no Estado do MT; Secretaria do Meio Ambiente do Município de Bonito; Conservation International (Cl); Secretaria de Turismo, Indústria e Comércio de Bonito; Instituto Meio Ambiente Pantanal; Secretaria de Meio Ambiente, Cultura e Turismo Mato Grosso do Sul; Secretaria do Desenvolvimento do Turismo no Estado do Mato Grosso do Sul e dois cidadãos não identificados. $35 \mathrm{Na}$ discussão da metodologia a ser aplicada nos zoneamentos, o MMA se posiciona sobre o Estado e as "ONGs" separadamente: "Estado é Estado, ONG é ONG. O Estado fica; a ONG hoje existe, amanhã, não. Portanto, as organizações não governamentais e o Estado têm, cada um, seu papel. O Estado tem que exercer seu papel e as organizações sociais, legitimamente, têm que exercer o seu. Mas, as responsabilidades do Estado não podem ser delegadas para as organizações não governamentais, assim como o Estado não vai exercer a função de ONG, ou seja, cada macaco no seu galho (...). As coisas acontecem no território. Nada acontece no espaço" (MMA/SDS, 2001, pp. 33-34). 
Amazônia prescindiu da avaliação dos impactos dos eixos de desenvolvimento, sendo feito em grande escala, não seguindo os princípios discutidos nos espaços de interação com a academia e a sociedade civil.

O resultado final das políticas no território, portanto, depende de contextos nos quais prima o desacordo entre as propostas e decisões, sendo o espaço político aquele onde esses impasses emergirão em forma de argumentos e estratégias de influência na decisão. Esse lobby não é feito em igualdade de condições, já que há hegemonias entre os atores e sujeitos sociais intervenientes. Quanto mais fortes as relações hegemônicas entre essas organizações e instituições, tão maior será a dificuldade de elaborar medidas que atendam, ao menos satisfatoriamente, à sociodiversidade em uma decisão pertinente ao socioambiente.

\subsection{O PPG7 e seu papel no processo de fomento à participação}

Para garantir um processo decisório que incluísse a participação de diversas esferas governamentais e não governamentais, o projeto de zoneamento na Amazônia foi um dos projetos suporte dentro do PPG7 (BRASIL, 1991) ${ }^{36}$.

Segundo o documento, o ZEE é um processo dinâmico de levantamento e análise que deveria ser desenvolvido em três fases: a primeira, de diagnóstico ambiental, no nível macrorregional, identificando áreas homogêneas, com base nos fatores bióticos, físicos e socioeconômicos. Nesta fase seriam definidas as divisões e os territórios geoambientais maiores, excluídos os inventários de recursos naturais. A segunda fase estabeleceria parâmetros de uso e ocupação dessas

36 O Programa Piloto foi proposto na reunião do Grupo dos Sete países industrializados (G-7), em Houston, Texas (EUA), em 1990. Foi aprovado pelo G-7 e pela Comissão Europeia em dezembro de 1991. Em 1992, durante a Conferência das Nações Unidas para o Meio Ambiente e o Desenvolvimento, a Rio-92, o programa foi oficialmente lançado no Brasil. Objetivava criar, validar e difundir conhecimentos gerados a partir das experiências desenvolvidas no âmbito da Amazônia brasileira e da Mata Atlântica; influenciar a formulação e implementação de políticas públicas para o desenvolvimento sustentável; apoiar a expansão de modelos e experiências bem-sucedidas; e fortalecer a capacidade de instituições públicas, privadas e da sociedade civil organizadas para implementar políticas e aplicar novos conhecimentos. Os primeiros projetos foram aprovados em 1994 e tiveram sua execução iniciada em 1995. Entre 2000 e 2005, oito projetos e subprogramas foram finalizados: Reservas Extrativistas I, Centros de Ciência, Pesquisa Dirigida I, Grupo de Trabalho Amazônico I, Rede Mata Atlântica, Proteger I, Resex I e Projeto Negócios Sustentáveis (PNS). 
terras, e a terceira seriam os estudos específicos em áreas críticas e em áreas ecológicas, socioeconômica e politicamente importantes, para a execução de ações preventivas, corretivas ou de recuperação (BRASIL, 1991, p. 20).

A estratégia adotada pelo PPG7 incluía a elaboração de um diagnóstico ambiental para a região amazônica, sob a coordenação da Comissão de Coordenação Interministerial de Zoneamento Ecológico-Econômico, a começar pela identificação e estudo de áreas intrarregionais (1:250.000), oferecendo informações para o ordenamento territorial (BRASIL, 1991, p. 20).

O gerenciamento deveria ser feito pelos Órgãos Estaduais de Meio Ambiente (OEMAs) e as (neste momento definidas com tal nomenclatura) ONGs, avaliando e adaptando periodicamente o processo, segundo as atribuições das esferas governamentais no uso e nas práticas do planejamento espacial e de organização territorial.

Especificamente sobre o ZEE, o Projeto Piloto apontava para a necessidade de apoio técnico local, com fortalecimento institucional dos OEMAs, para atendimento das demandas locais. Para tanto, o IBAMA realizou, no âmbito da PNMA, um levantamento das fragilidades e potencialidades da capacidade institucional. A metodologia utilizada para esse levantamento foi o Sistema de Análise de Capacidade Institucional (SACI) do BIRD.

Para fins de transferência do conhecimento sobre a capacidade institucional, foram objetivos constantes no PPG7:

Fortalecer institucionalmente os Órgãos Estaduais de Meio Ambiente da Amazônia Legal para potencializar a efetiva descentralização das ações de proteção e conservação ambiental, capacitando-os para o cumprimento de suas atribuições e funções, por meio do: apoio e reestruturação integrada dos modelos de gestão ambiental dos OEMAs da Amazônia Legal; aumento da capacidade técnica; e reforço da estrutura laboratorial, de transporte e comunicação. Formular projetos de reestruturação dos modelos de gestão ambiental (estrutura organizacional, rotinas técnico-administrativas, planejamento estratégico) para todas os OEMAs da região amazônica, com exceção do OEMA de Mato Grosso, satisfatoriamente atendida no bojo do subcomponente "Pantanal", PNMA IBAMA. Atender necessidades emergenciais dos OEMA Amazônicos, em infraestrutura de transporte e comunicação. Capacitar 395 funcionários nas áreas de legislação ambiental e fiscalização. Este último incluía módulos de formação dos agentes de fomento (agências financeiras), econômicos (setores primário, secundário e terciário) e das organizações sobre questões ambientais. (BRASIL, 1991a, p. 58). 
Os objetivos foram traçados segundo as identificações dos problemas de suficiência institucional, já que a concepção dos OEMAs amazônicos - estruturados entre os anos 1970 e 1980 e consolidados a partir de 1990 por demanda extrarregional - foi moldada segundo modelos de gestão de outras regiões do País, pouco aplicáveis à realidade amazônica. Nesse contexto, a PNMA havia destinado US\$ 2 milhões para a solução de problemas emergenciais nos OEMAs. Já o PPG7 se propunha a suprir necessidades de planejamento e execução por meio da reestruturação institucional (BRASIL, 1991, p. 59).

As análises realizadas pelo Banco Mundial na elaboração do Programa Piloto apontavam o isolamento e a desarticulação entre os OEMAs amazônicos e o distanciamento de órgãos congêneres no restante do País, bem como das agências de desenvolvimento estadual e de organizações da sociedade civil (BRASIL, 1991, p. 60).

A então apontada desorganização interna dos OEMAs amazônicos, com predominância de estruturas informais e consequente atropelamento da hierarquia, somava-se à falta de sintonia com a realidade local, às principais questões ambientais que afetam a região e à falta de planejamento, centralização administrativa e ausência de ação interiorizada (BRASIL, 1991a, p. 60).

Os mesmos problemas foram apontados como elementos que dificultavam o acesso das camadas basilares da sociedade civil aos processos decisórios. Nesse quesito, já no PPG7 eram discutidos aspectos da representatividade da sociedade civil e as características de sua participação no Programa Piloto baseadas na gênese de sua coletivização e em como as organizações ambientalistas colaboravam em suas redes.

Mello (2006) aponta que o PPG7 foi pensado em seus primeiros delineamentos de forma que parecia mostrar os problemas ambientais brasileiros maiores do que realmente eram, possivelmente por uma exacerbação da visão protecionista ambienta ${ }^{37}$. Esse padrão de entendimento externo, no que se refere às colaborações bi ou multilaterais em diversos níveis, repete-se desde então em sucessivas tentativas de colaboração na questão ambiental entre países

37 Comentário próprio a partir das minhas experiências em cooperação internacional em questões ambientais entre universidades, redes e organizações ambientalistas. Para evitar redundâncias, indicamos a leitura do capítulo de Mello (2006), texto com o qual articulamos as opiniões aqui mencionadas. 
desenvolvidos e em desenvolvimento ${ }^{38}$. Ademais, os estudos pré-investimento e a versão aprovada não definiam explicitamente uma estratégia ao território (MELLO, 2006), ainda que, ao longo do programa, tenham surgido efeitos espaciais diferenciados, como o esperado na dinâmica dos atores, abordada no Capítulo 2. Complementando a experiência de Mello (2006) no PPG7, afirmamos que as tentativas de influência sobre as dinâmicas territoriais são objeto de disputas geopolíticas entre doadores e receptores, sendo que o que está em jogo é quem tem o poder de decidir sobre o que deve ser feito. Nesse sentido, os diversos conflitos reportados por esta autora são reconhecíveis em outras esferas relacionais de cooperação.

Para Mello (2006), o PPG7 incentivou o ZEE como tema objeto de discursos, práticas e resultados diversos. No entanto, reside no caráter não estrutural do PPG7 (MELLO, 2006) um problema que se arrasta na questão ambiental brasileira. Ainda que a concepção brasileira de ordenamento territorial como um todo seja repleta de lacunas e incongruências, incluindo arbitrariedades em todas as esferas federativas, o ZEE se mostrou um dos mais bem-acabados instrumentos que incorpora simultaneamente aspectos ambientais e sociais (MELLO, 2006).

Mello (2006) também aponta a dificuldade de estabelecimento do programa dada a diversidade de interesses entre as agências financiadoras externas, as instituições formais nas esferas governamentais brasileiras e as organizações. Nesse quesito, o desafio de atender aos diferentes interesses é uma constante em qualquer atividade das redes ambientalistas. Não foi diferente na relação entre GTA e FORMAD, intrinsecamente ligados na construção dos zoneamentos tanto estadual quanto da BR-163, ambos ligados ao espaço estadual mato-grossense. Tanto foi o sucesso dos resultados do PPG7 e da participação da sociedade civil na construção do zoneamento que, como veremos adiante, foi necessária uma tática da Assembleia Legislativa mato-grossense que inviabilizasse toda a construção pertinente ao ZSEE, impondo a visão dos ruralistas.

Em outubro de 1991, portanto seis meses antes da CNUMAD de 1992, momento marco no ambientalismo brasileiro, tinha-se como intencionalidade aproveitar o entendimento dentro do GTA, dada sua abrangência na região amazônica, e das redes estaduais, como o FORMAD. Assim, estabelecer-se-iam 
posicionamentos sobre o Programa Piloto, procurando mecanismos de interação entre as organizações ambientalistas e a coordenação do programa.

Na estrutura do Programa Piloto, as organizações reivindicavam: o assento de representantes internacionais e nacionais como observadores no Comitê Misto (GOB/CCE/BIRD); a participação com voz e voto no Comitê Nacional de Coordenação, em paridade com as entidades governamentais, com dois membros do GTA e dois representantes de organizações de base; e a participação plena de um membro da secretaria-executiva do GTA, cumprindo o mesmo papel do assistente de Coordenação da Secretaria Executiva do Programa Piloto, integrando governo e sociedade civil e oferecendo uma interface contínua entre os projetos demonstrativos e estruturais (BRASIL, 1991a, p. 74).

Em relação aos mecanismos de participação, no Projeto Piloto era prevista não apenas a inferência nos projetos demonstrativos, mas também a legitimação, o aperfeiçoamento e reforço à participação. Isso porque às vésperas da CNUMAD de 1992, o papel das organizações ainda era muito reduzido nas reuniões viabilizadas pela SEMAM/PR. As críticas encaminhadas tinham pouca expressão, com pouca importância aos governos. A ineficácia do alcance das críticas aos governos, entretanto, não desmereceu o amadurecimento das relações mútuas entre organizações ambientalistas (BRASIL, 1991a, p. 75).

Aprofundou-se, ao longo da década de 1990, o fomento de recursos financeiros às ações das organizações para o engajamento na preparação do Programa Piloto, fosse por convênio com o Programa das Nações Unidas para o Desenvolvimento (PNUD), recursos orçamentários da SEMAM/PR e do IBAMA, empréstimos do BIRD via Programa das Nações Unidas para o Meio Ambiente (PNUMA), doação externa, dentre outros. O foco era ter representantes das organizações do GTA como interlocutores na preparação dos projetos estruturais e na montagem e implementação do Sistema de Monitoria e Avaliação Contínua do Programa Piloto (BRASIL, 1991a, p. 75).

A trajetória do PPG7, portanto, traz à baila as contradições e os conflitos históricos entre os stakeholders intervenientes na política, que também foram sentidos durante a elaboração do ZSEE mato-grossense. A realização deste vem atrelada ao desenvolvimento do PRODEAGRO, mas sua elaboração e consolidação se articulam, ou se relacionam, com diversos momentos políticos 
ambientais que se sucederam até sua promulgação (não consolidada) em 2010. Nesse processo, os grupos da sociedade civil historicamente marginalizados das conquistas econômicas e da atividade política perceberam realmente o que estava em jogo. Em 2011, após a abrupta mudança entre as propostas de zoneamento no Estado em relação às áreas produtivas consolidadas ou a se consolidarem, sobretudo entre as versões de 2008 e 2010, realizadas pelo governo estadual, as desigualdades na participação das políticas ambientais se evidenciaram de tal forma que o tema se tornou uma das pautas principais entre as diversas camadas da sociedade civil organizada.

\subsection{O zoneamento, o mais suspeito dos componentes do PRODEAGRO ${ }^{39}$}

Como foi discutido no Capítulo 1, as relações sociais imprimem formas no espaço relativas à época em que foram produzidas. A essa apropriação e criação de valores pelas sociedades atribui-se o nome de valorização do espaço (MORAES, 2002). A apropriação do valor espacial implica que se fixe um valor em um local. A exploração dos recursos naturais (os biomas e as diversas conformações ecossistêmicas aquáticas e terrestres), enquanto fundos territoriais, envolve a construção de uma infraestrutura na abrangência espacial onde há interesse. No entanto, essa infraestrutura é desigualmente distribuída, da mesma forma que o são os recursos naturais e a mensuração de quais impactos ambientais serão focos de adaptação e mitigação.

Os projetos de gestão de recursos naturais nos estados de Mato Grosso e Rondônia, conhecidos localmente como PRODEAGRO e PLANAFLORO, respectivamente, foram duas operações muito semelhantes financiadas pelo Banco Mundial no Noroeste do Brasil. O Plano Agropecuário e Florestal de Rondônia (PLANAFLORO) foi o primeiro a ser elaborado e avaliado, em 1993. Os projetos consistiam em grandes investimentos do Banco em uma sub-região da Amazônia Legal, para corrigir e compensar as deficiências do Programa Integrado de Desenvolvimento do Noroeste do Brasil (POLONOROESTE, 1981-1985), que, na década de 1980, foi conduzido mediante quatro empréstimos de US\$ 400.000 .000 de recursos do governo brasileiro e do Banco Mundial (FANK, 2007), sob a

39 Afirmação feita por Vicente José Puhl, coordenador do Fórum Mato-grossense de Meio Ambiente e Desenvolvimento (FORMAD), ao Diário de Cuiabá, em março de 2003: "o zoneamento há muito deixou de ser o mais importante para se tornar o mais suspeito dos componentes do PRODEAGRO". 
coordenação da Superintendência de Desenvolvimento do Centro-Oeste (SUDECO). Abrangeu a área de influência da rodovia BR-364, entre Cuiabá (MT) e Porto Velho (RO), tendo como objetivos principais a integração nacional e a ocupação demográfica regional para proteção das fronteiras brasileiras.

O crescimento populacional na região Centro-Oeste entre 1980 e 1991 foi de 2,99\% ao ano. Já no Censo Demográfico de 2000, registra-se uma população de 11.616.745 habitantes, com taxa de urbanização de 2,37\% por ano e urbanização de $86,7 \%$. Tais proporções indicam como se estabeleceu a dinâmica das relações agrícolas durante o período do POLONOROESTE, notadamente em escala industrial, baseadas na produção de grãos e gado para exportação. $\mathrm{Na}$ medida em que a sociedade política era composta por esses grandes produtores, - Estado passou a "adaptar" sua capacidade reguladora às necessidades do mercado, sobretudo no caso mato-grossense (CUNHA E BAENINGER, 2000; PIGNATTI, 2005).

Frente a essa conjuntura estabelecida, o POLONOROESTE foi internacionalmente criticado por contribuir para a destruição das florestas tropicais em 2 milhões de hectares sob a ação de companhias madeireiras, apoiando a pavimentação de estradas nacionais, a migração, os assentamentos e o desenvolvimento agrícola na floresta tropical (PIGNATTI, 2005).

Os subsequentes Programas de Desenvolvimento Integrado (PDIs) foram os instrumentos de captação de recursos para amortização das dívidas que possibilitaram a intervenção do Estado na fase auge da modernização agrícola (PIGNATTI, 2005).

O Programa de Desenvolvimento Agroambiental do Estado de Mato Grosso (PRODEAGRO) - que contou com um recurso de US\$ 285 milhões, sendo 75\% deste valor provindos do Banco Mundial com a finalidade de reparar os danos, principalmente socioambientais, causados pelo POLONOROESTE - pretendia promover uma maior descentralização e o fortalecimento da capacidade institucional local, distribuída e viabilizada pela participação de outros agentes executores nos níveis estadual e federal (SEPLAN, 2002). O prazo total de sua execução era de cinco anos, prevendo-se uma Avaliação de Meio Termo em 1994, a qual foi realizada somente em 1996. 
O Zoneamento Agroecológico e o Ordenamento Territorial da região florestal amazônica (nomeado como Projeto BRA/87/037) era o principal componente do POLONOROESTE e do PRODEAGRO. As instituições patrocinadoras eram o Ministério do Interior (por meio da Superintendência do Desenvolvimento da Região Centro-Oeste - SUDECO) e a Organização das Nações Unidas (FAO e PNUD).

O PRODEAGRO foi, em termos gerenciais, administrativos e técnico-operacionais, executado em ações de nível nacional, estadual e de cooperação técnica. Nacionalmente foi conduzido pela Secretaria de Desenvolvimento Regional (SDR) da Presidência da República (PR) e pelo Ministério da Integração nacional (MI). No estado do Mato Grosso, pelo Conselho Estadual de Administração do PRODEAGRO (CEAP), na Secretaria de Estado de Planejamento (SEPLAN).

As ações de gerência intermediária foram exercidas pela Gerência Estadual do PRODEAGRO (GEP), cuja estrutura funcional foi objeto de várias alterações ao longo do desenvolvimento do programa. A cooperação técnica foi feita por meio de uma estrutura organizacional-funcional estabelecida conforme o contrato PNUD BRA/94/006, nas ações em que o governo do estado de Mato Grosso demandasse aporte técnico no sentido de garantir a execução das atividades estabelecidas no contrato de empréstimo firmado entre o Governo Federal e o BIRD (contrato 3492BR-MT). As decisões no âmbito do PRODEAGRO foram tomadas segundo uma linha de autoridade que seguiu a estrutura organizacional do estado: governador, secretários e gerente estadual do PRODEAGRO.

Nesse contexto e com a presença física do escritório do BIRD em Cuiabá/MT para atender e agilizar as ações administrativas e contratuais do PRODEAGRO e PLANAFLORO, a participação da sociedade civil era fomentada pelo Banco como condicionante para o repasse de recursos para o governo. Havia, nesse momento, um compromisso crescente no Brasil para o desenvolvimento da gestão ambiental, com base em gradual fortalecimento das instituições essenciais e uma melhoria do conhecimento técnico. Frente a esse cenário deu-se um dos principais momentos na atuação das redes ambientalistas no Mato Grosso dentro do processo de negociação das organizações sociais com o Governo Federal, em relação ao estabelecimento do PRODEAGRO. As principais representações eram feitas pela colaboração entre FASE, CPT, ICV, OPAN, CIMI e MOPS, por meio de comitês, 
comissões, câmaras técnicas e conselhos.

Essa conformação de organizações, a qual compunha o Comitê Independente de Avaliação do PRODEAGRO (CIAP), atuou por meio da criação e distribuição de núcleos. Foram criados grupos de trabalho para estudar todos os componentes, em especial o de produção, o viário, ambiental e indígena, segundo a atribuição e o conhecimento das organizações sobre dados temas ${ }^{40}$.

Em princípio, o PRODEAGRO foi estruturado em componentes e subcomponentes, conforme sua estrutura organizacional (Quadro 16) ${ }^{41}$.

\section{Quadro 16. Estrutura original organizacional do PRODEAGRO}

\begin{tabular}{|l|}
\hline A. Zoneamento agroecológico e regularização de posse de terra \\
\hline A1. Zoneamento Sócio-Econômico-Ecológico \\
\hline A2. Regularização fundiária \\
\hline B. Proteção e monitoração de recursos naturais \\
\hline B1. Manejo sustentado de florestas \\
\hline B2. Regularização, racionalização e controle das atividades mineradoras \\
\hline B3. Identificação, demarcação e implantação de Unidades de Conservação \\
\hline B4. Educação ambiental informal \\
\hline B5. Licenciamento, monitoramento e fiscalização ambiental \\
\hline B6. Proteção e controle de áreas indígenas \\
\hline B7. Monitoramento da cobertura vegetal, de atividades mineradoras e sensoriamento remoto \\
\hline B8. Fortalecimento institucional \\
\hline \\
\hline C. Desenvolvimento agroflorestal \\
\hline C1. Crédito rural alternativo \\
\hline C2. Pesquisa agroflorestal \\
\hline C3. Extensão rural \\
\hline C4. Comercialização e informação de mercado \\
\hline \\
\hline D. Infraestrutura e serviços socioeconômicos \\
\hline D1. Saúde \\
\hline D2. Educação \\
\hline D3. Abastecimento rural de água \\
\hline
\end{tabular}

40 Entrevista realizada com o ex-coordenador do FORMAD Vicente Puhl, em setembro de 2014.

41 SEPLAN (2002). 


\begin{tabular}{|l|}
\hline D4. Transporte rodoviário \\
\hline E. Desenvolvimento institucional \\
\hline E1. Administração estadual \\
\hline E2. Administração nacional do PRODEAGRO \\
\hline
\end{tabular}

Fonte: SEPLAN (2002).

Desde o princípio, o PRODEAGRO estava entre as prioridades de ação das redes ambientalistas mato-grossenses, notadamente o FORMAD ${ }^{42}$. O desenvolvimento do programa e a emergência dos seus impasses acabaram por fomentar a articulação das organizações sociais. Assim, após o estudo e a análise dos componentes que compunham o PRODEAGRO, foi estabelecida a diretriz de promover mesas de negociação, em um diálogo mais intenso com o governo. Naquela ocasião havia uma maior abertura governamental no estado dada a sua conformação mais progressista, abrindo a possibilidade de negociação a uma série de componentes do programa ${ }^{43}$.

Segundo a SEPLAN (2002), "a participação da 'sociedade civil' foi relativa, sendo substituída em Meio Termo a participação direta por 'representantes' da sociedade civil organizada (FAMATO, FETAGRI e FORMAD, por exemplo)". O que a SEPLAN considerou como "sociedade civil organizada", entretanto, inclui desde a FAMATO (que representa os grandes produtores de soja do estado), a FETAGRI (que adotou o PRODEAGRO como elemento estratégico após a Avaliação de Meio Termo) e o FORMAD, com discrepantes orçamentos e permeabilidade nas decisões governamentais.

Uma das grandes críticas feitas pelo FORMAD e pela FETAGRI ao PRODEAGRO é que este havia sido negociado exclusivamente entre a esfera governamental e o Banco Mundial sem a participação da sociedade civil ou dos segmentos beneficiados. Em 1996, na Avaliação de Meio-Termo do PRODEAGRO, foi então proposta pela FETAGRO e pelo FORMAD ao Banco Mundial e governo uma reunião participativa. A proposta era consolidar uma metodologia de consultas públicas e monitoramento temporário por amostragem de unidades executivas do projeto, em que estivessem presentes e fossem escutados e considerados os

42 Vide anexa a matéria de jornal de 1997, mencionando detalhadamente a ação do FORMAD no PRODEAGRO.

43 Entrevista com Vicente Puhl, setembro de 2014. 
beneficiários diretos do programa. $\mathrm{O}$ apoio financeiro a essa ideia foi buscado junto à representação do Banco Mundial em Cuiabá, sendo rejeitado na ocasião. Tendo optado por selecionar uma equipe de consultores para uma "avaliação independente", entregue ao governo em outubro de 1996, os resultados avaliados foram semelhantes aos levantados pela rede:

1) Fraca capacidade de articulação intra e interinstitucional dos órgãos governamentais nas ações de gerenciamento, proteção e monitoramento dos recursos naturais do Estado.

2) Falta de metodologia que incorpore a dimensão social, política e ambiental no ZSEE.

3) Postura dúbia do governo e debilidade do BIRD nos processos de demarcação das terras indígenas.

4) Resultados insatisfatórios no processo de descriminação de terras públicas no estado.

5) Ineficiência do Instituto de Terras de Mato Grosso (INTERMAT) e ingerência político-partidária na sua cúpula em relação à programação para assentamentos.

6) Gasto excessivo com atividades intermediárias, levando a que somente $10 \%$ do valor destinado aos beneficiários chegassem a eles.

7) Desvio dos objetivos do programa na implementação e no gasto dos recursos do Fundo de Desenvolvimento Agroambiental de Mato Grosso (FUNDAGRO).

Apesar do fato de o PRODEAGRO haver sido criado para a reparação dos danos causados pelo POLONOROESTE e das diretrizes governamentais, a principal conclusão da rede de atores da sociedade civil que se conformou nesse momento e que monitorou o programa foi a de que, entre 1995 e 1996, os recursos chegavam precariamente ou sequer chegavam nas pontas que deveriam ser contempladas com os benefícios e recursos, ou seja, as comunidades tradicionais, os indígenas e agricultores familiares (FORMAD, 1997a). A Empresa de Assistência Técnica e Extensão Rural (EMATER) comprava veículos que nunca eram vistos nas comunidades, por exemplo. Frente a comprovação dessas evidências, identificadas pelo FORMAD, enquanto rede de atores organizacionais, e levadas pelo Ministério Público ao BIRD, estabeleceu-se a criação do Programa 
de Apoio Direto às Iniciativas Comunitárias (PADIC). Segundo a SEPLAN (2002), os gastos com esse programa alcançaram US $\$ 17.343 .711,14$, o que corresponde a

$43,36 \%$

(US\$ 40 milhões) do previsto no Termo de Compromisso de 1996. Esse montante representou 6,1\% dos recursos previstos no Appraisal para o PRODEAGRO e 7,8\% do total executado. $O$ uso dos recursos era monitorado pelo CIAP.

Novamente insistindo com o BIRD, foi realizado um seminário oficial em 4 e 5 de dezembro de 1996, contando com a participação de 150 lideranças sindicais, associativas, indígenas e das comunidades tradicionais e representantes de ONGs, do qual resultou um "Termo de Compromisso" que lançou bases para a composição da segunda etapa do PRODEAGRO. Para concretizar o Termo, assinado entre Governo Federal, estadual, Banco Mundial e sociedade civil, foram criados grupos temáticos de trabalho que, dentre outros temas, regulavam: as contrapartidas de financiamento; os critérios de elegibilidade de projetos; os procedimentos de análise pela Câmara Técnica e Deliberativa (onde o FORMAD estava inserido); as responsabilidades de monitoria (para as quais foi feito um Manual Operativo, proposto e levado adiante pelas organizações conformadas no FORMAD); e as regras para a prestação de contas e liberação de recursos. Após o seminário e a Avaliação de Meio Termo, o PRODEAGRO foi reformulado (Quadro 17), ampliando seu escopo de ação.

\section{Quadro 17. Estrutura organizacional do PRODEAGRO depois da Avaliação de Meio Termo}

\begin{tabular}{|l|}
\hline A. Zoneamento agroecológico e regularização fundiária \\
\hline A1. Zoneamento Sócio-Econômico-Ecológico do estado \\
\hline A2. Regularização fundiária \\
\hline \\
\hline B. Gerenciamento, proteção e monitoramento dos recursos naturais \\
\hline B1. Implantação de Unidades de Conservação \\
\hline B2. Projetos ambientais demonstrativos \\
\hline B3. Licenciamento, monitoramento e fiscalização ambiental \\
\hline B4. Fortalecimento institucional do Fundo Estadual do Meio Ambiente (FEMA) \\
\hline B5. Indígena \\
\hline B6. Proteção e Fiscalização de Áreas Indígenas e Unidade de Conservação (CIFA) \\
\hline \\
\hline C. Programa de Apoio a Iniciativas Comunitárias (PADIC) \\
\hline
\end{tabular}




\section{Fornecimento de água, eletrificação rural e recuperação de rodovias}

\begin{tabular}{|l|}
\hline D1. Setor de fornecimento de água \\
\hline D2. Setor de eletrificação rural \\
\hline D3. Recuperação de estradas \\
\hline
\end{tabular}

\section{E. Treinamento, assistência técnica e estudos}

\section{F. Administração do projeto, monitoramento e avaliação}

\section{G. Desenvolvimento agroflorestal}

\section{H. Saúde e desenvolvimento educacional}

\section{H1. Setor de saúde}

H2. Setor de educação

Fonte: SEPLAN (2002).

Segundo Vicente Puhl ${ }^{44}$, ainda, o FORMAD conseguiu intervir positivamente para que fossem aprovados os US\$ 40 milhões de apoio direto às iniciativas comunitárias, sendo que, se fosse uma iniciativa de cunho ambiental, poderia ser conduzida por uma associação social. Assim:

Dos 230 convênios previstos no Plano Operativo foram conveniados 395 (175\%) projetos, dos quais 223 implantados na primeira fase e 172 , referentes à segunda fase, em execução. Foram beneficiados 115 municípios, resultando na aplicação total de 26,56 milhões de reais de recursos do BIRD, abrangendo $82,73 \%$ do Estado, atendendo cerca de 27.200 famílias de pequenos produtores rurais e de populações indígenas. Registra-se o grande número de convênios firmados, quando se compara com a estrutura técnica reduzida PADIC/PRODEAGRO e a dimensão territorial do estado e suas deficientes condições de acesso às comunidades rurais. (SEPLAN, 2002).

Sobre a atuação da sociedade civil nos processos do PRODEAGRO, a SEPLAN (2002) complementa:

A forma de relacionamento do Governo com a "sociedade civil" foi feita com base em organizações institucionalizadas (FAMATO, FETAGRI e outras, poucas). As ONGs, em geral, participaram dos processos de descentralização operativa de alguns tipos de ação, particularmente aquelas de educação ambiental informal. (...) Não existiu diferença qualitativa entre a atuação das organizações da sociedade civil (inclusive das ONGs) em relação aos quadros funcionais do Estado que recomende uma transferência em princípio das ações do Estado para este outro setor. (SEPLAN, 2002).

44 Entrevista com Vicente Puhl, setembro de 2014. 
Os registros oficiais omitem informações importantes sobre o processo participativo. Um exemplo foi que, apesar do protagonismo no estabelecimento do PADIC, o nome do FORMAD foi suprimido desse parágrafo como forte participante nas negociações. Nas plenárias do seminário também foram críticas as participações do Conselho Estadual do Meio Ambiente (CONSEMA) e da FAMATO dentro da categoria de "sociedade civil" na Câmara Deliberativa. Isso porque o primeiro faz parte do governo estadual e a segunda representa os produtores do agronegócio, uma das camadas da sociedade civil que busca intervir nas decisões políticas ambientais ${ }^{45}$.

Segundo relatórios do FORMAD, o governo passou a impedir que um conselho de monitoramento fosse levado adiante, já que, a partir de certo momento, o FORMAD deixou de ser convidado às reuniões do PRODEAGRO, fato que demonstrou o desinteresse governamental na transparência das informações. A pouca participação que houve da sociedade civil certamente não foi promovida ou fomentada pelo governo estadual, que acatou a decisão do BIRD quanto à participação para poder, assim, ter acesso aos recursos do Banco ${ }^{46}$. Se essas exigências não houvessem sido feitas, em lugar de "poucas", provavelmente a redação seria substituída por "nenhuma", não por omissão das organizações da sociedade civil, mas por severa intransigência governamental, impossibilitando a participação social e evitando, sob qualquer hipótese, a accountability e transparência das informações.

Também foi na Câmara Deliberativa que se evidenciaram os principais problemas que perduram na dinâmica das redes ambientalistas, tais como: falta de recursos humanos exclusivamente dedicados a acompanhar as questões do PADIC; falta de rigor nos princípios orientadores de compromisso das organizações

45 Outros grupos, de diferentes camadas da sociedade civil, conformam os médios produtores, pequenos produtores, agricultores familiares, pantaneiros e indígenas. Denotamos por camadas a clara diferenciação do poder de cada um desses atores em intervir nas decisões, dependendo da expressividade numérica e territorial de cada grupo. Os dois últimos possuem menor protagonismo: os pantaneiros por não conseguirem que o Pantanal seja considerado como bioma, portanto, sem condições de reivindicação a uma gestão dos recursos coerente com o status das dinâmicas ecológicas que ali se desenvolvem. Os indígenas, em sua diversidade, possuem etnias com maior representatividade numérica, estabelecidas em maiores áreas. Estas, organizadas, possuem maior protagonismo do que a maioria que está sob risco de desaparecimento, tanto pela decrescente população quanto pela desapropriação de suas terras (observação pessoal).

46 Entrevista com Inacio Werner, Centro Burnier Fé e Justiça, janeiro de 2014. 
com a rede; esvaziamento e desarticulação das redes nas plenárias; dificuldades na comunicação e informação entre os representantes; e falta de registros das deliberações da rede.

Em 1997 o FORMAD, principalmente frente aos descumprimentos dos acordos estabelecidos na Avaliação de Meio Termo nas áreas indígena, fundiária e ambiental, evidenciados pela morosidade de ações do governo que impedissem a invasão das terras Nambikwara e Sararé por garimpeiros e madeireiros, solicitou sua retirada nas negociações do PRODEAGRO (vide Anexo; FORMAD, 1997) e pediu a instalação do Painel de Inspeção do Banco Mundial. Temendo o corte do envio dos recursos, o governo atendeu às solicitações da rede FORMAD, pressionado pelo Banco Mundial. ${ }^{47}$

Para Puhl, seria necessária uma avaliação de quais rumos seguiram os aproximadamente 500 projetos após seu desenvolvimento, já que, em alguns casos e onde existiam organizações sociais já estruturadas, o recurso do PADIC teve bons resultados, com boa aplicação dos recursos. Já em outras regiões criaram-se alguns "elefantinhos brancos", pois se construíram sedes de associações que foram posteriormente abandonadas porque a comunidade inteira migrou ${ }^{48}$.

Apesar dos avanços da participação social ocorridos nesse momento - o qual pode ter sido marcante no sentido de aprendizagem do "como fazer" política e pautar demandas de baixo para cima, por meio de organizações da sociedade civil -, a autora deste trabalho é cautelosa a atribuir ao Banco Mundial os louros à conquista de tal fenômeno. Apenas diria que o contexto proporcionado pelo Banco foi favorável a essa conjuntura, pontualmente favorável aos grupos marginalizados e importante no seu desenvolvimento futuro no avanço das negociações políticas. Também a autora vê com igual cautela o argumento de que o PRODEAGRO foi uma medida corretiva do Banco Mundial ao POLONOROESTE, já que não existem acasos nem nas decisões políticas, nem nas decisões econômicas: em um determinado contexto histórico, o que há é uma estratégia e uma agenda que atenda a tal momento.

Sobre o papel do Banco Mundial na questão agrária, Mendes-Pereira (2004) chama a atenção ao modelo de reforma agrária de mercado promovido pelo Banco.

47 Idem.

48 Entrevista com Vicente Puhl, setembro de 2014. 
Para o autor, cuja visão é compartilhada pela autora deste trabalho, o modelo direcionado para países com graves problemas agrários pouco ajudou na democratização da estrutura fundiária, inclusive por não parecer ser esse seu objetivo. A intenção dos modelos se mostrava mais na direção de "aliviar os efeitos socioambientais negativos provocados pelas políticas de ajuste estrutural", estando longe de se parecerem a programas de reforma agrária redistributiva que efetivamente garantiriam uma justiça socioambiental.

A diversidade de atores e interesses envolvidos e os altos valores repassados, conjugados ao engessamento que os condena a serem programas de pequena dimensão socioeconômica, sem a projeção a uma escala socioambiental que se autossustentasse, encurralaram o programa a uma situação de incapacidade de atender à magnitude do problema agrário existente. Foi nesse contexto de limitações que foram concebidas as premissas que balizaram o ZSEE no estado de Mato Grosso.

Sendo um dos principais instrumentos de planejamento ambiental em vista ao ordenamento territorial, o Zoneamento Ecológico-Econômico (ZEE) ${ }^{49}$ visa, juntamente aos planos diretores de bacias hidrográficas e os planos de manejo de Unidades de Conservação:

Subsidiar a formulação de políticas territoriais da União, Estados e
Municípios, orientando os diversos níveis decisórios na adoção de
políticas convergentes com as diretrizes de planejamento estratégico do
País, propondo soluções de proteção ambiental que considerem a
melhoria das condiçães de vida da população e a redução dos riscos de
perda de capital natural. O ZEE, ao dispor de um mecanismo integrado de
diagnóstico e fornecer diretrizes pactuadas de ação, pode contribuir para
que o sistema de planejamento oriente os esforços de investimentos do
governo e da sociedade civil segundo as peculiaridades das áreas
definidas como zonas e tratadas como unidades de planejamento.
(BRASIL, 2006, p. 150).

Apesar de o ZEE ter como intencionalidade "articular as ações das organizações sociais, induzindo os investimentos produtivos, integrando as ações públicas e combatendo o desperdício de recursos financeiros", há ressalvas expressas pelos próprios representantes da sociedade civil que acompanharam as negociações em vista a decisões - sobre a pouca transparência em informações, dados, audiências públicas, etc. Isso porque quem tem o instrumento político e 
financeiro para estabelecer o ZEE também tem seus interesses e quer preserválos. Nesse sentido, cabe lembrar que no governo estadual, na Assembleia Legislativa e em muitos governos municipais no estado do Mato Grosso há fortes e numerosos atores políticos que também são grandes produtores de soja e cana de açúcar.

\subsection{A Carta de Santarém como manifestação das demandas civis}

A convergência de esforços destinados à Carta de Santarém ${ }^{50}$ pode ser interpretada como um dos momentos importantes de ação das redes ambientalistas amazônicas. Com as exigências feitas para adequação do PRODEAGRO e do ZSEE, a carta configura como sendo uma evolução das estratégias de intervenção da rede FORMAD, em colaboração com outras redes. Se no momento anterior o apoio era externo, por meio de diretrizes do Banco Mundial, o apoio principal nesse momento passa a ser interno, por meio da contestação de diversas redes ambientalistas, heterogêneas em relação à condição estatutária dos seus membros, mas com leituras semelhantes das problemáticas socioambientais. Dentre esses entendimentos, ficou, a partir daí, claramente manifesta a necessidade de um maior preparo e capacitação dos órgãos governamentais para a implementação e evolução da participação da sociedade em políticas ambientais, bem como da criação de delegacias especiais de meio ambiente. Isso significa que amadurece a ideia não somente de haver espaços políticos para influir nas decisões relativas à gestão ambiental, mas que esses espaços estejam organizados e preparados para tal estrutura.

Em resposta à Carta de Santarém, em junho de 2006 o Governo Federal criou o Plano de Desenvolvimento Regional Sustentável para a Área de Influência da Rodovia BR-163 - Cuiabá-Santarém, marcante na trajetória do planejamento do

50 A Carta de Santarém, documentada em 31 de março de 2004, foi firmada por: Associação Floresta Protegida (AFP); Associação Terra Indígena Xingu (ATIX); Centro de Estudos, Pesquisa e Formação de Trabalhadores do Baixo Amazonas (CEFTBAM); Central Única dos Trabalhadores (CUT); EMBRAPA Amazônia Oriental; Federação de Órgãos para a Assistência Educacional e Social (FASE); Federação dos Trabalhadores na Agricultura do Estado do Pará (FETAGRI); Fórum da Amazônia Oriental (FAOR); Fórum dos Movimentos Sociais da BR-163; Fórum Mato-grossense de Meio Ambiente e Desenvolvimento (FORMAD); Fundação Viver, Produzir e Preservar (FVPP); Grupo de Defesa da Amazônia (GDA); Grupo de Trabalho Amazônico (GTA); Grupo Nova Proposta para a Agroecologia; Instituto Centro e Vida (ICV); Instituto de Pesquisa Ambiental da Amazônia (IPAM); Instituto Socioambiental (ISA); Museu Paraense Emílio Goeldi (MPEG); Universidade Estadual do Mato Grosso (UNEMAT); e Universidade Federal do Pará - Campus de Altamira (UFPA). 
desenvolvimento da Amazônia por haver sido elaborado a partir de uma reivindicação das organizações da sociedade civil.

Existia, no período de estabelecimento da Carta de Santarém - e ainda segue vigente -, um reconhecimento por parte dos atores sociais e de suas redes sobre a importância do asfaltamento da BR-163 e demais rodovias federais e estaduais. No entanto, indicava-se nesse momento que os métodos de análise técnica socioambiental, bem como as tecnologias de construção de grandes empreendimentos de infraestrutura no Brasil, não eram adequados nem à dinâmica ecossistêmica dos estados compreendidos, nem às relações territoriais que ali se desenvolviam.

Uma série de fenômenos advindos do asfaltamento da rodovia, entretanto, impactavam negativamente as localidades, dentre os quais incluímos os efeitos sociais da intensificação da grilagem de grandes áreas de terras públicas, da violência e da conversão acelerada de florestas e cerrados em monocultivos que empobrecem as oportunidades econômicas da região. Essas realidades foram identificadas tanto no Mato Grosso quanto no Pará, com desdobramentos políticos, econômicos, sociais, culturais e ambientais distintos, segundo as especificidades contextuais locais. Segundo o constante na Carta de Santarém:

\begin{abstract}
A BR-163 atravessa uma das regiões mais importantes da Amazônia do ponto de vista da diversidade social e biológica e das potencialidades econômicas dos usos de seus recursos naturais. Integram essa região trechos do Cerrado e da Floresta Amazônica e uma Zona de Transição, no Norte do Mato Grosso. Abrange também quatro bacias hidrográficas (Rios Teles Pires, Tapajós, Xingu e Araguaia) ricas em recursos naturais dos quais dependem populações tradicionais, agricultores familiares e mais de 30 etnias indígenas. Essas populações geram uma economia regional significativa baseada em diversos usos e manejos dos recursos naturais, que ocupam mão-de-obra e movimentam capital não contabilizado monetariamente nas contas nacionais. A precariedade e a secundarização de dados estatísticos sobre a representatividade desta economia têm favorecido o discurso dos grandes empreendedores como os únicos capazes de dinamizar e alavancar o desenvolvimento dessa região. (CARTA DE SANTARÉM, 2004).
\end{abstract}

A abrangência desses fenômenos era facilmente delimitada em suas grandezas cartográficas, mas, retomando o entendimento de escalas exposto na primeira parte deste trabalho, sua compreensão em termos de consequências derivadas para a territorialidade envolvida não era facilmente apreensível, nem para os atores sociais, nem para os governos locais envolvidos. 
A demanda dos atores e das organizações que firmaram e documentaram a Carta de Santarém era para que as ações na área de influência da BR-163 (e, de certa forma, nas demais propostas infraestruturais que envolviam a abertura de estradas ou suficiência energética) fossem acompanhadas pela integração dos governos (federal, estadual e municipal) e sociedade, assegurando o ordenamento territorial e garantindo o devido lugar aos segmentos sociais e produtivos e o uso diversificado da base de recursos naturais da região.

Tal como avalia Acselrad (2002), as organizações representativas do movimento social (indígenas, produtores familiares, extrativistas, entre outros), de ONGs, de órgãos governamentais e de instituições de pesquisa, em quatro polos regionais, nos estados do Pará e Mato Grosso, criticavam a perspectiva reducionista dos impactos e riscos socioambientais envolvidos consequente do entendimento da região como mero corredor de transporte para commodities agrícolas voltados à produção de energia limpa.

A autora ressalta a elevada capacidade das organizações e de seus representantes em formular diagnósticos atuais, com profundo conhecimento dos problemas existentes, disposição propositiva e visão abrangente de políticas públicas quando existe espaço para a mobilização ${ }^{51}$, mesmo que esta envolva a aberta contestação aos planejamentos ambientais, tendo em conta que as decisões em vista à gestão ambiental não estão isentas de conflitos.

No consenso à Carta de Santarém, foram priorizadas as linhas de desenvolvimento ${ }^{52}$ nas quais se concretizasse um sistema viário integrando a construção de rodovias com terminais fluviais, rodoviários e rodofluviais, projetados prioritariamente para o fortalecimento da economia regional.

Os investimentos infraestruturais abrangeriam, de forma integrada, o fortalecimento das instituições de pesquisa e ensino para fomentar o conhecimento científico e tecnológico, de forma a promover a economia local; a promoção de saúde preventiva para famílias rurais e urbanas; o abastecimento e a distribuição

51 A mobilização inter-regional possibilitou, em 2003, a realização de quatro seminários, reunindo mais de mil lideranças. Esse processo participativo produziu diagnósticos e propostas para o estabelecimento das diretrizes do Plano de Desenvolvimento Territorial Integrado e Sustentável da Região de Influência da BR-163.

52 As linhas de desenvolvimento incluíam: 1. Infraestrutura e serviços básicos; 2. Ordenamento fundiário e combate à violência; 3 . Estratégias produtivas e manejo dos recursos naturais; 4. Fortalecimentos social e cultural das populações locais; e 5. Gestão ambiental, monitoramento e áreas protegidas. 
de água tratada; a eletrificação rural (convencional e/ou alternativa); e o saneamento em todos dos núcleos urbanos e rurais das regiões incluídas no plano.

O ZSEE (por meio de metodologias participativas, com a inclusão de variáveis sociais e ambientais), o ordenamento fundiário e o combate à violência deveriam ser ações prioritárias para a governabilidade e o Estado de Direito na região, mediante a participação da sociedade civil organizada e a ação do Ministério Público Federal, Ministério Público Estadual, entre outros, no sentido de promover a segurança pública da região e o combate à violência no meio rural. Por esse instrumento de ordenamento, também se garantiria a ocupação de áreas e a permanência de produtores familiares, quilombolas, populações tradicionais e indígenas na região, regularizando e consolidando também as áreas protegidas ${ }^{53}$.

Também estava incluída como questão a ser levada em conta nos planos de sustentabilidade da BR-163 a incorporação às Terras Indígenas de parcelas importantes de territórios tradicionais de etnias que não foram contempladas nos processos demarcatórios, bem como a fiscalização e vigilância dos seus limites, o controle das atividades agropecuárias e extrativistas no seu entorno e o procedimento das demarcações e homologações pendentes.

A carta, importante não somente para esse momento de consolidação da BR-163, mas também para outras frentes de planejamento estratégico voltado à mobilização e intervenção política, criou consenso entre os membros das redes ambientalistas de que o fomento às condições indispensáveis ao usufruto da cidadania com garantias institucionais de funcionamento de um Estado de Direito seria condição fundamental para o desenvolvimento regional. Seria, para isso, necessária a diversificação dos sistemas produtivos locais, agregando valor à produção, com base em arranjos produtivos que utilizassem a biodiversidade e os recursos florestais e pesqueiros, e a implementação de políticas integradas de financiamento, legislação diferenciada e assistência técnica, privilegiando a inserção de pequenos e médios empreendimentos geradores de empregos locais duráveis. O manejo florestal deveria ser incentivado com legislação diferenciada

53 O PDS Anapu, as reservas extrativistas Verde para Sempre, Renascer, Bacajá e Riozinho do Anfrísio e o mosaico de Unidades de Conservação da Terra do Meio. 
para a escala da produção familiar e o estabelecimento de linhas de microcrédito ${ }^{54}$ solidário.

Tendo em vista o esforço no debate e na elaboração das propostas que constituiriam o Plano de Desenvolvimento Territorial Integrado e Sustentável da Região de Influência da BR-163, as organizações que assinaram a Carta de Santarém propuseram: que a abrangência territorial de impacto da construção da BR-163 considerasse como regiões de influência o norte do Mato Grosso e oeste do Pará, incluindo as bacias do Xingu, Araguaia, Teles Pires e Tapajós; que as ações propostas nesse Plano fossem incorporadas pelo planejamento governamental, nas escalas políticas correspondentes às áreas de influência; e que o Grupo de Trabalho Interministerial da BR-163 fosse instituído como um espaço permanente de debate e de negociação, envolvendo representantes dos movimentos sociais, das ONGs e instituições de pesquisa para debater os programas, as políticas e os projetos para a região.

Outras demandas expostas na carta diziam respeito à compensação do passivo ambiental dos assentamentos de reforma agrária e propriedades privadas onde não havia Reserva Legal, conforme previsto no anterior Código Florestal, com a criação de novas UCs. A criação de uma faixa de proteção de 10 quilômetros no entorno das Terras Indígenas também era apontada como solução para o ordenamento do processo de ocupação e o controle das atividades econômicas, de forma a minimizar seus impactos negativos sobre as terras e populações indígenas.

Posteriormente, o Fórum do Plano BR-163 Sustentável (Decreto Presidencial 6.290, de 6 de dezembro de 2007), composto por 30 membros $^{55} \mathrm{com}$ voto paritário, apareceu como uma proposta para coordenar as negociações entre os governos das esferas federativas e as representações da sociedade civil. $O$ foco era tratar das ações governamentais na região de influência da rodovia (Santarém - Cuiabá). Em algumas das reuniões do fórum, a ausência de representantes como os do Ministério de Desenvolvimento Agrário (MDA) e do Instituto Nacional de Colonização e Reforma Agrária representou, para muitos componentes, uma

54 Criação de novos polos do Programa de Desenvolvimento Socioambiental da Produção Familiar Rural (PROAMBIENTE) e incorporação de áreas alteradas/degradadas ao processo produtivo.

55 Dos 30 integrantes, 15 pertencem ao Comitê Executivo do Plano BR-163 Sustentável, conforme definido no Art. 3oA do Decreto 4.793, de 23 de julho de 2003, e 15 representantes da sociedade civil pertencentes à área de influência. 
manifestação de descaso por parte do governo. Neste ponto, acrescentamos a observação, ao longo de todo o período de estudo, do esvaziamento da participação de representantes do governo, em diversos setores, órgãos e instituições, em diferentes e várias reuniões propostas para negociação com a sociedade civil. Na percepção desta pesquisa, a proposta de acordo com a população, através de seus representantes, é clara e explicitamente deixada em segundo plano.

Destacavam-se nas discussões do fórum do Plano BR-163 Sustentável as anteriores propostas de planos infraestruturais na região amazônica, promovidas pelo Governo Federal, a grande maioria fracassada em seus objetivos de integração e sustentabilidade. As idealizações do Programa de Aceleração do Crescimento (PAC) e sua nova proposta integrativa para a região da BR-163 foram, portanto, vistas com desconfiança pelos membros do fórum. A falta de apoio aos pequenos produtores rurais, em detrimento dos grandes, para os quais as medidas integrativas foram, em verdade, pensadas e realizadas, trouxe à baila das discussões uma série de problemas correlatos à pavimentação da BR-163. O primeiro e principal deles é a ainda persistente carência de assistência técnica e apoio governamental à agricultura familiar. Com isso, foi relatada como frequente a situação de extração ilegal de espécies arbóreas das áreas dos pequenos produtores, além de a abertura de estradas apenas ter sido aceita pela necessidade urgente de que estas pudessem suprir suas necessidades fundamentais.

Nesse quesito, GTA, FORMAD e demais membros do fórum que discutiam o planejamento das ações na BR-163 concordavam com a ausência do poder público na região. A ineficiência dos OEMAs, tanto do paraense quanto do matogrossense, expressava-se pela já mencionada ausência desses órgãos em momentos de negociação com a sociedade. A carência de cargos técnicos e especialistas na temática ambiental na região amazônica é, certamente, uma das razões por sua inexpressividade em tais momentos de posta de acordo. No entanto, mais do que fruto do acaso ou de falta de recursos, a desigualdade na conformação dos quadros técnicos relativos ao ambiente e à agricultura familiar, comparados com aqueles de fomento à produção agrícola em escala industrial e à economia verde, não deixa de ser reflexo de relações de poder. 
$\mathrm{Na}$ ocasião do fórum ${ }^{56}$, relatou-se que, no caso da Polícia Federal, apenas 30 servidores cobriam a fiscalização em 21 municípios, na região de influência da BR-163.

A carência de informações sobre a prestação de contas das ações governamentais em andamento na BR-163 e as dificuldades de obtenção de licenciamento ambiental para os assentamentos agrícolas criados pelo Instituto Nacional de Colonização e Reforma Agrária (INCRA) também foram apontadas como questões contraditórias, sobre as quais seria necessária uma solução.

Apesar da insuficiência do Estado em prover informações ambientais de qualidade e estruturar seus quadros de recursos humanos, dificultando 0 funcionamento dos OEMAs, identificamos que os processos de zoneamento, tanto da BR-163 quanto do estado do Mato Grosso, foram importantes momentos de aprendizagem para as representações dos grupos marginalizados da sociedade civil demonstrarem sua capacidade técnica e - a partir desse momento, como demonstra o Projeto Mato Grosso Sustentável, exposto no Capítulo 5 - política de negociar. Diríamos inclusive que o Estado foi incapaz de incorporar esse movimento de forma produtiva ao planejamento e gestão inovando ao dar entrada às propostas das organizações socioambientalistas em suas pautas, insistindo nos mecanismos coercivos contraproducentes, com pouca repercussão em termos de desenvolvimento econômico e conservação dos recursos naturais na Amazônia Legal.

\subsection{Interação entre Estado e sociedade: os conflitos no caso do Zoneamento Socioeconômico e Ecológico do Estado do Mato Grosso}

O processo que culminou nas propostas de ZSEE mato-grossense remonta das elaborações do Zoneamento Agroecológico, de atribuição federal, entre os anos de 1988 e 1989. O conceito de zoneamento e suas finalidades surgiu mediante reflexões nacionais e internacionais, atendendo a objetivos pensados em ambas as escalas. No Brasil, foi consolidado pelo Decreto Federal 4.297, de 10 de julho de 2002, e alterado pelo Decreto Federal 6.288/07 que regulamenta o artigo 9o, inciso II da Lei 6.938, de 31 de agosto de 1981. 
Os documentos de trabalho do Zoneamento Agroecológico (primeira aproximação na escala 1:2.000.000), elaborados em uma cooperação técnica entre Ministério do Interior (MINTER), SUDECO, FAO e PNUD, estavam relacionados com a implementação do POLONOROESTE. O conceito de agroecologia por eles adotado difere da terminologia aplicada ao seu uso científico corrente, focado no equilíbrio ecossistêmico como condição si ne qua non à necessidade produtiva. Tratava-se, ao revés, "de um tipo de zoneamento que caracteriza ofertas e limitações biofísicas e espaciais, para ocupação e integração harmônica do homem às diversas paisagens produtivas de um território" (MINTER, 1989, p. 8). A fragilidade conceitual do conceito de "agroecologia" é flagrada no trecho que atribui o que seria a designação do agronegócio à expressão "insustentabilidade desses agroecossistemas" (p. 9). O ordenamento territorial é ressaltado como estratégia para assegurar "usos ecológica, social e economicamente adequados aos recursos naturais renováveis" (MINTER, 1989, p. 1). A derivação inapropriada do conceito de agroecologia foi tão ineficiente quanto o foi o próprio POLONOROESTE, no que diz respeito ao ordenamento territorial e sustentável do território mato-grossense.

Nesses documentos já se apontava a preocupação em torno das pastagens cultivadas nos então $80 \%$ de área de floresta desmatada no estado, pastagens estas encapoeiradas e desativadas naquele momento. A derrubada de novas florestas, a queima e as novas pastagens já eram, em seu todo, o primeiro estágio das monoculturas que ali se estabeleceriam, em um processo de expansão de fronteiras iniciado 20 anos antes (MINTER, 1989, p. 6).

O posteriormente denominado Zoneamento 1a Aproximação, oficialmente chamado de Bases Geográficas para o Zoneamento Socioeconômico Ecológico, deu origem à Lei 5.993/92, a qual define a Política de Ordenamento Territorial do Estado de Mato Grosso e as ações para sua consolidação. No entanto, segundo a SEPLAN, a lei teve como base um zoneamento realizado apenas com dados secundários, não contemplando o estudo de aspectos socioeconômicos e uma base de dados de aspectos naturais suficientes para identificar potencialidades e fragilidades ambientais. $\mathrm{Na}$ sequência, foi elaborado $\mathrm{o}$ Zoneamento Socioeconômico Ecológico (ZSEE), 2 ${ }^{\text {a }}$ Aproximação, pautado pelos princípios da democratização e descentralização, sustentabilidade e qualidade de vida, equidade social, convergência e parcerias. 
Os estudos iniciais e as possibilidades para o zoneamento foram realizados por um conjunto de especialistas de vários temas, em trabalho com as instituições responsáveis, isto é, o estado representado por suas secretarias, coordenadas pela SEPLAN/MT conforme suas competências legais. Contemplavam-se no Diagnóstico Socioeconômico Ecológico de Mato Grosso (DSEE-MT) estudos em geologia, geomorfologia, solos, aptidão agrícola, recursos hídricos, uso da terra e vegetação, aspectos legais, climatologia, dinâmica econômica e demográfica, dentre outros. Nesse momento o FORMAD participou avaliando os componentes do zoneamento propostos para que houvesse condições técnicas para conversar com o estado (Figura 10). O estudo realizado estava razoável dentro das análises das organizações da rede ambientalista que o avaliaram. No entanto:

Por ter muitas restrições às atividades agrícolas, o governo não queria aprovar aquele zoneamento. Por esta razão, houve uma longa disputa com pouco sucesso para os ambientalistas. [O estudo] foi refeito sob o argumento que ele estava muito antigo e precisava ser atualizado. ${ }^{57}$

No ano de 2002, constitui-se a Comissão Estadual do ZSEE. A segunda aproximação do ZSEE foi encaminhada pelo Executivo à Assembleia Legislativa em 2004. Nas negociações, que se estabeleceram durante o governo de Blairo Maggi, em 2005, o governo estadual retira o projeto de lei da Assembleia, após críticas do setor produtivo, e contrata a EMBRAPA Solos para avaliar o ZSEE ${ }^{58} \mathrm{e}$ para fazer a análise técnico-conceitual do projeto.

57 Entrevista com Vicente Puhl, setembro de 2014.

58 Os bastidores das negociações entre os formuladores do zoneamento e o Poder Legislativo eram violentíssimos. Houve vários episódios de assédio moral e violência psicológica. As mulheres eram as mais atingidas. 
Figura 10. Participantes da validação do ZSEE, cartilha divulgada pelo governo do estado do Mato Grosso

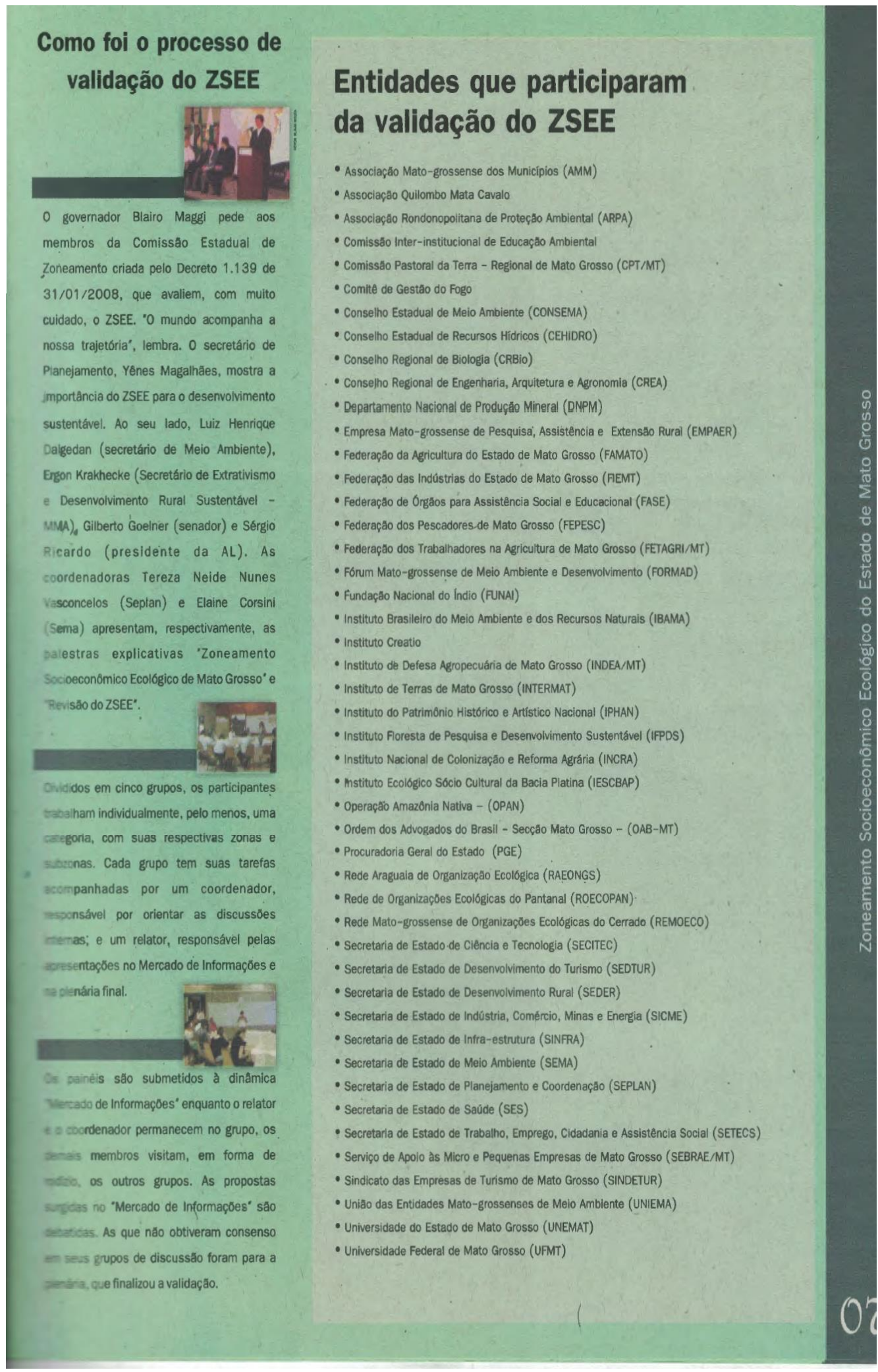

Fonte: Governo do Estado do Mato Grosso (2008). 
Já em 2007, o seminário realizado entre a Coordenação MMA - Consórcio ZEE Brasil (IBGE, Companhia de Pesquisa de Recursos Minerais - CPRM e EMBRAPA Solos) e a equipe SEMA/ SEPLAN para resolver as questões técnicas e encaminhar o projeto à Assembleia aprova o conteúdo do zoneamento em sua maioria, exceto pela FAMATO. Até março de 2008, o ZSEE é revisto pela SEPLAN e pela SEMA, sendo discutido com a sociedade por audiências e com a Comissão Estadual do ZSEE entre 2008 e 2009.

Após as revisões e discussões, a incorporação dos resultados dessas audiências se transformou em um substitutivo ao projeto do Executivo, semelhante ao projeto anteriormente encaminhado pelo relator Alexandre Cezar, o qual foi rejeitado pelos deputados membros da Comissão de Zoneamento da Assembleia Legislativa. Subitamente, surge o substitutivo 3 , com uma sequência de seis alterações, em um período de tempo recorde: uma semana (notemos que as revisões pela SEPLAN, SEMA e sociedade levaram meses de negociação para chegar a um substitutivo adequado à realidade mato-grossense). Não houve divulgação pública antes do encaminhamento para sanção do governo estadual.

Existiam, segundo o Instituto Centro Vida, três problemas principais na proposta de ZSEE encaminhada à sanção pela Assembleia Legislativa do MT: ela expandia as áreas de consolidação agropecuária sem consideração pelas restrições ambientais; permitia a regularização de desmatamentos recentes (até a data da publicação da lei); e eliminava a exigência de reserva legal em propriedades até 400 hectares. A escala do ZSEE realizada pelo governo do estado era de 1:1.500.000, diferente da concebida no PRODEAGRO, de 1:250.000. O parecer do procurador do estado foi contrário à aprovação.

Apesar dos problemas, o substitutivo 3 do ZSEE-MT foi aprovado em segunda votação, por 19 votos a 1, na sessão do dia 27 de outubro de 2010, na Assembleia Legislativa de Mato Grosso, sendo sancionado em abril de 2011 pelo então governador do Mato Grosso, Silval Barbosa, dando origem à Lei Estadual 9.523/11. 


\section{Figura 11. Cronologia do processo de ZEE no estado do Mato Grosso}

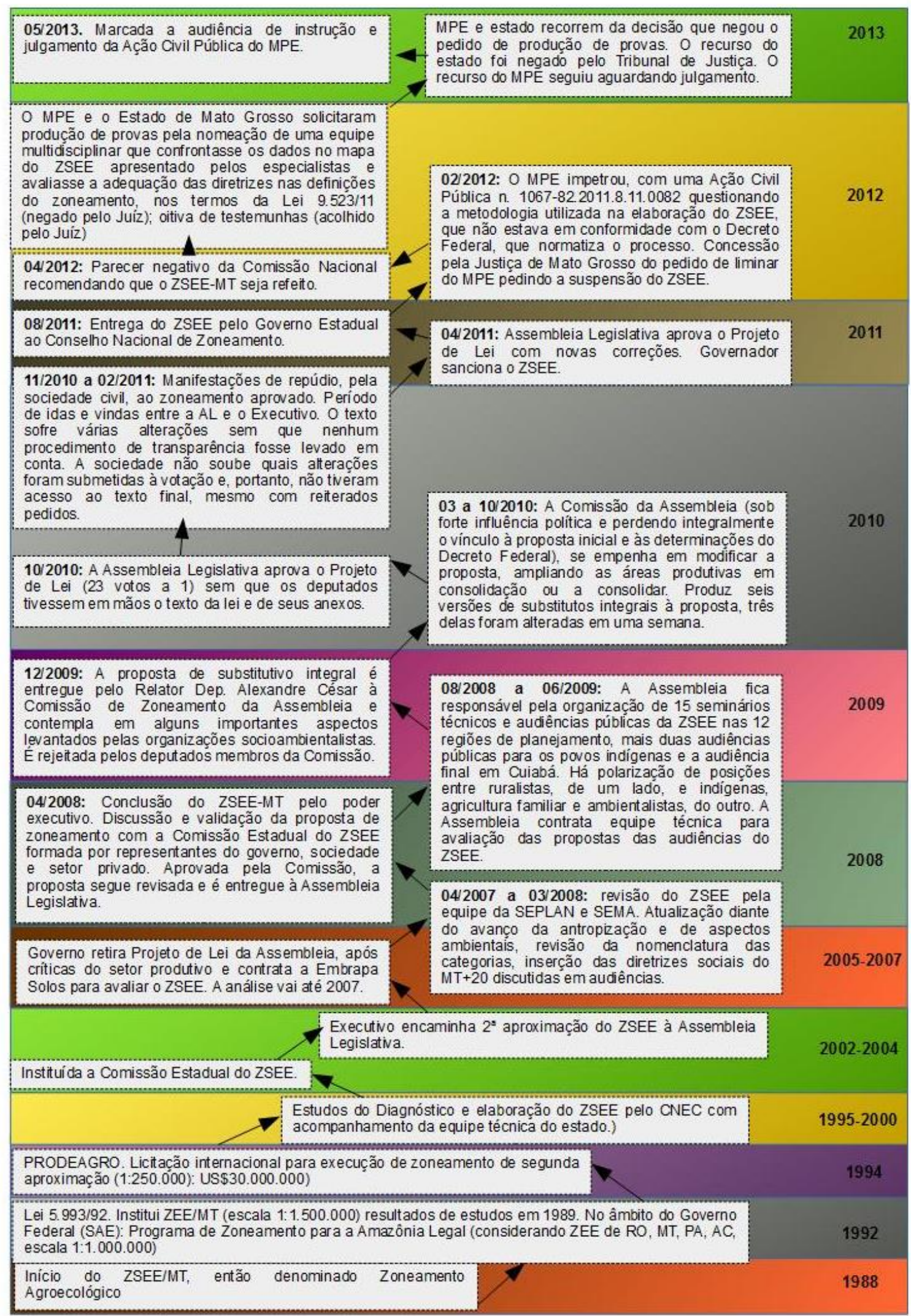

Fonte: Dados internos do FORMAD e SEPLAN. Elaboração própria. 
A Figura 11 sintetiza o processo de elaboração e aprovação do ZSEE matogrossense e evidencia os momentos nos quais os resultados das audiências e dos estudos de viabilidade foram bruscamente alterados por influência política. Não somente no FORMAD, mas também dentro da SEPLAN-MT, foram identificadas fortes repulsas à proposta de zoneamento elaborada no âmbito da Assembleia Legislativa.

Quase imediatamente, em maio de 2011,

Cerca de 250 pessoas, representando organizações que atuam com meio ambiente, indígenas, movimentos sociais, além de universidades e Ministério Público, participaram, na última sexta-feira (27), do seminário que avaliou e discutiu o Zoneamento Socioeconômico e Ecológico de Mato Grosso (ZSEE). O resultado foi a elaboração de uma Carta Pública que será enviada à Comissão Nacional de Zoneamento e ao Conselho Nacional de Meio Ambiente (CONAMA), em Brasília, cobrando providências no sentido de barrar o zoneamento elaborado pela Assembleia Legislativa e sancionado pelo governador Silval Barbosa. O documento marca a posição de descontentamento das organizações que consideram a proposta falha do ponto de vista jurídico, democrático, técnico e científico. (ICV, 2011a).

Em setembro de 2011, o Ministério Público do Estado de Mato Grosso propôs Ação Civil Pública, com pedido de liminar, em desfavor do estado de Mato Grosso, visando à suspensão dos efeitos de dispositivos da Lei Estadual 9.523/11, sob 0 argumento de que a referida lei encontrava-se viciada em sua forma e motivos.

Em outubro de 2011, uma comitiva mato-grossense formada por dez diferentes organizações da sociedade civil apresentou, em Brasília, os problemas no processo de criação, tramitação e aprovação do ZSEE/MT, relatando as suas principais implicações legais, sociais e ambientais. A apresentação provocou manifestações de preocupação com a lei mato-grossense, indicando a tendência do posicionamento da Comissão Nacional do Zoneamento (CNZEE), representada pelos Ministérios da Defesa, Agricultura, Pecuária e Abastecimento, Transporte, Justiça, Minas e Energia, Desenvolvimento Agrário e das Cidades (ICV, 2011b). O Ministério Público Estadual de Mato Grosso, nessa ocasião, indicou à CNZEE irregularidades, inconstitucionalidade e conflitos na lei aprovada, justificando a contestação dos seus efeitos práticos por meio da Ação Civil Pública protocolada na justiça de Mato Grosso. A comitiva também participou de uma reunião no Instituto Chico Mendes de Conservação da Biodiversidade (ICMBio), solicitando uma posição do órgão quanto ao fato de que 
a aprovação da lei faria crescer o desmatamento e ameaçar as Unidades de Conservação em Mato Grosso.

Paralelamente, foi feita, pelos ministérios que integram a Comissão Coordenadora do Zoneamento Ecológico-Econômico do Território Nacional (CCZEE), a análise do ZEE de Mato Grosso, em reunião realizada em março de 2012. Na ocasião, identificou-se que, para o reconhecimento do ZEE de Mato Grosso pelo Governo Federal, uma série de alterações e complementações necessitariam ser feitas, em atenção aos critérios estabelecidos nas Diretrizes Metodológicas para o Zoneamento Ecológico-Econômico do Brasil e também no Macrozoneamento Ecológico-Econômico da Amazônia Legal ${ }^{59}$. Um mês depois, em abril de 2012, a CCZEE se manifestou contrária à Lei 9.523/11. A recomendação foi de que o governo do estado procedesse à reformulação do ZSEE, atendendo às exigências apontadas.

No dia 16 de fevereiro de 2012, atendendo à Ação Civil Pública, foi concedida, pelo Juiz da Vara Especializada do Meio Ambiente da Comarca de Cuiabá, José Zuquim Nogueira, liminar suspendendo os efeitos da Lei Estadual 9.523/11, até julgamento definitivo do mérito da demanda.

\footnotetext{
É certo que, conforme demonstrado, aparentemente houve, de fato, os vícios de forma e motivo, capazes de viciar a lei, na qualidade de ato administrativo. No entanto, mais importante é que, se por razão destes vícios, houve comprometimento dos bens e serviços naturais e do desenvolvimento sustentável, logo, há o risco de comprometimento da vida humana. Este é, então, o argumento mais forte que, mais que permitir, impõe a concessão da medida liminar, na forma pleiteada pelo Ministério Público ${ }^{60}$
}

$\mathrm{Na}$ decisão liminar, reconheceram-se as graves consequências trazidas pela lei para a sustentabilidade da produção agrícola, dos processos ecológicos e dos serviços ambientais mantidos pelos diversos ecossistemas de Mato Grosso.

Em agosto de 2013 o Tribunal de Justiça de Mato Grosso determinou a realização de uma perícia no Zoneamento Socioeconômico e Ecológico do estado. A decisão foi tomada por unanimidade pela Quarta Câmara Cível que deu provimento ao recurso interposto pelo Ministério Público Estadual (MPE).

59 Decreto Federal 4.297/02, que orienta os zoneamentos no Brasil.

60 Diário de Justiça do Estado do Mato Grosso (DJMT) de 16 de fevereiro de 2012, p. 167. 
Nos mapas e registros do Ministério do Meio Ambiente, bem como na Secretaria Estadual de Meio Ambiente do Mato Grosso, entretanto, configura que - ZSEE do estado foi finalizado. No estágio atual, ainda há pendências de alterações necessárias para que o ZSEE do Mato Grosso atenda aos critérios estabelecidos pela CCZEE.

Com a Lei Federal 12.651/12, tornaram-se obrigatórios não somente o estabelecimento dos ZSEE estaduais segundo metodologia unificada, estabelecida pelo Governo Federal, mas também o Cadastro Ambiental Rural (CAR). A partir da implementação do CAR, a supressão de novas áreas de floresta ou de outras formas de vegetação nativa apenas será autorizada pelo órgão ambiental estadual integrante do SISNAMA se o imóvel estiver inserido no mencionado cadastro. Nesse quesito, notamos que, assim como o ZSEE mato-grossense, a conclusão do CAR tanto no Mato Grosso quanto em todos os demais estados da Federação (Gráfico 23) é procrastinada infinitamente pelos grandes proprietários, seguros de sua influência política para postergar os limites de prazo para a conclusão do cadastro nos estados.

A elaboração do ZSEE do Mato Grosso jamais foi um consenso entre as diversas classes sociais que compunham as organizações da sociedade civil, a sociedade política que fazia a mediação entre esta e o estado e o próprio estado. Os conflitos de interesse e as hegemonias se expressaram aí tão fortemente quanto a voracidade da expansão dos limites agrícolas que por essas épocas se consolidavam.

A principal crítica feita pelos membros da rede FORMAD foi a postura do governo estadual, que ignorou as demandas das organizações (participantes e responsáveis pela avaliação de aspectos técnicos) e do Ministério Público (apoio político e jurídico), os quais acompanharam o processo de construção do zoneamento e se manifestaram em relação aos problemas, deixando-os de fora do processo.

O ZSEE representa uma instrumentalização à qual todas as outras leis relativas à questão ambiental estariam submetidas. É por essa razão também que vários dos eixos de ação da rede ambientalista que consolida o FORMAD convergem para o zoneamento. $O$ direcionamento das atividades e do uso dos recursos disciplina o ordenamento. A restrição do Código Florestal poderia dar 
suporte à discussão da elaboração do zoneamento. Ambas são temáticas amplas, sob as quais a movimentação estratégica das redes ambientalistas para intervenção se dá de forma menos ágil que a da sociedade política que move o processo.

\section{Gráfico 23. Imóveis rurais cadastrados (\%) no Cadastro Ambiental Rural (CAR) até 31.03.2017}

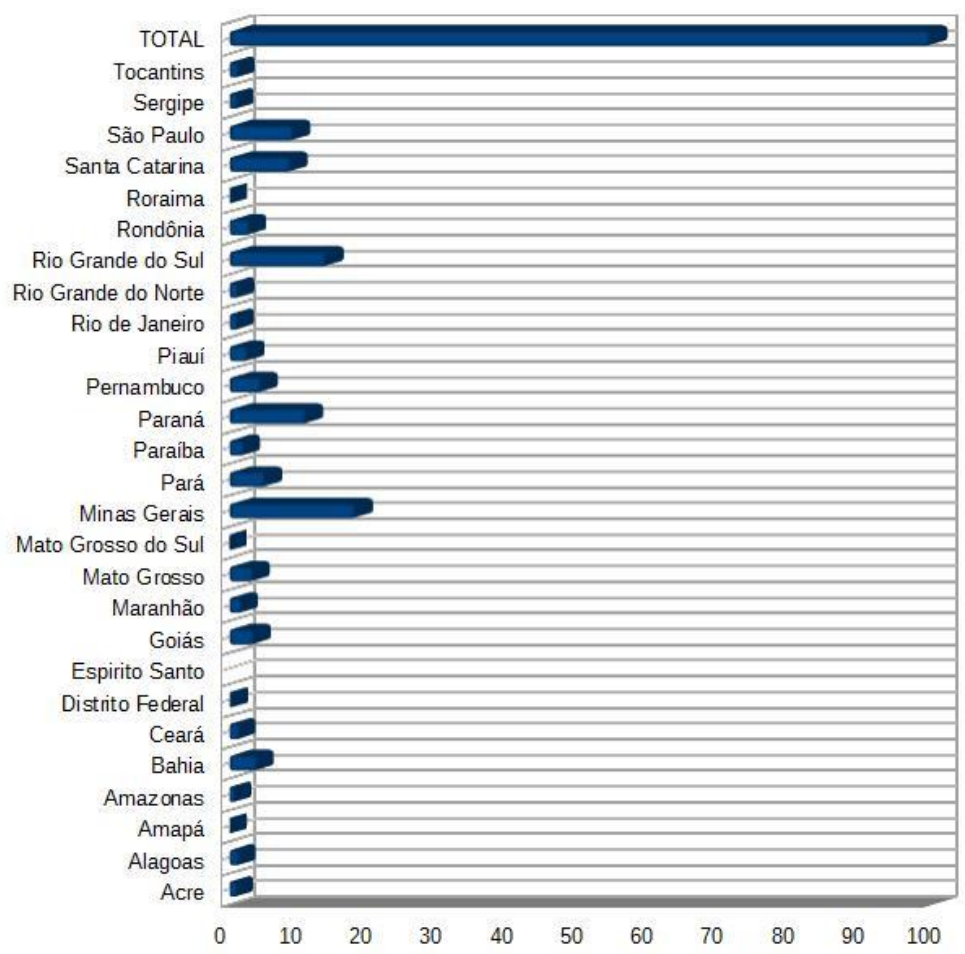

Fonte: Serviço Florestal Brasileiro (2017).

Neste ponto, a revisão e produção de um novo zoneamento repercute na composição de uma comissão de acompanhamento de todo o processo, como definido em Decreto. A SEPLAN elaborou uma minuta que seguiu do setor jurídico para a Procuradoria do Estado. A questão ficou parada até o final de março de 2016, quando se lançou o edital para conformação da comissão61. A ação judicial será retirada mediante a produção de novo ZSEE, seguindo as diretrizes do Decreto Federal 4.297/02.

61 O edital de formação da Comissão foi identificado, por acaso e um dia após sua publicação, pela própria pesquisadora, em trabalho de campo na SEPLAN. 
As organizações ambientalistas do FORMAD vêm apontando a importância de uma comissão estadual capacitada a discutir questões técnicas com instâncias como a FAMATO, que dispõe de grande prestígio político e influência decisória. Portanto, o fortalecimento da participação deveria ser técnico e político, de forma a repercutir mais que as audiências públicas, importantes, porém meramente consultivas, já que as propostas podem ser absorvidas ou não pelos tomadores de decisão.

A questão do zoneamento na Amazônia e a expectativa de integração entre - Macrozoneamento Ecológico Econômico (MacroZEE) e os ZEE estaduais mostraram-se difusas tanto no âmbito do PPG7 quanto na condução desses processos internamente nos estados, tendo em conta a diversidade dos seus respectivos atores e interesses. No primeiro, destacavam-se os múltiplos entendimentos dos doadores externos e do Governo Federal. Isso posto, a participação de doadores de recursos externos não é vista como proveitosa, já que dificulta a já complexa negociação interna brasileira sobre os objetivos de desenvolvimento sustentável ${ }^{62}$. Nos estados, destacam-se os embates entre os grupos sociais, seus representantes e as instâncias governamentais estaduais envolvidas.

Em termos de interlocução entre sociedade civil e Estado e a influência de cada ator nas dinâmicas territoriais estaduais, o papel de negociação não se limita à descentralização das responsabilidades às organizações ambientalistas segundo a agenda governamental - nomeada como monitoramento ou validação da sociedade civil, dentre outros termos - e, sim, à descentralização das decisões, nesse caso, entre Estado e organizações.

Se temos em conta a estrutura decisória política brasileira, é na profusão da confusão conceitual com que foram tratados problemas estruturais ao longo de negociações relativas aos ZEE estaduais que reside o dilema irresoluto da relação entre sociedade e Estado e os protagonistas nas dinâmicas territoriais. Estas se alteraram segundo interesses de um pequeno grupo de atores hegemônicos, notadamente as elites agrárias, com a consequência do aumento do processo do desmatamento, da violência a etnias indígenas e outras minorias e de diversos outros impactos socioambientais. 


\subsection{Novas amplitudes: escalas de influência das redes ambientalistas amazônicas, sua relação com o território e com as instituições governamentais}

Um dos grandes momentos de conexão entre as redes que se conformaram na Amazônia (GTA, FORMAD e outras) foi o debate sobre o monitoramento, os programas e projetos que envolviam o Plano BR-163 Sustentável, coordenados com o Ministério da Integração e o Ministério do Meio Ambiente, sendo que o segundo permitia uma maior abertura às negociações. Entrando nas discussões ambientais somente quando uma organização-membro estudasse especificamente o tema a ser tratado, o FORMAD passou a adotar a estratégia de delinear eixos de atuação que, apesar de contarem com um quadro de recursos humanos restrito, permitiam estabelecer uma agenda de temas e prioridades pautados no know how das organizações. Cada instituição dispunha de dados próprios, produzindo contra-argumentações políticas e mostrando os impactos dos projetos ${ }^{63}$.

O Projeto de Fortalecimento da Participação Social no Plano BR-163 (PROFOR) foi elaborado pelo Consórcio de Desenvolvimento Socioambiental (CONDESSA) para acompanhar a implementação das ações do plano nos estados de Mato Grosso e Pará. Foi financiado pelo Fundo Fiduciário das Florestas Tropicais (RFT) do Programa Piloto para a Proteção das Florestas Tropicais do Brasil (PPG7) e administrado pelo Banco Mundial, com execução da rede Grupo de Trabalho Amazônico (GTA) e do CONDESSA. Um dos principais objetivos do PROFOR 163 era estimular a discussão sobre a pavimentação da BR-163 por meio das lideranças locais dos municípios da área de influência da rodovia no entendimento da conjuntura regional e das ações do Plano BR-163 Sustentável. Este plano é uma experiência com base no Plano Amazônia Sustentável (PAS), com orçamento do Plano Plurianual (PPA) 2004-2007 e em relação com o PPCDAM. Pese a falta de regularização fundiária ao longo da estrada, o investimento de mais de $\mathrm{R} \$ 1$ bilhão para a pavimentação da BR-163 deveria abranger uma área de $974.000 \mathrm{~km}^{2}$, dos quais mais de metade seriam localizados

63 Entrevista com Vicente Puhl, setembro de 2014. 
no estado do Pará, um terço no Estado de Mato Grosso e apenas 15\% no estado do Amazonas.

Promovendo a informação dessas lideranças sobre aspectos técnicos do plano, o objetivo do PROFOR 163 era envolver suas bases de modo a fomentar a participação, o monitoramento e a influência no processo de implementação das obras, em especial a pavimentação da BR-163, bem como nas demais políticas públicas na região de abrangência do plano (MELLO et al, 2006).

Para tanto, foram criados cinco polos do projeto: dois em Mato Grosso (Cuiabá e adjacências e "nortão" de Mato Grosso) e três no Pará (Itaituba e adjacências, Transamazônica/Xingu e Baixo Amazonas). A abertura de novas áreas agricultáveis, destinadas à produção de grãos e silvicultura, era prevista como consequência da pavimentação, fato que, apesar de interessante para os grandes produtores agrícolas, abria as frentes de desmatamento e, portanto, os impactos socioambientais.

A transparência e a viabilidade de participação nos processos decisórios de políticas públicas, não podendo ser diferente nas políticas de ordenamento territorial e gestão ambiental, não ocorrem se não há uma vontade política e uma estruturação institucional que as viabilizem. No entanto, quando os interesses são difusos e não há claridade sobre as atribuições do Estado frente à forma como se estabelecem as relações de mercado (enfraquecimento institucional do Estado), as possibilidades de que as políticas públicas sejam pensadas pela sociedade e viabilizadas pelo Estado se veem diminuídas. Mesmo quando mencionamos o papel da sociedade enquanto propositora, temos dificuldades em avaliar até que ponto as informações necessárias para a mobilização social foram difundidas, como foram difundidas, sua idoneidade e a capacidade da sociedade em decodificar essas referências e submetê-las à análise.

Em um determinado momento da atuação das redes mato-grossenses, passam a fazer parte da pauta de discussão aspectos político-ambientais que se refletem na dinâmica não somente interestadual, mas também na nacional e internacional. O estabelecimento de vínculo com outras malhas de organizações ambientalistas da Amazônia Legal evidenciou necessidades de planejamento comuns. O principal, que se estabeleceu no âmbito do FORMAD, foi, no contexto do Plano BR-163 Sustentável, com a rede que conformava o GTA (Figura 12). 
Figura 12. Mapa de relações entre as redes GTA e FORMAD

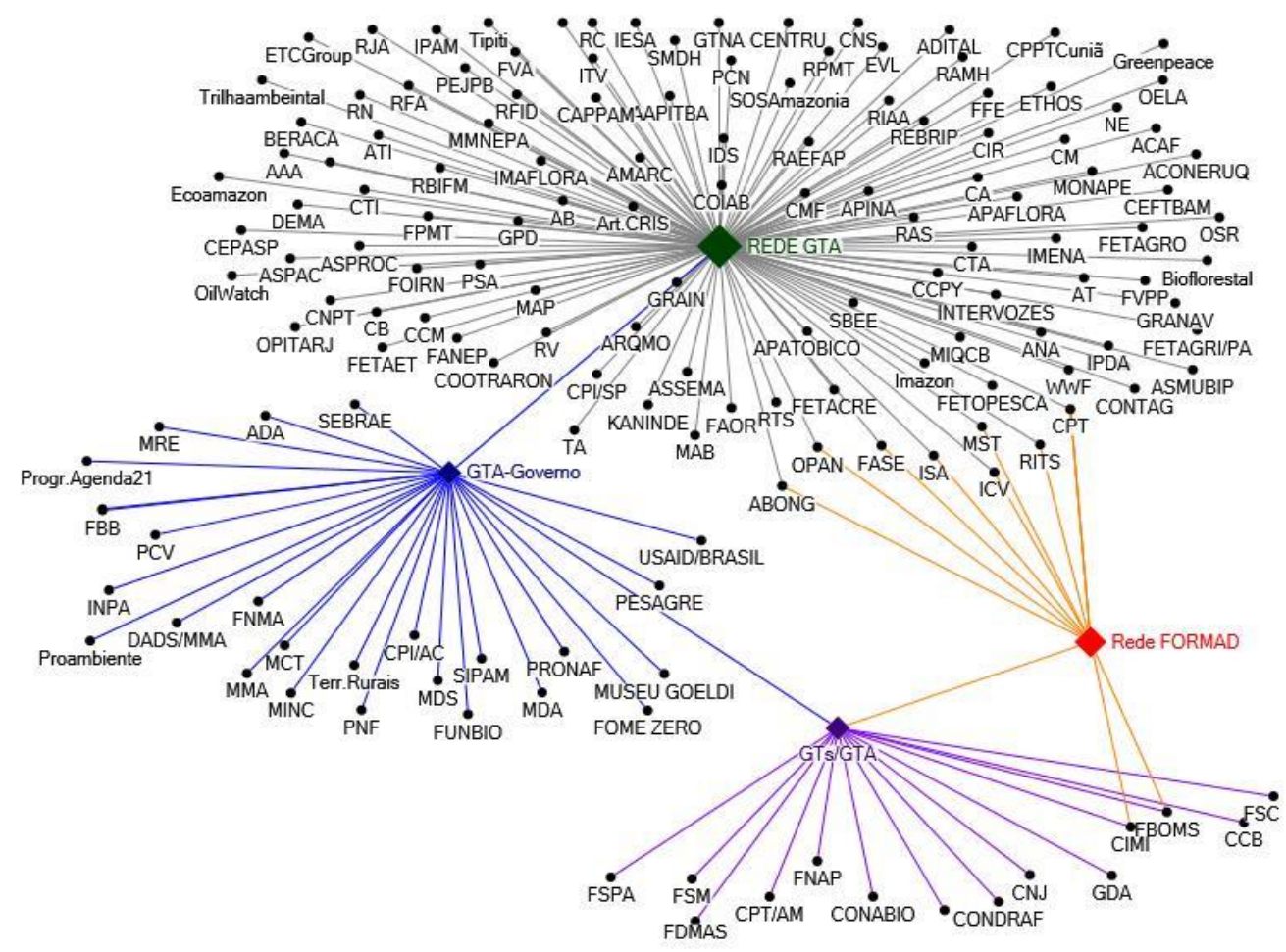

Fonte: GTA, FORMAD. Elaboração própria.

O esquema desta representação permite detectar os nós relacionais pertinentes à abrangência espacial da rede FORMAD, apresentada no Capítulo 3. O GTA, no transcorrer do processo do zoneamento, lidava com uma ampla gama de atores governamentais, empresariais e da sociedade civil. A relação com esta última é majoritária entre as teias relacionais, o que viabilizou negociações entre essa diversidade nas arenas decisórias.

Formalmente as instituições que compunham o FORMAD e o GTA trabalhavam eventualmente em mais de uma área temática, sendo que o GTA era mais amplo e contava com uma maior rede de membros distribuída por toda a Amazônia Legal. Entretanto, a ideia de ambas as redes era de que todas as instituições vinculadas perpassassem os temas, ainda que cada uma com sua individualidade institucional e de financiamento, fazendo transitar a informação. Ao GTA (que possuía representações regionais em cada estado amazônico) cabia 
monitorar tecnicamente os aspectos de dinâmica física e socioambiental dos 53\% da área de sua influência, correspondente à abrangência do bioma amazônico. 0 FORMAD se centrava nos $47 \%$ correspondentes à abrangência do bioma Cerrado ${ }^{64}$.

Tanto o GTA quanto o FORMAD tinham como centro do debate o modelo de desenvolvimento e o ordenamento amazônico. Ambos se sobrepunham em algumas escalas cartográficas na sua área de influência e, no estado do Mato Grosso, compartilhavam a mesma sede administrativa.

Assim, enquanto escala dos fenômenos estudados, as correspondentes coordenações do GTA e do FORMAD eventualmente compartilhavam dos mesmos objetos de análise, sobretudo no que diz respeito a grupos representados em comum, como ribeirinhos, comunidades indígenas, agricultores familiares, quilombolas, dentre outros.

\subsection{O Zoneamento Ecológico-Econômico no Plano BR-163 Sustentável}

O Plano de Desenvolvimento Regional Sustentável da área de influência da rodovia Cuiabá-Santarém (BR-163) foi realizado em parceria com os governos dos estados do Mato Grosso, Pará e Amazonas. A ação do Governo Federal (que incluía 68 municípios) estava prevista dentro do Programa Plurianual de Ação (PPA) 2004-2007. Este e os demais PPAs subsequentes incluíam investimentos em diversas frentes de infraestrutura, visando diminuir os custos de produção e de comercialização dos produtos e estimulando investimentos privados. Seguiu as diretrizes do Plano Amazônia Sustentável (PAS) e foi desenvolvido por um Grupo de Trabalho Interministerial, sob a coordenação da Casa Civil da Presidência da República.

Mello (2006, p. 6-7) aponta as marcas deixadas na paisagem amazônica pela colonização a partir da década de 1970 com o Programa de Integração Nacional. Mato Grosso se tornou o estado da Amazônia Legal com a maior diversidade de formas de ocupação. Nas proximidades da BR-163, surgiram grandes projetos de colonização públicos e privados, realizados em parceria ou 
espontâneos. Os pioneiros do desmatamento em larga escala no centro de Mato Grosso foram grandes empresas que compraram as centenas de hectares para implementar projetos de assentamento dentro de cinco anos. Outras empresas compraram terras ao longo da BR para implantar projetos pecuários. Esse panorama colaborou para o cenário atual de concentração de terras e de fomento à agroindústria e ao desmatamento, como reportado pelas imagens do satélite Landsat de 1992 e 1999, as quais indicam um desmatamento na região central do Estado de Mato Grosso de mais de $9000 \mathrm{~km}^{2}$, dos quais mais de metade é concentrada em Nova Ubiratã, Tapurah e Sorriso.

Ademais, apesar de, em âmbito mato-grossense, o processo de ZSEE estadual estar em pleno impasse, o eixo estruturante da pavimentação da BR-163 previa a inclusão social e a conservação dos recursos naturais, mediante a participação de prefeituras, entidades empresariais e dos trabalhadores e organizações da sociedade civil. Os grandes eixos de integração tinham, tanto nesse momento quanto nas ações derivadas do PAC, uma finalidade distinta às propostas de integração entre 1930 e 1980, já que não se limitavam a "colonizar" regiões remotas do País para a proteção de fronteiras, mas sim para a abertura econômica, baseada na exportação de produtos primários (PIGNATTI, 2005; GONÇALVES, 2001).

Sobre a elaboração e implementação tanto do ZSEE mato-grossense quanto do zoneamento da BR-163, cabe a análise de Mello e Théry (2001) sobre as iniciativas mais eficientes em vista ao crescimento econômico, baseadas na ação do Estado. Sendo um dos instrumentos do Estado a organização territorial, também o processo de pavimentação da BR-163 e o de zoneamento da área de influência atendem, mediante políticas de infraestrutura em transportes, energia e comunicações, às demandas da expansão no modelo econômico neoliberal.

(...) a perspectiva da sua pavimentação tem sido longamente reclamada por populações que hoje vivem em sua área de influência, que dela necessitam para o escoamento dos seus produtos e para a atenção às suas demandas de assistência básica. Mais recentemente, a pavimentação da BR-163 se tornou uma reivindicação de grandes produtores de soja do norte de Mato Grosso, que buscam a diminuição dos custos de frete, associados à utilização dos portos de Miritituba e de Santarém (PA). Outro setor da economia com interesse na pavimentação da rodovia é a Zona Franca de Manaus, que será beneficiada pela diminuição dos custos de transporte de seus produtos para o sul do Brasil. Trata-se, portanto, de reduzir o tempo e custos de transporte para dois 
setores econômicos significativos: a soja, de importância nacional para o balanço de pagamentos, e os produtos da Zona Franca, de importância para a economia regional. (CASA CIVIL, 2004, p. 4).

Mello e Théry (2001) também discutem a forma como se espacializam essas iniciativas infraestruturais na Amazônia. Conformando-se como linhas de força no território, ampliam o peso das cidades como pontos estratégicos (p. 185). Como adendo, analisamos aqui que, nessa espacialização, tais iniciativas convergem a malha das redes, sejam fisicamente distinguíveis, sejam abstratas, como relações de poder entre atores e agentes para uma finalidade em comum.

As políticas ambientais, dispersas pelo território (MELLO E THÉRY, 2001, p. 185), não são distribuídas ao acaso. A posição das iniciativas pode reforçar e reproduzir as desigualdades. As ações voltadas ao apoio à iniciativa privada, às populações carentes e aos rumos da futura expansão distribuem-se no território segundo uma finalidade específica, não aleatoriamente, visando tanto 0 crescimento econômico como a manutenção das desigualdades. Distinguem-se tipologias de ordenamento territorial de "ação produtiva", a "ação social" e a "ação pioneira" (MELLO E THÉRY, 2001).

Assim como outros programas e planos realizados na Amazônia, o Plano BR-163 Sustentável seguia um traço comum a todos: embora distintos entre si, guardam a semelhança da delimitação de um perímetro definido para a sua área de atuação, onde se "exercia a jurisdição do organismo encarregado de levá-los adiante" (MELLO E THÉRY, 2001, p. 188).

A gestão do Plano BR-163 Sustentável incluía: bases de dados georreferenciadas sobre características biofísicas do território (solos, vegetação, hidrografia, unidades de paisagem, entre outras); dinâmicas de ocupação territorial e utilização dos recursos naturais (situação fundiária, população, desmatamento e queimadas, atividades produtivas, entre outros); indicadores de desenvolvimento sustentável, relacionados aos objetivos e metas do Plano BR-163 Sustentável; e informações espacializadas sobre as atividades planejadas e indicadores de resultados do plano. Em termos gerais, o zoneamento era apenas uma viabilização das frentes de expansão e exploração florestal que já existiam, como se nota na Figura 14. 
Figura 13. Área de influência da BR-163 no estado de Mato Grosso
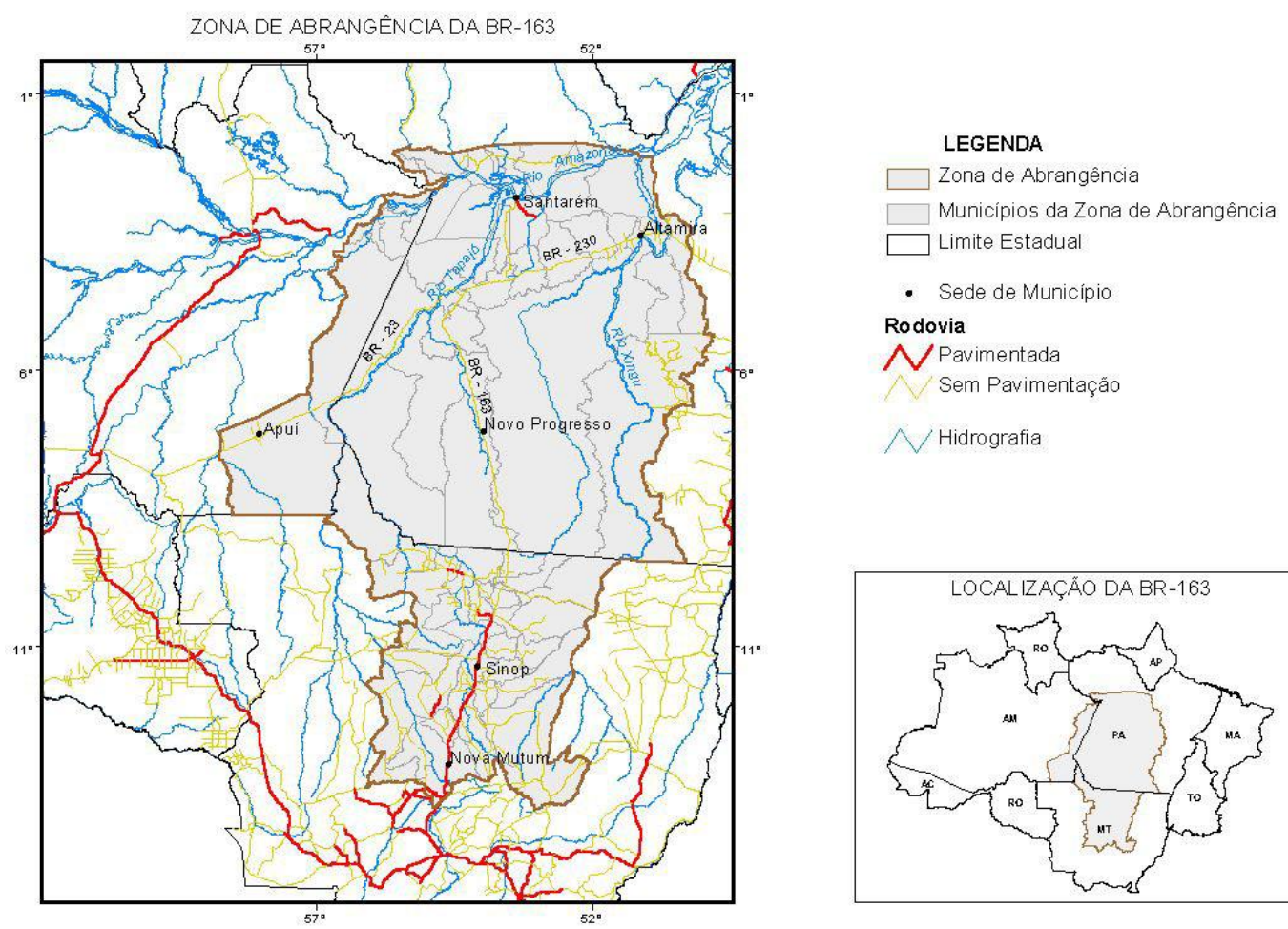

Fonte: Ministério do Meio Ambiente (2004).

As obras, estimadas em $\mathrm{R} \$ 760$ milhões, seriam realizadas em parceria com a iniciativa privada, entre as quais trades agrícolas como a Amaggi, Bunge e Cargill e empresas da Zona Franca de Manaus, e com recursos do Banco Nacional de Desenvolvimento Econômico e Social (BNDES). Por outro lado, o Plano BR-163 Sustentável também incluía a atividade de um observatório para o qual as organizações da sociedade civil eram chamadas a participar de seu planejamento, execução e monitoramento. Dessa forma, participando simultaneamente dos processos de consolidação tanto do Zoneamento Socioeconômico e Ecológico quanto do Plano BR-163 Sustentável, as organizações que compunham o FORMAD conformavam novas amplitudes de atuação, o que representava também uma nova escala de sua institucionalidade participativa. 
Figura 14. Zoneamento da área de influência da BR-163 por categoria de uso e frentes de exploração florestal

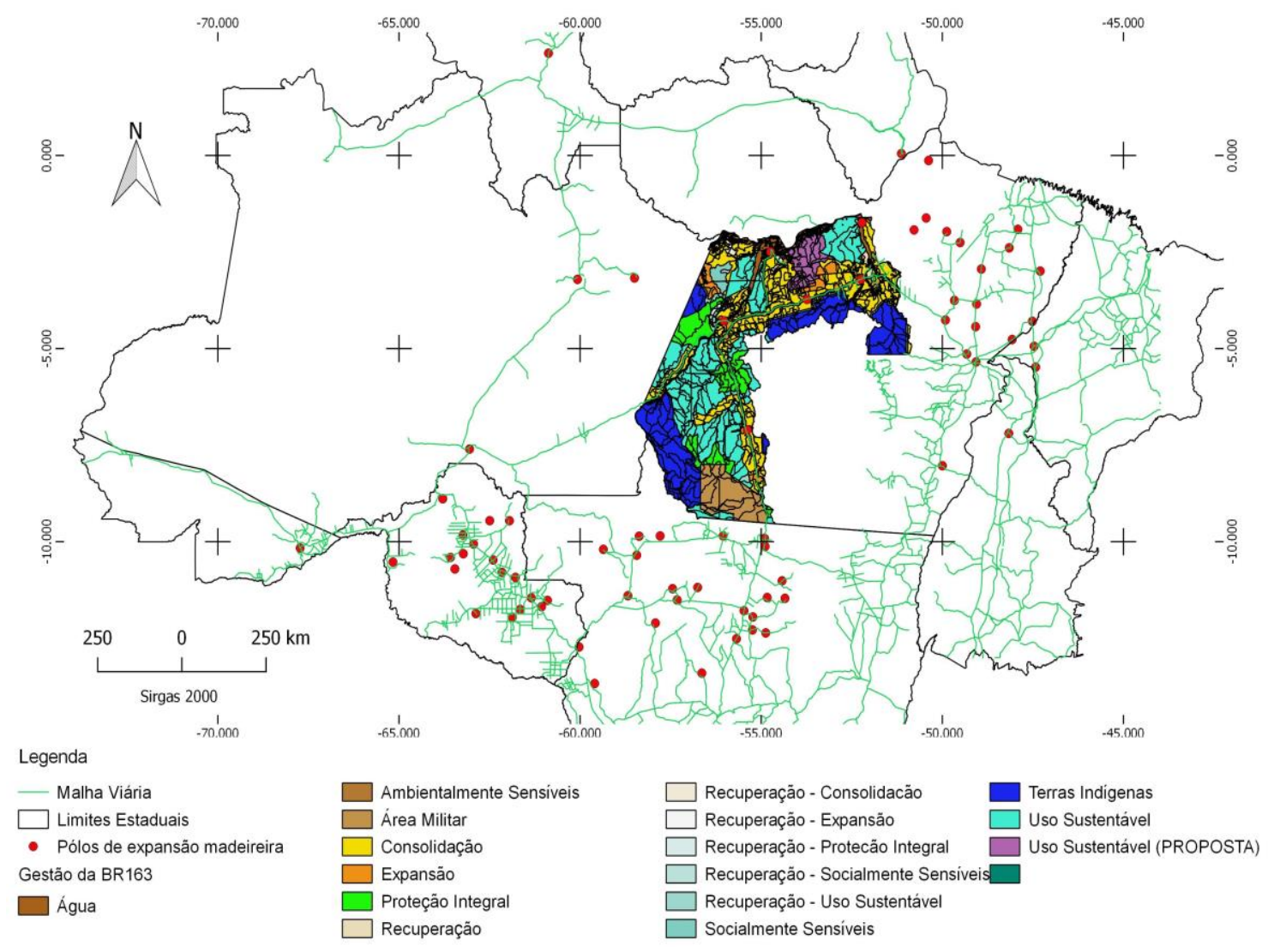

Fonte: MMA (2015); ISA (1999).

A conformação em redes, quando em análises ou deliberações sobre planos voltados à gestão ambiental, fortalece as demandas em relação às políticas, tanto em termos de argumentação, visto que a contratação de informações por esse tipo de colaboração é mais eficiente, quanto em termos de força institucional. No caso do Plano BR-163 Sustentável, o Encontro BR-163 Sustentável se deu por organização do Instituto Socioambiental (ISA) em parceria com o Fórum Mato-grossense de Meio Ambiente e Desenvolvimento (FORMAD), o Instituto Centro de Vida (ICV), a Universidade Estadual do Mato Grosso (UNEMAT), o Instituto de Pesquisa Ambiental da Amazônia (IPAM), a WWF-Brasil, a The Nature Conservancy (TNC) e a Conservation International (Cl), com o apoio do Grupo Agroflorestal de Proteção Ambiental (GAPA), do Greenpeace, da Fundação Viver, Produzir e Preservar (FVPP), do Sindicato dos Trabalhadores 
Rurais de Água Boa, da ONG Roncador-Araguaia, da Associação Terra Indígena Xingu (ATIX), do Grupo de Trabalho Amazônico (GTA), da Rainforest Foundation US, da Norwegian Rainforest Foundation, da Rainforest Action Network, da International Communications Consultancy Organization (ICCO), da União Europeia, da Moore Foundation e da Environmental Defense (EDF). No referido encontro, realizado na UNEMAT de Sinop (MT), estavam cerca de 230 participantes, entre os quais representantes do poder público e de organizações não governamentais, lideranças indígenas e pesquisadores (ISA, 2003).

No contexto político e econômico do estado em 2004, a consolidação da BR-163 foi impulsionada durante o governo de Blairo Maggi, já que o Mato Grosso despontava como o principal produtor do grão do País (tendo como referência a safra 2001/2002, que totalizou 12,6 milhões de toneladas, mais de $10 \%$ da safra nacional, dos quais $59 \%$ foi destinado à exportação). As principais trades agrícolas também possuíam, já nesse momento, unidades de recebimento, secagem e armazenagem de grãos em diversos municípios do estado. Por outro lado, a intensa produção de soja já avançava pelas imediações do Parque Indígena do Xingu (PIX), onde cerca de 100 projetos agropecuários instalados com incentivos fiscais da Superintendência do Desenvolvimento da Amazônia (SUDAM) passaram a sentir os efeitos do seu intenso e pouco regulado uso de defensivos agrícolas e fertilizantes, levando à contaminação das nascentes da Bacia do Xingu, por exemplo. As reivindicações foram encaminhadas ao Governo Federal em março de 2004, após a sistematização do conjunto de propostas, incluindo as que foram levantadas em relação ao eixo paraense durante um encontro realizado em dezembro de 2003, em Santarém (PA), que resultou na Carta de Santarém, importante marco nas negociações com o governo e que, dado seu grau de mobilização de organizações e redes, teve influência nos desdobramentos da participação de tais organizações nos anos subsequentes. Nesse documento estão refletidas as propostas do Plano de Desenvolvimento Territorial Integrado e Sustentável da Região de Influência da BR-163, que abrange 84 municípios dos estados do Pará e do Mato Grosso e envolve aproximadamente 2 milhões de habitantes.

Apesar das mobilizações promovidas não somente pelo FORMAD, mas também pelo GTA, as negociações sobre a duplicação da rodovia, ainda inconclusa, 
seguiram sem que nenhuma das ações emergenciais do plano governamental tivesse sido executada ${ }^{65}$. Isso se deve tanto pelo caráter instrumental do planejamento, abordado no Capítulo 2, quanto pela fragilidade da institucionalidade ambiental (Capítulo 1). Para Deroní Mendes, secretária-executiva do FORMAD ao longo do período das discussões da BR-163, a celeridade no andamento das obras de pavimentação, principalmente, residia na importância de sua conclusão para o escoamento de grãos e consequentemente para o crescimento econômico do estado, que poderá se tornar o maior exportador de grãos do Brasil e do mundo. Para a secretária, o Plano BR-163 Sustentável se transformou em apenas uma importante obra do PAC, como tantas outras. $O$ diálogo com a sociedade civil teria servido apenas para acalmar os ânimos.

Assim, após todos os esforços de mobilização e negociação por parte das organizações envolvidas, a proposta de construção de um plano de desenvolvimento regional sustentável para a área de influência da Rodovia BR-163 Cuiabá-Santarém sucumbiu à agenda governamental relativa à ampliação dos projetos infraestruturais.

Quanto ao ZSEE estadual, sua falta de conclusão gera um panorama favorável aos grandes produtores, já que, uma vez que existe a interdependência entre esse zoneamento e a aplicação do Código Florestal para fiscalização de novos desmatamentos, a incerteza dessas normativas inter-relacionadas permite que novos desmatamentos surjam, sem mecanismos estabelecidos de punição.

Esse intenso período de discussões sobre o ZSEE estadual e sobre o ZEE da BR-163 perpassou grande parte da história do FORMAD. Foi a partir dessas experiências que a rede conseguiu coesão suficiente para elevar-se como uma das maiores vozes estaduais em prol do ambiente. A conjunção dos laços de solidariedade com o alto grau de competência técnica conseguido pela rede tornoua apta a elaborar um plano estadual de sustentabilidade, análogo ao Plano Brasil Sustentável: o Projeto Mato Grosso Sustentável e Democrático. Nesse projeto, tratado no Capítulo 5, a rede ambientalista FORMAD reuniu todos os elementos

65 Agradeço a colaboração de Neli Aparecida ao atentar-me para esta questão e à Deroní, que colaborou não apenas em conversas sobre o tema, mas também com o material que deixou registrado sobre o asfaltamento da BR-163 em blogs, narrando suas experiências diárias com o tema. 
que a tornariam um importante jogador político nas transformações territoriais, pertinentes ao ambiente. 


\section{CAPÍTULO 5 - PROJETO MATO GROSSO SUSTENTÁVEL: ASPECTOS SOCIOAMBIENTAIS E POSSIBILIDADES DE INFLUÊNCIA DAS DECISÕES}

\section{AMBIENTAIS}

O conturbado transcurso do ZSEE no Mato Grosso marcou um período de aprofundamento da participação social no estado e o reconhecimento de suas limitações até então. As organizações ambientalistas que eram, direta ou indiretamente, vinculadas ao FORMAD passaram a ter maior clareza das regras do jogo político e das forças que sobre ele atuavam. Por essa razão, o delineamento de táticas de influência sobre as estratégias políticas passou a outro patamar de concepção.

Com isso, os nós concernentes às redes ambientalistas encontraram maiores possibilidades de exercer seus papéis como stakeholders nas políticas ambientais referentes aos eixos temáticos do fórum com maior eficiência e eficácia. A dinâmica de cooperações entre as organizações ambientais abriu um novo momento de participação após a CNUMAD de 2002, marcado por propostas estaduais que replicavam localmente princípios incorporados na concepção de iniciativas federais - como o Programa Amazônia Sustentável (PAS) -, a exemplo do aqui tratado Projeto Mato Grosso Sustentável e Democrático (MTSD). O PAS ${ }^{66}$ foi elaborado a partir do Termo de Cooperação, firmado em 2003 entre o então Presidente da República, Luiz Inácio "Lula" da Silva, e os governadores dos estados da região, de um diagnóstico abrangente e de consultas públicas com mais de cinco mil representantes (BRASIL, 2008). A expectativa do MTDS era uma maior interação nas tomadas de decisão orçamentárias nos PPAs, mas também a pressão ao Governo Federal para fazer valer suas demandas regionais.

66 O PAS incluía metas como promover a sustentabilidade, valorizando a diversidade sociocultural e ecológica; reduzir as desigualdades regionais; ampliar a presença do Estado, com a integração das ações dos três níveis de governo, da sociedade civil e dos setores empresariais; fortalecer os fóruns de diálogo intergovernamentais e esferas de governos estaduais para maior integração regional; garantir a integridade territorial, os interesses e a soberania nacionais, sem perder de vista a integração do Brasil com os países sul-americanos, fortalecendo a OTCA e o Foro Consultivo de Municípios, Estados, Províncias e Departamentos do Mercosul; combater o desmatamento ilegal e garantir a conservação da biodiversidade e dos recursos hídricos, e mitigar as mudanças climáticas; implementar o Zoneamento Ecológico-Econômico e acelerar a regularização fundiária; assegurar os direitos territoriais dos povos indígenas e das comunidades tradicionais e promover a equidade social; ampliar o crédito e o apoio para atividades e cadeias produtivas sustentáveis e serviços ambientais; apoiar a pesquisa científica e a inovação tecnológica; ampliar e modernizar o sistema multimodal de transportes, o sistema de comunicação, a estrutura de abastecimento e as potencialidades energéticas e a expansão, garantindo o acesso das populações locais. 
Este capítulo avalia a incidência dos múltiplos atores participantes e as posições dos tomadores de decisão. Iniciamos tratando de como as propostas de sustentabilidade desenhadas no Projeto Mato Grosso Sustentável pelas redes ambientalistas refletem uma maturidade científica sobre as vulnerabilidades e potencialidades socioambientais. Em seguida, avaliamos se o governo estadual evoluiu da mesma forma em termos de qualidade técnica e científica, e se houve sinergia entre ambas as vertentes. Considerando o distanciamento já apontado no Capítulo 2 entre as concepções procedimentais da política ambiental, bifurcada entre organizações ambientalistas e governos, partimos do princípio de que houve baixa influência sobre a agenda de planejamento territorial em vista da sustentabilidade socioambiental, apesar da alta qualidade técnica e científica alcançada pelas redes ambientalistas.

\subsection{Uma proposta em parceria com um projeto nacional}

O Projeto Mato Grosso Sustentável e Democrático (MTSD) propôs consolidar uma articulação interinstitucional que, a partir de uma leitura crítica conjuntural, incidisse na dinâmica socioeconômica, ambiental, cultural e política do estado de Mato Grosso. Com isso, esperava-se um aprofundamento democrático por uma maior participação social, com ações baseadas em propostas difundidas pela literatura especializada no tema de sustentabilidade ecológica e sociocultural para a sociedade mato-grossense.

O projeto foi formulado, desenvolvido e coordenado por iniciativa do FORMAD e da UNEMAT entre os anos 2006 e 2008, e contou com a consultoria dos pesquisadores e coordenadores do Projeto Brasil Sustentável e Democrático, estabelecido em 1996 pelo Governo Federal. Nesse momento a rede contava com 38 organizações socioambientais filiadas no estado de Mato Grosso. Distribuídas em dez grupos temáticos, participaram 21 dessas organizações.

Com uma trajetória de já 16 anos naquela ocasião, a rede já havia passado por aprendizados em mesas de negociação no PRODEAGRO, no ZSEE, no Plano BR-163 Sustentável e, relacionada a este, na discussão sobre o PPA 2004-2007. Isso significa que ela já havia passado de uma nucleação estadual entre organizações e já tinha projeção no contexto decisório regional amazônico, o que eleva sua atuação ao âmbito decisório federal. Nacionalmente, o momento era de 
reflexão sobre os dez anos posteriores à CNUMAD de 1992, bem como os programas e projetos que se desenvolveram no contexto de preparação da conferência.

As táticas de ação das redes e as estratégias internas de mobilização, mais elaboradas, integravam o conhecimento científico das instituições de pesquisa parceiras e a permeabilidade das associações, dos movimentos sociais e das ONGs nas municipalidades. Os nós da rede ambientalista estavam, então, coesos e apontando para uma direção: a formulação de políticas e ações que visassem à sustentabilidade regional, por meio da participação nas decisões em distintas esferas governamentais. O momento era propício, já que, ao longo da década anterior, experiências como o PPG7 e o PRONABIO incorporaram em projetos comuns uma diversidade de potencialidades de organizações e redes ambientalistas pulverizadas em ações pontuais. Outrossim, o desenvolvimento do MacroZEE da Amazônia Legal, ao longo de 2004 e 2005, e o desenvolvimento dos ZEE estaduais amazônicos (processo intensamente acompanhado tanto pelo FORMAD quanto pelo GTA), estavam atrelados a diversos projetos, programas e políticas que incidiam fortemente na região ${ }^{67}$.

Grande parte das articulações das redes ambientalistas, tanto do FORMAD quanto de outras, é resultado da atividade em seminários, palestras, plenárias, assembleias e outras técnicas formativas. Assim, o MTSD é a concretização das discussões realizadas no contexto de oportunidades, conduzidas no seminário "Brasil e Mato Grosso Sustentáveis e Democráticos", realizado em setembro de 2002. Esse evento se realizou com uma parceria entre o Projeto Brasil Sustentável e Democrático e organizações ligadas, direta ou indiretamente, ao FORMAD ${ }^{68}$, e resultou no processo de articulação com outras organizações socioambientalistas e em iniciativas individuais do estado, reativas à proposta do projeto.

67 O MacroZEE tem relação com outras iniciativas já em curso na Amazônia, referenciadas no Plano Amazônia Sustentável (PAS), como o Plano de Ação para Prevenção e Controle do Desmatamento na Amazônia (PPCDAM), as Políticas de Desenvolvimento Regional (PNDR) e de Defesa (PND), o Plano Nacional sobre Mudança do Clima (PNMC), o Programa Territórios da Cidadania, os Planos de Desenvolvimento Regionais (Planos Marajó, BR-163 e Xingu), o Programa de Regularização Fundiária da Amazônia Legal (Terra Legal), a Lei de Gestão de Florestas Públicas (Lei Federal 11.284/06), o Programa de Manejo Florestal Comunitário e Familiar (Decreto Federal 6.874/09) e o Plano Regional de Desenvolvimento da Amazônia (PRDA).

68 Participaram representações nacionais como a Associação Brasileira de Organizações Não Governamentais (ABONG), o GERA, da Universidade Federal de Mato Grosso (UFMT), o Programa de Mestrado em Agricultura Tropical da UFMT, a UNEMAT e o Centro Universitário de Várzea Grande (UNIVAG). 
Os debates no contexto do MTSD giravam em torno do modelo de desenvolvimento mato-grossense, tendo como base a realidade brasileira e o papel do Mato Grosso no cenário nacional. No projeto foram sistematizados enfoques analíticos e novos indicadores de sustentabilidade, buscando estimular experiências e ideias dos movimentos sociais, organizações populares e organizações não governamentais, como uma proposta de organização administrativa com base em um modelo sustentável, em áreas setoriais como mineração, indústria, turismo, infraestrutura, agricultura, cidades/saneamento, extrativismo, recursos hídricos, Unidades de Conservação e áreas indígenas. A proposta de análise do MTSD se mostrou inovadora por focalizar a perspectiva das consideradas "minorias" no diagnóstico da realidade mato-grossense.

Em julho de 2003 o FORMAD apresentou os resultados do esboço do Projeto Mato Grosso Sustentável e Democrático à Ministra do Meio Ambiente Marina Silva, com sugestões de ações para o desenvolvimento do estado. A rede ambientalista solicitava a integração de políticas e de ações de governo em benefício da preservação ambiental. Em abril de 2004, o projeto foi apresentado à sociedade pela Universidade Estadual do Mato Grosso (UNEMAT) juntamente aos representantes do Projeto Brasil Sustentável e ao IBAMA.

Paralelamente, o FORMAD caracterizava o Programa de Desenvolvimento Sustentável do Pantanal. O programa foi assinado em 2001, mas enfrentava problemas de ordem legal, política e administrativa que comprometiam seu andamento. Baseando-se em um compêndio de informações técnicas elaborado pela própria rede, em setembro de 2003 foram apresentadas atualizações dos dados sobre o programa e discutidas formas de participação social no processo de redesenho.

Tanto no MTSD, quanto na atualização dos dados para o Programa Pantanal, foi imprescindível convergir o conhecimento acadêmico e a experiência acumulada das diversas organizações envolvidas nas redes - muitas delas nesse momento já haviam compartilhado os espaços do GTA.

Retomemos, pois, a equação apresentada por Raffestin e contrastada, no Capítulo 2, com os eixos de ação do FORMAD e aqueles do Plano de Longo Prazo Mato-grossense. A partir do momento em que a rede ambientalista evolui da conversão de sua energia e informação para a produção de trabalho (L), o FORMAD também mapeia mediadores materiais $(M)$ que, ora existiam e estavam 
fora do campo de visão tático deste ator coletivo, ora surgiram a partir do esforço coletivo, resultante das cooperações estabelecidas pelas organizações ambientalistas. Mais do que isso, as estratégias e táticas da rede tornam-se, por si, um elemento mediador. Com essa nova dimensão, assimilada e divulgada, metas de ação $(P)$ passam a ser revistas e ampliadas. Isso significa que o FORMAD e outras redes ambientalistas agregadas, como o GTA, passam a ter instrumental suficiente para também produzir o território.

A incorporação do conhecimento técnico e a possibilidade de atuação sobre o ambiente orgânico, inorgânico (Sn) e social (So) aconteceriam paralelamente à elaboração do MTSD e com o apoio da rede GTA, mediante a avaliação das áreas prioritárias à conservação, ao uso sustentável e à repartição de benefícios da biodiversidade brasileira. Os resultados no Mato Grosso foram explicados no Capítulo 2. Em 2006, a atualização das Áreas e Ações Prioritárias da Biodiversidade contou com o apoio do IBAMA, Fundo Brasileiro para a Biodiversidade (FUNBIO), Fundação Biodiversitas, German Organisation for Technical Cooperation (GTZ), WWF, TCN, CI, IPAM, ISA, Coordenação das Organizações Indígenas da Amazônia Brasileira (COIAB), Conselho Nacional de Saúde (CNS), GTA, SOS Mata Atlântica, GEF CAATINGA e Associação Plantas do Nordeste (APNE). Por meio dessas parcerias, foi possível elaborar metodologias ${ }^{69}$ de integração de dados biológicos com informações sobre economia, programas de desenvolvimento, dados populacionais, atividade econômica, evolução do desmatamento, risco de fogo, dentre outros (BRASIL, 2001, p. 13). Entretanto, apesar da alta qualidade da informação produzida e das contundentes evidências da necessidade de preservação dos biomas da Amazônia Legal, o material produzido não sensibilizou a sociedade nem o Estado, permanecendo 0

$69 \mathrm{~A}$ metodologia usada para esse projeto buscou implementar um processo cumulativo, com ampliação gradativa da comunidade científica e acadêmica, OSCA, órgãos governamentais, empresas e movimentos sociais. $O$ trabalho foi realizado em quatro etapas com metodologias próprias: 1. Fase preparatória, com integração de informações sobre a Amazônia brasileira; 2. Reunião preparatória para o Seminário Consulta, realizada na cidade de Macapá em 1999, com a participação de 226 pessoas, dentre as quais representantes dos governos municipais, estaduais e federais, OSC, movimentos sociais, instituições de pesquisa públicas e privadas, empresas e imprensa. Foram definidas, nesta reunião, áreas prioritárias por tema, integração de dados biológicos e socioeconômicos e definição de ações prioritárias; 3. Síntese dos resultados em relatórios técnicos para cada área temática; e 4. Disseminação dos resultados e acompanhamento de sua implementação pela internet, em site atualmente desativado (www.socioambiental.org/website/bio/index.htm), mapas, CD-ROM e publicação completa dos resultados do projeto e de suas análises. 
protagonismo midiático da necessidade de avanço das fronteiras agrícolas.

Persiste, tanto no processo de consolidação do MTSD, quanto nas avaliações de áreas prioritárias para a conservação dos biomas brasileiros, um fio condutor que perpassa grande parte da história mato-grossense: os impactos socioambientais do cultivo de soja e cana-de-açúcar para a produção de agrocombustível. Sobre esse aspecto, foi e é um grande contratempo a busca de soluções apenas no âmbito da lógica econômica estrita, atribuindo ao mercado a capacidade institucional de resolver a degradação ambiental, "economizando" o meio ambiente e abrindo mercados para novas tecnologias limpas (ACSELRAD, 2002). Assim, a forma de lidar com a agenda ambiental no estado - sobretudo daqueles que podem garantir fontes de recursos governamentais aos produtores, por meio da responsabilidade socioambiental - frequentemente segue uma abordagem bastante definida. Os programas (ou os objetivos a serem alcançados) estabelecidos "de cima para baixo" diferem, e muito, das proposições "de baixo para cima", quando consideramos os resultados de iniciativas como o MTSD.

É possível que uma conjugação entre certa inabilidade de permear subsistemas sociais (So) e o bloqueio governamental à ação de tais redes tenha sido o ponto de inflexão que permitiu a contenção desses atores coletivos ambientalistas pelo Estado, em vista ao crescente potencial transformador dos territórios pelos primeiros, até então, de domínio único e exclusivo estatal. Afinal, na perspectiva conservadora é o Estado o responsável pleno pela gestão territorial. Às amplamente chamadas Organizações Não Governamentais, termo permeado de conotações ideológicas diversas, caberia apenas o papel de execução daquilo que o Estado brasileiro não consegue concretizar. Os que "não são governo" não governam: assimilam e reproduzem a agenda governamental, frequentemente orientada pelas demandas de elites. Por não ser Estado, não Ihes é facultado o direito de gerir o território, ainda que pertençam a esse processo. O resultado dessa possibilidade de gestão, em longo prazo, seria a produção dos espaços em territórios e a produção da própria natureza.

Apesar de tais percalços, é importante não perder de vista o potencial transformador das relações entre Estado, ambiente e sociedade que oferecem as redes de solidariedade em diversos setores. Também é importante não esquecer suas possíveis debilidades, presentes e futuras. 
No caso específico do FORMAD e das outras redes de teor regional, como - GTA, ou mesmo de caráter internacional (ARA), muitas das ocorrências políticas em diferentes níveis são mediadas por conexões em redes, que se defrontam com outras de maior poder, dado o cenário de agroexportação na região, elaborando táticas ou estratégias nos espaços de participação disponíveis para reversão desse quadro.

Santos (2006) reconhece três níveis de solidariedade das redes: o mundial, o nível dos territórios ou dos Estados e o nível local. Seria no nível local, segundo o autor, que as redes se consolidam como veículo de movimento dialético que opõe o território e o lugar ao mundo e "confronta o lugar ao território tomado como um todo" (SANTOS, 2006, p. 270). É no local que as redes ganham dimensão única e socialmente concreta, porque os fenômenos sociais agregados ocorrem contiguamente, em um acontecer solidário, diverso e repetitivo. As vivências locais podem gerar projeções e conclusões em outras abrangências espaciais, como foi o caso dos resultados dos seminários ocorridos no âmbito do MTSD, os quais alcançaram não só a amplitude da forma como se pensa a sustentabilidade no estado do Mato Grosso, mas também desempenharam seu papel no cenário da Amazônia Legal, quando ligados a outras conectividades, como o GTA e a COIAB, e na Pan-Amazônia, em exemplos como a ARA e a Coordinadora de Organizaciones Indígenas de la Cuenca Amazónica (COICA).

Sobre a hierarquia de inserção das redes, Haesbaert (2004) considera os territórios e as redes nele conformadas como categorias não dicotômicas, sendo as redes elementos constitutivos do território. Como elemento do território, redes como as ambientalistas também se incorporam nos processos de apropriação dos recursos naturais, tal como a apropriação do território tem o ambiente como elemento intrínseco.

Baseando-nos na equação exposta no Capítulo $2^{70} \mathrm{e}$ em suas variáveis, temos que o principal vínculo entre as redes ambientalistas e o território se deu por

70 Retomamos a equação definida por Raffestin pela seguinte representação:

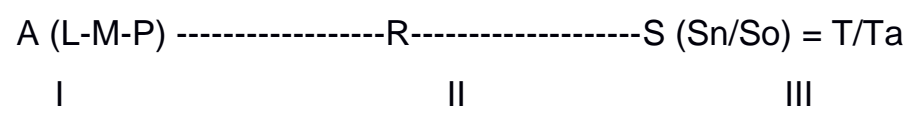

Reformulada neste trabalho para reforçar o caráter sistêmico de cada elemento:

$\{A[L+M+P(I p)] /(S n+S o)\}=T / T a$

II III 
meio de sua inserção nos processos decisórios através de múltiplas estratégias, pela análise conjuntural tanto do meio político por onde se caminha (nacional, local, estadual ou internacional) quanto dos aspectos técnicos de capacidade de carga dos ecossistemas. As variáveis, por sua vez, configuraram-se ao longo do tempo sob as forças dos conflitos de classe, nelas se reproduzindo. A relação entre territorialidade e território por tais atores, pois, está refletida e marcada pela maneira como se desenvolveu a apropriação dos territórios no Brasil. Isto é, o confronto entre as elites, notadamente agrárias, e as camadas a estas subalternas $^{71}$, ou seja, as etnias preexistentes que foram subjugadas e as novas derivações advindas das miscigenações entre estas e os migrantes.

A replicação das ações - quando dada questão ambiental engloba mais de uma localidade - pode se estender ao longo da abrangência da sociabilidade e de onde se repetem as situações de dominação, elitismo, clientelismo e hegemonias, aplicada a cada caso socioambiental específico e segundo a relatividade temporal de cada caso, dado que os tempos que animam os objetos técnicos não são iguais, considerando a particularidade dos tempos sociais de um grupo (SANTOS, 2006). Consequentemente, a manutenção do sistema de protagonismos na definição de territórios e territorialidades, no caso estudado, opera por meio da perpetuação das desigualdades entre as camadas sociais, da deslegitimação das diversidades sociais e, portanto, do peso desigual da participação destas nos processos de tomada de decisão.

71 Simionatto (2009) ressalta a demarcação feita por Gramsci em relação aos nexos dialéticos entre as classes (aqui, camadas) subalternas "com o Estado, a sociedade civil, a hegemonia, a ideologia, a cultura e a filosofia da práxis". Uma série de mediações as conforma, como suas relações com o "desenvolvimento das transformações econômicas"; sua "adesão ativa ou passiva às formações políticas dominantes"; as lutas travadas a fim de "influir sobre os programas dessas formações para impor reivindicações próprias"; a formação de "novos partidos dos grupos dominantes, para manter o consenso e o controle dos grupos sociais subalternos"; a caracterização das reivindicações dos grupos subalternos; e "as formas que afirmam a autonomia" (GRAMSCI, 2002, p. 140; SIMIONATTO, 2009). Aqui, definimos "camadas" porque, haja vista essa série de variáveis, observamos ao longo do estudo que há estratificações internas dentro da classe subalterna. 


\subsection{Disputa pela agenda ambiental e participação}

Por um lado, a análise do MTSD permite avaliar quais as posições e influências das redes ambientalistas e dos atores governamentais sobre a relação entre território e territorialidade. Por outro, permite a análise dos argumentos delineados pelos atores coletivos no documento como um todo e sua comparação com a qualidade dos documentos governamentais voltados ao planejamento.

O panorama ecossistêmico do estado do Mato Grosso, como mencionado anteriormente, provê muitas possibilidades de uso dos recursos conjugada à conservação. Os resultados do Projeto Mato Grosso Sustentável ${ }^{72}$ apontam a percepção das organizações da sociedade civil envolvidas na rede sobre quais necessidades Ihes são pertinentes na questão ambiental, dada sua realidade e contexto, e quais são as demandas socioambientais consideradas e pautadas na agenda governamental estadual. Faltam-lhes instrumentos de análise e abrangência territoriais para seus estudos, facilitados quando há institucionalidade ambiental na estrutura governamental que os permita. Igualmente, notam-se singularidades pertinentes à agenda interna dos atores coletivos, representados pelas redes ambientalistas. A elaboração dessas agendas, no entanto, segue similar método de seleção por prioridade temática ambiental, não sendo esse método desprovido de eventuais hegemonias internas.

De qualquer forma, o MTSD é um documento diagnóstico no qual a produção intelectual, construída conjuntamente entre os membros do FORMAD, sintetiza observações dos diversos temas ligados aos seus eixos de ação, convertendo-se em instrumento de reflexão, elaborado por membros de instituições de pesquisa, universidades e outras organizações, levado para conhecimento federal, por meio do Ministério do Meio Ambiente, em 2006. A partir desse momento, as já então múltiplas redes ambientalistas amazônicas passam a dedicar especial atenção à produção de informação ambiental, tanto em relação ao ambiente físico (biomas, bacias hidrográficas, geomorfologia) quanto ao relacional com as

72 Esse projeto foi conduzido dentro do âmbito de atuação das redes, em especial da rede estadual FORMAD e, em âmbito nacional, do FBOMS. Nesse momento de atuação estavam à frente das propostas a Federação de Órgãos para Assistência Social e Educacional - Regional de Cáceres (FASE), a Operação Amazônia Nativa (OPAN), o Instituto Centro de Vida (ICV), o Sindicato dos Trabalhadores do Ensino Público de Mato Grosso (SINTEP), o Grupo de Saúde Popular (GSP) e a Associação de Defesa do Rio Coxipó (ADERCO). 
sociedades e governos (infraestruturas, leis, trâmites no Executivo e Legislativo). No caso do FORMAD, consolida-se um eixo temático específico para a produção de estudos, análises e pesquisas além da sistematização de informações e de indicadores socioambientais e econômicos para subsidiar o trabalho das entidades parceiras e o acompanhamento e a incidência em políticas públicas.

O momento de amadurecimento decorrente das aprendizagens anteriores em termos de participação social na questão ambiental encontrou um terreno fértil para sua ampliação na esfera federal ao longo da primeira década do século XXI. Também nesse momento foi identificada pelas organizações das redes envolvidas a similaridade entre as preocupações socioambientais destas e do Ministério do Meio Ambiente em relação ao desenvolvimento e à participação da sociedade. Contraditoriamente a esse fluxo, naquele momento o MMA se encontrava em uma condição orçamentária que não respondia à diversidade de programas conduzidos, da mesma forma que sua reatividade com os outros ministérios ainda era um processo de construção, como mencionado no Capítulo 1. Também se aprofundava a dificuldade de entendimento sobre a gestão ambiental entre as instâncias governamentais. A tentativa então era de buscar parcerias e sinergias com o MMA que viabilizassem a discussão e condução do MTSD nos espaços consultivos e deliberativos dos níveis federativos e nos espaços de debate permanente das redes. Nestas, as organizações filiadas - sindicatos, ONGs, associações de produtores, entre outras - participariam na reflexão, articulação e definição de propostas para ações coletivas em relação às políticas públicas e privadas que dizem respeito ao meio ambiente e às sociedades.

As arbitrariedades nos processos decisórios relativos aos ZSEE e ZEE da BR-163, expostos no Capítulo 4, e o papel econômico e socioambiental do Mato Grosso no cenário nacional explicitaram as arenas de disputa entre as camadas da sociedade civil no que se refere ao tipo de ambientalismo em voga, consolidandose na sua relação com o Estado. Enquanto algumas camadas, hegemônicas, se aproximam e retêm cada vez mais poder, as camadas basilares (ou classes subalternas) se distanciam ou, ainda, são mais fortemente reprimidas e contundentemente excluídas pelo conjunto do aparelho do Estado, que dificulta a entrada de atores e sujeitos socioambientalistas, representantes dos grupos sociais excluídos, em espaços de deliberação política e instituições participativas. A invisibilização desses representantes e a coerção psicológica ou física também faz 
parte das estratégias de exclusão das minorias. Ainda nos casos de demarcações (Gráfico 24), as diversidades étnicas indígenas continuam sofrendo pressões, também seguidas de violência física e verbal, às suas áreas.

\section{Gráfico 24. Ocorrências de exploração de TI Regularizadas registradas nos arquivos do FORMAD até 2009}
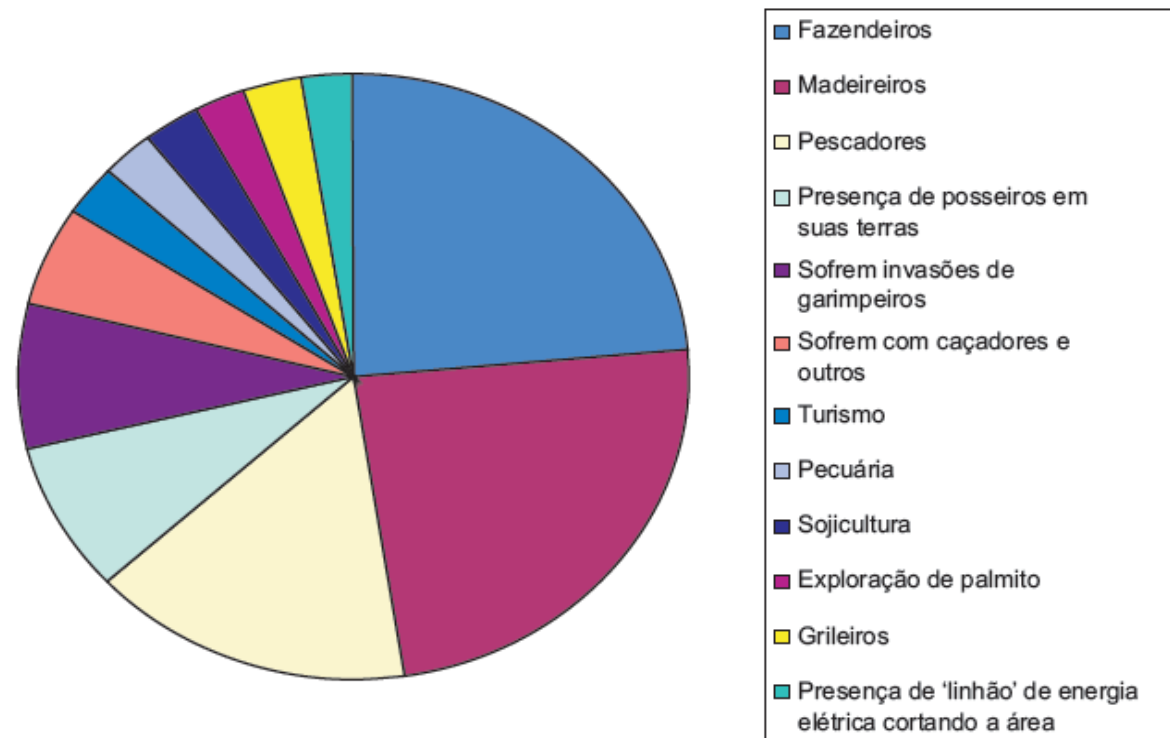

Fonte: ALVES et al (2006, p. 29); OPAN (2005). Elaboração: GT Terras Indígenas/FORMAD.

Mesmo com tal cenário, a motivação à participação consolidou laços de solidariedade entre as organizações ambientalistas que não puderam ser rompidos. Tal noção de solidariedade é empreendida aqui com o sentido de realização de tarefas acordadas e realizadas comumente, mesmo que o projeto não seja comum (SANTOS, 2006; COSTA E MENDES, 2014). Essa observação é pertinente à dinâmica entre as organizações das redes ambientalistas na medida em que, nestas, existem relevantes diferenças metodológicas e de objetivos. Essa diferenciação é desenhada pela tipologia de cada organização segundo as diversas linhagens em que se dividiu o ambientalismo no $\mathrm{Brasil}^{73}$, e repercute na forma como as organizações ambientalistas se relacionam entre si nas redes e com as esferas governamentais. 
A contemporaneidade e a coespacialidade dos eventos, dados em áreas e contextos comuns, impelem o território a se transformar em lugares de acontecer solidário. Essa sucessão de eventos não é, no entanto, isenta de embates, pois são neles que se originam e se alimentam as identidades territoriais, revelando frentes de emancipação e consolidação de novos territórios. A elaboração das relações que tornam o território único para um grupo e o seu sentimento de pertencimento a este território ajudam a estabelecer as fronteiras entre os diversos territórios e entre os panoramas locais e globais (COSTA E MENDES, 2014).

Os laços internos das redes ambientalistas se estreitaram à medida que aumentava a distância entre o discurso e a prática política e as demandas socioambientais. Essa distância, cada vez maior e mais evidente, também sobre a questão ambiental, veio a culminar em um profundo descolamento entre governo, Estado e sociedades, promovido por elites e com métodos de contenção cada vez mais violentos das revoltas populares.

\subsection{Metodologia, resultados e proposições do MTSD}

Para a elaboração do MTSD, as organizações e os indivíduos incluídos no FORMAD subdividiram-se em Grupos de Trabalho (GT). Neles, a construção dos estudos envolveu a coleta e sistematização de dados de amplo acesso, como anuários estatísticos, informações do ZEE, censos do IBGE, dentre outros. Propunha-se diagnosticar o estado da arte da questão ambiental em todas as regiões de atuação do FORMAD, ou seja, Araguaia, Noroeste, Nortão, Sudoeste, Pantanal, Sul, Aglomerado Urbano e o Médio Norte mato-grossenses.

Os grupos de trabalho conformados para cada um dos eixos setoriais e definidos na matriz analítica eram compostos por diferentes instituições, segundo seus focos de atuação, práticas e experiências. Cada GT analisou as condições do seu setor, em primeiro lugar em termos gerais, isto é, como se apresenta a realidade em termos macro (econômicos, espaciais, sociais, educacionais, ambientais, políticos) no estado de Mato Grosso e, em segundo, na forma de estudo de caso. A partir desse procedimento, criaram-se indicadores para a construção das propostas de políticas públicas em vista à concretização de ações que se configuram como sustentáveis e democráticas, na perspectiva da rede ambientalista. Esse processo delineava e integrava um cenário de inter-relação de 
instituições públicas, organizações socioambientalistas, universidades e movimentos sociais.

Por meio de concertação intraorganizacional, mantinha-se uma comunicação permanente, destacando as responsabilidades dos grupos de pesquisa, da gestão do projeto e dos financiadores para a concretização dos objetivos propostos. Externamente, eram propostos seminários de debate sobre os resultados do diagnóstico, estudos de caso para exemplificar situações representativas, e eventos de debate com a sociedade para levantamento de propostas alternativas para o desenvolvimento sustentável e democrático do estado de Mato Grosso. Finalmente, os dados foram publicados em material impresso e divulgados entre os parceiros da rede, as comunidades interessadas e em portais de Internet.

A composição dos temas analisados abordou aspectos históricos tanto da experiência das organizações e pessoas que compunham a rede FORMAD quanto da consolidação do estado do Mato Grosso no cenário nacional. A partir da reflexão sobre esses dois aspectos, projetaram-se ideias de gestão futuras, bem como os meios pelos quais as negociações poderiam transcorrer entre as esferas governamentais e a sociodiversidade (Quadro 18).

\section{Quadro 18. Relação temática entre o MTSD e os eixos de atuação FORMAD}

\begin{tabular}{|c|c|c|}
\hline $\begin{array}{c}\text { GT MTSD (2006- } \\
\text { 2008) }\end{array}$ & Objetivo & $\begin{array}{c}\text { Associação temática com os } \\
\text { eixos de atuação FORMAD } \\
\text { (2011-2013) }\end{array}$ \\
\hline GT Terras Indígenas & $\begin{array}{c}\text { Analisar a situação das terras } \\
\text { indígenas até o ano de 2005. }\end{array}$ & $\begin{array}{c}\text { Diversidade cultural } \\
\text { Populações tradicionais e } \\
\text { indígenas }\end{array}$ \\
\hline GT Mineração & $\begin{array}{c}\text { Tratar da exploração mineral no } \\
\text { estado, tendo como perspectiva um } \\
\text { recorte histórico: o surgimento da } \\
\text { capitania colonial de Mato Grosso } \\
\text { para proteger a fronteira e as minas } \\
\text { de ouro e diamantes encontradas. }\end{array}$ & $\begin{array}{c}\text { Grandes projetos - Brasil e } \\
\text { Mato Grosso }\end{array}$ \\
$\begin{array}{c}\text { Grandes obras: hidrelétricas, } \\
\text { rodovias, hidrovias e ferrovias }\end{array}$ & $\begin{array}{c}\text { Abordar aspectos físicos e de } \\
\text { biodiversidade, bem como projetos em } \\
\text { bacias e sub-bacias hidrográficas. }\end{array}$ & $\begin{array}{c}\text { Grandes projetos - Brasil e } \\
\text { Mato Grosso } \\
\text { Grandes obras: hidrelétricas, } \\
\text { rodovias, hidrovias e ferrovias }\end{array}$ \\
\hline $\begin{array}{c}\text { GT Recursos Hídricos } \\
\text { Conservação }\end{array}$ & $\begin{array}{c}\text { Abordar o ordenamento e sua relação } \\
\text { com a conservação da socio e } \\
\text { biodiversidade estaduais. }\end{array}$ & $\begin{array}{c}\text { Impactos ambientais e } \\
\text { legislação ambiental } \\
\text { (incidência em políticas } \\
\text { públicas) }\end{array}$ \\
\hline
\end{tabular}




\begin{tabular}{|c|c|c|}
\hline & & $\begin{array}{l}\text { a) Mudanças climáticas; b) } \\
\text { Ordenamento territorial: ZSEE, } \\
\text { legislação ambiental, Código } \\
\text { Florestal }\end{array}$ \\
\hline GT Educação & $\begin{array}{l}\text { Transpor a esperada fronteira } \\
\text { pedagógica, avaliar a trajetória da } \\
\text { movimentação ambientalista no } \\
\text { estado. }\end{array}$ & $\begin{array}{c}\text { - Relação de gênero } \\
\text { - Impactos ambientais e } \\
\text { legislação ambiental } \\
\text { (incidência em políticas } \\
\text { públicas) } \\
\text { a) Mudanças climáticas; b) } \\
\text { Ordenamento territorial: ZSEE, } \\
\text { legislação ambiental, Código } \\
\text { Florestal }\end{array}$ \\
\hline GT Agricultura & $\begin{array}{l}\text { Tratar da expansão das fronteiras } \\
\text { agrícolas e sua pressão aos aspectos } \\
\text { considerados pelos outros GTs }\end{array}$ & $\begin{array}{c}\text { Terra e modelo de } \\
\text { desenvolvimento (uso da } \\
\text { terra) } \\
\text { a) Agricultura familiar; b) } \\
\text { Agronegócio: concentração } \\
\text { fundiária, agrotóxico, } \\
\text { agrocombustível e respectivos } \\
\text { impactos; c) Ordenamento } \\
\text { territorial: ZSEE }\end{array}$ \\
\hline
\end{tabular}

Fonte: ALVES et al (2006); FORMAD (2011). Adaptação própria.

\subsubsection{Resultados sobre a conjuntura das Terras Indígenas}

Em relação às Terras Indígenas, a insuficiência institucional da Fundação Nacional do Índio (FUNAI) e a forte pressão política e econômica de grupos de pecuaristas, madeireiros e sojicultores foram apontadas como as principais razões para as dificuldades de demarcação de terras (FORMAD, 2011). Na avaliação dos GT sobre terras indígenas do MTSD (ALVES et al, 2006), os vínculos que esses produtores possuem com políticos de expressão local, regional ou nacional favorecem-nos em situações de incerteza legal. No contexto atual, essa constatação seria observável, por exemplo, na vulnerabilidade conformada pelo limbo jurídico e legal da combinação entre a não conclusão do ZEE estadual, a procrastinação na conclusão do CAR e a necessidade de aplicação do Código Florestal. Essa situação é aproveitada arbitrariamente por grandes produtores.

É comum que haja uma sobrecarga de exploração dos recursos naturais notadamente o desmatamento, por parte de grandes produtores - na esperança de uma anistia futura. Isto é, a estagnação do ZSEE, do CAR e, consequentemente, da aplicação do Código Florestal potencializa o avanço de desmatamento, já que os grandes produtores sempre buscarão usar sua influência nas esferas políticas de forma a serem perdoados de suas irregularidades passadas, uma vez essa tríade se consolide. A gestão territorial, incluindo um mapeamento dessas e de 
outras ameaças às terras indígenas, bem como a assessoria e o acompanhamento dessa gestão (gestão de recursos, produção e comercialização sustentáveis) foram, no momento do MTSD, apontados pela rede como instrumentos metodológicos para abordagem nas negociações políticas.

Foram reportadas no MTSD as parcerias entre membros das etnias Paresi e Tapirapé e grandes produtores para arrendamento de suas terras para o plantio de monoculturas de soja. Tendo em conta que esse não é o interesse das comunidades mencionadas, as ações individuais desses membros atrapalharam as ações coletivas em vista a resultados positivos às etnias como um todo e a articulação destas articuladas com outras (ALVES et al, 2006).

Desde a entrega das análises do MTSD para o MMA, as organizações da rede voltadas à temática indígena promoveram o estabelecimento de planos de gestão territorial e ambiental de algumas etnias. O povo Ashaninka, locado nas imediações do Rio Amônia, aponta para algumas diretrizes que podem ser consideradas comuns às necessidades de outras etnias, guardadas as devidas especificidades.

É interessante notar que no momento imediatamente posterior ao MTSD (2009) estabeleceu-se, em nível federal, o incentivo à criação da Comissão Nacional dos Povos e Comunidades Tradicionais (CNPCT) ${ }^{74}$, vinculada ao Ministério do Meio Ambiente (MMA) e, naquele momento, ao Ministério do Desenvolvimento Agrário (MDA). O FORMAD foi interlocutor direto no estabelecimento da comissão, resultado de sua forte articulação anterior na questão indígena e de diversidade cultural.

A CNPCT pretendia elaborar políticas públicas específicas para as populações tradicionais nos eixos territorial, de infraestrutura e segurança alimentar. O FORMAD assumiu uma vaga nessa comissão representando os pantaneiros, dado o seu histórico de atuação nesse bioma, abordando as questões das hidrovias e do agronegócio que ameaçavam a sustentabilidade ambiental e social dos pescadores tradicionais, ribeirinhos, indígenas e quilombolas. A pauta levada a esse espaço de participação girava em torno do controle social desses grupos em aspectos como educação, saúde, ambiente e direitos humanos (garantia,

74 Recentemente a CNPCT foi convertida em conselho, inicialmente deliberativo e, atualmente (2017), consultivo, por pressão governamental para tal conversão. 
promoção e proteção de defensores). A comissão foi composta por 15 representantes de órgãos e entidades da administração pública federal e 15 representantes de organizações não governamentais. Já o Plenário, órgão superior da anterior deliberação (hoje, de consulta) da CNPCT, reúne-se, em caráter ordinário, uma vez a cada três meses.

Vitórias à parte, a contrapartida do anterior governador do Mato Grosso e atual ministro da Agricultura, Blairo Maggi, foi a solicitação em 2003 ao Ministério da Justiça pela paralisação das demarcações de Terras Indígenas por dois anos. O reflexo dessa ação foi o decréscimo do encaminhamento de áreas de estudo, entre outros trâmites judiciais necessários à regularização das TIs, a partir de 2017. Com isso, mesmo dispondo de um espaço deliberativo na esfera federal, a aplicabilidade no estado se via diminuída por ação do governo estatal. Com o encolhimento da CNPCT de seu caráter deliberativo para consultivo em âmbito federal, o espaço de participação das diversidades culturais restringe-se. Aproveitando-se da grande dificuldade nas atribuições de responsabilidades, situações como esta são comuns nas mais diversas intervenções por organizações e redes: o avanço na participação em um espaço é quase sempre sucedido pelo retrocesso na participação de outro que inviabilize o primeiro.

Um exemplo histórico irresoluto que demonstra o bloqueio decisório conformado pela influência dos produtores no governo do estado é o caso Xavante referente à TI Marãiwatséde. Apesar das mobilizações desde a CNUMAD de 1992, durante o MTSD reportou-se que os problemas das invasões à referida TI por posseiros e grileiros ainda não haviam sido resolvidos. Grupos políticos e fazendeiros da região no entorno da TI desobedeceram aos 168 mil hectares identificados, demarcados e homologados. A permanência desses grupos foi amparada pelo TRF na medida em que este determinou que a extrusão fosse iniciada apenas após a resolução do mérito da ação civil pública. Desde 1992 as organizações indigenistas dentro do FORMAD pressionam os três poderes estaduais e federais para a solução dos impasses. Apesar dos anos de tentativa e muitas interposições na justiça pelo Ministério Público Federal, a desintrusão aconteceu apenas em 2012, mas não foi suficiente para resolver os conflitos. Após a posse definitiva de seu território, em 2014, novas aldeias foram fundadas, mas a comunidade ainda sofre com incêndios criminosos e tentativas de reinvasão. Por tal, a questão da TI Marãiwatséde segue sendo pauta de reivindicação das redes 
ambientalistas mato-grossenses, mesmo depois de 24 anos do início das discussões nesses espaços e de 56 anos de subsequentes invasões, em 2016.

No caso da defesa do território Marãiwatséde, a colaboração e articulação de todos os que estavam a favor da desintrusão na TI resultaram, apesar do tempo transcorrido, no êxito das solicitações. Isso não teria ocorrido se não fosse pela motivação duradoura da solidariedade nas redes e movimentos ambientalistas envolvidos.

Problemas como imprecisão dos dados, estatísticas das esferas governamentais e manipulação midiática são pontos que ainda perduram desde os levantamentos feitos para o MTSD, dificultando, por exemplo, a demarcação e regularização de $\mathrm{TI}$ e omitindo o número exato de etnias indígenas isoladas. As consequências disso, reportadas por todas as organizações da rede, vão desde a hostilidade dos não indígenas a esses grupos até repetidos eventos de violência de vários tipos. Sobre as TI pertencentes ao Mato Grosso, mas com amplitude interestadual segundo seus biomas, como a Amazônia, e os biomas ainda não reconhecidos como tais, como o Pantanal, o diagnóstico jurídico dos processos de demarcação, o mapeamento e relato de conflitos semelhantes em outras aldeias e os métodos de incentivo à agricultura tradicional ainda são questões não resolvidas.

\subsubsection{Conclusões sobre agricultura e uso da terra}

Das diversidades incluídas no GT que trata da agricultura e, portanto, do uso da terra, destaca-se o protagonismo da agricultura familiar frente à expansão do agronegócio. A incidência dessa temática em políticas públicas se deu em vista ao cumprimento da legislação (Lei 11.947/09), que estabelece que $30 \%$ da merenda escolar seja proveniente da agricultura familiar (ALVES et al, 2006). Paralelamente, a mobilização política se dava por meio de formação e discussões públicas sobre o ZSEE e a necessidade da reforma agrária, como base às estratégias do ordenamento territorial. Investiu-se esforço na tentativa de criar projetos demonstrativos para viabilidade da agricultura familiar em uma perspectiva integral: diversidade cultural, uso da terra, novas relações de produção e comercialização. Realizaram-se o acompanhamento e o apoio a acampamentos, aos assentamentos e à agricultura familiar na perspectiva da agroecologia, da segurança alimentar das famílias e da recuperação de áreas degradadas. 
O desafio dessa iniciativa foi enfrentar as dimensões da produção agrícola para fins de exportação. É pela dimensão que ocupa a agroexportação nos grupos preponderantes da sociedade civil, que permeiam também a sociedade política e, finalmente, têm protagonismo na agenda governamental, que as vozes de contestação às frentes da agricultura industrial são silenciadas nos espaços participativos estatais. A empresa a Amaggi Exportação e Importação Ltda., dentre diversas outras, está incluída no Programa de Desenvolvimento Industrial e Comercial de Mato Grosso (PRODEIC) ${ }^{75}$, usufruindo de incentivos fiscais, incluindo o Imposto Sobre Circulação de Mercadorias e Serviços (ICMS). De 2012 a 2014, o Mato Grosso deixou de arrecadar mais de $\mathrm{R} \$ 4$ bilhões em função de incentivos fiscais concedidos às empresas privadas.

Em termos locais, questões como os grandes projetos, a agricultura familiar e os zoneamentos (no caso dos municípios, os Planos Diretores) têm atingido os Conselhos Municipais de Defesa do Meio Ambiente (CONDEMAs), tendência que se agravará à medida que as demandas socioambientais forem aumentando, sem respostas governamentais. Por essa razão, todas as redes ambientalistas conformadas, não apenas o FORMAD, assumem a capilaridade de suas ações pelos municípios, através das organizações locais, como estratégia de ação. A maioria dos municípios mato-grossenses não tem projetos visando o planejamento e tem conselhos ainda desorganizados. Atender a essa demanda implica recursos financeiros e humanos e fortalecimento enquanto projeção de incidências.

\subsubsection{Considerações sobre grandes projetos e recursos hídricos}

No momento do MTSD a questão dos grandes projetos já era preponderante, mas tomou vulto nos anos posteriores, razão pela qual as redes como o FORMAD, o GTA e a ARA passaram a incluir o tema em suas pautas de atuação. Estudos sobre a geologia do estado e a atividade mineira desde a colonização até o aumento migratório em busca dos garimpos (1970-1980) conduzidos pelo GT de mineração - corroboraram para o entendimento da influência dos aspectos físicos na dinâmica socioambiental estadual. 1.432/03, vinculado à Secretaria do Estado de Desenvolvimento Econômico (SEDEC), que concede benefício fiscal, durante dez anos, sobre produtos que pertencem à seção de indústria de transformação, conforme a Classificação Nacional de Atividades Econômicas (CNAE). A Amaggi foi contemplada pela Resolução 036/06 em Lucas do Rio Verde e Resolução 093/16 em Comodoro. 
Especificamente, este GT tratava da ampliação da matriz energética que priorizava a construção de hidrelétricas e das infraestruturas para escoamento da produção agrícola, ou seja, a ampliação da malha viária e a construção de hidrovias e ferrovias amazônicas e internacionais previstas no planejamento brasileiro (PAC) e nos acordos internacionais (Iniciativa para a Integração da Infraestrutura Regional Sul-americana - IIRSA) (LOURENÇO E BORGES, 2012).

O panorama elaborado pelo MTSD em relação aos recursos hídricos baseou-se nos resultados de oficinas e espaços de diálogo sobre o projeto. Nestes, foram apontados alguns conflitos e propostas alternativas às bacias hidrográficas mato-grossenses. Uma grande dificuldade emergiu e segue vigente na temática: o tratamento dado a regiões alagadas e a falta de reconhecimento do Pantanal como bioma. Apontava-se que, apesar do estabelecimento da Lei 9.433/1997, seguia sendo um desafio à participação da sociodiversidade no processo decisório a implantação da gestão compartilhada e harmonizada e a construção territorial de gestão integrada dos usos múltiplos (ALVES et al, 2006).

Também no GT de recursos hídricos são abordadas as consequências do desmatamento da região entre os anos 1970 e 1980 e os processos de ocupação com a implementação de grandes projetos de colonização, mineração, usinas hidrelétricas, rodovias e agropecuária (ALVES et al, 2006, p. 49). Especificamente quanto à sustentabilidade em recursos hídricos, esses fatores foram relacionados ao deslocamento de populações indígenas, ribeirinhas e tradicionais e de pequenos produtores e à redução da disponibilidade de água.

A proliferação das hidrelétricas representou o maior motivo de preocupação do GT, tendo em vista as experiências prévias nesse assunto. A hidrelétrica de pequeno porte instalada no rio Culuene, um dos principais afluentes do rio Xingu e fonte de recursos às 14 etnias do Parque Nacional do Xingu, resultou de um acordo entre a empresa Paranatinga Energia, o governo do estado e algumas lideranças indígenas. As obras prosseguiram mesmo que o projeto da $\mathrm{PCH}$ fosse refutado posteriormente pela maioria das 14 etnias existentes no Xingu e pela maior parte dos caciques que o tinham assinado e após as medidas impetradas pela FUNAI e pelo MPF.

Já a barragem do rio Manso, inaugurada em 1998, pretendia gerar eletricidade, controlar as enchentes e irrigar lavouras, hortas e pomares. Sua área de alagamento é de $427 \mathrm{~km}^{2}$. O reservatório, cuja capacidade de geração é de até 
212 megawatts (MW), segundo a Furnas, oferece apenas $97 \mathrm{MW}$ de aproveitamento de energia à usina, o equivalente a três pequenas centrais elétricas com represamento de áreas até cem vezes menores. Segundo o Movimento dos Atingidos por Barragens (MAB) (2004; ALVES et al, 2006), 1.065 famílias perderam tudo com a construção da Usina Hidrelétrica de Manso. Somente 249 famílias foram reassentadas em cinco diferentes áreas, onde 92\% do solo era formado por areia, impróprio para a agricultura.

O comprometimento da qualidade da água das bacias amazônicas pelo garimpo de ouro e por herbicidas e agrotóxicos e das bacias dos rios Araguaia e Paraguai, com esgoto doméstico, bem como a viabilidade da hidrovia Paraguai-Paraná são outros aspectos abordados pelo MTSD.

Para suprir as necessidades de tratamento diferenciado à singularidade pantaneira, o Programa Pantanal (PP) foi realizado simultaneamente ao MTSD na rede FORMAD. O programa foi criado em 1995, com previsão de estabelecimento entre 2001 e 2009, após aprovação de financiamento externo para sua execução, sendo previstos US\$ 400 milhões do BID, do governo japonês, do Governo Federal e dos estados. Anteriormente, em 2000, a rede ambientalista já havia feito propostas, acatadas pelo Ministério do Meio Ambiente, de formação de comitês de acompanhamento do PP e capacitação de pessoas diretamente beneficiadas ou afetadas pelo programa, dentre outras. Apesar do diálogo com o Governo Federal, o FORMAD questionava, entretanto, a falta de informação sobre os objetivos e finalidades do programa. As versões atualizadas dos objetivos foram alteradas várias vezes naquele momento, sem divulgação dos documentos para discussão. Nesse período, o FORMAD tinha oito filiadas ativas em relação a essa questão. $O$ programa previa ações nas áreas de água, solo, agrotóxicos, conservação da fauna, saneamento, economia, além da construção de estradas e criação de parques e reservas. O Ministério do Meio Ambiente foi definido como coordenador do programa, responsável pela gestão ambiental e também pela construção de estradas e obras de saneamento, algo fora de suas atribuições, fator este que debilitou o andamento do programa, dentre outras questões.

Um dos desdobramentos da ação da rede, entretanto, foi o Programa de Formação de Educadores Ambientais e a deliberação da Portaria 113 de 2006, que institui o Conselho Deliberativo da Reserva da Biosfera do Pantanal. 


\subsubsection{Panorama das Unidades de Conservação}

O GT de Unidades de Conservação analisou o desmatamento nas UCs (Figura 15) mato-grossenses a partir das bases de dados cartográficos digitais fornecidas pela SEMA-MT e referentes ao ano de 2006. Resumidamente, o processo de análise espacial envolveu duas etapas distintas: a padronização das bases cartográficas e as análises do banco de dados espaciais. Não foram consideradas nas análises as UCs localizadas dentro de perímetro urbano. Foram considerados os períodos anteriores e posteriores à criação das unidades na análise comparativa das taxas de desmatamento ocorrido no interior das UCs, até 2005, classificando-as em grupos distintos. $\mathrm{Na}$ análise quantitativa do desmatamento no interior das unidades do estado foram consideradas 38 das 42 UCs (ALVES et al, 2006).

As três tipologias vegetais dos $905 \mathrm{mil} \mathrm{km}^{2}$ do estado do Mato Grosso, ou seja, a Amazônia (423 mil km²), o Cerrado (331 mil km²) e a Floresta de Transição (145 mil km²), tiveram desmatamento acumulado até o período de elaboração do MTSD, ou seja, em 2005, de 32,4\% da área de floresta, 40,0\% da área de Cerrado e $34,5 \%$ da área de transição.

Grande parte dos dados interpretados nas análises sobre desmatamento e Unidades de Conservação foi obtida por meio de fontes governamentais. Neste ponto, uma das atribuições que as organizações do FORMAD demonstraram foi a habilidade no tratamento dos bancos de dados voltados para a análise. 


\section{Figura 15. Desmatamento e Unidades de Conservação até 2005 no estado do Mato Grosso}

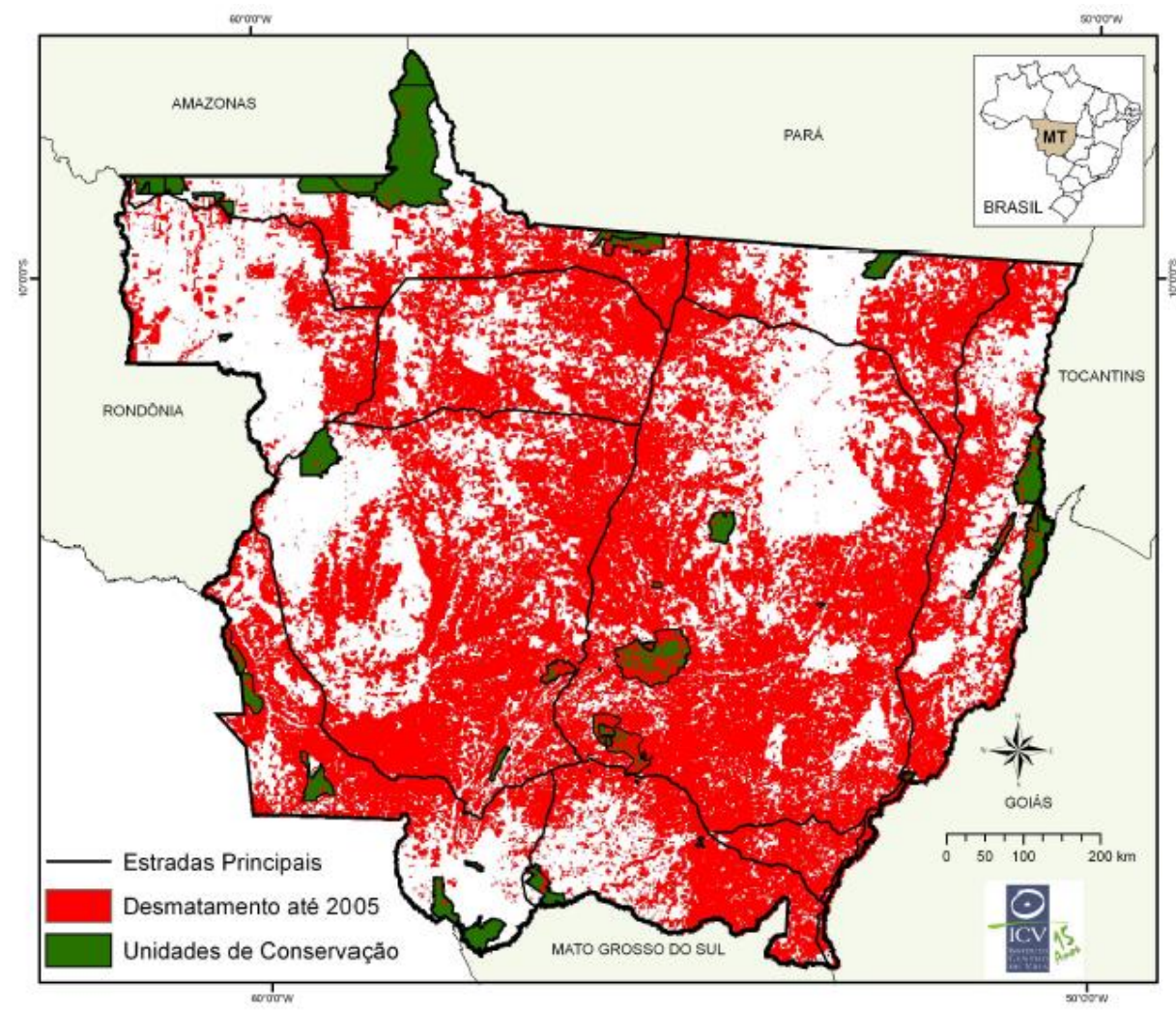

Fonte: ALVES et al (2006). Elaboração: ICV, 2006. ${ }^{76}$

Assim, outra inferência que pode ser feita é a possibilidade da participação da sociedade civil nos processos de validação dos dados, participativamente com o governo, de maneira a garantir a imparcialidade das coletas, o tratamento dos dados e sua interpretação.

76 Nesta versão do mapa, convertido para o padrão de regiões do ZSEE, estão, na Região de Planejamento (RP) 1, as UCs Parque Tucumã, REX Guariba Roosevelt, EE do Rio Roosevelt e Parque Igarapés do Juruena. Na RP2, o Parque Nacional do Juruena, a RE Apiacás e o Parque do Cristalino I, II, III. Na RP3, o Parque do Xingu. Na RP4, o Parque do Araguaia, RVS Corixão da Mata Azul, RVS Quelônios do Araguaia e APA dos Meandros do Rio Araguaia. Na RP5, a RE Culuene. O Parque Águas de Cuiabá e Parque da Chapada dos Guimarães, na RP6. O Parque do Pantanal Mato-Grossense, EE de Ique Juruena, Parque Serra Ricardo Franco, Parque Serra de Santa Bárbara, RPPN Jubran, Parque Guirá, na RP7; e a APA do Salto dos Magés, na RP10. 


\section{Quadro 19. Desmatamento por grupo de análise}

\begin{tabular}{|c|c|c|c|c|}
\hline & UCs do Grupo 1 & UCs do Grupo 2 & UCs do Grupo 3 & Total \\
\hline $\begin{array}{c}\text { Representatividade } \\
\text { em relação à área do } \\
\text { Estado }\end{array}$ & $\begin{array}{c}16 \text { UCs } \\
24.611 \mathrm{~km}^{2} \text { ou 2,7\% } \\
\text { do território }\end{array}$ & $\begin{array}{c}14 \mathrm{UCs} \\
6.080 \mathrm{~km}^{2} \text { ou } 0,7 \% \\
\text { do território }\end{array}$ & $\begin{array}{c}9 \mathrm{UCs}^{2} \\
10.500 \mathrm{~km}^{2} \text { ou 1,2\% } \\
\text { do território }\end{array}$ & $\begin{array}{l}41.191 \mathrm{~km}^{2} \text { ou } 4,6 \% \\
\text { do território estadual }\end{array}$ \\
\hline $\begin{array}{c}\text { Área total desmatada } \\
\text { nas UCs }\end{array}$ & $335 \mathrm{~km}^{2}$ ou $8 \%$ & $586 \mathrm{~km}^{2}$ ou $14 \%$ & $3.244 \mathrm{~km}^{2}$ ou $78 \%$ & $\begin{array}{c}4.165 \mathrm{~km}^{2} \text { ou } 10 \% \\
\text { da área total das UCs }\end{array}$ \\
\hline $\begin{array}{c}\text { Área desmatada } \\
\text { antes da criação da } \\
\text { UC }\end{array}$ & $258 \mathrm{~km}^{2}$ ou 6\% & $423 \mathrm{~km}^{2}$ ou 10\% & $2.149 \mathrm{~km}^{2}$ ou $52 \%$ & $\begin{array}{l}2.830 \mathrm{~km}^{2} \text { ou } 68 \% \\
\text { do total desmatado }\end{array}$ \\
\hline
\end{tabular}

Fonte: ALVES et al (2006).

A partir da análise comparativa das taxas de desmatamento até 2005, foram classificados três grupos de UCs: Grupo 1, formado por UCs com até $5 \%$ de área desmatada; Grupo 2, UCs com 5\% a 20\% de área desmatada; e Grupo 3, UCs com mais de $20 \%$ de área desmatada, segundo o Quadro 19.

É possível perceber que, apesar das UCs categorizadas no Grupo 3 perfazerem menor número que os demais grupos, a área desmatada é a segunda maior em relação à área do estado. Tais UCs cobrem vastas extensões florestadas, com alta biodiversidade. Assim, de acordo com os princípios sucessionais e de estabilidade ecológica no interior dos fragmentos, espera-se que o desmatamento repercuta no interior desses fragmentos, levando à perda de biodiversidade por deriva genética, tanto quanto ocorre nos pequenos fragmentos, ainda que estes cubram uma menor extensão territorial, com até $20 \%$ de área desmatada. Em relação ao período anterior ao estabelecimento das UCs, notou-se um aumento de 23\% no desmatamento do Grupo 1, de 27\% no Grupo 2 e de 34\% no Grupo 3.

Já no Quadro 20, nota-se que o desmatamento acumulado foi maior nas UCs estaduais, tanto no período anterior à criação destas quanto no posterior, evidência atribuída ao persistente conflito de limites e de regularização fundiária. Dentre as UCs federais, apenas as categorizadas como Estações Ecológicas Federais apresentaram taxa de desmatamento acumulado maior que as estaduais, depois do estabelecimento das UCs. Esse fato demonstra que a institucionalidade estadual deve ser fortalecida, de maneira a conter o desmatamento no interior das UCs sob sua jurisdição, sejam elas de responsabilidade do estado ou da União (ALVES et al, 2006). 


\section{Quadro 20. Dados do desmatamento por categoria de manejo}

\begin{tabular}{|l|c|c|c|c|c|}
\hline Categorias de Manejo & $\begin{array}{c}\text { Área Total } \\
\left(\mathrm{km}^{2}\right)\end{array}$ & \multicolumn{4}{|c|}{ Taxa de desmatamento acumulado } \\
\hline & & \multicolumn{2}{|c|}{ Antes da crião da UC } & \multicolumn{2}{c|}{ Depois da criação da UC } \\
\hline $\begin{array}{l}\text { PROTEÇÃO } \\
\text { INTEGRAL }\end{array}$ & & FEDERAL & ESTADUAL & FEDERAL & ESTADUAL \\
\hline Estação Ecológica & 4.191 & 0 & 0.7 & 1.1 & 0.2 \\
\hline Reserva Ecológica & 36 & & 0.0 & & 0.1 \\
\hline Refúgio Vida Silvestre & 1.139 & & 3.4 & & 0.5 \\
\hline Monumento Natural & 3 & & 0.02 & & 0 \\
\hline Parque & 25.524 & 1.9 & 16.8 & 0.7 & 9.2 \\
\hline USO SUSTENTÁVEL & & & & & \\
\hline Reserva Extrativista & 485 & & 0.04 & & 0.05 \\
\hline $\begin{array}{l}\text { Área de Proteção } \\
\text { Ambiental }\end{array}$ & 9.813 & 2.0 & 43 & 1.8 & 18 \\
\hline TOTAL & 41.191 & 3.9 & 64.1 & 3.6 & 28.4 \\
\hline
\end{tabular}

Fonte: ALVES et al (2006).

Dentre as reflexões que conformaram o MTSD, explicitam-se os principais diagnósticos regionais que giram em torno dos eixos de ação da rede e das possibilidades de intervenção junto aos órgãos governamentais. Em termos de resultados no panorama decisório político do estado, sutis foram as mudanças advindas com a proposição do projeto. No entanto, existiram resultados positivos, em nível regional, na Amazônia Legal e no Pantanal, que não podem ser desconsiderados.

Nota-se aí que o esforço de articulação, que já existia desde 1992, evoluiu em metodologias e competência técnica e analítica da abrangência territorial, da diversidade de grupos sociais e das estratégias políticas ao longo do tempo. Obviamente, conforme os temas eram trabalhados, novas necessidades surgiam e, mesmo com as parcerias, o FORMAD começou a ter dificuldades em seguir de perto todos os eixos nos quais atuava. Com os sinais de limitações de alcance, nos anos seguintes à elaboração do MTSD, a rede optou por restringir sua atuação, priorizando eixos e temas, de modo a aperfeiçoar seus recursos financeiros e humanos. Com isso, delineou-se qual seria a agenda do FORMAD, expressa pelos eixos de ação nos quais a rede transitava e influía, reavaliando-os periodicamente.

Apesar das limitações dos espaços oferecidos à participação e do reduzido protagonismo das minorias no âmbito do Estado, a rede soube aproveitar as ferramentas que tinha em mãos para chegar a resultados plausíveis. Mesmo que 
estes não tenham resolvido os conflitos ambientais no estado, ao menos impediram que possíveis cenários mais excludentes fossem criados.

\subsection{O mapeamento das possibilidades de participação em políticas públicas}

Como avanço esperado entre um diagnóstico e a intervenção, derivou-se, no âmbito no FORMAD, um processo de conscientização do potencial das redes ambientalistas em pressionar internamente as instituições do sistema político, a fim de influenciar na definição de agendas, na formulação de políticas e na alocação dos recursos públicos em meio ambiente. Posteriormente ao MTSD, dois seminários foram feitos nesse sentido, já em 2013: um seminário sobre políticas públicas (FORMAD, 2013b) e outro seminário estadual de conselhos (FORMAD, 2013c).

O Seminário de Políticas Públicas Socioambientais, em realidade, ocorreu em dois momentos da história do fórum, com resultados bastante diferentes, quantitativa e qualitativamente. Em 1997, o Seminário Políticas Públicas e Participação ainda centrava sua discussão no significado do termo "desenvolvimento sustentável". Dentre as interpretações levantadas como possíveis estavam o desenvolvimento sustentável como: "um potencial econômico a ser seguido; um crescimento econômico que requer uma abordagem social e ecológica; sustentabilidade planetária pela preservação" (FORMAD, 1997b, p.6). Uma das ideias levantadas nesse momento foi a seguinte:

\footnotetext{
Em 1992, 120 países se reuniram para montar a Agenda 21, que contém 40 capítulos de diversas questões importantes para a vida no mundo. De tudo se trata ali. O problema não é conhecer a Agenda 21, mas o estilo de vida que vamos adotar e só vai ser pertinente quando a gente retirar esses termos sustentabilidade e ecodesenvolvimento, para definitivamente concretizarmos o desenvolvimento. (FORMAD, 1997b, p. 7).
}

Temos algumas questões, já apontadas neste trabalho, como "de onde vem a interpretação das necessidades e dos problemas ambientais?", e "ela é exógena às sociedades que se valem dos ecossistemas ou endógena?". As linhas que se desenvolvem dentro de um contexto interno às comunidades, em geral, tentam resgatar ou conciliar conhecimento acadêmico com tradicional. Mesmo que, pouco a pouco, essa concepção tenha mais adeptos ao redor do mundo, seu protagonismo é pequeno quando comparado às influências externas do que é 
prioritário em termos de agenda (governamental ou empresarial) de intervenção e gestão ambiental.

Portanto, notou-se que as intervenções ao desenvolvimento deveriam ser articuladas à experiência e ao conhecimento acumulados sobre ecossistemas (e sociedades relacionadas) e vinculadas com a ação de sindicatos, a produção familiar, os povos indígenas, a conservação do patrimônio, dentre outros. Com foco no que poderiam representar as influências internacionais à política ambiental nacional, pouco foi discutido nesse seminário sobre aspectos locais, estaduais e regionais que influíssem sobre a forma como se gestionava o meio ambiente. Essa forma de pensar, projetada às mudanças ambientais globais, estava coerente com o cenário daquele momento político. Instrumentos como a Agenda 21 auxiliaram para que, pouco a pouco, a noção sobre a conservação dos recursos naturais fosse se introjetando à realidade das localidades.

Corroborava para essa perspectiva universalista da questão ambiental a falta de informações que, anos depois, passaram a ser disponibilizadas em portais cada vez mais sofisticados em termos de acesso a dados abertos. No entanto, o primeiro levantamento do Seminário de Políticas Públicas Socioambientais demonstra a importância do MTSD: a dimensão local e regional foi aí detectada, colaborativamente entre organizações ambientalistas e universidades, respaldando os posteriores encontros reflexivos da realidade mato-grossense.

Sobre a participação em conselhos, é possível notar semelhanças nas formas de exclusão, mas também perceber ao menos três diferentes momentos de interação entre a rede ambientalista e as instituições participativas de 1992 a 2012 , com dinâmica cíclica nesses espaços durante o período. Entre 1992 e 1997, o relatório reporta a baixa representatividade, por exemplo, de grupos de pequenos agricultores, panorama que passa a se transformar em 1996.

Nas nossas experiências de gestão 92/97, temos no nosso município três entidades que foram envolvidas: a União dos Lavradores, o CTA. Desde 96 conseguimos fazer com que eles tivessem a participação. Por quê? Pontes e Lacerda é um destes municípios que está no PRONAF e se exigiu um Plano de Desenvolvimento Rural. Conseguimos implantar - Conselho de Desenvolvimento Rural e temos o plano de desenvolvimento que precisa ser reformado já que foi feito de 1996 a 1999 e, como não foi realizado, precisa ser modificado para 1997 a 2000 . As decisões devem ser tomadas pelos lavradores e em cima do que estão querendo. É por isso que hoje temos participação nos planos de saúde. Em certos municípios até tem os conselhos, mas de que adianta ter os conselhos se não se tem o plano de desenvolvimento para cada esfera social. (FORMAD, 1997b, p. 11). 
Portanto, o mapeamento das possibilidades políticas e legais existentes, de forma a aproveitá-las para ampliação da participação, é significante desde meados da década de 1990. Na maioria das vezes, tal aproveitamento é feito por via jurídica, com apoio do MPF. Naquele momento, com menor visibilidade e transparência, a rede identificava como sendo necessário um aprofundamento das diretrizes orçamentárias e dos planos anuais, com garantia do valor que seria destinado a cada política. Posteriormente, as necessidades passaram a ser de disponibilidade de informações, como acesso a dados e estudos técnicos ambientais. Houve avanços em termos de controle social, porém não repercutindo necessariamente em um aprofundamento dos métodos participativos oferecidos pelo Estado em suas instituições.

É possível notar a expectativa que existe em torno da representatividade e das possibilidades de influência política a partir dos conselhos gestores. Assim, sintetizamos as dificuldades nesse espaço participativo, conforme o Quadro 21.

O Seminário de Políticas Públicas - realizado 16 anos depois, em março de 2013 - visava discutir até que ponto o poder público transita e apoia ou não a organização e organicidade de grupos sociais, de forma a aumentar a incidência política que permitisse o aumento do controle social (FORMAD, 2013b). O que se reafirmou, no entanto, foi o aprofundamento dos conflitos levantados no MTSD. A diferença se deu porque, nessa análise conjuntural, considerou-se também o contexto nacional e internacional para mapeamento de políticas convergentes ou divergentes em aspectos pertinentes à questão ambiental, como a agroecologia, o fortalecimento da coesão entre organizações socioambientalistas, a agricultura familiar, dentre outros.

Basicamente, o cerne da questão que se levantou nas discussões diz respeito à questão ambiental atrelada ao território entendido como suporte físico, com pouca ênfase no papel das dinâmicas que ali se desenvolvem. Apesar dessa limitação, o reconhecimento do panorama físico e biológico consistiu em um primeiro contato com as competências técnicas e de negociação que viriam a se desenvolver. 


\section{Quadro 21. Análise do escopo dos conselhos gestores pelo Seminário de Políticas Públicas FORMAD}

\begin{tabular}{|c|c|c|}
\hline Fragilidades do conselho & Consequências & $\begin{array}{c}\text { Possíveis adaptações } \\
\text { apontadas no Seminário de } \\
\text { Políticas Públicas (1997) }\end{array}$ \\
\hline $\begin{array}{l}\text { Forma de composição com } \\
\text { influência de políticos e } \\
\text { outras instâncias }\end{array}$ & $\begin{array}{c}\text { Representatividade implica } \\
\text { em um compromisso mais } \\
\text { pessoal que institucional } \\
\text { o conselho chama para si as } \\
\text { responsabilidades das } \\
\text { decisões e muitos } \\
\text { conselheiros justificam ações } \\
\text { do Executivo } \\
\text { Protagonismo de grandes } \\
\text { organizações ambientalistas } \\
\text { internacionais, em detrimento } \\
\text { das iniciativas locais }\end{array}$ & $\begin{array}{c}\text { Incremento do uso do } \\
\text { espaço do Ministério Público } \\
\text { Argumentação baseada em } \\
\text { evidências científicas, via } \\
\text { participação das } \\
\text { universidades } \\
\text { Tratamento de questões } \\
\text { maiores como } \\
\text { municipalização, } \\
\text { descentralização dos } \\
\text { recursos }\end{array}$ \\
\hline $\begin{array}{l}\text { Dificuldade de } \\
\text { estabelecimento da agenda, } \\
\text { influenciada por demandas } \\
\text { diversas e pouco pertinentes } \\
\text { à funcionalidade do conselho }\end{array}$ & $\begin{array}{c}\text { Dificuldade de } \\
\text { estabelecimento de projetos } \\
\text { Discussão de questões } \\
\text { periféricas, com deficiência } \\
\text { na discussão da execução } \\
\text { orçamentária ou prestação }^{\text {de contas }}{ }^{1} \\
\text { Falta de articulação entre as } \\
\text { entidades representativas } \\
\text { Centralização do poder }\end{array}$ & $\begin{array}{l}\text { Asseguração de conquistas } \\
\text { institucionais } \\
\text { Garantia de políticas e de } \\
\text { sua execução } \\
\text { Avaliação da legislação que } \\
\text { regulamenta os conselhos } \\
\text { Descentralização do poder } \\
\text { hierárquico dentro dos } \\
\text { conselhos }\end{array}$ \\
\hline $\begin{array}{l}\text { Falta de preparo dos } \\
\text { conselheiros }\end{array}$ & $\begin{array}{c}\text { Necessidade de o conselho } \\
\text { ter condições mínimas de } \\
\text { funcionamento (infraestrutura } \\
\text { e apoio técnico) }{ }^{1} \\
\text { Descontinuidade de } \\
\text { participantes }\end{array}$ & $\begin{array}{l}\text { Fórum permanente de } \\
\text { usuários } \\
\text { Atividades de formação de } \\
\text { conselheiros (atenção aos } \\
\text { grupos representados) } \\
\text { Conhecimento sobre } \\
\text { políticas públicas municipais } \\
\text { e estaduais }\end{array}$ \\
\hline $\begin{array}{l}\text { Diversificação na } \\
\text { institucionalidade } \\
\text { participativa }\end{array}$ & $\begin{array}{l}\text { Falta de condições de } \\
\text { participar de apenas um } \\
\text { espaço de participação por } \\
\text { disputa de poder político } \\
\text { entre governo e população } \\
\text { Pluralidade do entendimento } \\
\text { do que são as parcerias }\end{array}$ & $\begin{array}{l}\text { Aberturas para participação } \\
\text { da comunidade } \\
\text { Oportunidade de grupos } \\
\text { minoritários (indígenas, } \\
\text { quilombolas) decidirem } \\
\text { políticas } \\
\text { Abrangência da participação } \\
\text { para âmbito legislativo }\end{array}$ \\
\hline
\end{tabular}

Fonte: FORMAD (2013c; 1997b). 1. Reportado também no Seminário de Conselhos em 2013 (FORMAD, 2013c).

Neste ponto, Mello-Théry (2011) aponta que a compreensão dos nexos entre poder, ambiente e território implica o discernimento de como a sociedade e o 
Estado reagem à evidência da limitação dos recursos naturais e, a partir desse entendimento, como concebem a gestão dos problemas ambientais, entendidos como tal.

A partir das observações dessa autora, é importante ressaltar que, na medida em que os problemas ambientais são reconhecidos de diferentes formas, de acordo com a classe ou a camada social que os identifica, diferentes também serão seus pesos na agenda política, já que sua inserção nela depende de relações de poder e de hegemonias internas da sociedade civil. À medida que se fortalecia a agenda "de baixo para cima", frente à "de cima para baixo", acirraram-se os conflitos e o peso das negociações no contexto de transformação do ambiente derivada da apropriação das reservas territoriais.

Mello-Théry (2011) ainda enfatiza que nas transformações resultantes do território socialmente construído está incluída a dimensão territorial, representando os reflexos do contexto internacional e reafirmada pela noção de soberania nacional. Assim, "a malha ambiental, como malha política, resulta de uma decisão de um poder legitimado" (p. 26). Entendido como bem público necessário para o uso coletivo, o ambiente deve estar sujeito à ação do Estado.

Em verdade, a destituição da gestão ambiental das decisões da sociedade faz parte de um processo de alienação que veremos adiante, trabalhado por Smith (2008): alienar a sociedade civil de seu vínculo com a natureza é elemento constitutivo da produção desta. Um dos vários instrumentos utilizados para essa alienação, como já mencionado, é a separação conceitual do "governo" e do "não governo" quanto à sua legitimidade representativa e decisória. Essa seria uma das formas de privar os cidadãos organizados das decisões, pertinentes ao Estado e ao território, que incidem desigualmente sobre as sociedades.

Subsequente ao Seminário de Políticas Públicas Socioambientais, em sua segunda edição, o Seminário Estadual de Conselhos (FORMAD, 2013c) destinavase à capacitação de conselheiros, uma vez constatada a fraca incidência política destes. Participaram da ocasião 14 organizações ambientalistas do FORMAD, cerca de 80 representantes de $32^{77}$ conselhos de âmbito municipal, estadual e

77 Como expositores participaram representantes do Conselho Estadual de Meio Ambiente (CONSEMA); do Conselho de Defesa dos Direitos da Pessoa Humana (CEDDPH); do Conselho Estadual de Saúde (CES); da Comissão de Erradicação do Trabalho Escravo (COETRAE); do Conselho de Segurança Alimentar (CONSEA); e do Conselho Estadual dos Direitos da Mulher (CEDM). 
nacional. Em todos os conselhos foi diagnosticada a dificuldade de implementação da paridade nas decisões, os poucos recursos financeiros, humanos e estruturais para seu funcionamento, a carência de assessoria técnica para análise e encaminhamento das demandas da comunidade e a fragilidade dos mecanismos de prestação de contas. A utilização das redes foi concebida como estratégica na difusão dos resultados a organizações locadas em regiões pouco acessíveis do estado. No entanto, essa divulgação de resultados, em si, não supera a dificuldade de fazer valer a participação da sociedade civil nos conselhos, os quais decidem sobre as políticas estaduais e nacionais.

Nesse quesito, as ações das redes, nos seus laços de solidariedade e enquanto agentes de mobilização, impulsionaram avanços em discussões sobre a alocação de recursos nos conselhos e o seu papel em políticas de prevenção e de combate de diversas linhas setoriais, direta ou indiretamente ligadas à questão ambiental no Mato Grosso. O entrave apontado por essas redes, no entanto, diz respeito à inabilidade do estado em aplicar os recursos dos conselhos nas ações propostas para as finalidades necessárias, além de outras arbitrariedades na composição dos conselhos. No caso específico da Comissão Estadual de Erradicação do Trabalho Escravo (COETRAE):

O INCRA deveria estar participando, mas não está. Quem indica a representação é o fórum estadual contra o trabalho escravo. Este espaço é de constante enfrentamento e a COETRAE neste atual governo deixou de existir como atuante na incidência de políticas públicas; o ponto crucial, por exemplo, é quando o estado nomeia para a pasta da cultura alguém que está na lista suja do trabalho escravo; conseguimos fazer a pressão para expor isso e foi muito bom. Nossos documentos chegaram à OIT e essa instituição já estava pensando em realizar o seminário de boas práticas na erradicação do trabalho escravo e foi retirado o seminário devido à pressão sobre o governador para que tire a pessoa de ficha suja na pasta da cultura (FORMAD, 2013c, p. 4).

Nota-se, pelos registros dos debates entre os conselheiros e a sociedade civil, o papel da Constituição Federal na inclusão de instrumentos de democracia direta, criando instâncias de controle estatal. Os conselhos e as conferências, as ouvidorias e o orçamento participativo constituem instrumentos desse controle social. A essas possibilidades cabe o caráter deliberativo ou consultivo das decisões, sendo o primeiro mais favorável à paridade de opiniões entre os interessados (FORMAD, 2013c, p. 11). No âmbito do controle institucional atua o Ministério Público, o Tribunal de Contas, as controladorias, etc. No caso dos 
conselhos, aspectos como a proporcionalidade, sua missão e atribuições, e a articulação com outros órgãos, a imprensa e a sociedade civil aparecem como importantes, porém não únicos quando temos em conta que a questão do controle social não pode ficar restrita a um espectro reduzido de instrumentos (FORMAD, 2013c). Adicionalmente, existe uma tendência dos governos mais conservadores em restringir as institucionalidades participativas deliberativas, reclassificando-as como consultivas. O status dessas institucionalidades pode variar ao longo da história democrática estatal brasileira.

É, por isso, necessário retomar as possibilidades ou impossibilidades derivadas da forma como se estabeleceu a Constituição Brasileira de 1988. Sobre o papel desta na definição da relação entre Estado e sociedade, Moraes (2005, p. 145) aponta o fenômeno globalizador do momento histórico de sua elaboração e promulgação, que fez com que a Carta Magna acabasse por perpassar uma diversidade de temas, aprofundando-se em uns e esquivando-se de outros. Como lei maior, a Constituição se apresenta de forma a regular o específico e normatizar genericamente o singular. Atrai, assim, diversos discursos e esforços a diferentes áreas do conhecimento. No que se refere às ideologias geográficas, o autor ressalta que a própria convocação da Assembleia exprimiu claramente as concepções imperantes, expressas pelas regras de eleição de seus membros (aspecto este que também se replica na elaboração das instituições participativas).

A questão da relação entre a sociedade e seu espaço (MORAES, 2005, p. 146-147) é vista de forma que os habitantes são atributos de um país pensado como espaço. Mesmo com recentes atenuantes à sujeição da sociedade ao Estado, claramente manifesta nas instituições participativas, o que é aplicado na prática é, ainda, uma relação em que os seres humanos são "postos como instrumentos da lógica inexorável da expansão territorial dos Estados", com o poder de fato qualificando seres humanos e lugares.

Essa ideia corrobora outro elemento também levantado tanto pelo anteriormente citado MTSD quanto pelo Seminário Estadual de Conselhos, promovido pelo FORMAD: a constatação de que os conselhos ficam mais ou menos fortes dependendo do peso político dos sujeitos participantes. Além da técnica, da questão do planejamento e do financiamento, os conselhos se consolidam como espaços de disputa de hegemonia, sendo a participação social uma tentativa de 
reivindicar o Estado por dentro da institucionalidade deste. Na impossibilidade dessa conquista, há a tendência de essas institucionalidades tornarem-se espaços de legitimação das intenções dos governos.

Portanto, vemos que houve três momentos de ação do FORMAD, em específico: o primeiro deles, referente ao dimensionamento da questão ambiental mato-grossense no panorama mundial (1992-1997); a partir desse reconhecimento, - levantamento e diagnóstico técnico sobre os eixos de atuação priorizados, desenvolvido durante a elaboração e publicação do MTSD (2002-2009); e o terceiro momento (2011-2013), que se caracterizou por ser analítico da conjuntura política ambiental e de participação nessa temática, em âmbito estadual.

\subsection{A diversidade de organizações ambientalistas nos processos decisórios e seus contras}

Para além das potencialidades, faz-se necessário analisar e esclarecer as debilidades, procedimentais e relacionais, pertinentes ao escopo de atuação das redes ambientalistas. Seriam as organizações ambientalistas e suas redes realmente representativas dos anseios das populações marginalizadas? Há corrupção? Há igualdade de poder e de participação internamente nas redes ambientalistas?

A resposta a esses questionamentos também diz respeito à forma como se faz política em um Estado e ao histórico que o precede, já que ele, a sociedade política e a sociedade civil são categorias interdependentes. Assim, o entendimento do que é representatividade, corrupção e hegemonia corresponde a uma base estrutural que eleva um Estado como tal e todas as categorias que com ele se relacionam.

Vimos que, para Moraes (2005), o Estado brasileiro vê e apreende o território antes de reconhecer as sociedades que lhe são inerentes. Nesse caso, o território apreendido pela diversidade socioambiental que perpassa as camadas da sociedade civil se dá em processo inverso, contrapondo-se fortemente ao que prediz o Estado, em movimentações sociais cada vez mais veementes conforme a fragilidade democrática estatal não responde à demanda por um aprofundamento democrático.

Tanto entre governo e povo quanto na relação entre organizações ambientalistas e as diversidades sociais às quais elas se reportam, existe 0 
elemento comum da representatividade que as medeia. Em ambos os casos e também na questão ambiental, a representação política é delicada, sobretudo quando há falta de garantias institucionais, caindo no oposto do fluxo de opiniões e opções políticas que se movem de baixo para cima, em fluxo de modelos e opções políticas "de cima para baixo" (BOBBIO, 1998).

As decisões internas em uma rede de solidariedade podem funcionar segundo o modus operandi estatal e seus representantes podem adotar como conduta a parcialidade e arbitrariedade nas decisões coletivas. A limitação, porém, reside em seu status contestativo originário perante a ideologia dominante. Ou seja, optar por elementos alheios aos representados, baseados em decisões "de cima para baixo" ou em corrupção, ou em busca de uma hegemonia sobre os demais, não auxilia um grupo que se pretende vinculado às bases em suas relações políticas com outras organizações com condutas distintas. O resultado pode ser 0 ostracismo e a perda da confiança em uma teia relacional, ambos prejudiciais à imagem de uma organização ambientalista, podendo levá-la, em longo prazo, à falta de credibilidade perante suas redes relacionais, organizações similares e a população.

Os grupos, social e ambientalmente marginalizados, por isso, tendem a se apropriar dos espaços possíveis por suas experiências e vivências compartilhadas, ou seja, "de baixo para cima". Por meio das negociações entre as organizações ambientalistas e os "nós" que estas conformam nas suas redes, o que se vislumbra é um caminho de soluções que atenda a todas, ou pelo menos algumas, das interpretações de ambientalismo adotadas pelos membros de uma determinada coletividade, dentro de estratégias de apropriação territorial e territorialidades que Ihe concernem. Mesmo com as diferenças epistemológicas ambientalistas ou procedimentais, é por meio das negociações que as redes ambientalistas vislumbram tais objetivos comuns.

É importante ressaltar, no entanto, que mesmo com as distinções das tipologias de ambientalismo das organizações do FORMAD, tratadas no Capítulo 3, a existência de um objetivo norteador comum refuta temas que a ele sejam pouco adaptáveis. Por essa razão, temas como REDD+ e responsabilidade socioambiental pela iniciativa privada, por exemplo, jamais encontraram acordo entre as organizações da rede, mesmo com a ciência desta sobre suas perspectivas distintas de ambientalismo. Isso porque ideias como ecoeficiência e 
ecologismo verde, oriundas da linhagem corporativista - vinculada ao modelo econômico questionado pela rede - não encontram pares possíveis nos nós relacionais do FORMAD, que visa, em linhas gerais, a outros modelos de desenvolvimento econômico. É por isso que temáticas pouco reagentes a esse objetivo geral são amplamente refutadas pelo conjunto das organizações.

Outro aspecto a ser pensado é a sustentabilidade financeira das organizações ambientalistas que conformaram o FORMAD ao longo dos anos. A participação social das bases deu-se historicamente por incentivo financeiro externo. A multiplicidade de interesses e entendimentos do que seriam as metas entre agências financiadoras, agências intermediárias e pontas receptoras ${ }^{78}$ somava-se à polêmica do papel desempenhado pelas organizações, à preocupação dos objetivos dos financiadores externos, à evasão de recursos para interesses pessoais, dentre outras questões.

A margem para diversificação na obtenção de recursos para a sobrevivência das organizações ambientalistas foi minguando à medida que crescia a desconfiança popular sobre sua funcionalidade. $O$ arsenal ideológico para deslegitimação das organizações sociais, ambientalistas ou não, foi, nesse sentido, eficiente. Mantendo a característica falta de clareza de acusações e generalizações, às diversas vertentes organizativas populares foram atribuídos adjetivos diversos, levando-as à incredulidade perante a população.

A mudança nas linhas da política econômica brasileira ao longo da década de 1990 (ABONG, 2010) levou também à mudança, na década seguinte, do foco das agências financiadoras internacionais para outros países, entendidos como prioritários. Com a falta de habilidade em produzir ou buscar novas formas de financiamento, o que se viu foi um esfriamento de muitas organizações e a falência de outras. De um lado, isso implicou o enfraquecimento imediato dos nós relacionais da rede, a relação com redes parceiras e o aumento de hegemonias internas nas redes ambientalistas. Por outro, esses percalços também representaram tentativas de novas formas de fazer política, adaptando os recursos providos pelo governo brasileiro e por outros países às necessidades, e, na reflexão

78 Mello (2006) trata da mesma problemática, porém internamente nos programas governamentais, em especial, o PPG7. 
das organizações das redes, enfraquecidas ou não, de superar os rompimentos ou criar novas alianças.

\subsection{A diversidade de organizações ambientalistas nos processos decisórios e seus prós}

Posteriormente aos levantamentos dos grupos temáticos estaduais, levados diretamente pelo FORMAD no MTSD e nos seminários de avaliação das políticas públicas e dos conselhos, e regionais, conduzidos na parceria com o GTA na Amazônia Legal, o resultado foi o encadeamento de ações entre redes de diferentes abrangências geográficas. No âmbito da agricultura, a ação dessas parcerias impulsionou iniciativas em nível nacional, como o Plano Nacional de Produção Orgânica e Agroecológica (PLANAPO). Porém, medidas prioritárias, como o Programa Nacional de Redução de Uso de Agrotóxicos (PRONORA), sofreram longos processos de estagnação resultantes de disputas em âmbito ministerial.

Internamente, a rede fomentou as iniciativas, o fortalecimento e a autonomia das filiadas e parceiras locais na gestão de ações coletivas, com a finalidade de monitoramento e intervenções propositivas de políticas ambientais. Utilizando-se de ativo intercâmbio de informações, oriundas de fontes próprias ou governamentais, espaços não somente decisórios ou deliberativos - como seminários, debates, marchas, reuniões e mobilizações -, cujos temas sejam de interesse difuso, mas de alguma forma tangentes aos trabalhos desenvolvidos pelas organizações socioambientalistas vinculadas, são focais. A partir de 2011, os eixos de atividades do FORMAD foram reavaliados, passando a compor campanhas de ordenamento territorial (ZSEE/MT), Código Florestal, REDD+, agroecologia, mapeamento socioambiental, contra a privatização de serviços do setor público e os agrotóxicos, entre outras. Destacam-se aí seminários de formação sobre a tipificação da agricultura familiar e sobre formas de incidência para execução do Código Florestal no Mato Grosso e as oficinas sequenciadas de planejamento para incidir no ZSEE.

Existiu e ainda existe uma contrarresposta das elites a essa reestruturação das camadas marginalizadas, tentando reduzir a sua produtividade por boicote à sua atuação política. O entrave à participação nos processos decisórios ambientais deriva da necessidade do processo de produção da natureza e do espaço no 
capitalismo moderno. Estes, por sua vez, são elementos que impelem que as relações sociais de classe (dominantes e subordinadas) se reproduzam. Com isso, as possibilidades de abertura à participação, especialmente na questão ambiental, como vinculada à apropriação territorial, são pouco inclusivas no que se refere à sociodiversidade ligada à biodiversidade. A criação de mecanismos de participação "de baixo para cima" pelo Estado se torna pouco provável, pois sua estrutura é voltada a apaziguar os conflitos das bases.

Nesse ponto, um norteamento claro das clivagens do ambientalismo rumo a um projeto comum, princípio do qual se valem as redes ambientalistas, torna-se um obstáculo à apropriação da natureza, tal como é necessária ao capitalismo. Com todas as arbitrariedades que se pode supor em relação à ação das organizações ambientalistas, o que se vê é que há forte contrarresposta estatal, de forma a absorvê-las aos seus princípios. Quando isso não é possível, a resposta é a coerção. A violência aos atores individuais e coletivos, militantes de meio ambiente e reforma agrária, portanto, se justifica pela necessidade da produção da natureza e do espaço.

As manifestações contrárias a essa estrutura, isto é, a organização em grupos e, finalmente, em redes ambientalistas que problematizam tal sistema, corrompem o processo de alienação ${ }^{79}$ entre ser humano e natureza internamente

79 A primeira observação a ser feita é que o processo de alienação do indivíduo, primeiro como possibilidade e depois como necessidade, se dá a partir da produção visando à troca e não apenas ao uso direto. Nesse processo, a retomada de um raciocínio que inclua o ser humano como parte da natureza recebe diferentes interpretações, a depender das linhagens ambientalistas em voga. $O$ aumento da riqueza social em decorrência da produção de excedentes não é igualitariamente distribuído devido às distinções entre as camadas da sociedade, sendo apropriado pelas classes dominantes (SMITH, 2008). Mais do que isso, grupos marginalizados do processo, como indígenas, quilombolas, agricultores familiares, ribeirinhos, pantaneiros, etc., são deslocados de sua forma de produção e interação com o meio para serem incorporados a esses processos produtivos. A manutenção de uma ideologia geográfica que responda às atuais necessidades da divisão de funções das regiões brasileiras é feita com base nessa produção da natureza. Qualitativamente, essa produção envolve uma alienação. A relação das camadas basilares da sociedade civil com a natureza é impelida a se transformar, de forma que esses grupos, ainda que se relacionem diretamente com a natureza, se alienem de seus próprios produtos. O proprietário do produto está alienado da relação direta e prática com a natureza porque é privado do seu próprio trabalho. Há, entretanto, para a classe trabalhadora (e toda a abrangência das camadas marginalizadas), um embate constante, individual e coletivo, entre a consciência espontânea da experiência diária de trabalho, prática na natureza, e as ideias dominantes difundidas por uma classe igualmente dominante. Essa ideologia, abstrata, parece estar engessada em uma experiência imediata, mas na realidade não corresponde a ela. A produção para a troca, portanto, produz a natureza em escala estendida, pois os seres humanos não somente produzem a natureza imediata de sua existência, mas também toda a natureza social dela (SMITH, 2008). A complexa diferenciação da relação com a natureza, segundo o autor, divide-se segundo gênero, classe social, atividade mental ou manual, atividades de produção e distribuição, etc. Essa unidade da natureza produzida se reproduz de 
e, dependendo de seu sucesso, podem chegar a comprometê-lo. Tal êxito, mesmo que pequeno e pontual, causa preocupação nas elites quando instalado na institucionalidade estatal, que antes era de seu pleno controle. Por um lado, a deslegitimação da ação de tais organizações e redes, internamente originadas ou externamente atribuídas, colabora para levar essas mobilizações ao insucesso. Por outro, blinda-se o Estado através de instituições participativas cuja metodologia de funcionamento, se não deturpa os argumentos das representações da sociedade civil em benefício próprio, relega o esforço das organizações ambientalistas a uma situação de mero apaziguamento de conflitos maiores, em espaços onde há partilha de poder ou simplesmente consulta.

\subsection{O que oferece a institucionalidade do Estado: conjuntura governamental mato-grossense e seu avanço}

O aparente sentimento de isolamento das políticas públicas afetou a autoimagem do FORMAD por um longo período: a baixa autoestima generalizada mostrou-se concomitante à aparente impotência. Esse sentimento, fomentado pelos boicotes no interior das institucionalidades federais e estaduais e pelos cortes orçamentários, é instalado simultaneamente ao período em que a rede alcança seu melhor patamar de diálogo com as bases e com as esferas governamentais, alienando as organizações ambientalistas do papel que haviam conquistado nas negociações relativas ao meio ambiente, após décadas de aprendizagem. A desmotivação das redes ambientalistas (não só o FORMAD), no entanto, mostrou sua potencialidade quando as organizações viram que, sozinhas, eram menos produtivas politicamente do que conformadas em redes. Sobre as possibilidades de informação aos grupos sociais:

O modus operandi [das redes] acho que sempre foi produzir o conhecimento técnico, vamos fazer uma análise técnica e aí a gente vai via Ministério Público e tenta alterar o processo ou a formulação da construção de uma política, por exemplo, via uma análise técnica. (...) agora a gente tá vendo que a análise técnica, a via técnica não é a única. A gente tem que ser mais de pressão política mesmo. Então a

maneira elaborada. A generalização da produção de mercadorias e as relações de troca unem grupos de pessoas anteriormente isoladas em um conjunto social, por meio de uma institucionalidade que se desenvolve para o mercado e o Estado (SMITH, 2008, p. 65). A sociedade como distinguível da natureza emerge através da agência humana, entre primeira e segunda natureza. 
capacitação, seja de outras entidades e aí o FORMAD tem um papel importante porque através dele a gente consegue fazer essa capacitação, ou seja, além da capacitação você ter a mobilização também é outra via interessante, porque a mobilização é a forma que você consegue ter um posicionamento político. Então você tem uma via técnica que é importante pra você fazer uma discussão com os órgãos técnicos e com o Ministério Público. Também te dá mais argumentos pra você ter uma posição, mas a capacitação também é importante de forma a você disseminar essa informação, mobilizar outros grupos e também criar o movimento político por trás daquilo que você quer mudar. Então a gente tá trabalhando com essa visão. (...). As redes assumem um papel pra gente muito mais importante do que a gente via no passado. Porque as redes são a forma que a gente faz essa mobilização e a capacitação e ao mesmo tempo a rede ajuda como forma de proteger uma instituição também. Então se você quer atacar uma rede é muito mais difícil do que atacar uma instituição. ${ }^{80}$

As possibilidades dentro do formato de política estatal e sua abertura à participação da sociedade já demonstravam claros sinais de inoperabilidade, expressa pelo bloqueio dos governos às solicitações populares e pelo silenciamento destas demandas. No ano de 2010, por exemplo, a aprovação do projeto de lei que instituiria o Zoneamento Socioeconômico e Ecológico de Mato Grosso se deu 18 dias antes do Seminário sobre o Zoneamento de Mato Grosso: Planejamento Territorial em Foco, o qual seria realizado pelo Instituto Centro de Vida (ICV) em parceira com as Secretarias de Estado de Planejamento (SEPLAN) e de Meio Ambiente (SEMA), o Instituto Socioambiental (ISA) e o FORMAD. Na ocasião, inviabilizada pela aprovação, seriam discutidas entre diversos atores as intersecções entre o Código Florestal Brasileiro e o ZSEE de Mato Grosso, e como essas obscureceram a dimensão dos impactos negativos que o ordenamento territorial poderia provocar em longo prazo.

Paradoxalmente, propagaram-se no mesmo período iniciativas de promoção da accountability, por meio da transparência dos dados governamentais, cuja integridade e qualidade são medidas por órgãos como o MPF e a CGU. Considerando os rankings do MPF e o Índice de Transparência, podemos fazer algumas inferências sobre a qualidade dos dados gerais e ambientais. Sinteticamente, podemos adiantar que se percebe uma evolução na qualidade da divulgação da informação de dados fiscais, mas uma estagnação na qualidade informacional (validação de informações e tratamento estatístico) sobre o ambiente. 
Tendo como parâmetro a necessidade de bases de dados acessíveis à população, com o intuito de fomentar sua participação e promover o diálogo entre governos e sociedade, analisamos os principais índices de transparência dos governos municipais. Apesar de suas variáveis não versarem especificamente sobre questões ambientais, sua estrutura como um todo permite a averiguação das possibilidades de ciência da população sobre as principais políticas em desenvolvimento.

Ao longo do estudo, percebemos que a possibilidade de acesso a informações das instituições do Estado é um elemento importante na elaboração das estratégias de negociação das OSCA e, por conseguinte, das redes ambientalistas.

As análises efetuadas pelo MP, CGU e ICV apontam para um crescente fortalecimento das estruturas de acesso à informação pela população entre os anos de 2015 e 2016, como podemos averiguar nos Gráficos 25, 26 e 27. Esse processo de fortalecimento veio se consolidando desde os anos anteriores, com o advento da Lei 12.527/11, que regulamenta o direito constitucional de acesso às informações públicas.

O Gráfico 25 aponta a análise dos portais de transparência municipais. Vemos que, em uma escala de 0 a 10 , cerca de $50 \%$ dos estados permanecem abaixo da média dos requisitos básicos pertinentes a portais de transparência considerados na avaliação ${ }^{81}$.

81 Itens avaliados: 1) O ente possui informações sobre transparência na Internet?; 2) O site contém ferramenta de pesquisa de conteúdo que permita o acesso à informação?; 3) Há informações sobre a receita nos últimos seis meses, incluindo natureza, valor de previsão e valor arrecadado?; 4) As despesas apresentam dados dos últimos seis meses contendo: valor do empenho, valor da liquidação, valor do pagamento?; 5) O site apresenta dados nos últimos seis meses contendo: íntegra dos editais de licitação, resultado dos editais de licitação (vencedor é suficiente), contratos na íntegra?; 6) O ente divulga as seguintes informações concernentes a procedimentos licitatórios com dados dos últimos seis meses: modalidade, data, valor, número/ano do edital, objeto?; 7) O site apresenta: as prestações de contas (relatório de gestão) do ano anterior, o Relatório Resumido da Execução Orçamentária (RREO) dos últimos seis meses, o Relatório de Gestão Fiscal (RGF) dos últimos seis meses? 8) O site possibilita a gravação de relatórios em diversos formatos eletrônicos, abertos e não proprietários, tais como planilhas e texto (CSV), de modo a facilitar a análise das informações?; 9) Existe indicação precisa no site de funcionamento de um Serviço de Informações ao Cidadão (SIC) físico? Há indicação do órgão? Há indicação de endereço? Há indicação de telefone? Há indicação dos horários de funcionamento?; 10) Há possibilidade de envio de pedidos de informação de forma eletrônica (e-SIC)?; 11) Apresenta possibilidade de acompanhamento posterior da solicitação?; 12) A solicitação por meio do e-SIC é simples, ou seja, sem a exigência de itens de identificação do requerente que dificultem ou impossibilitem o acesso à informação, tais como: envio de documentos, assinatura reconhecida, declaração de responsabilidade, maioridade?; 13) No site está disponibilizado o registro das competências e 


\section{Gráfico 24. Índice de Transparência dos governos municipais por estado da Federação. Primeira Avaliação (2015) e Segunda Avaliação (2016)}

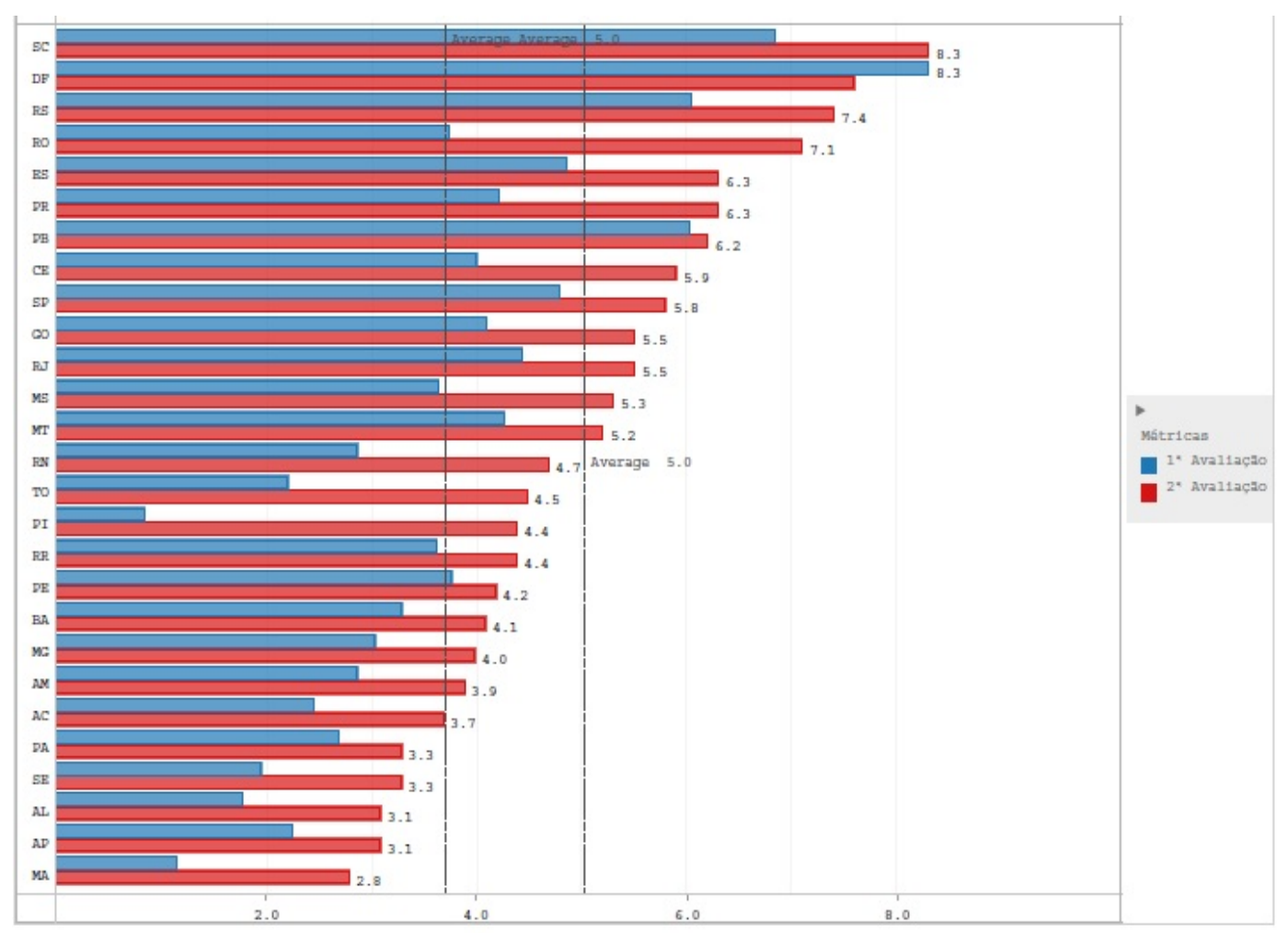

Fonte: Ministério Público Federal (2017).

Na segunda avaliação, feita em 2016, a transparência de informações dos municípios do estado do Mato Grosso apresenta desempenho mediano em relação à média geral dos demais estados.

Já o Gráfico 26 demonstra a qualidade dos portais de transparência dos governos estaduais, parâmetro no qual o Mato Grosso se apresenta acima da média da pontuação e, tendo como referencial o desempenho dos demais estados, também posição mediana na primeira avaliação $(8,0$ em 2015) e acima da média, na segunda avaliação $(9,8$, em 2016).

Outra forma de análise é possível por meio do Índice de Transparência ${ }^{82}$, que considera estados e capitais e possui um rol mais amplo de questões sobre a

estrutura organizacional do ente?; 14) O portal disponibiliza endereços e telefones das respectivas unidades e horários de atendimento ao público?; 15) Há divulgação de remuneração individualizada por nome do agente público?; 16) Há divulgação de diárias e passagens por nome de favorecido e constando data, destino, cargo e motivo da viagem?.

82 Ferramenta disponível em indicetransparencia.com, com séries históricas anteriores a 2015. 
gestão orçamentária e os convênios. Sendo um diferencial, analisa, ainda que brevemente, dados de outros poderes, a saber: Ministério Público, Tribunal de Contas, Judiciário e Legislativo. Na Amazônia Legal, o que se nota é um vazio de provimento de informações municipais nesses quesitos (Figura 16). É importante ressaltar que nem a atividade das organizações ambientalistas, sejam elas da rede FORMAD ou GTA, ou qualquer outra, foi capaz de reverter a situação de baixa disponibilidade de dados dos municípios em diversos setores.

Ainda sobre a análise dos portais de transparência governamentais, algumas organizações ambientalistas se dedicam ao estudo da qualidade de informações ambientais providas pelo estado do Mato Grosso. Apesar de não contemplarem a ampla gama de variáveis, inferem sobre questões de transparência passiva e ativa das plataformas de informação ambiental. Entende-se transparência passiva aquela informação que não é divulgada por iniciativa do estado em plataformas virtuais, mas sim solicitada pelo cidadão, mediante cumprimento da Lei de Acesso à Informação (LAl).

$\mathrm{Na}$ transparência ativa, o estado se propõe a divulgar informações ambientais por meio de seus portais de comunicação com o cidadão. Nesse quesito, temos que, em contraste com a realidade dos demais estados da Amazônia Legal, o Mato Grosso tem expandido sua proatividade em divulgação de dados ambientais de relevante interesse à sociedade, favorecendo o controle social nesse tema (Gráfico 27). 


\section{Gráfico 25. Índice de Transparência dos governos estaduais por estado da Federação. Primeira Avaliação (2015) e Segunda Avaliação}

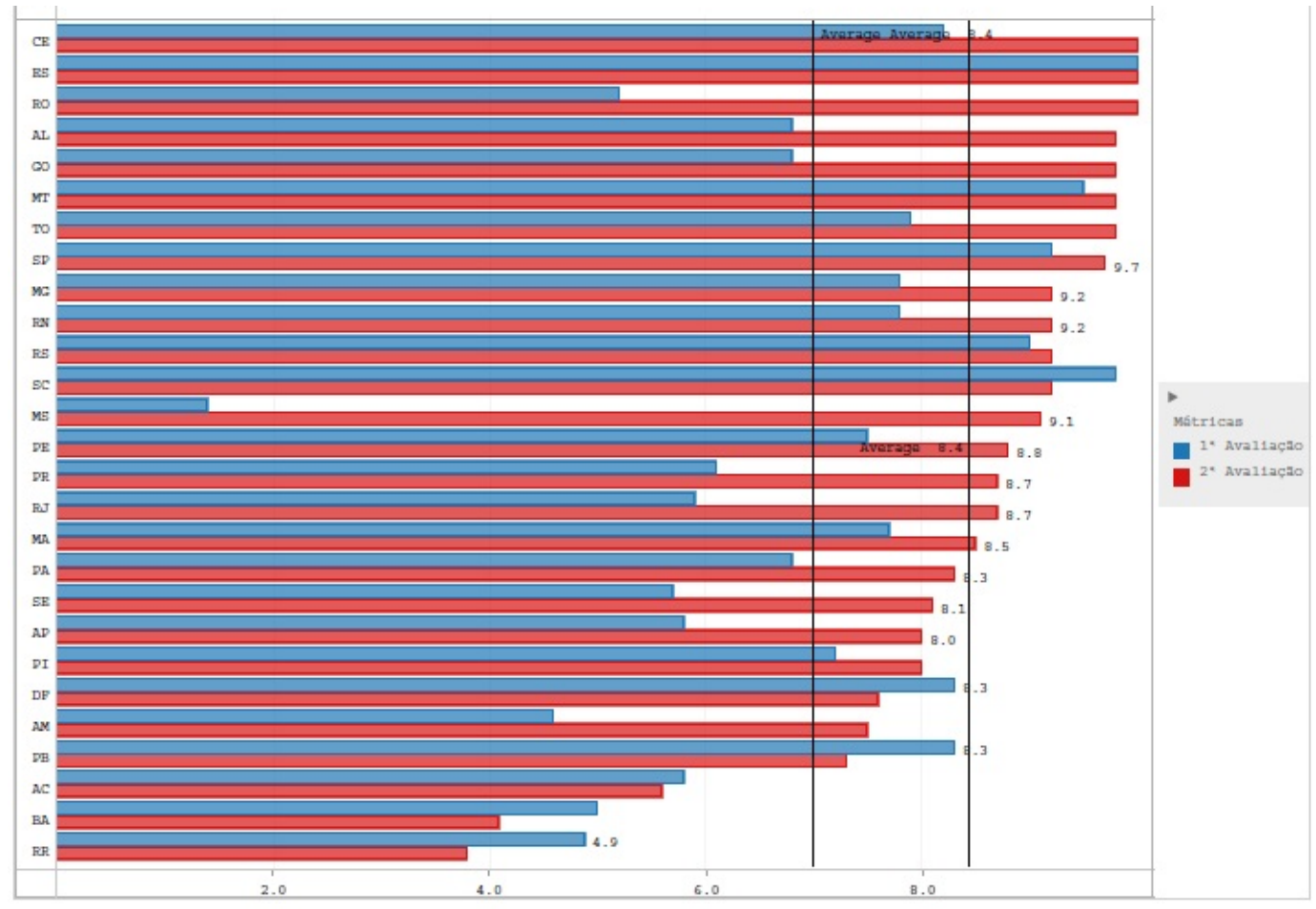

Fonte: Ministério Público Federal (2017).

Em termos de transparência passiva, a grande maioria dos estados provê as informações solicitadas nos tempos previstos. Tocantins (75\%), Acre (60\%) e Mato Grosso (33\%) tiveram desempenhos medianos, sendo o último em razão do atraso no provimento das informações em relação ao tempo estipulado de retorno. $O$ Amapá teve o pior resultado (0\%), por não ter nem LAI regulamentada, nem dispor de Serviço de Informação ao Cidadão (SIC).

A experiência prática da autora deste trabalho na busca de estatísticas e informações sobre questões ambientais aponta para outros problemas. Há uma obsolescência dos dados providos pelas bases das três esferas governamentais. 
Figura 16. Escala Brasil Transparente: Panorama dos Governos Municipais - Amazônia Legal (Segunda Avaliação)

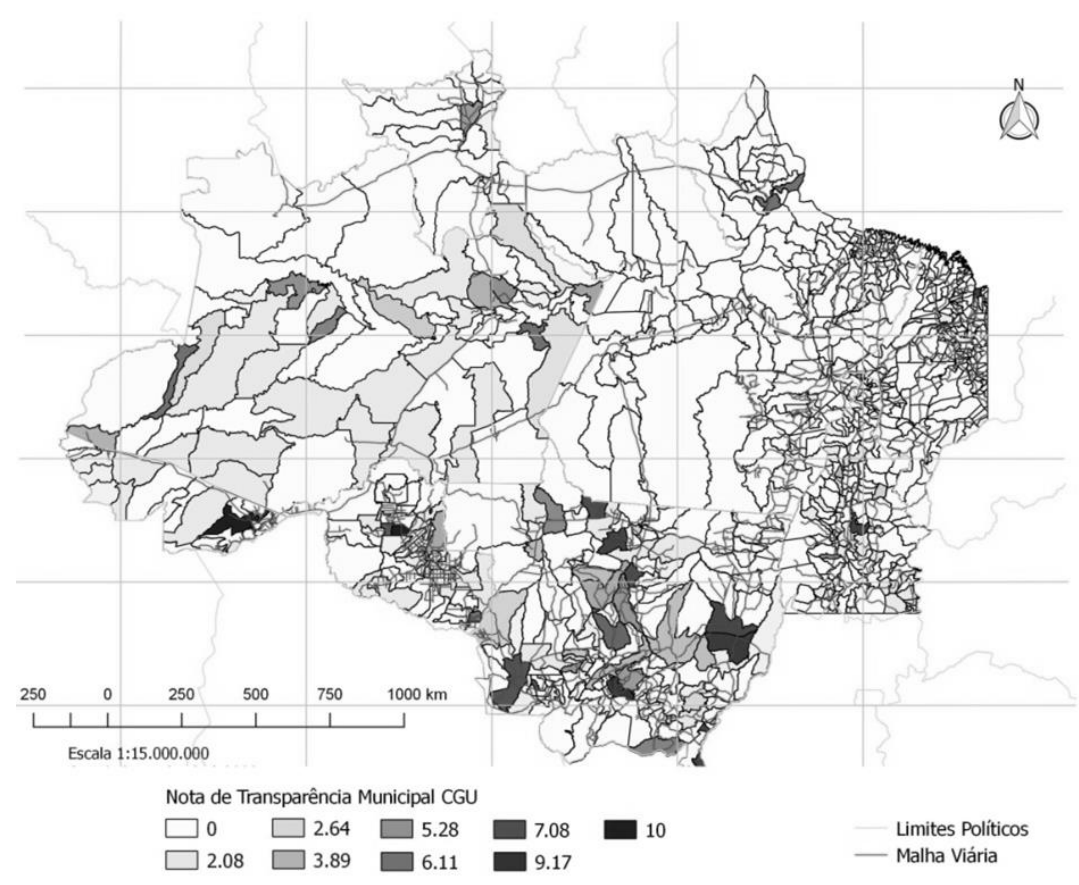

Fonte: Controladoria-Geral da União (2017). Elaboração própria.

Gráfico 26. Índices de transparência ativa (\%) das informações ambientais por estado e agenda prioritária

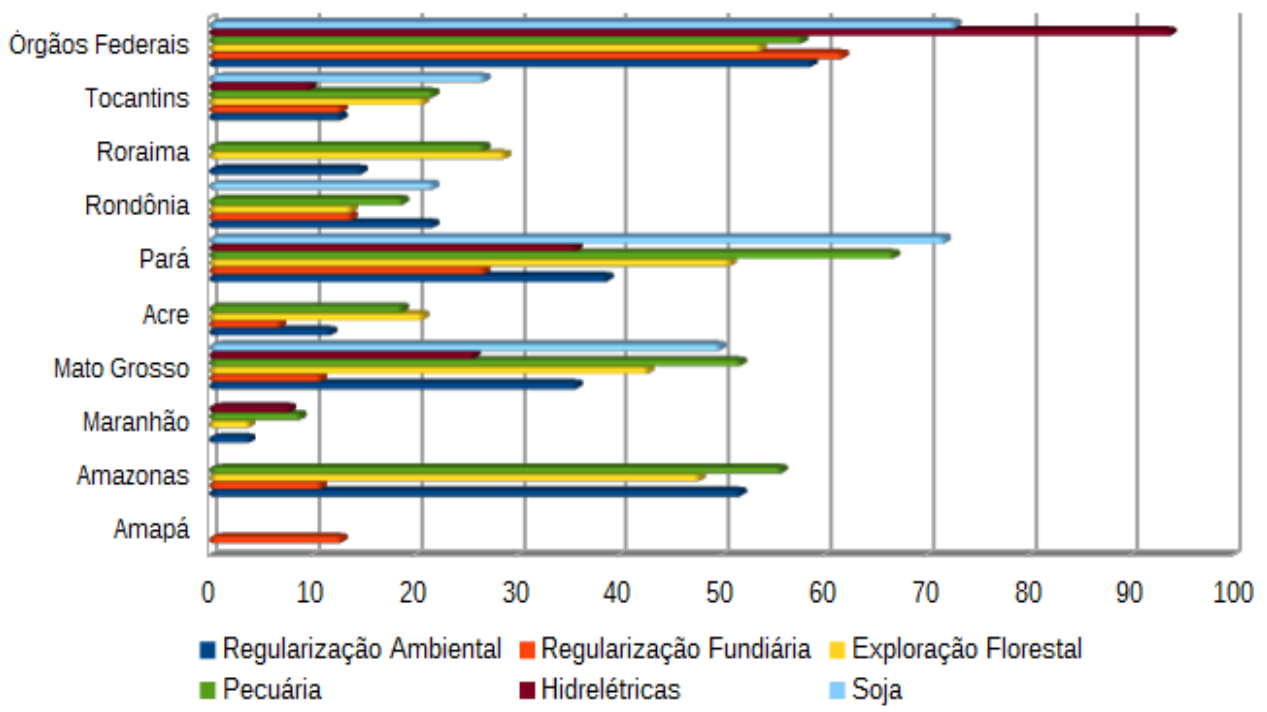

Fonte: ICV (2015). Elaboração própria. 
Igualmente, nessas bases, há uma infinidade de links quebrados ou inexistentes sobre muitos temas pertinentes aos eixos temáticos considerados na rede FORMAD. Mesmo as bases existentes são pouco intuitivas na sua navegação, dificultando o trabalho de busca por não especialistas em uso e produção estatística.

Por isso, não somente se faz necessário democratizar os processos decisórios, mas também o processo de apropriação territorial que os acompanha, em todas as variáveis que os concernem (informação, mediação e programa), de forma equânime entre os atores envolvidos. 


\section{CAPÍTULO CONCLUSIVO - REFLEXÕES SOBRE AS OPORTUNIDADES POLÍTICAS E O AMBIENTALISMO AMAZÔNICO}

Uma série de experiências participativas na questão ambiental, pós-1988, foram analisadas ao longo deste trabalho. A partir delas já se torna possível elencar uma série de lacunas, mas também de possibilidades, ao papel dos diferentes ambientalismos na política ambiental. A participação cidadã organizada sobre as políticas setoriais é um dos principais elementos constitutivos da democracia que permite mensurá-la quantitativa e qualitativamente.

Diversos mecanismos e critérios têm sido desenvolvidos para atender a essa demanda. $O$ aperfeiçoamento dos regimes está então relacionado à capacidade de intervenção e ativismo das diferentes camadas da sociedade civil, em igualdade de condições (DIAMOND E MORLINO, 2004). O termo "participativo", então, torna eufêmica uma condição que deveria ser, instrumental e ideologicamente, constitutiva na estrutura das instituições do Estado ou mesmo condição sine qua non para este. Diversos autores de diferentes áreas do conhecimento, dentre eles Scardua e Bursztyn (2003), defendem que a clareza da proposição política na construção de políticas públicas, desde sua elaboração à sua avaliação final, e a accountability deveriam ser princípios respondidos pela institucionalidade do Estado.

No intervalo entre as décadas de 1980 e 2000, o Brasil passou de um país com baixa propensão associativa e poucas formas de participação da população de baixa renda a um dos países latino-americanos com melhor estrutura de transparência de dados e participação de todas as camadas sociais (AVRITZER, 2008) nas decisões do Estado. Esse incremento, no entanto, não se estende aos estados e municipalidades, onde a oferta de informações ao cidadão ainda carece de validação das informações, amplitude e consistência de dados, como visto no Capítulo 5 (IBGE, 2016). A hierarquia de como se estabelecem as relações de poder, remontada na origem da concepção de Estado e não somente no histórico de colonização brasileira, pode ser um elemento importante no entendimento dos porquês da dificuldade na participação.

Considerando todas as restrições e gargalos à participação das diversas formas de organizações ambientalistas, faz-se necessário ver como o Estado 
brasileiro consolidado em seu momento atual, a forma como se pensa a territorialidade na região amazônica e as instituições participativas se refletem em aprofundamento democrático nas decisões ambientais.

Como capítulo conclusivo, discutimos as formas de participação relativas às questões socioambientais considerando a infraestrutura da participação na qual se inseriu o FORMAD desde 1992, sua forma e seu desenho. Usamos três parâmetros para tecer a discussão: a análise de Avritzer (2008) sobre desenhos participativos, a "escada de participação cidadã", de Arnstei (1969), e a análise da efetividade das instituições participativas (PIRES, 2011). Relacionamos essa argumentação ao abordado nos capítulos anteriores, a saber: 1) a construção de uma ideologia geográfica na concepção do ambientalismo brasileiro e a estruturação do poder que a permite; 2) as possibilidades de construção de territórios e territorialidades atribuídos a cada ator sintagmático; 3) a pluralidade epistemológica no interior das redes ambientalistas e a concepção do papel dos atores, segundo a atribuição da ideologia dominante sobre estes; 4) os embates nas arenas decisórias; e 5) o arcabouço técnico-científico e de negociação das organizações ambientalistas em rede.

\subsection{Oportunidades políticas}

A circunstância da participação social nos processos políticos setoriais da contemporaneidade é possível quando satisfeitas determinadas condições. A qualidade dos governos representativos inerentes ao Estado e a relação entre a representatividade "governamental" e a "não governamental", no aspecto do valor que as palavras agregam a estes universos, são dois elementos centrais. No caso do primeiro, Mill (1841, p. 47) considera como condições imprescindíveis para a sua aplicabilidade: 1) a disposição do povo em receber o governo representativo; 2) a disposição e capacidade para a sua preservação; 3) a disposição do governo de cumprir com as obrigações e as funções que lhe são impostas. A representatividade governamental e a não governamental deveriam atender a tais condições para sua manutenção.

$\mathrm{Na}$ medida em que "a natureza e os recursos naturais estão, reiteradamente, presentes na conceituação de espaço geográfico e território", cabe explorar os pontos de contato destes com a PNMA, como propõem Steinberger e Abichared (2013, p. 127). Nessa relação é que também se estabelecem as 
potencialidades de projeção da diversidade de atores nas decisões referentes à apropriação do território. Em linhas gerais, podemos dizer que a participação, tendo em conta esses três elementos (a saber: política ambiental nos níveis governamentais, território e participação), estaria sustentada sobre dois pilares: a igualdade política, ou seja, o reconhecimento do direito de os cidadãos expressarem seus interesses e preferências nas decisões; e a autodeterminação, expressa pela capacidade dos cidadãos em conceberem suas escolhas. Os efeitos da participação, no entanto, nem sempre refletem a unanimidade de opiniões ou são democráticos (MESQUITA, 2016).

As representações do espaço são apreensíveis a partir da relação entre política e cultura na formação nacional. Na luta ideológica de uma conjuntura concreta, há leituras do espaço que se hegemonizam, influindo nas representações coletivas de uma nação (enquanto ideologia do Estado burocrático centralizado), as quais orientaram a produção de seu território (MORAES, 2005).

No caso brasileiro, é possível pensar que o entendimento de nação enquanto ideologia do Estado não foi rompido com a iminência e os pactos federativos que descentralizaram suas estruturas de poder após 1988. Como elemento para essa observação, evidenciou-se durante o regime militar que a eleição indireta de governadores e prefeitos de capitais e em cerca de 150 cidades de médio e grande porte Ihes oferecia pouca autonomia fiscal e militar, as quais estavam sobre o controle do Exército Nacional (ARRETCHE, 2000). Relações dessa natureza caracterizam Estados unitários, onde o poder político nas localidades é uma delegação do governo central (RIKER, 1987).

Já a partir dos anos 1980, a democratização e a descentralização fiscal na Constituição de 1988 se propuseram a alterar a natureza das relações intergovernamentais. Além do voto popular direto, governadores e prefeitos passaram a ter mais autonomia administrativa e sobre os recursos fiscais. Os municípios foram declarados entes federativos autônomos, sendo os prefeitos as autoridades soberanas em suas circunscrições. No entanto, os passos dados ao pacto federativo mantiveram o peso das decisões orçamentárias e militares nas mãos do Governo Federal. De fato, o que a autora do presente trabalho identifica, é que se estabeleceu uma forma de vetores de forças no federalismo brasileiro, no qual Governo Federal e municipalidades funcionam em sincronia ditada pelas elites agrárias históricas, que têm na relação entre Estado, natureza e território a chave 
para a manutenção de sua obsoleta, mas ainda eficiente, forma de centralizar o poder.

Apesar do advento das mudanças legais e reestruturações políticas, detalhadamente explicadas por Steinberger e Abichared (2013), persiste a perda de espontaneidade no ordenamento territorial imposto pelo capitalismo tardio, exacerbando o apetite territorial do Estado brasileiro (MORAES, 2005). Assim, como principal ator na organização territorial, sua preponderância se revela pela centralização das variáveis equacionais da apropriação territorial. Explica-se, pois, a distância entre as possibilidades de intervenção sobre o território revelada no Capítulo 2, quando da análise entre a experiência da rede ambientalista FORMAD e o PLP mato-grossense.

O Estado, e o conceito de nação a ele vinculado, estrutura a sociedade sob os signos da subordinação, violência (guardando semelhança com as prévias sociedades escravocratas e seu legado) e dependência. Nesse aspecto, à forma como foram apropriados historicamente os espaços absolutos e abstratos e tal como está consolidado o território concreto, se sobrepõem territorialidades concretas e abstratas prévias, anteriores ou contemporâneas ao estabelecimento das elites agrárias. Portanto, em resposta à coesão identitária e de solidariedade de concepção territorial - e, por extensão, aos recursos naturais e sua distribuição - estabelecida na classe dominante, emergem coesões, específicas das classes subalternas, contrárias a essa concepção. Essa dicotomia de interpretações foi evidenciada ao longo deste trabalho, em especial nos Capítulos 4 e 5.

A diferença na forma e finalidade da apropriação dos espaços no Brasil e a inviabilidade da representatividade e inclusão política tal como elas se estabelecem na organização do Estado são, portanto, o cerne da problemática socioambiental atual, ao menos no que se refere ao escopo de ação da rede ambientalista FORMAD, caso central deste estudo. Derivam linhas do socioambientalismo que se reportam a este ou aquele processo de apropriação (Capítulo 3), tentando responder à questão central de como pensar a política ambiental brasileira para que satisfaça tais demandas. As contestações a esse modelo de Estado e seu legado de dependência e subordinação foram e ainda são contidas pela violência, como demonstrado no Capítulo 1.

Como essas linhas de socioambientalismo também são construções derivadas de um processo de formação ideológica, hegemônica, a relação entre as 
camadas da sociedade civil e sua sinergia com essas linhas também determina seu poder no processo decisório final.

O capitalismo, como forma de organização da produção, da distribuição e do consumo de bens, desde os seus primórdios, procurou ampliar os mercados mediante a incorporação de forma pacífica ou violenta de populações e de territórios ao seu sistema de produção, e assegurar a existência de sistemas políticos de elaboração e de execução de normas que garantissem sua expansão e seu funcionamento pacífico. (GUIMARÃES, 2008, p. 155).

Assim, a inibição dos grupos sociais marginalizados e as linhagens ambientalistas a eles associadas não se dá somente por limitações de acesso a recursos financeiros para seu desenvolvimento, mas também por condições de arranjo territorial, relacional, político e ambiental pertinentes à institucionalidade do Estado. Isso se dá, territorialmente, porque é frequente que esses grupos venham de um histórico de destituição de seus territórios; em sua relação com o Estado, pois se conformam estratificações entre aqueles que tomam decisões, quem sobre elas pode opinar e quem as recebe (os representados); e ambientalmente, pois a dinâmica que esses grupos estabelecem com seu ambiente não é prioritária no jogo de poderes, interesses e agendas governamentais.

Em países de capitalismo retardatário como o Brasil, as classes dominantes assumem o comando dos aparelhos estatais (MORAES, 2005, p. 99). Sinérgica e complementarmente a essa ideia, Guimarães (2008) interpreta o Estado como "o controle do sistema de normas e de instituições que definem e garantem as características fundamentais do sistema de produção e que, não importa a razão, consagram certos privilégios, essenciais para as classes dominantes". Portanto, o agir territorial tangível à multiplicidade de atores, como abordado no Capítulo 2, segundo as possibilidades do governo estadual mato-grossense e a rede ambientalista FORMAD, também depende da conjuntura supracitada para sua manutenção ou transformação.

Refletir sobre a abertura ou o fechamento das oportunidades de inserção política segundo essas características institucionais é, apesar de possível, problemático do ponto de vista teórico, como sublinha Saunders (2013). Isso porque a simplificação em uma categoria ou outra se soma ao fato de que essas tipologias de oportunidades podem se alterar ao longo do tempo. Porém, a mesma autora aponta que a realidade política, observada por ela nas experiências no Reino Unido e também percebida pela autora da presente tese, tende a pender para 
formas mais fechadas ou mais abertas à ação das organizações e redes ambientalistas segundo certas características das instituições. Nas tipologias abertas, assume-se que a ação ambientalista recebe atenção nas negociações, resultando em ganhos políticos. Já os Estados fechados apresentariam características centralizadas, corruptas e totalitárias, impedindo o acesso à participação (SAUNDERS, 2013), ou adaptando uma estrutura pseudoparticipativa, a qual dá a impressão de que a participação ocorre e é igualitária entre as classes sociais, porém não o é. Diante das impossibilidades, as formas de organização social passam a considerar as formas convencionais de participação política como um gasto de tempo e energia. São as oportunidades políticas disponíveis nessa estrutura que direcionam as ações das organizações (Figura 17).

Resumidamente, a proposição de Saunders é de que os Estados relativamente abertos, ou seja, descentralizados e que encorajam a participação, possivelmente produzirão mobilizações moderadas, com grande número de participantes. Já o Estado aberto ideal levaria à inexistência de protestos, já que não haveria necessidade de reclamação extrainstitucional. Contrastando com essa idealização de estruturas abertas estariam os Estados fechados. Estes são altamente centralizados e desencorajam ou mesmo reprimem a participação política. Oferecem terrenos mais hostis para tal participação, diminuindo a mobilização das organizações.

No entanto, esse modelo não explicaria as diferentes reações do Estado à diversidade das organizações ambientalistas, multifacetadas em suas tipologias e eixos norteadores, por exemplo, mais ou menos radicais às agendas governamentais. Portanto, não é suficiente também para explicar suas redes.

Para sanar essa limitação, Saunders (2013) lança mão da crítica ao que chama de versões fortes e fracas da teoria de estrutura de oportunidades políticas. Aprofundando a noção da possibilidade de influência de cada ator, demonstrada no Capítulo 2, Saunders defende que o contingente ${ }^{83}$ de oportunidades políticas se refere às variáveis que medem a presença e ausência de alianças políticas, divisões com as elites e tolerância política à contestação (KITSCHELT, 1986;

83 As variáveis das oportunidades políticas podem ser contingentes ou estruturais, e seriam determinadas pelo número de partidos políticos, segundo a natureza do sistema eleitoral, pelo grau de dependência entre legislativo e executivo, pelas ações no território demandadas pelos grupos de interesse e pela capacidade do Estado em estabelecer as políticas que incidirão sobre o território segundo as necessidades apontadas pela mobilização social. 
KRIESI, 1995; ROOTES, 1998). Tendo em conta as diversas linhagens de ambientalismo, no geral, os processos de tomada de decisão tenderão a ser mais abertos para grupos moderados do que para contrapartes mais radicais, já que estes, que apontam por mudanças mais estruturais, são reprimidos pelo Estado (TARROW, 1998), como vimos no Capítulo 1.

Uma forma de entender as oportunidades políticas é que elas seriam oferecidas segundo a qualidade das instituições formais, e que as redes ambientalistas responderiam a essas oportunidades dadas à participação, comportando-se de forma semelhante (LENTIN, 1999; XIE E VAN DER HEIJDEN, 2010; KITSCHELT, 1986; KRIESI, 1995). Essas oportunidades seriam mais abertas a determinadas vertentes de organizações ambientalistas e mais fechadas a outras, dependendo da agenda governamental.

A capacidade de um Estado forte e centralizado de regular os mercados e um sistema judiciário independente seriam qualidades positivas para que um Estado possa implementar as políticas exigidas pelas demandas sociais. No entanto, um Estado forte nem sempre é benéfico para estas, já que tanto pode tomar uma ação rígida contra os interesses de organizações e movimentos, quanto é capaz de concretizar políticas favoráveis a estes.

As estruturas políticas, portanto, fazem parte de um ambiente social e político no qual as redes ambientalistas devem negociar, sendo um dos muitos fatores que moldam a incidência e as formas das organizações ambientalistas (TARROW, 1998). Nesse sentido, o grau de policiamento e de repressão é importante medida das oportunidades políticas disponíveis para redes e movimentos ambientalistas (DELLA PORTA, 1995, p. 80).

Diante da evidência do fechamento de oportunidades políticas na realidade mato-grossense, e quiçá em várias experiências amazônicas, observamos a reticência constante de grande parte das organizações do FORMAD em se inserir em espaços de conselhos gestores, como os Conselhos de Meio Ambiente, nas três esferas federativas, por receio de como se conformará a negociação e se haverá coerção. O ambiente social (So), nesse caso, é o elemento no qual as redes ambientalistas encontram maior vulnerabilidade para sua ação. 
Instaura-se, pois, o convite à reflexão quanto à (não) analogia entre conceitos como participação e democracia. A primeira, como valor normativo essencial à segunda, não se consolida como dada a partir do momento em que se promulga a democracia, mas é um desenvolvimento a partir da forma como esta se constitui em um Estado. Mesmo as democracias mais consolidadas estariam passíveis de um aprofundamento, sendo a participação um dos seus elementos mais essenciais.

\section{Figura 17. Características de abertura e fechamento de oportunidades políticas pelos Estados}

\begin{tabular}{|c|c|c|c|}
\hline \multirow{2}{*}{$\begin{array}{l}\text { Estrutural ou } \\
\text { "permanente" }\end{array}$} & $\begin{array}{c}\text { Grau de } \\
\text { centralização }\end{array}$ & Descentralizado & Centralizado \\
\hline & $\begin{array}{l}\text { Configuração } \\
\text { do poder }\end{array}$ & $\begin{array}{l}\text { Representação } \\
\text { proporcional }\end{array}$ & Totalitário \\
\hline \multirow{6}{*}{$\begin{array}{l}\text { Contingente ou } \\
\text { "temporária" }\end{array}$} & $\begin{array}{l}\text { Capacidade de } \\
\text { policymaking }\end{array}$ & Igualitário & Corrupto/não igualitário \\
\hline & Cultura política & Forte & Fraca \\
\hline & $\begin{array}{l}\text { Divisões da } \\
\quad \text { elite }\end{array}$ & Dividida & Não dividida \\
\hline & $\begin{array}{l}\text { Estabilidade } \\
\text { eleitoral }\end{array}$ & Instável & Estável \\
\hline & $\begin{array}{l}\text { Controle/tolerância } \\
\text { a protestos }\end{array}$ & Tolerante & Repressivo \\
\hline & $\begin{array}{c}\text { Alianças e } \\
\text { contramovimentos }\end{array}$ & $\begin{array}{c}\text { Alianças entre } \\
\text { elites }\end{array}$ & Sem alianças \\
\hline $\begin{array}{l}\text { de oportunidade } \\
\text { política }\end{array}$ & $\begin{array}{l}\text { Indicador de } \\
\text { abertura }\end{array}$ & $\begin{array}{l}\text { Política aberta } \\
\text { idealizada }\end{array}$ & $\begin{array}{l}\text { Política fechada } \\
\text { idealizada }\end{array}$ \\
\hline
\end{tabular}

Fonte e elaboração: SAUNDERS (2013). Tradução própria.

Portanto, a análise que geralmente se faz sobre a institucionalidade da participação, baseando-se prioritariamente na oferta de tais espaços pelo Estado, é, em si, insuficiente. A existência de institucionalidades participativas ou de arenas políticas com diversificação de atores é conformada por uma série de polarizações de forças e valores historicamente construídos. Com isso, são muitas as variáveis que condicionam tanto quem participa nas decisões pertinentes ao ambiente quanto quem influi efetivamente sobre o território com essa finalidade. O quesito participação, portanto, pode apresentar uma face perversa quando o poder de 
decisão não é distribuído equanimemente entre as camadas da sociedade que usufruem dos biomas e ecossistemas para sua manutenção. A heterogeneidade da distribuição de poder é omitida da legitimidade atribuída a esses espaços. $O$ resultado é que se atribui, arbitrariamente, vozes e palavras aos grupos sociais excluídos que, em realidade, permanecem calados. Assim, surgem e se proliferam audiências e consultas públicas e outras deliberações sobre licenciamentos ambientais que juram ser fiéis às opiniões da população e de seus representantes presentes nas reuniões.

A educação política da sociedade como um todo pressupõe, em si, em um envolvimento na vida pública por meio da cooperação dos indivíduos. É através dela que os cidadãos se percebem pertencentes a um contexto social, reconhecem seu papel no Estado no qual estão inseridos e podem analisar as transformações de seus locais e territórios imediatos como resultado de um processo de decisões políticas (DIAMOND \& MORLINO, 2004). Sendo uma dimensão procedimental da democracia, a participação não se restringe à qualidade da escolha de quem está autorizado a governar, objetivo das eleições, mas consiste na participação ampla, inclusiva e extensiva de partidos políticos, em organizações sociais, nas políticas públicas, na accountability dos governantes, no ordenamento territorial e nos diversos pontos de contato entre as políticas ambientais e o território.

Para Cunha (2013) e Capella (2004), três elementos poderiam desencadear mudanças na agenda ambiental do governo, incorporando ou refutando questões: o humor nacional, as forças políticas das organizações que permeiam a política, e mudanças de governo ou dentro do governo (alterações de pessoas nos órgãos ou da estrutura governamental), no Congresso Nacional e nas configurações partidárias (CUNHA, 2013, p. 43). O cenário de possibilidades políticas de participação às organizações e suas redes ambientalistas depende de como esses fatores se configuram e reconfiguram, segundo as condições já mencionadas de possibilidades de influência nas decisões, transparência, dentre outras.

A atribuição da designação "não governamental" às redes de solidariedade ambientalistas e a ausência de um status jurídico desempenham duplo papel no rol de possibilidades internas dessas quanto à sua intervenção sobre a natureza e o território: positivo, pois as coloca em posição de representatividade sem vista para vantagens, políticas ou econômicas; negativo, porque seu funcionamento depende 
de quem tenha um status jurídico que as permita angariar recursos. Portanto, quem dispõe de número cadastral jurídico (CNPJ) pode ter vantagens sobre as demais organizações ambientalistas.

\subsection{Institucionalidade ambiental, participação e o pacto federativo}

Antes que entremos no mérito da questão do pacto federativo aplicado à questão ambiental, cabe retomar alguns aspectos históricos relativos à divisibilidade brasileira, aspecto mencionado no Capítulo 1. Uma vez próximos a essa reflexão, é importante pensar nas populações que acompanharam a trajetória histórica, na consolidação do povo brasileiro, em uma abordagem instrumental para os aspectos aqui tratados ${ }^{84}$.

Araújo (2015), avaliando o histórico cartográfico do Mato Grosso em relação à Amazônia Legal, levanta aspectos sobre a construção e função do estado no cenário nacional, importantes para que se entenda a sua intransponibilidade que se reflete, dentre outros aspectos, na institucionalidade da participação, a começar pela simbologia presente no seu nome. Mato Grosso não é, em termos geográficos, "nem mato e nem grosso" (CORREIA FILHO, 1969). É o nome do desconhecido e da dificuldade de incorporação do interior do País, ainda hoje marcante. O Mato Grosso é a barreira que existe entre o "Brasil" e a "Amazônia", ainda mitificada. O nome também é simbólico na construção e função territorial do estado. Como barreira, antes virtual e hoje política, para Araújo (2015) o Mato Grosso não foi nem conquistado, nem descoberto: foi desenhado como fronteira a partir do momento em que Portugal se viu obrigado a pensar nas divisas da colônia. Nesse processo, se consolidou igualmente a importância dos caminhos e eixos viários, demonstrados nas cartografias exploratórias da região no período colonial.

No que se refere às características populacionais e identitárias, Bitoun et alli (1995), discutindo os efeitos das migrações na Amazônia, apontam as alterações sociais e ambientais advindas do assentamento dos migrantes nordestinos após 1870, com predominância baiana em toda a extensão amazônica e uma concentração maranhense na sua divisa com o Pará e ao longo da Rodovia Transamazônica (BR-230). Já as migrações provenientes do Paraná, Rio Grande

84 A brilhante análise de Darcy Ribeiro sobre "O povo brasileiro" é leitura imprescindível para o completo entendimento das reflexões aqui postas. 
do Sul, Espírito Santo e São Paulo se estabeleceram sobre as extensões que hoje se destacam como expoentes do agronegócio no Mato Grosso e em Rondônia. Esses fluxos migratórios se deram entre as décadas de 1970 e 1980 e um fluxo menor na década de 1990 (THÉRY e MELLO, 2009), e tinham como objetivo não só a colonização, mas também a promessa da exploração agrícola.

Os reassentamentos dos migrantes nordestinos e, principalmente, a forma como se deu a migração sulina nas novas localidades criaram conformações que ora se mesclaram, ora tiveram prevalência sobre os sistemas ecológicos amazônicos (BITOUN et alli, 1995). O argumento do potencial agrícola amazônico não resolveu a estrutura fundiária anterior e aprofundou os problemas de desigualdade no campo com o advento do modelo agroindustrial de produção. Uma participação forte de baixo para cima depende da existência de uma sociedade civil coesa, processo dificultado quando é intensa e constante a atividade de migração, emigração ou transferência de grupos no território (como acontece com as etnias indígenas).

O fluxo populacional na região é, portanto, um dos fatores que podem também vir a dificultar o estabelecimento ou a continuidade das organizações sociais de base. Sem paradeiro definitivo, as populações excluídas política e economicamente, em constante situação de mobilidade, estão sempre desagregadas. Quando há, a criação de coletivos ou a adesão a grupos já estabelecidos é desestruturada pelo aparelho repressor do Estado e pelas elites agrárias. $O$ desdém da classe dirigente e das elites agrárias, estas bastante coesas desde o Império, evidenciam-se já nos manuscritos de Anchieta, em seus relatos sobre o iminente povo brasileiro, excluído dos planos da metrópole, como mostra o fragmento:

O segundo ponto é que os filhos dos Portugueses nascidos no Brasil eram tratados com desdém: faltos de engenho, diz o Autor [José de Anchieta] p. 37, afeiçoados aos costumes dos indios (sic) diz [José de Anchieta] p. 70. Cousas semelhantes diz elle (sic) em suas cartas, e repetem os contemporâneos.

Este ponto, -o desdem (sic) pela terra, o desdem (sic) aos naturaes, mazombos como então os chamavam em oposição aos reinoes (sic), - é capital em nossa história, e si quizermos (sic) definir em poucas palavras o periodo que começa com o descobrimento de Cabral e remata com conquista do Maranhão, nem um ha tão caracteristico. Neste periodo que se pode chamar transoceanico, de nosso ponto de vista particular, ou, segundo a classificação genial de Ratzel, período (sic) da distribuição peripherica, é elle que tudo domina, tudo explica e tudo systematisa. [a distribuição dos homens pode, segundo a conformação do território que habitam, ser apanhada no seguintes schema (sic): I. Distribuição em 
massa: a) distribuição cohesiva, por exemplo os Allemães entre o Rheno e o Elba; b) distribuição central, exemplo os M gyares do Danubie, os Makoloko no Zambese médio; c) distribuição peripherica, exemplo os Semitas ao N. e E. Da Africa, os Malaios na ilha do Archipelago (sic) malaio; d) distribuição transversal, exemplo os Lapões das montanhas Scandinavas; e) distribuição salteada, exemplo os Allemães a E do March e do Oder, os Indios nos Estados Unidos, os Yao no territorio (sic) do Nyassa, os Chinezes no archipelago (sic) malaio II. A distribuição isolada, na qual a separação pelo espaço dissolvem a cohesão do povo. Os melhores exemplos offerecem em toda a terra as raças commerciaes, como Judeus, Armênios, Arabes na Africa, etc., e os imigrantes (sic) que na America (sic) e alhures vivem de mistura com indígenas. Ratzel. Anthropo-geographic oder Grundzuege der Anwendung der Erdkunde auf die Geschichte, p.114-115 Stuttgart, 1882]. (ABREU, 1931, p. 395).

Os eventos que se sucederam na construção do Brasil atual guardam profundas semelhanças com as funcionalidades reportadas no período histórico imperial e republicano. Isso tem consequências sobre como se materializou o território, como foi construída a territorialidade, como o estado do Mato Grosso se inseriu no projeto nacional, como ele se relaciona com a Amazônia Legal e como se estabelecem as relações socioambientais e políticas no recente momento democrático. As circunstâncias históricas impeliram os grupos que ali se desenvolviam, marginalizados desde sempre e sempre à própria sorte, a estabelecerem um tipo de relação com a natureza, de acordo como se consolidou o território.

O advento do pacto federativo e dos seus instrumentos de organização dos níveis governamentais, como já dito sobre a própria Federação, não chegou a superar as heranças relativas à questão ambiental. Assim, temos que, paralelamente a uma estrutura de poder, oligárquica, se associa uma funcionalidade das regiões brasileiras, sistema no qual o Mato Grosso responde por ser um celeiro de produção voltado à agroexportação, epicentro do eixo das frentes pioneiras rumo aos rincões amazônicos, uma vez esgotada grande parte de suas reservas minerais.

No pacto federativo, os governos estaduais e municipais assumiram funções de gestores de políticas públicas, ou por iniciativa própria, ou por expressa imposição constitucional. Cada esfera governamental, na adesão à transferência de atribuições segundo suas condições, deve considerar os custos e benefícios derivados da decisão de assumir a gestão de uma dada política e avaliar os recursos administrativos e fiscais para desempenhar tal tarefa. Os acordos nesse sentido nunca são simples. Em um Estado que prima pela profunda desigualdade 
social e de acesso a recursos naturais, as diferenças reproduzidas nesses setores encontram, na descentralização entre os níveis federativos e na distribuição das responsabilidades entre eles, condição para serem aprofundadas. Com as dificuldades que surgem nessa descentralização, torna-se difícil a atribuição das (ir)responsabilidades, já que cada nível federativo tende a atribuir o dever a ser cumprido a outro, eximindo-se de culpa.

$\mathrm{Na}$ área social, Arretche (2000) aponta que as desigualdades vindas da variação dos níveis de riqueza econômica dos estados e municípios podem alterar o escopo da descentralização (p. 58), diferenciando o processo de transferência de atribuições. Ainda quanto à atribuição social, nas municipalidades com porte populacional maior a 50 mil habitantes, supostamente com estrutura financeira e administrativa suficientes para adesão à transferência de responsabilidades e atribuições, Arretche não encontrou correlação entre a habilidade municipal para assumir a gestão de políticas sociais e uma maior adesão dos municípios. Isso não significa, entretanto, que a dinâmica de receitas entre governos estaduais e municipais não influa nas decisões, para cada região do País, pela municipalização ou não da gestão.

Igualmente, analisando as taxas de filiação a organizações sociais, Arretche (2000) também não encontrou evidências que demonstrem que esse fator seja determinante para que governos locais se sintam decisivamente pressionados a assumir a gestão de programas sociais. Tendo em conta essa observação, especificamente no caso deste estudo, retomamos as reflexões sobre as oportunidades políticas de fazer valer as questões socioambientais tidas como prioritárias, demonstradas no Capítulo 3. Mesmo com ampla distribuição das organizações e sua conformação em redes socioambientalistas, a permeabilidade dos níveis administrativos do Estado às demandas das organizações, sobretudo subalternas, ainda é baixa.

Os pactos federativos são apontados como pouco eficientes para a melhoria da gestão local. Isso porque as prefeituras devem criar uma série de fundos municipais e conselhos nas diversas áreas (saúde, ambiente, educação, etc.), onerando o município, sobrepondo funções e perdendo eficiência e eficácia da máquina administrativa.

O amadurecimento dos acordos entre União, estados e municípios, segundo Arretche (2000), depende de estratégias de indução eficientemente 
conduzidas, desenhadas e implementadas para o sucesso das tentativas de pacto federativo. Para a autora, os requisitos de engenharia operacional para a política, o legado das políticas prévias e as regras constitucionais podem gerar incentivos para uma decisão local de adotar a descentralização. O processo de transferência das atribuições, nesse sentido, deveria permitir a superação desses obstáculos. A assunção de funções de uma determinada política depende de requisitos como os atributos institucionais que ela demanda, os custos operacionais decorrentes da sua gestão e as dificuldades à transferência de funções derivadas do legado de políticas prévias e das prerrogativas legais estabelecidas constitucionalmente (ARRETCHE, 2000).

Por outro lado, Faoro (1995) e Kugelmas (1986) ressaltam que há de se considerar que o federalismo assimétrico influiu na formação do pacto federativo brasileiro, já que as grandes assimetrias nas relações de poder permanecem irresolutas.

O pacto federativo, como um pacto com base territorial, reporta-se ao componente ambiental, ainda que a aplicabilidade do primeiro na descentralização das responsabilidades sobre a questão ambiental só tenha sido reconhecida em 2011. De Carlo (2006) aponta a deficiência do SISNAMA em estabelecer cooperações e coordenação entre as distintas esferas administrativas. Apesar de instituído há mais de 30 anos, faltava ao SISNAMA, ao menos até 2011, uma articulação e estruturação que the que permitisse a colaboração entre os entes federativos. Com o advento da Lei Complementar 140/2011, foram fixadas normas nos termos dos incisos III, VI e VII do caput e do parágrafo único do art. 23 da Constituição. Essas diretrizes orientam a cooperação entre a União, os estados, o Distrito Federal e os municípios "nas ações administrativas decorrentes do exercício da competência comum", no que se refere à proteção do meio ambiente. Para harmonizar políticas e ações administrativas, os entes federados podem se valer de instrumentos como consórcios públicos, convênios e acordos de cooperação técnica, comissão tripartite nacional, comissões tripartites estaduais e comissão bipartite do Distrito Federal, fundos públicos, privados ou outros instrumentos públicos e delegação de atribuições e da execução de ações de um ente federado a outro (BRASIL, 2011). O monitoramento da efetividade de cada instrumento deve servir de objeto de estudo ao longo dos anos consecutivos ao estabelecimento da lei, ainda que não pertença ao escopo de análise deste trabalho. 
É importante ressaltar, no entanto, que, além de todas as questões levantadas sobre o histórico do Estado brasileiro, o problema federativo passa por uma discussão sobre uma melhor distribuição ou alocação dos recursos tributários, apontados no Capítulo 1 deste trabalho.

O Novo Código Florestal representou outra mudança na legislação ambiental, que descentraliza poderes e obrigações para estados e municípios, dispondo do Cadastro Ambiental Rural (CAR) como instrumento para a contenção do desmatamento ilegal, um dos seus mais importantes mecanismos. Esse cadastro, de responsabilidade dos estados, tem demonstrado ser pouco eficaz no controle do desflorestamento, segundo o avaliado em mais de 49 mil propriedades no Mato Grosso e Pará após a adesão dessas ao cadastro. Ainda que não tenham ocorrido cortes imediatamente após o registro, pequenos desmatamentos foram cometidos, decorrentes da confiança dos proprietários de que não haveria multas. O problema foi detectado em $11 \%$ das propriedades no Mato Grosso e 48,5\% no Pará (GIRARDI, 2017). Os estudos que apontaram tal descumprimento também contaram com a realização de entrevistas a proprietários nesses estados, os quais desconsideram como desmatamento o corte realizado em áreas abaixo de mil hectares. A maior parte dos desmatamentos ocorreram em áreas com CAR menores de 10 hectares (51\% no Mato Grosso e 61\% no Pará).

Tanto na Lei Complementar 140/2011 quanto no Código Florestal enquanto exemplos de descentralização do poder entre os entes federativos na questão ambiental -, faz-se necessário atentar para como estão distribuídos os recursos (MENDES, 2013), para a reivindicação dos recursos e sua disponibilidade, em termos de quem recebe e para que são recebidos, e para os gastos públicos, se estão coerentemente compatíveis e bem utilizados pelo agente público, de forma a atender as demandas de todos os estratos da sociedade civil, em determinado município, estado ou região.

No que concerne a essas preocupações do MTSD, elucidado no Capítulo 5, sobressai-se a percepção, por parte das organizações, da inoperabilidade das instâncias governamentais mais próximas na solução dos impasses ambientais. $\mathrm{Na}$ ocasião da formulação do módulo estadual do Projeto Brasil Sustentável, as organizações se reportaram ao Governo Federal na esperança de terem suas demandas atendidas, uma vez saturadas as teias relacionais de negociação entre a rede ambientalista, o estado e os municípios. Também nas indefinições do ZSEE, 
o FORMAD buscou apoio institucional junto ao Ministério Público e à CNZEE, já que seus reclames eram pifiamente atendidos pelo governo estadual. Mesmo com uma pressão política por meio de organizações e redes ambientalistas na solução dos problemas e conflitos e com uma legislação mais rigorosa quanto aos crimes ambientais, descentralizando e chamando à responsabilidade os devidos entes federativos, existe uma baixa capacidade de atendimento a essas demandas.

Os mecanismos de participação cidadã em nível local são uma das particularidades brasileiras, concomitantes ao estabelecimento da democracia representativa (TRAJAN, 2016, p. 17). Uma vez consolidados os detalhamentos das responsabilidades dos níveis da Federação sobre a questão ambiental, mediante a PNMA e demais normativas posteriores, as decisões políticas e os mecanismos de intervenção a decisões políticas deixaram de ser exclusivamente de técnicos e dirigentes dos ministérios. Os cidadãos passaram a participar dos processos decisórios municipais diretamente ou por meio de representantes, sobretudo organizações sociais. Em escala nacional, as atuações nas localidades se desdobraram em participações na discussão em conferências nacionais, conselhos, ouvidorias, fóruns e mesas de diálogo.

\section{Quadro 22. Abrangência da atuação das organizações da sociedade civil}

\begin{tabular}{|c|c|c|c|c|c|c|c|}
\hline Categoria & $\begin{array}{l}\text { Atuação na } \\
\text { comunidade }\end{array}$ & $\begin{array}{l}\text { Atuação } \\
\text { municipal }\end{array}$ & $\begin{array}{l}\text { Atuação em } \\
\text { mais de um } \\
\text { municipio } \\
\text { do mesmo } \\
\text { estado }\end{array}$ & Estadual & $\begin{array}{l}\text { Mais de um } \\
\text { estado }\end{array}$ & Nacional & Internacional \\
\hline \multicolumn{8}{|c|}{ ATIVIDADES-FIM } \\
\hline $\begin{array}{c}\text { Ass ociações Patronais, Profissionais e } \\
\text { Sindic at os }\end{array}$ & 3 & 42 & 17 & 19 & 3 & 12 & 2 \\
\hline Educação, lazer e cultura & 11 & 51 & 11 & 10 & 3 & 8 & 5 \\
\hline Desenvolvimento e Defesa de Direitos & 19 & 51 & 7 & 9 & 3 & 6 & 4 \\
\hline Religião & 16 & 32 & 13 & 7 & 3 & 9 & 17 \\
\hline Outros & 19 & 55 & 7 & 6 & 1 & 6 & 4 \\
\hline \multicolumn{8}{|c|}{ PORTE } \\
\hline Nenhuma pessoa remunerada & 23 & 49 & 7 & 7 & 2 & 5 & 5 \\
\hline De 1 a 9 pessoas remuneradas & 12 & 46 & 12 & 10 & 2 & 9 & 8 \\
\hline De 10 pessoas remuneradas ou mais & 12 & 47 & 11 & 10 & 3 & 9 & 6 \\
\hline \multicolumn{8}{|l|}{ 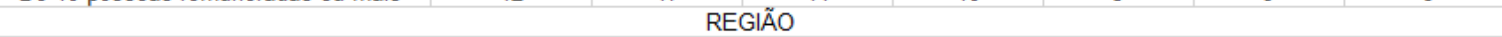 } \\
\hline Nordeste & 20 & 49 & 7 & 9 & 2 & 6 & 7 \\
\hline Sudeste & 17 & 46 & 10 & 7 & 3 & 9 & 6 \\
\hline Sul & 13 & 49 & 13 & 11 & 2 & 5 & 5 \\
\hline Norte / Centro-Oeste & 13 & 41 & 9 & 11 & 1 & 10 & 10 \\
\hline
\end{tabular}

Base: 3.546 organizações sem fins lucrativos. Por questões de arredondamento, a soma dos resultados pode não totalizar 100\%. Fonte e elaboração: CETIC, 2017.

É possível dizer, com base no Quadro 22, que a importância das municipalidades após o pacto federativo influiu no padrão da abrangência de 
atuação das organizações. Apesar de ser identificada uma tendência de que instituições participativas municipais visam, em realidade, mais ao acesso aos fundos municipais do que à participação das diversidades sociais (étnicas e de classes), centrar-se-á no comportamento das organizações - não somente ambientalistas, mas também dos demais setores - nas municipalidades. Nesses termos, há uma tendência de concentração de atuação nos municípios ou em mais de um município ainda maior do que nas comunidades, onde a influência política sobre os governos é menor. O porte das organizações de escopo municipal também tende a ser maior, segundo a amostragem nacional. Na região aqui considerada (Mato Grosso e sua abrangência na Amazônia Legal), nota-se uma maior distribuição na abrangência espacial das organizações, talvez até mesmo pela influência das redes ambientalistas nessa propagação, ainda que persista a tendência de adesão às municipalidades. É plausível, então, que o sentimento de pertencimento à localidade, a realidade compartilhada (inclusive nas experiências relacionais com os aparelhos do Estado) e a territorialidade dos grupos nessas localidades facilitem a coesão social em torno de questões territoriais e ambientais.

É, portanto, pertinente a afirmação do Capítulo 3 sobre o desenvolvimento dos nós das redes entre organizações que compartilham a mesma localidade, no caso, a municipalidade. Assim, a estrutura federativa de distribuição dos poderes pode condicionar a forma de organização social, que responde da mesma forma, segundo as possibilidades locais ou regionais. As dinâmicas referentes aos aspectos tocados pelo pacto federativo, como padrão aplicado ao território, condicionam um rol de possibilidades de ação e atuação das organizações ambientalistas.

Uma segunda explicação para essa distribuição das organizações no Quadro 22 está na restrição orçamentária e de recursos humanos que levam a uma menor abrangência espacial. Assim, focar-se nas localidades seria não só uma opção política, mas uma necessidade orçamentária.

Considerando essa informação e contrastando essa tendência com a Figura 8 (Capítulo 3), é possível inferir também que, apesar de as ferramentas disponíveis para o fluxo de informações entre os nós de redes como o FORMAD e - GTA sejam restritas (disponibilidade de dados ambientais, infraestrutura de comunicação e transporte, etc.), a rede conseguiu encontrar, nos mecanismos possíveis, uma boa comunicabilidade entre os nós, aumentando a escala de sua 
atuação. Isso pode ter sido importante para que os momentos de influência política, por meio da solidariedade entre as organizações de tais redes, tenham sido frutíferos em sua história.

\subsection{Pacto federativo, níveis decisórios e pluralidade de interesses no ambientalismo}

Quando questionados sobre a adesão das bases sociais aos processos decisórios, muitos membros de redes ambientalistas mencionam a dificuldade de trazer as populações excluídas politicamente envolvidas ao processo. Diversas, e muitas desconhecidas, são as razões para a baixa adesão da população em temas que, aparentemente, seriam de seu interesse, produzindo mobilização.

Já mencionamos a habilidade do Estado brasileiro em, por meio de uma ideologia dominante, manter submissa uma população com base no trabalho antes compulsório, hoje extenuante e exaustivo -, na manipulação midiática e na violência. Porém, outros elementos podem ser trazidos à baila da discussão, quando se trata da dimensão do controle ideológico nos vastos rincões do País: a manutenção de populações retirantes.

Em termos de representatividade, permanece sendo problemático o fluxo populacional dentro de um estado como condição à mobilização e organização social em prol de temáticas ambientalistas. O Censo Populacional do IBGE (2010), transcrito em mapeamento por Théry (2017, no prelo), mostra que em todo o vetor que cruza Mato Grosso e Pará predomina população de não naturais do município. Com as ondas migratórias, então, o Mato Grosso desenhado de Araújo (2015) continua cumprindo seu papel de fronteira. Esta - se não política, ideológica divide o Brasil, isolando a Amazônia Legal em uma zona tampão composta por uma população socialmente vulnerável. A "distribuição isolada, na qual a separação pelo espaço dissolve a cohesão do povo (sic)", de Abreu (1941), mostra, assim, sua face mais sinistra: a separação para sobrevivência.

A coerção às formas de organização social que se estabelecem mesmo sob tais condições é uma estratégia secundária de silenciamento, posterior à desagregação dos grupos. Atualmente, a associação da imagem da atuação de tais organizações sociais com o vandalismo é procedimento corriqueiro nas mídias de massa. 
Nesse panorama, a institucionalidade da participação encontra outra dificuldade. Tal foco acirra a pressão sobre os atores coletivos ambientalistas nas localidades (os nós das redes) por parte dos atores hegemônicos. Saunders (2013), nesse sentido, aponta como sendo inexequível contar com macro aspectos estruturais dos marcos institucionais - e dos produtos das relações de poder orientadas à resolução de conflitos sobre os bens públicos, ou seja, a polity (FREY, 2000) - para incorporar comportamentos e demandas de esta ou aquela organização social que emergem como únicas vozes contestatórias às hegemonias.

Outro aspecto a ser considerado é a representação presuntiva das lideranças das organizações socioambientalistas que pode vir a surgir em relação aos seus representados, geralmente grupos étnicos, de reivindicação de direitos de diversidade sexual e populações tradicionais. Nesse caso, então, as organizações ambientalistas formadas perdem uma característica que Ihes deveria ser inerente: a aproximação de indivíduos cujas aspirações e demandas são compartilhadas entre todos nas suas vivências cotidianas, o que as elevaria a um tipo de organização que visa a mudanças, mas sempre baseada no princípio do reconhecimento mútuo das necessidades a serem reivindicadas. Essa representatividade, baseada na intermediação, é discutida por Gramsci (2002) quando da formação da intelectualidade orgânica, externa à classe que representa, dotada de conhecimentos técnicos e científicos dos quais seus representados não são dotados. No caso específico das redes ambientalistas, esses dois perfis de organização são identificados e mantêm interação constante.

Essa intermediação entre grupos excluídos e Estado se daria porque, dadas as condições, a institucionalidade estatal não seria alcançada por esses grupos e suas organizações. $O$ centro de atenção sobre a legitimidade deixa de ser sobre a relação entre as organizações e suas bases e passa a ser entre as organizações e o Estado. Trajan (2016) e Houtzager e Lavalle (2010) apontam a semelhança desta relação com a dos sindicatos e partidos políticos com suas bases. Ademais, há uma tendência a que organizações se aproximem de agências governamentais, bem como líderes ou partidos políticos.

Frente a essa diversidade de interações e suas possíveis consequências, também há uma reação no âmbito das redes ambientalistas estudadas neste trabalho. A interação e os laços de solidariedade também servem de controle entre as organizações que conformam os nós relacionais. Assim, no contexto de atuação, 
monitoram-se quais os laços com líderes, partidos ou governantes que podem comprometer o todo da malha que conforma a rede.

Tendo em conta a trajetória da rede ambientalista FORMAD, como exemplo de outras redes que tiveram percurso semelhante, é possível dizer que o caminho por elas percorrido se deu a partir do reconhecimento de suas necessidades em relação ao todo das demandas ambientalistas (aspecto tratado no Capítulo 5) para uma atuação dentro dos espaços de deliberação estatal, em todos os seus níveis e segundo os preceitos do pacto federativo, aplicados à política ambiental.

A Figura 18 ilustra, dentre todas as formas de institucionalidade participativa oferecidas pelo Estado, aquelas às quais o FORMAD demonstrou maior sinergia e alinhamento ao longo de seu período de atuação.

Caminhando por essas veredas, Mello-Théry e Théry (2016) e Trajan (2016) apontam que, em âmbito nacional, 56\% dos municípios brasileiros dispunham de conselhos ambientais em 2009. Neles, a falta de um formato institucional bem definido para o funcionamento abre precedente para que haja, em sua dinâmica, grande influência dos governos estaduais e federais (TRAJAN, 2016). Nessas composições também podem ocorrer, como de fato já ocorrem e são apontados em diversos fóruns das redes ambientalistas, favoritismos a estes ou aqueles grupos preponderantes, o que retira da proposta de descentralização política idealizada o componente da representatividade da sociedade civil nos espaços decisórios. Existem registros de conselhos cujos membros são escolhidos diretamente pelo prefeito e instruídos a não levantarem questões, garantindo somente a transferência de verbas federais (TRAJAN, 2016; GOHN, 2001; COELHO, 2004; COELHO E VERÍSSIMO, 2004).

No que diz respeito ao grau de descentralização da política ambiental no Mato Grosso, a estrutura organizacional ${ }^{85}$ básica e setorial da Secretaria de Estado do Meio Ambiente (SEMA), a qual visa à implementação das políticas públicas em meio ambiente, inclui as seguintes diretorias de unidades desconcentradas,

85 De acordo com a Lei Complementar 214, de 23 de junho de 2005, Lei Complementar 220, de 29 de setembro de 2005, Lei Complementar 266, de 29 de dezembro de 2006, Lei Complementar 280, de 11 de setembro de 2007, Lei Complementar 332, de 10 de outubro de 2008, Lei Complementar 354, de 07 de maio de 2009, Lei Complementar 383, de 19 de janeiro de 2010, Lei Complementar 506, de 11 de setembro de 2013, Lei Complementar 520, de 26 de dezembro de 2013, Lei Complementar 522, de 30 de dezembro de 2013, Lei 8.366 e Lei 8.367, de 13 de setembro de 2005, Lei 8.370, de 10 de outubro de 2005, Lei 8.429, de 28 de dezembro de 2005, Lei 8.483, de 18 de maio de 2006 e Lei 9.878 , de 07 de janeiro de 2013. 
localizadas nos municípios de Barra do Garça, Juína, Rondonópolis, Sinop, Tangará da Serra, Alta Floresta, Guarantã do Norte, Aripuanã, Vila Rica e Juara.

Já os conselhos ambientais municipais, análogos à função do CONAMA e CONSEMA, possuem uma maior distribuição entre os municípios do estado. Eles têm, essencialmente, uma composição que busca a igualdade numérica, incluindo representantes do poder público e da sociedade civil organizada. Essa composição pode ser bipartite - poder público (municipal, estadual e federal) e outros segmentos (empresarial, sindical, academia, entidades ambientalistas, etc.) - ou tripartite - poder público, setor produtivo (empresarial e sindical) e entidades sociais e ambientalistas.

O Conselho Municipal de Meio Ambiente assessora o Poder Executivo municipal - a Prefeitura, suas secretarias e o órgão ambiental municipal - nas questões relativas ao meio ambiente. Nos assuntos de sua competência, é também um fórum para se tomar decisões, tendo caráter deliberativo, consultivo e normativo. Caberia ao conselho: propor a política ambiental do município e fiscalizar o seu cumprimento; analisar e, se for o caso, conceder licenças ambientais para atividades potencialmente poluidoras em âmbito municipal; promover a educação ambiental; propor a criação de normas legais, bem como a adequação e regulamentação de leis, padrões e normas municipais, estaduais e federais; opinar sobre aspectos ambientais de políticas estaduais ou federais que tenham impactos sobre o município; e receber e apurar denúncias feitas pela população.

Nos conselhos ambientais municipais, há diferentes periodicidades de reuniões, mensais ou bimestrais, dependendo da vontade política das representações (MMA, 2017). Nos polos produtores de monoculturas, observaramse distintos níveis de institucionalidades participativas, como é o caso de Campo Novo dos Parecis, município onde inexiste o conselho, Brasnorte, onde, apesar da existência de conselho, não são realizadas reuniões, ou Lucas do Rio Verde, em que, apesar de haver essa institucionalidade participativa com reuniões frequentes, as pautas de negociação pendem mais para os benefícios ambientais à produção que propriamente à conservação dos recursos ${ }^{86}$.

É necessário mencionar a insuficiência de informações completas sobre, por exemplo, o conteúdo das reuniões e deliberações nos conselhos municipais e 
estaduais, aspectos não mensurados nas análises de transparência discorridas no Capítulo 5. Tais informações são pontuais e não permitem, tal como estão, possibilidade de avaliação de como têm evoluído os espaços dessas institucionalidades participativas.

No que se refere à composição ambiental mato-grossense, vemos que a proporção de representantes da sociedade civil é igual ou inferior a 50\% em 26 dos 46 conselhos municipais de meio ambiente. Notamos no Quadro 24 que há poucos conselhos em comparação com o número de municípios na Amazônia Legal (32\%, média de 19,77, com desvio padrão de 16,15) ${ }^{87}$. Em 2002, destacava-se o caráter consultivo dos conselhos ambientais municipais. Haja vista a interrupção da atualização especificamente destas variáveis nos dados disponibilizadas pelo IBGE, não é possível identificar se essa tendência se confirmou com o passar dos anos.

Dessa proporcionalidade, sublinhamos os estados do Pará e Mato Grosso, já que compartilham de dilemas semelhantes de expansão de fronteiras agrícolas e momentos decisórios como o zoneamento da BR-163.

\section{Quadro 23. Municípios, total e com existência de conselhos municipais de meio ambiente, por características dos conselhos municipais de meio ambiente: Amazônia Legal}

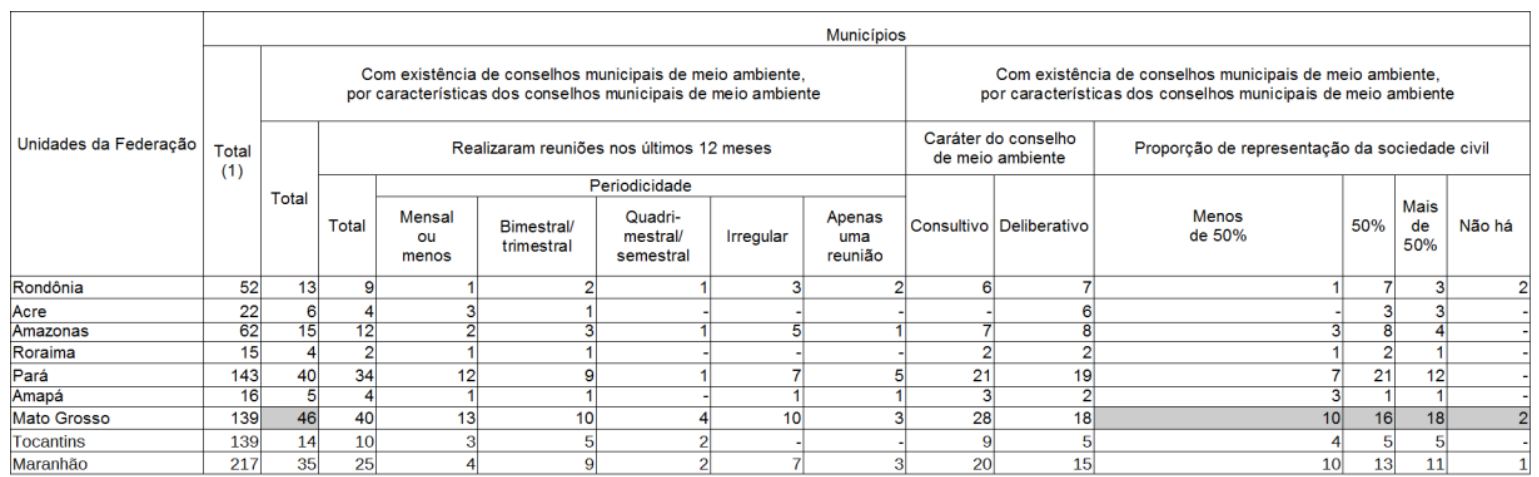

Fonte: IBGE (2002). (1) Inclusive os ignorados e sem declaração de existência.

Nesses estados, sobressai a participação de representações do poder público, associações de moradores e entidades de trabalhadores (Quadro 24). No Mato Grosso, a inserção das organizações ambientalistas é maior que nos demais

87 Incluímos o estado do Maranhão porque, apesar de não estar inteiramente incluído na Amazônia Legal, se insere em programas como o Programa Amazônia Sustentável em sua totalidade. 
estados. Não podemos atribuir essa participação à ação direta do FORMAD no período de 2002. No entanto, observou-se posteriormente que a atividade da rede impeliu organizações que a ele pertencem diretamente ou por outros tipos de colaboração a repensarem sua relação com as municipalidades segundo as informações, experiências e conhecimentos compartilhados com outras organizações ambientalistas.

Ou seja, se não se pode atribuir a maior participação das organizações ambientalistas pela ação de suas redes, também não é possível refutar essa possibilidade, sobretudo em redes com alta coesão, como foi o FORMAD em grande parte de sua atuação.

\section{Quadro 24. Municípios, total e com conselhos municipais de meio ambiente, por tipo de entidade participante, Amazônia Legal (2002)}

\begin{tabular}{|c|c|c|c|c|c|c|c|c|c|c|c|}
\hline \multirow[b]{3}{*}{ Unidades da Federação } & \multicolumn{11}{|c|}{ Municipios } \\
\hline & \multirow[b]{2}{*}{$\begin{array}{l}\text { Total } \\
\text { (1) }\end{array}$} & \multicolumn{10}{|c|}{ Com Conselho de Meio Ambiente, por tipo de entidade participante } \\
\hline & & $\begin{array}{c}\text { Total } \\
(2)\end{array}$ & $\begin{array}{c}\text { Outras } \\
\text { representaçōes } \\
\text { do } \\
\text { poder público }\end{array}$ & $\begin{array}{l}\text { Associação } \\
\text { ambientalista }\end{array}$ & $\begin{array}{c}\text { Associação } \\
\text { de } \\
\text { moradores }\end{array}$ & $\begin{array}{c}\text { Associação } \\
\text { profissional } \\
\text { (OAB, CREA, } \\
\text { etc.) }\end{array}$ & $\begin{array}{l}\text { Entidade } \\
\text { de ensino } \\
\text { e pesquisa }\end{array}$ & $\begin{array}{c}\text { Entidade } \\
\text { empresarial }\end{array}$ & $\begin{array}{l}\text { Entidade } \\
\text { religiosa }\end{array}$ & $\begin{array}{c}\text { Entidade } \\
\text { de } \\
\text { trabalhadores }\end{array}$ & Outra (s) \\
\hline Rondônia & 52 & 13 & 10 & 5 & 7 & 3 & 5 & 7 & 5 & 8 & 2 \\
\hline Acre & 22 & 6 & 4 & 4 & 5 & 1 & 3 & 4 & 3 & 5 & 5 \\
\hline Amazonas & 62 & 15 & 10 & 4 & 11 & 6 & 7 & 9 & 7 & 9 & - \\
\hline Amapá & 16 & 5 & 4 & - & 2 & - & 1 & - & 1 & 3 & 2 \\
\hline Mato Grosso & 139 & 46 & 29 & 24 & 27 & 17 & 17 & 21 & 15 & 24 & 17 \\
\hline Tocantins & 139 & 14 & 8 & 4 & 5 & 6 & 5 & 3 & 6 & 3 & 4 \\
\hline Maranhão & 217 & 35 & 22 & 11 & 21 & 5 & 7 & 5 & 24 & 28 & 9 \\
\hline
\end{tabular}

Fonte: IBGE (2002). (1) Inclusive os ignorados e os sem declaração de existência. (2) Um mesmo município que possui conselho municipal de meio ambiente pode apresentar mais de um tipo de entidade participante.

A ocupação dos espaços do CONSEMA mato-grossense foi a forma que o FORMAD encontrou de acompanhar as decisões ambientais com maior proximidade e possibilidade de intervenção. Em 2012, oito das nove cadeiras disponíveis à sociedade civil foram preenchidas após a articulação da rede. Já em 2014, conseguiu-se que organizações ambientais parceiras cumprissem os atributos necessários em tempo de ocupar as novas vagas, cujo provimento se dá por meio de edital. Este, de responsabilidade do nível federativo que lhe diz respeito, deve ser publicado em tempo hábil para que as organizações interessadas tenham possibilidade de levantar a documentação necessária para sua postulação. Por meio de observações e participação nas reuniões do FORMAD, foi possível perceber que os critérios de elegibilidade ao CONSEMA, apesar de claros em edital, 
segregavam participantes por diferentes estratégias. A principal era a publicação do edital com poucos dias de margem para que as organizações ambientalistas interessadas pudessem movimentar suas documentações para postulação.

Outra estratégia era a solicitação de documentos que não poderiam ser obtidos no período considerado para inscrição ou que fossem indisponíveis a determinadas organizações ambientalistas, dependendo do seu grau de formalidade jurídica perante o Estado. Ainda hoje as modificações de requisitos pertinentes à entrada nos conselhos ambientais é método para aumentar o grau de dificuldade de ingresso dos grupos subalternos organizados em tais espaços decisórios.

Grandes foram as subsequentes articulações do FORMAD para garantir que pequenas organizações fossem capazes de obter a documentação solicitada para a participação direta nos espaços deliberativos. Essa articulação nem sempre foi exitosa, mas demonstra a potencialidade da estrutura em rede de circular informação, conhecimento e respaldo a pequenos grupos organizados, em vista a uma maior inserção nos espaços de deliberação. Uma vez superada a etapa de entrada no CONSEMA, o grande entrave nas negociações do conselho entre 2009 e 2013 giraram em torno de seu regimento interno.

Conseguiu-se modificar o regimento para que os autos de infrações fossem resolvidos nas Juntas de Julgamento, e não mais no Conselho Pleno, prática pouco usual, mas recorrente no funcionamento anterior do conselho. A demanda pelo julgamento dos autos bloqueava o seu caráter consultivo e deliberativo. Com a mudança, abriu-se e consolidou-se a possibilidade de discutir e intervir sobre as políticas ambientais.

A estratégia de ocupação do CONSEMA de Mato Grosso pelo FORMAD consiste em organizar o maior número possível de organizações inscritas e qualificadas para votação, ou seja, conseguir um grupo de organizações que entra na eleição dos conselheiros para apoiar outras que efetivamente se inserem. Uma vez participantes, os conselheiros podem levar contribuições para mudar leis ambientais e solicitar estudos e relatórios para a SEMA, como quanto à incidência de agrotóxicos no estado ou a outras questões ligadas ao meio ambiente.

A participação nos espaços deliberativos ambientais para fins de monitoramento e de controle social foi uma questão polêmica dentro das redes ambientalistas entre 2000 e 2010. Dizia-se que a participação nesses espaços 
legitimava ações governamentais contrárias às demandas dos grupos sociais representados. No entanto, a partir das experiências negativas, as redes perceberam que poderiam fazer mais do que apenas participar com um membro dentro dos conselhos.

A inserção das organizações por meio da mediação do FORMAD e com atual representação no CONSEMA demonstra a necessidade de ocupação dos espaços deliberativos em meio ambiente, considerando que essa é uma das únicas aberturas possíveis oferecidas pelo Estado à sociodiversidade.

Pode-se identificar inconstitucionalidades. Nas reuniões do CONSEMA, quando se discutia o licenciamento, jogava-se a favor dos grandes projetos. Decidiu-se então sair do CONSEMA, chegando-se à conclusão depois que era melhor estar dentro do conselho para saber o que acontecia do que estar fora dele. Havia divergências no sentido de que alguns achavam que estar dentro do CONSEMA acabava legitimando o que ali era votado. No entanto, esta era uma oportunidade de se questionar o que estava por ser votado (...) começa logo um embate com o governo, uma discordância política com a linha do conselho e inclusive um rompimento, onde as organizações saem desse conselho, depois se arrependem porque saíram. ${ }^{8}$

Por sua influência e solidariedade, as redes poderiam promover a inscrição de vários de seus parceiros como votantes quando publicados os editais de seleção de representantes de, por exemplo, CONDEMAs, CONSEMAs ou mesmo o CONAMA. Também por sua abrangência, poderiam aumentar o número de votos à candidatura de seus representantes pela credibilidade obtida por organização nos "nós" estabelecidos pelas relações de solidariedade. A funcionalidade dessa estratégia levou a que diversos espaços institucionais que possuíam semelhante seleção de conselheiros pudessem ser ocupados por um grande número de representantes de diversas camadas da sociedade civil.

No caso do FORMAD (FORMAD, 2016), as organizações consideraram positivos os resultados da participação no CONSEMA como espaço de atuação conjunta. Nesse contexto, a rede, por meio de algumas de suas OSCA, pautou propostas concretas de implementação do Novo Código Florestal na SEMA, e preparou material didático para trabalhar com as demais organizações. A participação constante e uma formação continuada passaram a garantir, por exemplo, maior transparência na prestação de contas do Fundo Estadual do Meio 
Ambiente (FEMAN), nas políticas de resíduos sólidos, no Plano de Bacias (PAB) e no Código Florestal e alteração do Regimento Interno para dar celeridade aos processos.

Outros conselhos de atuação estratégica do FORMAD são o Conselho Estadual de Segurança Alimentar e Nutricional (CONSEA) e o Conselho Estadual de Saúde (CES). No CONSEA consegue-se informações mais fidedignas sobre abastecimento alimentar no Mato Grosso (FORMAD, 2016). Já o CES é um espaço decisório que pode auxiliar as organizações no estabelecimento de um plano estadual de controle sobre o uso de agrotóxicos. Tanto a esfera de saúde quanto a de segurança alimentar e nutricional vêm pautando a questão do uso dos agrotóxicos como alarmante à sustentabilidade ambiental no estado. Outros espaços importantes de incidência, pressionados pela rede FORMAD, são a Secretaria de Estado de Planejamento (SEPLAN) e a Secretaria Estadual do Meio Ambiente (SEMA). Nelas dá-se a discussão sobre o Zoneamento Socioeconômico Ecológico (ZSEE) via Ministério Público. Doze organizações foram indicadas para compor a Comissão Estadual do ZSEE, que, após 2012, reuniram-se em várias oficinas para discutir um plano de incidência na definição e implementação do zoneamento estadual.

No entanto, considerar que somente a participação em conselhos gestores e outros mecanismos nos quais a proporcionalidade da inserção de grupos excluídos se dá de forma tão incipiente não garante nem cidadania, nem um aprofundamento democrático, apesar de ser importante, considerando como se joga o jogo político na questão ambiental.

A incidência política em vista às transformações na política ambiental e seus pontos de contato com o território, entretanto, não é restrita ao âmbito do Executivo, esfera que parece prioritária na ação participativa e no gasto de energia direcionada à mobilização. O Poder Legislativo, apesar de monitorado, é pouco explorado em suas possibilidades de intervenção, a começar pela inserção de pessoas específicas elevadas à condição de sociedade política que possam fazer valer uma pauta de base. Ou seja, a atividade militante em vista ao preenchimento dos espaços parlamentares é pequena, mas deveria ser considerada uma importante manobra estratégica para alcance dos programas vislumbrados pelas minorias.

Ainda no que se refere ao Poder Legislativo, existem mecanismos de participação, como o E-Democracia, o qual permite a alteração dos projetos de lei, 
por artigo, por qualquer usuário de nacionalidade brasileira inscrito na plataforma. No Senado e no Congresso, a participação se dá, formalmente, por audiências públicas nas comissões. Especificamente sobre a gestão do território, sociedade e ambiente, destacam-se, no Senado, a Comissão Mista Permanente sobre Mudanças Climáticas (CMMC), Comissão de Agricultura e Reforma Agrária (CRA), Comissão de Meio Ambiente (CMA), Comissão de Transparência, Governança, Fiscalização e Controle e Defesa do Consumidor (CTFC) e a Comissão de Direitos Humanos e Legislação Participativa (CDH). No Congresso Nacional, destacam-se a Comissão de Agricultura, Pecuária, Abastecimento e Desenvolvimento Rural (CAPADR); Comissão de Integração Nacional, Desenvolvimento Regional e da Amazônia (CINDRA) e a Comissão de Meio Ambiente e Desenvolvimento Sustentável (CMADS).

No caso do estado do Mato Grosso, a atividade legislativa pertinente ao meio ambiente e que inclui a participação social se dá em câmaras setoriais de caráter temporário. Integra agentes públicos representantes dos poderes Executivo, Legislativo e Judiciário, e a sociedade civil representada, com o objetivo de diagnosticar, estudar e debater temas de relevante interesse para o Estado e discutir matérias em tramitação, visando ao seu aperfeiçoamento na legitimação do processo legislativo com a participação popular. Tanto as câmaras setoriais temáticas em andamento como as concluídas não incluem estatísticas de participação dos atores e agentes incluídos nos processos de negociação e discussão ${ }^{89}$.

Em tempo, cabe mencionar que são poucas as bases de dados ou cadastros que registram a atividade dos grupos de interesse nos espaços legislativos. Nos espaços deliberativos e consultivos federais existem registros mais precisos dos grupos de pressão e interesse que agem no processo. Já os estaduais e municipais ainda são institucionalmente frágeis em registrar atas e estatísticas de participação popular nas atividades legislativas, quando há.

89 As informações foram coletadas no portal das câmaras setoriais do Mato Grosso. Disponível em: http://www.al.mt.gov.br/parlamento/camara-setorial/. 


\subsection{A experiência do FORMAD nos espaços deliberativos e consultivos ambientais}

O desenho institucional à participação varia de acordo como esta se organiza, como o Estado com ela se relaciona e a forma como a legislação exige do governo o estabelecimento ou não da participação. Avritzer (2009, p. 45) considera as instituições participativas como "formas diferenciadas de incorporação de cidadãos e associações da sociedade civil na deliberação sobre políticas". Segundo o autor, existiriam três modalidades de desenho institucional para a participação das camadas da sociedade civil no processo decisório. O primeiro seria o desenho institucional de participação de baixo para cima, representado principalmente pelos orçamentos participativos; é aberto a qualquer cidadão interessado, sendo as medidas decididas por esse grupo de cidadãos.

No processo de partilha do poder, segunda modalidade de desenho institucional participativo, os atores estatais e da sociedade civil participam simultaneamente. Os conselhos participativos e os fundos públicos são exemplos dessa modalidade. São estabelecidos por lei e implicam sanções nos casos em que não se consolide o processo de participação.

O terceiro caso consiste nas ratificações públicas, quando os atores e sujeitos sociais que não participam do processo decisório são chamados a validá-los (AVRITZER, 2008).

Dado o fato de que a institucionalidade à participação se diversificou na última década desde as classificações de Avritzer (2008), consideraremos aqui os desenhos institucionais participativos em uma escala de graduação entre os "de cima para baixo" (top down) e "de baixo para cima" (bottom up).

Tendo essa observação em conta, uma das diversas razões pelas quais se optou por estudar o escopo de atuação do FORMAD ao longo dos 20 anos de sua atuação foi sua experiência transitando pelos diferentes espaços de participação oferecidos pelos governos municipais, mato-grossense e federal.

É possível dizer que o fórum testemunhou os prós e contras de cada um deles exatamente por ser uma das primeiras redes ambientalistas conformadas após a redemocratização, reconhecida nacionalmente como um forte jogador político por meio de sua enorme teia e nós relacionais, e ainda em atividade. Além 
disso, a longa experiência da rede nesse aspecto testemunha os pontos de contato do legado histórico territorial e ambiental regional com a contemporaneidade.

A institucionalidade participativa deve incorporar as diversidades socioculturais no processo de construção de políticas e como elas repercutem na dinâmica territorial. Com certo ceticismo vemos essa inserção, pois a prática vivida ao longo desta pesquisa aponta a institucionalidade do Estado brasileiro pouco permeável e acessível às diversidades socioculturais em grande parte do espectro de possibilidades à participação.

Consideremos a Figura 18 como análise das possibilidades de participação disponíveis e operativas na história do FORMAD, explicitadas nos capítulos anteriores. Entendemos as instâncias participativas bottom up como protagonizadas pelas diversas camadas da sociedade civil, em igualdade de forças em uma graduação de reatividade com o Estado. Já o espectro das instâncias classificadas aqui como top down conforma as diversas camadas da sociedade civil que não participam do processo decisório ou a tendência à não equidade de participação entre os atores governamentais, empresariais ou das camadas da sociedade civil. Temos que grande parte das instâncias participativas se localizam mais próximas à extremidade top down que à bottom up.

Essas tipologias de desenho de participação permitem a análise com base nos oito degraus de participação cidadã, propostos por Arnstein (1969). Embora essa graduação seja uma simplificação que pode ser subdividida em muito mais que oito patamares, ela auxilia o entendimento da contraposição que com ela se estabelece quando os extremos das camadas sociais excluídas e as dominantes se confrontam mediante negociação. Nessa elaboração, a autora separa esses oito degraus em três categorias. Os dois primeiros degraus (manipulação e terapia, respectivamente) seriam uma não participação. Nos três degraus seguintes (informação, consulta e pacificação) haveria uma concessão mínima de poder, e os três últimos (parceria, delegação de poder e controle cidadão) seriam os níveis de poder cidadão.

Como visto ao longo dos Capítulos 4 e 5 e ilustrado na Figura 18, a maioria das intervenções do FORMAD transitaram entre consultas e audiências públicas, mesas de negociação, ambientes virtuais de participação e conselhos. Nessas experiências, foi possível identificar a insatisfação de muitas das organizações ambientalistas, tanto do FORMAD quanto de outras redes. Em linhas gerais, os 
degraus de participação cidadã enquadram eficazmente as principais divergências levantadas no escopo de atuação das redes ambientalistas e suas estratégias para superação de tais adversidades à sua participação.

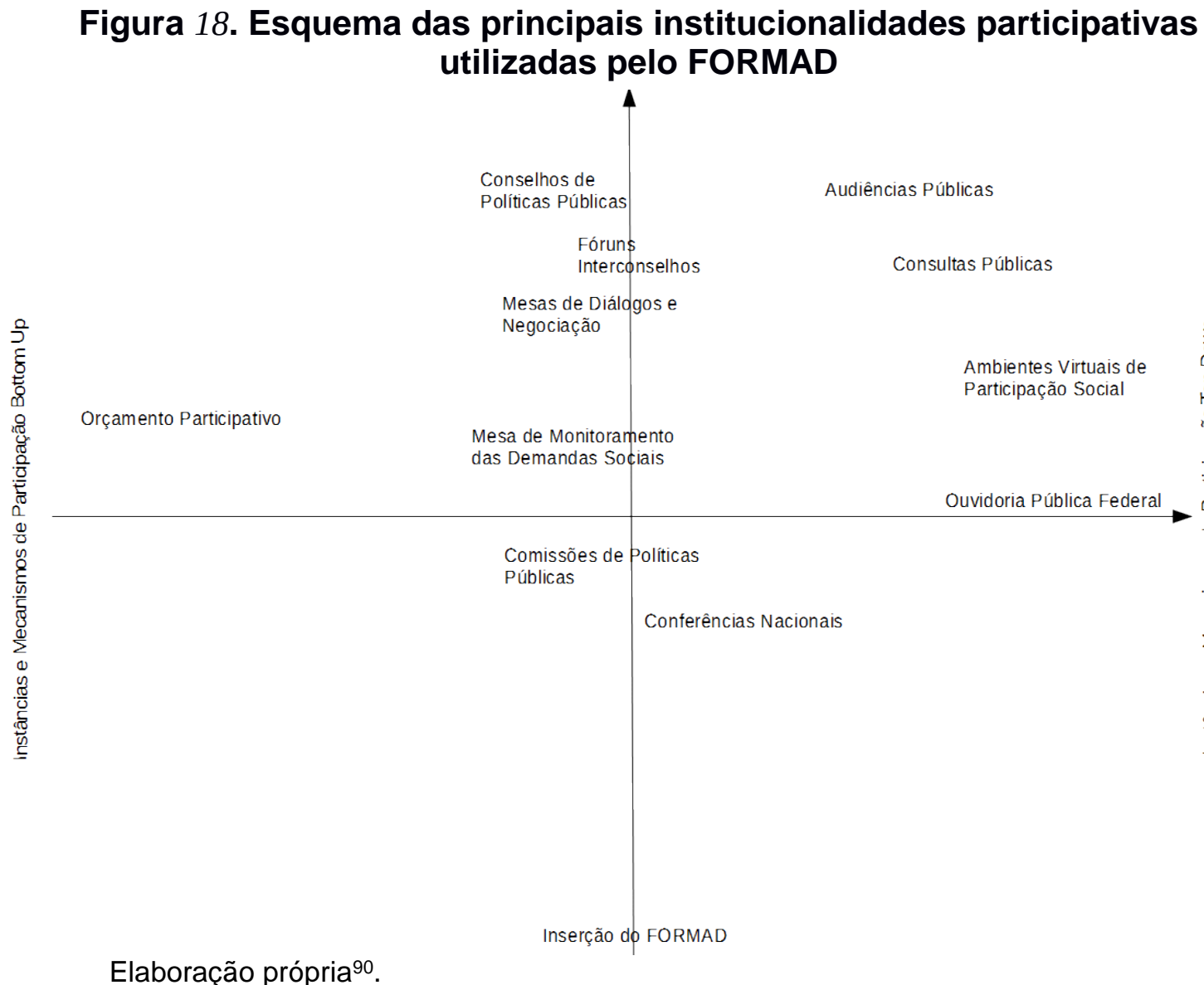

O primeiro patamar da classificação de Arnstein (1969) trata do pouco poder da intervenção das camadas sociais excluídas, e de um propósito de obtenção de seu apoio às propostas das camadas preponderantes. O primeiro degrau (manipulação) representa a distorção da participação em um instrumento de validação de agendas dos grupos com poder de decisão, mesmo que essas não estivessem em consonância com as demandas das camadas basilares da sociedade civil. Nesta etapa, o objetivo real não é permitir a participação nos processos decisórios, mas sim cooptar os participantes divergentes à agenda dominante. No caso da participação nos conselhos gestores, em especial os

90 Houve tentativa de construção coletiva de tal representação com o FORMAD, no qual esse tipo de esquema já foi utilizado. Na impossibilidade, a autora elaborou a representação baseada em suas experiências práticas na rede ao longo do período considerado neste estudo. 
conselhos ambientais nos níveis governamentais, essa evidência perdurou por muitos anos da atuação do FORMAD, o qual passou a buscar elementos internos de funcionamento dos conselhos que pudessem ser revertidos em favor de suas propostas, introduzindo-as nos processos decisórios.

O segundo degrau, a terapia, consiste em deslegitimar o argumento dos grupos excluídos do processo, atribuindo-lhes características psicológicas de desvio, como se estivessem exagerando em suas demandas, comportando-se com um suposto descontrole emocional. As ofensas nos bastidores das mesas decisórias, observadas pela autora no ZSEE, proferidas pela sociedade política local aos representantes das organizações ambientalistas envolvidas, e a atribuição indiscriminada do termo "vandalismo" a manifestantes e representantes de minorias são os exemplos mais claros desta etapa.

A forma de comunicação técnica unilateral, dos técnicos para o cidadão, e a ineficiente estrutura de consulta pelo cidadão se relacionam com a falta de transparência e validade dos estudos técnicos. São outros dois degraus (informação e consulta) que se apresentam como níveis mínimos de participação. Lembremos que o elemento "informação" foi apontado por Raffestin (2009) como crucial para a apropriação territorial dos atores (Capítulo 2). Por se tratar de uma linguagem acadêmica, por vezes ininteligível ao cidadão comum, a construção do conhecimento ambiental parece sempre vir de cima para baixo. Há alguma pouca consideração do conhecimento popular na construção e validação das ciências da natureza. Portanto, as etapas consultivas, respaldadas por esse conhecimento "de cima para baixo" e unilateral, apresentam-se apenas como uma formalidade. Retomando um aspecto tratado em diversos momentos deste trabalho, as análises sobre transparência e política de dados abertos têm sido uma das formas de se explicitar a qualidade das ações de abertura de dados. Mundialmente existem reconhecidas ferramentas de mensuração quantitativa das interfaces de transparência e opinião dos cidadãos ou organizações (Open Data Barometer, da World Wide Web Foundation; Open Data Watch; Global Open Data Index, da Open Knowledge International), tipologia de pesquisa esta que vem tomando fôlego com o crescimento da Internet. No entanto, mais do que dados quantitativos de oferta de dados, o cerne da questão é a sua qualidade. Esse aspecto ainda carece de aprofundamento de análises. 
Nas etapas de consulta e pacificação, os cidadãos ou seus representantes passam a ter certa influência, mesmo com limitações de poder. Nesses espaços políticos há abertura para o aconselhamento e planejamento pelos cidadãos e seus representantes, mantendo o direito de decidir aos tomadores de decisão. Um exemplo claro desta etapa são as conferências sobre meio ambiente (CNUMAD e Conferência das Partes - COP, notadamente). Nesses eventos, a negociação tende a se dividir em duas casas: uma, de acesso restrito a lideranças, negocia e decide as políticas em implantação; a outra, pertinente a toda diversidade social mundial, isolada das negociações, elabora uma única carta a ser submetida à mesa principal, para que talvez tenha algo de seu conteúdo contemplado nas macrodecisões ${ }^{91}$.

Esta é a singularidade da interação interpretada como pacificação e não como partilha de poder: os grupos são mais bem tranquilizados do que incorporados ao processo decisório. O grau desse apaziguamento varia de acordo com a assessoria técnica de que a sociedade civil e seus representantes dispõem para definir suas prioridades e o grau de sua organização. No caso da rede ambientalista FORMAD, foi exatamente a disponibilidade e um arcabouço técnico dos múltiplos participantes, demonstrados no Capítulo 5 , que permitiram a mudança qualitativa na participação nos conselhos ambientais estaduais e em algumas municipalidades.

No entanto, tais atribuições não chegam a ser suficientes para transpor o "ritual vazio da participação e dispor de poder real para influenciar os resultados do processo", já que a "participação sem redistribuição de poder é um processo vazio" (ARNSTEIN, 1969, p. 216), sentença esta que resume a essência do que se quis demonstrar neste trabalho por meio da prova da hipótese levantada.

O momento do PRODEAGRO, tratado no Capítulo 4, constituiu-se como um exemplo da parceria, proposta por Arnstein. Nesse momento do FORMAD, a redistribuição de poder se deu através da negociação entre as organizações ambientalistas da rede e os tomadores de decisão, compartilhando o planejamento e as responsabilidades, definidas por regras que não poderiam mais ser modificadas unilateralmente. No caso do GTA, corresponde o momento do PPG7 e, em menor escala, por se tratar de uma avaliação, do PRONABIO (Capítulo 2).

91 A autora deste trabalho participou em algumas mesas da Cúpula dos Povos da COP 20, em Lima, Peru, onde observou tais evidências. 
Nas etapas posteriores, quando se alcança um poder de decisão, Arnstein (1969) define que é permitida a negociação "de igual para igual" com aqueles que tradicionalmente detêm o poder. As aspas se justificam porque jamais houve essa igualdade de condições no contexto brasileiro, ideia esta elaborada nos três primeiros capítulos deste trabalho. Portanto, a coexistência das organizações ambientalistas da rede FORMAD em institucionalidades participativas com forte inserção das elites agrárias não representa ser uma igualdade de condições de poder. Ainda que ambos apresentem alta competência técnica, a balança das decisões penderá para a classe e ideologia dominantes e sua agenda.

Finalmente, nos estágios de delegação de poder e controle cidadão, o cidadão "sem-nada" detém a maioria nos fóruns de tomada de decisão, com amplo poder gerencial. Nesta etapa, as organizações ambientalistas em rede teriam em mãos as principais cartas do jogo para garantir que o programa atenda aos interesses pertinentes aos seus eixos. Segundo Arnstein, as divergências com os grupos poderosos podem ser resolvidas pela negociação, dispensando táticas de pressão. Novamente nos reportamos à Figura 18, para análise dos caminhos percorridos pelo FORMAD neste quesito. Os arranjos de poder delegado, em sua maioria, não estabelecem em seu rol procedimental o poder de veto sobre o planejamento, convocado pelos cidadãos às organizações sociais que os representam, no caso de divergências que não possam ser resolvidas pela negociação. No caso do ZSEE mato-grossense e do PRODEAGRO (Capítulo 4), os mecanismos de veto se deram por intermédio do Ministério Público, no primeiro caso, ou do financiador externo (Banco Mundial, no segundo caso). Não foram reportados mecanismos próprios da institucionalidade participativa referente às questões ambientais para tal finalidade.

A retórica do controle cidadão, último degrau da participação, não será alcançada enquanto o poder final de aprovação e prestação de contas estiver exclusivamente nas mãos dos Três Poderes (ARNSTEIN, 1969).

\subsection{A participação social como ameaça}

Arnstein (1969) ressalta que a participação dos governados no governo como princípio democrático é uma ideia que, apesar de aplaudida, emudece quando esse princípio é defendido pelos "sem-nada", assim definidos pela autora. 
Quando estes definem participação como redistribuição de poder, o consenso sobre os princípios fundamentais de uma nação democrática deixa de existir.

Sinérgica a essa observação, a exploração dos recursos naturais e das sociedades deles dependentes pelas classes dominantes é amplamente conhecida, bem como os mecanismos de ampliação dessa segregação e a desigualdade de acesso aos recursos, à medida que cresce a ganância das arcaicas elites brasileiras.

A apropriação dos territórios e da natureza jamais esteve sob o controle, sequer parcial, da população submetida às subversões que vêm caracterizando o exercício dos governos brasileiros. Se a perda de território é o fim de uma determinada sociedade (RATZEL, 1987), então a posterior transformação das técnicas de produção e da paisagem para novas exigências é incompatível com essa estrutura societária precedente, apartando os "sem-nada" da cidadania. No caso não só do Mato Grosso, mas na história recente de toda a Amazônia, aparece marcadamente o fenômeno da migração e da elaboração das técnicas produtivas agroindustriais como elementos profundamente transformadores do território e da natureza que o encerra. Ao deslocar as sociodiversidades e incorporar outras, na promessa de enriquecimento pelos meios produtivos, o que se provoca é, por um lado, a perda de território de grupos menos poderosos no jogo político, e por outro lado, a desagregação dos grupos, fator imprescindível para a segregação dos sujeitos e de atores sociais e coletivos no processo decisório.

O reagrupamento dessas diversidades se dá por formas distintas ao reconhecimento mútuo das necessidades em um grupo: a representatividade se dá de fora para dentro, muitas vezes, promovida por organizações sociais originalmente deslocadas desse pertencimento inerente a um grupo no seu território, mas com poder de argumentação suficiente para a "representação" desses grupos nas instâncias políticas. Isso leva a um duplo problema: por um lado, não se incorporam representantes diretos dos sujeitos sociais e políticos envolvidos; e, por isso, não se chega a alcançar um desenho institucional adequado à demanda dos grupos sociais política e territorialmente excluídos do processo.

Parece evidente que os atores sociais e coletivos que atuam nas decisões políticas deveriam ser sujeitos e autores das proposições, pertencentes a todas as camadas sociais interessadas, não somente agentes replicadores de um status quo 
estabelecido. Contestar a legitimidade ${ }^{92}$ dos que decidem o uso do solo é um empreendimento visualizável nas audiências públicas, exemplo de tolhimento de grupos de interesse e de pressão, mais que propriamente uma coação física.

Frente à máquina do Estado e à formalidade que ela apresenta, o indivíduo, o cidadão comum ou o coletivo, se sente impotente, já que se percebe alheio à imagem estigmatizada dos ambientes formais e parte do princípio de que a instituição estatal é a que tem razão.

Nas camadas basilares da sociedade civil, é essa estrutura que mantém o indivíduo marginalizado alheio aos processos decisórios, não por ser incapaz de participar dessa arena, mas por sentir-se alheio a ela. Desprovidas dos meios de produção e silenciadas nos processos decisórios, as camadas subalternas e suas formas de organização agem no sentido de diminuir as abismais desigualdades sociais e de acesso à natureza que as assolam.

Apenas na organização social, o conjunto de indivíduos, reconhecidos mutuamente em suas necessidades, nota sua realidade ambiental como ameaçada pela institucionalidade estatal que monopoliza a informação, esta geralmente equivocada tanto em sua coleta quanto na sua análise e interpretação. Muitas informações levantadas nas esferas governamentais, destinadas para esta pesquisa, apresentavam falhas grosseiras de redação, amostragem de dados, medidas de áreas, cartografia, etc.

A contestação da legitimidade dirige-se à ordem constituída, visando modificar fundamentos, o sistema do governo e sua estrutura. Em certa medida, o processo de redemocratização no Brasil e a abertura das estruturas da PNMA, Lei 140/2011, não conseguiram avançar para além da estrutura centrada no Poder Executivo, Legislativo e Judiciário. Isso se deve ao fato de que a Constituição

92 Temos que o processo de legitimação é formado pelo conjunto dos aspectos do Estado, ou seja, sua comunidade política (grupo social, com base territorial, que congrega indivíduos unidos pela divisão de trabalho político), regime (conjunto de instituições - princípios monárquicos, democráticos, socialistas, fascistas - que regulam a luta pelo exercício do poder, e o conjunto de valores que animam essas instituições) e o governo (conjunto de papéis em que se concretiza o exercício do poder político vinculado ao regime legitimado, com suas normas e valores), variáveis essas que cooperam, de forma relativamente independente, para sua afirmação (BOBBIO, 1998). É possível, então, contestar a legitimidade do Estado quando este é percebido, em suas estruturas e fins, como em contradição com as crenças e demandas, e esse julgamento leva a uma ação que visa mudar aspectos básicos ou estruturais da vida política. Opor-se ao governo difere de contestar sua legitimidade, na medida em que o primeiro (política reformista) busca alcançar mudanças mantendo as estruturas políticas existentes. A oposição contesta o governo, mas não as estruturas que condicionam sua ação, propondo somente uma mudança na gestão de seus sistemas. 
Brasileira de 1988 não conseguiu viabilizar organicidade compatível ao processo de descentralização (CAMARGO, 1993).

A essas observações está atrelada a relação entre os aspectos básicos da ação de um governo e a sua posição no mundo globalizado. O PLP, apesar de suas incongruências, relativiza o significado de escala e a posição do Estado no contexto global, ainda que o consideremos desfavorável pela dependência da agroexportação.

A escala atingida pelas estratégias está relacionada não só às arenas de tomada de decisões ou aos produtos de arranjos institucionais historicamente específicos, mas também às estratégias de regulação e geopolíticas. Não mais se trata de uma diferenciação entre as formas globais, nacionais, regionais e locais de organização político-econômica como um dado recurso fixo (BRENNER, 2005).

Para Mello-Théry (2011), a gestão do ambiente, enquanto objeto de política pública e dimensão territorial, deve ser entendida na sua acepção simbólica (insígnia da soberania de uma nação), concreta (suporte físico que é objeto do planejamento) e como artifício (categoria de análise).

Apesar de essa observação ser pertinente e coerente ao objetivo proposto, para Moraes (2011), a base do Estado brasileiro não esteve atrelada ao conceito de nação, já que a manutenção, formação e expansão de seu espaço territorial foram prioritárias para a sua consolidação. A formação do País foi mais ligada ao valor de seu território do que à sua unidade político-cultural, fator potencializado pela grande diversidade de biomas e sociedades envolvidos nessa realidade. Os casos do POLONOROESTE e do PRODEAGRO são emblemáticos para o entendimento dessa afirmação.

A consolidação dos ZSEE dos estados brasileiros evidencia a separação de suas distintas regiões por critérios de vocação produtiva. Tais regiões estão pressionadas, por um lado, pelo neoliberalismo estabelecido e consolidado a partir de 1990, e, por outro, pela herança do autoritarismo que dificulta a descentralização das decisões políticas, mantendo ênfase no Poder Executivo (LIMONGI E LIMONGI, 1999). Por isso, mesmo na construção de um modus operandi que prima pelo fomento à interação entre Estado e Sociedade em vista a uma maior participação dos atores distribuídos nos espaços como dentro dos processos de tomada de decisão, não é possível não considerar os conflitos inerentes às relações entre sociedade e natureza no contexto do capitalismo no Brasil. Nesse sentido - 
retomando Martin (2005), mencionado no Capítulo 2 -, distinção deve ser feita entre a questão do regionalismo no Brasil e o federalismo, se a intenção é superar a "distorção na representação", um dos "principais gargalos com o qual se defronta o federalismo brasileiro" (MARTIN, 2005, p. 57). Tal como nas diversas políticas setoriais, a fragilidade na estrutura de representação é prejudicial para o planejamento do uso dos recursos naturais e sua distributividade equânime às diversas representações sociais.

Há uma tendência crescente da consolidação do poder e a apropriação dos territórios serem processos marcados por crescente violência, preterindo necessidades sociais e ambientais fundamentais das agendas governamentais. É recorrente, no que se refere ao uso do solo, a dificuldade desde a regularização fundiária das propriedades, urbanas e rurais, até o estabelecimento de uma reforma agrária. A proliferação da construção de hidrelétricas e suas consequências às diversas etnias, a pressão nos entornos das áreas ambientalmente protegidas e a invasão às Tls, expostas nos Capítulos 2 e 5 , legitimadas nos processos de decisão do ZSEE (Capítulo 3), são contundentes exemplos dessa afirmação.

O abismo que existe entre as aspirações da população e os objetivos do Estado é minimizado, mas não resolvido, pela fórmula da organização social, seja por OSCA e redes ambientalistas, seja por grupos de interesse ou de pressão, como vimos no exemplo do FORMAD, GTA, dentre outras organizações concatenadas em redes.

É salutar que uma rede capta as várias dimensões ideológicas e práticas das organizações em separado, mantendo suficiente unidade dadas as preocupações comuns e compartilhadas sobre o processo político ambiental (CARTER, 2001, p. 134).

Como mencionado no Capítulo 3, a definição das escalas de atuação de redes ambientalistas é tão complexa quanto a definição de metodologias para o ordenamento territorial. Ressalta-se que as redes ambientalistas possuem muitos pontos de contato com a organização territorial e seus instrumentos. Vindo majoritariamente de cima para baixo, as propostas de ordenamento são mais um resultado de estratégias formatadas segundo as hegemonias do que propriamente uma metodologia de planejamento territorial em suas variações. Uma vez definidos os objetivos e a metodologia do ordenamento, geralmente depois que as políticas territoriais são consolidadas, e não antes, consegue-se identificar a escala. 
De forma a colaborar com o pensar sobre a participação ambiental, nos baseamos na análise dos referenciais teóricos e na experiência da rede FORMAD em participação para sintetizar propostas de dimensões dos efeitos das instituições participativas e sua aplicabilidade no fomento à participação cidadã (Quadro 25).

Quadro 25. Dimensões dos efeitos das instituições participativas ambientais

\begin{tabular}{|c|c|c|}
\hline Dimensão dos efeitos & $\begin{array}{c}\text { Possíveis indicadores, dados } \\
\text { ou evidências }\end{array}$ & Protagonismo à participação \\
\hline $\begin{array}{l}\text { Bem-estar social, qualidade de } \\
\text { vida dos cidadãos a partir da } \\
\text { qualidade de manutenção } \\
\text { ecossistêmica e minimização de } \\
\text { conflitos ambientais }\end{array}$ & $\begin{array}{c}\text { Indicadores socioambientais } \\
\text { atualizados }\end{array}$ & $\begin{array}{c}\text { Incorporação à rotina cidadã } \\
\text { dos indicadores econômicos e } \\
\text { ambientais }\end{array}$ \\
\hline $\begin{array}{l}\text { Alocação redistributiva de } \\
\text { recursos públicos }\end{array}$ & $\begin{array}{l}\text { Investimento e manutenção de } \\
\text { políticas públicas, dados } \\
\text { socioeconômicos, } \\
\text { agropecuários e } \\
\text { socioambientais sobre macro } \\
\text { ou microrregiões }\end{array}$ & $\begin{array}{l}\text { Ampliação do rol de } \\
\text { participação sobre orçamentos } \\
\text { e gestão dos fundos de } \\
\text { participação municipal }\end{array}$ \\
\hline $\begin{array}{l}\text { Gestão fiscal e } \\
\text { responsabilidade fiscal }\end{array}$ & $\begin{array}{l}\text { Arrecadação de tributos e } \\
\text { despesa governamental }\end{array}$ & $\begin{array}{l}\text { Ampliação e diversificação das } \\
\text { vagas às representaçoes } \\
\text { socioambientalistas de base } \\
\text { nas instituições participativas } \\
\text { existentes, ampliando seu } \\
\text { poder de decisão sobre os } \\
\text { recursos por pasta }\end{array}$ \\
\hline Gestão e administração pública & $\begin{array}{c}\text { Modernização dos } \\
\text { instrumentos, capacidade } \\
\text { administrativa, entre outros }\end{array}$ & $\begin{array}{l}\text { Desburocratização de acesso } \\
\text { às instituições participativas }\end{array}$ \\
\hline $\begin{array}{l}\text { Dinâmica eleitoral e construção } \\
\text { de apoio político }\end{array}$ & $\begin{array}{c}\text { Rastreamento das coligações e } \\
\text { estabelecimento de programas } \\
\text { de governo }\end{array}$ & $\begin{array}{l}\text { Disponibilidade de informações } \\
\text { completas e estatísticas de } \\
\text { participação na atividade nos } \\
\text { Três Poderes, bem como das } \\
\text { origens e destinos dos fundos, } \\
\text { acessíveis em plataformas } \\
\text { intuitivas ao público geral }\end{array}$ \\
\hline Escopo constitucional & $\begin{array}{l}\text { Desdobramento das leis e } \\
\text { ementas, aprofundamento para } \\
\text { além da descentralização do } \\
\text { poder, focada nas atribuições } \\
\text { setoriais e seu reflexo à } \\
\text { cidadania }\end{array}$ & $\begin{array}{l}\text { Diversificação das estratégias } \\
\text { participativas, valorizando } \\
\text { estratégias de baixo para cima }\end{array}$ \\
\hline $\begin{array}{l}\text { Diversificação e estímulo às } \\
\text { práticas cívicas }\end{array}$ & $\begin{array}{l}\text { Diversificação de opiniões, } \\
\text { veiculação destas por } \\
\text { diferentes meios de } \\
\text { comunicação, diversificação de } \\
\text { cadeias de comunicação } \\
\text { existentes ao grande público, } \\
\text { fomento ao respeito a opiniões } \\
\text { e atitudes }\end{array}$ & $\begin{array}{c}\text { Coexistência de múltiplas } \\
\text { representações da sociedade } \\
\text { civil em condições de diálogo e } \\
\text { busca de soluções } \\
\text { compartilhadas em temas } \\
\text { comuns }\end{array}$ \\
\hline
\end{tabular}


Tomada de decisões compartilhada e deliberação em organizações socioambientais
Índices de participação em todas as etapas de planejamento e gestão
Acesso à cultura política

Fonte: PIRES (2011). Adaptação própria.

Cada política setorial tem características distintas, bem como são distintas as institucionalidades participativas (conselhos gestores, orçamentos participativos, audiências públicas, etc.) em origens, regras e bases normativas e institucionais (PIRES, 2011). Portanto, o quadro é uma adaptação de um raciocínio voltado para o que este trabalho se propôs: pensar as necessidades para uma estrutura participativa pertinente à questão ambiental, com base no observado na trajetória do FORMAD. Cada setor político tem atribuições e variáveis distintas, ainda que compartilhem a mesma realidade histórica nacional e o seu legado ao ordenamento dos setores que sobre o território brasileiro se desenvolvem. Igualmente, há especificidades nas macro e microrregiões e municipalidades. Esses elementos, já presentes no nosso momento histórico, constituiriam um elenco de indicadores que apontariam para um aprofundamento democrático.

As limitações a esse aprofundamento da democracia se dão pela impermeabilidade das instituições formais em tratar aspectos fundamentais do processo político às claras, com transparência de dados e instrumentos de consulta e participação popular, Ademais, pela dificuldade de acesso dos grupos excluídos, seja por descuido das organizações ambientalistas em superar a tradição assistencialista, seja porque as bases, mesmo que interessadas ideologicamente, não possuem condições de tempo ou mobilidade para participar. Seja neste ou naquele caso, entendemos aqui os diversos impedimentos que impossibilitam uma realidade política baseada em ampla participação popular em processos decisórios, que, na atual conjuntura nacional, representam ser rico material de análise.

Finalmente, percebeu-se uma característica da rede estudada semelhante à forma como os processos das políticas públicas se desenvolvem nacionalmente: há uma tendência em se omitir a avaliação dos resultados obtidos pela ação do FORMAD em praticamente toda a sua atuação. São ressaltadas as dificuldades, mas a análise do que foi conquistado e de como foi conquistado, aspecto imprescindível para o planejamento e sucesso de ações futuras, praticamente não é feita. Essa característica se mostrou como um problema para o desenvolvimento 
desta tese em todo o seu percurso. Se não fosse a experiência vivida pela autora deste trabalho dentro das redes ambientalistas aqui tratadas, provavelmente esta análise seria impossível. 


\section{CONCLUSÕES}

Os objetivos e hipóteses dessa pesquisa, aparentemente simples, desembocam na complexidade da questão ambiental no Centro-Oeste do Brasil. Não somente isso, mas também a singular relação entre os seres humanos, o ambiente e como se conforma a questão do ambientalismo brasileiro frente à sociedade de classes. Se por um lado os objetivos podem ser interpretados como humildes, o mesmo não se pode dizer do processo histórico de relação com a disponibilidade de recursos naturais em território nacional.

Defendemos aqui, baseando-nos no estudo de caso do FORMAD, que as formas de participação foram, majoritariamente, desenhadas de modo a ser excludentes, refutando relatórios e estudos provenientes de organizações ou centros de pesquisa que não estejam alinhados à agenda ambiental governamental, a qual é dirigida por uma elite, notada e historicamente agrária. A incorporação das demandas das OSCA, ligadas às classes historicamente marginalizadas foi paulatinamente relegada ao segundo plano nas decisões sobre o uso do solo e dos recursos naturais, na relação entre as esferas governamentais via pacto federativo. Assim, foram também afastadas as desvantagens políticas e econômicas aos grupos da sociedade civil que exercem hegemonia sobre outros, marginalizados dos processos decisórios, à sociedade política resultante dessas relações hegemônicas e à relação desta com o governo.

As redes ambientalistas, segundo as tipologias de ambientalismos e eixos de atuação nas quais se basearam foram, nesse sentido, preponderantes em termos de permeabilidade política, inserindo-se e encontrando táticas e estratégias de ação na abrangência da territorialidade que concernem as arenas políticas, a partir do momento em que as ações e temáticas dessas malhas organizacionais ambientalistas são absorvidas pelas instituições do Estado, governos e sociedade civil em formas de políticas e planejamento ambiental. Mas também nessa relação entre atores coletivos, posicionados ideologicamente com discursos ambientais próprios, surgiram hegemonias que definiram quem decide a gestão ambiental no Brasil. Os possíveis caminhos desse processo se replicam a outros contextos nacionais na medida que tais malhas relacionais envolvem o particular, isto é, os caminhos definidos pelos eixos estabelecidos em um caso específico, e o geral - o contexto de inserção política na tomada de decisões sobre os recursos naturais e 
o ambiente.

Evidenciou-se, portanto, que, referente à relação ser humano-natureza, os conflitos de classe se reproduzem na esfera institucional, por participação baixa ou mesmo a supressão de umas classes e protagonismo de outras, notadamente as classes dominantes.

A repercussão disso é a constante espoliação dos recursos naturais, panorama este que parece estar longe de ser solucionado, não somente nas relações com o meio que se conformaram não somente na forma de se fazer esta política setorial, mas também no cotidiano das classes sociais indiretamente vinculadas ao meio natural, estritamente (por já ser a ele alienada), e também a estrutura institucional e legal para a sua gestão.

Por outro lado, as flutuações políticas, muitas vezes marcadas por crises, aprofundam os problemas ambientais no Brasil. Mesmo nos momentos de aprofundamento democrático, as implicações dos impactos ambientais prejudicam as classes subalternas imediatamente dependentes aos ecossistemas. A frequência desses impactos acaba por concatenar diversas situações de desastres naturais, muitas vezes ignorados pelo poder público, mesmo quando diante de intensa manifestação das camadas basilares da sociedade civil.

Em tempo, cabe ressaltar que diversas são as opções de igualdade de participação das diversas camadas sociais. Mesmo nas relações entre as esferas administrativas brasileiras ou nas relações internacionais, muitas são as oportunidades políticas para elevar os processos decisórios a ações efetivas e eficazes em gestão ambiental. Porém, na estrutura política nacional, a institucionalidade ainda se vê blindada por elites agrárias, cada vez mais obsoletas e ineficientes no contexto político internacional.

Ideias amplamente proliferadas de crises sucessivas que afetam as decisões políticas tornam eufêmico o fato do Brasil viver uma crise desde que foi descoberto. Isso se reflete mais fortemente na relação ambiente e sociedade do que em qualquer outro tipo de relação.

O FORMAD foi uma das coletividades que perdurou por mais de três décadas desde redemocratização, sendo sua história de inserções políticas um espelho do que foi o período recente do ambientalismo no Brasil. Ao longo de sua trajetória, redes de solidariedade como o Fórum contribuíram para desenhar a geografia da 
participação, o mapa da coerção ao ambientalismo e as possíveis formas de superá-la.

Por outro lado, das experiências apreendidas ao longo deste trabalho, vimos que a ação articulada entre atores coletivos pode modificar partes da estrutura institucional participativa quando encontra um (raro) contexto favorável para tal. Os momentos do Fórum que incluíam diretrizes claras entre financiadores e governos no sentido de garantir a participação igualitária das camadas da sociedade foi imprescindível para que resultados positivos fossem alcançados em gestão ambiental.

Em diversos momentos, no entanto, os prós foram menos frequentes que os contras para a participação. Essa constatação foi identificada ao longo de diversos momentos ao longo das reflexões aqui propostas. Retomemos os três mais relevantes.

Primeiramente, a atividade científica e a produção de pesquisas são bons indicadores da importância que se dá a determinado setor da política. Vimos que essa produção é desigualmente distribuída tanto nas regiões brasileiras quanto nas áreas de conhecimento. Os estados da Federação que contam com os principais pontos de biodiversidade têm uma estrutura informacional e de pesquisa inadequada à demanda. A atividade de pesquisa deve ser constante e abundante, já que a dinâmica da sociedade recria constantemente os territórios, possibilitando novas dinâmicas ecossistêmicas e sociais.

A validação dessas produções requer grande número de pesquisadores e técnicos em ambiente, cada vez mais raros nos quadros da administração pública nas esferas federal, estadual e, principalmente, municipal. Em grande medida, as fragilidades advindas do estabelecimento do pacto federativo brasileiro, assim como da gênese da própria Federação, competem para que este cenário tenha sido consolidado. Por outro lado, as iniciativas de estudos realizados fora do escopo acadêmico ou institucional, geralmente pelas OSCA, encontram pouca receptividade do meio científico e governamental, apesar de apresentarem rigor metodológico.

Em segundo lugar, o repasse de recursos, tanto no que diz respeito ao desenvolvimento de pesquisas quanto na manutenção das institucionalidades participativas, como os conselhos, também obedecem a determinadas lógicas de prioridade. Estas dependem das agendas governamentais pré-estabelecidas, não 
necessariamente com a concordância de todas as camadas sociais e, muito frequentemente, segundo fortes polarizações de interesses. Ressaltamos novamente o papel que as elites agrárias têm na definição de tais agendas e, portanto, nas diretrizes de planejamento aplicadas. Os Planos Plurianuais e as Leis orçamentárias refletem, na dotação de valores aos diferentes setores da política, essa priorização de interesses. As flutuações orçamentárias na institucionalidade ambiental indicam que a temática vem sendo tratada de forma secundária, apesar das necessidades evidentes pressões dos movimentos ambientalistas.

Terceiro, as diferentes possibilidades de inserção segundo as tipologias de ambientalismos. Nesse ponto, a dinâmica de relações entre sociedade e governo no que se refere ao meio ambiente gira em torno de como a questão tem ou não aderência à agenda governamental estabelecida. Cabe, aí, um esforço de negociação, principalmente na argumentação, usando a persuasão de maneira a convencer os tomadores de decisão referentes a aspectos socioambientais prioritários às minorias.

Em relação à dinâmica das próprias redes, deve-se ressaltar que o fluxo de comunicação é um dos aspectos cujo funcionamento deve ser eficiente e eficaz para que haja intervenção política. Isso porque o potencial do ator coletivo se dá na medida em que ele pode agir em relação às variáveis que condicionam a produção do território. Para isso, o intercâmbio de informações sobre as organizações que configuram a rede e sua posição nos estágios de negociação é imprescindível para a reflexão de táticas e estratégias de negociação conjunta.

Nesse sentido, é de suma importância que sejam realizadas avaliações sobre como a atuação da diversidade dos atores governamentais e sociais nesses trinta anos de democracia brasileira repercutiu nos diversos setores da política. No caso ambiental, é investida muita energia nos estágios iniciais de planejamento e implementação de programas, planos e projetos, bem como no seu transcurso. No entanto, obtidos os resultados (ou não), tende a haver um esquecimento da trajetória dessas ações tão logo elas parecem concluídas. Isso significa dizer que a fase de avaliação, pertinente a qualquer política pública, é deixada, erroneamente, em segundo plano.

O maior indicador dessa observação é a má qualidade da acomodação dos registros de programas como o PRODEAGRO, o PPG7 e outros. Ao longo da coleta de informações, foi possível constatar que grande parte deste material ou foi 
descartado deliberadamente, ou foi destruído pela ação do tempo, ou se encontra em arquivos particulares de profissionais que trabalharam nas etapas de implementação dos programas. Essa memória perdida é extremamente nociva à reflexão sobre os resultados ao longo dos anos. A fragilidade das bases de dados brasileiras é, nesse sentido, apenas um sintoma de um problema maior de perda de informações históricas úteis a outros momentos de planejamento e execução.

A má qualidade dos registros históricos somados e o insuficiente e desconectado sistema de informações de amplo acesso aos cidadãos são duas medidas das poucas possibilidades de sua inclusão nas decisões. Isso porque a existência eficiente e eficaz desses instrumentos é um processo mediado quando há uma igualmente eficiente e eficaz institucionalidade participativa.

O caso presentemente estudado não é isolado no contexto brasileiro. Replicase a realidade de dificuldades orçamentárias, tanto das organizações quanto da própria institucionalidade ambiental e participativa em outros estados da Federação. As singularidades regionais conferem, no entanto, particularidades a outras redes ambientalistas país afora, já que também o histórico de colonização brasileira não foi homogêneo na abrangência do território. Estas singularidades se dão, por exemplo, na validade e disponibilidade de dados ambientais em outros estados da Federação. A título de exemplo, São Paulo e Rio de Janeiro contam com bancos de dados e bases de georreferenciamento muito mais desenvolvidas que qualquer estado amazônico.

Finalmente, a ideia central a ser deixada é que a participação cidadã, seja na questão ambiental ou outra, seja por de atores coletivos ou individuais, é apenas um dos elementos que mostram a saúde de uma democracia. É o caráter sistêmico da institucionalidade brasileira que pode permitir a governança ambiental tão almejada. 


\section{Agradecimentos}

Agradeço às diversas pessoas que colaboraram, cada uma de sua forma e ao longo de toda minha história, para a realização deste trabalho. Por ser impossível condensar tantas pessoas em uma lista, cito as amizades, as orientações, aos professores, à Universidade e agências de fomento (especialmente a CAPES) e ao FORMAD. Acima de tudo, aos meus pais (ao meu pai, in memorian) e ao meu irmão.

Somos mais fortes quando estamos juntos. 
ANEXO

316 
ANEXO 1 - Reivindicações do FORMAD ao PRODEAGRO

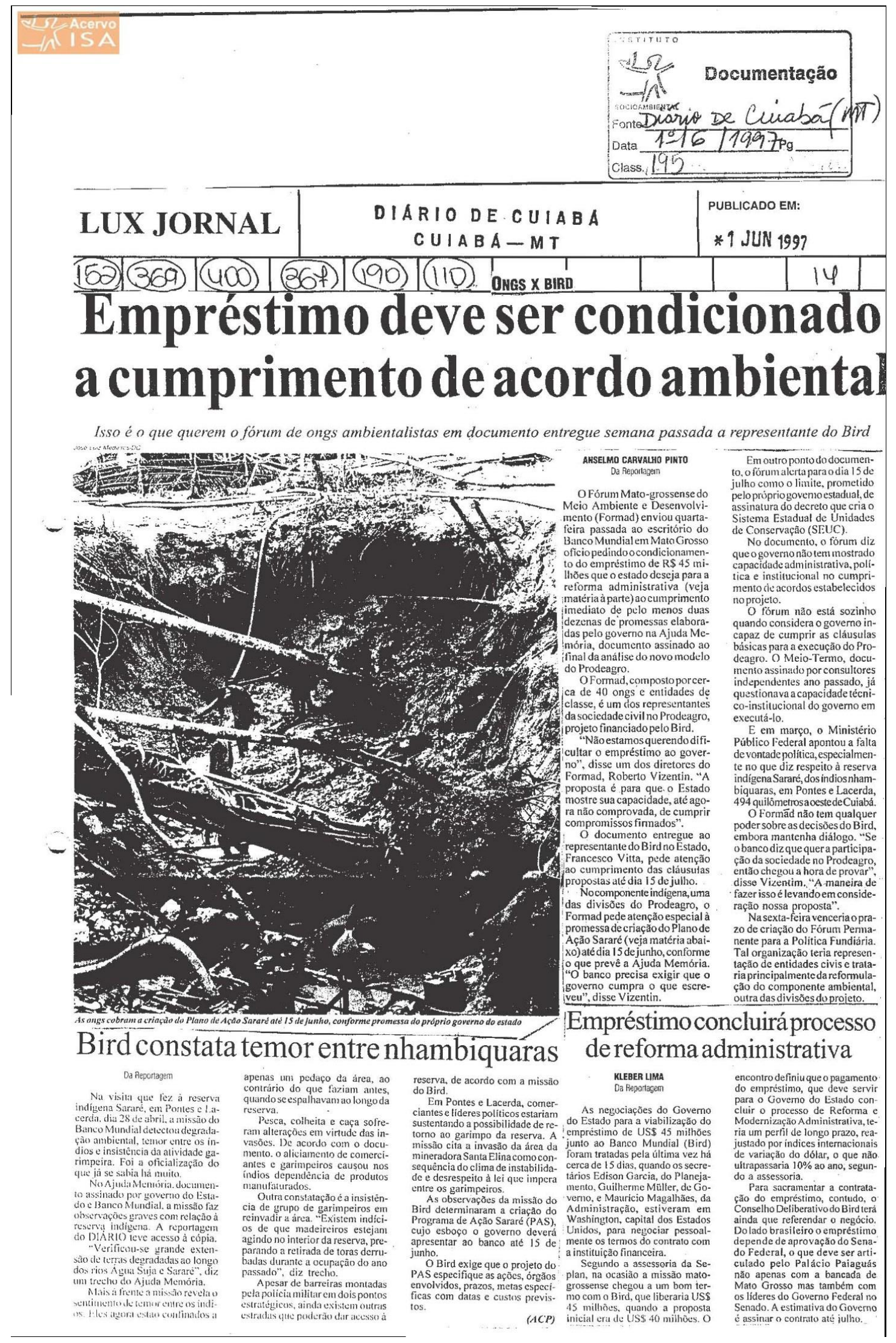




\section{BIBLIOGRAFIA}

ABREU, C. Informações e fragmentos históricos do Padre Joseph de Anchieta, S.J. In: NOBREGA, M. da. [1517-1570] Cartas do Brasil: 1549-1560. Rio de Janeiro: Officina Industrial Graphica, 1931.

AÇÃO DA CIDADANIA CONTRA A FOME, A MISÉRIA E PELA VIDA. Relatório do Comitê Estadual da Ação da Cidadania contra a Fome, a Miséria e pela Vida em Mato Grosso. FORMAD, 1994.

ACSELRAD, H. Ambientalização das lutas sociais - o caso do movimento por justiça ambiental. Estudos Avançados, 24 (68), pp. 103-119, 2010. . Justiça ambiental e construção social do risco. Desenvolvimento e meio ambiente, n. 5, 2002.

ALBAGLI, S. Geopolítica da biodiversidade. Brasília: IBAMA, 1998.

ALIMONDA, H. (ed.). La natureza colonizada. Ecologia política y minería em America Latina. Buenos Aires: CICCUS/CLACSO, 2011.

ALMEIDA, A. Sobre a estimação de efeitos causais: uma nota metodológica com aplicações à pesquisa sobre os efeitos das instituições participativas. In: PIRES, R.; ROCHA, C. Efetividade das instituições participativas no Brasil: estratégias de avaliação. Brasília: IPEA, 2011.

ALVES, A.; PUHL, J.I.; FANK, J. (Orgs.). Mato Grosso sustentável e democrático. Cuiabá: Defanti, 2006.

ANDRADE, M.C. Territorialidades, desterritorialidades, novas territorialidades: os limites do poder nacional e do poder local. In: SANTOS, M. et alli. Território: globalização e fragmentação. 5ª ed. São Paulo: Hucitec/Anpur, 2002. pp. 213-220.

ANDRADE, M.C. Formação territorial no Brasil. In: BECKER, B.K. et al. Geografia e meio ambiente no Brasil. Rio de Janeiro: Hucitec, 1995.

ARANTES, R.B. Direito e política: o Ministério Público e a defesa dos direitos coletivos. Revista Brasileira de Ciências Sociais, 14 (39), 1999.

ARAÚJO, R. Os mapas do Mato Grosso, Terra Brasilis (Nova Série), 4, 2015.

ARENDT, H. A condição humana. Rio de Janeiro: Forense Universitária, 1999.

ARISTÓTELES. The politics (vol. 1). The Online Library of Liberty, 1885.

ARNSTEIN, S. A ladder of participation. Journal of the American Institute of Planners, 35 (4), pp. 216-224, 1969.

ARRETCHE, M.T. da S. Estado federativo e políticas sociais: determinantes da descentralização. São Paulo: APEOESP/Rio de Janeiro: REVAN, 2000.

ARTICULAÇÃO XINGU ARAGUAIA. Experiências socioambientais desenvolvidas na região do Araguaia Xingu. Série: a resposta da terra, v. 3, 2014.

ARTICULACIÓN REGIONAL AMAZÓNICA. Miembros ARA Regional. Disponível em: https://araregional.wordpress.com/miembros-ara-regional/. Acessado em: agosto de 2015.

ASSEMBLEIA LEGISLATIVA DE MATO GROSSO. Desigualdades regionais em Mato Grosso. Cuiabá: COTRADE, 2003. 
ASSOCIAÇÃO BRASILEIRA DE ORGANIZAÇÕES NÃO GOVERNAMENTAIS. Sustentabilidade das ONGs no Brasil: acesso a recursos privados. Rio de Janeiro: ABONG, 2010.

. Reunião da ABONG: regional Mato Grosso. São Paulo: ABONG, 1999. . Relatório de planejamento da ABONG: regional Mato Grosso. São Paulo: ABONG, 1999a.

. Resenha ABONG: regional Mato Grosso. São Paulo: ABONG, 1998.

. Carta de São Paulo. Asociaciones Nacionales de ONGs de América Latina, 1995.

. Reunião ABONG: região Sul. São Paulo: ABONG, 1995a.

AVRITZER, L. A qualidade da democracia e a questão da efetividade na participação: mapeando o debate. In: PIRES, R.; ROCHA, C. Efetividade das instituições participativas no Brasil: estratégias de avaliação. Brasília: IPEA, 2011. pp. 13-28.

Instituições participativas e desenho institucional: algumas considerações sobre a variação da participação no Brasil democrático. Opinião Pública, Campinas, 14 (1), junho, pp. 43-64, 2008.

Participatory institutions in democratic Brazil. Baltimore: John Hopkins University Press, 2009.

BARKDULL, J.; DICKE, L.A. Globalization, civil society and democracy? An organizational assessment. Seton Hall Journal of Diplomacy and International Relations, 5 (2), 2004.

BECKER, B. Geografia política e gestão do território no limiar do século XXI: uma representação a partir do Brasil. Revista Brasileira de Geografia. Rio de Janeiro, 53 (3), pp. 169-182, 1991.

. Geopolítica da Amazônia. Estudos Avançados, 19 (53), 2005.

BECKER, B.K.; EGLER, C.A.G. Detalhamento da metodologia para execução do Zoneamento Ecológico-Econômico pelos estados da Amazônia Legal. LAGET/UFRJ. Laboratório de Gestão do Território/Secretaria de Assuntos Estratégicos/Ministério do Meio Ambiente, 1996.

BERNARDES, J.A. Espaço e movimentos reivindicatórios: o caso de Nova Iguaçu. 1983. 229 p. Dissertação de Mestrado - Universidade Federal do Rio de Janeiro, Rio de Janeiro, 1983.

BERTONE, L.F.; MELLO-THÉRY, N.A. de. Perspectiva do ordenamento territorial no Brasil: dever constitucional ou apropriação política. In: STEINBERGER, M. (Org.). Território, ambiente e políticas públicas espaciais. Brasília: Paralelo 15 e LGE Editora, 2006. pp. 125-147.

BITOUN, J.; GUIMARÃES NETO, L.; ARAÚJO, T.B. de. Amazônia e Nordeste: os trópicos brasileiros e o desenvolvimento auto-sustentável. In: BECKER, B. et alli. Geografia e Meio Ambiente no Brasil. Rio de Janeiro: Hucitec, 1995.

BOBBIO, N.; MATTEUCCI, N.; PASQUINO, G. Dicionário de política I. Brasília: Editora Universidade de Brasília, 1ํㅡㄹ., 1998. 
BOHMAN, J. Public deliberation. Pluralism, complexity, and democracy. Cambridge, MA: The MIT Press, 1996.

BORÓN, A. Estado, capitalismo y democracia en América Latina. Buenos Aires: CLACSO, 2004.

BOURDIEU, P. Méditations pascaliennes. Paris: Seuil (Liber), 1994.

BRANDÃO, C. A busca da utopia do planejamento regional. Revista Paranaense de Desenvolvimento, 120, Curitiba, pp. 17-37, 2012.

BRASIL. Avaliação e identificação de ações prioritárias para a conservação, utilização sustentável e repartição dos benefícios da biodiversidade na Amazônia Brasileira. Brasília: Ministério do Meio Ambiente/SBF, 2001.

. Lei Complementar no 140, de 8 de dezembro de 2011. Brasília, 2011.

Plano Amazônia Sustentável: diretrizes para o desenvolvimento sustentável da Amazônia brasileira. Brasília: Presidência da República/MMA, 112 p. : il. color.; 28 cm, 2008.

. Programa piloto para proteção das florestas tropicais do Brasil: Proposta Preliminar. Brasil: Banco Mundial e Comissão da Comunidade Europeia, 1991.

- Programa piloto para proteção das florestas tropicais do Brasil: Informações adicionais. Brasil: Banco Mundial e Comissão da Comunidade Europeia, 1991a.

Subsídios para a definição da Política Nacional de Ordenamento Territorial - PNOT (versão preliminar). Projeto "Elaboração de subsídios técnicos e documento-base para a definição da Política Nacional de Ordenação do Território - PNOT". Brasília: Ministério da Integração Nacional, 2006.

BRENNER, N. Review geographies of power: placing scale. American Journal of Sociology, v. 111, n. 1, pp. 290-292, 2005.

BRENTANO, F. Psicologia. Madrid: Revista Occidente, 1935.

BRUNET, R.; FERRAS, R.; THÉRY, H. Les mots de la géographie. Dictionnaire critique. Montpellier-Paris: Reclus/La Documentation Française, 1993.

BULKELEY, $\mathrm{H}$. Reconfiguring environmental governance: towards a politics of scales and networks. Political Geography, 24, pp. 875-902, 2005.

BURSTEIN, P.; LINTON, A. The impact of political parties, interest groups, and social movement organisations on public policy: some recent evidence and theoretical concerns. Social Forces, 81 (2), pp. 380-408, 2002.

CAMARGO, A. La federación sometida: nacionalismo desarrollista e inestabilidad democrática. In: CARMAGNANI, M. Federalismos latinoamericanos: México, Brasil, Argentina. Ciudad de México: El Colegio de México, 1993. pp. 300362.

CAMARGO, L. Atlas de Mato Grosso: abordagem socioeconômico-ecológica. Cuiabá: Entrelinhas, 2011.

CAMELY, N.C. A geopolítica do ambientalismo ongueiro na Amazônia brasileira: um estudo sobre o estado do Acre. 2009. Tese de Doutorado - Universidade Federal Fluminense, Rio de Janeiro. 2009. 
CAPELLA, A.C.N. O processo de agenda-setting na reforma da administração pública (1995-2002). 2004. Tese (Doutorado em Ciências Sociais) Universidade Federal de São Carlos, São Carlos. 2004.

CARVALHO, J.M. Cidadania no Brasil. São Paulo: Civilização Brasileira, 2001.

CARTA DE SANTARÉM. Publicada em 31 de março de 2004. Disponível em www.camara.gov.br/sileg/integras/211401.doc, acessada em maio de 2017.

CARTER, N. The politics of the environment: ideas, activism, policy. Cambridge University Press, 2001.

CASA CIVIL. Plano de desenvolvimento sustentável para a região de influência da rodovia BR-163. Plano Cuiabá-Santarém Sustentável, 2004.

CASTELLS, M. A sociedade em rede. São Paulo: Editora Paz e Terra, 2001.

CASTREE, N. Environmental issues: relational ontologies and hybrid politics. Progress in Human Geography, vol. 2, n. 27, pp. 203-211, 2003.

CASTRO, I.E. de. Geografia e política: território, escalas de ação e organizações. Rio de Janeiro: Bertrand Brasil, 2005.

. Geografia: conceitos e temas. $2^{\mathrm{a}}$ ed. Rio de Janeiro: Bertrand Brasil, 2000. $117 \mathrm{p}$.

CASTRO, J.A. Saldo da balança comercial reflete queda da atividade econômica, diz AEB. Entrevista com o presidente da Associação de Comércio Exterior do Brasil (AEB). Agência Brasil, 2016. Disponível em: http://agenciabrasil.ebc.com.br/ economia/noticia/2016-11/saldo-positivona-balanca-comercial-reflete-queda-da-atividade-economica. Acessado em: maio de 2017.

CATÃO, E.C.P.; LOPES, F.A.C.; RUBINI, M.R.; NARDOTO, G.B.; PROSSER, J.I.; KRÜGER, R.H. Short-term impact of soybean management on ammonia oxidizers in a Brazilian savanna under restoration as revealed by coupling different techniques. Biology and Fertility of Soils, v. 52, n. 3, pp. 401-412, 2016.

CAVALCANTE, C. Economia e ecologia: problemas da governança ambiental no Brasil. Revista Iberoamericana de Economía Ecológica, vol. 1, pp. 1-10, 2004.

CERTAU, M. A invenção do cotidiano. $3^{\text {a }}$ ed. Petrópolis: Vozes, 1998.

CESÁRIO, P.S. A influência em Brasília: os grupos de interesse no Poder Legislativo. In: MESQUITA, N.C. Brasil, 25 anos de democracia. São Paulo: Konrad Adenauer Stiftung/NUPPs, 2016.

CENTRO DE ESTUDOS SOBRE AS TECNOLOGIAS DA INFORMAÇÃO E DA COMUNICAÇÃO (CETIC). Organizações sem fins lucrativos: Portal de dados. Disponível em: http://data.cetic.br/cetic/ explore?idPesquisa=TIC_OSFIL. Acessado em: janeiro de 2017.

CHEPTULIN, A. A dialética materialista: leis e categorias da dialética. São Paulo: Alfa-Ômega, 2004 [1975].

CLARK, J. P. Marx's inorganic body. Environmental Ethics, 11, pp. 243-258, 1989. 
CLIFFORD, N. et al. Key methods in geography. $2^{a}$ ed. Los Angeles: SAGE, 2012.

COELHO, V.S.P. Brazil's health councils: the challenge of building participatory political institutions. IDS Bulletin, v. 35, n. 2, pp. 33-39, 2004.

COELHO, V.S.P.; VERÍSSIMO, J. Considerações sobre o processo de escolha dos representantes da sociedade civil nos conselhos de saúde em São Paulo. In: AVRITZER, L. (Org.) A participação em São Paulo. São Paulo: Editora da UNESP, 2004.

COHEN, S.B. Geography and politics in a world divided. Nova lorque: Oxford University Press, 1973.

CONSELHO INDIGENISTA MISSIONÁRIO. Relatório "Violência contra os povos indígenas no Brasil". CIMI, 2010.

CONSELHO NACIONAL DE DESENVOLVIMENTO CIENTÍFICO E TECNOLÓGICO. Plano Tabular: Censo 2000, 2002, 2004, 2006, 2010. Disponível em: http://dgp.cnpq.br/planotabular/index.jsp. Acessado em: maio de 2016.

CONSELHO NACIONAL DE MEIO AMBIENTE. 24aㅡ Ata das Reuniões Plenárias CONAMA. Junho/1990. In: Atas do Conselho Nacional do Meio Ambiente (CONAMA) - 1992 a 2012. Disponível em: http://www.mma.gov.br/port/ conama/reunoe.cfm. Acessado em: junho de 2015.

. 6aㅡ Reunião Extraordinária do CONAMA. Abril/1989. Ministério do Meio Ambiente. In: Atas do Conselho Nacional do Meio Ambiente (CONAMA) 1992 a 2012. Disponível em: http://www.mma.gov.br/port/ conama/reunoe.cfm. Acessado em: junho de 2015.

CONTROLADORIA-GERAL DA UNIÃO. Escala Brasil Transparente (EBT). Disponível em: http://www.cgu.gov.br/assuntos/transparencia-publica/escalabrasil-transparente. Acessado em: março de 2017.

CORREIA FILHO, V. História de Mato Grosso. Rio de Janeiro: INL, 1969.

COSTA, S.L.; MENDES, R. Redes sociais territoriais. São Paulo: FAP-UNIFESP, 2014.

COSTA, W.M. da. Ordenamento territorial e Amazônia: vinte anos de experiências de Zoneamento Ecológico-Econômico. In: BATISTELLA, M.; MORAN, E.; ALVES, D. (Orgs.). Amazônia: natureza e sociedade em transformação. São Paulo: EDUSP, 2008. pp. 241-274.

COX, K. Spaces of dependence, spaces of engagement and the politics of scale, or: looking for local politics. Political Geography, v. 17, n. 1, pp. 1-23, 1998.

CROZIER, M.; FRIEDBERG, E. L'acteur et le système. Paris: Seuil (Points), 1977.

CUEVA, A. Las democracias restringidas de América Latina: elementos para una reflexión crítica. Quito: Planeta, 1988.

CUNHA, P.R. O Código Florestal e os processos de formulação do mecanismo de compensação de reserva legal (1996-2012): ambiente político e política ambiental. 2013. Dissertação (Mestrado em Ciência Ambiental) Universidade de São Paulo, São Paulo. 2013.

CUNHA, J.M.P.; BAENINGER, R. A migração dos estados brasileiros no período recente: principais tendências e mudanças. In: HOGAN, D.J.; CUNHA, 
J.M.P.; BAENINGER, R.; CARMO, I.R. (Orgs.) Migração e ambiente em São Paulo: aspectos relevantes da história recente. Campinas: Núcleo de Estudos de População/UNICAMP, 2000.

DAGNINO, E. Sociedade civil, participação e cidadania: de que estamos falando? In: MATO, D. (Coord.). Políticas de ciudadanía y sociedad civil en tiempos de globalización. Caracas: FACES, Universidad Central de Venezuela, 2004. pp. 95-110.

DAGNINO, R. Metodologia de análise de políticas públicas. In: DAGNINO, R. et al (Org.) Gestão estratégica da inovação: metodologias para a análise e implementação. Taubaté: Editora Cabral Universitária, 2002.

DALLABRIDA, V.R. A dinâmica territorial do desenvolvimento: uma compreensão a partir da análise da trajetória de um âmbito espacial periférico. 2005. Tese (Doutorado em Desenvolvimento Regional) - UNISC, Santa Cruz do Sul. 2005.

DALTON, R. The green rainbow: environmental groups in Western Europe. New Haven, CT: Yale University Press, 1994.

DEAN, W. A ferro e fogo: a história e a devastação da Mata Atlântica brasileira. $1^{\underline{a}}$

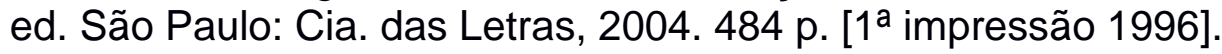

DE CARLO, S. Gestão ambiental nos municípios brasileiros: impasses e heterogeneidades. Brasília: CDS/UNB, 2006.

DELLA PORTA, D. Social movements, political violence and the State. Cambridge: Cambridge University Press, 1995.

DELLA PORTA, D.; DIANI, M. Social movements: an introduction. Londres: Blackwell, 1999.

DE-SHALIT, A. Is liberalism environmental friendly?. Social Theory and Practice, v. 21, n. 2, 1995.

DIAMOND, L.; MORLINO, L. The quality of democracy. CDDRL: Working papers, n. 20, 2004.

DIANI, M. The concept of social movement. Sociological Review, v. 40, n. 1, pp. 125, 1992.

DIAS, L.C. Redes: emergência e organização. In: CASTRO, I.; GOMES, P.C. da Costa; CORRÊA, R.L. Geografia: conceitos e temas. $2^{\underline{a}}$ ed. Rio de Janeiro: Bertrand Brasil, 2000.

DIEWALD, C.; BALTAR, S.; CHAVES, F.; VITA, F.; IRVING, M.; RESENDE, M.L.; CONCEIÇÃO, P.H.Z. (Consultants). Implementation completion report (CPL34920) on a loan in the amount of US\$205.0 million to the Federative Republic of Brazil for a Mato Grosso Natural Resources Management Project (LOAN 3492-BR). 2003.

DIKEN, B.; LAUSTSEN, C. 7/11, 9/11, and post-politics. Lancaster: Department of Sociology, Lancaster University, 2004.

DI PIETRO, M.S. Direito administrativo. $8^{\text {a }}$ ed. São Paulo: Atlas, 1997.

DOHERTY, B. Ideas and actions in the green movement. Londres: Routledge, 2002. 
DOWBOR, L. Governabilidade e descentralização. São Paulo em Perspectiva, v. 10, n. 3, 1996.

DRYZEK, J.S. Discursive democracy. Politics, policy, and political science. Cambridge: Cambridge University Press, 1990.

DUBAR, C. Agente, ator, sujeito, autor: do semelhante ao mesmo. $1^{\circ}$ Congresso da Associação Francesa de Sociologia, 2004.

DUPUY, G. Villes, systèmes et réseaux: le rôle historique des techniques urbaines. Réseaux, v. 1, n. 4, 1984.

DYE, T.R. Understanding public policy. $12^{\mathrm{a}}$ ed. New Jersey: Pearson/Prentice Hall, 2008 [1978].

Mapeamento dos modelos de análise de políticas públicas. In: HEIDEMANN, F.G.; SALM, J.F. Políticas públicas e desenvolvimento: bases epistemológicas e modelos de análise. Brasília: Editora Universidade de Brasília, 2009. pp. 99-129.

EIZENSTAT, S. Nongovernmental organizations as the Fifth State. Seton Hall Journal of Diplomacy and International Relations, v. 5, n. 2, 2004.

FAIRCLOUGH, N. Discurso e mudança social. Brasília: EdUnb, 2008, p. 91.

FANK, J. Flores, cores e saberes do movimento ecológico de Mato Grosso em frutificação na educação ambiental. 2007. Dissertação de Mestrado Universidade Federal de Mato Grosso. 2007.

FAORO, R. Os donos do poder: formação do patronato político brasileiro. 10ª ed. São Paulo: Globo, 1995.

FARHI NETO, L. Concepções filosóficas ambientalistas. Ethic@. v. 5, n. 3, pp. 3356, 2006.

FEARNSIDE, P.M. Desmatamento na Amazônia brasileira: história, índices e consequências. Megadiversidade, v. 1, n. 1, 2005.

. Zoneamento nos estados amazônicos. In: Seminário Avaliação da Metodologia do Zoneamento Ecológico-Econômico para a Amazônia. 03 a 05 de outubro de 2000, Manaus-AM. Programa Piloto de Conservação das Florestas Tropicais do Brasil (PPG7), Ministério do Meio Ambiente, BrasíliaDF. (CD-ROM), 2001.

FELDMAN, F. Rio +10 Brazil: a decade of change. Quickgrafic, 2002.

FIGUEIREDO, A.; LIMONGI, F. Executivo e Legislativo na nova Ordem Constitucional. Rio de Janeiro: Ed. FGV, 1999.

FINOT, I. Descentralización en América Latina: teoría y práctica. Santiago de Chile: Ilpes/Cepal, Serie Gestión Pública, v.12, 2001.

FISCHER, F.; MILLER, G.J.; SIDNEY, M.S. Handbook of public policy analysis: theory, politics, and methods. CRC press, 2007.

FOLADORI, G. O metabolismo com a natureza. Crítica Marxista, n. 12. São Paulo: Boitempo, 2001.

FOLKE, C. Adaptative governance of social ecological systems. Annual Rev. Environment Resources, v. 30, pp. 441-473, 2005. 
FONSECA, I.F. da. (Coord.) Processo político e decisório no âmbito do Conselho Nacional do Meio Ambiente (CONAMA). Relatório Técnico. Brasília: Coordenação de Desenvolvimento Sustentável (CODES); Diretoria de Estudos e Políticas Regionais, Urbanas e Ambientais (DIRUR); Instituto de Pesquisa Econômica Aplicada (IPEA), 2011.

FORESTA, R. Amazonia and the politics of geopolitics. Geographical Review, v. 82, n. 2, pp. 128-142, 1992.

FORO DE LA CIUDADANÍA DE ECUADOR. Relatório: la sociedad civil frente a la política social en America Latina. Quito: Foro de la Ciudadanía de Ecuador, 1995.

FÓRUM DE DIREITOS HUMANOS E DA TERRA. Relatório Estadual de Direitos Humanos e da Terra Mato Grosso. Cuiabá: FDHT, 2011.

Relatório Estadual de Direitos Humanos e da Terra Mato Grosso. Cuiabá: FDHT, 2013.

FÓRUM MATO-GROSSENSE DE MEIO AMBIENTE E DESENVOLVIMENTO; FÓRUM DIREITOS HUMANOS E DA TERRA. Carta por um Mato Grosso decente: manifesto da sociedade civil. Cuiabá, 2011 (mimeo).

FÓRUM MATO-GROSSENSE DE MEIO AMBIENTE E DESENVOLVIMENTO. Relatório da Assembleia. Cuiabá: FORMAD, 2016.

. Dois casos sérios em Mato Grosso: a soja e a cana-de-açúcar. Cuiabá: FORMAD, 2013.

. Relatório da Assembleia. Cuiabá: FORMAD, 2013a.

. Relatório do Seminário de Políticas Públicas, 2013b. Disponível em: www.formad.org.br.

. Relatório do Seminário Estadual de Conselhos, 2013c. Disponível em: www.formad.org.br.

. Relatório da Assembleia. Cuiabá: FORMAD, 2012.

. Relatório da Assembleia. Cuiabá: FORMAD, 2011.

. Relatório da Assembleia. Cuiabá: FORMAD, 2010. 2003.

. Compêndio do Programa de Desenvolvimento Sustentável do Pantanal.

Assembleia Geral: Retirada do FORMAD das negociações do PRODEAGRO, 1997 (mimeo). (mimeo).

. Carta de solicitação de cumprimento de compromissos ao BIRD. 1997a

- Relatório do Seminário de Políticas Públicas e Participação Social. FORMAD/ABONG, pp. 6-7, 1997b (mimeo).

- Propostas de reformulação do PRODEAGRO: deliberações do Seminário de Avaliação Pública. 1996 (mimeo).

. Seminário de avaliação do PRODEAGRO/PADIC. [s/d] (mimeo).

. Propostas de reformulação do PADIC. [s/d] (mimeo). 
. Documento-base do seminário de avaliação do PADIC. [s/d] (mimeo).

FOSTER, J.B. A ecologia de Marx. Rio de Janeiro: Civilização Brasileira, 2005 (2000).

FOUCAULT, M. Microfísica do poder. Rio de Janeiro: Ed. Graal, 1979.

FREY, K. Políticas públicas: um debate conceitual e reflexões referentes à prática da análise de políticas públicas no Brasil. Planejamento e Políticas Públicas, n. 21, 2000.

GERVAIS-LAMBONY, P. Space matters: identity, justice and democracy at the ward level in South African cities. Transformation: Critical Perspectives on Southern Africa, v. 66, n. 67. pp. 83-97, 2008.

GIRARDI, G. Cadastro rural não impede desmatamento na Amazônia, alerta estudo. Jornal O Estado de São Paulo. Publicado em: 03 de julho de 2017. Acessado em: 03 de julho de 2017.

GOHN, M.G. Conselhos gestores e participação sociopolítica. São Paulo: Cortes Editora, 2001.

Participação de representantes da sociedade civil na esfera pública na América Latina. Política e Sociedade, v. 10, n. 18, pp. 233-244, 2011.

Teorias dos movimentos sociais: paradigmas clássicos e contemporâneos. São Paulo: Loyola, 1997.

GONÇALVES, C.V.P. Amazônia, Amazônias. São Paulo: Contexto, 2001.

GOUVEIA, T.; DANILIAUSKAS, M. ABONG: panorama das associadas. São Paulo: ABONG, 2010.

GOVERNO DO ESTADO DE MATO GROSSO. Plano Plurianual 2012-2015, Lei no 9.675 de 20 de dezembro de 2011. Secretaria de Estado de Planejamento e Coordenação Geral, 2011.

. Tudo sobre o ZSEE (cartilha). 2008.

Zoneamento Socioeconômico e Ecológico. Cuiabá: SEPLAN, 20082011.

GOVERNO FEDERAL. Portal da Transparência: transferências do Governo Federal por função e UF. Disponível em: http://www.transparencia.gov.br. Acessado em: junho de 2015.

GRAMSCI, A. Cadernos do cárcere (6 vols). Edição de Carlos Nelson Coutinho/ Luiz Sérgio Henriques e Marco Aurélio Nogueira. Rio de Janeiro: Civilização Brasileira, 1999-2002.

GRUGEL, J. Romancing civil society: European NGOs in Latin America. Journal of Interamerican Studies and World Affairs. Special Issue: The European Union and Latin America: Changing Relations, v. 42, n. 2, pp. 87-10, 2000.

GRUPO DE TRABALHO AMAZÔNICO. FORMAD, MDA, INCRA e SEMA/PA não comparecem à reunião do Fórum da BR-163 em Itaituba, 2009. Disponível em: formad.org.br. Acessado em: 2016.

Parceiros/parceiros não governamentais. Disponível em: http://www.gta.org.br. Acessado em: 2015. 
GUDYNAS, E. El mandato ecológico: derechos de la naturaleza y políticas ambientales en la nueva constitución. Quito: Abya-Yala, 2009.

GUIMARÃES, S.P. Nação, nacionalismo, Estado. Estudos Avançados, v. 22, n. 62, 2008.

HABERMAS, J. New Social Movements. Telos, v. 21, n. 49, pp. 33-37, 1981.

HAESBAERT, R. Concepções de território para entender a desterritorialização. In: Território Territórios. Programa de Pós-Graduação em Geografia da UFF. Niterói: UFF/AGB, 2002. pp. 17-38.

. Lógica zonal y ordenamiento territorial: para rediscutir la proximidad y la contigüidad espaciales. Cultura y Representaciones Sociales, ano 8, n. 16, 2014.

O mito da desterritorialização: do "fim dos territórios" à multiterritorialidade. Rio de Janeiro: Bertrand Brasil, 2004.

. Região, regionalização e regionalidade: questões contemporâneas. Antares, n. 3, 2010.

HANNIGAN, J. Environmental sociology: a social constructionist perspective. Londres: Routledge, 1995.

HARTSHORNE, R. The nature of geography. Annals of Association of American Geographers, v. 29, n. 3 e 4, Lancaster, Pennsylvania, 1939.

HARVEY, D. A produção capitalista do espaço. Annablume, 2006.

. Neoliberalismo: história e implicações. São Paulo: Loyola, 2005.

HAWKEN, P. The environment: opposing viewpoint. San Diego: Green Island Press, 1996.

HEIDRICH, A.L. Conflitos territoriais na estratégia de preservação da natureza. In: SAQUET, M.A.; SPOSITO, E.S. Territórios e territorialidades: teorias, processos e conflitos. São Paulo: Expressão Popular/UNESP, 2009.

HETTNER, A. La naturaleza de la geografia y sus metodos (1927). In: MENDOZA, J.G.; JIMÉNEZ, J.M.; CANTERO, N.O. El Pensamiento Geográfico. $2^{\underline{a}}$ ed. Madrid: Alianza, 1994.

HIDALGO-CAPITÁN, A.L. et al. Antologia del pensamiento indigenista ecuatoriano sobre Sumak Kawsay. Universidad de Huelva y Universidad de Cuenca, 2014

HOBBES, T. Leviatã: ou matéria, forma e poder de um Estado eclesiástico e civil. $1^{\text {a }}$ ed. Edipro, 1651.

HOUTZAGER, P.P.; GURZA LAVALLE, A. Civil's society claims to political representation in Brazil. Studies in Comparative International Development, v. 45, n. 1, pp. 1-29, 2010.

HOWLeTT, M; RAMESH, M.; PERL, A. Política pública: seus ciclos e subsistemas: uma abordagem integral. Trad. técnica: Francisco G. Heidemann. Rio de Janeiro: Elsevier, 2013. 
INSTITUTO BRASILEIRO DE GEOGRAFIA E ESTATÍSTICA. 3a Conferência Nacional de Produtores e Usuários de Informações Estatísticas, Geográficas e Ambientais. Rio de Janeiro: INFOPLAN, 2016.

. Brasil, série histórica de área plantada e produção agrícola: safras 1998 a 2010. Disponível em: http://www.sidra.ibge.gov.br. Acessado em: março de 2011. 2006 .

. Censo Agropecuário: índice de Gini. Censo Agropecuário (1985-2006),

Mapeamento das Unidades Territoriais. Disponível em: ftp://geoftp.ibge.gov.br/organizacao do territorio/malhas territoriais/malhas municipais/municipio 2001/mt/, 2001.

. Mudanças na cobertura e uso da terra no Brasil, 2000, 2010, 2012, 2014. Rio de Janeiro: Coordenação de Recursos Naturais e Estudos Ambientais, 2016a.

. Pesquisa de Informações Básicas Municipais. Diretoria de pesquisas, coordenação de população e indicadores sociais, 2002.

. Pesquisa de Informações Básicas Municipais. Diretoria de pesquisas, coordenação de população e indicadores sociais, 2004.

. Pesquisa de Informações Básicas Municipais. Diretoria de pesquisas, coordenação de população e indicadores sociais, 2012.

. Pesquisa de Informações Básicas Municipais. Diretoria de pesquisas, coordenação de população e indicadores sociais, 2015. $2012 a$.

INSTITUTO DE DEFESA AGROPECUÁRIA DE MATO GROSSO. Relatório de consumo de agrotóxicos em Mato Grosso, 2005 a 2010. Banco eletrônico. Cuiabá: INDEA-MT, 2011.

INSTITUTO CENTRO DE VIDA. Sociedade mato-grossense elabora carta cobrando zoneamento mais justo e responsável. Publicado em: 31 de maio de 2011 (2011a). Disponível em: http://www.icv.org.br/2011/05/31/ sociedade-mato-grossense-elabora-carta-cobrando-zoneamento-maisjusto-e-responsavel/. Acessado em: 2015.

- Sociedade mato-grossense vai a Brasília cobrar reprovação do zoneamento do estado. Publicado em: 29 de setembro de 2011 (2011b). Disponível em: http://www.icv.org.br/site/2011/09/29/sociedade-matogrossense-vai-a-brasilia-cobrar-reprovacao-do-zoneamento-do-estado/. Acessado em: 3 de agosto de 2015.

INSTITUTO DE PESQUISA ECONÔMICA APLICADA. Mapa das OSC. Disponível em: http://www.ipea.gov.br/extrator/mapa_oscs.html. Acessado em: setembro de 2016.

INSTITUTO NACIONAL DE PESQUISAS ESPACIAIS. Sistema de monitoramento do desmatamento na Amazônia Legal. Disponível em: http://www.obt.inpe.br/prodes/prodes_1988_2016.htm. Acessado em: setembro de 2016. 
INSTITUTO PRO BONO. Manual do Terceiro Setor. São Paulo: Ford Foundation, [s/d].

INSTITUTO SOCIOAMBIENTAL. Limites da Amazônia Legal brasileira. Arquivo SHP, 1999.

. Pela sustentabilidade da BR-163: Encontro BR-163 Sustentável desafios e sustentabilidade ao longo da Cuiabá-Santarém, 2003. Publicado em: 17 de novembro de 2003. Disponível em: https://siteantigo.socioambiental.org/noticias/nsa/detalhe?id=1482. Acessado em: junho de 2017.

JABER-SILVA, M.T. O mapeamento dos conflitos socioambientais de Mato Grosso: denunciando injustiças ambientais e anunciando táticas de resistência. 2012. 253f. Tese (Doutorado em Ciências - Programa de Pós-Graduação em Ecologia e Recursos Naturais) - UFSCar, São Carlos. 2012.

JACKSON, W.A.D. Politics and geographic relationships. Nova Jersey: Englewood Cliffs, 1964.

JAYAL, N.G. Balancing political and ecological values. In: HUMPHREY, M. Political theory and the environment. Londres: Frank Cass Publishers, 2001.

JIMÉNEZ, J.M.; CANTERO, N.O. El pensamiento geográfico. $2^{2}$ ed. Madrid: Alianza, 1994.

JUNQUEIRA, C.B. A rede dos lugares. In: Encontro internacional: lugar, formação socioambiental. Universidade de São Paulo: ANPEGE (Associação de Pesquisa e Pós-Graduação em Geografia), setembro de 1994.

KA'APOR, E. Em terreno perigoso. Londres: Global Witness, 2016.

KASPERSON, R.E.; MINGHI, J.V. The structure of political geography. Chicago: Aldine Publishing Company, 1969.

KEKES, J. The morality of pluralism. Princeton, NJ: Princeton University Press, 1993.

KITSCHELT, H. Political opportunity structures and political protest: anti-nuclear movements in four democracies. British Journal of Political Science, v. 16, n. 1, pp. 57-86, 1986.

KRIESI, H.; KOOPMANS, R.; DUYVENDAK, J.W.; GUIGNI, M.G. New social movements in Western European: a comparative analysis. Minneapolis: University of Minnesota Press, 1995.

KOSIK, K. Dialética do concreto. $2^{\mathrm{a}}$ ed. São Paulo: Paz e Terra, 1976.

KUGELMAS, E. Difícil hegemonia: um estudo sobre São Paulo na Primeira República. Tese de Doutorado. São Paulo: DCS/FFLCH/USP, 1986 (mimeo).

LA BLACHE, V. Princípios de geografia humana. $2^{\mathrm{a}}$ ed. Lisboa: Cosmos, 1954.

LACOSTE, Y. La géographie, ca sert d'abord, pour faire la guerre. Paris: La Découverte, 2012 [1976].

LANDIM, L.; FERNANDES, R.C. Sem fins lucrativos: as organizações não governamentais no Brasil. Rio de Janeiro: ISER, 1988. 
LAVALLE, A. G. Participação: valor, utilidade, efeitos e causa. In: PIRES, R.R.C. Efetividade das instituições participativas no Brasil: estratégias de avaliação. Brasília: IPEA, 2011. pp. 33-42.

LEEUWESTEIN, J. Aquabio: diagnóstico institucional e legal: relatório final. Brasília: MMA, 2005. Disponível em: http://www.mma.gov.br/estruturas/ 205/_arquivos/diagnostico_institucional_completo_205_1.pdf.

LEFÉBVRE, H. A produção do espaço. Trad. Doralice Barros Pereira e Sérgio Martins (do original: La production de l'espace). 4a ed. Paris: Éditions Anthropos, 2000.

LENCIONI, S. Região e geografia: a noção de região o pensamento geográfico. In: CARLOS, A.F.A. Novos caminhos da geografia. $5^{\mathrm{a}}$ ed. São Paulo: Contexto, 2005.

LENTIN, A. Structure, strategy, sustainability: what future for new social movement theory?. Sociological Research Online, v. 4, n. 3, 1999.

LIMONGI, A; LIMONGI, F.V. Executivo e Legislativo na Nova Ordem Constitucional. Rio de Janeiro: FGV, 1999.

LITTLE, P.E. Políticas ambientais no Brasil. Análises, instrumentos e experiências. São Paulo: Peirópolis, 2003.

LOCKE, J. Two treatises of government. Livro II, 1689.

LOURENÇO, S.C. Ideologias ambientalistas e a participação das classes sociais nas decisões ambientais. Oralidades, n. 14, pp. 107-130, 2015.

LOURENÇO, S.C.; BORGES, L.R.M. Discurso e políticas ambientais brasileiras e bolivianas aplicadas a grandes obras infraestruturais. Cadernos PROLAM/USP, v. 2, 2012.

LOWI, T.J. Four systems of policy, politics, and choice. Public Administration Review, v. 32, n. 4., pp. 298-310, 1972.

MAQUIAVEL, N. O príncipe. São Paulo: Companhia das Letras, 2010.

MARQUES H.R. Local development at a human scale. Revista Polis, n. 22, 2009.

MARSTON, S.A.; JONES III, J.P.; WOODWARD, K. Human geography without Scale. Transactions of the Institute of British Geographers, New Series, v. 30, n. 4, pp. 416-432, Dec., 2005.

MARTIN, A.R. Dilemas do federalismo: entre o estadualismo oligárquico e o regionalismo burocrático. Perspectivas, São Paulo, v. 27, pp. 55-68, 2005.

MARTÍNEZ-ALIER, J. O ecologismo dos pobres: conflitos ambientais e linguagens de valoração. São Paulo: Contexto, 2007.

MARTÍNEZ-ALIER, J.; SEJENOVICH, H.; BAUD, M. El ambientalismo y ecologismo latinoamericano. In: DE CASTRO, F. et al. Gobernanza ambiental en América Latina. 1aㅡ ed. Ciudad Autónoma de Buenos Aires: CLACSO, ENGOV, 2015.

MARTINS, E.R. Geografia e ontologia: o fundamento geográfico do ser. GEOUSP - Espaço e Tempo, São Paulo, n. 21, pp. 33-51, 2007.

MARX, K. Manuscritos Econômico-Filosóficos. Lisboa: Edições 70, 1989[1844] 
MCADAM, D. Beyond structural analysis: towards a more dynamic understanding of social movements. In: DIANI, M.; MCADAM, D. (Eds.). Social movements and networks: relational approaches to collective action. Oxford: Oxford University Press, 2002. pp. 281-98.

MCCARTHY, J.; ZALD, M. Resource mobilization and social movements: a partial theory. American Journal of Sociology, v. 82, n. 6, 1977.

MELLO, N.A. de. Políticas territoriais na Amazônia. São Paulo: Annablume, 2006.

MELLO, N.A. de.; NÉDÉLEC, V.; DUBREUIL, V; FERREIRA, C.M.; MENDEZ, P. Soja ou forêt? Ou, comment le projet d'asphaltage de la BR163 peut encourager un véritable (ré)aménagement du territoire. In: MENDONÇA, F.; BERTRAND, F. Le Brésil: géopolitique et environnements actuels. PRODIG, 2006. pp. 79-96 e 183-200.

MELLO, N.A. de; THÉRY, H. A armadura do espaço amazônico: eixos e zoneamentos. Alceu, v. 1, n. 2, pp. 181-214, 2001.

MELLO-THÉRY, N.A. de. Território e gestão ambiental na Amazônia. Terras públicas e os dilemas do Estado. São Paulo: Annablume, 2011.

MELLO-THÉRY, N.A. de; THÉRY, H. Cenários urbanos contemporâneos: novas ou velhas práticas no Brasil e na Amazônia? 1. PRACS: Revista Eletrônica de Humanidades do Curso de Ciências Sociais da UNIFAP, v. 9, p. 107, 2016.

MENDES, C.C. Arranjos federativos e desigualdades regionais no Brasil. In: BOUERI, R.; COSTA, M.A. Brasil em desenvolvimento 2013: estado, planejamento e políticas públicas. Brasília: IPEA, 2013. 3 v. pp. 199-220.

MENDES-PEREIRA, J.M. O modelo de reforma agrária de mercado do Banco Mundial em questão: o debate internacional e o caso brasileiro. Teoria, luta política e balanço de resultados. 2004. Dissertação (Mestrado em Desenvolvimento, Agricultura e Sociedade - CPDA) - Universidade Federal Rural do Rio de Janeiro (UFRRJ). 2004.

MENY, Y.; THOENIG, J.C. Las políticas públicas. Barcelona: Editorial Ariel, 1992.

MESQUITA, N.C. Brasil: 25 anos de democracia: participação, sociedade civil e cultura política. Rio de Janeiro: Fundação Konrad Adenauer, 2016.

MÉSZAROS, I. O poder da ideologia. São Paulo: Boitempo Editorial, 2004.

. Structural crisis needs structural change. Monthly Review, v. 63, n. 10, 2012.

MICOL, L.; THUAULT, A.; ANDRADE, J. Dez ações prioritárias para conciliar o desenvolvimento rural com a conservação ambiental em Mato Grosso. Instituto Centro Vida, v. 4, ano 3, 2014.

MILANI, C.R.S. Atlas da política externa brasileira. Buenos Aires: CLACSO, 2015.

MILANI, C.; SOLINIS, G. Pensar a democracia na governança mundial: algumas pistas para o futuro. In: MILANI, C.; ARTURI, C.; SOLINIS, G. Democracia e governança mundial - que regulações para o séc. XXI. Porto Alegre: UFRGS/Unesco, 2002. pp. 266-291.

MILL, S. Representative government. Ontario: Batoche, 2001 [1841]. 
MINISTÉRIO DA INTEGRAÇÃO. Documento-base para a definição da Política Nacional de Ordenação do Território - PNOT. Brasília, 2006.

MINISTÉRIO DO DESENVOLVIMENTO, INDÚSTRIA E COMÉRCIO EXTERIOR. Base de dados sobre balança comercial. Disponível em: http://www.mdic.gov.br/balanca-comercial. Acessado em: julho de 2015.

. Exportações pelo estado de Mato Grosso 2000-2012. Recuperado em 9 de julho de 2014, de http://www. desenvolvimento.gov.br/.

MINISTÉRIO DO INTERIOR. PRODEAGRO - Informações gerais. 1989 (mimeo). MINISTÉRIO DO MEIO AMBIENTE. Base de dados em geoprocessamento. Brasília: MMA, 2015.

. Conselhos de Meio Ambiente do Brasil. Banco de dados. Disponível em: http://www.mma.gov.br/port/conama/conselhos/ cons_municipios1.cfm. Acessado em: outubro de 2017.

Orçamento do Ministério do Meio Ambiente. Disponível em: http://www.mma.gov.br/mma-em-numeros/orçamento. Acessado em: 29 de dezembro de 2015 (2015a).

. Projeto BR-163 - Floresta, desenvolvimento e participação. Disponível em: http://www.mma.gov.br/florestas/projeto-br-163. Acessado em: 29 de dezembro de 2013.

. Relatório de gestão do exercício de 2013. Brasília: Fundo Nacional de Meio Ambiente, 2014.

. Zona de Abrangência da BR-163. In: Começam hoje audiências sobre BR-163. Notícias MMA, 2004. Disponível em: http://www.mma.gov.br/informma/item/2042-comecam-hoje-audienciassobre-br163.

MINISTÉRIO DO MEIO AMBIENTE/SECRETARIA DE POLÍTICAS PARA O DESENVOLVIMENTO SUSTENTÁVEL. Avaliação da metodologia de zoneamento ecológico-econômico para a Amazônia: transcrição dos debates. In: Workshop de Avaliação da Metodologia de Zoneamento EcológicoEconômico para a Amazônia. Brasília, 2001. 463 p.

MINISTÉRIO DO PLANEJAMENTO. Planos Plurianuais. Disponível em: www.planejamento.gov.br. Acessado em: junho de 2015.

MINISTÉRIO PÚBLICO FEDERAL. Ranking Nacional da Transparência. Disponível em: http://www.rankingdatransparencia.mpf.mp.br. Acessado em: março de 2017.

MIZUBUTI, S. O movimento associativo de bairro em Niterói (RJ). 1986. Tese de Doutorado - Faculdade de Filosofia, Letras e Ciências Humanas, Universidade de São Paulo, São Paulo. 1986.

MONTECINOS, E. Los estudios de descentralización em América Latina: una revisión sobre el estado actual de la temática. EURE (Santiago de Chile), v. 31, n. 93, pp. 73-88, 2005.

MORAES, A.C.R. Bases da formação territorial do Brasil: o território colonial brasileiro no longo século XV. São Paulo: Hucitec, 2000. 
. Geografia histórica do Brasil: capitalismo, território e periferia. São Paulo: Annablume, 2011.

Ideologias geográficas: espaço, cultura e política no Brasil. 5ª ed. São Paulo: Annablume, 2005. 2002.

. Meio ambiente e ciências humanas. $3^{a}$ ed. São Paulo: Editora Hucitec,

. Território e história no Brasil. São Paulo: HUCITEC/Annablume, $2002 a$.

MOURA, L.H.G. de. Código Florestal: elementos sobre a expressão ambiental da luta de classes no Brasil. Campo-território: revista de geografia agrária. Edição especial do XXI ENGA-2012, pp. 1-25, jun. de 2014.

MOVIMENTO DOS ATINGIDOS POR BARRAGENS. MAB: 0 atual modelo energético. 2004.

MUSSO, P. Communique demain: nouvelles technologies de l'information et de la communication. Paris: L'Aube/Datar, 1994.

NABUCO, M.R. Estado e projeto nacional nas obras de Celso Furtado. In: TAVARES, M.C. Celso Furtado e o Brasil. São Paulo: Fundação Perseu Abramo, 2000.

NORTH, D.C. Institution, institutional change and economic performance. Nova lorque: Cambridge University Press, 1990.

OBSERVATÓRIO DO CLIMA. Sistema de estimativas de emissões de gases de efeito estufa. Disponível em: http://seeg.eco.br. Acessado em: outubro de 2016.

OLIVEIRA, A.C. La autorregulación de las OSCs. Un marco jurídico para la participación ciudadana: memoria. In: III Taller Regional Centroamericano. San José: Fundación Arias para la Paz y el Progreso Humano, 1998. pp. 70-82.

OLIVEIRA, A.C.; HADDAD, S. As organizações da sociedade civil e as ONG de educação. Cadernos de Pesquisa, v. 112, 2001.

ONG REPÓRTER BRASIL. Impactos da soja sobre Terras Indígenas no estado do Mato Grosso. Centro de Monitoramento de Agrocombustíveis. Disponível em: $\quad$ http://reporterbrasil.org.br/documentos/indigenas_soja_MT.pdf. Acessado em: maio de 2015.

. Zoneamento no Mato Grosso: planejamento do estado em disputa. Disponível em: http://reporterbrasil.org.br/agrocombustiveis/exibe. $p h p ? i d=49$. 2009.

OPERAÇÃO AMAZÔNIA NATIVA. Relatório do Encontro do Movimento dos Povos Indígenas de Mato Grosso. Chapada dos Guimarães, 2005. Disponível em: www.formad.org.br/index.php/bibliotecas/ler/22.

ORGANISATION FOR ECONOMIC CO-OPERATION AND DEVELOPMENT. Employment in the public sector. In: Government at a Glance 2015. Paris: OECD Publishing, 2015. Disponível em: http://dx.doi.org/ 10.1787/gov_glance-2015-22-en. Acessado em: maio de 2016. 
PAGNOCCHESCHI, B.; BERNARDO, M. Política ambiental no Brasil. In: STEINBERGER, M. Território, ambiente e políticas públicas espaciais. Brasília: Paralelo 15 e LGE Editora, 2006.

PEDON, N.R. Geografia e movimentos sociais: dos primeiros estudos à abordagem socioterritorial. São Paulo: Editora Unesp, 2013.

PERISSINOTTO, R.M. Classes dominantes e hegemonias na República Velha. Campinas: Editora UNICAMP, 1994.

PIGNATTI, M.G. As ONGs e a política ambiental nos anos 90: um olhar sobre Mato Grosso. São Paulo: Annablume, 2005.

PIGNATI, W.A.; MACHADO, J.M.H. O agronegócio e seus impactos na saúde dos trabalhadores e da população do estado de Mato Grosso. In: GOMEZ, M. Saúde do trabalhador na sociedade brasileira contemporânea. Rio de Janeiro: Editora FIOCRUZ, 2011. pp. 245-272.

PIRES, R.R.C. Efetividade das instituições participativas no Brasil: estratégias de avaliação. Brasília: IPEA, 2011. pp. 13-28.

PORTELLI, H. Gramsci e o bloco histórico. Rio de Janeiro: Paz e Terra, 1977.

POULANTZAS, N. O Estado, o poder, o socialismo. Rio de Janeiro: Graal, 2000 [1968].

RACINE, J.B.; RAFFESTIN, C.; RUFFY, V. Escala e ação: contribuição para uma interpretação do mecanismo de escala na prática da Geografia. Revista Brasileira de Geografia, Rio de Janeiro, v. 45, n. 1, pp. 123-135, 1983.

RAFFESTIN, C. A produção das estruturas territoriais e sua representação. In: SAQUET, M.A; SPOSITO, E.S. Territórios e territorialidades - Teorias, processos e conflitos. São Paulo: Expressão Popular, 2009. pp. 17-35. . Por uma geografia do poder. São Paulo: Ática, 1993.

. Space, territory, territoriality. Environment and planning. Society and Space, v. 30, pp. 121-141, 2012.

RATZEL, F. La geógraphie politique. France: Fayard, 1987.

RAWCLIFFE, P. Environmental pressure groups in transition. Manchester: Manchester University Press, 1998.

REIS, L.E. O terceiro setor e a sustentabilidade do meio ambiente sob a luz da Constituição de 1988. Belo Horizonte: Procuradoria-Geral do Município de Juiz de Fora (RPGMJF), ano 1, v. 1, 2011. pp. 167-194.

RIBEIRO, W.C. A ordem ambiental internacional. São Paulo: Contexto, 2001.

Desenvolvimento sustentável e segurança ambiental global. Revista Bibliográfica de Geografía y Ciencias Sociales, Barcelona, v. 6, n. 312, pp. 1-10, 2001a. Disponível em: http://www.ub.es/geocrit/b3w-312.htm.

RIKER, W.H. The development of american federalism. Norwell Kluwer Academic Publishers, 1987.

RODRIGUES, D.L.P. A necessidade e a convivência: o conceito de Estado em Espinosa. 2005. Tese de Mestrado - PUC Rio Grande do Sul, Porto Alegre. 2005. 
RONDINELLI, D.A. Analyzing decentralization policies in developing countries: political-economy framework. Development and Change, v. 20, n. 1, 1989.

ROOTES, C. Environmental protest in Western Europe. Cambridge: Cambridge University Press, 2007.

Political opportunity structures: Promise, problems and prospects. La Lettre de la Maison Française 10, Michaelmas-Hilary, pp. 75-97, 1998.

ROSSETO, A.M. et al. Governança territorial e desenvolvimento: descentralização político-administrativa, estruturas subnacionais de gestão do desenvolvimento e capacidades estatais. Rio de Janeiro: Garamond, 2011.

ROUSSEAU, J.J. The social contract. 1792.

SANCHEZ, J.E. Geografia política. Madri: Editorial Sintesis, 1992.

SANTOS, M. A natureza do espaço: técnica e tempo, razão e emoção. $4^{\underline{a}}$ ed. (2a reimpr.). São Paulo: EDUSP, 2006.

SANTOS, R.; MICOL, L.; IRGANG, G.; VASCONCELLOS, J. O desmatamento nas Unidades de Conservação em Mato Grosso. Alta Floresta e Cuiabá: Instituto Centro Vida, setembro de 2006.

SAUNDERS, C. Environmental networks and social movement theory. Londres: Bloomsbury Publishing, 2013.

SAUNDERS, C.; ANDRETTA, M. The organizational dimension: the effect of formality, voice and influence on mobilization and participation in the global justice movement. In: DELLA PORTA, D. (Ed.) Another Europe: conceptions and practices of democracy in the European social forums. Abingdon: Routledge, 2009. pp. 128-48.

SCARDUA, F.P.; BURSZTYN, M.A.A. Descentralização da política ambiental no Brasil. Sociedade e Estado, Brasília, v. 18, n. 1/2, pp. 291-314, 2003.

SCHUMPETER, J. Capitalismo, socialismo e democracia. Trad. R. Jungmann. Rio de Janeiro: Fundo de Cultura, 1961.

SCHWANDT, T.A. Evaluation as practical hermeneutics. Evaluation, v. 3, n. 1, pp. 69-83, 1997.

SEARLE, J.R. Intencionalidade. $2^{\underline{a}}$ ed. São Paulo: Martins Fontes, 2002.

SERVIÇO FLORESTAL BRASILEIRO. Números do CAR - Serviço Florestal Brasileiro (base de dados). Disponível em: www.florestal.gov.br/numeros-docar. Acessado em: 2017.

SECRETARIA DE ESTADO DE PLANEJAMENTO. Plano de Longo Prazo de Mato Grosso: macro-objetivos, metas globais, eixos estratégicos e linhas estrutantes. José Gonçalves Botelho do Prado, Regiane Berchieli, Lucieni Grassi de Oliveira (Orgs.). Cuiabá, MT: Central de Texto, 2012.

. Plano de Desenvolvimento do Estado de Mato Grosso (MT+20). 2015.

. Projeto de desenvolvimento agroambiental do estado de Mato Grosso: avaliação final. 2002 (mimeo).

. Regiões de Planejamento de Mato Grosso. Governo do Estado do Mato Grosso, [s/d]. Disponível em: http://www.seplan.mt.gov.br/documents/ 
363424/4118877/Regionalizaçao+de+Planejamento+do+Estado.pdf/48643 dc1-763e-43d5-be40-2b845088a00e. Acessado em: julho de 2016.

SECCHI, L. Políticas públicas: conceitos, esquemas de análise, casos práticos. São Paulo: Cengage Learning, 2012.

SIMIONATTO, I. Classes subalternas, lutas de classe e hegemonia: uma abordagem gramsciana. Rev. Katálysis, Florianópolis, v. 12, n. 1, pp. 41-49, junho, 2009.

SMITH, N. Uneven development: nature, capital, and the production of space. Georgia: University of Georgia Press, 2008.

SOARES, G.A. Sociedade e política no Brasil. São Paulo: Difel, 1973.

SOUZA, J.M.A. Estado e sociedade civil no pensamento de Marx. Serv. Soc. Soc., São Paulo, v. 101, pp. 25-39, 2010.

SPINOZA, B. Ethics, 1675.

STEINBERGER, M. Território, ambiente e políticas públicas espaciais. Brasília: Paralelo 15 e LGE Editora, 2006.

. Território, Estado e políticas públicas espaciais. Brasília: Ler Editora e CNPq, 2013.

STEINBERGER, M., ABICHARED, C.F.A. Política ambiental: intervenção do Estado no uso da natureza e do território. In: STEINBERGER, M. Território, Estado e políticas públicas espaciais. Brasília: Ler Editora, 2013. pp. 115-140.

STEWART, J. British pressure groups. Oxford: Clarendon Press, 1958.

SUPERINTENDÊNCIA DO DESENVOLVIMENTO DA REGIÃO CENTRO-OESTE; MINTER; FAO; PNUD. Projeto BRA/87/37 - Cooperação Técnica de Implementação do Programa Integrado de Desenvolvimento POLONOROESTE: Zoneamento Agroecológico e Ordenamento Territorial da Região Florestal Amazônica - Documento de Trabalho no 4. Novembro de 1989 (mimeo).

SWYNGEDOUW, E. Globalisation or "glocalisation"? Networks, territories and rescaling. Cambridge Review of International Affairs, v. 17, n. 1, pp. 25-48, 2004.

Scaled geographies: nature, place, and the politics of scale. In: SHEPPARD, E.; MCMASTER, R.B. Scale and geographic inquiry: nature, society, and method. Malden, MA: Blackwell Publishing Ltd., 2004a.

Whose environment? The end of nature, climate change and the process of post-politicization. Ambiente \& Sociedade, Campinas, v. 14, n. 2, pp. 69 87, 2011.

TARROW, S. Power in movement: social movements and contentious politics. Cambridge: Cambridge University Press, 1998.

TEIXEIRA, A.C.; DAGNINO, E.; ALMEIDA, C.C. La constitución de la sociedad civil en Brasil. In: DAGNINO, E. (Org.) Sociedad civil, espacios públicos y democratización: Brasil. México: Fondo de Cultura Económica, 2002. pp. 21-76. 
TENDLER, S. O veneno está na mesa. Documentário. 2011 (transcrição própria).

THÉRY, H.; MELLO, N.A. de. Atlas do Brasil: disparidades e dinâmicas do território. São Paulo: EDUSP, 2009.

THÉRY, H.; MELLO, N.A. de. Atlas do Brasil: disparidades e dinâmicas do território. $3^{a}$ ed. São Paulo: EDUSP, 2017 (no prelo).

THÉRY, H. Pouvoir et territoire au Brésil: de l'archipel au continent. Paris: Éditions de la Maison des Sciences de l'Homme, 1995.

THUAULT, A. Avaliação das condições para uma efetiva participação dos setores da sociedade civil de Mato Grosso em processo de REDD+. Cuiabá: ICV, 2012.

THUAULT, A.; FERNANDES, E.; VALDIONES, A.P.; MICOL, L. Transparência das informações ambientais na Amazônia. Transparência Florestal - Mato Grosso, Cuiabá, n. 6, ano 4, novembro de 2015.

TOURAINE, A. Critique de la modernité. Paris: Fayard, 1992.

TRAJAN, R. A sociedade civil brasileira pela lente da participação cidadã. In: MESQUITA, N.C. Brasil: 25 anos de democracia. São Paulo/Rio de Janeiro: Fundação Konrad Adenauer, 2016.

UNAC et al. Open letter from Mozambican civil society organizations and movements to the presidents of Mozambique and Brazil and the Primer Minister of Japan. 2013.

VELHO, O.G. Frente de expansão e estrutura agrária: estudo do processo de penetração numa área da Transamazônia [on-line]. Rio de Janeiro: Centro Edelstein de Pesquisas Sociais, 2009. 172p. Disponível em: http://books.scielo.org.

VIEIRA, L.; CADER, R. A política ambiental na década 2002-2012. In: SADER, E. (Org.) 10 anos de governos pós-liberais no Brasil: Lula e Dilma. São Paulo: Boitempo; Rio de Janeiro: Flacso Brasil, 2013.

VIEIRA FILHO, E. Expansão da fronteira agrícola no Brasil: desafios e perspectivas. Relatório técnico. Rio de Janeiro: IPEA, 2016.

SILGUEIRO, V. Exploração madeireira atinge $46 \%$ da área florestal de Mato Grosso. Entrevista. Instituto Humanitas Unisinos, 2015. Disponível em: http://www.ihu.unisinos.br/159-noticias/entrevistas/543726-exploracaomadeireira-atinge-46-da-area-florestal-do-mato-grosso-entrevista-especialcom-vinicius-silgueiro.

WAGENAAR, $\mathrm{H}$. Value pluralism in public administration: two perspectives on administrative morality. In: JUN J.S. (Ed.) Rethinking administrative theory. The challenge of the new century. Westport, CT: Praeger, 2002. pp. 105-130.

WOODGATE, G.; REDCLIFT, M. From a sociology of nature to environmental sociology: beyond social construction. Environmental Values, Cambridge, n. 7, pp. 3-24, 1998.

WORLD BANK. Approaches to the environment in Brazil: a review of selected projects. Volume II: pollution control in Sao Paulo. 1992. 
WORLD WILD FUND. Amazon deforestation front points. Disponível em: ArcGis.com. Acessado em: agosto de 2015.

XIE, L.; VAN DER HEIJDEN, H.A. Environmental movements and political opportunities: the case of China. Social Movement Studies, v. 9, n. 1, pp. 5168, 2010.

ZANIRATO, S.H.; RIBEIRO, W.C. Conhecimento tradicional e propriedade intelectual nas organizações multilaterais. Ambiente e Sociedade, v. 10, n. 1, pp. 39-55, jan./jun, 2007.

ZIMMERER, K.S. Human geography and the "New Ecology": the prospect and promise of integration. Annals of the Association of American Geographers, v. 84, n. 1, pp. 108-125, 1994.

ZIZEK, S. Looking awry: an introduction to Jacques Lacan through popular culture. Cambridge, MA: M.I.T. Press, 2002.

i Enquanto Marx entende a sociedade civil hegeliana como um conjunto de relações econômicas, Gramsci a vê como um complexo de superestrutura ideológica. A primeira noção é útil na medida em que entende as relações materiais dos indivíduos, e seu metabolismo com o ambiente, em um estágio de desenvolvimento determinado pelas forças produtivas. Reporta-se à concepção hegeliana na medida em que entende "na sociedade civil o complexo das relações econômicas e a formação das classes sociais" (PORTELLI, 1977, p. 20). No entanto, é em Gramsci que o entendimento da sociedade civil evolui, considerando a função da hegemonia que um grupo dominante exerce sobre toda a sociedade. A sociedade política seria uma extensão da sociedade civil, de caráter coercivo e vinculada ao aparelho do Estado enquanto guardião da ordem pública. Ainda que a primeira ideia a que a palavra coerção nos remeta, sua real aplicação está concentrada na Administração Pública, tendo a burocracia como o mais eficiente instrumento do poder coercivo do Estado, já que o uso recorrente somente da força colocaria em crise o bloco histórico. Sendo um conjunto complexo, a sociedade civil dirige todo o bloco histórico, adaptando seu conteúdo segundo as categorias sociais que atinge. A ideologia da classe dirigente, ou hegemônica, funda-se e baseiase na filosofia, a qual se consolida os momentos históricos que se sucederam e influencia as normas de vida de todas as classes sociais. História e filosofia se consolidam, assim, como um bloco ideológico, na medida em que a classe dirigente determina as concepções de mundo segundo uma realidade precedente por ela pensada e difundida no interior das classes subalternas (PORTELLI, 1977). Essa esfera ideológica da sociedade civil se estende a todas as estratificações sociais da estrutura do bloco histórico. É a partir da estrutura ideológica que a classe dirigente difunde a sua ideologia. Essa estrutura está distribuída no fundamento das instituições, das organizações e também nos meios de comunicação, que servem de instrumento para influenciar a opinião pública. Conserva-se uma certa homogeneidade no bloco ideológico, dado que as camadas sociais são heterogêneas, por meio de um movimento progressivo que satisfaça as diferentes exigências científicas e filosóficas nessa diversidade. Em relação à consolidação do que se pode chamar de um bloco histórico que se estabeleceu no Brasil, a estrutura ideológica foi eficaz na transmissão da ideia da necessidade de ocupação dos territórios e dos vazios territoriais e da necessidade de 
integração dos povos originais a uma gestão baseada na agroexportação, alternando o uso da força com gargalos burocráticos que pudessem conter os conflitos por meio da exclusão das classes subalternas do processo. Em realidade, essa ideologia, que permeou todas as esferas sociais, foi eficaz e eficiente para permitir à classe dominante a apropriação dos territórios historicamente, desconsiderando as classes subalternas que ali já estavam estabelecidas por meio de sua invisibilização. O brasileiro pobre mato--grossense, amazônico, nordestino, caiçara, foi e é invisível aos olhos do Estado, e na estrutura do bloco histórico de seu próprio ambiente. Torna-se o sertanejo migrante, o indígena que, apesar de preceder a todas as outras etnias, se vê estrangeiro em sua própria terra, o quilombola que perde direitos após a sanção do governante. Para Gramsci, o nó do bloco histórico a ser superado estava no vínculo orgânico entre estrutura e superestrutura e, nesse vínculo, na importância dos intelectuais orgânicos. A força das classes subalternas em uma sociedade civil estaria na emergência de uma intelectualidade orgânica própria que desagregue o bloco ideológico. Na construção da superestrutura que se deu no Brasil, a forma como se estabeleceu a designação de "organizações da sociedade civil" traz para si a complexidade que reside no seu conceito original, centrado na mesma classe dominante discutida anteriormente sobre o Estado brasileiro que tivemos como legado desde a colonização. Em si elas não constituem um rompimento com o bloco ideológico e, por isso, não superam o bloco histórico estabelecido. O termo foi apropriado nessa estrutura. Por um lado, elas seriam operativas como parte da sociedade política: serve à Administração Pública brasileira por meio de parcerias e acordos que "descentralizariam" funções do Estado sob a justificativa do maior dinamismo burocrático das OSC, menos "engessadas" que as instituições e órgãos do Estado. Ora, essa justificativa não é suficiente justamente porque a sociedade política tem exatamente no engessamento de suas burocracias sua melhor estratégia de coerção. Por outro lado, a cooptação das OSC pelo Estado é uma das formas de apaziguar os conflitos dentro das estratificações sociais, driblando as demandas das classes subalternas e homogeneizando o bloco ideológico, como citado anteriormente. 